


\section{예술향유정책 분석 및 방향 연구}

A Study of Arts Engagement Policy and Its Prospects

조현성·최보연 



\section{연구책임}

조현성 한국문화관광연구원 선임연구위원

최보연 상지대학교 문화콘텐츠학과 조교수

\section{공동연구}

전민정 프락시스 교육연극연구소 책임연구원

유지연 창원대학교 문화테크노학과 조교수

서지혜 인컬쳐컨설팅 대표 

예술향유정책 분석 및 방향 연구

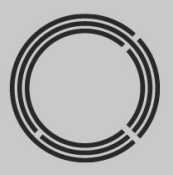

연구개요 



\section{1. 연구 개요}

\section{1-1. 연구 목적}

연구목적은 현재 예술향유정책에 내재된 문제점 분석을 통해 향후 예술향유정책 이 지향해야 할 궁극적 가치와 목적을 제시하고, 이를 실현하기 위한 정책방향을 제언하는 데 있다. 예술정책 논의 내에서 '향유지원의 가치정향 모호성', '시혜적' 정책으로 오인되는 문제, '급변하는 시대변화에 정책적 대응 부족' 등의 문제를 종 합적으로 점검하기 위해서는 예술향유정책 전반을 포괄적 관점에서 살펴볼 필요가 있다. 이에 연구에서는 중앙주도의 향유지원 정책을 주요 분석대상으로 삼되, 향유 지원의 목적 및 가치정향에 대한 이론적 검토를 비롯하여, 일반시민의 입장에서 '예 술향유'가 가진 다원적 양태와 수요의 복합성 및 중층성 등에 관해 심도있게 분석했 다. 이를 통해 예술을 통한 국민의 삶의 질 제고에 기여할 수 있는 예술향유정책의 방향성을 탐색·제시한다.

\section{1-2. 기대 효과}

연구는 시대적 환경변화를 반영한 예술정책 논의 내에서 예술향유정책의 문제와 지향점에 관한 포괄적이고 입체적 분석을 다루고, 이를 위한 정책방향을 제시한다 는 측면에서 기존 연구와 차별성을 갖는다. 그간 예술향유 관련 정책연구가 단위사 업 혹은 특정제도 중심으로 이뤄져 오는 과정에서 예술정책의 전체 방향성 속에서 의 ‘향유' 지원 관련 논의가 포괄적, 유기적으로 다뤄지지 못했었기 때문이다. 연구 가 제시하는 예술향유 정책 분석 및 방향에 관한 제언은 향후 예술향유정책의 방향 성 설정 및 정책사업 발굴과 입안을 위한 기초자료로 활용될 수 있을 것이며, 현 정책의 문제 및 개선방향 탐색에 실질적으로 기여할 수 있을 것이다.

\section{1-3. 분석대상 및 연구 방법}

연구에서 분석대상의 '예술향유정책' 은 '문화체육관광부 중심의 중앙에서 주도하 는 정책'에 한정한다. 구체적 '예술향유정책' 분석대상은 크게 '예산 및 지원구조', 
'지원사업' 으로 구분하여 접근한다.

연구방법은 문헌조사, 설문조사, 초점집단면담조사(FGI) 등이다. 첫째, 예술향유 관련 이론 및 정책담론 관련 해외 발간 정책보고서, 학술논문을 비롯하여, 문화체육 관광부 및 향유지원 관련 공공기관에서 발간된 정책연구보고서, 정책 비전서, 사업 계획서, 사업실적보고서, 향유 실태와 관련된 통계자료 등을 다각적으로 검토했다. 둘째, 일반 시민의 예술향유에 대한 인식 및 예술향유 활동의 다양한 양태 변화 분 석을 위해 15 세 이상 시민대상 온라인 설문조사를 진행했다. 셋째, 시민의 예술향 유 인식 및 양태 관련 심층 분석 수행을 위해 FGI를 진행했다. 총 24 명을 선정하여, 이들의 '예술' 및 '예술향유'에 대한 인식, '예술향유활동' 실태의 다원적 측면(동기, 매개, 효과 및 외적·내적 걸림돌 등), 정부 정책 인식을 분석했다. 참여자는 무관심 자(G1), 직접 관람 고관여자(G2)/저관여자(G3), 온라인 주이용자(G4), 참여활동자 (G5) 등 총 5개 집단이다. 부가적으로 향유정책 단위사업 담당자 및 문화예술 연구 자와 자문회의를 가졌다.

\section{2. 예술향유에 대한 새로운 관점과 유형화}

예술향유에 대한 최근 국내외 논의는 다음과 같이 정리할 수 있다. 첫째, '예술'에 대한 새로운 관점이 제시된다. 국내는 물론 외국에서도 '예술향유'는 보편적으로 예 술 관람과 유사하게 이해하고 '소비'의 개념에 비중을 둔 관점에서 접근되어 왔다. 그러나 최근 10 여 년 사이에 점차 향유자 개인의 향유 활동을 둘러싼 동기와 영향, 향유의 다양한 스펙트럼과 이를 구성하는 주체성과 능동성 등 개인 경험의 관점으 로 비중이 이동되고 있다. 이제 예술향유는 예술이 지닌 복합적인 측면들과 관계를 맺는 여러 형태로, 향유자가 주체성의 존재로 삶에서 영위해가기라는 궁극적인 모 습을 지향하는 가운데에 향유자마다의 개인적 특성과 역량, 상황, 환경적 요인들로 인해 취할 수 있는 다양한 형태의 스펙트럼으로 이해된다.

둘째, 예술향유는 유동적 개념으로 이해된다. 예술향유를 논하는 데에 있어서 닫 힌 정의를 내리기보다는 포괄적이며 유동적인 개념으로 정의하는 것이 유용하다. 예술향유는 '향유자'의 주체적 입장뿐 아니라, 외적 요소가 개입된 매개적 맥락과 
영향요인의 결합으로 발현된다. 또한 예술향유는 사회의 변화, 기술변화 등과 상호 작용하는 변화적 속성을 지닐 수밖에 없다. 따라서 엄격한 정의나 측정 지표의 표준 화에 집중하기 보다는 시대변화를 반영할 수 있는 객관적 조사 기제와 함께 열린, 상호적 해석 하에서 의미와 가치가 구성될 수 있도록 고려해야 한다.

셋째, 향유자 중심성, 즉 대상이 아닌 '주체자'의 역할이 강조된다. 향유의 동기, 장벽, 장소에 주목하면서 향유를 포괄적으로 이해하고자 한다. 또한 "비형식의 예 술, 아마추어 예술활동'을 예술향유의 일부로 포괄하거나 예술향유에 기여하는 활 동으로 재조명하기 시작한다.

넷째, 창작과 향유의 연계, 즉 예술계의 관객개발 관점이 제기된다. 최근 $\mathrm{EU}$ 의 Creative Europe은 '관객개발'을 "예술이 더욱 폭넓게 접근성을 확보할 수 있도록 하는 전략적이며 다이내믹하고 상호적인 프로세스"로 정의한다.

다섯째, 예술생태계 가치사슬을 넘어선 문화적 삶의 맥락에서의 '예술향유'를 인 식하는 동향이다. 예술향유를 정책적으로 지원함에 있어 예술생태계적 관점을 포함 하는 것도 주요하나, 장기적으로 보다 확장적인 관점, 즉 사회적 문화적 삶의 맥락 으로서의 문화생태 체계 내에 '예술향유'를 위치시키고 이를 문화리터러시, 문화생 태와 연계시키는 방식의 이해가 중요해진다.

여섯째, '예술향유' 이해를 위한 복합적 관점, 즉 '예술향유' 활동이 발생되는 맥 락은 개인 외에도 사회적 맥락 속에서 함께 매개되어 발현되기에 개인 고유의 향유 에서부터 지역적, 사회적 가치로 확장되는 가치체계와 연계되는 복합적이며 다양한 향유의 양태를 구성하는 요인들을 종합적으로 바라보아야 한다는 논리다. 이 같은 관점을 고려하여, 예술향유의 양태를 분류하면 다섯 가지로 유형화할 수도 있다.

〈표 1〉 예술향유 양태유형 분류(안)

\begin{tabular}{|c|c|c|}
\hline \multicolumn{2}{|c|}{ 구분 } & 향유양태, 활동의 예시 \\
\hline & $\begin{array}{l}\text { 전통적 } \\
\text { 관람형 }\end{array}$ & 예술의 창작이나 재현, 프로그램 등을 보거나 듣는 유형 \\
\hline 관람형 & $\begin{array}{l}\text { 참여적 } \\
\text { 관람형 }\end{array}$ & $\begin{array}{l}\text { 관람 대상의 예술적 활동이나 작업, 작품에 대해 자신의 해석이나 의도를 부여하며 교감 } \\
\text { 하거나 관람 차원의 참여적 활동에 응하는 향유 유형. 예를 들어 자신의 예술 향유 콘텐 } \\
\text { 츠를 수집하거나 목록화하는 활동, 이머시브 공연의 관람활동, 커뮤니티 아트에 참여 등 } \\
\text { 을 들 수 있음 }\end{array}$ \\
\hline
\end{tabular}




\begin{tabular}{|c|c|c|}
\hline \multicolumn{2}{|c|}{ 구분 } & 향유양태, 활동의 예시 \\
\hline \multicolumn{2}{|c|}{$\begin{array}{l}\text { 매개된 경험형 } \\
\text { (교육) }\end{array}$} & $\begin{array}{l}\text { 사람이나 기술로 인해 향유하는 방식이나 과정, 개인적 동기나 활동이 촉발되거나 조력 } \\
\text { 된 향유 유형. 예를 들어 예술교육의 특성을 지닌 활동, 버츄얼 공간이나 현존 공간에서 } \\
\text { 기술적 매체나 프로그램 된 기술활동에 의한 향유로 AR/VR 기기가 조력하는 전시관람 } \\
\text { 이나 게이미피케이션이 적용된 버츄얼 공간에서의 예술향유 활동 등이 포함됨 }\end{array}$ \\
\hline \multirow[b]{2}{*}{ 창작형 } & $\begin{array}{l}\text { 공동 } \\
\text { 창작형 }\end{array}$ & $\begin{array}{l}\text { 창작 주체에 의해 초대된 향유로 창작과 표현에 대한 권한의 일부를 부여받은 예술 활동. } \\
\text { 창작의 과정은 물론 결과물에 대한 자신의 기여를 인지할 수 있는 유형임 }\end{array}$ \\
\hline & $\begin{array}{l}\text { 개인 } \\
\text { 창작형 }\end{array}$ & $\begin{array}{l}\text { 온전히 자신의 주체적 의지에 의해 예술 창작 활동이 이뤄지는 활동. 전문예술가는 물론 } \\
\text { 아마추어 예술가들의 창작 활동도 포함함. 이 때 전문성과 수월성을 창작 작업의 주요 } \\
\text { 기준으로 두고 있는 지에 따라 일상예술형 향유와 구분지을 수 있음 }\end{array}$ \\
\hline \multicolumn{2}{|c|}{$\begin{array}{l}\text { 일상예술형 } \\
\text { (동호회) }\end{array}$} & $\begin{array}{l}\text { 예술적 감성과 예술적 표현, 예술적 훈련이 일상에서 루틴하게 이뤄지는 자발적 유형의 } \\
\text { 활동. 예를 들어 악기 연습이나 시의 습작, 일상 드로잉, 동호회 활동 등을 들 수 있음 }\end{array}$ \\
\hline \multicolumn{2}{|c|}{ 자원봉사/기부형 } & $\begin{array}{l}\text { 예술작품의 보존이나 예술활동의 지속성을 지지하고 지원하는 활동. 예를 들어 기부나 } \\
\text { 예술기관에서의 도슨트 자원봉사, 시설 등을 찾은 나눔연주 등을 들 수 있음 }\end{array}$ \\
\hline
\end{tabular}

\section{3. 시민의 예술향유 인식 및 예술향유활동 분석}

예술향유에 대한 인식 및 예술향유활동의 다양한 양태 변화 분석을 위한 시민대 상 온라인 설문조사(15세 이상 1,000 명)와 심층 분석을 위해 수행된 FGI(24명) 결 과로부터 도출된 시사점은 다음과 같다.

첫째, 예술향유 범주에 관한 인식 확장, 즉 기존 예술향유 정책지원과의 간극이 존재한다. 예술향유 활동 범주에 대한 인식은 여전히 '관람' 중심의 활동, 즉, 영화 관람, 공연관람, 전시감상에 대한 인식이 높은 편으로 나타났다. 하지만 이와 함께 주목해야 할 부분은 온라인 매체를 통한 예술향유 활동과 관람 이외의 활동도 예술 향유 활동 범주에 포함시켜 폭넓게 인식되고 있다는 점이다.

둘째, 예술향유 걸림돌을 파악해보면, 세분화된 예술향유 지원 접근이 부재함을 알 수 있다. 예술향유 집단별로 내적·외적 걸림돌 요인들이 작용하고 있으며, 특히 무관심자 그룹의 경우에는 예술에 대한 문화자본의 부재가 예술에 대한 부정적 이 미지 및 수용에 대한 저항으로까지 이어지고 있음을 알 수 있다. 이러한 결과와 결 부시켜 예술향유 정책 영역의 시사점은 과연 예술향유 지원정책의 역할은 어떻게 이러한 내적·외적 요인들을 세분화하여, 물리적·심리적 장벽을 낮출 수 있을지에 대한 고려가 필요하다고 하겠다.

셋째, 기술 환경변화에 따른 예술향유 양상 변화를 보면, 예술향유 지원의 범주와 
개념적 변화가 필요하다. 다양한 방식으로 온라인 매체를 통한 예술향유 활동이 행 해지고 있음을 알 수 있다. 최근에는 특히 코로나19로 인해 온라인 매체를 통한 예 술향유가 증가하고 있음이 확인되었고, 최근 1 년간 유튜브, 넷플릭스, 왓차, 오디오 북 등의 온라인 매체를 통해 영화, 콘서트, 뮤지컬, 무용, 디지털 출판물 등의 다양 한 콘텐츠를 접해온 것으로 나타났다. 따라서 기존 공간, 관람, 장르 중심의 향유 정책에서 디지털 기술 기반의 다양한 온라인 예술향유 양태를 포용할 수 있는 방향 성으로의 재정비가 필요하며, 이러한 예술향유의 범주와 양태의 변화를 반영할 수 있는 정책적 접근이 반드시 동반되어야 할 것이다.

넷째, 예술향유자의 내적 요소로서 예술향유 가치 인식 변화를 위한 정책지원 관 점이 필요하다. '예술이 무엇인가'에 대해 사회적인 가치는 전반적으로 동의하고 있 음에도, 동기, 가치 인식, 효능감과 같은 개인적이고 주체적인 맥락에서는 예술향유 활동 정도에 따라 간극이 존재하고 있음을 알 수 있다. 따라서 이러한 내적 동기 및 가치 인식 차원의 차이가 시사하는 바는 과연 예술향유 정책상에서 시민들에게 개인적 차원의 예술향유에 대한 가치 인식 변화를 가져다 줄 수 있는 방안은 무엇이 있을지에 대한 논의가 필요하다는 것이다.

다섯째, 정부정책 인식 및 의견을 종합해보면, 인지도 제고 및 지원제도 다각화가 필요하다. 정책지원 사업에 대한 인식은 일부 존재하나 전반적으로 예술향유를 위 한 정부지원의 체감도는 아직 미진했다. 장기적 관점에서 예술향유의 저변을 확대 할 수 있는 교육지원 등은 물론, 변화하는 수요에 따른 정부의 다각적인 지원이 함 께 병행될 필요가 있음이 확인되었다.

\section{4. 예술향유정책 사업 분석}

현재 진행 중인 예술향유정책 사업 분석의 주요 결과를 요약하면 다음과 같다. 첫째, 시혜적인 공급형 사업 진행과 향유자는 수동적 대상으로 인식된다. 전반적 으로 다수의 사업들에서 성과지표가 참가자수, 프로그램수와 같은 '숫자'로만 되어 있어, 정책지원의 목적 자체가 사업의 양적인 확대에 치중되었고 사업의 질적 점검 부분이 부족했다. 일회성 방문과 사업 운영으로 횟수는 늘어났지만, 정작 수혜자 입 
장에서의 변화라든가 지속성이 없었다.

둘째, 향유를 표방하는 사업 목적의 주객전도 경향성이 보인다. 이것은 다시 몇 가지로 나눠볼 수 있다. 첫 번째로 명목은 향유 지원, 내용은 창작 지원 대체재인 경우가 있다. 두 번째로 향유 확대와 일자리 확대가 병행된 사업이 있다. 일반 국민 대상의 향유 지원사업의 한 유형으로 예술계 인력의 일자리 창출 목적을 병행하는 사업이 다수 진행 중인데, 이러한 인력 배치형 사업들은 향유를 1 차적 목표로 내세 우지만 일자리 창출이라는 성과지표가 숨어있거나, 일자리 창출이 사실상 궁극적인 목표인 경우가 많은 것이다.

셋째, 예산구조가 복잡하고 유사한 사업들이 진행된다. 복권기금과 국민체육진흥 기금으로 진행되는 사업이 상당수이다. 그리고 사업을 주관하고 있는 기관별로 살 펴보면 유사한 유형의 사업이 진행되고 있다. 이때 유사사업 존재 자체가 문제라기 보다는 정책지원의 효과를 제고하기 위한 이들 사업들 간의 연계 혹은 조정 등이 실질적으로 필요하다는 점이 확인되었다.

넷째, 중앙과 지역의 역할 분담이 모호한 경우가 있다. 현재 향유 관련 예산의 비율은 중앙 $20 \%$, 지역 $80 \%$ 정도로 추정된다. 지역문화진흥원이 생기면서 지역밀 착형으로 가야 유의미한 생활문화형의 사업은 중앙 주도가 아닌 지역으로 내리고, 중앙의 정책적 역할은 다르게 가져가기 위한 전환을 논의 중이다. 그런데 아직까지 중앙과 지방이 담당해야 할 정책사업의 구분이 명확하지는 않다.

다섯째, 사회 변화 반영 및 향유 정책 대상의 다변화가 시도된다. 문화예술교육 분야에서는 4차 산업혁명 시대에 대비해 신기술을 반영한 새로운 유형의 프로그램 을 개발하거나, 예술과 기술의 융합형 교육도 새롭게 시도되고 있다. 사업의 목표 측면에서도 '긍정적인 삶의 변화 추구’라는 개인 차원의 목표를 내세우는 변화가 감 지된다. 이 같은 변화는 교육 분야뿐 아니라 다른 향유정책에서도 나타난다.

여섯째, 일상성 vs 특수성, 그리고 무료 vs 유료의 딜레마가 존재한다. 예를 들어 공연(관람)의 경우, 정책에서 일상적 차원의 예술을 강조하기는 하지만, 수요자도 똑같이 일상성을 중요하게 느끼고 가치를 부여한다고 보기는 쉽지 않다. 정식 공연 장이 아닌 곳에서 무료로 제공되는 약식의 예술을 반복적으로 접하면서 감동보다는 오히려 예술에 대한 반감이나 부정적 인식이 생길 수도 있기 때문에, 정식 공연장에 서 수준 높은 공연을 한 번 접하는 것이 더 효과적일 수도 있는 것이다. 무료 운영의 
취지가 보편적 복지 차원에서 접근성 확대를 위한 것이라면, 앞으로는 유료 관객개 발과 접목하면서 갈 수 있는 방식을 고민해봐야 한다. 무료로 향유한 경험이 차곡차 곡 쌓여 능동적이고 주체적으로 향유하는 유료 관객을 견인해 내고, 예술생태계 창 작활성화의 선순환을 만들어 낼 수 있을 것이다.

\section{5. 예술향유정책 방향}

\section{5-1. 예술향유 개념 정립을 위한 기본 원칙}

향후 예술향유정책의 가치정향 명확화를 위해서는 '예술향유' 의 정책적 개념에 대한 정립이 가장 우선적으로 필요하다. 첫째, '예술'에 대한 확장적 이해가 전제되 어야 한다. '예술향유'를 정책적으로 논함에 있어 향후 개념 정립은 '예술'에 대한 확장적 이해를 바탕으로 이뤄질 필요가 있다. 이때 새로운 '예술' 개념 설정에 있어 주요 요소는 정의규정 기준의 '유연성'과 범주의 '개방성'을 들 수 있다. 이러한 유 연적, 개방적 관점을 적용함에 있어 '예술'에 대한 이해가 '작품' 중심의 결과물 중 심 정의가 아닌 '과정', 즉 프로세스 중심으로 '예술을 이해하는 관점' 또한 필수적 이다.

둘째, '향유자' 관점에서의 접근, 즉 향유를 '주체적·적극적·즐거운 권리'로 인식 해야 한다. 그간 정책 논의에서는 향유자를 수동적으로 대상화할 수 있는 언어적 뉘앙스가 농후한 공급자 관점에서의 ‘향수’라는 고루한 표현을 관성적으로 견지해 왔다. 따라서 향후 '예술향유'의 개념적 정의 및 관련 논의는 '향유(享有) $=$ 누리어 가짐'이라는 단어 고유의 취지를 십분 되살리는 방향으로 정립될 필요가 있다. 더불 어 이때 주요한 지점은 '예술향유활동'이 향유자 입장에서 ‘흥미롭고', ‘재미나고', '신나는' 요소를 느낄 수 있는 영역으로서도 인식될 필요가 있다는 것이다.

셋째, '향유' 개념 정립에 있어 관련 활동영역을 다원적이고 입체적으로 이해해야 한다. 향유활동의 영역을 크게 관람형과 참여형으로 보되, '관람형'의 영역은 전통 적 관람형과 참여적 관람형, '참여형' 영역은 매개된 경험형(교육), 창작·실연형(공 동창작 및 개인창작 포함), 일상예술형(동호회), 자원봉사.기부형 등 다시 4 개 영역 중심으로 볼 수 있다. 물론 각 영역의 구분 기준 역시 상호배타적으로 설정하기보다 
는, 상호 간 전이와 연계가 가능할 수 있음을 전제로 바라보아야 한다.

넷째, 창작과 향유가 배타적으로 대척점에 있는 것이 아닌, 중첩적 속성을 가질 수 있다는 점을 반드시 고려할 필요가 있다. 기존 예술지원정책 일부 논의에서 지속 적으로 지목되어 온 ‘창작 vs 향유 지원 간 불균형' 논의가 이제는 층위를 달리하여 전개될 필요가 있다. 향후 '예술향유' 개념 정립의 방향성은 '예술가를 포함한 모든 시민'의 입장에서 예술을 접하고, 누리고, 즐기는 예술향유활동이 이후 아마추어 활 동을 넘어서서 직업적 전문예술가로서의 창작행위까지 연계·발전될 수 있는 가능성 까지 포함하는 관점에서 이뤄져야 한다.

다섯째, 정책개념으로서의 ‘문화향유’와의 차별성의 기준을 제시하는 것이 필요 하다. 이미「문화기본법」을 통해 포괄적 개념으로서의 '문화'가 제시된 바 있고, '문 화'의 영역 중 일부로 '예술'이 포함된 것임을 감안할 때, 문화향유는 예술분야를 포함한 스포츠, 관광, 종교, 젠더 등을 비롯한 개인의 다양한 가치관 및 삶의 양식을 포괄한 넓은 의미의 문화활동으로 상정하되, '예술향유'의 경우 '프로세스로서의 '예술', 더불어 예술양식과 범주의 확장성, 유연성, 개방성을 반영한 '예술' 영역에 서 이뤄지는 다양한 활동들로 이해할 필요가 있다.

\section{5-2. 예술향유정책의 방향과 과제}

예술향유정책의 방향을 네 가지, 즉 (1) 보편적 국민 예술향유 진작을 위한 정책 환경 조성, (2) 향유수요 변화 및 복합성을 반영한 다원적 정책접근 개발, (3) 창작-향 유의 선순환 구조 형성, (4) 예술향유지원 추진체계(거버넌스) 재정비로 설정했다.

첫째, 향후 예술향유지원 정책의 새로운 방향성을 모색함에 있어 무엇보다 국민 의 입장에서 그들의 실제 예술활동과 결합하여 경험하는 '향유'를 복합적으로 이해 하는 한편, 이를 정책적으로 지원하기 위한 고민이 보다 입체적으로 진행될 필요가 있다. 이를 위해서는 「문화예술진흥법」 개정 추진, 향유지원 정책 환경 재정비, 대 국민 예술향유 인식 제고 같은 과제를 실현해야 한다.

둘째, 예술향유 정책지원에 있어 예술이라는 범주를 어떻게 바라볼 것인지, 사회 적·기술적 환경 변화에 따라 예술향유라는 개념이 어떻게 인식되고 변화하고 있는 지, 얼마나 다양한 형태의 예술향유 활동이 이미 행해지고 있는지, 그리고 예술향유 
를 하는 사람들의 내재적인 요인들 또한 얼마나 다변화되고 있는지 등을 이해하고, 이러한 변화 및 복합성이 향유정책에 반영될 수 있도록 면밀하게 검토할 필요가 있 다. 이를 위해서는 향유환경 변화를 고려한 실태조사 개편, 보편적 예술향유자에 대 한 입체적 지원정책, 능동적 향유자를 위한 지원사업 모델 개발 같은 과제를 실현해 야 한다.

셋째, 예술생태계의 관점에서 보았을 때 창작과 향유의 선순환 고리를 정책적으 로 좀 더 강하게 하고 여러 개의 고리가 입체적으로 돌아갈 수 있게 만들어 줄 필요 가 있으며, 이는 코로나19로 인해 도래한 예술 환경의 변화와도 맞물려 돌아가야 한다. 이를 위해서는 향유자-창작자 간의 소통 활성화, 향유자에 대한 이해와 새로 운 관객개발을 위한 리서치 강화, 사회적 거리두기·비대면 관람과 향유-창작지원의 연계 관련 사업들을 수행해야 한다.

넷째, 현재 예술향유 지원사업의 문제점은 자발성이 미흡한 공급형 위주의 사업, 일부 창작·향유·일자리 사업 성격의 중첩성으로 인한 정체성 모호, 복잡한 재원 출 처로 인한 예산구조 및 사업의 중복성, 무료 관람정책이 가진 딜레마 등으로 요약할 수 있다. 이러한 예술향유 지원사업의 구조상 문제와 관련하여 효율적인 추진을 위 한 체계 재정비 및 협력체계 구축이 필요하다. 구체적으로는 향유 지원사업 운영 체계 및 역할 재정비, 일률적인 무료지원 모델 재설계, 유사 사업 운영 주체 간/사 업 간 연계 강화를 위한 사업이 추진되어야 한다. 



\section{목차}

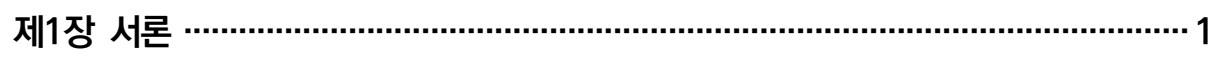

제1절 연구 배경 및 목적 3

1. 연구 배경 3

2. 연구 목적 및 기대효과 9

제2절 연구 범위 및 방법 11

1. 연구 범위 11

2. 연구 방법 및 연구 체계 16

제2장 예술향유 이론적 논의 및 정책환경의 변화 …………………………….... 21

제1절 예술향유의 환경변화 및 최근 정책담론 23

1. 예술계를 둘러 싼 환경변화 23

2. '복합적·능동적 프로세스'로서의 예술향유 28

3. '예술향유' 영향요인 및 속성에 관한 학문적 관심 43

4. 최근 예술향유 정책담론 58

제2절 예술향유 정책 분석 및 논의를 위한 시사점 69

1. '예술'과 '향유'에 대한 새로운 관점 69

2. 예술향유 이해를 위한 프레임워크(안) 74

제3장 시민의 예술향유 인식 및 예술향유활동 분석 …………............................... 79

제1절 예술향유 실태와 특징: 선행조사 검토 81

1. 실태조사와 예술향유 현황 81

2. 국민문화예술활동조사 분석: 예술향유 유형화 시도 98

3. 실태조사 현황 및 향유유형 분석의 시사점 119

제2절 시민의 예술향유에 관한 인식 및 활동 양태 123

1. 시민 예술향유 인식 및 예술향유활동 설문조사 123

2. 시민 예술향유 인식 및 예술향유활동 FGI 162

3. 예술향유 인식 및 양태 분석의 종합 시사점 174 
제1절 예술향유정책의 전개과정과 특징

1. 예술향유정책의 전개과정 193

2. 예술향유정책의 특성 및 시사점 212

제2절 예산을 통해서 본 예술향유정책 지원구조 220

1. 문화체육관광부 예산구조 $\quad 220$

2. 예술향유지원 예산구성 222

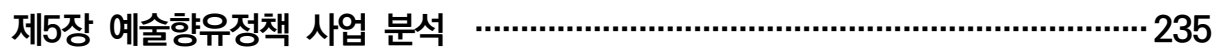

제1절 주요 지원사업 현황 237

1. 예산항목별 예술향유 지원사업 237

2. 사업목적과 내용에 따른 (유형) 분석 288

제2절 예술향유 지원사업 특성 및 시사점 300

1. 시혜적인 공급형 사업 진행과 수동적 대상으로 인식되는 향유자 300

2. 향유를 표방하는 사업 목적의 주객전도 경향성 302

3. 복잡한 예산구조 및 유사사업 진행 305

4. 중앙과 지역의 역할 분담의 모호성 306

5. 사회 변화 반영 및 향유 정책 대상의 다변화 시도 307

6. 일상성 vs. 특수성, 무료 vs. 유료의 딜레마 309

제6장 예술향유정책 방향 ………………………………………………………3 311

제1절 예술향유정책 가치정향 명확화 313

1. 예술향유 개념 정립을 위한 기본 원칙 313

2. 예술향유정책 설정의 기본방향 321

제2절 예술향유정책 방향과 과제 324

1. 보편적 국민 예술향유 진작을 위한 정책 환경 조성 324

2. 향유수요 변화 및 복합성 반영한 다원적 정책접근 개발 332

3. 창작-향유의 선순환 구조 형성 338

4. 예술향유 지원을 위한 추진 체계 재정비 346

\section{참고문헌 / 353}

ABSTRACT / 367 


\section{표 목차}

〈표 1-1〉 용어정의: 향수 vs. 향유 12

〈표 1-2〉 용어정의: 문화 vs. 예술 13

〈표 1-3〉 용어정의: 문화향유 vs. 예술향유 14

〈표 1-4〉예술향유정책 분석대상 15

〈표 1-5〉 설문조사(시민 예술향유 인식 및 예술향유활동 조사) 개요 17

〈표 1-6〉 FGI(시민 예술향유 인식 및 예술향유활동) 개요 18

〈표 2-1〉 해외 학술논의에서의 '예술향유' 개념 29

〈표 2-2〉5가지 예술향유 프레임워크(Brown 2004) 32

〈표 2-3〉 Brown \& Ratzkin 6가지 관객유형 41

〈표 2-4〉「문화예술진흥법」: ‘향수', ‘향유’ 단어 사용 44

〈표 2-5〉「문화예술진흥법」: ‘향유’ 관련 조항 45

〈표 2-6〉 선행연구: 향유의 구성 요소 50

〈표 2-7〉 선행연구: 문화향유에 영향을 미치는 요인 52

〈표 2-8〉 문화 참여 유형 구분: 문화소비 다양성과 문화생산 다양성 고려 55

〈표 2-9〉 문화 선호와 문화 활동 참여 다양성에 따른 유형 구분 56

〈표 2-10〉 최근 해외 예술향유 정책담론의 특성 58

〈표 2-11〉 외국의 향유실태조사: '예술향유' 정의 62

〈표 2-12〉IFCD Cultural Participation Indicators 66

〈표 2-13〉예술향유의 구성요소 75

〈표 2-14〉예술향유 양태유형 분류(안) 76

〈표 2-15〉예술향유 양태유형의 특성화 요인(안) 77

〈표 3-1〉 2019 국민여가활동조사 개요 81

〈표 3-2〉 2019 국민여가활동조사 내용 82

〈표 3-3〉2019 국민여가활동조사: 용어 정의 83

〈표 3-4〉 연간 한 번 이상 참여한 여가활동(복수응답): 2019 국민여가활동조사 84

〈표 3-5〉 가장 많이 하는 여가활동 상위 10개(복수응답): 2019 국민여가활동조사 85

〈표 3-6〉 여가활동 유형별 참여 실태 및 변화: 2019 국민여가활동조사 86

〈표 3-7〉 여가활동이 삶에 긍정적 영향을 미치는 정도: 2019 국민여가활동조사 86

〈표 3-8〉2019 국민문화예술활동조사 개요 87 
〈표 3-9〉 2019 국민문화예술활동조사 내용

〈표 3-10〉 2019 국민문화예술활동조사: 용어 개념 및 정의 89

〈표 3-11〉 분야별 문화예술행사 관람률 추이: 2019 국민문화예술활동조사 90

〈표 3-12〉 문화예술행사 참여율 변화: 2019 국민문화예술활동조사 $\quad 90$

〈표 3-13〉 문화예술행사 참여 실태: 2019 국민문화예술활동조사 91

〈표 3-14〉2018 서울시민 문화향유 실태조사 개요 91

〈표 3-15〉서울시민 문화향유 실태조사 대상 분류 변화: 2014 2016 vs. 201892

〈표 3-16〉 2018 서울시민 문화향유 실태조사 내용 93

〈표 3-17〉 2018 서울시민 문화향유 실태조사: 용어 개념 및 정의 94

〈표 3-18〉 최근 1년간 문화예술관람 실태: 2018 서울시민 문화향유 실태조사 95

〈표 3-19〉 문화예술활동 참여 실태: 2018 서울시민 문화향유 실태조사 96

〈표 3-20〉 일상생활에서의 미디어 문화예술 활동 실태: 2018 서울시민 문화향유 실태조사 96

〈표 3-21〉 문화예술의 정서적 효과: 2018 서울시민 문화향유 실태조사 97

〈표 3-22〉 문화예술이 본인 삶에서 중요한 정도: 2018 서울시민 문화향유 실태조사 97

〈표 3-23〉 예술향유자 분류를 위한 변수별 특성: 2019 국민문화예술활동조사 100

〈표 3-24〉 직접 관람자와 비관람자 및 매체를 통한 관람자와 비관람자 구분:

2019 국민문화예술활동조사 $\quad 100$

〈표 3-25〉K-means 군집 분석 투입 변수의 특성: 2019 국민문화예술활동조사 102

〈표 3-26〉 군집분석 결과(1-5개 군집의 변수별 평균과 전체 평균): 2019 국민문화예술활동조사 102

〈표 3-27〉 분류나무를 적용한 예술향유자의 분석 시도: 2019 국민문화예술활동조사 105

〈표 3-28〉6가지 변수를 조합한 예술향유 유형과 해당자 수: 2019 국민문화예술활동조사 107

〈표 3-29〉5가지 형태의 대표적인 문화예술향유자 유형: 2019 국민문화예술활동조사 110

〈표 3-30〉예술향유자 유형별 인구사회학적 특성 비교1(평균 비교): 2019 국민문화예술활동조사 111

〈표 3-31〉 예술향유자 유형별 인구사회학적 특성 비교2(분포 비교): 2019 국민문화예술활동조사 112

〈표 3-32〉 문화예술과 관련하여 향후 지출을 늘리고 싶은 항목: 2019 국민문화예술활동조사 114

〈표 3-33〉 문화예술행사 관람 시, 기준과 어려움: 2019 국민문화예술활동조사 116

〈표 3-34〉 문화예술교육을 받고자할 때 가장 큰 어려움: 2019 국민문화예술활동조사 117

〈표 3-35〉 2020 시민 예술향유 인식 및 예술향유활동 조사 개요 123

〈표 3-36〉 2020 시민 예술향유 인식 및 예술향유활동 조사 영역 124

〈표 3-37〉 2020 시민 예술향유 인식 및 예술향유활동 조사: 응답자 특성 124

〈표 3-38〉 응답자 특성별 예술향유활동 범주 인식: 2020 시민 예술향유 인식 및 예술향유활동 조사 127

〈표 3-39〉 응답자 특성별 예술향유활동 범주 인식: 2020 시민 예술향유 인식 및 예술향유활동 조사 128

〈표 3-40〉 응답자 특성별 환경변화에 따른 예술인식 변화: 2020 시민 예술향유 인식 및 예술향유활동 조사 133

〈표 3-41〉 응답자 특성별 직접 관람 동기: 2020 시민 예술향유 인식 및 예술향유활동 조사 138

〈표 3-42〉 응답자 특성별 직접 관람 외적·물리적 걸림돌:

2020 시민 예술향유 인식 및 예술향유활동 조사 
〈표 3-43〉 응답자 특성별 직접 관람 내적·심리적 걸림돌:

2020 시민 예술향유 인식 및 예술향유활동 조사

〈표 3-44〉2019년 온라인 매체 관람 경험 및 경험 매체: 2020 시민 예술향유 인식 및 예술향유활동 조사 146

〈표 3-45〉 응답자 특성별 온라인 매체 관람 동기: 2020 시민 예술향유 인식 및 예술향유활동 조사 148

〈표 3-46〉 예술참여 활동별 활동 참여 경로: 2020 시민 예술향유 인식 및 예술향유활동 조사 153

〈표 3-47〉 예술참여 활동별 활동 참여 동기: 2020 시민 예술향유 인식 및 예술향유활동 조사 154

〈표 3-48〉 예술참여 활동별 활동 후 인식/효과: 2020 시민 예술향유 인식 및 예술향유활동 조사 154

〈표 3-49〉 예술참여 활동별 활동 참여 외적·물리적 걸림돌:

2020 시민 예술향유 인식 및 예술향유활동 조사

155

〈표 3-50〉예술참여 활동별 활동 참여 내적·심리적 걸림돌:

2020 시민 예술향유 인식 및 예술향유활동 조사

155

〈표 3-51〉 응답자 특성별 예술향유활동 지원 정책 인지도:

2020 시민 예술향유 인식 및 예술향유활동 조사

156

〈표 3-52〉 응답자 특성별 예술향유활동 지원 정책 인지 및 경험률:

2020 시민 예술향유 인식 및 예술향유활동 조사

〈표 3-53〉 시민 예술향유 인식 및 예술향유활동 FGI 개요

〈표 3-54〉 시민 예술향유 인식 및 예술향유활동 FGI: 그룹별 구성 및 선별 기준

〈표 3-55〉시민 예술향유 인식 및 예술향유활동 FGI: 조사영역

〈표 3-56〉 G1 예술향유 무관심자: 2020 시민 예술향유 인식 및 예술향유활동 FGI

〈표 3-57〉 G2·G3 예술향유 직접관람 저·고관여자:

2020 시민 예술향유 인식 및 예술향유활동 FGI

〈표 3-58〉 G4 온라인 매체 주이용자: 2020 시민 예술향유 인식 및 예술향유활동 FGI 165

〈표 3-59〉 G5 예술향유활동 참여 경험자: 2020 시민 예술향유 인식 및 예술향유활동 FGI 165

〈표 3-60〉 FGI 참여자 특성별 예술향유 관심도 및 동기 166

〈표 3-61〉 FGI 참여자 특성별 예술향유 연상 이미지 167

〈표 3-62〉 FGI 참여자 특성별 예술의 가치(개인/사회적) 인식 168

〈표 3-63〉 FGI 참여자 특성별 예술향유 효능감 169

〈표 3-64〉 FGI 참여자 특성별 예술향유활동 동기 및 효과 170

〈표 3-65〉 FGI 참여자 특성별 예술향유활동 걸림돌 171

〈표 3-66〉 FGI 참여자 특성별 기술변화 및 예술향유 영향 인식 172

〈표 3-67〉 FGI 참여자 특성별 예술의 범주에 대한 인식 173

〈표 3-68〉 FGI 참여자 특성별 예술향유 확대를 위한 정책수요 174

〈표 3-69〉 예술향유 경험자별 외적·물리적 걸림돌: 2020 시민 예술향유 인식 및 예술향유활동 조사 177

〈표 3-70〉예술향유 경험자별 내적·심리적 걸림돌: 2020 시민 예술향유 인식 및 예술향유활동 조사 177

〈표 3-71〉 예술향유 경험자별 예술향유의 경험동기: 2020 시민 예술향유 인식 및 예술향유활동 조사 184 
〈표 3-72〉 시민 예술향유 인식 및 예술향유활동 조사(설문조사 및 FGI)의 종합시사점 189

〈표 4-1〉1973년「제1차 문예중흥 5개년 계획」 195

〈표 4-2〉1983년「제5차 경제·사회발전 5개년 수정계획」 중 문화부문계획 196

〈표 4-3〉1990년「문화발전 10개년 계획」 198

〈표 4-4〉1993년「문화창달 5개년 계획」 199

〈표 4-5〉1998년「국민의 정부 새문화정책」 201

〈표 4-6〉2004년「참여정부 새 예술정책 기본방향 및 14대 역점추진과제 203

〈표 4-7〉「이명박 정부 예술정책 3대 기본방향 및 9개 역점추진과제」 205

〈표 4-8〉 문재인 정부「새 예술정책(2018-2022)」 208

〈표 4-9〉 문재인정부「새 예술정책 수립 기본방향」 210

〈표 4-10〉 정부 시기별 예술향유정책 지원 목표, 대상 및 주요 정책수단 211

〈표 4-11〉예술향유정책의 특성 및 시사점 219

〈표 4-12〉 2020년 문화체육관광부 예산 및 부문별 편성 내역 220

〈표 4-13〉2020년 문화예술부문 중점 편성 내용 221

〈표 4-14〉 문화체육관광부 재정 구조(2020) 221

〈표 4-15〉예술향유 지원 예산 규모(2020) 222

〈표 4-16〉2020년 문체부 예술정책관 일반회계 예산 내역 223

〈표 4-17〉 2020년 문체부 지역문화정책관 일반회계 예산 내역 224

〈표 4-18〉2020년 문체부 지역문화정책관 일반회계 예산 세부내역 중 향유사업 225

〈표 4-19〉2020년 문화예술진흥기금 예산 226

〈표 4-20〉2020년 문체부 문화예술진흥기금 예산 내역 227

〈표 4-21〉2020년 문화예술진흥기금 예산 세부내역 중 향유사업 228

〈표 4-22〉 복권기금 문화예술진흥기금 전출 내역(2014 2020) 229

〈표 4-23〉 문화예술진흥기금 내 예술향유 지원사업 변동내역(2010 2020) 230

〈표 4-24〉 문화예술진흥기금 사업비상 문예진흥기금 및 복권기금 비중 변화(2004 2020) 231

〈표 4-25〉 2020년도 국민체육진흥기금 예산 232

〈표 4-26〉 2020년 국민체육진흥기금 예산 내역 232

〈표 4-27〉 2020년 체육기금 ‘체육·문화예술사업의 지원’(5161-307) 중 문화예술취약분야육성 사업내역 233

〈표 5-1〉 '시각예술 진흥기반구축' 중 예술향유 지원사업(2020) 240

〈표 5-2〉 학교예술강사지원 교급별 운영 현황(2019) 241

〈표 5-3〉 학교예술강사지원 운영 실적(2019) 241

〈표 5-4〉 학교예술강사지원 운영 실적(2016 2020) 242

〈표 5-5〉예술꽃 씨앗학교 추진실적(2016 2019) 242

〈표 5-6〉 예술꽃 씨앗학교 지역별, 분야별 운영 현황(2019) 243 
〈표 5-7〉 사회문화예술교육 지원 예산 구성(2020)

〈표 5-8〉사회문화예술교육 지원사업 대상별 수혜자수(2019)

〈표 5-9〉 꿈다락 토요문화학교 운영 현황(한국문화예술교육진흥원 운영사업 기준, 2012 2019) 247

〈표 5-10〉 꿈다락 토요문화학교 추진실적(한국문화예술교육진흥원 운영사업, 2019) 248

〈표 5-11〉 소외 아동청소년 오케스트라 교육 운영 현황(2010 2020) 249

〈표 5-12〉 문화예술치유 프로그램 지원 사업 대상 및 추진실적(2019) 250

〈표 5-13〉'생애전환 문화예술학교 운영'사업 추진실적(2019) 251

〈표 5-14〉예술동아리 교육 지원 사업 운영 현황(2019) 252

〈표 5-15〉 지역문화예술교육 기반구축 사업 구성-경기문화예술교육지원센터(2020) 254

〈표 5-16〉 문화예술교육사 인턴십 지원 지역별 운영안(2020) 256

〈표 5-17〉 '문화예술교육 지원' 중 예술향유 지원사업(2020) 257

〈표 5-18〉 국·공립 문화시설 개관시간 연장 사업 성과지표(2016 2020) 259

〈표 5-19〉국·공립 문화시설 개관시간 연장 사업 성과지표(2016 2020) 260

〈표 5-20〉 '박물관 정책 활성화' 중 예술향유 지원사업(2020) 261

〈표 5-21〉어르신 문화프로그램 운영 사업 구성(2020) 263

〈표 5-22〉 문화가 있는 날 혜택 265

〈표 5-23〉 문화가 있는 날 사업 성과지표(2016 2020) 265

〈표 5-24〉 문화가 있는 날 기획프로그램 운영지원사업 현황(2019 2020) 266

〈표 5-25〉 문화가 있는 날 ‘참여문화시설 지원’ 프로그램 운영 실적(2019. 11) 267

〈표 5-26〉 문화가 있는 날 기획프로그램-지역문화진흥원 주관 사업 내용 268

〈표 5-27〉 문화가 있는 날 기획프로그램 운영: 지역문화진흥원 운영 결과(2019) 269

〈표 5-28〉 생활문화동호회 지원 사업 연도별 실적(2018 2014) 271

〈표 5-29〉여가친화기업 선정 현황(2012 2019) 272

〈표 5-30〉 '지역문화 진흥' 중 예술향유 지원사업(2020) 273

〈표 5-31〉 통합문화이용권 사업 주요 경과 275

〈표 5-32〉 통합문화이용권 분야별 이용금액 비율(2014 2019) 276

〈표 5-33〉 통합문화이용권 성과지표 및 연도별 변화추이(2016 2020) 276

〈표 5-34〉 통합문화이용권 이용자 만족도 조사 결과(2018 2019) 277

〈표 5-35〉 신나는 예술여행의 사업유형과 분야(2020) 278

〈표 5-36〉 신나는 예술여행 사업 성과지표(2016 2020) 279

〈표 5-37〉 방방곡곡 문화공감 사업 유형 279

〈표 5-38〉 방방곡곡 문화공감 지역별 수혜자수(소외계층포함, 2019) 280

〈표 5-39〉'예술향유기회확대' 중 예술향유 지원사업(2002) 281

〈표 5-40〉 작가와 함께하는 작은 서점 지원사업 내용(2020) 283

〈표 5-41〉 생활문화공동체 지원사업 구성 286 
〈표 5-42〉 생활문화공동체 지원사업 고려사항 287

〈표 5-43〉 '생활체육 활성화' 중 예술향유 지원사업(2020) 287

〈표 5-44〉예술향유 지원사업 유형 분류(2020) 290

〈표 5-45〉예술향유 지원사업 보편적 복지형 사업(2020) 292

〈표 5-46〉예술향유 지원사업 선별적 복지형 사업(2020) 294

〈표 5-47〉예술향유 지원사업 교육 지원형 사업(2020) 296

〈표 5-48〉 예술향유 지원사업 활동 지원형 사업(2020) 299

〈표 5-49〉예술향유 지원사업 분석 시사점(종합) 310

〈표 6-1〉예술향유 양태유형 분류 - 수정(안) 318

〈표 6-2〉 문화향유와 예술향유 개념 정의(안) 320

〈표 6-3〉 예술향유권(예시) 322

〈표 6-4〉「문화예술진흥법 개정을 위한 정비-정의(안) 예시 326

〈표 6-5〉「문화예술진흥법」개정을 위한 정비(안) 326

〈표 6-6〉서울시 빅데이터 분석 결과 '나홀로 전시관람' 342 


\section{그림 목차}

[그림 1-1] 연구 체계 및 흐름도

[그림 2-1] 향유 형태의 설명틀(McCarthy \& Jinnett 2001) 31

[그림 2-2] 5가지 예술향유 프레임워크(Brown 2004) 32

[그림 2-3] 예술향유의 가치체계(Brown 2004) 33

[그림 2-4] 관객유형 분류(습관, 선택, 우연)(Kawashima 2000) 34

[그림 2-5] 관객 인게이지먼트를 위한 방법론적 프레임워크 35

[그림 2-6] 예술의 온라인 향유를 위한 편익 분류틀 36

[그림 2-7] 예술향유 양태를 결정하는 기준요소 37

[그림 2-8] 예술향유의 단계별 유형 39

[그림 2-9] 창의적 제어권 부여에 따른 예술향유의 유형 39

[그림 2-10] 인게이지먼트 포물선 40

[그림 2-11] 인게이지먼트의 4가지 차원(Brown \& Ratzkin 2011) 42

[그림 2-12] 콘텐츠 향유의 구조 50

[그림 2-13] 문화환경 만족도와 문화향수 수준에 따른 유형 54

[그림 2-14] 영국 ACE(2020-2030) Let's Create 60

[그림 2-15] 아일랜드예술위원회(2016 2025) 비전 61

[그림 2-16] 예술향유 발현 맥락 (1): 개념도(안) 75

[그림 2-17] 예술향유 발현 맥락 (2): 개념도(안) 76

[그림 3-1] 예술향유(자) 유형화를 위한 분류나무 적용의 예시: 2019 국민문화예술활동조사 104

[그림 3-2] 예술향유활동 범주 인식: 2020 시민 예술향유 인식 및 예술향유활동 조사 126

[그림 3-3] 예술의 가치에 대한 인식: 2020 시민 예술향유 인식 및 예술향유활동 조사 131

[그림 3-4] 예술에 대한 개인 관심도: 2020 시민 예술향유 인식 및 예술향유활동 조사 131

[그림 3-5] 예술에 대한 개인 차원의 효능감: 2020 시민 예술향유 인식 및 예술향유활동 조사 132

[그림 3-6] 환경변화에 따른 예술인식 변화: 2020 시민 예술향유 인식 및 예술향유활동 조사 133

[그림 3-7] 2019년 직접 관람 경험 및 관람 빈도: 2020 시민 예술향유 인식 및 예술향유활동 조사 135

[그림 3-8] 2019년 직접 관람 장르: 2020 시민 예술향유 인식 및 예술향유활동 조사 136

[그림 3-9] 직접 관람 동기: 2020 시민 예술향유 인식 및 예술향유활동 조사 137

[그림 3-10] 직접 관람 결정 방법: 2020 시민 예술향유 인식 및 예술향유활동 조사 139

[그림 3-11] 직접 관람 후 인식/효과: 2020 시민 예술향유 인식 및 예술향유활동 조사 140 
[그림 3-12] 직접 관람 외적·물리적 걸림돌: 2020 시민 예술향유 인식 및 예술향유활동 조사 141

[그림 3-13] 직접 관람 내적·심리적 걸림돌: 2020 시민 예술향유 인식 및 예술향유활동 조사 143

[그림 3-14] 2019년 온라인 매체 관람 경험 및 경험 매체: 2020 시민 예술향유 인식 및 예술향유활동 조사 145

[그림 3-15] 온라인 매체 관람 동기: 2020 시민 예술향유 인식 및 예술향유활동 조사 148

[그림 3-16] 온라인 매체 관람 후 인식/효과: 2020 시민 예술향유 인식 및 예술향유활동 조사 150

[그림 3-17] 온라인 매체 관람 외적·물리적 걸림돌: 2020 시민 예술향유 인식 및 예술향유활동 조사 151

[그림 3-18] 온라인 매체 관람 내적·심리적 걸림돌: 2020 시민 예술향유 인식 및 예술향유활동 조사 151

[그림 3-19] 온라인 매체 관람의 장점 인식: 2020 시민 예술향유 인식 및 예술향유활동 조사 152

[그림 3-20] 예술 참여활동 경험률: 2020 시민 예술향유 인식 및 예술향유활동 조사 153

[그림 3-21] 예술향유활동 지원 정책 인지도: 2020 시민 예술향유 인식 및 예술향유활동 조사 156

[그림 3-22] 예술향유활동 지원 정책 인지 및 경험률: 2020 시민 예술향유 인식 및 예술향유활동 조사 158

[그림 3-23] 예술향유활동 정책 지원 충분성 인식: 2020 시민 예술향유 인식 및 예술향유활동 조사 161

[그림 3-24] 필요 예술향유활동 정부 지원: 2020 시민 예술향유 인식 및 예술향유활동 조사 162

[그림 4-1] 박근혜 정부 국정비전과 문화융성 207

[그림 4-2] 문화예술진흥기금 사업비 내 문예진흥기금 및 복권기금 연도별 변동 내역(2004 2020) 231

[그림 5-1] 어르신문화프로그램 운영 및 행복온도 조사 결과(2019) 264

[그림 5-2] 생활문화동호회 지원사업의 목적과 지원방식 270

[그림 5-3] 여가친화기업 인증 신청용 근로자 대상의 수요조사 항목(2019) 272

[그림 5-4] 도서관 상주작가 지원사업 참여 도서관(2019) 284

[그림 6-1] 예술 ‘향유활동'의 다원적 입체성 316

[그림 6-2] 예술 '향유활동'의 다원적 영역(안) 317

[그림 6-3] '예술향유' 개념 정립을 위한 기본원칙 및 예술향유 개념 정의(안) 321 
예술향유정책 분석 및 방향 연구

\section{제1장}

서론 



\section{제1절 연구 배경 및 목적}

\section{1. 연구 배경}

\section{가. 연구 배경}

\section{口 예술향유지원의 양적 성장 및 외연적 확대}

국내 예술향유 관련 정책논의의 태동은 1980 90년대 경제사회발전, 문화부문 계획 등에서 '국민 문화향수 확대' 표현에서 살펴볼 수 있다. 1996년 문민정부(김영 삼정부) 시기 한시적으로 문화복지기획단이 구성되고 '문화복지 기본계획’이 수립 되는 과정에서 문화향수권 논의가 '문화복지' 개념과 연계되어 발전되기 시작하였 다(정광렬 외 2015: 16).1) 그러나 예술향유 관련 본격적인 지원은 2000년대 이후 참여정부 시기 ‘문화민주주의' 정책기조 확산을 배경으로 이루어졌다. 특히 '수요자 중심성' 및 '문화복지'가 주요 정책개념으로 급부상하기 시작하면서 전략보다는 취 약계층 중심의 사업단위 차원에서 발전하기 시작했다고 하겠다.

현재 문화체육관광부(이하 문체부로 줄여 쓰기도 함)가 주관하는 향유사업의 예 산규모는 총 3,409억 원 규모에 달한다.2) 이들 중 2006년 문화바우처로 시작된 통합문화이용권 지원은 현재 1,033 억으로 향유지원 단위사업으로는 가장 규모가 큰 사업으로 성장하였다. 더불어 예술향유의 핵심토대로 강조되는 문화예술교육은 현재 1,300 억 규모로 2006년 대비 총예산이 8.4배 확대되기도 하였다.

이렇듯 향유지원 예산이 급속도로 확대된 배경으로는 2000년대 초중반을 기점으 로 예술지원에서의 복권기금이 유입되고, '문화민주주의' 가 예술지원의 정책기조로 급부상한 것이 예술향유사업 정책지원의 양적 확대를 추동한 핵심동력으로 지목되

1) 당시 문화복지 기본계획은 이후 곧바로 외환위기가 닥치게 되면서 정부계획으로 채택·발표되지 못하고, 개 념과 단편적 사업으로만 남게 되었다(정광렬 외 2015: 16).

2) 제4장 1절의 2. 예술향유지원 예산구성 참조. 
기도 한다(정광렬 외 2015: 16; 허은영 외 2018: 18). 그러나 이러한 예술향유 지 원사업의 양적 성장에도 불구하고, 현재 예술향유정책의 문제점은 다음의 세 가지 로 보인다.

\section{口 향유정책의 가치정향 모호성 및 목적의 불명확성}

첫째, 예술정책 논의에서 ‘향유’ 지원의 궁극적 가치정향 및 정책목적이 모호하고 불명확하다는 점이다. 예술생태계 내에서의 창작, 유통-매개, 향유가 순환적 고리로 연계되고, 이들 영역에 대한 지원을 통해 전체적인 '예술진흥'을 추구함으로써 예술 을 통한 국민의 삶의 질 제고에 기여하는 것은 예술정책의 본연의 목적이라 할 수 있다(정광렬 외 2010: 23). 이런 관점에서 보면 향유지원은 예술정책을 구성하는 주요한 핵심영역일 수밖에 없다. 현재 대부분의 향유지원 사업에서 제시되는 목적 은 ‘향유권 확대' 혹은 ‘향유기회 제공'을 통한 '향유권 시장' 등으로 표현되고는 있 다. 그러나 구체적으로 이러한 '향유권 확대’ 혹은 신장이 '예술을 통한 국민의 삶의 질 제고'라는 측면에서 구체적으로 어떠한 의미와 맥락을 가지는 것인지, 이와 관련 된 심도 깊은 논의는 상대적으로 많지 않다.3)

\section{— 담론상 '보편적' 문화복지 강조, 정책실제는 선택적, 시혜적 접근}

둘째, 가치정향의 불명확성은 향유정책의 두 번째 문제점과 긴밀히 연동되는 데, 이는 곧 ‘향유'지원이 마치 예술지원의 부가적인 영역 혹은 '시혜적인' 정책인 것으 로 오인되고 있다는 점이다.4)

이는 향유지원이 '문화복지' 개념과 중첩되어 발전되어온 정책 전개과정 상의 독 특한 맥락에서 그 연원을 찾을 수 있다(정광렬 외 2015). 최근 '문화복지' 관련 정책 논의는 초기의 '소외계층' 중심성을 벗어나 '보편적 복지' 지향의 필요성을 강조하 는 방향으로 선회하고 있는 추세다. 그러나 여전히 향유지원사업은 주로 소외계층

3) 정광렬 외(2010: 24)는 그간 예술정책이 정책 기조상 공급자 중심에서 수요자 중심을 강조하는 가운데 ‘문화향유권' 신장을 최우선 목표로 설정하고 있었음에도 불구하고, 사실상 이에 대한 기본적 관점이 불명 확함을 지적한다.

4) 예술계가 제기하는 창작 vs. 향유 간 불균형 문제는, 다른 한편으로 예술지원의 핵심 혹은 궁극적 정체성이 '창작'에 집중되어야 한다는 인식의 반영이라고 해석할 수 있으며, 이러한 관점에만 천착할 경우 향유논의 의 입지와 위상이 좁아지는 위험이 상존한다. 
등 특정 계층을 대상으로 한 물리적 '격차해소' 관점에 정책의 주된 방점을 두고 구 조화된 채 양적 확대가 이뤄져 왔음을 부인하기 어렵다.

그러나 전체 예술향유 관련 논의를 시혜적 관점의 ‘복지’ 개념에만 천착하여 접근 할 경우, 예술향유지원의 궁극적 가치지향에 관한 논의가 특정계층, 집단을 위한 물 리적 '격차 해소'에만 소극적으로 한정되는 제약이 발생할 수밖에 없다. 일부 바우 처, 방문형 사업에서 강조되는 물리적 차원의 '격차해소'가 그 자체만으로 '향유진 작'의 효과성 및 파급력을 이끌어 내기 어렵다는 실증적 사실 역시도 이를 보여 준다.

더욱이 예술향유활동에 참여하는 이들은 외적·물리적 제약요소(경제적·지리적· 사회적·신체적) 외에도 다양한 내적·심리적 요소(정서적·문화적)에 제약을 받고 있 다(이호영·서우석 2010; 서우석·양효석 2013; 허은영 외 2018). 물론 그 내부 사 회구성원 그룹별 특성에 따른 차이는 있을 수 있지만, 이들을 포괄한 보편적 관점에 서 외적·물리적 요소 외에 내적-심리적 요소를 함께 파악하고 해소하는 방식의 접 근은 아직까지 미진한 상황이다.

\section{口 예술향유 환경변화 및 예술향유수요 다원화에 대한 정책대응 부족}

현재 향유정책의 세 번째 문제점은 예술계를 둘러싼 다양한 환경변화 및 예술향 유수요 중층성 및 복합성을 충분히 대응하지 못하고 있다는 점이다. 특정계층을 대 상으로 '격차해소'라는 명분하에 주요하게 확대되어 온 예술향유 정책지원은 주로 특정대상 중심의 획일화된 사업구조 속에서 주로 '관람형' 향유진작이라는 측면에 만 집중하고 있기 때문이다.5) 그동안 예술계 및 사회적 환경은 기술혁신 변화로 예 술창작과 향유 두 측면 모두에 큰 영향을 미치고 있다. 실제로 예술향유양태는 특정 장소, 특정장르 중심의 수동적 관람을 넘어서서 활동의 층위가 상당히 다층화, 입체 화되고 있음이 지적되고 있다(지역문화진흥원 2019). 더불어 주52시간제 도입 등 삶의 질 향상의 지표로 일과 여가의 균형 등이 강조되어 오는 가운데, 일반시민들의 예술향유 양태는 다원화되고, 중층적으로 변화하고 있는 상황이다(김혜인·김연진 외 2018). 이로 인해 삶의 경로에 따라 활동형 여가 및 취미생활과 예술향유가 맞물

5) 현재 예술향유 지원사업 유형 중 방문형(12.0\%), 바우처형(30.7\%), 기반조성형(14.3\%)은 모두 특정장소 와 장르의 "관람" 중심의 향유진작을 전제로 추진되는 사업이다. 
리는 복합적 수요의 확대가 두드러지는 경향이 확산되고 있다(김현경 외 2019; 박 근화 2019).6)

이러한 환경적 변화는 곧 향후 예술향유에 대한 수요가 더욱 다원화되고 복합화 될 전망임을 암시한다. 따라서 이를 고려하되, 현재 향유지원사업의 정책적 접근 방 식의 한계를 검토하고 미래지향적 관점에서 향유정책의 방법론적 전환 모색이 필요 한 시점이라 하겠다.

\section{나. 선행연구 검토}

\section{1) 기존 예술향유 관련 선행연구의 경향성}

‘예술향유’라는 정책개념은 예술정책을 구성하는 핵심요소라 할 수 있다. 그러나 기존 선행 정책연구에서 “예술향유" 자체를 연구대상으로 한 연구는 상대적으로 미 흡했던 것이 특징적이다. 대부분 제도나 단위사업 중심으로 이들은 다시 성과평가 혹은 사업평가 형태로 진행되어 왔거나, 특정 장르 혹은 사업 중심 관점에서의 향유 진작 방안 등에 천착한 연구가 주로 진행되어 왔기 때문이다(양혜원 외 2015; 염신 규 외 2018; 윤혜란 외 2016; 장현선 외 2019; 정광렬 외 2015; 김세훈 2018; 지역문화진흥원 2018; 지역문화진흥원 2019; 최인호 외 2018).

이런 가운데「예술향유정책 현황 및 개발방안」(허은영 외 2018) 연구는 "예술향 유”라는 정책 화두를 본격적으로 다룬 연구라는 차원에서 주목된다. 해당 연구는 예 술지원에 있어 향유정책이 창작지원에 비해 상대적으로 확대되어 온 것에 대한 문 제의식에서 출발하고 있는 것이 특징적이다. 2000년대 이후 문화민주주의가 정책 기조로 강조되고 ‘수요자 중심 정책패러다임’이 강화되는 과정에서 향유정책의 확 대가 이뤄져왔다는 점을 지목하고, 그 과정에서 발생한 창작과 향유지원 간 불균형 등의 문제점을 지적한다. 또한 그간 추진된 일련의 향유사업들이 자발적 수요개발 과 시장수요확대 등에 기여하지 못했음을 지적한다. 이 연구의 경우 예산 관점에서 접근한 향유사업 분석, 그리고 예술향유에 있어 외적 요소 외에도 내적 요소 등 복

6) 박근화(2019), “관람에서 활동으로! - 빅데이터로 살펴본 문화예술향유 패턴,”「예술경영」, 421호. http://www.gokams.or.kr/webzine/wNew/column/column_view.asp?idx=2196\&page=2\&c_ $\mathrm{idx}=85 \&$ searchString=\&c_idx_2= (최종접근: 2020.02.24) 
합적 요인이 함께 작동하고 있음을 지적한 것이 특히 주목할 만하나, 몇 가지 아쉬 운 지점이 있다. 가령, 향유의 핵심토대로 지목되는 '문화예술교육'이 연구분석 대 상에 포함되지 않았고 예술향유를 둘러싼 환경변화 및 실제 향유당사자인 일반시민 들의 인식이나 수요변화 관련 분석은 다뤼지지 못했다.

\section{2) 창작 vs.향유 불균형, 향유정책 효과성 관련 논의}

일부 선행연구에서 다뤄지는 '예술향유' 정책에 제기되는 문제점을 크게 유형별 로 나눠 보면 두 가지로 압축된다(윤혜란 외 2016; 허은영 외 2018; 이규석 2017; 염신규 외 2018). 하나는 창작과 향유지원 간 불균형에 관한 지점, 다른 하나는 향 유사업이 수요창출이나 예술시장 확대에 기여하지 못했다는 정책효과성 관련 문제 제기다.

창작 vs 향유지원 불균형의 경우, 가령 예술정책지원의 핵심재원이라 할 수 있는 문화예술진흥기금(이하 문예진흥기금으로 줄여 쓰기도 함)을 보면 2020년 기준 총 사업비예산 2,678 억 중 향유사업은 $53.5 \%(1,433$ 억)를 차지하는 것으로 나타난 다.7) 이는 창작 대비 향유지원이 예산 배분상 우세하다는 현장의 비판을 받는 근거 가 되기도 한다. 더불어 최근 '생활문화활성화' 지원이 확대됨에 따라 '창작지원'이 소외되고, 향유지원이 비대해지는 것에 대한 우려 역시 제기되고 있다(윤혜란 외 2016: 134; 이규석 2017: 258); 허은영 외 2018: 35).

또한 향유사업이 자발적인 수요창출이나 예술시장 확대 등에 기여하지 못한다는 '효과성' 관련 비판 역시 주요하게 제기되는 지점이다(허은영 외 2018: 192). 일례 로 현재 한국문화예술위원회(이하 예술위로 줄여 쓰기도 함)가 주관하는 향유사업 중 가장 큰 비중을 차지하는 ‘통합문화이용권' 경우, 도서, 영화 외에 예술분야에서 의 정책효과가 상당히 저조하게 나타나고 있는 점이 대표적으로 거론되는 근거 이다.9)

7) 2010 년 문화예술진흥기금의 향유지원사업 비중 $47.8 \%$ 에 비해 지속적으로 확대되어 왔다.

8) 이규석(2017), "문화예술 지원구조의 혁신을 위한 정책과제들," ‘새 정부 문화정책, 문화사회를 위한 정책 과제들 토론회 자료집 $($ 장정숙의원실 및 문화연대 문화정책센터 주최)

9) 2017 년 기준 분야별 카드사용 비중에서 도서 $37 \%$, 영화 $35.9 \%$ 인 반면, 공연은 $1.7 \%$, 전시는 $0.02 \%$ 로 나타났다(허은영 외 2018: 60 재인용). 


\section{3) 외연적 현상의 중층적 함의에 대한 복합적 이해 필요성}

하지만 '창작 vs. 향유 불균형' 비판과 관련된 논의는 보다 신중한 관점에서 논의 될 필요가 있는 것으로 보여진다. 현재 불균형 주장의 근거는 대부분 예술위 문예진 흥기금 사업구조상의 예산 분포 등을 기준으로 제기되는 측면이 강하다(허은영 외 2018: 3510); 이규석 2017: 25).

그 배경에는 최근 통합이용권 사업 예산 확대가 주된 요인이었는데(통합이용권의 확대 등이 국정과제로 지목되는 등), 해당 사업의 경우 현재 예술뿐 아니라 여행 등 관광 및 스포츠 영역까지 아우르는 바, '예술향유' 신장을 위한 정책만으로 보기는 어렵다는 점도 감안할 필요가 있다. 즉, 현재 문예진흥기금 사업에서 향유사업 예산 분포의 확대는 사실상 '통합이용권' 사업의 예산 확대로 인한 것이며, 해당 사업은 예술만이 아닌 문화, 관광, 체육 전반에서의 격차해소를 목표로 한 사업이다. 따라 서 이러한 사업이 예술진흥에 초점을 둔 '문예진흥기금' 사업에 포함되어 진행되는 것에 대한 '타당성' 논의가 선결되지 않은 채, 예산 확대만을 근거로 '창작지원'과의 불균형이라고만 지적하는 것은 검토의 여지가 있다.

흥미로운 지점은 창작과 향유지원의 불균형 논의의 대부분이 '예산상의 불균형' 을 현상적 문제이자 근거로 제시하고, 향유비중이 높음을 지적하지만, 궁극적 차원 에서 창작지원과 향유지원의 이상적 균형이 무엇인지를 구체적으로 제시하고 있지 는 않다는 점이다. 이러한 주장을 뒤집어 보면, 사실상 예술지원의 근본적 목적이 향유정책 보다는 예술창작지원에 초점이 맞춰져야 한다는 정책적 인식의 반영으로 해석이 가능하다.

그러나 여기서 더 근본적인 검토가 필요한 지점은 '단순히 예산의 비중만을 가지 고 창작과 향유 지원의 균형을 논의할 수 있는가' 하는 문제다. 비중의 문제로만 접 근할 경우 단순히 숫자와 수치상에 천착하게 될 가능성이 클 뿐 아니라, 보다 근본적 인 창작과 향유의 선 순환적 연계 논의는 주변화될 수 있는 가능성이 크기 때문이다.

‘향유정책 효과성’ 문제의 경우 사실상 대부분의 향유지원사업이 소외계층을 대

10) 허은영 외(2018) 연구에서는 문예진흥기금 사업비 외에 예술정책관 및 지역문화정책관 예산 분석도 포함 하여 논의하였다. 2018년 기준 예술정책관 전체 예산 중 $42.4 \%$ 가 향유지원인 문화예술교육에 할애되고, 지역문화정책관 예산 중 $16.6 \%$ 가 '문화가 있는 날' 및 '생활문화활성화'에 배정된다. 따라서 향유예산 총 사업비(예술정책관 및 지역문화정책관 일반회계, 문예진흥기금 사업비 등 3개 영역 합계) 대비 $41.2 \%$ 가 향유예산으로 ‘해외에서 찾아보기 어려운 이례적인’ 비중`이라고 지적했다. 
상으로 하고 있음을 고려하여 이해할 필요가 있다. 사실상 취약계층을 타겟으로 한 정책사업의 경우 해당 사업만을 가지고 비자발적 참여자를 자발적 참여자로 전환하 는 것은 구조적으로 어려울 수밖에 없음을 고려해야 하기 때문이다. '예술수요확대' 효과성 저조라는 비판보다는 오히려 효과적인 관객개발이나 수요확대를 겨냥한 복 합적인 정책관점과 사업설계가 미진했던 점에 대한 검토가 선결될 필요가 있다. 이 는 곧 현재 향유정책에 대한 근본적인 문제제기는 그간의 향유사업 접근 방식과 관 점 자체가 ‘취약계층 중심', ‘복지, 시혜적’ 정책접근에 천착했던 지점에서 방점을 두고 접근해야함을 의미한다고 할 수 있다.

선행연구 검토를 통한 시사점을 종합하자면, 이들 연구에서 지적하는 창작 vs 향 유 불균형, 효과성 문제와 관련된 비판적 논의들은 이러한 외연적 현상을 둘러싼 정 책접근, 구조, 재원 등을 고려한 포괄적 관점에서 이해되어야 하는 사안이라 하겠다.

\section{2. 연구 목적 및 기대효과}

\section{가. 연구 목적}

\section{■ 예술향유정책 가치정향 및 목적 명확화를 통한 정책방향 제시}

본 연구의 목적은 현재 예술향유정책에 내재된 문제점 분석을 통해 향후 예술향 유정책이 지향해야 할 궁극적 가치와 목적을 제시하고, 이를 실현하기 위한 정책방 향을 제언하는 데 있다.

전술한 바와 같이 예술정책 논의 내에서 '향유지원의 가치정향 모호성', '시혜적' 정책으로 오인되는 문제, '급변하는 시대변화에 정책적 대응 부족' 등의 문제를 종 합적으로 점검하기 위해서는 예술향유정책 전반을 포괄적 관점에서 살펴볼 필요가 있다. 연구에서는 중앙주도의 향유지원 정책을 주요 분석대상으로 삼되, 향유지원 의 목적 및 가치정향에 대한 이론적 검토를 비롯, 일반시민의 입장에서 '예술향유' 가 가진 다원적 양태와 수요의 복합성 및 중층성 등에 관한 심도 깊은 분석을 다룬 다. 이를 통해 예술을 통한 국민의 삶의 질 제고에 기여할 수 있는 예술향유정책의 방향성을 탐색·제시한다. 


\section{나. 기대효과}

연구는 시대적 환경변화를 반영한 예술정책 논의 내에서 예술향유정책의 문제와 지향점에 관한 포괄적이고 입체적 분석을 다루고, 이를 위한 정책방향을 제시한다 는 측면에서 기존 연구와 차별성을 갖는다. 그간 예술향유 관련 정책연구가 단위사 업 혹은 특정제도 중심으로 이뤄져 오는 과정에서 예술정책의 전체 방향성 속에서 의 ‘향유' 지원 관련 논의가 포괄적, 유기적으로 다뤄지지 못했었기 때문이다. 연구 가 제시하는 예술향유 정책 분석 및 방향에 관한 제언은 향후 예술향유정책의 방향 성 설정 및 정책사업 발굴과 입안을 위한 기초자료로 활용될 수 있을 것이며, 현 정책의 문제 및 개선방향 탐색에 실질적으로 기여할 수 있을 것이다. 


\section{제2절 연구 범위 및 방법}

\section{1. 연구 범위}

\section{가. 개념적 범위11)}

\section{口 '향유' 개념의 정의}

본 연구에서의 사용하는 '예술향유' 용어에 있어 '향유(享有)'는 예술분야와 관련 된 적극적 의미의 향유자 활동을 의미한다. 일반적인 의미에서의 관람을 비롯, 교육 및 다양한 참여적 형태의 활동을 포괄하되, 예술을 누리고 즐기는데 있어 개인의 적극적·소유적 의미 및 '권리’를 내포한 개념으로 상정한다.

기존 정책논의에서는 ‘향수’와 ‘향유'가 명확한 구분 없이 복합적으로 쓰여왔으 나, '향수’와 '향유'는 사전적 정의상 미세하지만 중요한 차이점이 존재한다. 표준국 어대사전 정의를 준용하면 먼저 '향수(享受)'는 '어떤 혜택을 받아 누림, '예술적인 아름다움이나 감동 따위를 음미하고 즐김' 으로 제시된다.12)

반면, '향유(享有)'는 '누리어 가짐' 으로, 유사어는 정책적으로 흔히 혼용하여 쓰 는 '향수(享受)'가 아닌 '소수(消受)'다. '누리다’라는 의미는 '생활 속에서 마음껏 즐 기거나, 맛보다'라는 의미로 이해될 수 있으며, 함께 제시된 '가지다'는 소유의 개념 이 내재되어 있다. '자유를 향유할 권리' 등의 예문을 통해 ‘향유'에는 '적극적 주체 로서의 개인의 권리'라는 의미가 함축되어 있음이 확인된다.

11) 추후 연구진행 과정에 따라 필요시 조작적 정의는 일부 수정될 수 있다

12) 제시된 예문을 보면 '복지혜택을 향수하다', '미술작품을 향수하다'처럼 복지 혹은 예술과 연관하여 사용되 고 있는데, 우리에게 익숙한 '문화향수실태조사(현재 국민문화예술활동조사)'처럼 정책영역에서 사용했던 예를 반영한 것으로 이해할 수 있다. 
〈표 1-1〉 용어정의: 향수 vs. 향유

\begin{tabular}{|c|c|c|c|}
\hline 구분 & 의미 & 공통점 & 차이점 \\
\hline \multirow{2}{*}{$\begin{array}{l}\text { 향수 } \\
\text { (享受) }\end{array}$} & $\begin{array}{l}\text { (1) 어떤 혜택을 받아 누림 } \\
\text { (2) 예술적인 아름다움이나 감동 따위를 음미하고 즐김 }\end{array}$ & \multirow{4}{*}{$\begin{array}{l}\text { 누리다 } \\
\text { 즐기다 }\end{array}$} & \multirow{2}{*}{$\begin{array}{l}\text { ‘수동적' } \\
\text { 의미 내재 }\end{array}$} \\
\hline & $\begin{array}{l}\text { (예문) } \\
\text { • 복지혜택을 향수하다, 미술작품을 향수하다 }\end{array}$ & & \\
\hline \multirow[b]{2}{*}{$\begin{array}{l}\text { 향유 } \\
\text { (享有) }\end{array}$} & ‘누리어 가짐' (누리다, 가지다) $\fallingdotseq$ 소수(消受)하다 & & \multirow[b]{2}{*}{$\begin{array}{l}\text { ‘적극적·소유적 } \\
\text { 의미 내재 }\end{array}$} \\
\hline & $\begin{array}{l}\text { (예문) } \\
\text { - 자유를 향유할 권리, 문화생활을 향유하다, } \\
\text { - 대중들이 예술을 향유할 수 있는 기회를 많이 제공해야 } \\
\text { 한다. }\end{array}$ & & \\
\hline
\end{tabular}

자료: 국립국어원 표준국어대사전(https://stdict.korean.go.kr/main/main.do)

그러나 그간 정책영역에서 '향수(享受)'와 '향유(享有)'를 사전적 의미에 따라 명 확히 구분하고 사용하지는 않았던 것으로 보인다. '문화향수실태조사'에서의 '향수' 는 사실상 ‘향유' 의미와 유사하게 사용된 예였다고 볼 수 있다.13) 다만 ‘향수’와 ‘향유'가 적어도 정책논의 차원에서 완전히 상호 대체되는 용어로 보기는 어렵다. ‘향수’라는 단어는 주로 '문화'와 연동되어 '문화향수' 형태로 익숙하게 사용되었던 반면, 예술에 특정된 '문화예술향수', '예술향수’라는 표현은 거의 쓰이지 않았기 때 문이다.

주지하다시피 최근 예술을 포괄한 문화정책 논의 전반에서 개인의 적극적 권리를 강조하고(문화권 등), 생활예술 등 개인 예술활동에 있어서의 주체성과 권리의 보장 을 보다 적극적으로 지원하는 추세다. 실제로 2014년 처음 제정된 「문화기본법」 역시 제4조(국민의 권리) 조항을 통해 '문화권' 개념을 명시함으로써 적극적 주체로 서의 개인이 성별, 종교, 인종, 세대, 지역, 정치적 견해, 사회적 신분, 경제적 지위 나 신체적 조건 등에 관계없이 문화표현과 활동에서 차별받지 아니하고 자유롭게 문화를 창조하고 문화활동에 참여하며 문화를 향유할 권리가 있다고 지목한 바 있 다. 이러한 정책흐름의 변화는 이미 용어상 '향수’ 보다는 '향유’의 의미를 강조하는 방향으로 발전되고 있음을 방증한다. 이에 이 연구에서는 ‘향유’라는 용어로 통일하

13) 실태조사의 제목은 ‘문화향수로 되어 있지만 조사목적을 보면 ‘문화향유실태분석’이라는 표현이 제시되고, 향유와 향수가 혼용되어 쓰이고 있다(이경언 외 2016: 23). 그러나 최근 2019년 조사를 기준으로 실태보 고서 제목이 '국민문화예술활동조사'로 변경된 것은 '향수'에 내재된 수동적이고 다소 고루한 용어를 벗어 나 보다 적극적 관점에서의 국민들의 ‘문화예술활동’의 다원성을 파악하려는 시도로 이해될 수 있다. 
여 사용하되, ‘향유자’의 적극성, 주체성, 권리 등을 반영한 개념으로 이해한다.

\section{口 '예술' 개념의 조작적 정의}

연구에서 사용되는 '예술향유' 개념의 조작적 정의는 우선 「문화예술진흥법 $($ (이 하 문예진흥법으로 줄여 쓰기도 함)상에서 제시된 '문화예술' 영역을 중심으로 한 다. 이는 넓은 의미의 '문화'에 속하지만, 예술관련 분야에 한정된 향유활동을 보다 효과적으로 분석하기 위함이다.

그러나 동시에「문화예술진흥법」 기준 '예술’의 정의는 그 한계도 명확히 존재한 다. 해당 정의는 제도적 적용 대상 설정을 위한 규정으로 '예술'에 대한 인문사회학 적 개념규정으로 보기는 어렵다. 그간 장르 중심으로 나열된 '문화예술' 정의가 예 술현장의 적용에 적절치 않다는 지적은 지속적으로 제기되어 온 사안이기도 하기 때문이다.

연구에서는 해당 정의를 준용하되, 최근 예술계 내에서 예술관이 결과물(작품) 중 심 관점에서 과정(프로세스) 중심 관점으로 선회하고 있는 점, 장르별 다원화 및 융 복합화 등 기존의 근대적 예술론에 입각한 경직된 '장르' 중심 관점의 극복이 예술 현장에서 강조되고 있는 점, 고답적 관점의 예술장르 개념 역시 기술혁신에 따라 대중예술과의 중첩이 활발하게 일어나고 있는 점, 수동적인 향유자로 전제되었던 일반시민이 예술창작의 주체로서 활동하고 있는 최근의 환경 변화 등을 고려하여 좀 더 유연한 관점에서 '예술’로 이해하고자 한다.14)

〈표 1-2〉 용어정의: 문화 vs. 예술

\begin{tabular}{|c|c|c|}
\hline 구분 & 근거 & 정의 \\
\hline $\begin{array}{l}\text { 문화 } \\
\text { (文化) }\end{array}$ & $\begin{array}{l}\text { 「문화기본법 } \\
\text { (법률 제12134호, } \\
\text { 2013.12.30. 제정) }\end{array}$ & $\begin{array}{l}\text { 제3조(정의) 이 법에서 “문화”란 문화예술, 생활 양식, 공동체적 삶 } \\
\text { 의 방식, 가치 체계, 전통 및 신념 등을 포함하는 사회나 사회 구성 } \\
\text { 원의 고유한 정신적·물질적·지적·감성적 특성의 총체를 말한다. }\end{array}$ \\
\hline $\begin{array}{c}\text { 예술 } \\
\text { (藝術) }\end{array}$ & $\begin{array}{l}\text { 「문화예술진흥법 } \\
\text { (법률 제16595호, } \\
\text { 2019.11.26. 일부개정) }\end{array}$ & $\begin{array}{l}\text { 제1장 제2조(정의)에 따르면 “문화예술”이란 “문학, 미술(응용미술 } \\
\text { 을 포함한다), 음악, 무용, 연극, 영화, 연예, 국악, 사진, 건축, 어 } \\
\text { 문, 출판 및 만화”를 말한다. }\end{array}$ \\
\hline
\end{tabular}

자료: 국가법령정보센터(http://law.go.kr 최종접근: 2020.05.14)

14) '예술'에 대한 인식 및 관점의 변화 등은 제2장의 '예술계를 둘러싼 환경변화' 논의에서 다룬다. 


\section{口 문화향유 vs. 예술향유}

상대적으로 정책논의에서 '문화향유'라는 넓은 의미의 용어가 그간 활발히 사용 되어 온 점을 감안할 때, 이 연구에서는 조작적으로 '문화향유'와 '예술향유'를 구분 하여 접근하는 한편, '예술향유'에 집중하여 논의를 개진한다.

〈표 1-3〉 용어정의: 문화향유 vs. 예술향유

\begin{tabular}{|c|c|c|c|c|}
\hline 구분 & 근거 & 정의 & 예시 & 공통 \\
\hline $\begin{array}{c}\text { 문화 } \\
\text { (文化) }\end{array}$ & $\begin{array}{l}\text { 「문화기본법 } \\
\quad \text { (법률 } \\
\text { 제12134호, } \\
\text { 2013.12.30. } \\
\quad \text { 제정) }\end{array}$ & $\begin{array}{l}\text { 제3조(정의) 이 법에서 "문화"란 문화예 } \\
\text { 술, 생활 양식, 공동체적 삶의 방식, 가치 } \\
\text { 체계, 전통 및 신념 등을 포함하는 사회나 } \\
\text { 사회 구성원의 고유한 정신적·물질적·지 } \\
\text { 적·감성적 특성의 총체를 말한다. }\end{array}$ & $\begin{array}{c}\text { 문화예술분야를 포함 } \\
\text { 스포츠, 관광, 종교 및 } \\
\text { 삶의 양식 등을 } \\
\text { 포괄한 넓은 의미의 } \\
\quad \text { 문화활동 }\end{array}$ & \multirow{2}{*}{$\begin{array}{c}\text { 개인의 } \\
\text { 적극적 } \\
\text { 권리, } \\
\text { 주체성 } \\
\text { 등의 } \\
\text { 개념이 } \\
\text { 내포됨 }\end{array}$} \\
\hline $\begin{array}{l}\text { 예술 } \\
\text { (藝術) }\end{array}$ & $\begin{array}{l}\text { 「문화예술진흥법 } \\
\text { (법률 } \\
\text { 제16595호, } \\
\text { 2019.11.26. } \\
\text { 일부개정) }\end{array}$ & $\begin{array}{l}\text { 제1장 제 } 2 \text { 조(정의)에 따르면 “문화예술” } \\
\text { 이란 “문학, 미술(응용미술을 포함한다), } \\
\text { 음악, 무용, 연극, 영화, 연예, 국악, 사진, } \\
\text { 건축, 어문, 출판 및 만화"를 말한다. }\end{array}$ & $\begin{array}{l}\text { ‘(문화)예술’ 분야에 } \\
\text { 한정된 활동 }\end{array}$ & \\
\hline
\end{tabular}

자료: 국가법령정보센터(http://law.go.kr 최종접근: 2020.05.14)

'문화향유'는 ‘문화기본법」상의 '문화’ 개념 규정에 근거를 둔 넓은 의미의 일련 의 활동으로 이해될 수 있다.15)「문화기본법」상에서의 '문화’가 "문화예술, 생활양 식, 공동체적 삶의 방식, 가치체계, 전통 및 신념을 포함하는 사회나 사회구성원의 고유한 정신적·물질적·지적·감성적 특성의 총체”를 의미하는 바, 이에 따른 '문화향 유'는 예술영역 외에 스포츠, 관광 활동, 또한 종교 및 젠더 같은 개인의 다양한 가 치관 및 삶의 양식과 연관된 분야가 폭넓게 포괄될 수 있다.16)

‘예술향유'는 「문화예술진흥법 기준 '문화예술' 영역 중심으로 이뤄지는 일련의 활동으로 전통적 의미에서의 '관람(특정장소 기반 및 온라인 등)'을 비롯, 교육과 다 양한 형태의 ‘참여' 활동을 포괄한다. 현재「국민문화예술활동조사」(구(舊] 문화향 수실태조사) 및「국민여가활동조사」에서 제시된 문화예술활동은 '관람'과 ‘참여'로 양분되어 제시되는데, '향유'에 대한 이러한 이원적 관점은 현재 해외 유사조사에서

15) '예술향유’에서의 ‘참여'가 의미하는 다양한 스펙트럼 관련 이론적 논의 및 유형 관련 내용은 제 2 장을 참조 할 수 있다.

16) 문화체육관광부 소관 업무에 한정하여 이해한다면 문화향유는 '예술향유' 이외에도 스포츠, 관광, 종교 등 다양한 활동범위를 아우른다고 하겠다. 
도 유사하게 확인된다. 17) 대부분의 경우 '관람' 은 관객으로서의 행사관람, '참여'는 행사 ‘직접참여’로 각각 구분된다. 그러나 ‘참여’의 경우 세부적인 정의 규정이나 기 준이 제시되지 않아, 교육, 동호회활동 등과의 차별성에 대한 명확한 기준이 제시되

지 않는 한계가 존재한다. ${ }^{18)}$

연구에서는 예술향유활동 입체적 양태를 바라보는 다양한 시각 및 이론적 논의를 기반으로 향유활동에 영향을 미치는 구성 요소 및 관련 영역을 살펴본다. 관람 vs. 참여의 단순 분류적 시각을 넘어 관람(참여적 관람), 매개적 예술경험, 공동창작, 창 작, 일상예술, 후원·기부 등 '향유자' 입장에서의 다양한 활동적 층위를 고려하여 논의한다.

\section{나. 내용적 범위}

본 연구에서 분석대상으로서의 ‘예술향유정책'은 ‘문화체육관광부 중심의 중앙에 서 주도하는 정책'에 한정한다. 구체적 '예술향유정책' 분석대상은 크게 '예산 및 지 원구조', '지원사업'으로 구분하여 접근한다.

〈표 1-4〉예술향유정책 분석대상

\begin{tabular}{c|c|l}
\hline 구분 & \multicolumn{2}{|c}{ 분석대상 } \\
\hline \multirow{2}{*}{$\begin{array}{c}\text { 예산 및 } \\
\text { 지원구조 }\end{array}$} & (일반회계) & 예술정책국, 지역문화정책국 내 ‘예술향유' 관련 예산 한정 \\
\cline { 2 - 3 } & (기금) & 문화예술진흥기금 및 체육기금 내 '예술향유' 관련 예산에 한정 19) \\
\hline \multirow{2}{*}{ 지원사업 } & $\begin{array}{c}\text { 문체부 '예산 및 기금운용계획'에서 제시된 '예술향유’, '문화향유(문화향유로 적시하되 구체 } \\
\text { 적 예술장르와 결합된 사업에 한정)' 지원을 사업목적/내용으로 제시하는 사업에 한정 }\end{array}$ \\
\hline
\end{tabular}

현재 향유사업은 문체부 직제 기준 예술정책국뿐 아니라 지역문화정책국까지 포 괄되어 진행되는 상황이다. 가령, 지역문화정책국 주관사업인 '생활문화활성화', '어르신 문화프로그램', '문화가 있는 날', '국·공립 문화시설 개관시장 연장' 등은

17) 미국 NEA의 'Survey on Public Participation in the Arts', 영국의 'Taking Part Survey'의 경우 역시 향유를 각각 Attendance(관람)와 Participation(참여)로 구분하여 조사한다.

18)「국민문화예술활동조사」의 경우, 문화예술활동의 조사항목으로 '관람', ‘참여', '교육', '자원봉사 및 동호 회 활동' 등으로 제시되고 있으며, 관련 분야는 문학, 미술, 서양음악, 전통예술, 연극, 뮤지컬, 무용, 영화, 대중음악, 연예 등의 장르로 한정되어 있다.

19) 한국문화예술위원회와 한국문화예술교육진흥원(예술정책과 소관), '지역문화진흥원' 주관사업 등은 분석에 포함된다. 
실질적 차원에서 예술향유지원 성격을 갖는다.

또한 예산관점에서 볼 때 전통적으로 문화예술진흥기금이 예술향유지원을 많이 담당해왔으나, 최근 '체육기금'에서의 향유지원 역시 활성화되고 있음이 주목된다. 가령 최근 일반회계에서 체육기금으로 전환된 '생활문화공동체만들기' 지원사업 외 에도 작은미술관 조성사업, 발달장애인 대상 교육프로그램, 노인요양시설 전통예술 프로그램 지원 등 향유지원에 투입되고 있는 바 '체육기금' 내 '예술향유' 진작을 위한 지원사업은 포함하여 분석한다.

\section{다. 시간적 범위}

제4장에서 다루는 '국내 예술향유정책 전개과정'의 경우, 예술정책이 발현되기 시작한 70년대 후반부터 현재까지를 아울러 '통시적 관점'에서의 각 정부시기 별 '예술향유' 관련 정책관점 변화상을 분석하였다. 또한 지원구조 및 예산 관점에서 접근한 사업 분석 및 제5장에서의 사업별 세부 분석은 최근 일부 주요 사업의 예산 변동 등을 고려해 2020년을 기준으로 하되, 사업성과 및 실적 관련 부분은 2019년 사업실적보고서 등을 참고하여 진행하였다.

\section{2. 연구 방법 및 연구 체계}

\section{가. 연구 방법}

\section{1) 문헌분석}

예술향유정책과 관련된 그간의 사업 및 최근 향유지원 관련 국내외 담론의 변화, 예술계 및 사회적 환경변화에 대한 검토가 필수적인 바, 문헌분석을 기초적 연구방 법으로 활용하였다.

예술향유 관련 이론 및 정책담론 관련 해외 발간 정책보고서 및 학술논문을 비롯 하여, 문화체육관광부 및 향유지원 관련 공공기관에서 발간된 정책연구보고서 및 정책 비전서, 사업 계획서, 사업실적보고서, 향유 실태와 관련된 통계자료 등을 다 각적으로 검토하였다. 


\section{2) 시민 예술향유 인식 및 예술향유활동 조사}

일반 시민의 예술향유에 대한 인식 및 예술향유 활동의 다양한 양태 변화 분석을 위해 '설문조사: 시민 예술향유 인식 및 예술향유활동 조사'를 수행하였다.

〈표 1-5〉 설문조사(시민 예술향유 인식 및 예술향유활동 조사) 개요

\begin{tabular}{|c|c|}
\hline 구분 & 내용 \\
\hline 조사 방법 & 구조화된 설문지를 활용한 온라인 정량(패널) 조사 \\
\hline 표본수 & 1,000 명 \\
\hline 모집단 & 전국 17 개 시도 거주하는 만15세 이상 일반 시민 \\
\hline 표집 방법 & 지역×성×연령별 비례 할당 \\
\hline 조사 기간 & 2020년 7월 30일 8월 6일 \\
\hline 조사수행기관 & (주) 글로벌리서치 \\
\hline \multirow{5}{*}{ 조사영역 } & 예술에 대한 인식(범주, 가치, 관심도) \\
\hline & 예술 직접 관람 실태(동기, 매개, 효과 및 외적·내적 걸림돌) \\
\hline & 예술 온라인 관람 실태(동기, 매개, 효과 및 외적·내적 걸림돌) \\
\hline & $\begin{array}{l}\text { 예술참여활동(창작·실연, 교육, 동호회, 자원봉사·기부) 실태 } \\
\text { (동기, 매개, 효과 및 외적·내적 걸림돌) }\end{array}$ \\
\hline & 예술지원에 관한 정책인식(정책인지도, 경험, 정부지원 충분성 인식) \\
\hline
\end{tabular}

조사영역의 구성은 제 2 장 예술향유 관련 이론적 논의를 기반으로 하되, 제 3 장에 서 다룬 기존 향유실태조사 조사의 문제와 한계를 보완하는 방식으로 설계하였다. 크게 4개 영역으로 구분하여 설문을 구성하였으며, 기존 조사에 포함되거나 반영되 지 않았던 영역을 포함하여 예술에 대한 인식, 예술 관람(온라인/직관) 실태(동기, 매개, 효과 및 외적·내적 걸림돌), 예술참여 실태(참여여부, 동기, 효과, 외적·내적 걸림돌), 마지막으로 예술지원에 관한 정책인식(정책인지도, 경험, 정부지원 충분성 인식, 정책수요) 등이다. 


\section{3) 초점집단 면담조사(FGI)}

시민의 예술향유 인식 및 양태 관련 심층 분석 수행을 위해 FGI를 진행하였다. 아래 제시된 대상기준(예시)에 따른 총 24 명을 선정하여, 이들의 '예술' 및 '예술향 유'에 대한 인식, '예술향유활동'의 실태 의 다원적 측면(동기, 매개, 효과 및 외적. 내적 걸림돌 등), 정부 정책 인식 및 수요 등에 관한 영역 중심으로 진행하였다.

총 24 명의 인원은 무관심자(G1), 직접 관람 고관여자(G2)/저관여자(G3), 온라인 주이용자(G4), 참여활동자(G5) 등 총 5개 그룹별 특성을 고려하되, 별도 선정질문 지를 통해 참여자를 모집하였다.

〈표 1-6〉 FGI(시민 예술향유 인식 및 예술향유활동) 개요

\begin{tabular}{c|l}
\hline 구분 & \multicolumn{1}{|c}{ 내용 } \\
\hline 조사 방법 & $\mathrm{FGI}$ (그룹별 심층 면접) \\
\hline 표본수 & 전체 24명, 그룹별 4 6명 \\
\hline 모집단 & 서울 포함 수도권 거주 만15세 이상 일반 시민 \\
\hline 표집 방법 & 선정질문지를 이용하여 모집 \\
\hline 조사 기간 & 2020년 8월 5일 8월 10일 \\
\hline 조사수행기관 & (주) 글로벌리서치 \\
\hline \multirow{5}{*}{ 조사영역 } & 예술에 대한 인식(범주, 가치, 관심도, 연상이미지, 여가시간에서의 예술활동 비중) \\
\cline { 2 - 3 } & 예술 관람 실태(직접관람 및 온라인: 동기, 매개, 효과 및 외적·내적 걸림돌) \\
\cline { 2 - 3 } & $\begin{array}{l}\text { 예술참여활동(창작·실연, 교윤, 동호회, 자원봉사·기부) 실태 } \\
\text { (동기, 매개, 효과 및 외적-내적 걸림돌) }\end{array}$ \\
\cline { 2 - 3 } & 예술지원에 관한 정책인식(정책인지도, 경험, 정부지원 충분성 인식) \\
\hline
\end{tabular}

\section{4) 전문가 자문회의 및 이해관계자(사업담당자 등) 심층면접}

문헌분석으로 살펴 본 예술향유 관련 정책환경 변화에 대한 현장의 의견 및 향유 지원 사업 1 차 문헌분석을 통해 도출된 향유정책 관련 주요 이슈 및 문제점, 정책대 안 관련 의견 수렴을 위해 전문가 및 이해관계자(사업담당자 등)를 대상으로 심층면 접 성격의 자문회의를 진행하였다. 


\section{나. 연구 체계 및 흐름도}

본 연구의 전체적인 체계 및 흐름은 다음과 같다.

[그림 1-1] 연구 체계 및 흐름도

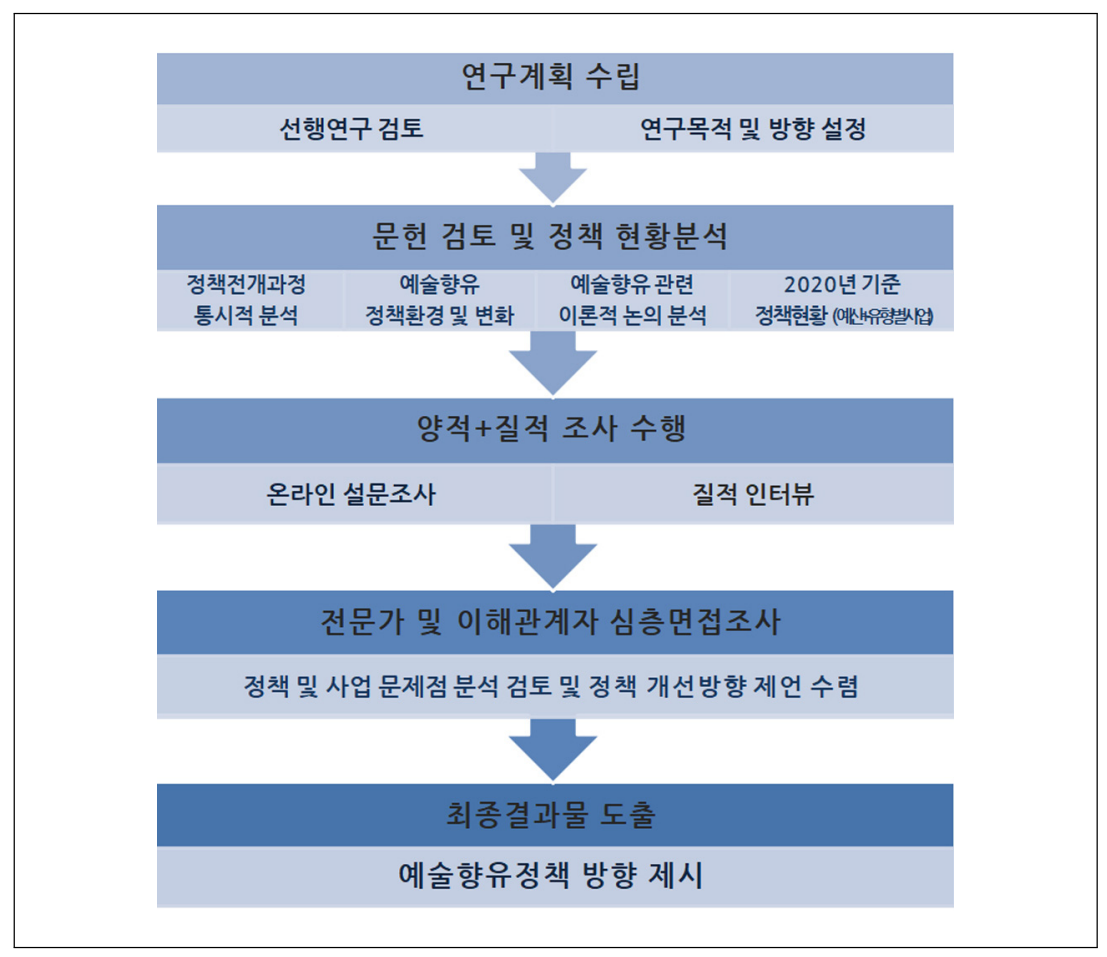



예술향유정책 분석 및 방향 연구

제2장

$$
\begin{array}{r}
\text { 예술향유 이론적 논의 및 } \\
\text { 정책환경의 변화 }
\end{array}
$$





\section{제1절 예술향유의 환경변화 및 최근 정책담론}

\section{1. 예술계를 둘러 싼 환경변화}

\section{가. 예술을 바라보는 관점 변화}

1) 예술의 사회적 가치 강조 및 예술관 변화

1990년대 이후 예술의 사회적 영향에 관한 관심이 대두되기 시작하였고, 2010 년대 이후 경제적 가치에 대한 관심과 함께 사회 갈등 해결을 위한 예술의 사회적 가치가 주목 받게 되었다(양혜원 외 2019). 기존의 예술이 지닌 본질적 가치나 예술 지상주의적 관점을 넘어 예술이 삶의 질을 제고하고 웰빙에 기여하는 차원에서의 역할에도 주목하기 시작한 것이다. 예술은 개인적 차원에서 정서적 안정을 제공하 고 삶의 여유를 제공해줄 뿐만 아니라 사회적 차원에서 타인과의 협동 및 포용력을 증가시켜줌으로서 공동체 의식을 강화시켜주고 구성원 간의 의사소통을 촉진하는 수단이 되고 있다.

이러한 변화는 기술 발전으로 인해 점차 인간의 역량을 발휘할 수 있는 영역이 기술로 대체되는 시대를 맞게 되면서, 과연 예술이 할 수 있는 역할이 무엇인지에 대한 재고찰이 이루어졌고, 이로 인해 예술의 사회적 역할에 대한 가치 및 중요성에 대한 인식이 높아졌기 때문이다(양혜원 외 2019). 예술은 이제 세대 간 소통과 이 해, 건강 증진 및 치유, 그리고 나아가 사회 갈등 해소, 공동체의식 확산 등에 기여 하고 있다(양현미 외 2012).

예술이 갖는 사회적 속성에 대한 재성찰은, 예술이란 작품이라는 결과물이 아닌 창조되는 그 과정 자체에 가치를 두는 '과정 중심적' 관점으로 선회하고 있는 예술 관의 변화와도 연결된다. 에릭 부스(2009: 17)가 강조한 것처럼 예술이란 결과가 아니라 과정이며, 삶의 질을 향상시킬 수 있는 일련의 경험으로서 이해되고 있는 
것이다. 예술의 창작과 소비가 분리된 영역이 아니라 그 경계가 허물어지고 모호해 지면서 예술 영역에 대한 기존의 범주가 변화하고 있으며, 예술을 창작하고 참여하 는 주체 또한 전문적인 예술가뿐만 아니라 일반인들에게도 확장됨으로서 결과보다 는 과정에 의미를 부여하고자 하는 관점으로 변화가 일어나고 있다. 예술가들이 창 작하는 전문예술이 아니라 누구나 예술 창작에 참여하고 그 과정을 통해 참여자들 은 소통을 도모한다.

또한 예술을 개인의 삶과는 상관없는 일부 계층의 고급예술이 아니라 개인의 삶 과 직결된 활동이라는 인식으로 이어지고 있다. 이 과정에서 예술은 수동적이든 혹 은 적극적이든 예술이라는 매개를 통해 공동의 경험을 제공하기 때문에, 구성원들 은 공유된 경험을 토대로 실질적 관계를 발전시키고 유지시킬 수 있다는 점에서 일 상과 밀접한 사회자본을 형성하는 데에도 기여한다(김인설 2012).

\section{2) 일상적 예술활동의 확산}

전술하였듯이 예술에 대한 관점은 과정 자체에 의미를 갖는 예술관의 변화와 함 께 예술을 전문가가 창작하는 엘리트주의적 고급 예술이 아닌 비전문가에 의해서도 일상에서 창작되는 예술활동으로 보는 관점이 확산되고 있다. 즉, '보는' 예술을 넘 어 '하는' 예술로의 변화에 대한 논의가 확산되고 있는 것이다. 이러한 변화는 특히 사회 소득 수준이 증가하고, 삶의 질이 중요한 가치로 대두되면서 전통적 의미의 생산자와 소비자 간의 창작과 향유라는 이분법적 구분이 허물어지고, 예술의 생활 화를 통해 향유하고 직접 참여함으로써 새롭고 자발적인 예술 활동이 활동화되고 있기 때문이다(강윤주 외 2012). 이른바 일상에서 누구나 예술을 창조하는 즐거움 을 누릴 수 있는 생활예술 개념이 강화되고 있다. 이를 통해 예술은 지역 공동체의 삶을 긍정적으로 변화시키는 힘으로 작용하며, 개인의 행복을 추구하고 사회적 통 합 등의 삶의 질을 높일 수 있는 효과를 가져다준다.

이러한 예술의 사회적 가치에 대한 관심 및 예술관의 변화를 통해 일상에서의 예 술활동이 확장되고 있는 변화는 결국 예술이란 예술가만의 고립된 작업이 아니라, 개인 차원의 감성적이고 창조적인 활동인 동시에 공동의 경험을 기반으로 다른 구 성원들과 경험을 공유하고 관계를 발전·유지시키며 사회적 소통까지 가능케 하고 
있음을 알 수 있다. 즉, 예술은 자신을 표현하고 이해시킬 뿐만 아니라 타인과 소통 하기 위한 고도화된 방식이자 기술로서 작동하고 있는 것이다(백선혜 2017).

따라서 예술 자체를 참여자 간의 끊임없는 의사소통이 발현되는 과정으로 볼 수 있으며, 이러한 과정을 통해 현대 사회가 야기하는 다양한 문제들을 해결해주거나 완화시켜 주는 역할을 수행하고 있다. 더욱이 미래사회에서 예술은 예술 향유 및 예술 활동을 통해 공동체 의사소통의 수단으로서의 역할이 더욱 중요할 것으로 전 망되기에, 예술이 가지는 사회적 가치와 의미에 대한 심도있는 논의가 필요할 것으 로 보인다. 따라서 이렇게 변화하고 있는 예술 향유에 대한 방식 및 관점에 대응하 여 향후 예술 가치에 대한 재인식과 예술의 사회적 가치를 활용하기 위한 정책적 방안 모색이 더욱 중요한 시점이라 하겠다.

\section{나. 예술향유 환경 변화}

\section{1) 개인 가치관의 변화}

1 인 가구 증가 및 인구와 세대 구조의 변화는 문화예술 향유 방식에도 영향을 미 치고 있다. 개인 중심의 가치관으로서의 선회는 일방적인 대중매체를 통한 집단적 소비가 아닌 개인을 중심으로 한 문화 소비 양식이 확산되고 있다. 특히 직장 등의 사회 공동체를 벗어나 개인 라이프스타일을 선택하고 자아 추구를 위한 사회관계를 형성하는 것에 관심이 높아지고 있다. 취미와 취향이 곧 정체성을 드러내는 수단으 로 인식되면서 개인의 취향과 관점을 충족시켜주는 방향으로 문화예술 소비가 이루 어지고 있으며, 단순히 관람-감상의 단계를 넘어 직접 참여와 창작을 통해 전문성을 가진 취미 모임이 하나의 문화로 자리 잡고 있다.

서로의 취향을 나누고 자유롭게 대화하는 사교모임인 살롱(Salon) 문화의 등장이 대표적이다. 살롱문화는 SNS를 기반으로 비대면의 피상적 인간관계와 직장 등의 정형화된 공동체에서 피로감을 느끼는 젊은 세대에게 나이나 직업 등에 대한 사회 적 기준 없이 오직 공통의 취미나 취향에 기반한 특정 콘텐츠를 중심으로 모이는 오프라인 플랫폼이다. 살롱문화가 가진 경험하는 결과보다 과정과 지식을 공유하는 소통방식, 그리고 타인에 대한 존중과 공감의 감수성 등의 요인들이 이러한 문화를 빠르게 확산시키는데 큰 영향을 주는 것으로 분석된다. 집단보다는 개인의 가치가 
중시되고 워라밸의 중요성이 인식되는 시대를 맞아, 이러한 젊은 세대를 중심으로 형성되는 취향 공동체는 단순히 문화예술을 소비한다는 차원을 넘어 문화예술 활동 이 결국 삶의 가치관 및 지향점과도 연결되어 있으며, 새로운 형태의 문화예술 향유 트렌드를 만들어 가고 있음을 알 수 있다.

\section{2) 디지털기술 발전과 향유경험의 변화}

미디어와 기술 환경 변화는 예술향유의 방식에 있어 물리적 환경의 경계를 넘어 새로운 방식으로 예술향유를 가능하게 해주고 있다. 또한 수동적 수용자가 아니라 능동적 참여자이자 생산자가 될 수 있게 해준다. 일상생활을 통해 경험하고 공유하 는 것이 모두 생산이자 소비의 산물이 되고 있으며, 특히 유튜브나 SNS 등의 소셜 플랫폼을 통해 가속화되고 있다.

정보통신기술 발달과 함께 디지털 기술이 결합하여 다양한 문화예술 향유 방식이 증가하고 있으며, 스마트 기기와 인터넷 통신망의 발전으로 인한 융복합화를 통해 새로운 결합의 문화예술 콘텐츠들이 등장하고 있다. 또한 디지털 기반의 온라인 미 디어 확산은 기술적 진입 장벽을 완화시켜주었으며, 단순한 향유 차원을 넘어 누구 나 콘텐츠를 제작·편집·업로드 할 수 있는 콘텐츠의 생산자로서의 역할을 수행하게 해준다. 스마트폰이나 태블릿 PC 등 스마트기기의 대중화와 유튜브를 중심으로 한 동영상 기반 플랫폼의 확산을 통해 동영상 기반의 1 인 미디어 환경이 조성되고 있 으며, 이러한 1 인 미디어의 증가는 '예술인'에 대한 경계를 흐려지게 하고 있다.

기술의 발전으로 일상생활에서 예술을 접할 수 있는 기회가 확대됨으로서 예술콘 텐츠에 대한 접근성을 높여주고, 새로운 예술 관련 콘텐츠와 상호작용하거나 향유 할 수 있는 기회도 증가시켜주고 있다. 더욱이 2020년 초부터 시작된 코로나19 사 태가 장기화되면서 모바일, 태블릿 등을 통해 시공간 제약 없이 어디서나 공연 영상 콘텐츠를 감상할 수 있는 이른바 '랜선 공연'과 온라인 전시 등이 새로운 예술향유 방식의 대안으로 떠오르고 있다. 코로나19 장기화로 취소된 공연을 대상으로 무관 중 공연 생중계, 공연 영상 콘텐츠 스트리밍, 나아가 가상현실(VR)을 이용한 온라인 중계 등 그 방식도 다채로워지고 있으며 대중들의 관심도 높아지고 있다. 이를 계기 로 코로나 19 가 종식된 이후에도 그간 철저히 오프라인에서의 물리적 접촉 영역이라 
간주되던 공연 및 전시의 향유가 온라인을 통한 보다 다양한 방식으로 전개될 것으 로 예측되고 있기에, 장기적 관점에서 이러한 온라인 기반의 예술향유 방식 변화에 대해 정책적으로 어떻게 접근해야 하는지에 대한 다면적 차원에서의 고려가 필요할 것으로 보인다.

\section{3) 향유 주체의 다양화}

중·노년층이라 불리며 문화소비의 영향력이 약했던 베이비부머를 중심으로 한 5060 세대가 새로운 문화소비층으로 떠오르고 있다. 일본에서 처음 소개된 일명 OPAL(Old People with Active Lives)이라 불리는 이 세대는 고령화 사회의 주축 으로 떠오른 액티브 시니어를 지칭한다(김난도 외 2019). 길어진 기대수명과 함께 은퇴와 자녀의 독립으로 능동적이고 삶의 질을 위해 투자하는 소비자층으로 부상하 고 있으며, 자신의 흥미와 취향에 대한 관심과 의지가 높아지고 있다. 최근 10 년간 의 급속도로 발전한 인터넷 기술과 편리한 스마트 기기의 등장은 기존 아날로그 세 대로 불리던 베이비부머 세대들에게 카카오톡이나 유튜브와 같은 온라인 플랫폼을 쉽게 이용할 수 있도록 해주었고, 5060 신중년의 디지털 기기와의 친밀도 및 높아 진 소비력은 문화 소비 시장에도 영향을 미치고 있다.

이와 함께 1980년대 초 2000년대 초에 출생한 밀레니얼 세대와 1990년대 중 반 2000년대 초반에 출생한 Z세대를 통칭하는 MZ세대 또한 새로운 문화 소비세 대로 떠오르고 있다. 이들은 기성세대와는 달리 태어났을 때부터 디지털 환경에 가 장 익숙한 디지털 네이티브로, 스마트폰을 통해 소통하고, 소비 및 여가활동까지 디 지털 디바이스를 통해 수행한다. 이들은 소유보다는 특별한 경험이 중요하며, 자기 표출과 자신의 취향을 우선으로 삼기에, 앞으로 이들은 기존 세대와는 전혀 다른 문화소비 방식을 취할 것으로 예상된다.

이러한 5060의 중년층과 MZ세대가 새로운 문화예술 향유 계층으로 떠오르면서, 이들이 문화예술 향유에 관해 가지는 가치관이나 인식은 이전과는 확연하게 다를 것임은 명백하다. 각각의 새로운 세대적 경험 및 문화를 공유하는 향유 주체의 다양 화는 향후 한국에서 예술향유 양상이 어떻게 변모할 것이지, 어떠한 문화현상을 이 끌 것인지, 그리고 문화예술 영역에 어떠한 영향을 줄 것인지에 대응하여 향후 정책 
적 방향성 역시 시대적 변화에 맞게 변모하기 위한 고민이 필요한 시점이라 할 수 있다.

\section{2. '복합적·능동적 프로세스'로서의 예술향유'20)}

\section{가. 해외 예술향유 개념적 논의}

본격적인 논의에 앞서, '예술향유'를 논의하는 용어와 개념을 먼저 짚어보고자 한 다. '예술향유' 관련 연구가 활발하게 진행되어온 영·미, 유럽권에서는 주로 'Arts Participation'과 'Arts Engagement'가 교차되어 사용되고 있는데, 두 용어 역시 보고서나 연구의 목적성, 맥락에 따라 종종 혼재되어 사용되고 있어서 무엇을 어떤 취지에서 해당 용어로 일컫는지를 밝히며 정의가 내려진다. 그러나 동시에 각각의 용어는 맥락에 따라 그 개념의 폭과 의미가 구체적으로 전제되는 경우도 있다.

먼저, 'Arts Participation'의 경우, 광의의 개념으로는 우리가 흔히 이해하는 관 람부터 창작에 이르는 포괄적인 활동을 아우를 때에 사용하는 '예술향유'를 지칭할 때 종종 사용된다. 반면 협의의 Arts Participation은 시민 참여성의 개념을 담은 능동적, 주체적 관점에서의 ‘참여’를 의미하며 활용되기도 한다.

반면, 'Engagement' 역시 유사한 개념으로 폭넓은 '향유'를 일컫기도 하지만 예 술적 경험이 개인에게 발하는, 혹은 개인이 투입하는 경험적 주체성과 헌신적 관계 맺기의 정도와 영향에 대한 인지를 보다 적극적으로 내포한 개념이다. 따라서 그러 한 주체성과 관계맺기를 위한 특정 경험을 지원하는 프로그램의 특성적 요소들 (attributes)을 전제하기도 하며, 이를 위한 매개가 동반된 상이한 활동 등과 프로세 스, 조직적 행동을 의미하기도 한다(Lee and Gean 2017; Bollo et al. 2017). 따 라서 본 연구에서는 포괄적 개념으로서의 용어로 사용되는 경우에는 '예술향유'로 통일하되, 구체적 개념이 전제된 경우에는 '예술 참여'와 ‘예술 인게이지먼트'로 구 분하여 명시하고자 한다.

20) 해외에서 진행되어 온 ‘예술향유' 관련 이론 및 학문적 논의를 중심으로 구성하였다. 


\section{나. 복합적 프로세스로서의 예술향유 양태 및 유형화 논의}

최근 해외 예술향유 관련 학술논의에서 주목되는 점은 우선 기존의 예술향유 (arts participation)개념이 예술 소비 및 관람과 동일시되고 있는 사회적, 통념적 이해의 극복, 더 나아가 물론 정책이나 기관들에서의 태도가 이러한 평면적 이해에 서 벗어나 '예술향유'를 입체적, 복합적으로 이해해야 한다는 것을 강조하고 있다는 점이다. 물론 아직까지 '예술향유' 관련 공통된, 혹은 합의된 정의들이 통용되는 것 은 아니다. 그러나 적어도 이들의 논의를 살펴보면 '예술향유'의 정의를 내리는데 있어 공통적 요소로 '능동성,' '관련성,' ‘주체성,' '동태성(vs. 정태성)'과 '스펙트럼' 이나 '프로세스'로서의 이해가 반영되어 있다는 점이 특징적이다.

특히 예술향유를 현장에서의 실천들로 인해 구성되는 개념으로 상정하되, 고정된 것이 아닌 유기적 개념으로 접근하고 있다. 그 가운데 '인게이지먼트(engagement)' 라는 용어는 이러한 '향유'의 유기적·유동적 측면과 입체성을 함의하는 단어로 폭넓 게 사용되고 있으며, 이는 매개적 조력과 기획이 결부된 예술향유의 다양한 양태유 형을 포착하고자 하는 시도로 해석이 가능하다.

〈표 2-1〉 해외 학술논의에서의 '예술향유' 개념

\begin{tabular}{|c|c|}
\hline 학자/기관 & 정의 \\
\hline $\begin{array}{l}\text { Kreidler and Trounstine } \\
\text { (2005) }\end{array}$ & $\begin{array}{l}\text { - 문화향유의 개념모델은 예술의 전문가들에 의한 생산과 전달이라는 가 } \\
\text { 장 협의의 렌즈에 고정되어 널리 알려진 정의에 대해 참여적 활동을 포 } \\
\text { 함할 수 있도록 하는 데에 목적을 두며, 가장 광의의 렌즈로서 문화 리 } \\
\text { 터러시를 포괄한다. 문화리터러시란 전통, 미학, 예절, 관습, 언어 및 예 } \\
\text { 술의 유창성, 비판적 사고와 창의력을 적용하는 역량을 포함한다. }\end{array}$ \\
\hline $\begin{array}{l}\text { McCarthy, Ondaatze, and } \\
\text { Zakaras(2001) }\end{array}$ & $\begin{array}{l}\text { - 예술향유 arts participation란 “행하기 doing," 관람, 혹은 미디어를 } \\
\text { 통한 참여이다... 마치 균일한 현상인 듯 하지만 여러 형태로 나타날 수 } \\
\text { 있다. }\end{array}$ \\
\hline $\begin{array}{l}\text { Tepper } \\
(2008)\end{array}$ & $\begin{array}{l}\text { - "인게이지먼트는 관계맺거나 to interlock, 참여하거나 to involve, 영 } \\
\text { 향을 미치는 to cause 활동... 예술에 능동적으로 관계를 맺는 활동으 } \\
\text { 로 새로운 의미를 발견하거나 자신만의 목적에 맞춰 활용하고 } \\
\text { appropriate, 다른 스타일과 장르를 창의적으로 섞거나, 자신만의 비평 } \\
\text { 을 내놓는 관객(의 활동)" }\end{array}$ \\
\hline $\begin{array}{c}\text { Brown(2010) } \\
\text { (Brown and Ratzkin, 2011) }\end{array}$ & $\begin{array}{l}\text { - 예술 인게이지먼트 arts engagement란 사람들이 예술에 참여할 수 있 } \\
\text { 는 모든 가능한 방법들의 스펙트럼이다. ...또한 마케팅과 교육, 예술 프 } \\
\text { 로그램이 관객에게 미치는 영향을 극대화하는 공동의 서비스로 통합하 } \\
\text { 게 하는 철학이다. }\end{array}$ \\
\hline
\end{tabular}




\begin{tabular}{|c|c|}
\hline 학자/기관 & 정의 \\
\hline $\begin{array}{l}\text { Johanson et al. } \\
\qquad(2014)\end{array}$ & $\begin{array}{l}\text { - “향유 participation를 넓고 포용적인 개념으로 전문적 활동과 비전문적 } \\
\text { 활동 모두를 아우름...예술과 문화활동에 참여하는 사람들은 여러 다른 } \\
\text { 스킬을 갖고-작업가, 교사, 학생, 비평가, 후원자, 소비자- 다양한 방식 } \\
\text { 으로 참여할 수 있으며 개별적으로 혹은 집단의 형태로, 정기적으로나 } \\
\text { 산발적으로 참여할 수 있다.” }\end{array}$ \\
\hline $\begin{array}{c}\text { Reeves, } \\
\text { (2015) }\end{array}$ & $\begin{array}{l}\text { - 예술향유는 예술소비와 구분되는 개념으로 ‘참여한다 to take part'는 } \\
\text { 개념의 향유 participation이 수동적 의미로 대체되어 관람이나 소비 } \\
\text { (attendance or consumption)로 국한되었다. }\end{array}$ \\
\hline $\begin{array}{l}\text { UNESCO } \\
(2017)\end{array}$ & $\begin{array}{l}\text { - 예술 인게이지먼트 arts engagement는 활동들과 매개체를 통한 다양 } \\
\text { 하고 기획된 다양한 프로세스와 활동들, 조직행동들로 구성된 단계다. } \\
\text { 활동과 매개는 워크숍을 통한 능동적 참여, 교육적 활동, 디지덜 디바이 } \\
\text { 스, 문화간 접근 방법들, 문화기획에의 참여, 예술 작업에의 참여적 기 } \\
\text { 여, 아웃리치 등이 있다. }\end{array}$ \\
\hline $\begin{array}{c}\text { Walmsley } \\
\text { (2018) }\end{array}$ & 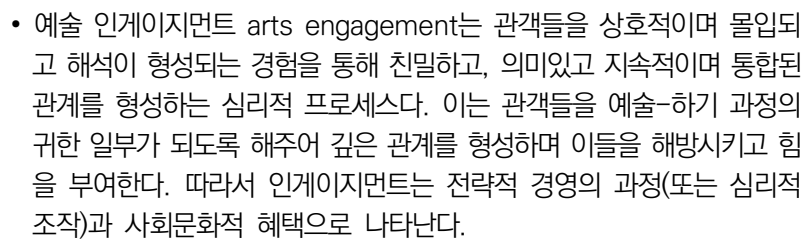 \\
\hline
\end{tabular}

그간 주요 학자들과 정책기관에서 예술향유를 다루는 데에 있어서 예술향유의 복 잡성을 이해하기 위해 향유의 유형을 구분하는 시도들이 있었다. 예술향유를 다루 는 학자들은 종종 예술참여와 인게이지먼트 활동 사례들, 인터뷰를 통해 예술 향유 자 관점에서의 이해와 해석을 더해가며 향유의 양태를 몇가지 유형으로 구분하여 살펴보고 있다. 가령, 설문조사 항목으로 “'예술 향유(arts participation)’를 들으 면 무엇이 떠오르는가?”를 연구주제로 삼은 Getting in on the act(2011) 연구보 고서가 시민들의 경험과 사례들을 통해 예술향유를 5가지로 유형화한 과정은 이러 한 노력의 대표적인 사례다. 몇 가지 대표적인 향유의 유형화에 대한 검토는 예술향 유의 복잡하고 다양한 양태를 좀 더 구체적으로 이해하고 접근하는 데에 필요한 구 성틀을 개발하는 데에 유용한 이해기반을 형성한다. 이를 살펴보면 다음과 같다.

\section{1) 관람, 참여, 미디어 향유}

예술향유에 대한 본격적인 연구에 초기 기반을 닦았다고 볼 수 있는 RAND Institute의 연구 A New Framework for Building Participation in the $\operatorname{Arts(McCarthy~\& ~Jinnett~2001)ㄴㅡㄴ~ㅇㅖㅅㅜㄹㅅㅐㅇㅅㅏㄴㅈㅏ~ㄱㅘㄴㅈㅓㅁㅇㅔㅅㅓ~ㄱㅘㄴㄱㅐㄱㅇㅢ~ㅇㅖㅅㅜㄹㅎㅑㅇㅇㅠㄱㅏ~ㅇㅓㄸㅓㄴ~}$ 
과정으로 이뤄지는지를 이해하고 이들의 향유과정을 예술기관이 효과적으로 진작 시킬 수 있는 방법을 모색하는 데에 목적을 두었다. 따라서 이들이 예술향유 유형을 설명하는 프레임워크는 이전 연구들이 간과해 온 지점들, 즉 예술기관 입장에서 예 술향유자들의 개인의 동기나 선택의 과정에 대한 이해를 보강하고 이를 의사결정 과정에 반영하는 데 중점을 두고 있다.

[그림 2-1] 향유 형태의 설명틀(McCarthy \& Jinnett 2001)

\begin{tabular}{|c|c|c|c|}
\hline \multirow{4}{*}{$\begin{array}{l}\text { partidipation } \\
\text { Preference }\end{array}$} & & \multicolumn{2}{|c|}{ What Person Seeks } \\
\hline & & Entertainment & Fulfillment \\
\hline & $\begin{array}{l}\text { Developing } \\
\text { proficiency } \\
\text { (self-focused) }\end{array}$ & $\begin{array}{l}\text { Participation } \\
\text { through media }\end{array}$ & $\begin{array}{l}\text { Hands-on } \\
\text { participation }\end{array}$ \\
\hline & $\begin{array}{c}\text { Social } \\
\text { experience }\end{array}$ & $\begin{array}{l}\text { Attendance } \\
\text { (casual) }\end{array}$ & $\begin{array}{l}\text { Attendance } \\
\text { (aficionado) }\end{array}$ \\
\hline
\end{tabular}

McCarthy \& Jinnett(2001)은 실증 연구 문헌들을 토대로 향유의 수준(level), 참여자의 특성, 참여의 동기를 중심으로 이해의 틀을 구성해 나갔다. 동시에 이론적 배경에는 향유의 의사결정을 소비자행동론의 틀에서 설명한 경제학 기반의 이론 (Helbrun \& Gray 1993)과 레져 분야에서 레져 시간에 대한 결정에 있어서의 근본 적 동기(무엇을 좇는지)와 사회적 맥락상에서의 선호(개인적 동기와 사회적 경험의 추구)를 중심으로 예술향유를 나누고 있다.

이 연구에서 드러난 관람과 미디어를 통한 참여, 직접적 참여의 세가지 구분 기준 은 NEA의 SPPA의 결과 분석에서도 유효하게 적용되고 있다. 또한 Rabkin \& Hedberg(2011)는 이 분류체계에 근거하여 예술교육을 통한 예술향유를 연구 분석 한 결과 세 가지 양태 모두에 걸쳐 나타난다는 사실을 확인하며, 예술교육을 통합해 서 살펴보기 보다는 예술교육이 세 가지 유형의 예술향유에 어떤 영향을 미치는 지 보는 것이 더 유효할 것이라는 판단을 내리기도 했다(Rabkin \& Hedberg 2011). 


\section{2) 가치연구: 예술향유의 의미와 가치 재발견(Brown 2004)}

미국 예술향유 분야에서 컨설턴트로 오랜기간 활약해온 Alan Brown은 예술향 유의 의미와 가치를 되짚으며, 예술향유에 있어서 향유자의 참여 정도와 창의성에 대한 제어권리를 행사하는 정도에 따라 다섯 가지의 모드로 구분할 수 있음을 제시 하였다.

[그림 2-2] 5가지 예술향유 프레임워크(Brown 2004)

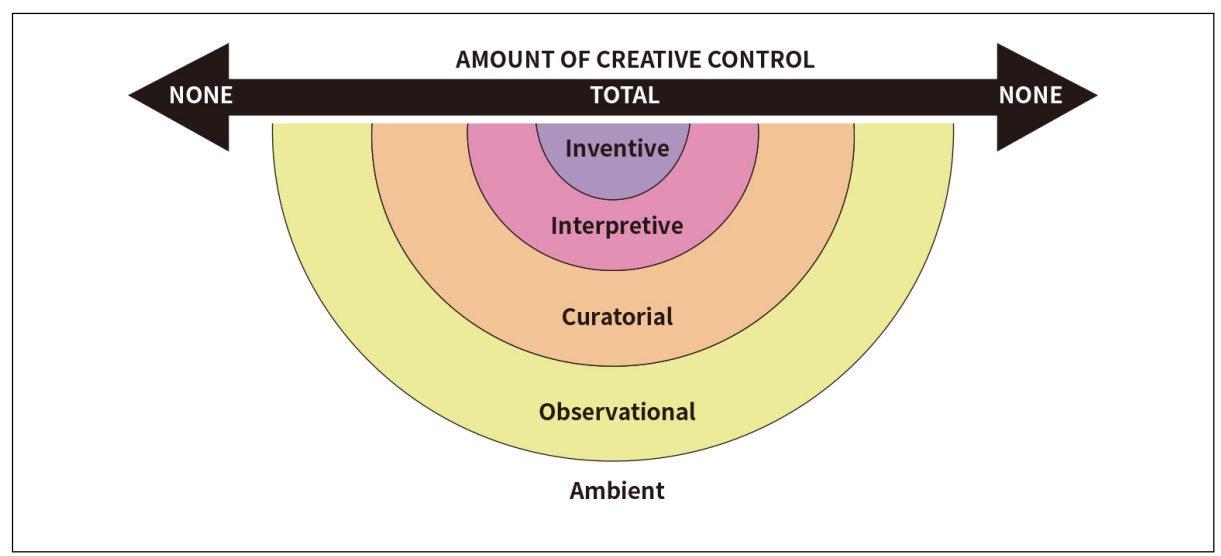

위에서 구분한 다섯 가지 모드의 특징과 기준은 아래와 같이 요약될 수 있다.

〈표 2-2〉 5가지 예술향유 프레임워크(Brown 2004)

\begin{tabular}{|c|c|}
\hline 구분 & 정의 \\
\hline $\begin{array}{c}\text { 창작형 참여 } \\
\text { (Inventive Participation) }\end{array}$ & $\begin{array}{l}\text { 수준(예: 작곡, 시 쓰기, 그림 그리기)에 상관없이 독특하고 색다른 예 } \\
\text { 술적 창조 행위에 마음과 몸, 영혼을 결속(engage)시킴 }\end{array}$ \\
\hline $\begin{array}{c}\text { 해석적 참여 } \\
\text { (Interpretive Participation) }\end{array}$ & $\begin{array}{l}\text { 기존의 예술 작품에 개별적으로 혹은 협력적으로 생기나 가치를 부여 } \\
\text { 하거나 개인을 예술 학습(예: 밴드 연주, 춤 배우기)에 참여(engage) } \\
\text { 하는 창의적인 자기표현(self-expression) 행위임 }\end{array}$ \\
\hline $\begin{array}{c}\text { 큐레이터형 참여 } \\
\text { (Curatorial Participation) }\end{array}$ & $\begin{array}{l}\text { 자신의 예술적 감수성(예: 예술 수집, 음악 다운로드 및 } \mathrm{CD} \text { 굽기)을 } \\
\text { 만족시키기 위해 의도를 갖고 예술을 선택, 구성 및 수집하는 창조적 } \\
\text { 행위임 }\end{array}$ \\
\hline $\begin{array}{c}\text { 관찰형 참여 } \\
\text { (Observational Participation) }\end{array}$ & $\begin{array}{l}\text { 타인(예: 라이브 공연 참석, 미술관 방문)에 의해 창작, 구성 또는 연 } \\
\text { 주된 예술 프로그램 또는 예술 작품을 보거나 들을 때 발생함. 이 유 } \\
\text { 형은 1) 라이브 이벤트 참여, 2) 전자 미디어 기반 참여의 두 가지 } \\
\text { 하위 유형으로 구분될 수 있음 }\end{array}$ \\
\hline $\begin{array}{l}\text { 주변환경으로 인한 참여 } \\
\text { (Ambient Participation) }\end{array}$ & $\begin{array}{l}\text { 참여자가 선택하지 않은 예술과의 만남을 포함시킴(예: 건축 및 공공 } \\
\text { 예술 감상, 상점에서 음악 감상) }\end{array}$ \\
\hline
\end{tabular}


예술향유의 다섯가지 모드를 도출한 데에는 예술향유를 1) 예술가나 향유자 스킬 의 수준, 2) 예술적 표현의 형태, 3) 예술향유의 환경, 4) 창조 권한을 분류 기준으 로 적용했다. Brown(2004)은 나아가 이렇게 구분된 예술향유의 양태들이 형성하 는 다차원적 가치를 체계화하여 아래 그림과 같이 제시해준다. 이를 통해 개인의 신체적, 감정적, 영적, 심미적, 인지적, 사회문화적, 정치적 차원에서의 가치와 관련 하여, 예술기관이나 정부가 프로그램이나 정책사업을 향유자 관점에서의 가치를 살 펴보며 접근할 수 있는 틀을 제공해준다.

[그림 2-3] 예술향유의 가치체계(Brown 2004)

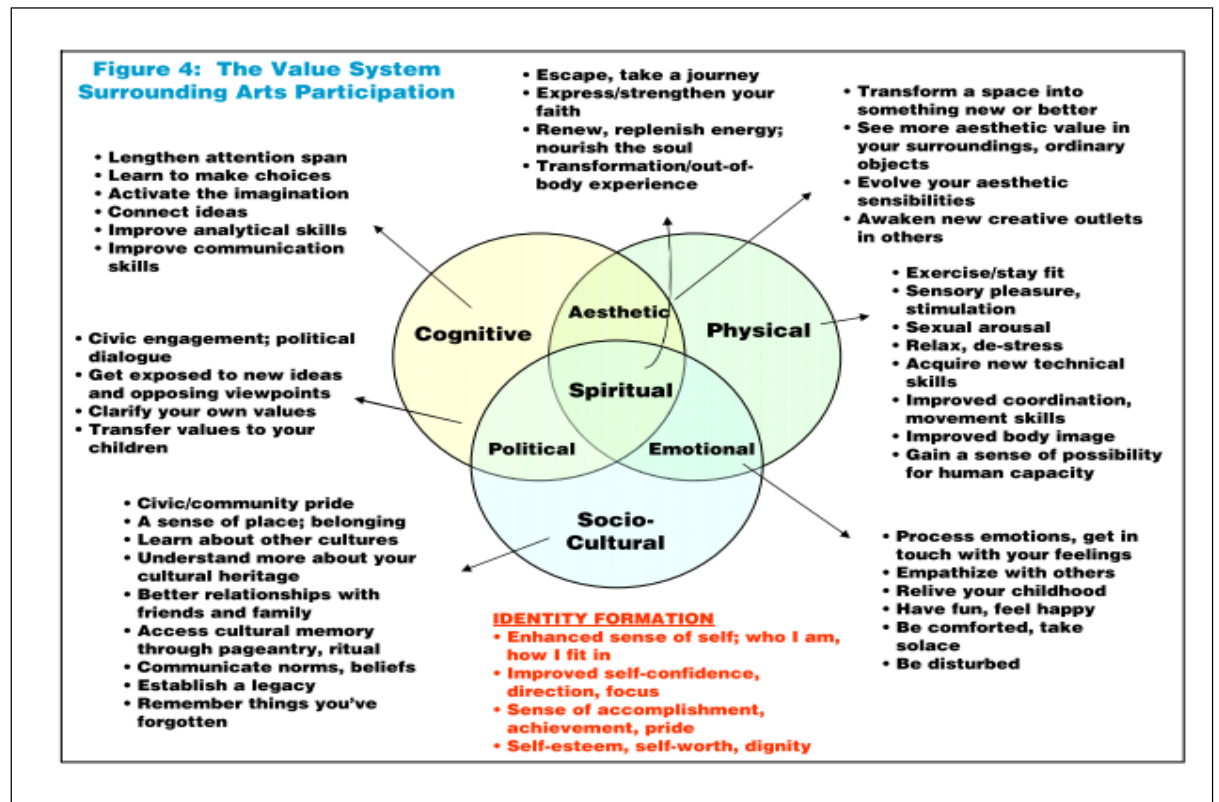

3) EU Audience Development에서 활용한 이해 모델: Kawashima 모델 기반의 관객 유형 분류와 ‘By Habit, By Choice, By Chance’(Bollo et al. 2017)

Kawashima(2000)는 예술향유 이상으로 복합적인 구성이 내포된 '관객'을 개발 하는 전략 방향을 모델로 제시하였는데, 이를 토대로 EU에서의 관객개발을 위한 연 구에서는 해당 모델이 전제한 복합구성체로서의 관객을 세가지 유형으로 구분하였 다. 예술향유를 자신의 정체성이나 개념과도 관련시키고 종종 예술향유에 참여하고 있는 향유자를 ‘습관적 관객 audience by habit' 으로 분류하고 있다. 예술 향유가 
일상적인 일은 아니지만 가끔 예술 관람을 선택하기도 하는 자를 '선택적 관객 audience by choice'로, 예술에 대한 무관심하거나 적대적이거나 혹은 다른 이유 로 접근하기에 어려운 대상을 '우연한 관객 audience by surprise'으로 정의하고 있다. 특히, '우연한 관객’의 경우 향유에 장벽으로 작용하는 요소들이 복합적으로 존재하는 유형으로 구분하고 있다.

[그림 2-4] 관객유형 분류(습관, 선택, 우연)(Kawashima 2000)

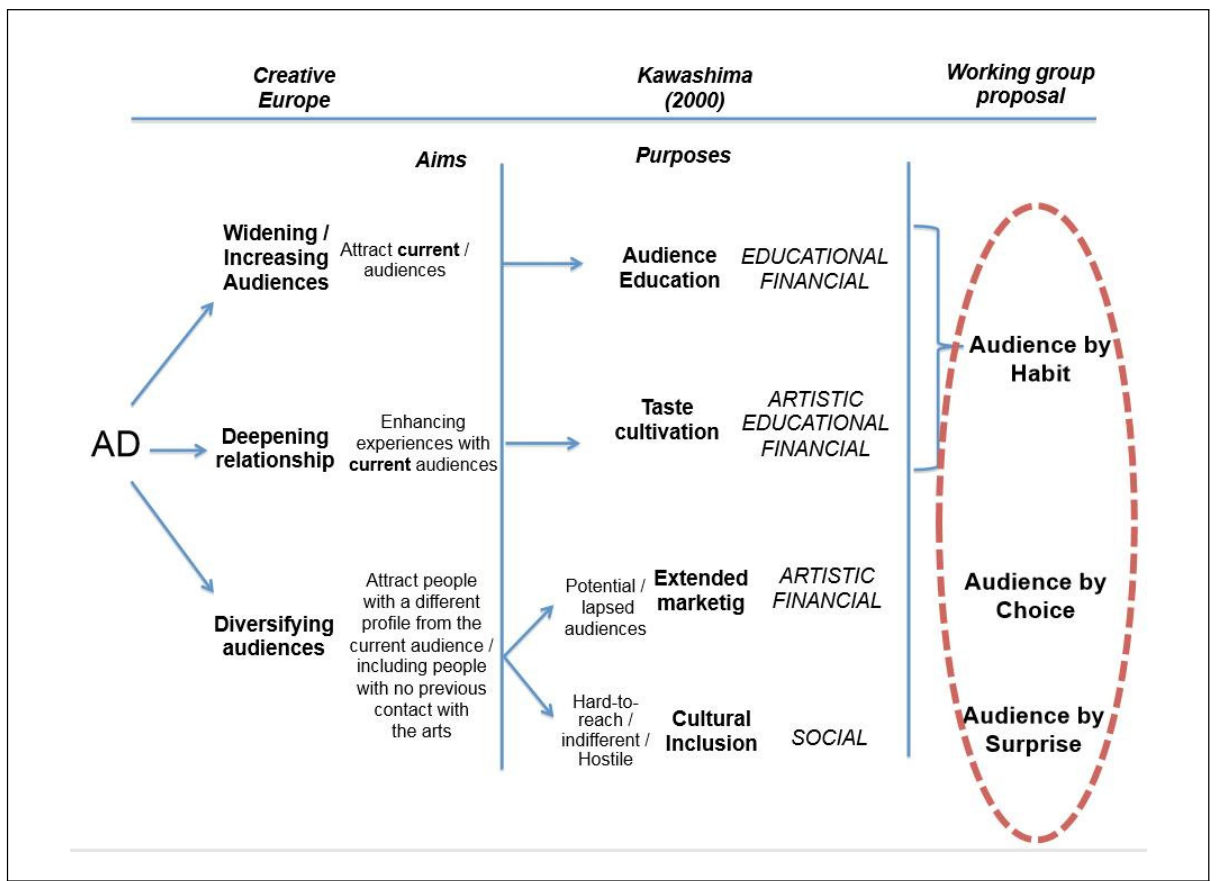

Bollo 외(2017)는 이러한 관객 구분을 통해 관객개발에 있어서의 노력이 관객 유형별로 달리 접근되어야 함을 제안하고 있다. '습관적 관객' 은 이미 예술과 주체 적 관계을 맺고 있는 대상으로 예술향유의 노력은 이들의 경험 범주를 더욱 넓혀주 거나 개인적 취향을 개발해주며 깊이를 더해가는 데에 집중될 수 있어야 한다. 반 면, '선택적 관객'은 능동적 향유를 해 본 경험이 있는 대상으로 예술향유에 새롭게 동기부여될 다각적 예술향유 제공을 공략한다. 마지막으로 향유의 경험이라고는 ‘우연한 경험' 으로만 존재하는 관객의 경우, 자신의 능동적 경험이 이뤼지지 않는 대상이다. 이들은 종종 사회통합의 대상이 되며, 예술향유에 장벽이 되는 요소들을 
안고 있어서 그 장벽들을 제거해주는 노력과 예술의 다각적인 측면을 열어줌으로써 관객의 능동성, 향유 동기를 일으킬 수 있어야 한다.

[그림 2-5] 관객 인게이지먼트를 위한 방법론적 프레임워크

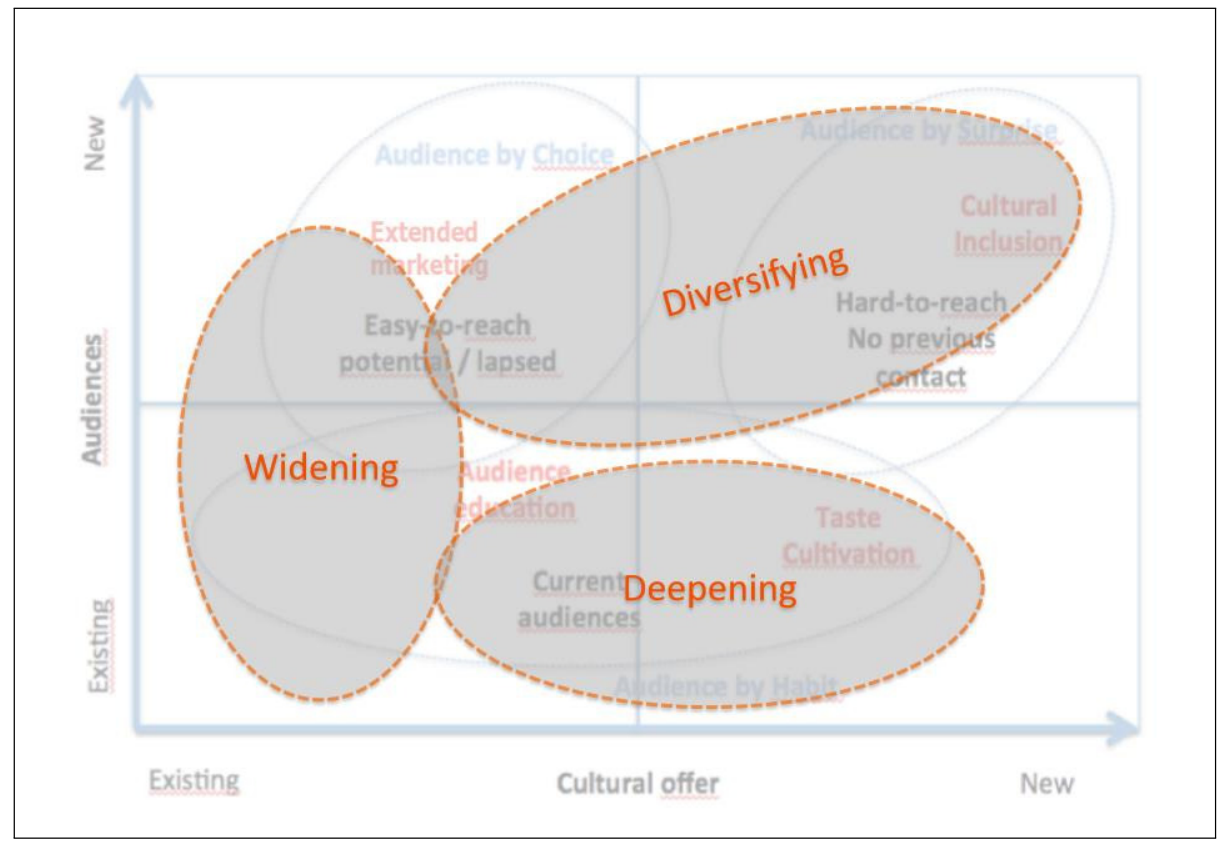

\section{4) 영국 디지털 향유 조사에 기반한 예술향유 유형(2010)}

연구는 디지털 환경에서 예술향유가 이뤄질 때 편익의 유형을 통해 예술향유의 다면적 측면을 살펴보고 있다. 특히, 국민의 $53 \%$ 가 지난 1 년간 디지털 미디어를 통해 예술을 향유하는 추이를 확인하며 인터넷이 변화시킨 예술의 향유(소비, 공유, 창조) 방식에 주목했다. 이러한 현상이 예술향유를 대체하기보다는 확증(augment) 시키고 있다고 보며, 예술향유를 확산할 수 있는 기회점으로 활용할 방안에 대해 제시하고 있다. 이때 예술향유의 유형, 즉 온라인 플랫폼에서 예술향유의 유형을 다 섯 가지로 구분하여 제시하고 있다. 
[그림 2-6] 예술의 온라인 향유를 위한 편익 분류틀

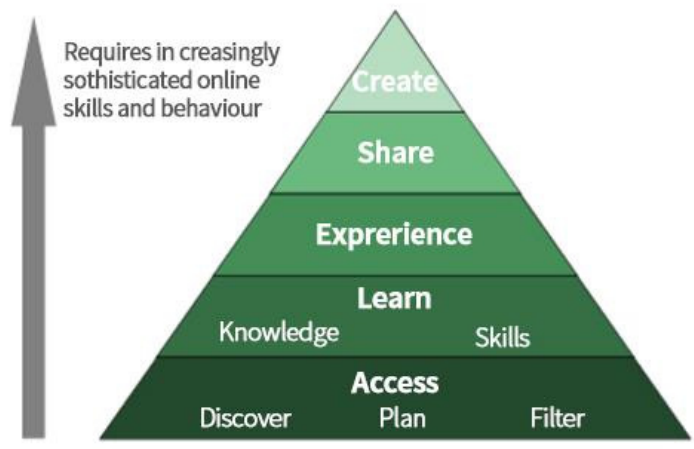

Note: Based on combined analysis of quantitative and qualitative research data

- 창조(create): 창작 프로세스 그 자체에 인터넷을 활용할 수 있다.

- 공유(share): 인터넷을 활용하여 콘텐츠나 경험, 의견을 공유할 수 있다.

- 경험(experience): 창의적이거나 예술적인 작업을 온라인상에서 온전히 경험할 수 있다.

- 학습(learn): 새로운 스킬과 지식을 획득할 수 있다.

- 접근(access): 무엇이 있는 지 찾아볼 수 있고 관람 또는 참여를 계획하며 기회에 대한 선택을 할 수 있다.

5) 예술향유의 다중모드(Novak et al. 2011)

NEA에서 실시한 2007-2008 SPPA(Survey of Public Participation in the Arts, 예술향유실태조사)는 2001 2002년에 실시한 조사와 비교하여 커다란 변화 를 보였고 이는 많은 연구자들의 연구를 이끌었다. 특히, Y세대(또는 밀레니얼 세 대)의 설문 참여와 미디어를 통한 향유가 활성화된 시기를 반영하였기에 NEA는 예 술향유를 입체적으로 이해할 수 있도록 미디어와 기술, 예술교육, 예술창작, 연령과 인종, 민족성의 다섯 가지 주제로 연구를 수행했다. 이러한 연구들은 예술향유 실태 변화가 연령이나 세대와 큰 상관관계를 보이지 않는다는 사실, 그리고 예술교육과 참여가 예술향유에 가장 밀접한 영향요인으로 확인됐다(Rabkin \& Hedberg 2011).

이 시기에 NEA 연구분석팀은 SPPA 데이터를 활용하여 예술향유에 대한 더 나은 이해 기반을 마련하는 데에 목적을 둔 Novak-Leonard \& Brown(2011)의 '다중모드로서의 예술향유'의 독립연구 역시 별도로 지원했다. 이들은 그간 예술향유를 측정해오는 데에 가장 널리 사용되어온 관람 중심의 벤치마킹 구조에 질문을 던지 
며, 문화향유 실태조사 데이터를 기반으로 점점 줄어드는 관람의 양태와 함께 예술 창작과 미디어를 통한 향유가 중복되어 이뤄진다는 사실을 바탕으로 예술향유를 이 해하는 데에 세 가지 양태를 둘러싸고 있는 주요한 기준요소(벤치마크)들을 아래와 같이 짚었다.

[그림 2-7] 예술향유 양태를 결정하는 기준요소

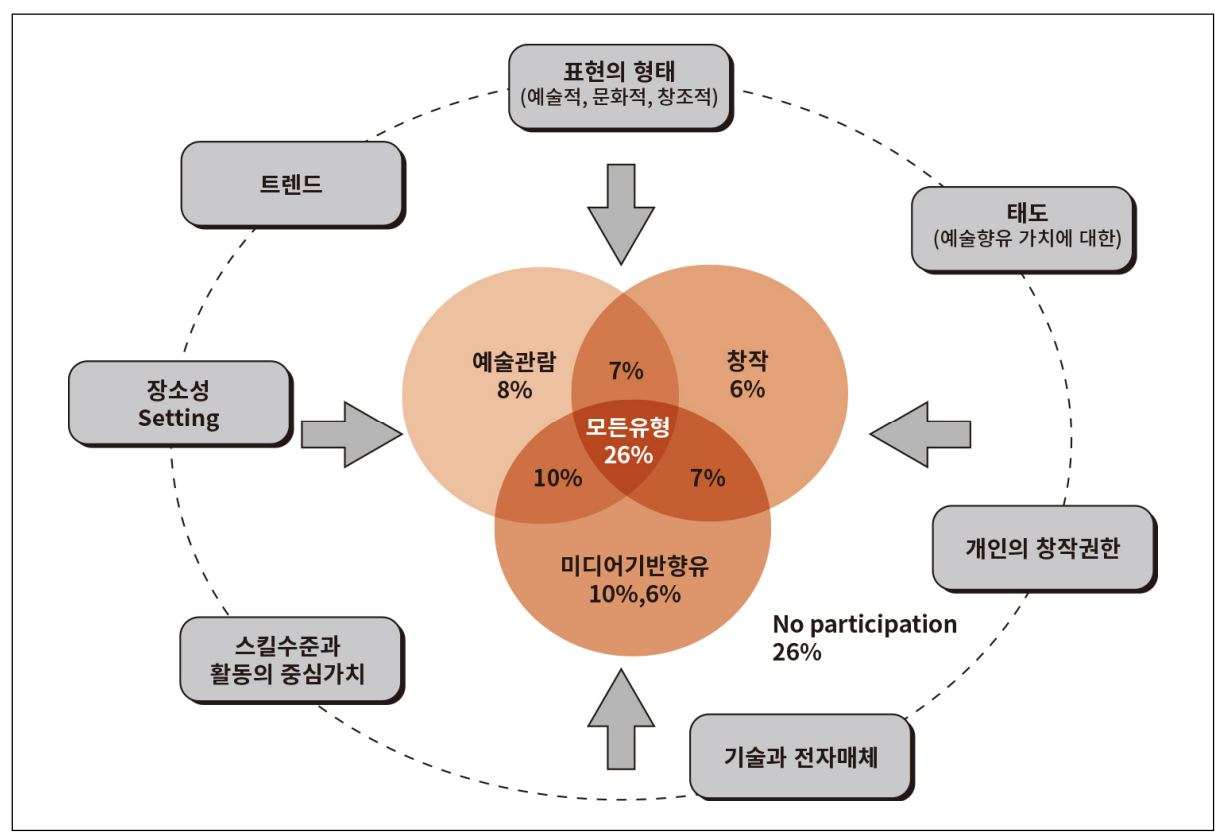

특히, 이들은 예술 형태 자체의 진화가 이뤄지고 있다는 점과 시민들의 예술향유 환경이 예술목적 시설의 경계를 넘어 도서관이나 종교시설, 가정에 이르는 지역의 다양한 공간으로 이동확장하면서 향유자는 세 가지 유형(관람, 창작 및 공연, 미디 어를 통한 향유)의 경계를 넘나들고 있음을 확인하고 있다. 나아가 개개인의 예술향 유 가치에 대한 태도와 예술과 관련된 스킬의 수준, 중심을 두는 가치, 부여받은 창 작의 권한 등을 토대로 다중적인 향유 형태를 경험하고 있음을 성찰하고 있다.

이 논의는 예술향유에 대한 폭넓은 관점이 삶의 질과 깊은 관련성을 두고 삶의 맥락으로 확장하며 형성되는 양상을 반영한 결과이기도 하다. 따라서 '문화생태' 의 확장된 틀을 예술향유의 장으로 넓혔을 때 문화정책이 전통적인 예술기관 밖에서 일어나는 유의미한 예술향유에 대한 진흥이나 개인적인 예술창작에 대한 가치와 예 
술관람의 가치를 어떻게 볼 것인지, 지역사회와 개인에 따라 삶에서 어떤 예술향유 를 중요하다고 볼 것인지에 대한 고민을 남겼다.

6) 능동적 참여에 대한 이해(Brown, Novak-Leonard and Gilbride 2011)

“예술 참여 arts participation라는 어구를 들으면 무엇을 떠올리나?”를 연구주 제로 삼은 Getting in on the act 보고서는 시민들의 경험과 사례들을 통해 예술 향유를 수용적 향유에서 참여적/능동적 향유의 스펙트럼상에서 5가지로 유형화하 면서, 특히 참여적 예술 실천을 통해 예술 향유자의 참여적 예술경험에 대한 이해를 구체화하였다.21) 이들은 크게 참여를 수용적, 참여적으로 구분하고 개념화하였는 데, 이를 도식화하면 다음과 같다.22)

21) 이는 특히 미국과 영국, 호주 등 참여적 예술 활동이 활발한 국가의 100 개의 개별 프로그램을 선별적으로 분석한 것으로 예술향유의 시대적 트렌드를 반영하고 있다.

22) - 수용적 단계

- 관람: 완결된 창작물을 관람하는 것으로 참여 영역에 포함되지 않음

- 강화된 참여: 창의적 사고를 진작시키는 교육적 혹은 "enrichment" 프로그램 등을 통해 예술적 경 험을 맥락화하고 해석하는 등의 활동을 포함하지만 관객의 창의적 표현이 일어나지는 않음

- 참여적 단계

- 크라우드소싱 예술적 콘텐츠: 예술가가 기획한 예술 창작 과정에 관객이 선택이나 기여가 통합됨 예) 트윗으로 오페라 리브레토 창작에 참여

- 공동창작: 예술가가 기획한 창작 작업에 직접적으로 참여함 예) 아마추어 단원들의 전문오케스트라단 에서의 공동연주

- 예술가로서의 관객: 관객이 예술 창작에 대한 제어권을 부여받고 참여 관객들에 의해 예술적 작업이 결정되는 프로그램임. 이 때 중심은 결과물에서 창작 프로세스로 옮겨감

예) 3 4분 길이의 안무를 교육해준 후 함께 그룹댄스를 추는 Bal Moderne 
[그림 2-8] 예술향유의 단계별 유형

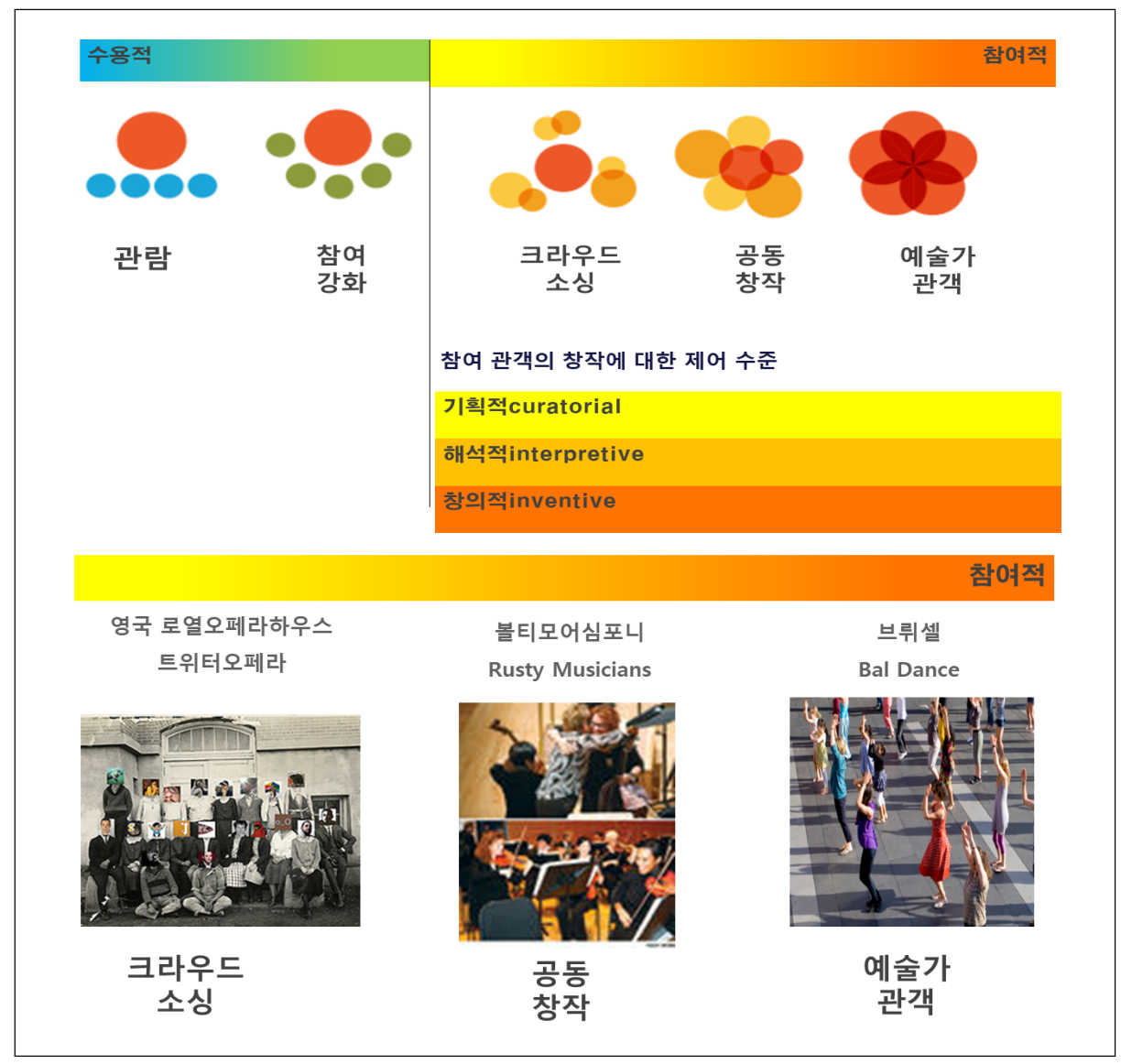

Brown과 동료들은 특히 참여적 단계의 활동에 관객의 예술향유가 일어나는 것 을 상호성 또는 창의적 제어권에 따라 3 가지 단계로 나누고 함께 고려할 또 다른 차원의 세 가지 분류로 기획적, 해석적, 창의적 향유를 제시하고 있다.

[그림 2-9] 창의적 제어권 부여에 따른 예술향유의 유형

\begin{tabular}{|ll|}
\hline 기획적 curatorial & 선택, 편집, 조직화, 투표 등 \\
해석적 interpretive & 실연, 기존 작업을 재창조 \\
창의적 inventive & 완전히 새로운 것을 창조 \\
\hline
\end{tabular}


참여적 단계로 분류되는 세 가지 형태의 예술향유가 이 세 가지 분류에 따른 특성 들의 활동들로 복합적으로 구성될 수 있음을 제안하고 있다. 예술가로서의 관객의 예술향유 형태는 예술가들과의 접점면을 넓게 형성하며 향유자의 주체적 창작 권한 이 상당부분 제공된다면, 크라우드소싱 유형의 예술향유는 매개자나 예술가의 기획 과 해석이 결부되어 참여를 매개하는 유형으로 이해할 수 있다.

\section{7) 예술향유에 대한 과정적 이해}

Brown \& Ratzkin(2011)이 제안한 관객 '인게이지먼트 포물선(Arc of Engagement)'은 관객이 예술향유를 통해 예술과의 관계를 깊이해가는 과정을 이해하는 데 에 유용하다. 이 포물선을 구성하는 다섯 단계는 향유자 관점에서 예술향유가 이뤄 질 때, 참여를 결정한 순간부터 궁극적으로 개인이 누리는 영향에 이르는 과정을 설명한다.

[그림 2-10] 인게이지먼트 포물선

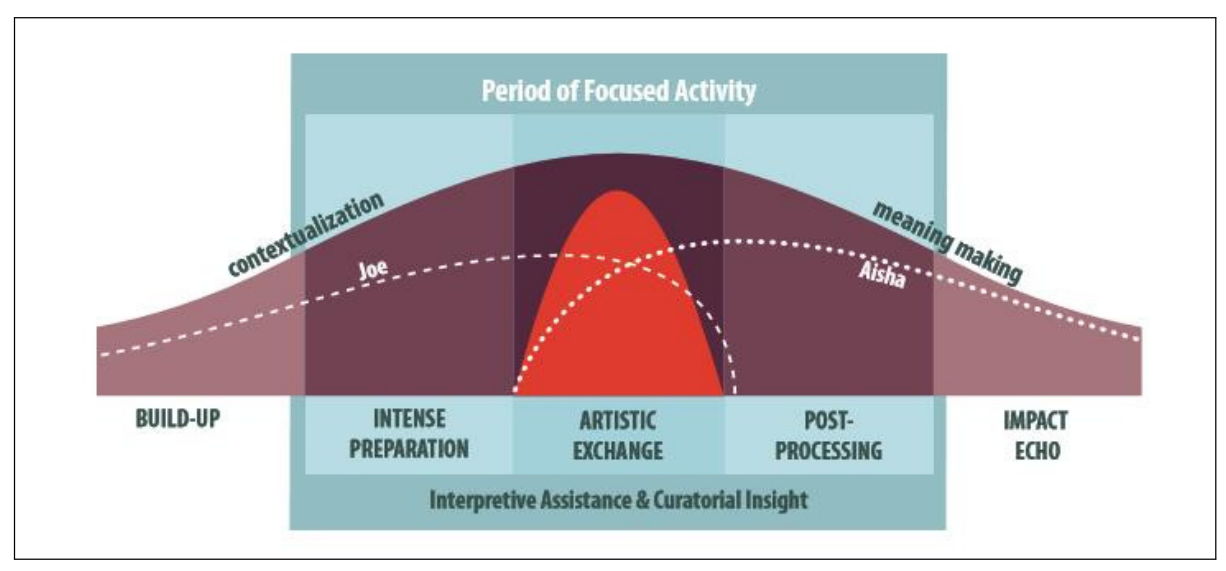

인게이지먼트(engagement) 과정으로 제시된 다섯 단계는 아래와 같다:

- 1 단계 준비와 맥락화: 예술향유를 위한 관람을 결정하게되는 단계로 마케팅 메 시지나 정보를 접한 단계

- 2단계 집중 준비: 행사 바로 직전 수시간이나 수분 사이에 무엇을 기대해야하 는 지를 파악하는 단계 
- 3단계 예술적 교류: 예술과 직접적인 교류가 이뤄지는 단계

- 4단계 사후 프로세싱과 의미부여: 어떤 일이 벌어졌는지 의미를 짚고 비판적 반응을 형성하는 단계

- 5단계 영향/메아리: 잠시 동안이든 평생이든 예술적 경험이 남는 단계

이어서 Brown \& Ratzkin은 위의 향유과정을 토대로 관객을 6가지 유형으로 구 분하고 있다.

〈표 2-3〉Brown \& Ratzkin 6가지 관객유형

\begin{tabular}{|c|c|}
\hline 구분 & 정의 \\
\hline $\begin{array}{c}\text { 독자 } \\
\text { Readers }\end{array}$ & $\begin{array}{l}\text { ‘라이트 관여자’로 공연프로그램북이나 전시장의 벽면(글), 혹은 가끔 기사 } \\
\text { 를 보는 정도에 그친다. }\end{array}$ \\
\hline $\begin{array}{c}\text { 비판적 리뷰어 } \\
\text { Critical reviewers }\end{array}$ & 공연 혹은 전시 관람 전에 평론이나 정보를 찾아본다. \\
\hline $\begin{array}{l}\text { 캐쥬얼 대화형 } \\
\text { Casual talkers }\end{array}$ & $\begin{array}{l}\text { 친구나 가족들과 가볍게 예술 향유 경험에 대해 애기를 나누며 경험을 소화 } \\
\text { 한다. }\end{array}$ \\
\hline $\begin{array}{c}\text { 기술기반 가공형 } \\
\text { Technology-based processors }\end{array}$ & $\begin{array}{l}\text { 온라인상의 블로그나 포럼, 예술기관 홈페이지 등에 글을 작성하거나 } \\
\text { 읽는다. }\end{array}$ \\
\hline $\begin{array}{l}\text { 통찰 추구형 } \\
\text { Insight seekers }\end{array}$ & $\begin{array}{l}\text { 오픈리허설이나 사전 렉처, 공연후 대화의 장 등에 참여하여 예술의 의미를 } \\
\text { 파고들고 큐레이터의 통찰력을 살펴보는 것을 즐긴다. }\end{array}$ \\
\hline $\begin{array}{l}\text { 능동적 학습형 } \\
\text { Active learners }\end{array}$ & 자신의 경험을 온전히 자신을 중심으로 관련성을 갖고 흡수하려고 한다. \\
\hline
\end{tabular}

이렇게 관객들을 유형별로 구분해서 살펴봄으로써 예술기관들이나 정책차원에서 지향하는 관객개발이나 예술향유 증진을 위한 접근에 있어서 유용한 기준으로 제시 하고 있다. 유형별 관객이 기관과 상호작용하는 방식과 동기나 활동 선호에 대한 이해는 관객 혹은 잠재적 관객과의 관계를 맺어가는 관객개발 도구나 정책 개발에 있어서 효과적인 접근을 가능하게 하기도 하고, 정책상 우선순위를 두어야 할 대상 을 구분하는 기준이 되기도 한다.

앞서의 구분이 관객의 선호를 기준으로 뒸다면, 이들을 예술유형을 가능하게 하 는 프로그램을 네 가지 차원의 특성요인에 따라 또한 구분했다. 연구자들은 이 유형 화는 예술가들과 문화기관들이 관객개발 프로그램을 기획할 때 고려할 주요한 준거 들을 제시해주는 데에 두고 있다고 명시하고 있다. 
먼저 '사회적-독자적(social-solitary)'는 향유의 방식이 타인들과 함께 하는지 홀로 하는 것인지를 구분한다. '동료기반-전문가주도 Peer-based to expert-led' 의 경우, 기획자의 의도와 통찰을 전하고 이해시키는 데에 목적을 둔 전문가 주도형 과 동료 간 각자의 이해를 교류하는 유형으로 구분하며, 두 가지의 유형을 함께 공 존하게 하는 구현이 도전적임을 짚고 있다. '능동-수동 Active to passive'는 관객 의 주도성과 권한이 얼마나 부여되는 향유인지를 구분한다. 마지막으로 '지역사회관객 Community to audience'의 경우는 근본적으로 예술향유의 목적이 더욱 폭 넓은 지역사회로의 영향에 두고 있는지 관객 자체에 두고 있는지의 정도를 가늠하 는 척도로 제시된다.

[그림 2-11] 인게이지먼트의 4가지 차원(Brown \& Ratzkin 2011)

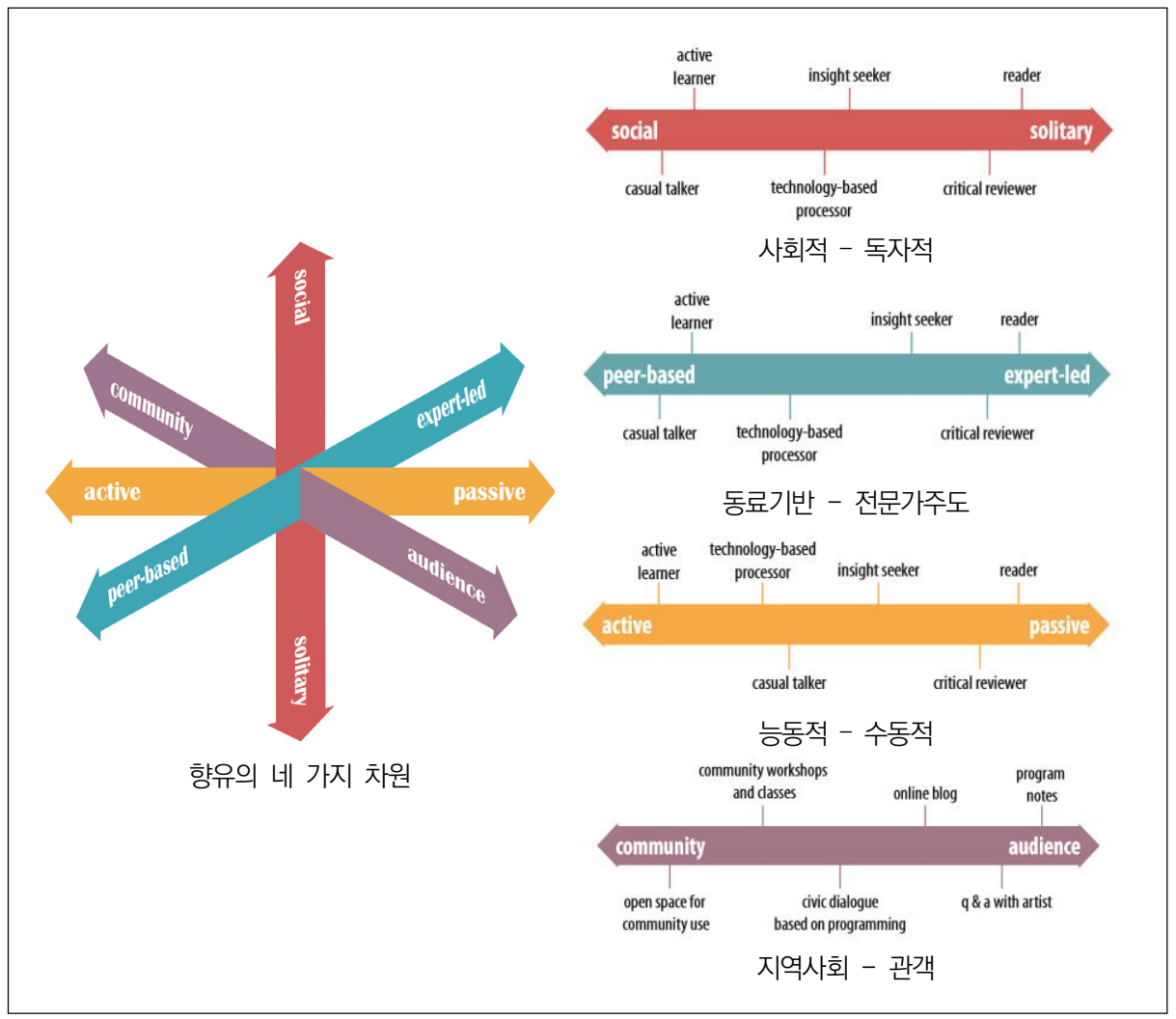




\section{3. '예술향유' 영향요인 및 속성에 관한 학문적 관심23)}

앞서 해외 논의에 이어 예술향유에 대한 국내 논의를 살펴본다. 먼저 '정책영역' 에서의 예술향유의 개념을 점검하기 위해「문화예술진흥법」의 조항에 ‘향유'라는 단어와 사용되고 '향유' 개념이 적용된 역사적인 흐름을 살펴보고, 향유 관련 국내 학술연구와 정책연구를 검토한다. 선행연구에서의 향유의 개념 정의와 함께 '향유 의 구성 요소와 속성', ‘향유에 영향을 주는 요인', ‘향유 행위의 유형'을 살펴본 다.24)

\section{가. 국내 예술향유의 개념적 논의}

1)「문화예술진흥법 으로 본 정책 영역에서의 향유

앞서 논의한 바와 같이 정책 영역에서 '향유’와 ‘향수’의 사전적인 의미를 고려해 구분해서 사용하지 않았던 것은 「문화예술진흥법. 에서의 ‘향유'와 ‘향수' 단어를 사 용한 조항을 통해서도 확인된다. 2019년 11월26일 개정된「문화예술진흥법」 조항 41 개 중 '향수'라는 단어가 들어있는 조항은 1 개이며, '향유'는 3 개 조항에서 사용 하고 있다. '향수'는 문화 향수 기회 확대를 위한 문화시설 설치와 이용 확대에 관한 내용의 제 5 조에서만 사용한다. 반면 향유는 창작 및 향유 활동 활성화를 위한 상품 권 인증제도 관련 조항, 문화소외계층의 문화 예술 향유 기회 확대를 위한 문화예술 복지 관련 조항과 예술의전당 관련 조항에서 사용하고 있다.

연도별 변화를 살펴보면 ‘향수’는 1995년 1월 조항 신설시 처음 사용했지만 ‘향 유'라는 단어는 2005년에서야 등장하며, 문화복지와 관련한 조항에 사용된 것은 2012년으로 '경제적·사회적·지리적 제약 등으로 문화예술을 향유하지 못하고 있는 문화소외계층의 문화예술 향유 기회를 확대'한다는 내용이다. 2000년 신설된 '제 23조의2(예술의 전당)'에서는 '문화향수 기회의 확대'로 사용했던 것을 2007년 4월 11 일 문예진흥법 전부개정 시에 '문화향유 기회의 확대’로 변경한 것을 보면, 일반 적으로 정책 영역에서 ‘향수’와 ‘향유’를 상호 대체하는 단어로 사용해온 것을 알

23) 여기에서는 국내에서 '향유' 그리고 예술향유와 연계하여 진행되는 최근의 논의를 중심으로 살펴본다.

24) '예술향유'라고 명시한 연구의 수는 많지 않아 문화예술향유, 문화향유, 문화향수 외에도 활동, 관람, 참여. 소비 등을 주제로 한 연구와 콘텐츠 분야의 향유 연구도 포괄해서 분석했음을 밝힌다. 
수 있다.25) 현재 '문화 향수’는 문화시설관련 조항에만 사용한다는 점과 '향유'는 창작에 대응하는 활동, 문화복지 관련 조항에 사용했다는 특징이 발견되기는 하지 만 관련 조항수 자체가 많이 않아서 어떤 일관성이나 공통점을 찾아내기는 어려운 상황이다.

〈표 2-4〉「문화예술진흥법」 : ‘향수’, ‘향유’ 단어 사용

\begin{tabular}{|c|c|c|c|}
\hline 조항 & 내용 & 신설(제정) & 개정 \\
\hline $\begin{array}{l}\text { 제5조 } \\
\text { (문화예술 공간의 } \\
\text { 설치 권장) }\end{array}$ & $\begin{array}{l}\text { (1) 국가와 지방자치단체는 문화예술 활동을 진흥시키 } \\
\text { 고 국민의 문화 향수 기회를 확대하기 위하여 문화시 } \\
\text { 설을 설치하고 그 문화시설이 이용되도록 시책을 강구 } \\
\text { 하여야 한다. }\end{array}$ & 1995.01.05 & $\begin{array}{l}2000.01 .12 \\
\text { (주민 } \rightarrow \text { 국민) }\end{array}$ \\
\hline $\begin{array}{l}\text { 제15조 } \\
\text { (도서·문화 전용 } \\
\text { 상품권 인증제도) }\end{array}$ & $\begin{array}{l}\text { (1) 국가는 문화예술 창작 및 향유 활동을 활성화하기 } \\
\text { 위하여 도서(圖書)나 문화예술 재화·용역의 구입을 주 } \\
\text { 된 사용 목적으로 하는 상품권을 인증(認證)하고, 그 } \\
\text { 사용을 촉진할 수 있는 방안을 강구할 수 있다. }\end{array}$ & 2005.01.27 & \\
\hline $\begin{array}{l}\text { 제15조의3 } \\
\text { (문화소외계층의 } \\
\text { 문화예술복지 } \\
\text { 증진 시책 강구) }\end{array}$ & $\begin{array}{l}\text { 국가 및 지방자치단체는 경제적·사회적·지리적 제약 } \\
\text { 등으로 문화예술을 향유하지 못하고 있는 문화소외계 } \\
\text { 층의 문화예술 향유 기회를 확대하고 문화예술 활동을 } \\
\text { 장려하기 위하여 필요한 시책을 강구하여야 한다. }\end{array}$ & 2012.02.17 & \\
\hline $\begin{array}{c}\text { 제37조 } \\
\text { (예술의 전당) }\end{array}$ & $\begin{array}{l}\text { (1) 문화예술을 창달하고 국민의 문화 향유 기회를 확 } \\
\text { 대하며, 그 밖에 문화예술 진흥을 위한 사업을 추진하 } \\
\text { 기 위하여 예술의 전당을 둔다 }\end{array}$ & 2000.01.12 & $\begin{array}{l}2007.04 .11 \\
\text { (향수 } \rightarrow \text { 향유) }\end{array}$ \\
\hline
\end{tabular}

참고로 ‘향유’라는 단어를 직접적으로 사용하지 않았지만 서술하는 내용이 정책 영역에서의 향유 활동과 관련된 조항도 있다. 이는 문화예술활동 단체(동호회), 문 화강좌(문화예술교육), 장애인 문화복지와 관련조항이다. 이 조항들은 학생이나 직 장인의 문화예술활동을 직접 지원하거나, 문화예술강좌를 보급하거나, 장애인의 문 화예술교육 기회를 확대하고 문화예술단체를 지원하는 내용을 담고 있다. 이 조항 에 사용된 '정서와 교양을 높이기 위하여', ‘높은 문화예술을 누리도록 하기 위하 여' '문화적 권리를 증진하기 위하여’ 의 문구에서 향유 정책이 ‘수월성'과 ‘권리’의 의미를 담고 있다는 것을 유추할 수 있다. 더불어 문화예술활동을 위한 단체를 권장 하는 내용은 1972년「문화예술진흥법」 제정 당시부터 지금까지 그대로 유지되고 있다는 점에서 예술향유 정책을 표방하지는 않았지만, '활동'을 오랜 기간 동안 중

25)「문예진흥법 상에 개정 사유가 명시되어 있지 않지만 향수보다는 ‘문화 향유 확대’라는 말이 더 일반적으 로 사용되기에 변경한 것으로 추정해 볼 수 있다. 
요한 요소로 인식해왔음을 알 수 있다. 이와 함께 '문화의 날' 조항은 1972년 제정 당시부터 줄곧 유지되다가 2013년 12월 30일 개정 시 삭제되긴 했지만, '문화가 있는 날'이라는 전 국민 대상의 보편적 복지 성격의 향유 정책으로 명맥을 이어가고 있다.

〈표 2-5〉「문화예술진흥법」: ‘향유’ 관련 조항

\begin{tabular}{|c|c|c|c|}
\hline 제정 & 내용 & 개정 & 구분 \\
\hline $\begin{array}{l}1972 . \\
08.14\end{array}$ & $\begin{array}{l}\text { 제9조(문화의 날 등) (1)국민으로 하여금 문화예술에 대한 } \\
\text { 이해를 깊게 하고 이에 적극 참여하게 하기 위하여 문화의 } \\
\text { 날과 문화의 달을 설정한다. }\end{array}$ & 2013.12.30 삭제 & $\begin{array}{c}\text { 보편적 } \\
\text { 복지 }\end{array}$ \\
\hline $\begin{array}{l}1972 . \\
08.14\end{array}$ & $\begin{array}{l}\text { 제 } 11 \text { 조(학교등의 문화예술진흥) 국가와 지방자치단체는 학 } \\
\text { 교 및 직장의 학생, 직원 기타 종업원의 정서와 교양을 높 } \\
\text { 이기 위하여 학교 및 직장에 학생, 직원 기타 종업원으로 } \\
\text { 구성하는 } 1 \text { 개이상의 문화예술활동을 위한 단체를 두도록 } \\
\text { 권장하여야 한다. }\end{array}$ & $\begin{array}{c}1987.11 .28 . \\
\text { (+그 단체의 육성을 } \\
\text { 위하여 필요한 경우에는 } \\
\text { 활동비의 일부를 지원할 } \\
\quad \text { 수 있다. })\end{array}$ & $\begin{array}{l}\text { 활동 } \\
\text { 지원 }\end{array}$ \\
\hline $\begin{array}{l}1995 . \\
01.05\end{array}$ & $\begin{array}{l}\text { 제14조(문화강좌 설치) (1)국가 및 지방자치단체는 국민이 } \\
\text { 높은 문화예술을 누리도록 하기 위하여 문화강좌 설치기관 } \\
\text { 또는 단체를 지정하여 문화예술을 보급할 수 있다. }\end{array}$ & - & $\begin{array}{l}\text { 교육 } \\
\text { 지원 }\end{array}$ \\
\hline $\begin{array}{l}2008 . \\
01.17\end{array}$ & $\begin{array}{l}\text { 제15조의2(장애인 문화예술 활동의 지원) (1) 국가 및 지방 } \\
\text { 자치단체는 장애인의 문화예술 교육의 기회를 확대하고 장 } \\
\text { 애인의 문화예술 활동을 장려·지원하기 위하여 관련 시설 } \\
\text { 을 설치하는 등 필요한 시책을 강구하여야 한다. } \\
\text { (2) 국가 및 지방자치단체는 장애인의 문화적 권리를 증진 } \\
\text { 하기 위하여 장애인의 문화예술 사업과 장애인 문화예술단 } \\
\text { 체에 대하여 경비를 보조하는 등 필요한 지원을 할 수 있 } \\
\text { 다. }\end{array}$ & - & $\begin{array}{l}\text { 교육, } \\
\text { 지원, } \\
\text { 선별적 } \\
\text { 복지 }\end{array}$ \\
\hline
\end{tabular}

\section{2) 선행연구에서의 향유의 정의와 속성}

국내 학술연구와 정책연구는 먼저 ‘향유’라는 단어 자체의 정의에 초점을 두고 살 펴보았다. 문화예술향유 정책관련 연구들에서는 '향유' 혹은 '예술향유', '문화향유' 가 무엇인지 정의내리기 보다는 향수, 소비 등을 향유와 동일한 의미로 제시하고 있다. '문화향유'라는 용어도 개념에 대한 명확한 규정 없이 '스스로 문화를 즐기고 누린다'는 개인의 적극적인 의지에 대한 표현과 연관된 의미로 포괄적으로 사용되 어 왔다(김태형·김미현 2016: 3; 이재호 외 2010: 106; 홍윤미 외 2015: 188; 최 은용 2014: 224; 이경언 외 2016: 22).

한편, 문화예술향유는 문화소비와 같은 의미로 구별 없이 사용되기도 한다(김수 
현 외 2013: 525). 문화예술은 예술가 또는 제작자에 의해 생산(창작)되고 공연이 나 전시 형태로 유통되어 마지막 소비자가 소비(향유)하는 과정을 거치게 되는데, 문화예술향유는 이 과정 중 마지막 단계라 할 수 있다는 것이다(류태건 2008; 홍윤 미 외 2015: 188). 여기서 나아가 문화예술향유는 문화예술 생산물을 직접 소비하 거나(류태건 2008; 김수현 외 2013; Chan \& Goldthorpe 2007; Lopez-Sintas \& Garcia-Alvarez 2002), 여기에 문화예술을 즐기려는 의지나 선호 같은 태도 (Bourdieu 1984; Peterson 2005)를 포함하는 개념으로 본다.26) 선택이라는 적극 적 의도와 양태를 반영하기 위해 문화향유보다는 문화소비라는 개념의 필요성을 제 기하는 견해도 있으나 연구에서는 일반적으로 문화향유와 문화소비를 동일한 개념 으로 사용한다는 지적도 있다(김두이·금현섭 2018: 117).

문화예술향수 또한 문화예술향유와 거의 동일한 의미로 사용된다. 홍윤미 외 (2015)27)는 '문화예술적인 아름다움이나 감동 따위를 음미하고 즐김'이라는 사전 적인 정의를 가지고 있는 문화예술향수라는 용어도 대부분의 문화예술 관련 연구에 서 문화예술향유와 구별 없이 사용하고 있으므로 문화소비, 문화예술향유, 문화예 술향수는 같은 의미로 사용한다고 설명했다(홍윤미 외 2015: 188).

콘텐츠 분야에서는 상대적으로 '향유’ 의 자발성과 즐거움, 소유의 개념을 강조한 다. 이원 외(2010)28)는 인간과 관계되는 모든 대상을 즐기며 누리어 가지는 모든 것들을 향유라 하고 특히 문화 활동과 관련하여 많이 나타난다고 했으며, 향유는 “포괄적 즐거움을 획득하기 위해 자발적인 참여와 상호작용 행위를 통해 긍정적인 정서를 지속하거나 강화시키는 일련의 과정”이라고 정의했다(이원 외 2010: 27, 34). 이기현 외(2011)29)는 향유는 인간이 일상적인 삶을 영위해가는 과정에서 필 요한 모든 것을 소유하고 즐긴다는 뜻의 용어이고, 결국 향유의 대상은 인간의 삶을 유지하기 위한 평범한 일상생활에서부터 시간을 내고 부가적 비용을 지출하며 즐기 는 여가생활에 이르기까지 그 범위가 다양하다고 했다(이기현 외 2011: 10). 향유

26) 김두이·금현섭(2018), “문화예술향유의 다양성 측면에 대한 분석: 혼종성과 균등성을 중심으로," 「문화정 책논총」, 32(2), 115-143쪽.

27) 홍윤미 외(2018), “문화예술향유에 영향을 미치는 결정요인에 관한 연구,"「GRI 연구논총」, 17(1), 185-211쪽.

28) 이원 외(2010), 「콘텐츠 향유 격차 해소를 위한 지수 개발 연구」, 문화체육관광부.

29) 이기현 외(2011), 「콘텐츠의 문화적 향유 확대방안 연구」. 문화체육관광부. 
란 즐거움 그 자체뿐만 아니라 문화를 즐기며 누리는 것으로서 좀 더 적극적인 의미 에서의 인간의 정서적, 심리적, 정신적 욕구 충족을 통해 삶의 질을 확보하는 포괄 적인 활동이라는 것이다(이기현 외 2011:19). 이경언 외(2016)30)은 콘텐츠 향유 연구의 정의를 따라 예술교육관련 연구를 통해서 예술을 향유한다는 것은 '예술을 생활 속에서 자기 것으로 하여 즐기는 것'이라 하고, 예술향유는 '예술을 능동적으 로 이해하고 경험하고자 하는 개인의 지적, 정의적, 실천적 과정 및 그 결과'로 정의 했다(이경언 외 2016: 22-26).

이는 생활예술분야 정책연구에서 향유를 바라보는 관점과도 일맥상통하는 부분 이 있다. 정종은 외(2017 b)는 '개인'의 관점에서 고급예술과 대중예술 모두 수동적 인 예술 감상자와 소비자로 참여한다면 '예술 향유’가 주체적 활동 경험으로 연결되 기 어렵다며(정종은 외 2017 b: 76), ‘주체성'을 예술 향유의 주요 속성으로 보았 다. 장기적인 관점에서 생활문화와 생활예술을 정책적으로 구분해야 한다며, 생활 문화를 '문화 향유'로, 생활예술은 '예술 활동' 으로 표현했다. 생활문화와 생활예술 은 행위자의 활동을 기준으로 보았을 때 질적 차이가 있으므로, 생활문화의 영역은 감상자, 피교육자 시점에서 개인의 문화예술 향유와 감상, 지식 확장을 목표로 하는 '양적 가치' 증진 사업에 초점을 맞추어 왔으나, 생활예술 영역은 행위자, 창작자의 시점을 취해 개인의 자발적, 직접적 예술 창작 및 활동 기회를 부여하고, 장기간의 수련을 독려하여 개인의 '질적 가치' 증진에 초점을 맞추어 정책 방향이 구축되어야 한다고 했다(정종은 외 2017 b: 83-84).

향유의 정의 외에 향유 분야 연구에서 한 축을 이루는 부분은 향유의 질적인 개념 에 대한 논의이다. 어떤 사람의 향유가치가 다른 사람보다 질적으로 더 우수하다거 나 낮다고 표현하는 데 한계가 있기 때문에, 문화향유의 수준은 질적인 개념을 사용 하기 상당히 어렵다. 특정 지방자치단체의 시민들은 누릴 수 있는 문화적 자산 등의 기반 자체가 많기 때문에 타 지방자치단체보다 문화향유의 수준이 높다고 할 수 없 고, 문화 관련 시설이 많다고 이것이 문화향유의 가치를 제대로 반영한 것이라 할 수 없으며, 실제로 대부분 시민의 관심에 따라 좌우되기 때문이라는 것이다(김태형. 김미현 2015: 3).31)

30) 이경언 외(2016), 「예술 향유 능력 제고를 위한 중학교 예술교육 지원 방안, 한국교육과정평가원

31) 김태형·김미현(2015), "서울시민의 문화향유 유형에 관한 연구: 문화환경 만족도와 문화향수 수준을 중심 
김두이·금현섭(2018)은 국가 발전의 목표가 경제성장에서 삶의 질로 전환되면서 문화예술의 향유에 있어서도 새로운 접근의 필요하다고 했다. 이전의 경우 문화예 술향유는 경제성장에 의해 견인될 것으로 가정되었기 때문에 문화예술향유에서의 문제는 충분한 기회의 제공 여부로 보았고, 따라서 문화예술의 공급 측면이 강조되 었지만 삶의 질에 초점을 맞추게 되면서 경제성장의 효과와 차별화되는 문화예술향 유의 효과에 주목하게 되었다는 것이다. 따라서 향유의 양과 같은 전반적 향유수준 에 더해 어떤 집단이, 어떤 장르의 문화예술을, 얼마나 향유하는지와 같이 다양한 문화예술의 귀착(incidence) 정도에 관심이 높아졌다고 보았다. 기존의 문화예술향 유에서 주목하던 향유량(quantity) 자체가 향유의 질(quality)을 담보하지 못하기 때문에, 가치재(merit goods) 소비로서 문화향유는 다양한 장르의 문화예술에 대 한 직간접적 경험을 통해 개인의 인성과 감성 차원에서 균형 있는 성장에 기여한다 는 점에서 향유의 대상이 일부 특정 장르에 한정되어 있거나, 영화 관람 같은 수동 적 향유에 한정되는 경우 향유의 질이 높다고 볼 수 없다고 보았다(김두이·금현섭 2018: 116). 과거 예술향유 정책은 고급 예술을 경험하게 해준다는 측면에서 공급 위주로 이뤄졌지만 점차 수요자에 대한 관심이 증가하고 있는 추세가 이를 반영한 것이라 볼 수 있다.

향유자 관점의 연구로 나보리·나은(2019)은 문화예술향유활동을 관람과 참여로 구분하여 각 활동에서 향유자가 느끼는 만족도를 비교했다. 문화예술향유자들의 다 양한 문화예술향유 방식을 선호경험의 종류, 경험의 성향, 직접적 참여 여부로 구분 해 관람(attendance)과 참여(participation) 크게 두 가지로 나누고 문화예술향유 의 영향 요소로 보유 자원, 동기, 제약 및 촉진요인, 만족 수준을 검토했다. 그 결과 문화예술활동 참여자는 문화예술 관람자보다 여가 만족이 높으며, 자기계발과 자기 만족을 위해 문화예술을 향유했으며 문화예술 활동 동기가 명확하고 장기적인 목적 을 가질수록 참여자가 될 가능성이 컸다는 결론을 도출했다.

으로,"「지방정부연구」, 19(3), 1-28쪽. 


\section{3) 향유의 구성 요소}

향유자 개인을 기준으로 본 향유의 구성 요소에 관한 연구는 문화예술분야 보다 는 콘텐츠 향유 분야의 연구에서 상대적으로 활발히 이루어졌음을 알 수 있다. 영 화, 만화와 같은 콘텐츠 분야의 향유는 개인의 취향에 따라 일상에서 비용과 시간을 들여서 하는 행위라는 것에 초점을 맞추었기 때문일 것으로 추정된다. 이원 외 (2010)는 향유는 다른 것에 의존해야 하지만 즐기고 누리는 행위 자체는 독립적 행 위이며, 향유란 사람들이 주체적으로 즐기고자 하는 행동을 할 때 성립되며, 자신의 주체성에 의해 독립성이 강해진다고 보았다(이원 외 2010: 28). 여기에서 주목할 만한 향유의 속성은 ‘독립성', ‘주체성', '즐거움’이다. 이어 향유를 구성하는 요인으 로는 ‘긍정적 정서', ‘지속성', ‘즐거움 추구’, ‘접근성', ‘상호작용성', ‘자의성', '경제 력, '관련지식, ‘참여', ‘수행', ‘자기목적적 경험, '몰입', '만족도', ‘혜택'을 꼽았다. 개인적인 속성 이외에 '접근성', '경제력', '관련지식'은 향유에 영향을 주는 요인으 로 작용할 수 있는 속성들이다.

이어 이기현 외(2011)는 콘텐츠 향유란 단순히 특정 상품이나 서비스를 수용 (acceptance), 활용(use), 응용(appliance)하는 것에 머무는 것이 아니라 적극적 인 이용의 개념을 더욱 확장시켜 "개인의 삶을 즐기며 만족감을 얻기 위한 다차원적 과정(process)"이며 향유를 구성하는 여러 요소들을 조합하는 행위라고 했다. 향유 를 구성하는 요소로는 주체성, 즐거움, 욕구충족, 참여, 상호작용, 긍정적 정서, 몰 입, 자의성, 관련지식, 경제력, 접근성 12개를 제시했다(이기현 외 2011: 10). 향유 란 문화수용의 행위과정에서 능동적이고 적극적인 자세를 참여적 수행을 통해서 텍 스트를 주체적으로 즐기는 것이고, 이중 관련 지식, 경제력, 접근성 등은 필요한 경 우 정책적으로 지원되어야 한다고 했다(이기현 외 2011: 19). 
[그림 2-12] 콘텐츠 향유의 구조

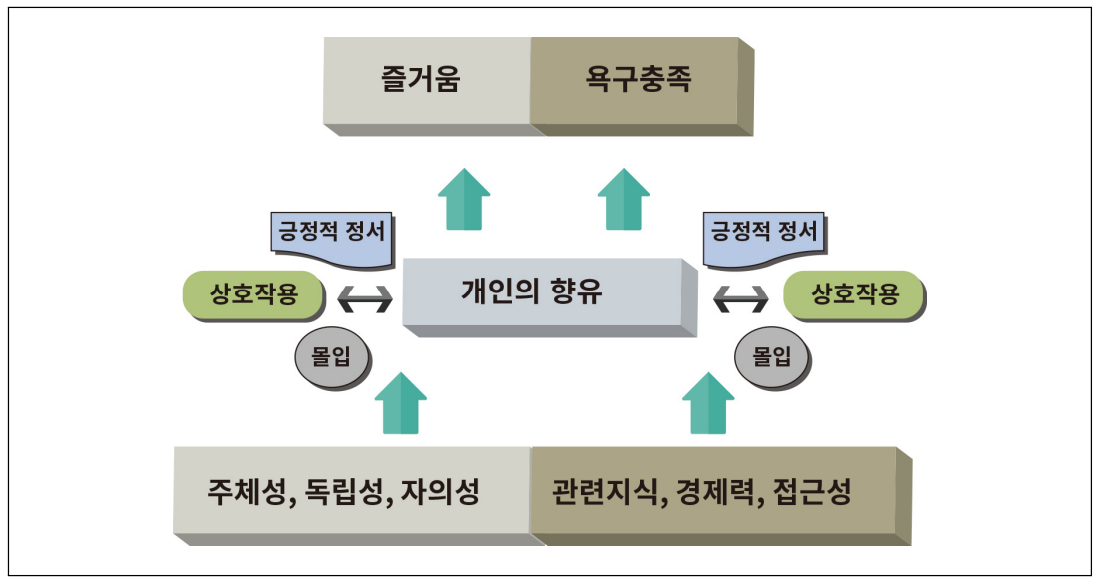

자료: 이기현 외 2011: 10

이경언 외(2016)은 문화콘텐츠 분야의 향유를 '문화수용 행위에서 능동적으로 참 여적인 자세로 참여적 수행과정을 통해서 텍스트를 주체적으로 즐기는 것'으로 정 의하고, 이를 예술향유과 연계해 예술을 향유한다는 것은 예술을 단순히 즐기거나 수용하고 활용하는 것에 그치지 않고 향유자 의지적, 정의적, 실천적 관여를 포함한 복합적인 과정으로 보았다. 예술향유의 구성 요소로는 능동성, 긍정적 정서, 참여의 세 가지를 들었다(이경언 외 2016: 25-26). 이상의 연구에서 나타난 바와 같이 향 유하는 개인이 주체성을 갖고 참여하는 능동적인 속성와 향유하는 과정에서 즐거움 을 통해 만족감을 느끼는 긍정적인 정서가 중요한 향유의 속성이라는 것을 파악할 수 있다.

〈표 2-6〉 선행연구: 향유의 구성 요소

\begin{tabular}{l|l}
\hline 이원 외(2010) & $\begin{array}{l}\text { 긍정적 정서, 즐거움 추구, 자의성, 상호작용성, 몰입, 참여, 접근성, 경제력, 관련지식, } \\
\text { 지속성, 수행, 자기목적적 경험, 만족도, 혜택 }\end{array}$ \\
\hline 이기현 외(2011) & $\begin{array}{l}\text { 긍정적 정서, 즐거움, 자의성, 상호작용, 몰입, 참여, 접근성, 경제력, 관련지식, } \\
\text { 욕구 충족, 주체성, }\end{array}$ \\
\hline 이경언 외(2016) & 긍정적 정서, 참여, 능동성, \\
\hline
\end{tabular}




\section{나. 예술향유의 영향요인과 유형}

\section{1) 예술향유에 영향을 주는 요인}

문화예술향유가 문화적 환경, 체험, 교육에 의해 후천적으로 획득되는 개인의 취 향 및 선호에 의해 영향을 받는다(성제환 2012; 장미혜 2001; 최영섭·김민규 2000; 홍윤미 외 2015: 188)는 문화자본론은, 향유의 영향요인을 논의할 때 반드시 언급 되는 개념이다. 대중문화예술은 특별한 교육이나 훈련 없이도 향유가 가능한 반면 (성제환 2012), 순수문화예술은 후천적인 문화 교육과 체험에 의해 배양된다는 것이 다. 이러한 교육 및 체험을 문화자본으로 개념화한 부르디외(Bourdieu)는 문화자본 의 축적 정도에 따라 문화예술향유의 수준이 달라지고, 이러한 차이는 사회적 계급 간뿐만 아니라 동일한 사회적 계급 내에서도 존재하고, 경제적-사회적 지위가 동일 할지라도 문화자본의 축적 수준에 따라 문화예술향유의 차이가 나타날 수 있다고 했 다(홍윤미 외 2015: 188). 문화자본론은 문화예술에 대한 개인의 취향은 타고나는 것이기보다는 문화자본에 의해 결정된다는 점을 강조한다(김두이·금현섭 2018: 117-118). 부르디외는 계급 간에 문화적 차별성이 존재하며, 계급에 따라 문화 취향 이 서열화 된다고 주장했다. 즉, 지배계급은 차별화의 감각을 통해 정통적 취향을 향유하며, 중간계급은 문화적 선의를 통해 중간적 취향을 그리고 민중계급은 필요한 것의 선택을 통해 대중적 취향을 향유한다는 것이다(이상수·이명진 2014: 28).

문화자본 외에도 홍윤미 외(2015)는 문화예술향유에 영향을 미치는 요인들을 성 별, 연령, 취향, 소득, 가격, 교육수준, 지리적 접근성 등으로 보고 이를 경제자본, 문화자본, 인구통계학적 요인, 지역 규모 등 4 개 요인으로 분류해 상대적인 영향력 을 분석했다(홍윤미 외 2015: 207). 검증 결과 4 개 요인에 따라 문화예술향유의 차이가 존재하는 것으로 나타났다. 정철현·황소화(2010)32)는 문화향수에 영향을 미치는 요인을 개인적 변수와 환경적 변수로 구분했다. 개인적 변수에는 인구통계 학적 변수, 문화예술 경험 변수, 관람편익 변수가 있고 환경적 변수에는 가족 및 준 거집단 변수와 물리적 환경 변수가 있다(정철현·황소화 2010: 213-5).

신나리·박치성(2019)33)은 관련 선행연구 검토를 통해 문화향유에 영향을 미치는

32) 정철현·황소하(2010), "예술마케팅 기법을 통한 서울시민의 문화향수 확대 방안," 「서울도시연구」, 11(1), 211-225쪽.

33) 신나리·박치성(2019), “문화복지 정책대상 범위에 대한 탐색적 연구 문화향유를 중심으로,”「한국사회정 
요인으로 문화예술교육과 향유경험 등 개인의 문화적 특성(최영섭·김민규 2000; 김 서용·김혜선 2007; 성제환 2012; 배영 2013; 허식·윤수영 2013)과 경제적 요인 (소득)이 중요하게 논의되고 있다고 했다(성제환 2012; 정광호·최병구 2006; 최영 섭·김민규 2000; 홍윤미 외 2015). 이외에도 여가지출비(최영섭·김민규 2000), 배 우자의 유무(허식·윤수영 2013), 6세미만 자녀 유무(홍윤미 외 2015), 지리적 특성 (허식·윤수영 2013) 등이 영향을 미친다는 연구가 있었다. 문화향유에 영향을 미치 는 요인은 개인의 문화적 특성과 경제적 요인 외에도 매우 다양함을 알 수 있다.

〈표 2-7〉 선행연구: 문화향유에 영향을 미치는 요인

\begin{tabular}{|c|c|c|c|}
\hline 저자 & 연구목적 & 주요내용 & 결론 및 함의 \\
\hline $\begin{array}{l}\text { 최영섭. } \\
\text { 김민규 } \\
\text { (2000) }\end{array}$ & $\begin{array}{l}\text { 문화소비에 다양한 요인 } \\
\text { 들이 미치는 영향 분석 }\end{array}$ & $\begin{array}{l}\text { 경제적 자본(개인소득, 여가지출비), 문화 } \\
\text { 자본(교육수준), 지역규모, 연령, 성별이 } \\
\text { 전시회/공연/영화 관람 횟수에 미치는 } \\
\text { 영향 }\end{array}$ & $\begin{array}{l}\text { 문화자본이 경제자본보다 } \\
\text { 문화소비에 더 큰 영향을 } \\
\text { 미침 }\end{array}$ \\
\hline $\begin{array}{l}\text { 정광호. } \\
\text { 최병구 } \\
\text { (2006) }\end{array}$ & $\begin{array}{l}\text { 문화격차에 대한 } \\
\text { 실증분석 }\end{array}$ & $\begin{array}{l}\text { 거시차원에서 시대적 흐름 분석, 미시차원 } \\
\text { 에서 문화비지출 유무 및 규모에 대한 변인 } \\
\text { 분석 }\end{array}$ & $\begin{array}{l}\text { 소득과 문화리터러시 차 } \\
\text { 이에 따른 문화격차 현상 } \\
\text { 이 심각함 }\end{array}$ \\
\hline $\begin{array}{l}\text { 김서용. } \\
\text { 김혜선 } \\
\text { (2007) }\end{array}$ & $\begin{array}{l}\text { 문화자본이 삶의 질에 } \\
\text { 미치는 영향과 문화자본 } \\
\text { 결정요인 분석 }\end{array}$ & $\begin{array}{l}\text { 문화적 경험의 여부, 빈도, 다양성, 지출이 } \\
\text { 주관적 안녕에 미치는 영향과 문화자본의 결 } \\
\text { 정요인 분석(성별, 연령, 소득, 교육, 계층) }\end{array}$ & $\begin{array}{l}\text { 문화적 경험 내용의 다양 } \\
\text { 성을 제고하는 정책적 노 } \\
\text { 력이 요구됨 }\end{array}$ \\
\hline $\begin{array}{l}\text { 성제환 } \\
\text { (2012) }\end{array}$ & $\begin{array}{l}\text { 문화소비자본과 문화예 } \\
\text { 술수요의 상관관계 분석 }\end{array}$ & $\begin{array}{l}\text { 인적자본(문화소비자본, 학력) 상품 가격, } \\
\text { 대체재 가격, 개인적 특성(성별, 나이, 직 } \\
\text { 업), 소득 수준이 문화예술소비에 미치는 영 } \\
\text { 향 분석 }\end{array}$ & $\begin{array}{l}\text { 문화예술향수에 대한 수 } \\
\text { 요 분석에서 문화적 가치 } \\
\text { 를 고려해야 함 }\end{array}$ \\
\hline $\begin{array}{c}\text { 배영 } \\
(2013)\end{array}$ & $\begin{array}{l}\text { 문화콘텐츠소비의 } \\
\text { 영향요인 도출 }\end{array}$ & $\begin{array}{l}\text { 개인속성(성별·지역·소득·여가형태·여가시 } \\
\text { 간), 문화자본(본인/부모 교육수준·문화예술 } \\
\text { 교육 경험), 경제자본요인(소득·주관적 계층 } \\
\text { 인식)이 문화예술관람 정도에 미치는 영향 분 } \\
\text { 석 }\end{array}$ & $\begin{array}{l}\text { 매체를 통한 간접적 문화 } \\
\text { 체험보다 오프라인 관계 } \\
\text { 중심 여가활동을 늘리는 } \\
\text { 것이 개인의 사회성 함양 } \\
\text { 에 도움이 될 것 } \\
\end{array}$ \\
\hline $\begin{array}{l}\text { 허식. } \\
\text { 윤수영 } \\
\text { (2013) }\end{array}$ & $\begin{array}{l}\text { 문화서비스 소비 지출 } \\
\text { 결정요인 분석 및 문화 } \\
\text { 서비스 간의 수요특성에 } \\
\text { 대한 비교 }\end{array}$ & $\begin{array}{l}\text { 가구의 인구통계학적 요인, 사회격제적 요 } \\
\text { 인, 지역적 요인과 문화자본이 문화서비스 } \\
\text { 지출액에 미치는 영향 분석 }\end{array}$ & $\begin{array}{l}\text { 특정 문화서비스 분야의 } \\
\text { 자본축적은 문화서비스 } \\
\text { 전체의 소비촉진을 가져 } \\
\text { 올 수 있음 }\end{array}$ \\
\hline $\begin{array}{l}\text { 홍윤미. } \\
\text { 이명우. } \\
\text { 윤기웅 } \\
(2015)\end{array}$ & $\begin{array}{l}\text { 문화예술 관람횟수 결정 } \\
\text { 요인 도출 }\end{array}$ & $\begin{array}{l}\text { 경제자본(소득), 문화자본(교육수준, 문화예 } \\
\text { 술교육 경험 유무), 인구통계학적 요인(성 } \\
\text { 별, 연령, 6세미만 자녀 유무), 지역규모가 } \\
\text { 문화예술 관람횟수에 미치는 영향 분석 }\end{array}$ & $\begin{array}{l}\text { 문화예술전체관람횟수에 } \\
\text { 연령이 가장 큰 영향을 } \\
\text { 미치므로 노년층을 위한 } \\
\text { 정책이 필요함 }\end{array}$ \\
\hline
\end{tabular}

자료: 신나리·박치성 2019: 72, 재인용

책」, 26(2), 65-88쪽. 
이후에도 사회경제적, 혹은 개인의 신체적 여건 등으로 인해 문화예술 활동에 대 한 접근과 이용이 개인마다 다르게 작용하기 때문에(박용치 2003) 문화향유수준에 격차와 불평등이 생긴다는 연구도 나왔다.

최근 들어서는 문화예술활동 향유자 개인의 입장에서 영향 요인을 분석한 연구가 나오고 있다. 이는 정책의 공급자가 아닌 그동안 수혜를 받는 입장이었던 향유자에 주목하기 시작했다는 관점의 전환이 반영된 것으로 볼 수 있다. 나보리·나은(2019) 은 문화예술향유자를 관람자와 참여자로 구분하고 문화예술 향유의 영향 요소로 보 유 자원, 동기, 제약 및 촉진요인, 만족 수준을 검토했다. 문화예술활동 참여자는 문화예술 관람자보다 여가 만족이 높으며, 자기계발과 자기만족을 위해 문화예술을 향유하며, 문화예술 활동 동기가 명확하고 장기적인 목적을 가질수록 참여자가 될 가능성이 크다고 했다. 그러나 전반적으로 향유자 중심에서의 영향 요인과 향유 행 위의 속성에 대한 연구는 해외의 연구에 비해서는 아직 미흡하다고 할 수 있다.

예술향유를 논할 때 자주 거론되는 옴니보어(omnivore) 관련 연구 또한 성별, 연령, 가구소득, 거주지역 규모, 사회인구학적 변수와 같은 향유의 영향 요인을 밝 히는데 집중하고 있다. 1990년대 초반 미국 사회 내에서 사회경제적 지위가 높은 사람들이 폭넓은 문화 취향을 지니고 있다는 연구에서 시작되어, 다양한 문화 활동 에 참여하거나 폭넓은 문화 장르를 선호하는 사람들을 '옴니보어(omnivore)'라고 부르기 시작했으며, 고급문화(highbrow culture)에 대한 취향뿐만 아니라 대중문 화(popular culture)를 아우르는 폭넓은 문화 취향이 문화자본의 중요한 형태로서 인식되기 시작했다는 것이다(이상수·이명진 2014: 26). 그동안 옴니보어와 관련된 많은 경험적 연구들은 교육수준, 계급, 사회자본, 연령과 같은 다양한 변수들이 폭 넓은 문화 참여에 영향을 미치고 있음을 밝혀왔다(이상수 2013: 936).

\section{2) 예술향유의 유형}

예술향유를 유형화 한 연구는 문화환경, 문화향수 수준, 문화참여방식과 문화선 호도와 같은 요인을 주요 기준으로 잡고 향유 형태를 분석했다. 김태형·김미현 (2016)은 문화환경 만족도와 문화향수 수준34)을 두 축으로 놓고 문화향유형, 문화

34) 문화향유의 유형화 틀을 위의 두 축으로 제시한 것은 문화향수 수준이 높더라도 경제적·사회적 배경에 
안주형, 문화도약형, 문화빈곤형으로 서울시 25 개 자치구의 유형을 구분했다. 문화 향유형은 시민들의 문화환경 만족도와 문화향수 수준이 모두 높은 네 가지 유형 중 가장 바람직한 유형으로, 서울시 문화정책이 궁극적으로 달성하고자 하는 목표에 부합하는 형태로 보았다. 문화안주형은 문화환경 만족도는 높지만 문화향수 수준이 상대적으로 낮은 유형을 가리킨다. 문화안주형에 속하는 자치구는 문화향수 수준의 향상을 유도하여 문화향유형으로 이동할 수 있는 정책 대안을 마련할 필요성이 있 다고 했으며, 문화 도약형은 문화환경 만족도는 낮지만 문화향수 수준이 높은 자치 구, 문화빈곤형은 문화환경 만족도와 문화향수 수준이 모두 낮은 자치구가 속한다 고 구분했다. 문화 인프라와 문화생활의 수준이 반드시 정비례하지 않는다는 점에 서 주변에 인프라는 많지만 향유를 하지 않는 이유와, 인프라는 부족하지만 ‘향유를 많이 하게 하는 주요 요인을 파악해 내는 것'이 예술향유정책에서 주요하게 다뤄야 할 부분이라 하겠다.

[그림 2-13] 문화환경 만족도와 문화향수 수준에 따른 유형

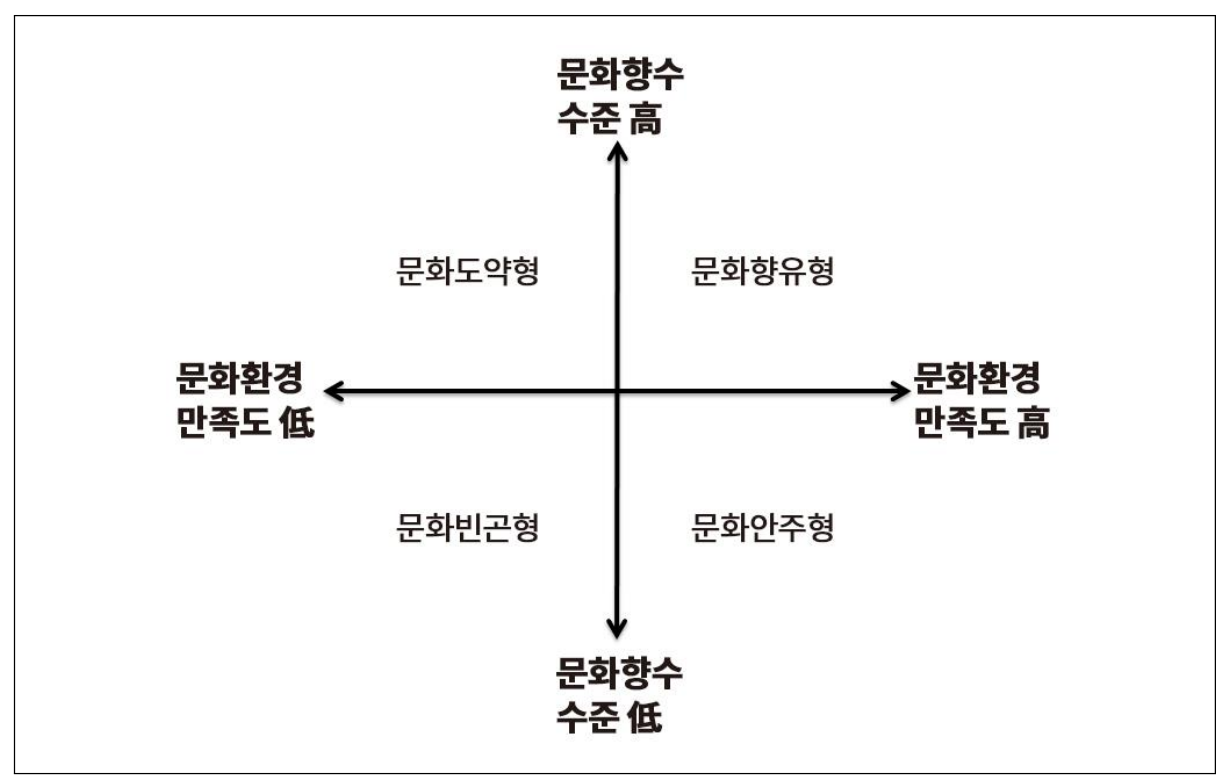

자료: 김태형·김미현 2016: 7

따라 문화환경에 대한 만족도에서 차이가 나타날 수 있고, 또한 반대의 경우도 존재할 수 있기 때문이다. (김태형/김미현 2016: 6) 
이상수(2013)35)는 앞서 언급한 문화 선호나 직접적인 문화소비 활동에 비해 연 구자들이 크게 주목하지 않았던 문화생산 활동을 끌어들여 문화소비와 문화생산을 두 축으로 한 옴니보어의 새로운 유형화를 시도했다. 문화소비의 영역에서는 다양 한 활동에 참여하며 옴니보어적 취향을 보이는 사람이 문화생산의 영역에서는 폭이 좁은 유니보어일 수도 있으며, 정반대의 경우도 가능하다는 것이다. 요컨대, 문화소 비 다양성과 문화생산 다양성을 두 축으로 설정해 유니보어, 생산중심형 옴니보어, 소비중심형 옴니보어, 혼합형 옴니보어, 총 4집단으로 구분했다(이상수 2013: 934). 유니보어는 문화소비와 생산 다양성이 모두 낮은 집단이다. 생산중심형 옴니보어는 문화생산 다양성의 폭이 넓은 반면 문화소비 다양성은 폭이 좁은 집단이며 반대로 소비중심형 옴니보어는 문화소비 다양성은 폭이 넓으나 문화생산 다양성은 폭이 좁 은 집단이다. 마지막으로 혼합형 옴니보어 문화소비와 생산 다양성의 폭이 모두 넓 은 집단이다(이상수 2013: 940-941).

〈표 2-8〉 문화 참여 유형 구분: 문화소비 다양성과 문화생산 다양성 고려

\begin{tabular}{c|c|c|c}
\hline \multicolumn{2}{c|}{ 구분 } & \multicolumn{2}{c}{ 문화소비 다양성 } \\
\cline { 3 - 4 } \multicolumn{2}{c|}{} & 낮음 & 높음 \\
\hline \multirow{2}{*}{ 문화생산 다양성 } & 높음 & 생산중심형 옴니보어 & 혼합형 옴니보어 \\
\cline { 2 - 4 } & 낮음 & 유니보어 & 소비중심형 옴니보어 \\
\hline
\end{tabular}

자료: 이상수 2013: 941

이어 2014년 연구36)에서는 문화 선호와 문화 참여의 다양성이 결합되는 방식을 살펴보고 전반적으로 문화 활동에 무관심한 유형을 '문화적 고립자(culturally isolated)', 다양한 문화 활동을 선호하는 것과 달리 여러 문화 활동에 폭넓게 참여 하지는 않는 '옴니보어적 선호자(omnivorous likers)', 대중적인 문화 활동을 위주 로 하는 '대중적 선호 및 참여자(popular likers and participants)', 다양한 문화 활동을 선호할 뿐만 아니라 실제 문화 실천의 폭도 넓은 '옴니보어적 선호 및 참여 자(omnivorous likers and participants)' 네 가지 집단으로 유형화 했다. 한국

35) 이상수(2013), "문화 참여의 유형과 그 결정요인에 관한 연구; 소비활동과 생산활동의 결합을 통하여," 「한국사회학회 사회학대회 논문집」, 933-950쪽.

36) 이상수·이명진(2014), "문화 선호와 참여의 다양성에 관한 연구: 사회경제적 지위와 사회 연결망의 영향 을 중심으로,"「한국사회학」, 48(5), 25-57쪽. 
사회에는 거의 모든 문화 활동에 대해 무관심한 '문화적 고립자' 집단과 상대적으로 적은 수의 대중적인 문화 활동만을 배타적으로 선호하며 참여하는 '대중적 선호 및 참여자' 집단과 문화 선호와 참여 다양성이 모두 높은 수준으로 일치하는 '옴니보어 적 선호 및 참여자’ 집단과 이와 달리 문화 선호와 참여 다양성의 수준이 일치하지 않는 ‘옴니보어적 선호자' 집단(이상수·이명진 2014: 45)이 있다는 것이다. ‘옴니보 어적 선호 및 참여자' 집단은 결과적으로 가장 높은 수준의 문화 자본을 향유하고 있는 반면, 옴니보어적 선호자 집단은 폭넓은 문화 활동을 선호함에도 불구하고 실 제로 참여하고 있는 문화 활동의 폭은 상대적으로 좁은 것으로 나타났다. 이를 통해 한국 사회에서 다양한 문화 활동을 선호함에도 여러 가지 제약으로 인해 실질적으 로 여러 문화 활동을 향유하지 못하는 사람들이 존재한다고 보았다(이상수, 이명진 2014: 49).

〈표 2-9〉 문화 선호와 문화 활동 참여 다양성에 따른 유형 구분

\begin{tabular}{c|c}
\hline 유형 & 특성 \\
\hline $\begin{array}{c}\text { 문화적 고립자 } \\
\text { (culturally isolated) }\end{array}$ & 전반적으로 문화 활동에 무관심 \\
\hline $\begin{array}{c}\text { 옴니보어적 선호자 } \\
\text { (omnivorous likers) }\end{array}$ & 다양한 문화 활동 선호, 문화 활동 참여 다양성 수준 낮음 \\
\hline $\begin{array}{c}\text { 대중적 선호 및 참여자 } \\
\text { (popular likers and participants) }\end{array}$ & 대중적인 문화 활동 위주 \\
\hline $\begin{array}{c}\text { 옴니보어적 선호 및 참여자 } \\
\text { (omnivorous likers and participants) }\end{array}$ & 다양한 문화 활동 선호, 문화 활동 참여 다양성 수준 높음 \\
\hline
\end{tabular}

자료: 이상수·이명진 2014: 45

\section{다. 분석 및 시사점}

그동안 문화정책에서 '향유'와 ‘향수’를 혼용해왔다는 사실은 문예진흥법에 사용 된 '향수'와 '향유'를 사용한 조항에서도 확인되었다. '향수'라는 단어에 '혜택을 받 는다'는 수동적인 입장과 복지적인 성격이 일차적으로 내포되어 있고, ‘향유'에는 '누리어 가진다'는 개인이 즐기고 소유하는 개념이 있다는 차이가 있음에도, 주로 문화 복지 사업에서 ‘향수’보다는 ‘향유 기회를 확대’ 한다는 목적을 표방해 왔다.

한편, 콘텐츠 향유 분야의 선행연구에서 향유의 과정에서는 개인의 주체성, 능동 
성이 매우 중요한 요소로 작용하며, 그 과정에서 얻는 즐거움, 만족감, 행복감이 예 술향유 행위를 하는 주된 목적이 될 수 있다는 사실은 예술향유에도 매우 유의미한 지점이라 볼 수 있다. 예술향유 분야의 향유자 개인에 대한 연구가 콘텐츠 분야에 비해 상대적으로 부족했으며, 향유자 개인보다는 공급자적인 관점에서 경제력, 접 근성과 같은 외적인 요인들을 제거하는 방식으로 복지 차원의 정책을 추진해온 부 분에 대한 방향의 전환과 범위의 확대가 필요하다는 것을 시사한다고 할 수 있다. 이는 경제적인 요인을 없애기 위한 '통합문화이용권'이나 어린이, 노인, 장애인 대 상의 복지기관 문화예술교육, 지리적인 문화 격차를 해소하기 위해 '찾아가는'방식 으로 프로그램을 공급하는 '신나는 예술여행'과 같은 선별적 복지 차원의 사업들과 도 연결된다고 볼 수 있다. 향유의 양이 향유의 질을 담보하지 못한다는 점에서 다 량의 프로그램을 수동적으로 공급 받는 개념의 향유가 아닌 개인의 취향과 선호도 가 반영될 수 있는 향유 정책의 필요성을 다시 한 번 확인할 수 있다.

또한 용어가 혼용되어 온 경향이 있지만 문화소비는 문화향유보다 적극적인 의도 가 반영되어 구매로 이어지는 개념이며, 관람과 대비되는 활동하는 개념의 문화참 여자는 자기계발과 자기만족을 위해 향유 활동을 하며 동기가 명확하다는 차이가 나타났다는 점에서 예술향유 정책영역에서 보다 세심한 용어 선택과 접근이 필요하 다 하겠다.

향유의 유형화를 시도한 선행연구에서는, 문화 인프라가 풍부하지만 향유 수준이 낮은 지역과 문화 활동은 선호하지만 실제로는 참여하지는 않는 집단에 주목하고, '관심'과 같은 요인과 지역과 집단의 특성을 파악해 정책적으로 반영해야 할 필요가 있다는 점을 강조한다. 문화참여에 있어서도 문화소비를 중심으로 하거나 문화생산 만을 중심으로 하는 유형이 별도로 존재하며, 문화소비의 활발한 참여가 반드시 문 화생산 참여로 연결되지 않는다는 사실을 입증하고 있다. 즉, 공연이나 전시 관람을 선호하는 예술향유자들이 실제 악기를 연주한다거나 그림을 그리는 활동형의 단계 로 가는 것은 아니며 향유자의 다양한 속성과 유형을 인지하고 정책적으로 접근해 야 할 필요가 있음 의미한다. 


\section{4. 최근 예술향유 정책담론37)}

최근 해외 예술정책 관련 정책 논의에서 주목되는 현상은 그간 암묵적으로 예술 정책의 핵심적 방점이 '창작지원'에 있는 것으로 전제하고 접근했던 것에서 '향유' 지원과의 균형적 접근을 강조하는 경향이 나타나고 있다는 점이다.

이러한 논의의 흐름은 정책지원에 있어 '예술'의 범주를 어떻게 설정해야하는 가 의 문제, 사회적 환경변화에 따른 '예술향유' 개념에 대한 재인식, 일반 시민의 입장 에서의 '예술향유' 양태, 동기 등의 다변화를 어떻게 반영할 것인가의 문제와 긴밀 히 연동되면서 전개되고 있는 특성이 나타나고 있다. 더욱이 궁극적으로 이러한 담 론적 논의의 확산이 정부정책에 있어 예술향유 지원의 목적의 재설정 및 이를 구현 하기 위한 정책적 방법론의 다원화를 필연적으로 요청하고 있다는 점에서 주목된다 고 하겠다.

〈표 2-10〉최근 해외 예술향유 정책담론의 특성

최근 해외 예술향유 정책담론의 특성

예술정책에서의 ‘향유’지원 논의 강화

예술의 정의, 범주에 대한 재성찰 필요성 제기

예술향유 양태에 대한 입체적 인식

향유지원 목적 및 정책적 접근 방법론의 변화

\section{가. 예술정책에서의 ‘향유’지원 논의 강화}

지난 2020년 1월 영국 잉글랜드예술위원회(Arts Council England, 이하 ACE) 는 향후 10년간의 예술지원정책 비전서인 Let's Create: Introducing Our Vision 2020-2030 발표를 통해 앞으로의 예술지원 방향성이 예술의 수월성과 더 불어 '접근성' 확대에 보다 중점을 둘 것임을 발표하였다.

영국 예술지원 정책의 경우 수월성(Excellence)과 접근성(Access)라는 양대 가

37) 여기에서 다루는 향유정책 담론 논의는 주로 영국 및 유럽, 미국에서 진행되는 해외 논의에 한정된 것임을 밝힌다. 
치를 중심으로 발전되어 왔다. 이들의 예술지원 역사에 있어 예술지원의 철학적 토 대로서 '문화의 민주화' 와 '문화민주주의' 가치는 시기별 정치적 패러다임 및 사회 경제적 변화를 반영하여 수월성과 접근성을 강조하는 양상이 각각 조금씩 다르게 나타나곤 했었다.

가령, 신노동당 시기(1997 2010) 영국 예술정책이 문화민주주의와 접근성에 대 한 강조가 두드러졌던 반면, 2008년 경제위기 이후 영국 예술정책은 축소된 예술지 원 예산 하에서 수월성 중심의 지향에 방점을 두고 진전되어 왔다(ACE 2010). 상 대적으로 '우수하고 수월한 예술 중심의 지원'을 강조하고, 이에 기반을 둔 대중적 확산을 모색했던 셈이다. 이런 배경에서 $\mathrm{ACE}$ 가 이번에 발표한 Let's Create의 경 우 지난 2010년 발표한 Achieving great art and culture for all의 후속 계획이 라고 할 수 있다.

그러나 앞선 1 차 계획과 달리 2 차 계획은 ‘향유증진 및 접근성 확대’ 담론에서의 큰 변화가 주목된다. 시민의 '일상적 삶' 속에서 나타나는 '다층적인 예술향유 양태 변화'를 보다 적극적인 차원에서 정책영역으로 포용하고 이를 진작시키기 위한 다 원적 접근을 모색하겠다는 의지를 담고 있기 때문이다.

이번에 발표된 비전서 Let's Create는 그간 예술의 대중화를 위해 정책적 노력을 지속해 왔음에도 불구하고 여전히 예술향유에서의 지리적, 사회경제적 격차가 크다 는 점, 예술이 여전히 '고급예술' 차원에서만 이해되고, 예술계 내에서의 문화다양 성이 충분히 반영되고 있지 못하고 있는 등의 한계가 있음을 지적하고 있다. 이런 점에서 향후 정책지원 방향성에 있어 변화가 감지되는데, 그간 정책지원의 방점을 "한정된 몇몇 장소에서의 수월성(excellence)에 방점을 두던 것을 향후 일반 시민 삶에 가장 가까운 곳에서 예술향유의 기회가 발현될 수 있는데 집중하겠다"는 지점 이 바로 그 것이다.38)

38) Mark Brown(2020.01.27.), Arts Council England aims to foster culture in every 'village, town and city'. The Guardian. 


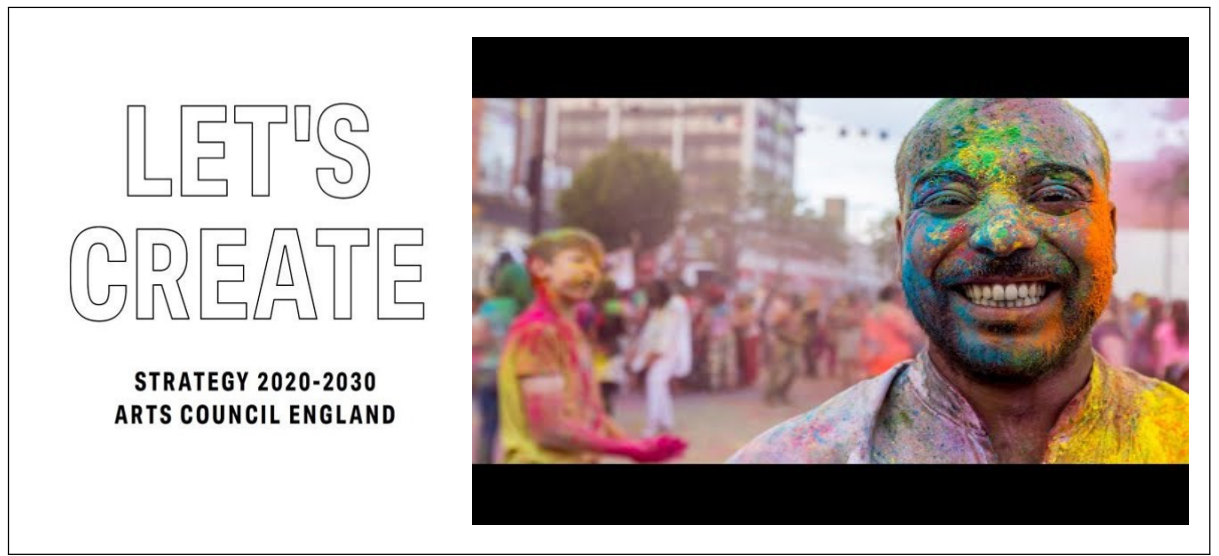

자료: Arts Council England 홈페이지 https://mww.artscouncil.org.uk/letscreate (최종접근: 2020,07.27)

실제로 최근 영국에서는 64 million artists39), Get Creative Festival40) 같은 일반시민들을 위한 일종의 생활예술 캠페인 및 지원사업이 상당히 활발하게 진행되 고 있는 상황이다. 전 국민이 일상생활 속에서 크고 작은 창의적 발상과 도전을 할 수 있도록 독려하는 64 Million Artists 캠페인이나, 공공기관 주도로 이뤄지는 Get Creative Festival 같은 정책 사업들은 모두 공통적으로 ‘일상성', ‘근린성' 등 의 가치를 강조하고 하는 한편, 고급예술 중심이 아닌 '시민들이 스스로 선택하고 원하는 예술'을 전제로 하고 있어 특징적이다.

공공 예술지원에서의 ‘향유’에 대한 정책인식의 변화는 이웃국가인 아일랜드 등 타 유럽국가이나 미국에서도 확인된다.

39) 모든 이들은 창의적이라는 전제 하에 사람들이 일상적 삶(회사, 학교 등)에서 창의적 생각과 상상력을 발 현할 수 있는 도전기회를 독려하는 캠페인으로 2014년 사회적기업에 의해 시작되었음. 매월 새로운 "창 의적 도전(creative challenge)" 주제를 제시하여 참여자들이 다양한 예술적 방식으로(시쓰기, 만들기/공 예, 춤, 공연, 패러디, 그림, 사진, 캘리그래피, 등) 자신의 생각을 표현할 수 있도록 하고, 이들 작품을 온라인 상에서 공유할 수 있도록 하는 플랫폼을 제공한다.

40) "Get Creative" 캠페인은 2014년 발간된 Warwick Commission's year long investigation into the Future of Cultural Value의 후속 결과로 탄생했다. 이 캠페인은 일반시민들이 자신의 가정이나 가장 가까운 지역 공간에서 일상적 창의성을 발현할 수 있도록 생활예술 활동을 독려하기 위한 것으로 영국 공영방송인 $\mathrm{BBC}$ 와 협업 하에 다양한 예술기관 진행되고 있다. 
[그림 2-15] 아일랜드예술위원회(2016 2025) 비전

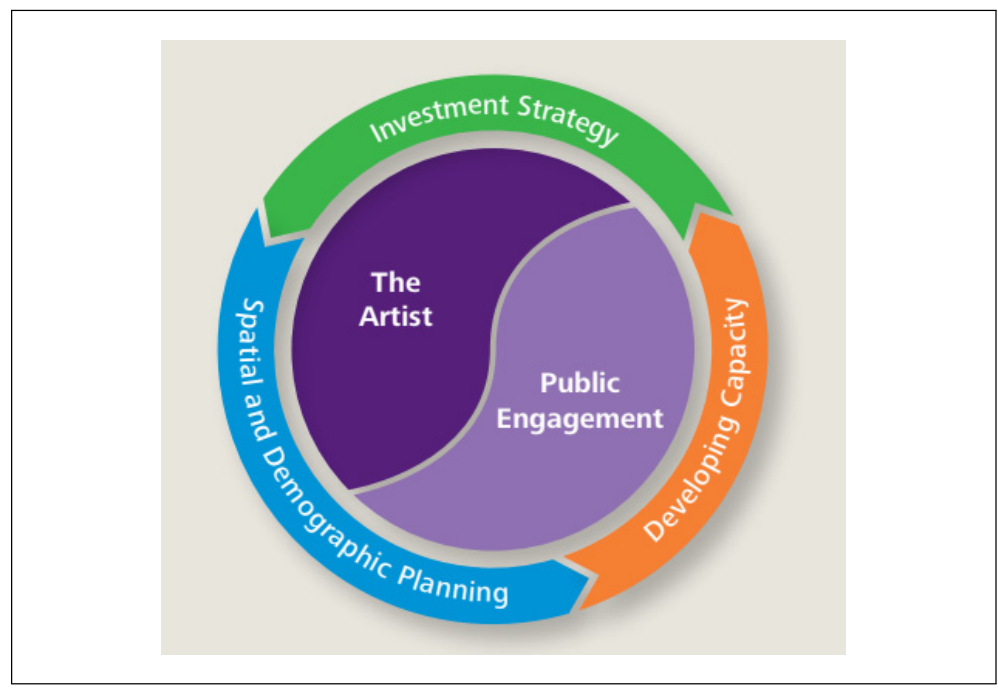

자료: Arts Council Ireland(2016), Making Great Art Work: Leading the Development of the Arts in Ireland. p.15

영국의 이웃 국가인 아일랜드예술위원회는(Arts Council Ireland, 이하 ACI) 역 시 2016년 발표한 10개년 계획을 통해 ACI가 추구하는 예술지원의 핵심적 가치에 서의 창작(The Artist)과 향유(Public Engagement)의 균형적 접근을 강조하고 있 다. 얼핏 보면 영국 중심의 예술정책 논의에서 전형적으로 나타나는 excellence와 access, 양대 가치의 균형적 강조로 보여질 수도 있다. 그러나 동시에 접근성과 향 유를 강조하는 방식이 이전과 달라지고 있음이 확인되어 주목된다.

이들의 ACCESS의 개념은 한편으로 문화민주화 관점에서의 다양한 예술장르가 더 많은 이들에게 다가갈 수 있도록 하는 것에 가깝다. 그러나 방법론에 있어 '향유' 의 개념을 넓게 규정하고 접근한다. 공연장과 전시장을 방문하는 전형적이고 전통 적인 '향유'방식의 한계를 지적하고, '예술가와 일반시민이 협업하는 방식의 확산' 을 강조하고 있기 때문이다(Developing Capacity). 더불어 갈수록 인구구성의 다 양성 등 사회변화를 반영하여 일반시민들이 자신과 가장 가까운 곳에서 예술을 다 양하게 접할 수 있는 '공간적', '인구통계적' 접근(Spatial and Demographic Planning)의 필요성을 제기한다. 


\section{나. ‘예술’의 정의, 범주에 대한 재성찰 필요성 제기}

두 번째로 주목되는 지점은 전통적인 고급예술 중심의 '예술’이 현재 사회를 살아 가는 다양한 이들의 '예술'을 대변하고 있는가에 대한 질문이 보다 적극적으로 제기 되고 있다는 점이다. 1990년대 후반부터 본격화된 예술향유에 대한 연구는 여전히 정착된 개념이라기보다는 기술변화나 사회의 변화에 따라 변화하는 사람들의 행동 과 태도, 또 지속적으로 진화 발전하는 예술의 형식과 형태를 반영하는 동적인 개념 이라는 사실을 그간의 논의와 변화된 조사 내용과 분석에서 살펴볼 수 있다 (UNESCO 200941); UNESCO Institute for Statistics 2012; NEA 2015; Novak-Leonard et al. 2014; Novak-Leonard, Wong and English 205; Stallings \& Mauldin 2016). 연구목적에 따라 때론 문화향유로 포괄하여 정의내 리고 그 안에서 예술의 영역을 범주화하기도 하고(UNESCO 2009), 개념적 이해를 배경으로 예술향유를 살피기 위한 대상 분야(예: 장르)와 조사되어야 할 요소들을 나열하며 도구적 정의(Australia Council for Arts 2018)를 내리기도 한다. 이는 측정될 수 있는 범주와 대상을 구체화시켜, 예술향유의 용어가 지니는 경계의 모호 성을 보완하는 구체적 판단기준을 제공하되, 어떤 맥락 하에서 분석되고 해석될 지 의 맥락을 제공하는 방식이기도 하다.

〈표 2-11〉 외국의 향유실태조사: ‘예술향유’ 정의

\begin{tabular}{|c|c|}
\hline 구분 & 예술향유 정의 \\
\hline $\begin{array}{l}\text { UNESCO Cultural Participation } \\
\text { Survey(2009) }\end{array}$ & $\begin{array}{l}\text { - “개인들에게 있어서 자신들의 정체성을 정의하고 개인적 표현을 가 } \\
\text { 능하게 하는 데에 자신들의 문화적, 정보적 역량과 자본을 증대하는 } \\
\text { 방식을 대표하는 활동에 참여하는 것” } \\
\text { * “문화’를 지역사회에서 삶의 질이나 전통, 신념을 반영한 소비는 물 } \\
\text { 론 활동(activities)들을 포괄하는 것으로 범위를 정립하고 있다는 } \\
\text { 점과 더불어 “향유(participation)를 관람은 물론 행사참여나 아마 } \\
\text { 추어 ㅎㅘㅘ동 등 비공식적 향유를 포함하는 동시에 능동적인 양태로서 } \\
\text { 의 향유와 수동적인 양태로서의 향유를 모두 포함함 }\end{array}$ \\
\hline $\begin{array}{c}\text { 호주 } \\
\text { Australian participation } \\
\text { in the arts(2010) }\end{array}$ & $\begin{array}{l}\text { - 시각예술, 연극, 무용, 문학, 음악, 공예에 창의적 참여와 수용적 } \\
\text { 참여 }\end{array}$ \\
\hline
\end{tabular}

41) Measuring cultural participation

42) 참여 대상의 예술을 7 개의 순수 예술장르를 중심으로 시작하여 점차 그 범주를 넓혀갔는데, 영화, 사진, 레져목적의 독서(2002 ), 인터넷(2002 ), 라틴, 살사음악(2008 ), 예술작업의 공연, 창작, 공유의 형태 


\begin{tabular}{|c|c|}
\hline 구분 & 예술향유 정의 \\
\hline $\begin{array}{l}\text { 미국 NEA } \\
\text { Survey of Public Participation } \\
\text { in the Arts42)(2019) }\end{array}$ & $\begin{array}{l}\text { - 예술향유는 예술과 관련된 다중의 참여 형태로 관람, 전자미디어를 } \\
\text { 통한 상호성, 예술학습, 예술창작 등을 의미한다 }\end{array}$ \\
\hline $\begin{array}{l}\text { 미국 캘리포니아 } \\
\text { Cultural Lives of Californians } \\
\text { survey(2016) }\end{array}$ & $\begin{array}{l}\text { - 예술관람을 중심에 둔 조사를 탈피하여 캘리포니아 인들이 예술에 } \\
\text { 참여하고 가치를 인지하는 방식은 어떻게 나타나며, 어디서 이뤄지 } \\
\text { 고, 이들의 문화적 삶에 기술은 어떻게 활용되고 있으며, 어떤 사람 } \\
\text { 들이-배경, 연령, 교육수준, 사회경제적 배경 등-이 어떤 종류/형 } \\
\text { 태의 예술에 참여하는 지를 이해하기 위한 조사 }\end{array}$ \\
\hline $\begin{array}{c}\text { 캐나다 } \\
\text { Arts, Culture, and Heritage } \\
\text { Participation(2018) }\end{array}$ & $\begin{array}{l}\text { - 예술활동 관람, 문화재 방문, 독서, 창작 또는 실연으로 구성된 문화 } \\
\text { 예술 향유 실태 조사로 예술관람과 예술 창작 또는 실연이 예술향유 } \\
\text { 에 포함됨 }\end{array}$ \\
\hline $\begin{array}{l}\text { 영국 } \\
\text { Taking Part: The National survey } \\
\text { of Culture, leisure, and Sports } \\
\text { UK(2010) }\end{array}$ & $\begin{array}{l}\text { - 무용, 악기, 연극, 오페라, 카니발, 스트리트 아트, 북클럽, 공예 등 } \\
\text { 의 활동에 참여하는 것으로 '관람과 '참여'를 모두 포괄한다. } \\
\text { * 2018-2019 설문에서는 그림그리기, 서커스 스킬 훈련하기, 혹은 } \\
\text { 라이브 음악이나 공연을 관람하는 것을 모두 포함 }\end{array}$ \\
\hline
\end{tabular}

앞서 '실태조사'에 반영된 예술향유 개념 논의는 예술향유가 개념화하는 주체의 관점과 목적성에 따라(McCarthy and Jinnett 2001) 경계가 지어지는 개념이기도 함을 보여준다. 향유실태조사 도구를 고안하는 주체인 정부가 전제하는 예술향유의 가치와 정책적 목적성과 지향에 따라 전환될 수 있음을 일련의 과정에서 살펴볼 수 있었으며, 국가마다의 관점과 지향가치에 따른 정의와 초점 요인들의 차이를 볼 수 있었다. EU와 미국, 캐나다, 뉴질랜드 등의 국가들이 문화적 다양성과 시민의 참여 성과의 관련성을 두고 예술향유를 해석하고 있으며, ‘행복'과 '웰빙' , '사회적 통합' 을 형성하는 중추적 지표가 될 수 있다는 점에 주목하고 있음이 확인된다.

그러나 무엇보다 주목되는 지점은 이들은 공통적으로 향유가치를 예술의 사회적 영향(social impact)의 논의와 연계 지으며 향유자의 지속적이며 동태적인 활동으로 서 주요하게 다루려는 시도를 하고 있다는 점이다. 이러한 지점은 예술기관이나 정부 와 같은 공급자 입장에서 출발할 것이 아니라, 이들이 '향유자' 및 향유자가 사회적으 로 바라보고 경험하는 관점에서 예술향유를 이해할 필요가 있음을 의미한다. 동시에 ‘접근성' 논의 역시 엘리트 지향의 예술(기관)에 대한 접근성 보다는 지역사회의 다양 한 활동에 개인의 능동적이며 주체적 참여로서의 향유 접근성을 강조하고 있다.43)

와 소셜댄싱, 아마추어 노래 등 포함(2012)한다.

43) 물론 이들 간의 상관관계를 입증하는 측정방식 및 논리 타당성에 일부 논쟁의 여지가 존재하기도 하고 (UNESCO 2012), 예술의 도구화 관련 논쟁도 있으나, 이렇게 예술향유를 둘러싸고 변화하는 지형과 지 
이러한 논의들을 종합해보면 '예술향유'와 관련된 논의는 문화다양성 등 사회변 화를 반영한 공적 지원체계에서의 '예술'의 정의와 범주에 관한 재성찰의 요구로 이 어지고 있다고 하겠다. 특히 실태조사 중심으로 제시되는 예술향유 개념에 관한 논 의들은 공통적으로 공적지원 체계에서의 '예술'이 과거의 전통적 영역에만 한정하 여 접근할 것이 아니라, 현재를 살아가는 사람들의 예술에 대한 다양한 관점과 시각 등을 적극 포용하는 방향으로 선회될 필요가 있음을 역설하고 있다는 점에서 주목 할 필요가 있다.

\section{다. 새로운 ‘향유양태’ 및 유형에 대한 포괄적 인식}

세 번째로 주목되는 지점은 통신기술 발달로 인한 인터넷 기반 온라인 향유 양태 뿐 아니라, 여가와 결합된 예술향유 양태에 대한 포용이 필요하다는 인식이 제고되 고 있다는 점이다. 시대의 변화와 그에 따른 예술향유의 가치와 실천의 맥락을 재구 성하기도 하는데, Web2.0과 함께 도래한 참여적, 능동적 성향의 시민에 대한 인식 (Leadbeater 2009)과 그에 따라 관람하는 관객에서 함께 다양한 방식으로 교감하 고 공동창작에까지도 이르는 참여적 방식을 새롭게 포괄하는 이해(Novak-Leonard \& Brown 2011; Wallace Foundation 2012; Bollo et al. 2017; Bonet et al. 2018; EU 2020)나, 기술이나 미디어로 매개된 예술의 향유 등에 대한 고려가 지속 적으로 병행되며 반영되는 추세다.

미국의 경우 최근 제임스 얼바인 재단과 랜드 인스티튜트를 중심으로 생산되는 예술향유관련 연구는 새로운 예술향유 양태에 대한 적극적 포용을 강조하는 대표적 사례라 할 수 있다. 이들의 논의를 살펴보면 궁극적으로 예술향유를 단순히 관람과 활동으로 구분하여 바라보는 것이 아니라 향유자 관점에서의 향유동기 및 실제 향 유양태의 다원성과 수요의 복합적 층의를 반영한 정책지원의 필요성을 강조한다 (Brown, J., Novak-Leonard, J.L. \& Gilbride, S 2011).

이들이 예술향유를 주요한 화두로 다루고 있는 배경은 문화적 생산과 관련하여 더 이상 "앉아서 듣거나, 보는 문화(sit-back and to be told culture)"가 아닌

향, 사회적 요구는 예술향유가 나타나는 양태와 측정 대상 등을 정의해가는 데에 있어서 필요한 기틀 마련 에 주요한 시사점들을 제시한다. 
“직접 만들고 참여하는(making and doing culture)"방향으로 선회했다는 점에 있다. '관람'역시도 이전까지는 전통적으로 특정장소, 장르 중심의 'arts-going'으 로 이해되었다면, 이제는 향유자 개인의 일상적 삶 속에서 다양한 방식으로 예술을 향유하는 (스트리밍 서비스를 통한 관람, 청취 및 인터액티브 기술 사용 등) 양태가 보다 확산되고 있기 때문이다.

앞서 언급했던 아일랜드 예술위원회의 경우에도, 기술혁신 및 사회변화에 따라 예술향유 양태가 여가와 접목되는 등 다양화·다층화 되고 있다는 점을 강조하고 있 다. 일상생활과의 접점에서 예술향유 영역이 확대되는 가운데 예술위원회는 예술향 유증진을 위한 3 가지 층위의 향유양태(관객-활동형향유-자원봉사-아마추어예술)에 주목한다(Arts Council Ireland 2015).44)

이들 세 가지 층위 중 아일랜드 예술위원회가 특히 중요하게 여기는 부분은 전통 적인 '관객'을 넘어 활동형 향유(arts participation) 및 그 파급력이다. 활동적 참 여를 이해하는 방식 역시 수동적인 향유자의 교육, 워크숍 참여 등을 넘어서서, 적 극적인 형태의 예술가들과의 공동창작과 협업을 강조하고 있는 것이 특징적이다. 이들은 활동형 향유(arts participation)가 지속가능한 향유저변 확대를 위한 핵심 적 영역으로 강조하고, 이와 관련하여 예술창작과 향유를 긴밀히 연계하는 방법론 의 개발을 예술가 및 예술단체 지원을 통해 접근하고 있다.45)

아일랜드예술위원회 사례에서 또 하나 주목되는 부분은 '아마추어예술(생활예 술), 예술단체나 기관에서의 자원봉사나 기부활동' 등을 포괄적 시각에서 '예술향 유'의 양태로서 적극 포용한다는 점이다.46) 이러한 유사한 인식은 지난 2017년 Council of Europe이 발간한 “문화향유와 포용사회(Cultural Participation and Inclusive Societies)"에서도 확인된다.47) 이 연구는 문화예술에의 참여가 한 사회

44) 아일랜드 예술위원회는 이들의 10 개년 전략과 관련된 다양한 용어 및 개념을 글로서리 형태로 정리하여 배포하고 있는데, 해당 자료에 따르면 일반인들의 예술향유를 'public engagement'로 표현하면서 이를 구성하는 다양한 층위 중 하나로 arts participation(활동형 예술참여)을 제시. 단 여기서의 arts participation은 전문예술가와의 공동협업이나 협력을 기반으로 하는 것에 한정되어 쓰인다. 자세한 내용 은 Arts Council Ireland(2015), Glossary: Making Great Art Work 참조.

45) Arts Council Ireland(2015), Making Great Art Work: Leading the Development of the Arts in Ireland. Arts Council Strategy(2016-2025)

46) 현재 국내 일부 향유실태조사에서 예술분야에서의 자원봉사활동 등을 조사항목에 포함하는 경우도 있지 만, 이들 활동을 ‘예술향유활동’ 중 주요한 유형으로 적극 인식한다고 보기는 어렵다.

47) 이들 유형은 Council of Europe이 베를린 소재의 한 대학과 연계하여 개발한 "The Indicator 
의 민주주의와 포용성을 제고하는 데 긴밀히 기여함을 강조하면서, 향유(participation)의 유형을 다양하게 이해하는 방식을 7가지 지표를 통해 제시한다.

〈표 2-12〉 IFCD Cultural Participation Indicators

\begin{tabular}{c|l}
\hline $\begin{array}{c}\text { 지표(Indicators) } \\
\begin{array}{c}\text { Artistic Expression and } \\
\text { Creation }\end{array}\end{array}$ & $\begin{array}{l}\text { acting, dancing, playing instruments, singing, producing art, writing } \\
\text { a book }\end{array}$ \\
\hline $\begin{array}{c}\text { Interest in Foreign } \\
\text { Cultures }\end{array}$ & willingness to learn a new language, study abroad \\
\hline $\begin{array}{c}\text { Non-Partisan Involvement } \\
\text { Online Creativity }\end{array}$ & polunteering, donating cultural content online, creating a website, uploading videos \\
\hline $\begin{array}{c}\text { Online Cultural } \\
\text { Participation }\end{array}$ & $\begin{array}{l}\text { downloading movies or music, reading online newspapers or } \\
\text { cultural blogs, visiting museum websites }\end{array}$ \\
\hline Passive Cultural & $\begin{array}{l}\text { visiting a historical site, going to a concert or performance, } \\
\text { reading a book }\end{array}$ \\
\hline Participation & $\begin{array}{l}\text { studing in culture-related fields, graduating from colleage arts } \\
\text { programmese }\end{array}$ \\
\hline
\end{tabular}

자료: Council of Europe(2017), Cultural Participation and Inclusive Societies, pp.19-20.

이들 지표에는 공연장이나 전시장을 방문하거나 독서를 하는 '수동적(passive cultural participation)' 참여 외에도 '예술적 표현과 창작(artistic expression and creation)'에의 직접 참여, 온라인 등 웹(Web)상에서 음악콘서트나 공연, 전 시를 관람하는 '온라인 향유(online cultural participation)', 온라인상에서의 창 작활동(online creativity)' 뿐 아니라, 문화관련 분야나 대학 전공프로그램을 포괄 한 '예술교육(Students in the Arts)', 새로운 언어를 배우거나 타 국에서의 유학 등 '타 문화에 대한 관심'(Interest in foreign cultures), '자원봉사와 기부활동 (Non-partisan Involvement)' 등이 포함된다.

'예술 향유'가 결부되는 공간에 대한 이해도 변화했다. 종종 예술향유를 공연이나 전시 관람을 목적성으로 지어진 베뉴나 축제라는 시간적 공간적 개념의 틀에서 찾 아왔는데, 관객들의 행태를 보면 더 이상 이에 적합하지 않다(Bill Ivey 2013. 4. 17). 예술향유가 일어나는 장소가 전통적인 공연장이나 미술관을 벗어나고 있다는 사실은 기존의 문화시설이나 프로그램 기반의 향유조사가 포착하지 못하는 활동들

Framework on Culture and Democracy, 이하 IFCD)로 통칭된다(Council of Europe 2017: 19) 
이 존재한다는 점과 것이다(Brook 2017; Delrieu \& Gibson). 나아가 장소성은 참여를 커뮤니티를 작동시키고 정의하는 과정과 관계, 감정의 구조로 위치시키는 데에 유용한 역할 요인으로 작용할 수 있으며(Miles \& Gibson 2016), 지역이나 장소를 예술향유의 주요 연계 요소로 확보할 필요성을 확인할 수 있다.

Novak et al.(2015)은 캘리포니아에서 향유실태 조사(California Survey of Arts\& Cultural Participation)48)에 대한 확장된 관점에서의 새로운 접근을 시도 하면서 시민들의 참여적 문화의 수용, 문화민주주의의 실현, 그리고 주체적 시민성 이 포용되는 시대상을 반영하겠다는 세 가지 목적을 갖고 예술향유 개념의 재구성 을 시도했다(Novak-Leonard, Reynolds, English, and Bradburn 2015). 향유자 들이 예술작업을 하고 공연하는 자발적 활동들을 포괄한다면 전통적인 "고급" 예술 의 향유가 지속적으로 축소된다는 문제를 달리 접근할 수 있다는 것이다. 시민의 '새로운 참여적 문화(Jenkins \& Bertozzi 2008)' 현상을 수용하면서 소수의 천재 예술가의 세계에서 탈피하여 소규모의 틈색 작업들을 포함한 다양한 작품이 다양한 공중들과 만날 수 있는 사회로의 전환을 가능하게 하며, 나아가 시민들이 자신의 관점에서 의미를 부여하며 선택하고 주체적으로 관계맺기를 할 수 있다는 점 (Novak-Leonard, Wong, and English 2015: 8)을 짚고 있다. 이는 예술향유에 영향을 미치는 환경적 변화들과 적극적으로 상호작용할 때 예술향유의 행태들을 충 분히 포용적으로 포착하여 이해하고 또한 예술향유 촉진에 포괄적이며 맥락적적으 로 접근할 수 있는 여지를 확보할 수 있음을 의미한다.

\section{라. 예술향유 지원 목적 및 정책적 방법론 변화}

\section{口 일상성, 근린성, 탈공간적 지향, 예술계와의 협업}

해외 예술정책 논의에서 최근 부상하는 ‘향유’ 논의의 확산은 비록 지역별 국가별 로 조금씩 차별점은 있으나, 사회 변화를 반영한 예술향유 지원의 목적을 새롭게

48) It begins with individuals' own interpretations of what they do and find meaning in, and which forms of art and artistic expression engage them in their everyday lives. The results in this report suggest a need to reframe the parameters of how arts participation is understood and experienced and perhaps, in turn, to reconceptualize the structure and dynamics of the arts field as a whole. 
설정하는 한편 이를 구현하기 위한 정책적 접근 방법론의 변화를 함께 강조하고 있 다는 점에서 공통점을 보인다.

먼저 이들의 ‘향유' 지원 관련 정책논의는 예술을 향유하지 못하는 이들에 대한 기회제공이라는 관점에만 한정적으로 머무르지 않는다. 고급예술 중심으로 '관람' 에 천착하여 접근하던 '예술향유' 지원 논의에서 벗어나 사회를 구성하는 다양한 구 성원들의 정체성과, 예술을 이해하는 다양한 인식과 관점의 포용이 전제되어야 함 을 강조하고 있기 때문이다. 이는 결과적으로 공적 지원체계에서의 '예술'에 대한 이해가 포용적 개념으로 전환되어야 함을 촉구하는 담론으로 연계되고 있다. 또한 전통적인 향유방식을 벗어나, 인터넷 등 온라인을 통한 자발적 생산 및 참여활동, 일상적 삶이나 여가활동과 접목된 복합적이고 다양한 예술향유 양태를 정책적으로 적극 포용할 것을 강조하고 있다. 이로 인해 정책적 접근에 있어서도 '일상성', '근 린성', ‘탈공간적 지향 등의 가치를 강조하는 가운데 예술향유의 다양하고 입체적 인 양태를 고려한 다원적 접근을 강조하는 추세다.

그 가운데 특히 주목되는 것은 '향유'를 위한 지원이 단순히 최종수혜자로서의 시 민을 직접대상 중심으로 지원하는 것에 주로 천착하기 보다는, 예술기관, 예술단체, 예술가 등 '예술계와의 협업'의 중요성을 강조한다는 데 있다. 예술계 스스로 일반 시민들이 바라보는 예술에 대한 복합적 인식과 다양하게 진화하는 예술향유 양태에 대한 분석을 통해 예술과 시민이 만나는 다양한 접점을 고민하고 접근할 수 있게끔 독려하고 있기 때문이다. 이는 향후 국내 예술향유 지원정책의 방향성을 모색하는 데 주요한 시사점을 제시한다고 하겠다. 


\section{제2절 예술향유 정책 분석 및 논의를 위한 시사점}

지금까지 예술계를 둘러 싼 환경변화, 예술향유 개념에 관한 해외 및 국내의 선행 논의, 그리고 해외 예술향유 정책담론의 흐름을 살펴보았다. 이들 논의를 바탕으로 이 절에서는 먼저 예술향유와 관련된 정책 분석 및 논의를 위한 시사점을 짚어보고, 이어 예술향유를 이해하기 위한 복합적 프레임워크를 제시하고자 한다.

\section{1. '예술'과 '향유'에 대한 새로운 관점}

\section{가. '예술’에 대한 새로운 관점, 변화된 이해}

예술향유는 즐거움(enjoyment)과 소유(ownership)를 포괄하는 개념적 의미에 있어서 이미 포괄적 용어다. 여기에 참여(participation)와 관계맺기(engagement) 라는 활동적 맥락의 개념이 부가되며 포괄하는 활동의 다양한 범주를 대변하며 용 어의 두께를 키워왔다. 반면, 문화정책 차원에서 정책의 목적성으로 주로 사용되어 온 용어의 씀임은 그 두께에 결부되어온 향유자의 능동성이나 주체성의 관점으로 확장하지 못한 채, 수렴적 수요 관점에 한정된 개념에 국한한 이해가 수반되었다. ‘공연순회'라는 형태의 예술향유정책은 ‘예술향유'를 관람이라는 극히 제한적인 형 태의 과정과 성과를 전제하는 대표적인 모델이라 할 수 있다.

국내는 물론 해외에서도 역시 '예술향유'는 보편적으로 예술 관람과 유사하게 이 해하고 '소비' 의 개념에 비중을 둔 관점에서 접근되어왔음을 확인할 수 있었다. 그 러나 최근 10 여년 사이에 점차 향유자 개인의 향유 활동을 둘러싼 동기와 영향, 향 유의 다양한 스펙트럼과 이를 구성하는 주체성과 능동성 등 개인 경험의 관점으로 비중이 이동되고 있음이 확인되었다. 그리고 그 이해는 예술 현장에서 예술의 잠재 
적 관객을 개발하기 위해 다양한 경험 경로를 형성하고 예술적 경험과의 관계를 형 성해주는 노력들과 그로 인한 향유의 경험들을 토대로 해석되고 구성되고 있다.

이러한 논의들은 결국 '예술'에 대한 정책적 이해가 보다 확장적으로 접근되어져 야 함을 시사한다. 앞서 확인한 바와 같이 여전히 정책적 논의에서 '예술'의 정의와 범주는 여전히 장르를 근간으로 구분지어지기는 하나, 향유자가 정의하는 예술을 역으로 질의하며 예술의 범주의 정의 또한 상호적으로 구성해가는 진보적인 접근 (Novak-Leonard, Reynolds, English, and Bradburn 2015)이 나타나고 있기 때문이다. 이미 '예술'을 비롯 '향유'와 관련된 담론적 논의는 '예술' 의 절대적 형태, 절대적 가치를 전제하고 이에 대한 지식, 정보, 경험을 부여받아야할 '객체적 대상 으로서 향유자'를 상정해온 계몽주의적·낭만주의적 예술관을 벗어나야 함을 강조하 고 있다.

이들이 공통적으로 강조하는 예술의 핵심요소로서 '즐거움'에 대한 전제는 '주체 자/향유자' 관점이 개념정립과 이해의 중심에 놓이게 된다는 것을 의미한다. 이제까 지 '예술'을 중심에 둔 시혜적이거나 교육적 관점 지향의 인식과 상호적 이해 구성 이 필요하다는 인식을 하고 있다. 나아가 예술가 역시 칸트나 러스킨이 상상했던 권위주의적 예술에 비해 향유자의 능동적이고 주체적인 상호성의 경험이 더 큰 창 의적 힘을 부여할 수 있음을 인식해야한다는 관점들이 강조되고 있는 상황이다 (Matarasso 2010).

'예술향유' 에 대한 확장적 개념은 더 이상 예술을 고답적 '대상' 으로만 두지 않는 다. 이제는 예술과 예술가의 창작 활동을 넘어, 향유자의 개인적 삶에 필요한 자기 개발, 창의성, 웰빙을 매개하는 실천적이며 상호적 관계를 형성하는 '동태적인 과 정'이기도 하다. 그런 의미에서 예술향유는 예술이 지닌 복합적인 측면들과 관계를 맺는 여러 형태로, 향유자가 주체성의 존재로 삶에서 영위해가기라는 궁극적인 모 습을 지향하는 가운데에 향유자마다의 개인적 특성과 역량, 상황, 환경적 요인들로 인해 취할 수 있는 다양한 형태의 스펙트럼으로 이해될 필요가 있다.

더욱이 정책적 차원에서도 이미 정부나 기관, 학자들은 '예술'을 이해함에 있어 '공공 참여(public participation)' 의 의미와 가치를 연계하여 예술향유의 스펙트 럼을 개인차원에서 지역사회 차원의 가치로 확대시킬 수 있음을 강조하고 있는 추 세다. 여기에는 필연적으로 '예술'의 가치에 대한 철학과 관점이 결부될 수 밖에 없 
다. '예술의 사회적 영향', '예술을 통한 사회변화'라는 예술의 확장된 가치 체계에 대한 이해를 바탕으로 예술향유의 복합적 양상을 바라볼 수 있을 때, '예술향유' 관 련 정책의 방향성이 보다 명료하게 제시되어 질 수 있다고 하겠다.

\section{나. 유동적 개념으로서의 예술 ‘향유'}

앞서 지적한 바와 같이 예술향유를 논하는 데에 있어서 닫힌 정의를 내리기보다 는 포괄적이며 유동적인 개념으로 정의하는 것이 유용하다는 제기들은 정책적 관점 에서 보다 주요하게 검토될 지점이라고 할 수 있다.

예술향유는 '향유자'의 주체적 입장 뿐 아니라, 외적 요소가 개입된 매개적 맥락 과 영향요인의 결합으로 발현된다. 또한 예술향유는 사회의 변화, 기술변화 등과 상 호작용하는 변화적 속성을 지닐 수밖에 없다. 따라서 엄격한 정의나 측정 지표의 표준화에 집중하기 보다는 시대변화를 반영할 수 있는 객관적 조사 기제와 함께 열 린, 상호적 해석 하에서 의미와 가치가 구성될 수 있도록 고려하는 것이 필요하다.

앞서 서론에서도 언급한 바와 같이 한자어(향유享有)의 어원적 의미를 살펴보면 생활 속에서 '마음껏 즐기고 누리는 권리를 갖는다'는 뜻을 담고 있다. 예술향유는 즐거움(enjoyment)과 소유(ownership)를 포괄하는 개념적 의미에 있어서 이미 포괄적 용어인 셈이다. 여기에 참여(participation)와 관계맺기(engagement)라는 활동적 맥락의 개념이 부가되며 포괄하는 활동의 다양한 범주를 대변하는 가운데 용어의 두께를 키워왔다. 반면, 문화정책 차원에서 정책의 목적성으로 주로 사용되 어온 용어의 씀임은 그 두께에 결부되어온 향유자의 능동성이나 주체성의 관점으로 확장하지 못한 채, 수렴적 수요 관점에 한정된 개념에 국한한 이해가 수반되었다.49)

해외에서 역시도, 예술향유는 보편적으로 예술 관람과 유사하게 이해하고 '소비' 의 개념에 비중을 둔 관점에서 당초 접근되어왔음을 확인할 수 있었다. 그러나 최근 10 여년 사이에 점차 향유자 개인의 ‘향유' 활동을 둘러싼 동기와 영향, 향유의 다양 한 스펙트럼과 이를 구성하는 주체성과 능동성 등 개인 경험의 관점으로 비중이 이 동되고 있다. 그리고 그 이해는 예술 현장에서 예술의 잠재적 관객을 개발하기 위해

49) ‘공연순회’라는 형태의 예술향유정책은 예술'향유’를 관람이라는 극히 제한적인 형태의 과정과 성과를 전 제하는 대표적인 모델이라 할 수 있다. 
다양한 경험 경로를 형성하고 예술적 경험과의 관계를 형성해주는 노력들과 그로 인한 향유의 경험들을 토대로 해석되고 구성되고 있다고 하겠다.

\section{다. 향유자 중심성: 대상이 아닌 “주체자"}

최근 해외에서 개진된 정책담론 논의의 흐름은 물론, 예술향유 관련 이론적 논의 에서도 시민들의 예술향유(문화) 접근성을 확보하는 것을 예술정책의 가장 중심에 두는 방식으로 선회하고 있음을 앞서 확인했다. 세계대전 이후 예술정책이 활성화 된 이래 접근성과 향유의 대상은 주류를 형성하는 고급예술 장르와 그 장르를 진흥 하는 예술단체와 기관이 되었다. 그러나 이는 설문 결과를 재현(presenting)하고 관람하는(spectating) 형식의 예술에 국한시키는 한계를 보였고, 이를 극복하기 위 해 향유의 동기와 장벽(Blume-Kohout, Leonard \& Novak-Leonard 2015)과 향유하는 장소를 살펴보며 향유를 포괄적으로 이해하고자 했다. 또 한편에서는 "비 형식의 예술, 아마추어 예술활동'을 예술향유의 일부로 포괄하거나 예술향유에 기 여하는 활동으로 재조명하기 시작했다(Peters and Cherbo 1998; Wali et al. 2002). 또한, Novak-Leonard(2015)가 주축이 된 〈캘리포니아의 문화적 삶 서베 이〉의 조사를 고안하는 데에 있어서 개개인에게 자신의 관점에서 "문화적 혹은 예 술적” 앞에 “창의적” 활동이 무엇인지 질의50)하여 예술참여에 대한 정의를 재구조 화51)하는 시도를 하기도 했다.

향유자를 중심에 둔 예술향유 개념의 재정립에 있어서 Johnson et al., (2014)이 Wallace Foundation에서 출간한 보고서에서 제시한 관객개발에 필요한 세 가지 방향-“넓혀가기(더 많은 향유자), 깊이를 더해가기(기존 향유자의 경험을 풍요롭게), 예술향유의 다각화(새로운 관객 포용)”의 세 가지 목표는 간단하면서도 중요한 기준 으로 작용할 수 있다. 특히, 그간 예술향유정책 차원의 노력들이나 각 예술기관의 향유 사업들을 세 가지 방향성을 기준으로 분류하여 살펴봄으로써, 향후 기울여야 할 노력의 방향을 확인할 수 있을 것이다.

50) "People are involved in different types of activities that they enjoy or that are important to them. Please briefly tell me about any creative, cultural or artistic activities that you do."

51) 향유의 유형을 예술학습, 예술창작, 예술방문/관람, 미디어 기반 소비, 후원, 소셜미디어 통한 향유, 기타 활동으로 구분하였고, 이를 다시 물리적 참여(arts-going, arts-making)와 예술학습, 후원, 디지털기술 을 매개로 한 향유의 네가지 차원으로 구분하였다. 


\section{라. 창작과 향유의 연계: 예술계의 관객개발 관점 수용 필요성}

최근 EU의 Creative Europe은 '관객개발'을 "예술이 더욱 폭넓게 접근성을 확 보할 수 있도록 하는 전략적이며 다이내믹하고 상호적인 프로세스"로 정의하고 있 는데, 이 때 그 목적에서 예술향유에 대해 전제된 개념을 읽을 수 있다. "개인과 지 역사회가 예술을 경험하고, 즐기고, 참여하면서 그 가치를 인지하도록 하는 것”을 목표로 하는 문화(예술)향유는 디지털 도구부터 자원봉사, 공동창작이나 파트너십 등 다양한 형태와 방법을 열어놓고 있다. 여기서의 '관객개발' 은 예술향유 정책에 방향을 제시하고 있으며, 특히 장기간의 시간을 요구하는 일이며, 이를 위한 기획과 매개의 전문적 역량과 변화를 촉발하는 트리거의 개발이 요구된다고 짚고 있다.

반면, 지역 사회의 문화예술기관/문화예술생산자들의 예술과 예술향유에 대한 인 식이 여전히 칸트의 영향 하에 형성된 계몽주의, 낭만주의 사조에서 자유롭지 못하 고, 따라서 예술과 향유자와의 관계에 대한 상호성 기반의 이해 정립이 더디게 확산 되고 있다는 점(LACAC, Public engagement in arts 2016)이 한계로 거론된다.

이에 $\mathrm{EU}$ 가 '관객을 중심에 이동시켜 놓는 관객개발'이라는 보고서를 통해 예술기 관들이 자기중심적 주장을 덜하고 지역사회의 삶에 더 뿌리내리고, 청중들과 다른 이해관계자들의 요구에 더 개방적 태도를 지녔을 때(예술지상주의에서 벗어날 때) 더 많은 참여/향유를 위한 전략과 실천을 채택할 수 있음을 제안하고 있다.

\section{마. 예술생태계 가치사슬을 넘어선 문화적 삶의 맥락에서의 '예술향유'}

정책적 관점에서 그간 '예술향유' 관련 논의는 예술창작과 분리된 부가적 영역(복 지, 혹은 시혜적 관점의 접근 등)으로 치부되는 경향이 컸다. 이로 인해 그간 향유 관련 국내 논의는 예술생태계 속에서의 창작-유통-향유/소비가 선순환적 가치사슬 로서 연계된다는 관점에서 접근하지 못하고, 각 영역을 분절적으로 연계하는 방식 으로만 이해했던 특성이 나타난다.

그러나 Kreidler와 Troustine(2005)제시한 개념도를 통해 확인하는 '예술향유' 를 정책적으로 지원함에 있어 예술생태계적 관점을 포함하는 것도 주요하나, 장기 적으로 보다 확장적인 관점, 즉 사회적 문화적 삶의 맥락으로서의 문화생태 체계 내에 '예술향유'를 위치시키고 이를 문화리터러시, 문화생태와 연계시키는 방식의 
이해가 필요함을 고려할 필요가 있다.

따라서 '예술향유' 관련 새로운, 균형적 정책적 접근을 고민함에 있어 예술향유가 위치지워지는 가치체계와 주체성 분배에 대한 고려 역시 함께 이뤄질 필요가 있으 며, 동시에 여러 다양하고 복합적 형태의 일부로 여전히 존재해야 하는 예술향유의 측면이 새롭게 확장된 틀과 전환적 관점으로 인해 부정되거나 왜곡되는 점을 유의 할 필요가 있을 것으로 보인다.

\section{바. '예술향유' 이해를 위한 복합적 관점의 필요성}

'예술향유'는 한편으로 개인적 차원에서 발생하는 것이지만, '예술향유' 활동이 발생되는 맥락은 개인 외에도 사회적 맥락 속에서 함께 매개되어 발현된다. 따라서 개인 고유의 향유에서부터 지역적, 사회적 가치로 확장되는 가치체계와 연계되는 복합적이며 다양한 향유의 양태를 구성하는 요인들을 종합적으로 바라보아야 한다. 동기와 인지, 역량과 같은 개인적 요소는 물론 외부적으로, 종종 정책차원에서, 부 가되는 목적성과 성과나 특성적 맥락을 제공하는 지역성-장소성이 통합적으로 고려 될 필요가 있다.

또한, 예술향유의 확장적 영향 및 가치에 있어서 향유에 있어서의 개인차원의 '주 체성' 은 주요하게 다뤄져야 할 요소로 부각되고 있다. 향유자의 예술에 대한 주체적 동기와 가치, 인식에 대한 데이터를 수집하고 분석해가는 과정은 전통적인 고급 예 술장르이 부가해온 전제들로부터 균형점을 찾아가는 데에 있어서 유의미할 것이다.

\section{2. 예술향유 이해를 위한 프레임워크(안)}

\section{가. 예술향유의 맥락적 이해}

향유는 향유자 개인적이며 주체적 맥락에서의 향유와 외적 요소가 개입된 매개적 맥락에서의 향유로 크게 나눌 수 있다.

우선 “주체적 맥락"에서의 향유에 주요하게 적용되는 향유자 개인적 요소로는 향 유의 동기나 목적, 예술의 가치에 대한 인식이나 기대 정도, 예술과 관련된 스킬의 
수준, 창작에 대한 효능감을 주요하게 들 수 있다. 여기에 장소성은 예술향유에 그 자체로 개입적 성격을 지니는 요소로 주체적 맥락에서의 향유활동의 행태에서도 고 려될 수 있어야 한다. “매개적 맥락”의 향유는 향유자의 경험이 제3자 혹은 제3의 개체에 의해 기획, 조력, 매개되는 경우를 의미한다. 매개성은 향유의 목적이나 기 대 영향에 대한 의도가 무엇인지에 따라, 매개하는 사람의 전문가 여부에 따라, 혹 은 기술의 매개 여부에 따라 특성지어진다. 예술향유에 있어서 개인의 “주체성” 여 부와 “빈(번)도”는 향유와 향유자의 특성을 구분하는 주요한 구성요인이다. 활동으 로서의 '예술향유'는 개인적 차원의 동기와 목적에 의한 행동이기도 하지만, 외적 요소가 복합적으로 결합된 매개적 맥락에서 발현된다. 이들 4가지 요소를 고려하여 예술향유가 발현되는 구성적 맥락을 제시하면 다음과 같다.

〈표 2-13〉 예술향유의 구성요소

- 예술향유자의 내적 구성요소(동기/목적, 스킬 수준, 인지된 가치, 태도, 창작의 권한/효능감)

- 예술향유가 일어나는 장소성과 환경의 특성

- 매개된 외적 조건(전문가/동료, 예술지향/사회적 목적 지향, 개인작업 지향/공동체지향, 사람/미디어)

- 예술향유의 실천성: 수용적/능동적, 빈번도

[그림 2-16] 예술향유 발현 맥락 (1): 개념도(안)

\begin{tabular}{|c|c|c|}
\hline \multirow{8}{*}{$\begin{array}{c}\text { 향유활동 양태 } \\
\text { 일상 } \\
\text { 예술 } \\
\text { 창작 } \\
\text { 참여적 } \\
\text { 관람 }\end{array}$} & \multicolumn{2}{|c|}{ 특성화 요인 } \\
\hline & 주체성 & \multirow{7}{*}{ - 내적요소 } \\
\hline & $\begin{array}{c}\text { 창작(표현)의 } \\
\text { 권한 }\end{array}$ & \\
\hline & 사회지향성 & \\
\hline & 빈도 & \\
\hline & 장소성 & \\
\hline & 매개여부 & \\
\hline & $\begin{array}{l}\text { 기대영향 } \\
\text { (목적성) }\end{array}$ & \\
\hline
\end{tabular}


[그림 2-17] 예술향유 발현 맥락 (2): 개념도(안)

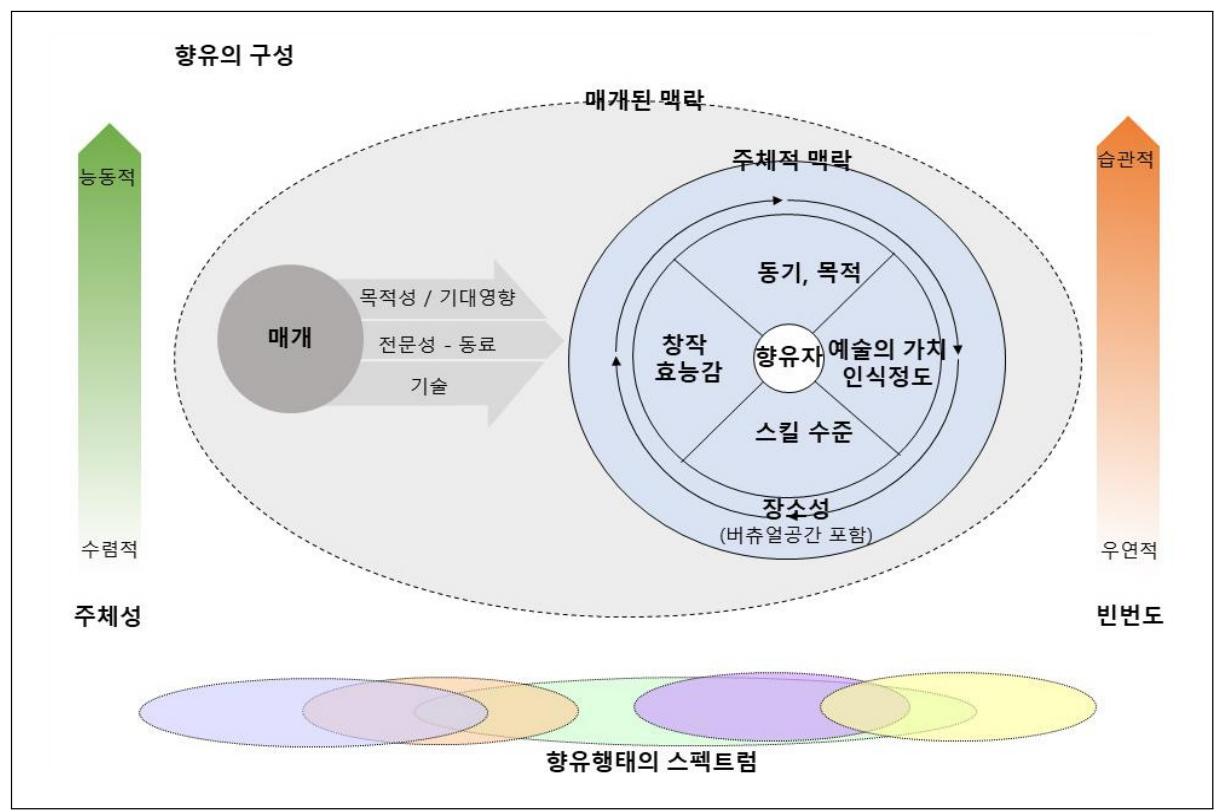

\section{나. 예술향유양태 스펙트럼(안)}

\section{口 예술향유의 양태 유형(안)}

예술향유를 구성하는 요소들과 향유의 활동적 특성의 결합에 의해 예술향유의 경 험적 양태는 특성화에 따라 다양한 스펙트럼상에서 나타날 수 있다. 이들은 크게 5가지 양태유형으로 분리하여 볼 수 있다.

〈표 2-14〉 예술향유 양태유형 분류(안)

\begin{tabular}{|c|c|c|}
\hline \multicolumn{2}{|c|}{ 구분 } & 향유양태, 활동의 예시 \\
\hline \multirow[b]{2}{*}{ 관람형 } & $\begin{array}{l}\text { 전통적 } \\
\text { 관람형 }\end{array}$ & 예술의 창작이나 재현, 프로그램 등을 보거나 듣는 유형 \\
\hline & $\begin{array}{l}\text { 참여적 } \\
\text { 관람형 }\end{array}$ & $\begin{array}{l}\text { 관람 대상의 예술적 활동이나 작업, 작품에 대해 자신의 해석이나 의도를 부여하며 교감 } \\
\text { 하거나 관람 차원의 참여적 활동에 응하는 향유 유형. 예를 들어 자신의 예술 향유 콘텐 } \\
\text { 츠를 수집하거나 목록화하는 활동, 이머시브 공연의 관람활동, 커뮤니티 아트에 참여 등 } \\
\text { 을 들 수 있음 }\end{array}$ \\
\hline \multicolumn{2}{|c|}{$\begin{array}{l}\text { 매개된 경험형 } \\
\text { (교육) }\end{array}$} & $\begin{array}{l}\text { 사람이나 기술로 인해 향유하는 방식이나 과정, 개인적 동기나 활동이 촉발되거나 조력 } \\
\text { 된 향유 유형. 예를 들어 예술교육의 특성을 지닌 활동, 버츄얼 공간이나 현존 공간에서 } \\
\text { 기술적 매체나 프로그램 된 기술활동에 의한 향유로 AR/NR 기기가 조력하는 전시관람 } \\
\text { 이나 게이미피케이션이 적용된 버츄얼 공간에서의 예술향유 활동 등이 포함됨 }\end{array}$ \\
\hline
\end{tabular}




\begin{tabular}{|c|c|c|}
\hline \multicolumn{2}{|c|}{ 구분 } & 향유양태, 활동의 예시 \\
\hline \multirow[b]{2}{*}{ 창작형 } & $\begin{array}{l}\text { 공동 } \\
\text { 창작형 }\end{array}$ & $\begin{array}{l}\text { 창작 주체에 의해 초대된 향유로 창작과 표현에 대한 권한의 일부를 부여받은 예술 활동. } \\
\text { 창작의 과정은 물론 결과물에 대한 자신의 기여를 인지할 수 있는 유형임 }\end{array}$ \\
\hline & $\begin{array}{l}\text { 개인 } \\
\text { 창작형 }\end{array}$ & $\begin{array}{l}\text { 온전히 자신의 주체적 의지에 의해 예술 창작 활동이 이뤄지는 활동. 전문예술가는 물론 } \\
\text { 아마추어 예술가들의 창작 활동도 포함함. 이 때 전문성과 수월성을 창작 작업의 주요 } \\
\text { 기준으로 두고 있는 지에 따라 일상예술형 향유와 구분지을 수 있음 }\end{array}$ \\
\hline \multicolumn{2}{|c|}{$\begin{array}{l}\text { 일상예술형 } \\
\text { (동호회) }\end{array}$} & $\begin{array}{l}\text { 예술적 감성과 예술적 표현, 예술적 훈련이 일상에서 루틴하게 이뤄지는 자발적 유형의 } \\
\text { 활동. 예를 들어 악기 연습이나 시의 습작, 일상 드로잉, 동호회 활동 등을 들 수 있음 }\end{array}$ \\
\hline \multicolumn{2}{|c|}{ 자원봉사/기부형 } & $\begin{array}{l}\text { 예술작품의 보존이나 예술활동의 지속성을 지지하고 지원하는 활동 예를 들어 기부나 } \\
\text { 예술기관에서의 도슨트 자원봉사, 시설 등을 찾은 나눔연주 등을 들 수 있음 }\end{array}$ \\
\hline
\end{tabular}

\section{口 예술향유 양태 특성화 요인(안)}

이들 다양한 예술향유 양태를 결정하는 특성화 요인 역시 7 가지 요소로 구분하여 볼 수 있다.

〈표 2-15〉 예술향유 양태유형의 특성화 요인(안)

\begin{tabular}{|c|c|}
\hline 구분 & 향유양태, 활동의 예시 \\
\hline (1) 경험의 주체성 & $\begin{array}{l}\text { 향유의 경험에 대한 향유자의 선택에 대한 주체성 여부와 과정적 참여에서의 능동성 } \\
\text { 의 정도를 의미한다. }\end{array}$ \\
\hline (2) 창작(표현)의 권한 & $\begin{array}{l}\text { 예술의 창작의 프로세스 및 결과물에 기여하거나 주도하는 데에 있어서 향유자에게 } \\
\text { 부여되는 권한의 정도를 의미한다 }\end{array}$ \\
\hline (3) 장소성: & $\begin{array}{l}\text { 예술향유가 일어나는 장소의 특성의 구분을 의미한다. 공연장이나 전시장과 같이 예 } \\
\text { 술향유를 위한 전통적인 전문 공간인지 카페나 공원, 동네 공공공간 등 일상적 공간 } \\
\text { 인지, 혹은 버츄얼 공간인지의 여부에 따라 부여되는 특성을 의미한다. }\end{array}$ \\
\hline (4) 사회적 지향성 & $\begin{array}{l}\text { 향유의 형태가 오롯이 개인에게 집중하는 활동인지 타인들과 어우러져 공동으로 향 } \\
\text { 유하는 사회적 지향의 활동인지의 여부를 의미한다. 이는 개인의 예술향유에 대한 } \\
\text { 동기와 연계된다. }\end{array}$ \\
\hline (5) 빈도 & 우연한 참여에서 습관적 활동으로 영위하는 예술향유의 경험빈도 정도를 의미한다. \\
\hline (6) 매개성: & $\begin{array}{l}\text { 예술향유에 사람이나 개체, 혹은 기술이 매개되는 지, 매개의 정도(강---약)와 매개 } \\
\text { 자의 전문성에 따라 예술향유의 성격이 결정될 수 있다. 매개는 설명이나 안내에서 } \\
\text { 향유 환동을 기횧하거나 활동 과정상에서 촉발하고 조력하는 사람이나 기술의 존재 } \\
\text { 와 활동을 의미한다. 예를 들어 도슨트의 관람 매개, AR/VR을 도입한 전시관람, } \\
\text { 예술교육 등에서 볼 수 있다. }\end{array}$ \\
\hline (7) 기대영향/목적성 & $\begin{array}{l}\text { : 예술향유의 복합적이며 확장적 가치를 전제로 활동에 따라 개인적으로 혹은 기획 } \\
\text { 자에 의해 계회된 목적성에 의해 예술향유 활동은 구분될 수 있다. 목적성의 영역구 } \\
\text { 분은 예술을 통한 변화 프레임워크를 개발한 Durphy(2015)의 세부 구분을 참고하 } \\
\text { 여 구분할 수 있으며, 목적성에 따라 예술향유의 연계 영역은 문화적 영역, 개인의 } \\
\text { 웰빙 영역, 지역사회의 경제적 영역, 사회적 영역, 환경적 영역, 시민주의 영역으로 } \\
\text { 구분될 수 있다. }\end{array}$ \\
\hline
\end{tabular}


앞서 제시한 예술향유의 양태 유형(안) 및 결정요인과 관련된 논의는 추후 진행될 온라인 설문조사 및 FGI 설계에 주요한 기준 및 관점으로 고려된다. 다만, 제시된 예술향유 양태유형(안) 및 결정요인들을 그대로 적용하기보다는 이들 논의에서 강 조하는 지점들에 주목하여 일부 수정 및 보완을 거쳐 적용토록 한다. 
예술향유정책 분석 및 방향 연구

제3장

\section{시민의 예술향유 인식 및 \\ 예술향유활동 분석}





\section{제1절 예술향유 실태와 특징: 선행조사 검토}

예술향유 관련 인식 및 양태에 관한 조사를 들어가기에 앞서, 현재 예술향유 현황 을「국민여가활동조사」,「국민문화예술활동조사」,「서울시민 문화향유 실태조사」 등 3개의 기존 실태보고서를 중심으로 살펴본다. 예술향유 현황에서 나타난 특징을 분석하고 이후 일반인 대상 예술향유 인식 및 양태 조사를 위한 시사점을 제시한다.

\section{1. 실태조사와 예술향유 현황}

\section{가. 2019 국민여가활동조사}

1) 조사 개요

국민여가활동조사의 개요는 다음과 같다.

〈표 3-1〉 2019 국민여가활동조사 개요

\begin{tabular}{c|l}
\hline 구분 & \multicolumn{1}{c}{ 내용 } \\
\hline 조사 목적 & $\begin{array}{l}\text { 다양하고 변화되는 국내 여가환경변화에 따라 국민의 여가수요에 미치는 활동실태를 분석 } \\
\text { 하여 생활양식의 변화 및 삶의 질 수준을 파악 }\end{array}$ \\
\hline 조사 대상 & 만 15세 이상 남녀 10,000명 \\
\hline 조사 지역 & 전국 17개 시·도(제주 및 세종 포함) \\
\hline 조사 기간 & 2019.9.9. 2019.11.14 \\
\hline 조사 방법 & 조사원에 의한 1:1 가구방문 면접조사 \\
\hline 조사 연혁 & - 2006년 〈국민여가조사〉 실시 \\
\hline 조사 주기 & - 2007년 〈국민여가활동조사〉로 명칭 변경 \\
\hline & - 2018년까지: 2년 주기로 실시 \\
\hline
\end{tabular}




\section{2) 조사 내용}

15 세 이상의 국민 여가활동 참여 실태, 여가 만족도 분석을 통해 국민여가양태를 파악할 수 있는 내용으로 이루어져 있으며, 기존 조사 결과와의 시계열 분석을 통해 향후 추이 변화 예측이 가능하도록 구성되어 있다.

〈표 3-2〉 2019 국민여가활동조사 내용

\begin{tabular}{|c|c|c|}
\hline 항목 & 내용 & 세부 내용 \\
\hline \multirow{6}{*}{ 참여 실태 } & 한번 이상 참여한 여가활동 & - 여가활동 유형 \\
\hline & $\begin{array}{c}\text { 가장 많이 참여한 } \\
\text { 여가활동 }\end{array}$ & $\begin{array}{l}\text { - 여가활동 유형 } \\
\text { - 여가활동 동반자 } \\
\text { - 여가활동 빈도 } \\
\text { - 여가활동 소요 시간 } \\
\text { - 여가활동 비용 } \\
\text { - 여가활동 만족도 }\end{array}$ \\
\hline & 여가활동 목적 & - 여가활동의 주된 목적 \\
\hline & 여가활동 만족도 & - 가장 만족스러운 여가활동 \\
\hline & 여가경력 & $\begin{array}{l}\text { - 지속적 여가활동 유무 } \\
\text { - 지속적 여가활동 분야 } \\
\text { - 여가활동 지속기간 } \\
\text { - 여가정보 습득여부 }\end{array}$ \\
\hline & 여가비용 & $\begin{array}{l}\text { - 월평균 여가활동 비용 및 만족도 } \\
\text { - 희망하는 월평균 여가활동 비용 }\end{array}$ \\
\hline \multirow{5}{*}{$\begin{array}{c}\text { 평일 및 휴일 } \\
\text { (휴가, 연휴) 여가활동 }\end{array}$} & 평일 여가활동 & $\begin{array}{l}\text { - 평일에 참여한 여가활동 } \\
\text { - 평일에 참여한 여가활동 만족도 } \\
\text { - 평일에 희망하는 여가활동 }\end{array}$ \\
\hline & 휴일 여가활동 & $\begin{array}{l}\text { - 휴일에 참여한 여가활동 } \\
\text { - 휴일에 참여한 여가활동 만족도 } \\
\text { - 휴일에 희망하는 여가활동 }\end{array}$ \\
\hline & 여가시간 & $\begin{array}{l}\text { - 평일 및 휴일의 하루 평균 여가시간 } \\
\text { - 평일 및 휴일의 여가시간 충분정도 } \\
\text { - 평일 및 휴일의 여가시간 활용정도 } \\
\text { - 평일 및 휴일의 하루 평균 희망 여가시간 }\end{array}$ \\
\hline & 휴가 활용 & $\begin{array}{l}\text { - 휴가 유무 } \\
\text { - 휴가 기간 및 휴가 일수 } \\
\text { - 휴가 기간 동안의 여가 활동 }\end{array}$ \\
\hline & 연휴 활용 & - 연휴 기간 동안의 여가 활동 \\
\hline 여가 공간 & 여가 공간 & $\begin{array}{l}\text { - 가장 많이 이용한 여가 공간 } \\
\text { - 향후 이용하고 싶은 여가 공간 } \\
\text { - 공공문화여가시설에 대한 만족도 } \\
\text { - 여가산업에 대한 평가 및 만족도 }\end{array}$ \\
\hline
\end{tabular}




\begin{tabular}{|c|c|c|}
\hline 항목 & 내용 & 세부 내용 \\
\hline \multirow{3}{*}{$\begin{array}{l}\text { 다양한 } \\
\text { 여가활동 }\end{array}$} & 동호회 활동 & $\begin{array}{l}\text { - 동호회 활동 여부 } \\
\text { - 동호회 활동 유형 }\end{array}$ \\
\hline & 사회성 여가 활동 & $\begin{array}{l}\text { - 자원봉사 활동 경험 } \\
\text { - 자원봉사 시간 및 활동 분야 }\end{array}$ \\
\hline & $\begin{array}{c}\text { 스마트기기를 } \\
\text { 활용한 여가활동 }\end{array}$ & $\begin{array}{l}\text { - 스마트기기 활용시간 } \\
\text { - 스마트기기를 이용한 여가활동 }\end{array}$ \\
\hline \multirow[t]{2}{*}{ 여가인식 및 만족도 } & 여가인식 & $\begin{array}{l}\text { - 정책 중요도 및 만족도 평가 } \\
\text { - 일(학업)과 여가의 균형 } \\
\text { - 향후 여가 시간 활용 } \\
\text { - 여가생활 만족도 및 불만족 이유 } \\
\text { - 여가에 대한 인식 }\end{array}$ \\
\hline & 행복수준 & - 현재 행복 수준 \\
\hline
\end{tabular}

\section{3) 용어 개념 및 정의}

국민여가활동조사에 나오는 예술향유와 관련된 주요 용어 및 유형은 다음과 같다.

〈표 3-3〉 2019 국민여가활동조사: 용어 정의

\begin{tabular}{|c|c|}
\hline 구분 & 내용 \\
\hline \multirow[b]{2}{*}{ 문화예술관람활동 } & 정의: 교양 함양을 위해 문화예술 공연 등을 관람하는 행동 \\
\hline & $\begin{array}{ll}\text { - 전시회 관람 } & - \text { 박물관 관람 } \\
\text { - 음악연주회 관람 } & - \text { 전통예술공연 관람 } \\
\text { - 연극공연 관람 } & - \text { 무용공연 관람 } \\
\text { - 영화보기 } & - \text { 연예공연 관람 }\end{array}$ \\
\hline \multirow[b]{2}{*}{ 문화예술참여활동 } & 정의: 문화예술 공연, 창작활동, 미술, 연주 등에 직접 참여하는 활동 \\
\hline & $\begin{array}{ll}\text { - 문화행사 참여 } & - \text { 글짓기/독서토론 } \\
\text { - 미술활동 } & - \text { 악기연주/노래교실 } \\
\text { - 전통예술 배우기 } & - \text { 사진촬영 } \\
\text { - 춤/무용 } & \end{array}$ \\
\hline \multirow[b]{2}{*}{ 취미오락활동 } & 정의: 전문성보다는 자신의 흥미에 중점을 두고 자유 시간에 즐기는 다양한 활동 \\
\hline & $\begin{array}{l}\text { 수집활동 / 생활공예 / 요리하기·다도 } \\
\text { 반려동물 돌보기 / 노래방 가기 / 인테리어 } \\
\text { 등산 / 낚시 / 미니홈피·블로그 관리 } \\
\text { 인터넷 검색·채팅·UCC 제작·SNS } \\
\text { 게임 / 보드게임·퍼즐 맞추기 / 바둑·장기·체스 } \\
\text { 겜블·복권구입 / 쇼핑 / 외식 / 음주 } \\
\text { 독서(웹소설 포함) / 미용 } \\
\text { 어학·기술·자격증 취득 공부·학원 등 이용 } \\
\text { 이색·테마카페 체험 / 원예 }\end{array}$ \\
\hline
\end{tabular}




\section{4) 주요 조사 결과}

(1) 지난 1 년간 참여한 개별 여가활동

지난 1 년간 주 여가활동은 ‘TV시청’이 92.8\%로 가장 많았으며, 문화예술관람활 동 중에는 '영화관람'이 포함되었다. 10 20대를 중심으로 연령이 낮을수록 '영화관 람'을 많이 하는 것으로 나타났다.

〈표 3-4〉연간 한 번 이상 참여한 여가활동(복수응답): 2019 국민여가활동조사

\begin{tabular}{|c|c|c|c|c|c|c|c|c|c|c|c|}
\hline \multicolumn{2}{|c|}{ 구분 } & TV시청 & $\begin{array}{l}\text { 잡담/ } \\
\text { 통화/ } \\
\text { 문자 }\end{array}$ & $\begin{array}{l}\text { 쇼핑/ } \\
\text { 외식 }\end{array}$ & $\begin{array}{l}\text { 친구만남 } \\
\text { /이성 } \\
\text { 교제 } \\
\text { /미팅 } \\
\text { /소개팅 }\end{array}$ & $\begin{array}{l}\text { 산책 및 } \\
\text { 걷기 }\end{array}$ & $\begin{array}{c}\text { 목욕/ } \\
\text { 사우나/ } \\
\text { 찜질방 }\end{array}$ & \begin{tabular}{|c|} 
인터넷 \\
검색/1인 \\
미디어 \\
/SNS
\end{tabular} & $\begin{array}{c}\text { 가족 및 } \\
\text { 친지 } \\
\text { 방문 }\end{array}$ & $\begin{array}{l}\text { 영화 } \\
\text { 관람 }\end{array}$ & $\begin{array}{c}\text { 스포츠 } \\
\text { 경기 } \\
\text { 간접관람 }\end{array}$ \\
\hline \multicolumn{2}{|c|}{ 전체 } & 92.8 & 82.3 & 82.3 & 79.3 & 72.2 & 71.2 & 71.2 & 68.9 & 67.5 & 58.5 \\
\hline \multirow{2}{*}{ 성별 } & 남성 & 91.9 & 78.9 & 79.0 & 79.5 & 67.7 & 66.1 & 72.2 & 66.2 & 68.2 & 75.6 \\
\hline & 여성 & 93.8 & 85.8 & 85.5 & 79.1 & 76.7 & 76.2 & 70.1 & 71.6 & 66.8 & 41.4 \\
\hline \multirow{7}{*}{ 연령 } & $15-19$ & 85.0 & 89.2 & 74.5 & 87.8 & 54.4 & 52.6 & 86.2 & 58.1 & 90.1 & 61.0 \\
\hline & 20대 & 88.0 & 86.8 & 84.5 & 91.0 & 64.3 & 59.3 & 86.4 & 61.8 & 92.2 & 66.9 \\
\hline & 30대 & 92.2 & 83.1 & 85.8 & 83.1 & 67.5 & 66.6 & 81.9 & 72.1 & 84.1 & 62.7 \\
\hline & 40대 & 92.2 & 83.6 & 86.4 & 77.5 & 72.6 & 74.5 & 78.8 & 76.2 & 78.7 & 68.9 \\
\hline & 50대 & 94.6 & 81.9 & 86.6 & 75.9 & 76.8 & 75.9 & 71.7 & 70.2 & 65.9 & 55.2 \\
\hline & 60대 & 96.5 & 76.7 & 76.8 & 74.4 & 81.2 & 81.3 & 51.5 & 67.4 & 38.2 & 49.5 \\
\hline & 70세 이상 & 98.0 & 77.1 & 71.3 & 67.6 & 79.8 & 78.4 & 38.1 & 67.4 & 18.6 & 39.2 \\
\hline
\end{tabular}

(2) 가장 많이 하는 여가활동 및 변화

우리나라 국민들이 가장 많이 하는 여가활동은 TV시청을 포함한 휴식활동임을 알 수 있다. 가장 많이 하는 1 5순위 기준으로 주 여가활동은 ‘TV시청’이 71.4\%로 가장 많은 반면, 예술향유와 관련된 문화예술관람 및 참여 활동은 상위 10 위 내에 포함되지 않았다. 
〈표 3-5〉 가장 많이 하는 여가활동 상위 10개(복수응답): 2019 국민여가활동조사

(단위: \%)

\begin{tabular}{|c|c|c|c|c|c|c|c|c|c|c|c|}
\hline \multicolumn{2}{|c|}{ 구분 } & TV시청 & $\begin{array}{l}\text { 잡담/ } \\
\text { 통화/ } \\
\text { 문자 }\end{array}$ & $\begin{array}{l}\text { 쇼핑 } \\
\text { /외식 }\end{array}$ & \begin{tabular}{|c|} 
인터넷 \\
검색/1인 \\
미디어 \\
/SNS
\end{tabular} & $\begin{array}{l}\text { 산책 및 } \\
\text { 걷기 }\end{array}$ & \begin{tabular}{|l|} 
친구만남 \\
/이성 \\
교제/ \\
미팅/ \\
소개팅
\end{tabular} & $\begin{array}{l}\text { 모바일 } \\
\text { 콘텐츠 } \\
\text { 동영상, } \\
\text { VOD } \\
\text { 시청 }\end{array}$ & 음주 & $\begin{array}{c}\text { 목욕/ } \\
\text { 사우나/ } \\
\text { 찜질방 }\end{array}$ & 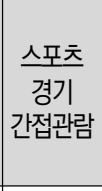 \\
\hline \multicolumn{2}{|c|}{ 전체 } & 71.4 & 38.2 & 37.4 & 35.5 & 32.1 & 27.1 & 20.8 & 16.8 & 16.8 & 15.1 \\
\hline \multirow{2}{*}{ 성별 } & 남성 & 69.0 & 31.1 & 33.9 & 36.3 & 26.6 & 27.7 & 23.0 & 27.0 & 11.7 & 23.2 \\
\hline & 여성 & 73.8 & 45.3 & 41.0 & 34.6 & 37.6 & 26.5 & 18.7 & 6.7 & 21.8 & 7.0 \\
\hline \multirow{7}{*}{ 연령 } & $15-19$ & 42.3 & 44.9 & 21.7 & 55.1 & 7.2 & 35.9 & 46.3 & 2.2 & 5.0 & 9.5 \\
\hline & 20대 & 46.5 & 37.9 & 33.1 & 54.3 & 12.9 & 34.7 & 42.5 & 14.8 & 4.5 & 12.8 \\
\hline & 30대 & 62.6 & 36.4 & 39.8 & 47.4 & 21.5 & 22.8 & 34.4 & 16.0 & 9.5 & 15.0 \\
\hline & 40대 & 76.3 & 39.8 & 39.2 & 42.7 & 29.2 & 21.4 & 17.4 & 19.2 & 14.6 & 18.8 \\
\hline & 50대 & 80.0 & 39.4 & 42.2 & 30.5 & 36.2 & 22.8 & 10.1 & 22.7 & 20.0 & 15.7 \\
\hline & 60대 & 86.5 & 34.7 & 38.4 & 15.4 & 52.2 & 28.3 & 5.5 & 19.3 & 30.1 & 15.3 \\
\hline & 70세 이상 & 92.3 & 37.6 & 36.0 & 3.4 & 60.2 & 33.0 & 0.6 & 12.1 & 32.1 & 13.7 \\
\hline \multicolumn{2}{|c|}{ 2016년 } & 72.7 & 26.7 & 28.6 & 39.1 & 29.9 & - & - & 20.3 & 14.6 & 11.2 \\
\hline \multicolumn{2}{|c|}{ 2018년 } & 71.8 & 32.2 & 32.5 & 36.7 & 28.7 & - & - & 21.4 & 17.3 & 12.0 \\
\hline \multicolumn{2}{|c|}{ 2019년 } & 71.4 & 38.2 & 37.4 & 35.5 & 32.1 & 27.1 & 20.8 & 16.8 & 16.8 & 15.1 \\
\hline
\end{tabular}

(3) 여가활동 유형별 참여 실태 및 변화

여가활동 유형별로는 ‘휴식활동’(92.0\%)이 가장 많으며, ‘문화예술참여활동’(5.1\%) 이 가장 적은 것으로 나타났다. '문화예술관람활동'은 10 20대에서 가장 많고 60대 이상은 적은 반면, '문화예술참여활동'은 10 대를 제외하고 50 대 이상의 연령에서 많 은 것으로 나타난다. 2019년의 '문화예술관람활동'과 '문화예술참여활동' 은 2018년 에 비해 감소한 것으로 나타났다. 
〈표 3-6〉 여가활동 유형별 참여 실태 및 변화: 2019 국민여가활동조사

(단위: \%)

\begin{tabular}{|c|c|c|c|c|c|c|c|c|c|}
\hline \multicolumn{2}{|c|}{ 구분 } & $\begin{array}{l}\text { 휴식 } \\
\text { 활동 }\end{array}$ & $\begin{array}{c}\text { 취미 } \\
\text { 오락활동 }\end{array}$ & $\begin{array}{l}\text { 사회 및 } \\
\text { 기타활동 }\end{array}$ & $\begin{array}{l}\text { 스푸츠 } \\
\text { 참여활동 }\end{array}$ & $\begin{array}{l}\text { 문화예술 } \\
\text { 관람활동 }\end{array}$ & $\begin{array}{l}\text { 스포츠 } \\
\text { 관람활동 }\end{array}$ & 관광활동 & 문화예술 \\
\hline \multicolumn{2}{|c|}{ 전체 } & 92.0 & 85.9 & 65.9 & 25.4 & 16.7 & 16.6 & 15.9 & 5.1 \\
\hline \multirow{2}{*}{ 성별 } & 남성 & 90.4 & 88.1 & 59.7 & 31.1 & 15.2 & 25.6 & 16.3 & 3.3 \\
\hline & 여성 & 93.6 & 83.7 & 72.0 & 19.7 & 18.1 & 7.5 & 15.4 & 6.8 \\
\hline \multirow{7}{*}{ 연령 } & $15-19$ & 85.8 & 93.9 & 67.7 & 26.1 & 23.0 & 14.8 & 7.4 & 7.4 \\
\hline & 20대 & 84.9 & 93.0 & 60.6 & 26.5 & 27.9 & 15.8 & 11.1 & 4.0 \\
\hline & 30대 & 90.2 & 90.7 & 60.2 & 29.3 & 21.1 & 17.3 & 20.0 & 3.3 \\
\hline & 40대 & 91.5 & 89.6 & 62.4 & 28.4 & 19.2 & 20.0 & 18.7 & 4.2 \\
\hline & 50대 & 94.3 & 86.3 & 67.9 & 27.7 & 13.7 & 16.1 & 16.7 & 6.4 \\
\hline & 60대 & 96.5 & 78.5 & 71.3 & 20.2 & 7.8 & 15.5 & 16.4 & 5.5 \\
\hline & 70세 이상 & 98.8 & 67.5 & 76.1 & 15.1 & 3.3 & 13.9 & 14.4 & 6.3 \\
\hline \multicolumn{2}{|c|}{ 2016년 } & 86.9 & 86.5 & 62.5 & 36.4 & 19.2 & 14.3 & 16.9 & 5.9 \\
\hline \multicolumn{2}{|c|}{ 2018년 } & 86.0 & 90.5 & 65.2 & 35.3 & 21.1 & 15.4 & 14.6 & 6.5 \\
\hline \multicolumn{2}{|c|}{ 2019년 } & 92.0 & 85.9 & 65.9 & 25.4 & 16.7 & 16.6 & 15.9 & 5.1 \\
\hline
\end{tabular}

(4) 여가활동이 미치는 영향

삶에 여가활동이 긍정적인 영향을 끼친다고 평가한 비율은 전체 중 $89.7 \%$ 임을 알 수 있다. 전체 응답자의 평균이 크게 차이나지는 않으나, 고연령층 대비 젊은층 의 평균이 소폭 높은 것으로 나타났다.

〈표 3-7〉 여가활동이 삶에 긍정적 영향을 미치는 정도: 2019 국민여가활동조사

(단위: \%, 점/7점)

\begin{tabular}{|c|c|c|c|c|c|c|c|c|c|}
\hline \multicolumn{2}{|c|}{ 구분 } & $\begin{array}{c}\text { 전혀 } \\
\text { 그렇지않다 }\end{array}$ & $\begin{array}{l}\text { 그렇지 } \\
\text { 않다 }\end{array}$ & $\begin{array}{c}\text { 약간 } \\
\text { 그렇지않다 }\end{array}$ & 보통이다 & $\begin{array}{l}\text { 약간 } \\
\text { 그렇다 }\end{array}$ & 그렇다 & $\begin{array}{c}\text { 매우 } \\
\text { 그렇다 }\end{array}$ & 평균(점) \\
\hline \multicolumn{2}{|c|}{ 전체 } & 0.0 & 0.1 & 0.8 & 9.4 & 36.3 & 36.4 & 17.1 & 5.6 \\
\hline \multirow{2}{*}{ 성별 } & 남성 & 0.0 & 0.1 & 0.9 & 9.0 & 37.2 & 36.0 & 16.8 & 5.6 \\
\hline & 여성 & - & 0.1 & 0.7 & 9.7 & 35.3 & 36.8 & 17.4 & 5.6 \\
\hline \multirow{7}{*}{ 연령 } & $15-19$ & 0.2 & 0.3 & 0.3 & 8.1 & 32.5 & 36.2 & 22.3 & 5.7 \\
\hline & 20대 & - & 0.1 & 0.6 & 7.2 & 32.9 & 39.7 & 19.5 & 5.7 \\
\hline & 30대 & - & 0.0 & 0.3 & 6.6 & 35.1 & 38.0 & 20.0 & 5.7 \\
\hline & 40대 & - & 0.1 & 0.5 & 7.9 & 36.8 & 36.9 & 17.9 & 5.6 \\
\hline & 50대 & 0.0 & 0.2 & 1.2 & 9.9 & 37.2 & 34.7 & 16.7 & 5.5 \\
\hline & 60대 & - & 0.1 & 0.7 & 11.4 & 39.4 & 35.7 & 12.7 & 5.5 \\
\hline & 70세 이상 & - & 0.1 & 2.0 & 15.7 & 38.3 & 32.5 & 11.5 & 5.4 \\
\hline
\end{tabular}




\section{나. 2019 국민문화예술활동조사}

1) 조사 개요

국민문화예술활동조사 개요는 다음과 같다.

〈표 3-8〉 2019 국민문화예술활동조사 개요

\begin{tabular}{|c|c|}
\hline 구분 & 내용 \\
\hline 조사 목적 & $\begin{array}{l}\text { - 우리나라 국민의 문화 활동 향유의 필요성 및 인식이 높아짐에 따라 실태 파악을 위한난 } \\
\text { 문화향유 경로와 방식에 대하여 통계적으로 분석하여 궁극적으로 국민 문화 향유 진흥 } \\
\text { 을 도모하기 위함 } \\
\text { - 문화수요 파악과 실태 분석, 시계열 분석 등을 통해 그간 문화 정책의 개선점을 도출하 } \\
\text { 고 향후 정책수립에 필요한 정보를 제공 }\end{array}$ \\
\hline 조사 대상 & 15세 이상 남녀 10,102 명 \\
\hline 조사 지역 & 전국 17개 시·도(제주 및 세종 포함) \\
\hline 조사 기간 & 2019.9.9-2019.11.14 \\
\hline 조사 방법 & 1:1 가구방문 면접조사 \\
\hline 조사 연혁 & $\begin{array}{l}\text { - 1988년「문화예술 수용 및 향수능력 실태조사」라는 명칭의 표본조사 실시 } \\
\text { - 1991년 통계청 승인통계로 인정되면서 「문화향수실태조사」로 명칭 변경 } \\
\text { (문화부·한국문화예술진흥원) } \\
\text { - 1994-2000년 〈문화향수실태조사〉 실시 (문화체육부·한국문화정책개발원) } \\
\text { - 2003년 〈문화향수실태조사〉 실시 (문화관광부·한국문화관광정책연구원) } \\
\text { - 2019년 「국민문화예술활동조사」로 이름 변경하여 실시 }\end{array}$ \\
\hline 조사 주기 & $\begin{array}{l}\text { - 2005년 이전: 3년 주기 } \\
\text { - 2005년: 2년 주기로 변경 } \\
\text { - 2019년: 1년 주기로 변경 }\end{array}$ \\
\hline
\end{tabular}

\section{2) 조사 내용}

국민문화예술활동조사는 만 15 세 이상 국민의 문화에 대한 문화예술 관람 및 교 육활동과 문화관련 활동 분석을 통한 문화향유 실태를 파악하기 위한 내용으로 구 성된다. 구체적인 조사 내용은 아래와 같다. 
〈표 3-9〉 2019 국민문화예술활동조사 내용

\begin{tabular}{|c|c|c|}
\hline 항목 & 내용 & 세부 내용 \\
\hline \multirow{6}{*}{$\begin{array}{l}\text { 문화예술관람 } \\
\text { 및 참여 }\end{array}$} & 문화예술행사 관람 실태 & $\begin{array}{l}\text { - 직접 관람 횟수 } \\
\text { - 직접 관람 만족도 } \\
\text { - 향후 1년 이내 직접 관람 의향 } \\
\end{array}$ \\
\hline & 복합문화예술관람실태 & - 복합문화예술행사 참여 경험 \\
\hline & 직접관람 실태 & $\begin{array}{l}\text { - 관람 지역 } \\
\text { - 관람 방법 } \\
\text { - 관람 시 동행인 } \\
\text { - 문화예술행사 참여 시간대 } \\
\text { - 문화예술행사에 대한 정보 습득 경로 } \\
\text { - 문화예술행사에서 보완해야 할 부분 } \\
\text { - 관람할 문화예술행사 선정 시 중요한 기준 } \\
\text { - 문화예술행사 관람 시 어려움 }\end{array}$ \\
\hline & $\begin{array}{l}\text { 매체이용 } \\
\text { (문화예술행사 } \\
\text { 관람 실태) }\end{array}$ & $\begin{array}{l}\text { - 매체를 통한 이용 경험 } \\
\text { - 이용 매체 및 주 이용 매체 } \\
\text { - 매체 이용에 대한 만족도 } \\
\text { - 온라인 동영상 제공서비스(OTT)를 통한 관람 경험 }\end{array}$ \\
\hline & 문화예술행사 참여 실태 & $\begin{array}{l}\text { - 참여 경험 } \\
\text { - 참여 활동에 대한 만족도 } \\
\text { - 향후 1년 이내 참여 활동 의향 }\end{array}$ \\
\hline & 문화예술 관련 지출 & $\begin{array}{l}\text { - 항목별 가장 지출을 많이 하는 항목 } \\
\text { - 향후 지출을 늘리고 싶은 항목 }\end{array}$ \\
\hline \multirow{2}{*}{ 문화예술교육 } & 문화예술교육 경험 & $\begin{array}{l}\text { - 유아기 및 청소년기에 문화예술교육 경험 } \\
\text { - 1년 이내 학교교육 외에 강좌나 강습 경험 } \\
\text { - 1년 이내 경험한 강좌나 강습에 대한 만족도 } \\
\text { - 향후 1년 이내 문화예술교육 의향 }\end{array}$ \\
\hline & 문화예술교육 실태 & $\begin{array}{l}\text { - 교육 시설 } \\
\text { - 문화예술교육 시 보완되어야 할 부분 } \\
\text { - 선호하는 교육방법 } \\
\text { - 학교교육 외 문화예술교육 시 어려운 점 }\end{array}$ \\
\hline \multirow{2}{*}{$\begin{array}{l}\text { 문화예술활동 } \\
\text { 공간이용 실태 }\end{array}$} & 문화예술활동 공간이용 & $\begin{array}{l}-1 \text { 년 이내 이용 횟수 } \\
- \text { 이용 공간 위치 및 만족도 } \\
- \text { 문화행사 참석 횟수 및 만족도 }\end{array}$ \\
\hline & $\begin{array}{l}\text { 문화예술활동 } \\
\text { 공간방문 의향 }\end{array}$ & $\begin{array}{l}\text { - 문화행사 참여 시 어려운 점 } \\
\text { - 향후 1년 이내 문화행사에 참여할 의향 및 선호 프로그램 } \\
\text { - 참여할 문화예술행사 선정 시 중요한 기준 }\end{array}$ \\
\hline \multirow{2}{*}{ 문화관련 활동 } & 문화 자원봉사 활동 & $\begin{array}{l}\text { - 자원봉사 활동 경험 및 참여 횟수 } \\
\text { - 금전기부 경험 여부 }\end{array}$ \\
\hline & 문화관련 동호회 참여 & $\begin{array}{l}\text { - 참여 경험 } \\
\text { - 참여한 동호회 성격 및 활동 공간, 참여 빈도 }\end{array}$ \\
\hline \multirow{2}{*}{$\begin{array}{l}\text { 역사문화 유적지 및 } \\
\text { 축제 }\end{array}$} & $\begin{array}{l}\text { 역사문화유적지 } \\
\text { 방문실태 }\end{array}$ & $\begin{array}{l}\text { - 최근 1년 이내 역사문화유적지 방문 경험 및 만족도 } \\
\text { - 향후 방문 의향 }\end{array}$ \\
\hline & 축제 관람 실태 & $\begin{array}{l}\text { - 최근 1년 이내 축제 경험 및 만족도 } \\
\text { - 향후 참여 의향 }\end{array}$ \\
\hline
\end{tabular}




\section{3) 용어 개념 및 정의}

국민문화예술활동조사에 나오는 주요 용어 및 유형은 다음과 같다.

〈표 3-10〉 2019 국민문화예술활동조사: 용어 개념 및 정의

\begin{tabular}{|c|c|}
\hline 구분 & 내용 \\
\hline 문화예술행사 & $\begin{array}{l}\text { - 문학행사(시화전, 도서전시회, 작가와의 대화) } \\
\text { - 미술(사진·서예·건축·디자인 포함) 전시회 } \\
\text { - 서양음악(클래식, 서양악기 관련) } \\
\text { - 전통예술(국악, 풍물, 민속극) } \\
\text { - 연극 } \\
\text { - 뮤지컬 } \\
\text { - 무용(서양무용, 한국무용, 현대무용) } \\
\text { - 영화 } \\
\text { - 대중음악(가요콘서트), 연예(방송 프로그램 등) }\end{array}$ \\
\hline 문화예술활동 & $\begin{array}{l}\text { - 문학행사 개최 및 창작활동(시짓기, 개인도서출판, 시화전 개최 등) } \\
\text { - 미술 전시회 및 창작활동(사진찍기, 서예, 사진전시회 개최 등) } \\
\text { - 서양음악 발표회 및 창작활동(연주회, 합주활동, 오케스트라 활동 등) } \\
\text { - 전통예술 발표회 및 창작활동(국악, 풍물, 민속극 등) } \\
\text { - 연극 발표회 및 창작환동 } \\
\text { - 뮤지컬 발표회 및 창작활동 } \\
\text { - 무용 발표회 및 창작활동(서양무용, 한국무용, 현대무용) } \\
\text { - 영화 제작 및 발표회 } \\
\text { - 대중음악, 연예(비보잉, 밴드활동 참여 등) }\end{array}$ \\
\hline
\end{tabular}

\section{4) 주요 조사 결과}

(1) 문화예술행사 관람 실태

지난 1년간 문화예술행사 관람률은 2018년 대비 0.3\%p 증가한 81.8\%로 나타났 다. 2019년 가장 관람률이 높은 분야는 '영화'(77\%)이며, 2018년 대비 관람률이 가장 증가한 분야는 ‘대중음악/연예’로 $2.2 \%$ 상승했다. 
〈표 3-11〉 분야별 문화예술행사 관람률 추이: 2019 국민문화예술활동조사

(단위: \%)

\begin{tabular}{|c|c|c|c|c|c|c|c|c|c|c|}
\hline 구분 & 2003 & 2006 & 2008 & 2010 & 2012 & 2014 & 2016 & 2018 & 2019 & $\begin{array}{l}18 \text { 대비 } \\
\text { 증감률 }\end{array}$ \\
\hline 전체 & 62.4 & 65.8 & 67.3 & 67.2 & 69.6 & 71.3 & 78.3 & 81.5 & 81.8 & 0.3 \\
\hline 문학행사 & 4.0 & 4.4 & 4.0 & 3.8 & 6.1 & 6.2 & 5.8 & 8.9 & 6.7 & -2.2 \\
\hline 미술전시회 & 10.4 & 6.8 & 8.4 & 9.5 & 10.2 & 10.6 & 12.8 & 15.3 & 13.5 & -1.8 \\
\hline 서양음악 & 6.3 & 3.6 & 4.9 & 4.4 & 4.8 & 4.9 & 4.5 & 5.5 & 6.1 & 0.6 \\
\hline 전통예술 & 5.2 & 4.4 & 4.4 & 5.7 & 6.5 & 5.7 & 7.6 & 9.3 & 10.3 & 1.0 \\
\hline 연극 & \multirow{2}{*}{11.1} & \multirow{2}{*}{8.1} & \multirow{2}{*}{11.0} & \multirow{2}{*}{11.2} & 11.8 & 12.6 & 13.0 & 14.4 & 14.9 & 0.5 \\
\hline 뮤지컬 & & & & & 11.5 & 11.5 & 10.2 & 13.0 & 13.5 & 0.5 \\
\hline 무용 & 1.1 & 0.7 & 0.9 & 1.4 & 2.0 & 2.4 & 1.3 & 1.7 & 2.4 & 0.7 \\
\hline 영화 & 53.3 & 58.9 & 61.5 & 60.3 & 64.4 & 65.8 & 73.3 & 75.8 & 77.0 & 1.2 \\
\hline 대중음악/연예 & 10.3 & 10.0 & 8.2 & 7.6 & 13.5 & 14.4 & 14.6 & 21.1 & 23.3 & 2.2 \\
\hline
\end{tabular}

(2) 문화예술행사 참여 활동

문화예술행사 직접 참여 경험률은 2010년 $2.2 \%$ 이후 지속적으로 증가하여 2019년에는 $10.4 \%$ 로 나타났다. 동일시기 관람률의 증감률과 비교할 때, 직접 참여 경험률은 거의 5 배에 달하는 증가가 주목된다. 2019년 기준 전체 $10.4 \%$ 중에서는 '미술전시회'에 참여한 경우가 $2.9 \%$ 로 가장 많았고, 그 다음은 '대중음악/연예' (2.5\%)인 것으로 나타났다. 연령별로는 10 대와 20 대가 각각 $12.3 \%, 12.9 \%$ 로 참여 율이 높게 나온 반면, 연령이 높아질수록 점차 감소세를 보임을 알 수 있다.

〈표 3-12〉 문화예술행사 참여율 변화: 2019 국민문화예술활동조사

(단위: \% )

\begin{tabular}{c|c|c|c|c|c|c|c}
\hline 구분 & 2008 & 2010 & 2012 & 2014 & 2016 & 2018 & 2019 \\
\hline 전체 & 2.4 & 2.2 & 3.7 & 4.7 & 7.6 & 9.0 & 10.4 \\
\hline
\end{tabular}


〈표 3-13〉 문화예술행사 참여 실태: 2019 국민문화예술활동조사

(단위: \%)

\begin{tabular}{|c|c|c|c|c|c|c|c|c|c|c|c|c|}
\hline \multicolumn{2}{|c|}{ 구분 } & $\begin{array}{l}\text { 참여 } \\
\text { 안함 }\end{array}$ & 참여함 & $\begin{array}{l}\text { 문학 } \\
\text { 행사 }\end{array}$ & $\begin{array}{l}\text { 미술 } \\
\text { 전시회 }\end{array}$ & $\begin{array}{l}\text { 서양 } \\
\text { 음악 }\end{array}$ & $\begin{array}{l}\text { 전통 } \\
\text { 예술 }\end{array}$ & 연극 & 뮤지컬 & 무용 & 영화 & $\begin{array}{l}\text { 대중음악 } \\
\text { /연예 }\end{array}$ \\
\hline \multicolumn{2}{|c|}{ 전체 } & 89.6 & 10.4 & 2.0 & 2.9 & 1.7 & 1.8 & 1.1 & 0.7 & 0.5 & 2.2 & 2.5 \\
\hline \multirow{2}{*}{ 성별 } & 남성 & 90.3 & 9.7 & 1.7 & 2.6 & 1.8 & 1.8 & 1.1 & 0.8 & 0.3 & 2.3 & 2.3 \\
\hline & 여성 & 88.8 & 11.2 & 2.4 & 3.1 & 1.6 & 1.8 & 1.1 & 0.7 & 0.7 & 2.2 & 2.7 \\
\hline \multirow{7}{*}{ 연령 } & $15-19$ & 87.7 & 12.3 & 4.2 & 3.3 & 1.6 & 1.1 & 1.2 & 0.9 & 0.5 & 1.5 & 4.0 \\
\hline & 20대 & 87.1 & 12.9 & 1.8 & 3.0 & 1.1 & 0.7 & 2.0 & 1.0 & 0.3 & 3.7 & 5.1 \\
\hline & 30대 & 89.2 & 10.8 & 2.6 & 3.4 & 2.4 & 1.6 & 1.1 & 1.3 & 0.4 & 2.2 & 2.0 \\
\hline & 40대 & 88.8 & 11.2 & 2.2 & 3.1 & 1.8 & 1.9 & 1.5 & 0.9 & 0.4 & 2.5 & 2.5 \\
\hline & 50대 & 90.1 & 9.9 & 1.7 & 2.4 & 2.0 & 2.7 & 0.9 & 0.6 & 0.7 & 2.2 & 1.7 \\
\hline & 60 대 & 89.7 & 10.3 & 2.3 & 2.8 & 1.9 & 2.5 & 0.3 & 0.3 & 0.9 & 2.0 & 2.1 \\
\hline & 70세 이상 & 94.7 & 5.3 & 0.6 & 2.1 & 0.4 & 1.7 & 0.3 & 0.0 & 0.3 & 0.4 & 0.9 \\
\hline
\end{tabular}

\section{다. 2018 서울시민 문화향유 실태조사}

\section{1) 조사 개요}

서울시민 문화향유 실태조사 개요는 다음과 같다.

〈표 3-14〉 2018 서울시민 문화향유 실태조사 개요

\begin{tabular}{c|l}
\hline 구분 & \multicolumn{1}{|c}{ 내용 } \\
\hline 조사 목적 & 서울시민의 전반적인 문화향유 실태를 파악하여 정책방향 설정의 기초자료로 활용 \\
\hline 조사 대상 & 문화관심집단52) 3,789명과 서울 거주 일반시민 2,545명 \\
\hline 조사 지역 & 서울시 \\
\hline 조사 기간 & 2018.11.1-2018.11.19 \\
\hline 조사 방법 & 설문지 활용한 web 조사 \\
\hline & -2014 년부터 실시 \\
조사 연혁 & -2016 년 일반시민 대상 조사 추가 실시 \\
& -2018 년 문화관심집단 확장 및 일상생활 문화예술활동 문항 추가 \\
\hline 조사 주기 & 2년 주기 \\
\hline &
\end{tabular}

52) 이는 서울시 산하기관 홈페이지 통합 회원(서울시 통합회원, 서울시립미술관, 서울문화재단, 서울디자인재 단, 세종문화회관, 서울역사박물관, 서울시립교향악단, 한성백제박물관, 서울도서관 회원)에 해당된다. 
2014 2016년 조사에서는 연령·결혼·자녀 유무 등에 따라 문화에 대한 관심도 나 참여 방식 등의 양태에서 보이는 차이를 종합하여, 8개의 문화향유 특성 그룹을 도출 및 적용하여 인구학적 특성(생애주기별) 계층별 문화패턴을 분석하였다. 반면 2018년은 아래 표와 같이 2014 2016년에 적용한 인구학적 특성(생애주기별) 계 층 분류를 사용하지 않고, 이를 세대와 성별, 혼인 유무, 자녀 유무에 따라 나눈 분 류로 재구성하여 사용하였다. 조사 결과 분석 또한 5개의 대표 키워드를 도출하여 제시하였다.53)

〈표 3-15〉 서울시민 문화향유 실태조사 대상 분류 변화: 2014 2016 vs. 2018

\begin{tabular}{|c|c|c|c|}
\hline 구분 & \multicolumn{2}{|c|}{ 2014 2016년 } & 2018년 \\
\hline \multirow{8}{*}{ 문화향유 특성 그룹 } & 20대 & 문화열광족 & 29세 이하 \\
\hline & \multirow{2}{*}{ 30대 } & 화려한 싱글녀 & 3040 미혼남 \\
\hline & & 육아맘 & 3040 미혼녀 \\
\hline & \multirow{3}{*}{ 40대 } & 프렌디 & 3040 기혼(자녀무) \\
\hline & & 컬쳐맘 & 3040 기혼남(자녀유) \\
\hline & & 블루 싱글녀 & 3040 기혼녀(자녀유) \\
\hline & 50대 & 낭만족 & 50대 \\
\hline & 60대 & 액티브 시니어 & 60대 \\
\hline
\end{tabular}

\section{2) 조사 내용}

2018년 조사는 이전 조사와 달리 변화하는 문화 트렌드에 발맞춰 전통적인 문화 예술관람 활동뿐만 아니라 미디어를 통해 이루어지는 문화예술 활동, 거주지 근처 에서 이루어지는 생활권 문화예술 활동(작은도서관, 북카페, 복합문화공간 등)을 측 정하기 위하여 문항을 새로 구성하였다.

53) 1) 세대역전?: 50대 꽃중년의 문화바람, 20대 앞지르기 직전, 2) 문화소비: 부부, 가족끼리 $\cdots 50$ 대 남성 이 가장 많은 문화비 지출, 3) 문화편식: 장르평중 현상 여전 $\cdots$ 문화활동 위해서는 한 번의 경험이 중요!, 4) 문화로 소확행: 문화활동을 통해 느끼는 소확행도 세대별로 달라!, 5) 생활권문화: 거주지 주변에서 문화활동, 일상 속 공간의 중요성 
〈표 3-16〉 2018 서울시민 문화향유 실태조사 내용

\begin{tabular}{|c|c|}
\hline 항목 & 세부 항목 \\
\hline 문화/여가 활동 실태 & $\begin{array}{l}\text { - 하루 평균 여가 시간, 여가 시간 충분성 } \\
\text { - 주로 하는 여가 활동 및 여가활동 동반자 } \\
\text { - 가장 희망하는 여가 활동 } \\
\text { - 문화예술 관심도 }\end{array}$ \\
\hline $\begin{array}{c}\text { 문화예술 } \\
\text { 관람 경험 및 만족도 }\end{array}$ & $\begin{array}{l}\text { - 최근 1년 문화활동 관람(총 횟수/본인 지불 횟수/총 비용) } \\
\text { - 과거 관람 경험 } \\
\text { - 문화예술관람 의향 } \\
\text { - 문화 프로그램 관람 의향 } \\
\text { - 문화예술관람(참석) 동반자 } \\
\text { - 문화예술 행사 주 관람 지역 } \\
\text { - 관람 만족도 } \\
\text { - 문화예술관람 애로 사항 }\end{array}$ \\
\hline $\begin{array}{c}\text { 문화예술 활동 } \\
\text { 참여 경험 및 만족도 }\end{array}$ & $\begin{array}{l}\text { - 문화예술활동 참여 경험/참여 형태/참여 빈도 } \\
\text { - 문화예술교육 최초 시기/기간 } \\
\text { - 문화예술 참여 만족도 }\end{array}$ \\
\hline $\begin{array}{l}\text { 일상생활 문화예술활동 } \\
\text { 경험 및 만족도 }\end{array}$ & $\begin{array}{l}\text { - 일상생활 문화예술활동 수준 } \\
\text { - 공간/공연·행사 참여 수준 } \\
\text { - 이동 공간 문화예술 콘텐츠 향유 경험 } \\
\text { - 일상생활 문화예술활동 만족도 }\end{array}$ \\
\hline $\begin{array}{l}\text { 문화예술활동 } \\
\text { 경험과 인식 }\end{array}$ & $\begin{array}{l}\text { - 문화예술활동 동기 및 전이 } \\
\text { - 문화예술활동 장애 요인 } \\
\text { - 문화생활 전반적 만족도 } \\
\text { - 문화예술 중요도 } \\
\text { - 문화예술 정서적 효과 } \\
\text { - 좋아하는 음악 }\end{array}$ \\
\hline $\begin{array}{c}\text { 문화예술 } \\
\text { 만족도 및 행복지수 등 }\end{array}$ & $\begin{array}{l}\text { - 서울 문화환경 전반적 만족도 } \\
\text { - 거주 자치구 문화환경 전반적 만족도 } \\
\text { - 거주 자치구 문화환경 수준 } \\
\text { - 삶의 만족도(행복 정도) }\end{array}$ \\
\hline
\end{tabular}

\section{3) 용어 개념 및 정의}

서울시민 문화향유 실태조사에 나오는 주요 용어 및 유형은 다음과 같다. 
〈표 3-17〉 2018 서울시민 문화향유 실태조사: 용어 개념 및 정의

\begin{tabular}{|c|c|}
\hline 구분 & 내용 \\
\hline 여가활동 & $\begin{array}{l}\text { - TV 또는 비디오(DVD) 시청 } \\
\text { - 문화예술관람(연극, 영화, 연주회, 전시회 등) } \\
\text { - 문화예술활동(글쓰기, 악기연주 등) } \\
\text { - 독서 및 음악감상 } \\
\text { - 운동경기 관람 } \\
\text { - 운동(축구, 테니스, 조깅, 등산, 산책 등) } \\
\text { - 여행, 야외 나들이 } \\
\text { - 컴퓨터 게임, 인터넷 검색 등 } \\
\text { - 사회봉사활동(자원봉사, 사교모임 등) } \\
\text { - 종교활동 } \\
\text { - 휴식(다른 활동을 하지 않음) }\end{array}$ \\
\hline 문화예술관람 & $\begin{array}{l}\text { - 미술관, 전시회 관람(미술, 사진, 건축, 디자인 등) } \\
\text { - 박물관 관람 } \\
\text { - 음악공연관람(클래식, 오페라 등) } \\
\text { - 무용공연관람(현대무용, 발레 등) } \\
\text { - 전통예술공연 관람(국악, 민속놀이 등) } \\
\text { - 연극공연 관람(뮤지컬 포함) } \\
\text { - 문학행사 관람(시낭독회, 도서전시회 등) } \\
\text { - 극장에서 영화관람(TV, 컴퓨터를 이용한 영화시청은 제외) } \\
\text { - 대중공연 관람(쇼, 콘서트, 마술쇼 등) } \\
\text { - 축제(야외행사 포함) 관람 }\end{array}$ \\
\hline 문화프로그램 & $\begin{array}{l}\text { - 홍대 인디밴드 공연(인디밴드, 락페스티벌, 비보이, 스트리트댄스 등 공연) } \\
\text { - 독립예술 영화(국내외 독립예술영화나 영화제 출품작, 서울독립영화제·인디포럼 } \\
\text { 등) } \\
\text { - 대안공간 및 창작공간 등의 전시·공연(미디어아트 설치, 아카이빙, 다원예술 등 } \\
\quad \text { 현대미술 전시 및 공연) }\end{array}$ \\
\hline 문화예술참여 & $\begin{array}{l}\text { - 문화예술 취미활동(창작, 연주, 전시, 공유 등) } \\
\text { - 문화예술교육(학교교육 제외) } \\
\text { - 문화예술 자원봉사 }\end{array}$ \\
\hline $\begin{array}{c}\text { 일상생활의 매체를 통한 } \\
\text { 문화예술 활동 }\end{array}$ & \begin{tabular}{|ll} 
- 드라마 & - 대중 음악 \\
- 클래식 음악 & - 현재 상영 영화 \\
- 상영 종료 영화 & - 무용 공연(현대무용, 발레 등) \\
- 전통 공연(국악 등) & - 연극(뮤지컬 포함) \\
- 전자책 및 오디오북 & - 웹소설 및 웹툰 \\
- 미술작품/사진 전시 & - 박물관 전시 \\
\end{tabular} \\
\hline $\begin{array}{c}\text { 일상생활의 공간을 통한 } \\
\text { 문화예술 활동 }\end{array}$ & $\begin{array}{l}\text { - 북카페 } \\
\text { - 복합문화공간(예술의 전당, 문예회관, 다목적 소규모 문화공간 등) } \\
\text { - 독립 서점 } \\
\text { - 작은 도서관 }\end{array}$ \\
\hline $\begin{array}{c}\text { 일상생활의 문화예술 } \\
\text { 프로그램 }\end{array}$ & $\begin{array}{l}\text { - 거리 음악공연 } \\
\text { - 거리 일반 공연(마술, 버블쇼 등) } \\
\text { - 캐리커처 } \\
\text { - 아트 플리마켓 }\end{array}$ \\
\hline
\end{tabular}


4) 주요 조사 결과

(1) 최근 1년 문화예술관람 경험

서울시민의 $75.6 \%$ 는 연간 1 회 이상 문화예술관람 경험을 가지고 있는 것으로 나 타났다. '영화 관람'이 $65.2 \%$ 로 가장 높고, 다음으로 축제 관람 및 연극공연이 높게 나타났다. 극장 영화 관람은 여성/50대에서, 축제 관람은 남성/60세 이상에서, 연 극은 여성/30 40대에서 상대적으로 높은 편으로 나타났다.

〈표 3-18〉 최근 1년간 문화예술관람 실태: 2018 서울시민 문화향유 실태조사

\begin{tabular}{|c|c|c|c|c|c|c|c|c|c|c|c|c|c|}
\hline \multicolumn{2}{|c|}{ 구분 } & 사례수 & $\begin{array}{l}\text { 극장 } \\
\text { 영화 }\end{array}$ & $\begin{array}{l}\text { 축제 } \\
\text { 관람 }\end{array}$ & $\begin{array}{l}\text { 연극 } \\
\text { 공연 }\end{array}$ & 박물관 & $\begin{array}{l}\text { 미술관 } \\
\text { 전시회 }\end{array}$ & $\begin{array}{l}\text { 대중 } \\
\text { 공연 }\end{array}$ & $\begin{array}{l}\text { 전통 } \\
\text { 예술 } \\
\text { 공연 }\end{array}$ & 음악 & $\begin{array}{l}\text { 문학 } \\
\text { 행사 }\end{array}$ & $\begin{array}{l}\text { 무용 } \\
\text { 공연 }\end{array}$ & 없음 \\
\hline \multicolumn{2}{|c|}{ 전체 } & $(2,500)$ & 65.2 & 25.2 & 20.9 & 14.1 & 11.3 & 9.4 & 5.2 & 4.3 & 2.8 & 1.8 & 24.4 \\
\hline \multirow{2}{*}{ 성별 } & 남성 & $(1,216)$ & 61.8 & 27.0 & 17.1 & 12.5 & 9.9 & 6.8 & 6.1 & 4.1 & 3.6 & 1.7 & 26.1 \\
\hline & 여성 & $(1,284)$ & 68.3 & 23.5 & 24.4 & 15.6 & 12.7 & 11.8 & 4.4 & 4.4 & 2.1 & 1.8 & 22.8 \\
\hline \multirow{5}{*}{ 연령 } & 29세 이하 & (555) & 56.8 & 19.1 & 17.8 & 7.5 & 9.7 & 13.9 & 2.7 & 3.9 & 3.0 & 1.5 & 33.8 \\
\hline & 30대 & (447) & 69.2 & 22.8 & 25.3 & 16.2 & 16.1 & 11.2 & 2.5 & 3.7 & 1.5 & 2.1 & 23.5 \\
\hline & 40대 & (464) & 66.4 & 27.3 & 27.6 & 19.5 & 8.5 & 9.0 & 3.8 & 4.6 & 2.7 & 1.1 & 22.3 \\
\hline & 50대 & (445) & 76.0 & 23.9 & 19.2 & 11.5 & 10.3 & 6.6 & 4.4 & 3.3 & 3.1 & 1.3 & 16.9 \\
\hline & 60세이상 & (589) & 60.9 & 32.0 & 16.4 & 16.4 & 12.4 & 6.1 & 11.1 & 5.5 & 3.5 & 2.7 & 23.6 \\
\hline
\end{tabular}

(2) 문화예술 참여 경험

문화예술참여 경험을 온라인과 오프라인 채널로 구분해 취미활동과 교육, 자원봉 사 경험에 대해 확인한 결과, 취미활동(창작, 연주, 전시, 공유 등) 경험률이 9\% 수 준으로 가장 높고, 다음으로 교육(학교교육 제외), 자원봉사 순으로 나타났다. 10 30대의 경우 온라인 활동 비중이 타 연령 대비 높은 특성을 보인 반면, 오프라 인 활동은 60세 이상에서 높게 나타났다. 
〈표 3-19〉 문화예술활동 참여 실태: 2018 서울시민 문화향유 실태조사

(단위: \%)

\begin{tabular}{|c|c|c|c|c|c|c|c|c|}
\hline & 구분 & 사례수 & 취미_온라인 & 취미_오프 & 교육_온라인 & 교육_오프 & 봉사_온라인 & 봉사_오프 \\
\hline & 전체 & $(2,500)$ & 9.2 & 9.7 & 5.3 & 5.6 & 3.7 & 4.9 \\
\hline & 남성 & $(1,216)$ & 11.0 & 7.7 & 5.0 & 5.0 & 5.0 & 5.2 \\
\hline & 여성 & $(1,284)$ & 7.5 & 11.6 & 5.5 & 6.1 & 2.5 & 4.7 \\
\hline & 29세 이하 & (555) & 11.4 & 12.7 & 9.2 & 7.5 & 6.2 & 10.0 \\
\hline & 30대 & (447) & 13.0 & 8.3 & 6.8 & 4.9 & 4.2 & 3.4 \\
\hline 연령 & 40대 & (464) & 7.4 & 7.3 & 3.7 & 4.7 & 3.1 & 3.9 \\
\hline & 50대 & (445) & 5.2 & 7.6 & 2.4 & 3.9 & 2.3 & 2.9 \\
\hline & 60세이상 & (589) & 8.8 & 11.5 & 3.8 & 6.2 & 2.6 & 3.7 \\
\hline
\end{tabular}

(3) 일상생활 매체를 통한 문화예술 활동

$\mathrm{TV}$, 스마트폰 등 일상생활의 매체를 통한 문화향유 활동에서는 대중음악과 영화, 드라마의 경험률이 $65 \%$ 이상으로 높게 나타났다. 음악과 드라마는 여성의 경험률 이 상대적으로 높게 나타났으며, 웹소설/웹툰의 경우 29세 이하에서 $71.7 \%$ 로 높게 나타났다.

〈표 3-20〉 일상생활에서의 미디어 문화예술 활동 실태: 2018 서울시민 문화향유 실태조사

\begin{tabular}{|c|c|c|c|c|c|c|c|c|c|c|c|c|c|c|}
\hline \multicolumn{2}{|c|}{ 구분 } & 사례수 & $\begin{array}{l}\text { 대중 } \\
\text { 음악 }\end{array}$ & $\begin{array}{l}\text { 상영 } \\
\text { 종료 } \\
\text { 영화 }\end{array}$ & 드라마 & $\begin{array}{l}\text { 현재 } \\
\text { 상영 } \\
\text { 영화 }\end{array}$ & $\begin{array}{l}\text { 웹소설 } \\
\text { 웹툰 }\end{array}$ & \begin{tabular}{|l} 
클래식 \\
음악
\end{tabular} & 연극 & $\begin{array}{c}\text { 전자책 } \\
\text { 오디오 } \\
\text { 북 }\end{array}$ & $\begin{array}{l}\text { 박물관 } \\
\text { 전시 }\end{array}$ & $\begin{array}{l}\text { 미술 } \\
\text { 작품 } \\
\text { 사진 } \\
\text { 전시 }\end{array}$ & $\begin{array}{l}\text { 전통 } \\
\text { 공연 }\end{array}$ & $\begin{array}{l}\text { 무용 } \\
\text { 공연 }\end{array}$ \\
\hline \multicolumn{2}{|c|}{ 전체 } & $(2,500)$ & 74.1 & 70.2 & 69.3 & 65.7 & 39.1 & 31.1 & 24.6 & 18.7 & 16.4 & 13.3 & 9.6 & 5.9 \\
\hline \multirow{2}{*}{ 성별 } & 남성 & $(1,216)$ & 70.9 & 70.9 & 64.1 & 65.1 & 36.4 & 29.6 & 20.4 & 17.4 & 14.3 & 11.3 & 12.2 & 5.3 \\
\hline & 여성 & $(1,284)$ & 77.0 & 69.6 & 74.2 & 66.3 & 41.7 & 32.5 & 28.6 & 19.9 & 18.2 & 15.1 & 7.2 & 6.4 \\
\hline \multirow{5}{*}{ 연령 } & 29세 ! & $(555)$ & 81.5 & 72.8 & 68.8 & 69.0 & 71.7 & 24.3 & 20.8 & 18.5 & 10.0 & 6.9 & 4.7 & 5.3 \\
\hline & 30대 & (447) & 76.7 & 69.3 & 70.8 & 65.9 & 40.2 & 36.0 & 30.4 & 22.5 & 17.0 & 17.2 & 5.2 & 7.3 \\
\hline & 40대 & (464) & 65.0 & 72.5 & 71.6 & 69.1 & 42.5 & 26.4 & 28.4 & 23.1 & 17.8 & 13.6 & 8.3 & 5.2 \\
\hline & 50대 & (445) & 76.8 & 71.3 & 68.9 & 64.7 & 26.5 & 36.1 & 18.9 & 19.8 & 14.2 & 10.5 & 9.3 & 2.7 \\
\hline & 60세 $\uparrow$ & (589) & 70.1 & 65.8 & 67.0 & 60.8 & 14.6 & 33.5 & 25.1 & 11.6 & 22.3 & 18.1 & 19.0 & 8.2 \\
\hline
\end{tabular}




\section{(4) 문화예술 활동 관련 정서적 경험}

관람활동, 참여/교육 활동, 일상의 문화활동을 통해 전반적으로 절반 이상이 문 화예술 활동과 관련하여 정서적 경험을 하고 있는 것으로 나타났다. 남성보다는 여 성의 경험 수준이 상대적으로 높음을 알 수 있다. '기분이 좋아졌다', '스트레스가 해소되었다', '여가 시간을 잘 활용했다'는 느낌을 경험했다고 응답한 비율은 $70 \%$ 이상으로 높은 반면, '자존감이 높아졌다', '다른 사람과 관계가 좋아졌다', '삶의 의 미를 찾았다'는 응답은 상대적으로 낮게 나타났다.

〈표 3-21〉 문화예술의 정서적 효과: 2018 서울시민 문화향유 실태조사

(단위: \%)

\begin{tabular}{|c|c|c|c|c|c|c|c|c|c|}
\hline \multicolumn{2}{|c|}{ 구분 } & 사례수 & $\begin{array}{l}\text { 기분 } \\
\text { 전환 }\end{array}$ & $\begin{array}{l}\text { 시간 } \\
\text { 활용 }\end{array}$ & $\begin{array}{l}\text { 스트레스 } \\
\text { 해소 }\end{array}$ & $\begin{array}{c}\text { 자존감 } \\
\text { 향상 }\end{array}$ & $\begin{array}{l}\text { 관계 } \\
\text { 개선 }\end{array}$ & $\begin{array}{l}\text { 삶의 } \\
\text { 의미 }\end{array}$ & $\begin{array}{l}\text { 전반적 } \\
\text { 행복감 }\end{array}$ \\
\hline \multicolumn{2}{|c|}{ 전체 } & $(2,500)$ & 76.3 & 75.8 & 77.0 & 52.3 & 52.0 & 51.9 & 74.2 \\
\hline \multirow{2}{*}{ 성별 } & 남성 & $(1,216)$ & 68.7 & 69.6 & 72.3 & 46.2 & 46.9 & 48.0 & 67.5 \\
\hline & 여성 & $(1,284)$ & 83.4 & 81.5 & 81.5 & 58.1 & 56.8 & 55.6 & 80.6 \\
\hline \multirow{5}{*}{ 연령 } & 29세이하 & (555) & 68.6 & 70.4 & 67.7 & 42.2 & 47.7 & 44.2 & 67.5 \\
\hline & 30대 & (447) & 77.0 & 77.0 & 76.6 & 48.1 & 48.7 & 52.0 & 79.2 \\
\hline & 40대 & (464) & 80.8 & 79.5 & 82.6 & 56.8 & 57.5 & 55.3 & 77.1 \\
\hline & 50대 & (445) & 78.5 & 75.7 & 82.2 & 62.1 & 58.1 & 54.6 & 78.3 \\
\hline & 60세이상 & (589) & 77.7 & 76.9 & 77.6 & 54.0 & 49.7 & 54.4 & 71.3 \\
\hline
\end{tabular}

(5) 문화예술의 중요도

문화예술이 본인의 삶에서 얼마나 중요한지에 대한 응답 결과, 문화예술이 본인 의 삶에서 '중요하다'는 응답은 38.7\%로 나타났으며, '보통' 응답은 $49.6 \%$ 로 나타 났다. 성별로는 여성(48.5\%)이 남성(28.2\%) 대비 높은 특성을 보였다.

〈표 3-22〉 문화예술이 본인 삶에서 중요한 정도: 2018 서울시민 문화향유 실태조사

(단위: 점/5점)

\begin{tabular}{c|c|c|c|c|c|c|c|c}
\hline \multicolumn{2}{c|}{ 구분 } & 사례수 & $\begin{array}{c}\text { 전혀 중요 } \\
\text { 하지 않다 }\end{array}$ & $\begin{array}{c}\text { 중요하지 } \\
\text { 않은 편 }\end{array}$ & 보통 & 중요한 편 & $\begin{array}{c}\text { 매우 } \\
\text { 중요하다 }\end{array}$ & 5점 평균 \\
\hline \multicolumn{2}{c|}{ 전체 } & $(2,500)$ & 2.2 & 9.5 & 49.6 & 33.7 & 5.0 & 3.30 \\
\hline \multirow{2}{*}{ 성별 } & 남성 & $(1,216)$ & 2.7 & 11.6 & 57.5 & 25.3 & 2.9 & 3.14 \\
\cline { 2 - 10 } & 여성 & $(1,284)$ & 1.8 & 7.6 & 42.2 & 41.6 & 6.9 & 3.44 \\
\hline
\end{tabular}




\begin{tabular}{|c|c|c|c|c|c|c|c|c|}
\hline \multicolumn{2}{|r|}{ 구분 } & 사례수 & $\begin{array}{l}\text { 전혀 중요 } \\
\text { 하지 않다 }\end{array}$ & $\begin{array}{l}\text { 중요하지 } \\
\text { 않은 편 }\end{array}$ & 보통 & 중요한 편 & $\begin{array}{c}\text { 매우 } \\
\text { 중요하다 }\end{array}$ & 5점 평균 \\
\hline \multirow{5}{*}{ 연령 } & 29세 이하 & (555) & 3.6 & 6.2 & 49.1 & 31.4 & 9.7 & 3.37 \\
\hline & 30대 & (447) & 4.1 & 7.4 & 43.5 & 41.4 & 3.7 & 3.33 \\
\hline & 40대 & (464) & 1.1 & 8.8 & 54.7 & 28.7 & 6.7 & 3.31 \\
\hline & 50대 & (445) & 1.6 & 7.5 & 52.6 & 35.6 & 2.6 & 3.30 \\
\hline & 60세 이상 & (589) & 0.9 & 16.4 & 48.4 & 32.4 & 1.9 & 3.18 \\
\hline
\end{tabular}

\section{2. 국민문화예술활동조사 분석: 예술향유 유형화 시도}

앞에서 다룬 예술향유 관련 이론적 논의가 국민들의 실제 예술향유활동에 어떻게 반영되고 있는지를 살펴보기 위해「2019 국민문화예술활동조사」 결과를 분석·검 토한다. 이는 '일반 시민 대상 예술향유 인식 및 활동 양태 조사' 설계와 시행을 위 한 사전 작업이다. 분석을 바탕으로 일반시민 대상 예술향유 관련 설문 설계의 방향 성을 보다 명확히 설정하고자 한다. 설문 설계의 방향성은 예술향유(자)를 어떻게 분류할 것인지의 문제이다. 다시 말해서, 「2019 국민문화예술활동조사」에 나타난 예술향유(자) 집단을 어떻게 나눌 수 있는지를 살펴보고, 이를 참조하여 '일반시민 대상 예술향유조사’ 설문 문항을 제시한다는 것이다. ‘2019 국민문화예술활동조사 \lrcorner 를 활용하는 이유는 이것이 시민의 예술향유를 가장 세부적으로 파악하는 전국단 위 조사이기 때문이다.

\section{가. 예술향유(자) 유형화 기준}

\section{1) 기준변수 설정}

예술향유의 유형을 구분하는데 적용할 수 있는 개인별 특성은 무수히 많지만, 「 2019 국민문화예술활동조사」에서는 총 6가지 조사항목을 분류의 기준 변수로 사용 할 수 있다. 그것은 (1) 문화예술행사 직접 관람, (2) 매체를 통한 문화예술 관람, (3) 문화예술교육 경험, (4) 문화관련 동호회 참여, (5) 문화예술 관련 자원봉사 참여, (6) 문화예술 창작(참여) 경험이다.

여섯 가지 기준 변수를 자세히 살펴보면 다음과 같다. 첫 번째 변수는 9개 장르의 
문화예술행사(=문학행사, 미술, 서양음악, 전통예술, 연극, 뮤지컬, 무용, 영화, 대중 음악)를 지난 1 년 동안 각각 몇 번이나 관람했는지 측정한다(= [직접 관람]), 각각의 문화예술행사 중 한 가지 행사에 한 번이라도 참여한 응답자의 비율은 $79.8 \%(=$ 8,056 명)로 매우 높은 편이다. 모든 문화예술행사의 직접 관람 횟수의 더할 경우 응답자들의 총 관람횟수는 0회에서 153회에 이르기까지 매우 폭넓다.

두 번째 변수는 이들 각 형태의 행사를 몇 번이나 '매체'를 통해 관람했는지를 묻고 있다(=[매체 관람]). 이 항목의 경우 1 회 이상 관람자의 비율이 $97 \%$ 로 거의 모든 응답자들이 매체를 통해서는 문화예술행사를 관람하고 있는 것으로 나타났다. 9개 모든 행사의 매체를 통한 관람횟수 총합을 더할 경우의 응답 범위는 0회에서 500회로 [직접 관람]의 경우보다 더 큰 편차를 나타냈다.

세 번째 변수는 지난 1 년 동안 각 형태의 문화예술활동에 대해 교육(강습)을 받아 본 적이 있는지에 관한 것이다(= [교육 경험]). 이 변수와 앞의 두 가지 변수 간 차이 점은, 앞의 두 변수의 경우 각 형태의 문화예술행사에 참여한 횟수를 묻고 있지만 [교 육 경험]의 경우에는 단지 경험 유무만을 묻고 있다는 점이다. 이는 한 가지 이상의 문화예술 관련 교육을 받은 응답자의 비율이 9.8\%(= 994명)에 불과하기 때문이다.

네 번째 변수는 지난 1 년 동안 문화관련 동호회 활동에 참여한 경험이 있는지의 여부를 묻고 있으며(= [동호회]), 질문의 형식은 앞의 [교육 경험] 변수와 동일하다. [동호회] 참여 경험이 한 가지 형태의 문화예술 영역에서라도 있는 응답자는 전체 8.3\%(= 838명)로 [교육 경험]과 비슷한 수준을 나타냈다.

다섯 번째 변수는 지난 1 년 동안 문화관련 단체, 지역 문화시설, 문화재 관리 등 과 관련된 자원봉사 활동을 해 본 경험 유무이다(= [자원봉사] $) 54)$. 이 항목의 수집 결과에 따르면 자원봉사 참여 경험이 있는 응답자는 전체의 3.6\%에 불과한 361명 으로 매우 적은 비중을 나타냈다.

마지막변수는 9개 종류의 문화예술활동에 참여해 본 경험에 관한 것(= [창작.실 연])으로 질문의 형식은 앞선 [직접 참여]나 [매체 관람]과 동일하다. 다만 이 변수의 경우에는 한 번이라도 참여해 본 경험이 있는 응답자가 $10.4 \%$ 에 불과할 정도로 참 여율이 매우 낮다는 특성을 가지고 있다.

54) 자원봉사 경험 유무를 먼저 질문한 후, 경험이 있는 경우 2차적으로 횟수를 묻고 있으나 여기에서는 앞의 변수만을 고려했다. 
〈표 3-23〉 예술향유자 분류를 위한 변수별 특성: 2019 국민문화예술활동조사

\begin{tabular}{c|c|c|c|c|c|c|c}
\hline 변수명 & 최소 & 최대 & 범위 & $\begin{array}{c}\text { 1회 이상 } \\
\text { 경험 }\end{array}$ & 비중(\%) & 무경험 & 비중(\%) \\
\hline 직접관람 & 0 & 153 & 153 & 8,056 & 79.7 & 2,046 & 20.3 \\
\hline 매체관람 & 0 & 500 & 500 & 9,797 & 97.0 & 305 & 3.0 \\
\hline 교육경험 & 0 & 9 & 9 & 994 & 9.8 & 9,108 & 90.2 \\
\hline 동호회 & 0 & 9 & 9 & 838 & 8.3 & 9,264 & 91.7 \\
\hline 자원봉사 & 0 & 52 & 52 & 361 & 3.6 & 9,741 & 96.4 \\
\hline $\begin{array}{c}\text { 참여 } \\
\text { (창작·실연) }\end{array}$ & 0 & 9 & 9 & 1,053 & 10.4 & 9,049 & 89.6 \\
\hline
\end{tabular}

자료: 2019 국민문화예술활동조사」 통계자료(raw data)를 분석한 것이며, 아래의 표들도 마찬가지이다.

\section{2) 변수 가공: 이항(binary)변수화}

이들 6가지 변수들은 기본적으로 일정 범위(range) 내에서(ex. [직접 관람] - 0 회 153회, [동호회] - 0회 9회) 일정한 간격을 갖는 척도로 측정되었기 때문에 원 래의 측정수준(level of measurement) 그대로 등간수준(interval-level)으로 활용 할 수 있다. 하지만 보다 많은 양의 정보를 지닌 높은 측정수준을 그대로 활용하는 것이 대상자들의 분류를 필요이상으로 복잡하게 만들 수도 있다. 따라서 분류의 편 의성을 위해서는 측정수준을 단순화하여 각 변수에서 측정하고자 하는 속성(ex. '직 접 관람하는 사람', '문화예술교육에 참여하는 사람' 등)을 응답자들이 지니고 있는 지의 여부만을 구분하는 이항(binary)변수의 형태로 변형할 필요가 있다. 특히 세 번째 [교육 경험]부터 여섯 번째 [창작·실연] 변수의 경우에는 측정 대상 활동을 한 번이라도 경험해 본 응답자의 비율 자체가 매우 낮기 때문에 특정 속성이 있는 경우 와 그렇지 않은 경우를 0 과 1 로 코딩하는 이항변수의 형태로 활용하는 것이 합리적 이다.

〈표 3-24〉 직접 관람자와 비관람자 및 매체를 통한 관람자와 비관람자 구분: 2019 국민문화예술활동조사

\begin{tabular}{c|c|c|c|c}
\hline 변수 & 범위 & 분류 기준 & 비해당 (\%) & 해당 (\%) \\
\hline 직접 관람 & 0 153회 & 0 4회 vs. 5회 이상 & 5,206 (51.5) & 4,896 (48.5) \\
\hline 매체 관람 & 0 500회 & 0 15회 vs. 16회 이상 & 5,163 (51.1) & 4,939 (48.9) \\
\hline
\end{tabular}

자료: $\ulcorner 2019$ 년 국민문화예술활동조사」 통계자료(raw data) 기반 재구성 
그러나 [직접 관람과 [매체 관람]의 경우에는 1회 이상 경험자의 비율이 너무 크 기 때문에 이를 기준으로 직접(또는 매체를 통해) 관람에 참여한 사람을 구분하는 것은 적합하지 않다. 따라서 직접 관람 참여자와 비참여자, 매체를 통한 참여자와 비참여자를 구분할 수 있는 새로운 기준이 필요한데, 본 분석에서는 각 변수에서 응답자들을 참여/비참여자로 규모에서 양분하려는 목적에서 중간값(median)을 포 함한 관람횟수를 분류의 기준으로 적용하였다. 앞서 언급한 바와 같이 9개 문화예 술활동에 대한 응답자들의 직접 관람 횟수 범위는 0 회에서 153 회인데, 4 회까지의 누적 \%가 $51.5 \%$ 를 나타냈다. 따라서 [직접 관람]의 경우 0 회 4회의 관람 경험이 있다고 답한 응답자를 '비관람자'로, 5 회 또는 그 이상 관람했다고 답한 사람들을 '관람자'로 분류하였다. [매체 관람]의 경우에도 이와 같은 기준을 적용하여 응답자 를 양분하였으며 그 결과는 〈표 3-24〉에 제시되어 있다55).

\section{나. 예술향유(자) 분류}

6 가지 변수를 이용하여 응답자들의 예술향유 형태 분류하고, 그것의 적합성과 타 당성 등을 논의한다. 이를 위해 세 가지 방법을 시도했다. 첫 번째는 K-means 군 집분석, 두 번째는 분류나무(Classification Tree) 방식, 세 번째는 여섯 개의 기준 변수를 바탕으로 한 사후 해석적 (단순) 분류이다.

\section{1) K-means 군집분석}

$\mathrm{K}-\mathrm{means}$ 군집분석은 임의 군집 중심(centroid)과 각 개체들의 거리를 최소화 시키는 동시에 군집 중심 간의 차이는 최대화시키는 분류방식이다(Norǔsis 2003). 계산 원리가 비교적 간단하며 연구자의 판단에 의해 군집의 수를 임의대로 조절할 수 있다는 장점이 있다. 본 분석에서는 우선 앞서 소개했던 6가지 예술향유자 구분 을 위한 변수들을 적용하여 어떤 특성을 지닌 군집으로 분류되는지를 검토하였다. 군집의 수는 집단내 분산 총량의 감소 추이 및 해석의 용이성을 따져 5 개로 설정하 였다.

55) 이러한 분류는 다음 단계에서 제시된 예술향유자의 분류를 위한 편의적/임의적인 기준일 뿐, 절대적인 기준에 근거하는 것은 아님을 밝혀둔다. 
우선 첫 번째 시도에서는 위〈표 3-23〉에서와 같이 [직접 관람]과 [매체 관람]의 경우 각각 0 153과 0 500의 범위를 갖는 등간척도의 형태로 나머지 4개의 변수 의 경우 각 문항이 묻고 있는 경험의 유무만을 0 과 1 로 표시한 명목척도의 형태로 적용하였다(아래 표 참조).

〈표 3-25〉K-means 군집 분석 투입 변수의 특성: 2019 국민문화예술활동조사

\begin{tabular}{c|c|c|c|c|c}
\hline 변수 & 범위 & 최소값 & 최대값 & 평균 & 표준편차 \\
\hline [직접 관람] & 153 & 0 & 153 & 6.28 & 7.637 \\
\hline [매체 관람] & 500 & 0 & 500 & 23.61 & 33.000 \\
\hline [교육 경험] & 1 & 0 & 1 & 0.098 & 0.298 \\
\hline [동호회] & 1 & 0 & 1 & 0.083 & 0.276 \\
\hline [자원봉사] & 1 & 0 & 1 & 0.036 & 0.186 \\
\hline [창작.실연] & 1 & 0 & 1 & 0.104 & 0.306 \\
\hline
\end{tabular}

자료: 「2019년 국민문화예술활동조사」 통계자료(raw data) 기반 재구성

그러나 아래〈표 3-26〉에 나타난 군집의 결과는 명확한 예술향유자의 구분으로 해석하기에는 많은 어려움이 나타났다. 군집의 중심이라고 할 수 있는 변수별 평균 값을 보면, [직접 관람]과 [매체 관람]의 경우 5개 군집 중 4개가 모두 전체 평균값 을 상회하고 있음을 알 수 있다. 특히 [직접 관람]의 경우 1번 군집은 9.07회, 4번과 5 번 군집은 8 회의 조금 상회하는 수준, 그리고 2 번 군집의 경우 7.13 회를 나타내고 있어 군집별 변별력을 논하기가 매우 어려운 상황이다.

〈표 3-26〉 군집분석 결과(1-5개 군집의 변수별 평균과 전체 평균): 2019 국민문화예술활동조사

\begin{tabular}{c|c|c|c|c|c|c|c}
\hline 군집 번호 & 1 & 2 & 3 & 4 & 5 & 전체평균 & 표준편차 \\
\hline [직접 관람] & 9.07 & 7.13 & 5.45 & 8.32 & 8.09 & 6.28 & 7.64 \\
\hline [매체 관람] & 110.61 & 343.13 & 10.99 & 206.92 & 38.36 & 23.61 & 33.00 \\
\hline [교육 경험] & 0.15 & 0.21 & 0.08 & 0.11 & 0.13 & 0.10 & 0.30 \\
\hline [동호회] & 0.10 & 0.05 & 0.09 & 0.08 & 0.14 & 0.08 & 0.28 \\
\hline [자원봉사] & 0.08 & 0.03 & 0.08 & 0.04 & 0.10 & 0.04 & 0.19 \\
\hline [창작·실연] & 0.05 & 0.05 & 0.03 & 0.03 & 0.05 & 0.10 & 0.31 \\
\hline case 수 & 261 & 38 & 6,999 & 72 & 2,732 & & \\
\hline
\end{tabular}

자료: 2019년 국민문화예술활동조사」통계자료(raw data) 기반 재구성 
또한 0 과 1 의 이항변수로 투입된 나머지 변수들의 경우에도 어떤 군집에 특정 속성을 지닌 응답자들이 집중적으로 모여 있기 보다는 평균에서 조금 상회하거나 하회하는 수준에서 5 개 군집에 고루 흩어져 있는 상황이라 해석이 쉽지 않다. 또한 3 번과 5 번 군집에 거의 모든 응답자들이 집중되어 있다는 사실도 기대했던 분류 형 태와는 큰 차이가 있다.

이러한 결과가 [교육 경험] 등 4개 변수를 이항변수로 투입하였기 때문일 수 있다 는 추정 하에 변수의 측정 수준을 0 9회 또는 0 52회를 가지는 등간척도 형식으로 변형하여 두 번째 K-means 군집분석을 시도하였지만 결과는 첫 번째 분석과 크게 다르지 않았다. 이는 [직접 관람]과 [매체 관람]에서만 매우 큰 범위와 평균 및 표준 편차를 보이고 나머지 4 개 변수에서는 각 문항이 측정하고자하는 대상을 경험한 응 답자의 수가 극히 적다는 사실에서 기인하는 것으로 추정할 수 있다. 또한 이는 $\mathrm{K}-\mathrm{means}$ 군집분석을 통해 응답자들을 몇몇 변별력 있는 예술향유자 집단으로 구 분하기가 어려움을 방증한다.

\section{2) 분류나무(Classification Tree)}

분류나무는 의사결정나무(Decision Tree) 방법 중 한 가지로, 설명하고자하는 목표변수가 이산형(discrete)일 때 카이제곱 통계량이나 지니 지수 등의 기준을 통 해 응답자를 분류하는 방법이다. 의사결정나무는 채택된 결정규칙에 근거하여 나무 모양의 도표를 산출하며, 이를 통해 어떤 예측변수가 목표변수를 구분(또는 설명)하 는데 도움을 주는지 단계적으로 제시한다(최종후 외 2002). 본문에서는 문화예술활 동에 참여했는지의 여부를 나타내는 [창작-실연] 변수를 목표변수로, 나머지 5개의 변수를 예측변수로 설정하여 CHAID 알고리즘을 적용하였다(Tree Depth $=3$, Max. cases in Parent Node =100, Min. case in Child Node = 50). 분류 및 해석의 용이성을 위해 6 개의 모든 변수를 이항변수로 변형하여 사용하였으며, [직 접 관람]과 [매체 관람]의 응답자들의 분류를 위해서는 앞서 〈표 3-24〉에서 소개하 였던 기준을 적용하였다. 
[그림 3-1] 예술향유(자) 유형화를 위한 분류나무 적용의 예시: 2019 국민문화예술활동조사

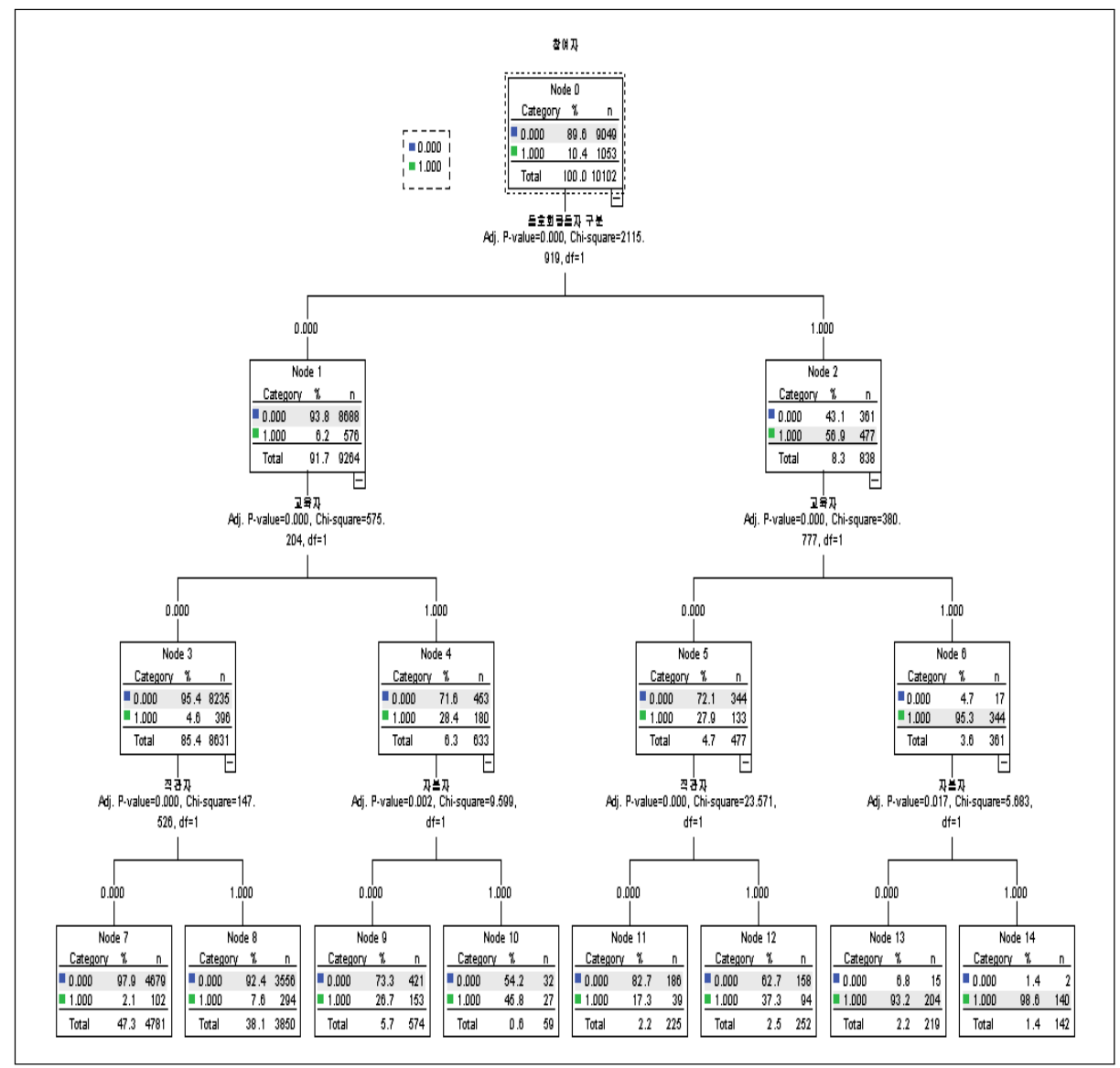

[그림 3-1]에 제시된 결과를 보면 우선 첫 번째 단계에서는 [동호회] 참가 경험 여부를 기준으로 응답자들을 구분하였고 두 번째 단계에서는 [교육 경험]을 기준으 로 다시 한 번 마디(Node)를 양분하였다. 마지막 세 번째 단계에서는 [직접 관람] 여부와 [자원 봉사] 참가 여부를 기준으로 총 8개의 마디를 분류하였다. 
〈표 3-27〉 분류나무를 적용한 예술향유자의 분석 시도: 2019 국민문화예술활동조사

\begin{tabular}{|c|c|c|c|c|c|c|c|c|c|}
\hline & $\begin{array}{c}\text { Node } \\
7\end{array}$ & $\begin{array}{l}\text { Node } \\
8\end{array}$ & $\begin{array}{c}\text { Node } \\
9\end{array}$ & Node 10 & Node 11 & Node 12 & Node 13 & Node 14 & 합계 \\
\hline 직관자* $=$ [직접 관람 $]$ & $x$ & 0 & & & $x$ & 0 & & & \\
\hline \multicolumn{10}{|l|}{ 매관자 $=$ [매체 관람 $]$} \\
\hline 교육자 $=$ [교육 경험 $]$ & $x$ & $x$ & 0 & 0 & $x$ & $x$ & 0 & 0 & \\
\hline 동호자 = [동호회] & $x$ & $x$ & $x$ & $x$ & 0 & 0 & 0 & 0 & \\
\hline 자봉자 $=[$ 자원봉사 $]$ & & & $x$ & 0 & & & $x$ & 0 & \\
\hline 참여자 $=[$ 창작·실연 $]$ & $x$ & $x$ & $x$ & $x$ & $x$ & $x$ & 0 & 0 & \\
\hline $\begin{array}{l}\text { 정(正)분류자 수 } \\
\text { (Node內 비율) }\end{array}$ & $\begin{array}{c}4679 \\
(97.9 \%)\end{array}$ & \begin{tabular}{|c|}
3556 \\
$(92.4 \%)$
\end{tabular} & \begin{tabular}{|c|}
421 \\
$(73.3 \%)$
\end{tabular} & $\begin{array}{c}32 \\
(54.2 \%)\end{array}$ & $\begin{array}{c}186 \\
(82.7 \%)\end{array}$ & \begin{tabular}{|c|}
158 \\
$(62.7 \%)$
\end{tabular} & \begin{tabular}{|c|}
204 \\
$(93.2 \%)$
\end{tabular} & \begin{tabular}{|c|}
140 \\
$(98.6 \%)$
\end{tabular} & $\begin{array}{c}9376 \\
(92.8 \%)\end{array}$ \\
\hline $\begin{array}{l}\text { 오(誤)분류자 수 } \\
\text { (Node內 비율) }\end{array}$ & $\begin{array}{c}102 \\
(2.1 \%)\end{array}$ & $\begin{array}{c}294 \\
(7.6 \%)\end{array}$ & $\begin{array}{c}153 \\
(26.7 \%)\end{array}$ & $\begin{array}{c}27 \\
(45.8 \%)\end{array}$ & $\begin{array}{c}39 \\
(17.3)\end{array}$ & $\begin{array}{c}94 \\
(37.3)\end{array}$ & $\begin{array}{c}15 \\
(6.8)\end{array}$ & $\begin{array}{c}2 \\
(1.4)\end{array}$ & $\begin{array}{c}726 \\
(7.2 \%)\end{array}$ \\
\hline
\end{tabular}

자료: 2019 년 국민문화예술활동조사」 통계자료(raw data) 기반 재구성

이러한 방법을 통해 구분된 첫 번째 집단(= 마디)의 경우(〈표 3-27〉에서 Node 7로 표시됨), [직접 관람], [교육 경험], [동호회], [창작·실연] 등에서 모두 경험이 없는 사람들의 집단임을 알 수 있다. 그러나 모든 사람이 참여 경험이 없는 것은 아니며 이 집단(=마디)에 속하는 전체 4,781명 중 102명(2.1\%)의 경우 실제로는 [창작·실연] 변수에서 참여자로 구분되는 사람들이기에 $2.1 \%$ 의 오차율을 나타내고 있다. 반면 여덟 번째 집단(= Node14)의 경우 [교육 경험], [동호회], [자원봉사], [창작·실연]의 네 가지 변수에 있어 모두 (참여) 경험이 있는 경우에 해당하는 사람 들의 모임이며, 전체 142 명 중 단지 2 명만 [창작-실연]의 경험 없는 사람들이기 때 문에 오차율은 단지 $(1.4 \%=2$ 명 $)$ 에 불과하다.

이와 같은 분류 방법을 적용하여 전체 10,102 명의 응답자를 8 개의 집단으로 구 분한 후, 각 집단의 특성을 규정해보는 것도 괜찮은 분류방식으로 보일 수 있다. 그 러나 다음 세 가지 이유로 인해 분류나무 역시 적절한 분류 방법으로 수용하기 어렵 다. 첫째, 분류나무에서는 하나의 변수를 목표변수로 정하고 이 변수의 분포나 구분 형태를 설명해 줄 수 있는 변수들을 예측변수로 지정해야만 한다. 앞서 제시한 예시 에서는 문화예술행사에 직접적으로 [창작·실연]하는지의 여부를 목표변수로 설정했 는데 이는 이 변수가 나머지 문화예술 관련 활동과 관련된 항목에서의 활동 유무에 따라 어느 정도 결정되어진다는 가정이 필요하다. 즉 일반적인 회귀모형에서의 설 
명(또는 독립)변수와 결과(또는 종속)변수의 관계에서처럼 [창작-실연라는 변수가 나머지 예측변수와 어느 정도 인과적 관계가 있어야만 하지만 현실적으로 예술향유 자의 분류에서는 그러한 가정을 갖기가 쉽지 않다.

둘째, 원래 본 분석에서는 고려된 여섯 개의 문화예술 활동 관련 변수들을 모두 고려하여 응답자들의 예술향유 유형을 구분해내려 했지만 [그림 3-1]과 〈표 3-27〉 에 제시된 바와 같이 [매체 관람]은 고려의 대상에서 아예 제외가 되어버렸다. 이는 궁극적으로는 [창작·실연]라는 목표변수의 구분(=창작·실연자와 비참여자)을 설명 하는데 있어 [매체 관람]의 중요성이 떨어지기 때문이지만 의도치 않게 원래는 고려 하려했던 요소 하나가 특정 방법의 규칙에 의해 제거되어 버린 것으로 이해할 수 있다.

셋째, 앞에서 제시된 8개의 집단(= Node)에서는 분류의 의도에 맞지 않게 오(誤) 분류된 사례들이 포함되어 있다. 이러한 사례들을 모두 더할 경우 전체 응답자 10,102 명의 7.2\%에 해당하는 726명이 나머지 응답자와는 [창작·실연] 변수에 있 어 일치하지 않음에도 임의적으로 분류되어 있음을 말한다. $7.2 \%$ 의 수치는 전체를 기준으로 본다면 대단히 큰 비중은 아니기에 그 정도의 오분류를 감수하는 것도 나 브지 않은 선택일 수 있다. 그러나 실상 [창작-실연] 변수가 규정하고 있는 문화예술 활동에 참여한 사람들 1,053 명 중에서 단지 344 명만 '참여자'로 인지되어 분류되 고 나머지 709(=67.3\%)명은 실제로는 '참여자' 임에도 불구하고 '비참여자' 집단으 로 구분된 점은 간과할 수 없는 문제이다.

\section{3) 사후 해석적 분류}

위에서 살펴 본 바와 같이 앞서 제시한 두 가지 분류 방법(K-means 군집분석, 분류나무 방식)이 예술향유자의 유형을 설득력 있게 분류했다고 보기 어렵다. 이는 주어진 실제 데이터가 상대적으로 고차원적인 알고리즘을 적용한 기존 방법들에 적 합하지 않기 때문이라고 해석할 수 있으며, 따라서 관점을 바꿔 적용하는 분류 방법 을 단순화해 볼 필요가 있다.

앞의 두 가지 분석에서 사용된 총 6 개의 변수를 이항변수화 시키면 해당 변수가 측정하는 속성이 있고 없음을 조합하여 이론상 총 64개(= 26)의 예술향유 유형을 
가정할 수 있다. 예를 들면 어떤 사람은 [직접 관람]과 [매체 관람], [교육 경험], [동 호회] 활동, [자원 봉사], 문화예술 [창작-실연]을 지난 1 년 동안 모두 경험한 했는가 하면(아래〈표 3-28〉에서 유형번호 1번), 반대로 이들 6개 영역의 경험이 전무한56) 사람이 있을 수 있다(유형번호 59번).

〈표 3-28〉6가지 변수를 조합한 예술향유 유형과 해당자 수: 2019 국민문화예술활동조사

\begin{tabular}{|c|c|c|c|c|c|c|c|c|}
\hline 유형번호 & 직접 관람 & 매체 관람 & 교육 경험 & 동호회 & 자원 봉사 & 창작-실연 & 해당자 수 & $\%$ \\
\hline 1 & 0 & 0 & 0 & 0 & 0 & 0 & 76 & 0.75 \\
\hline 2 & 0 & O & 0 & 0 & 0 & $x$ & 1 & 0.01 \\
\hline 3 & 0 & 0 & 0 & 0 & $x$ & 0 & 101 & 1.00 \\
\hline 4 & 0 & 0 & 0 & 0 & $x$ & $x$ & 8 & 0.08 \\
\hline 5 & 0 & $\mathrm{O}$ & 0 & $x$ & 0 & 0 & 11 & 0.11 \\
\hline 6 & O & 0 & 0 & $x$ & 0 & $x$ & 20 & 0.20 \\
\hline 7 & O & O & 0 & $x$ & $x$ & 0 & 89 & 0.88 \\
\hline 8 & 0 & 0 & 0 & $x$ & $x$ & $x$ & 183 & 1.81 \\
\hline 9 & O & O & $x$ & O & O & 0 & 6 & 0.06 \\
\hline 10 & 0 & 0 & $X$ & 0 & $X$ & 0 & 42 & 0.42 \\
\hline 11 & 0 & 0 & $x$ & 0 & $x$ & $x$ & 86 & 0.85 \\
\hline 12 & 0 & 0 & $x$ & $x$ & 0 & 0 & 11 & 0.11 \\
\hline 13 & 0 & 0 & $x$ & $x$ & 0 & $x$ & 39 & 0.39 \\
\hline 14 & 0 & 0 & $x$ & $x$ & $x$ & 0 & 155 & 1.53 \\
\hline 15 & 0 & 0 & $x$ & $x$ & $x$ & $x$ & 1,869 & 18.50 \\
\hline 16 & 0 & $x$ & 0 & 0 & O & $\mathrm{O}$ & 38 & 0.38 \\
\hline 17 & 0 & $x$ & 0 & 0 & O & $x$ & 1 & 0.01 \\
\hline 18 & 0 & $x$ & 0 & 0 & $x$ & 0 & 63 & 0.62 \\
\hline 19 & 0 & $x$ & 0 & 0 & $x$ & $x$ & 5 & 0.05 \\
\hline 20 & 0 & $X$ & 0 & $X$ & 0 & 0 & 7 & 0.07 \\
\hline 21 & 0 & $x$ & 0 & $x$ & 0 & $x$ & 11 & 0.11 \\
\hline 22 & 0 & $X$ & 0 & $X$ & $X$ & 0 & 46 & 0.46 \\
\hline 23 & 0 & $x$ & 0 & $x$ & $x$ & $x$ & 134 & 1.33 \\
\hline 24 & 0 & $X$ & $x$ & 0 & 0 & 0 & 9 & 0.09 \\
\hline 25 & 0 & $x$ & $X$ & 0 & 0 & $x$ & 1 & 0.01 \\
\hline 26 & 0 & $x$ & $x$ & 0 & $x$ & 0 & 37 & 0.37 \\
\hline
\end{tabular}

56) [직접 관람]과 [매체 관람]의 경우 관람 경험이 전혀 없음을 말하는 것이 아니라 〈표 3-24〉에 제시된 기준에 의해 '비관람자'로 분류된 것을 말한다. 


\begin{tabular}{|c|c|c|c|c|c|c|c|c|}
\hline 유형번호 & 직접 관람 & 매체 관람 & 교육 경험 & 동호회 & 자원 봉사 & 창작·실연 & 해당자 수 & $\%$ \\
\hline 27 & 0 & $x$ & $x$ & O & $x$ & $x$ & 71 & 0.70 \\
\hline 28 & 0 & $X$ & $x$ & $X$ & 0 & 0 & 7 & 0.07 \\
\hline 29 & 0 & $X$ & $X$ & $X$ & 0 & $X$ & 26 & 0.26 \\
\hline 30 & 0 & $x$ & $X$ & $X$ & $x$ & 0 & 121 & 1.20 \\
\hline 31 & $\mathrm{O}$ & $x$ & $x$ & $x$ & $x$ & $x$ & 1,622 & 16.06 \\
\hline 32 & $x$ & O & O & 0 & O & O & 10 & 0.10 \\
\hline 33 & $x$ & O & O & O & $x$ & O & 26 & 0.26 \\
\hline 34 & $x$ & 0 & $\mathrm{O}$ & 0 & $x$ & $x$ & 1 & 0.01 \\
\hline 35 & $x$ & 0 & O & $x$ & $\mathrm{O}$ & 0 & 4 & 0.04 \\
\hline 36 & $x$ & 0 & 0 & $x$ & $x$ & 0 & 8 & 0.08 \\
\hline 37 & $x$ & O & O & $x$ & $x$ & $x$ & 49 & 0.49 \\
\hline 38 & $x$ & 0 & $x$ & 0 & 0 & 0 & 3 & 0.03 \\
\hline 39 & $x$ & O & $x$ & 0 & 0 & $x$ & 2 & 0.02 \\
\hline 40 & $x$ & 0 & $x$ & 0 & $x$ & 0 & 15 & 0.15 \\
\hline 41 & $x$ & O & $x$ & 0 & $x$ & $x$ & 75 & 0.74 \\
\hline 42 & $x$ & O & $x$ & $x$ & 0 & 0 & 1 & 0.01 \\
\hline 43 & $x$ & O & $x$ & X & O & $x$ & 22 & 0.22 \\
\hline 44 & $x$ & O & $x$ & $x$ & $x$ & O & 33 & 0.33 \\
\hline 45 & $x$ & O & $x$ & $x$ & $x$ & $x$ & 1,993 & 19.73 \\
\hline 46 & $x$ & $x$ & 0 & 0 & 0 & O & 16 & 0.16 \\
\hline 47 & $x$ & $X$ & O & O & $x$ & 0 & 14 & 0.14 \\
\hline 48 & $x$ & $x$ & 0 & 0 & $x$ & $x$ & 1 & 0.01 \\
\hline 49 & $x$ & $x$ & O & $x$ & 0 & 0 & 5 & 0.05 \\
\hline 50 & $x$ & $x$ & 0 & $x$ & 0 & $x$ & 1 & 0.01 \\
\hline 51 & $X$ & $x$ & 0 & $x$ & $X$ & 0 & 10 & 0.10 \\
\hline 52 & $x$ & $x$ & O & $x$ & $x$ & $x$ & 55 & 0.54 \\
\hline 53 & $x$ & $x$ & $x$ & 0 & 0 & 0 & 4 & 0.04 \\
\hline 54 & $x$ & $x$ & $x$ & 0 & 0 & $x$ & 1 & 0.01 \\
\hline 55 & $x$ & $x$ & $x$ & 0 & $x$ & 0 & 17 & 0.17 \\
\hline 56 & $x$ & $x$ & $x$ & 0 & $x$ & $x$ & 108 & 1.07 \\
\hline 57 & $x$ & $x$ & $x$ & $x$ & 0 & $x$ & 28 & 0.28 \\
\hline 58 & $x$ & $x$ & $x$ & $x$ & $x$ & 0 & 68 & 0.67 \\
\hline 59 & $x$ & $x$ & $x$ & $x$ & $x$ & $x$ & 2,636 & 26.09 \\
\hline 총합 & & & & & & & 10,102 & 100.00 \\
\hline
\end{tabular}

자료: 2019 년 국민문화예술활동조사」 통계자료(raw data) 기반 재구성 
〈표 3-28〉에서는 6가지 변수를 기준으로 가능한 조합의 예술향유 유형과 각각의 유형에 해당하는 예술향유자의 수를 제시하고 있다. 이론상 64개의 유형이 가능하 지만, 5 가지 유형은 데이터상에서 해당자가 없어 총 59개의 유형만 표시되어 있다. 이들 59개의 유형 중 각각의 유형별 응답자가 속한 규모 순서로 상위 4개 집단을 구분해 보면 다음과 같다. 우선 가장 많은 수의 응답자가 속한 집단은 모든 문화예 술 관련 활동 경험이 전무한 사람들로 총 2,636명(26.09\%)이 여기 속한다. 이들은 문화예술활동에 아무런 경험이 없는 사람들이기 때문에〈표 3-29〉에서는 '완전 무 관심자로 명명했다. 다음으로 흔하게 발견되는 예술향유 유형은 오직 매체를 통해 서만 관람하는 사람들이다. 총 1,993 명(19.73\%)이 여기에 해당하며 이들의 경우 '매체 관람 선호자'로 규정했다. 반대로 매체는 적극적으로 활용하지 않고 오히려 직접 관람만을 선호하는 사람들도 있는데, 이들은 '직접 관람 선호자'로 부를 수 있 으며 네 번째로 많은 사람들이 여기에 해당한다(1,622명, 16.06\%). 세 번째로 큰 규모의 향유자 유형에 해당하는 집단은 직접 관람과 매체를 통한 관람을 모두 경험 한 사람들이며 '직접/매체 관람자’로 명명 했다(1,869명, 18.50\%).

앞서 설명한 4 가지 형태의 예술향유자들의 경우 '완전 무관심자'를 제외하고는 [직접 관람]이나 [매체 관람] 수준에서 문화예술행사를 경험한 사람들이며 나머지 4가지 활동(= [교육 경험], [동호회], [자원봉사], [창작·실연])을 통해서는 문화예술 을 접해 본 적이 없는 사람들이다. 하지만 마지막 다섯 번째 유형은 [직접 관람]과 [매체 관람] 경험 유무와는 상관없이 나머지 네 영역에서 최소 한 가지 이상의 참여 나 경험을 가지고 있는 사람들이다. 다섯 번째 유형은 총 55가지 각기 다른 조합의 총합이기에 사실 내부적으로는 매우 이질적인 사람들이라고 할 수 있다. 예를 들어 6가지 변수 중에서 나머지 변수에는 해당되지 않음에도 불구하고 오직 [교육 경험] 만 가지고 있는 사람이 55명(= 52번 유형), [자원봉사] 경험만 있는 사람이 28명(= 57번 유형), 예술 [창작·실연]의 경험만 가지고 있는 사람들 68명(= 58번 유형)이 포함되어 있다. 또한 [직접 관람]과 [매체 관람]을 포함하여 모든 측정 영역에서 경 험을 가지고 있는 사람이 76명(= 1번 유형)이 있는가 하면, [직접 관람]과 [매체 관 람]만을 제외한 나머지 영역에서 모두 참여/경험을 가지고 있는 사람들도 16명(= 46번 유형) 포함되어 있다. 
〈표 3-29〉5가지 형태의 대표적인 문화예술향유자 유형: 2019 국민문화예술활동조사

\begin{tabular}{|c|c|c|c|c|c|c|c|c|}
\hline 구분 & 직접 관람 & 매체 관람 & 교육 경험 & 동호회 & 자원 봉사 & 창작·실연 & 해당 인원 & $\%$ \\
\hline $\begin{array}{c}\text { 완전 } \\
\text { 무관심자 }\end{array}$ & $x$ & $x$ & $x$ & $x$ & $x$ & $x$ & 2,636 & 26.09 \\
\hline $\begin{array}{c}\text { 매체관람 } \\
\text { 선호자 }\end{array}$ & $x$ & $\mathrm{O}$ & $x$ & $x$ & $x$ & $x$ & 1,993 & 19.73 \\
\hline $\begin{array}{c}\text { 직접/ } \\
\text { 매체관람자 }\end{array}$ & $\mathrm{O}$ & $\mathrm{O}$ & $x$ & $x$ & $x$ & $x$ & 1,869 & 18.50 \\
\hline $\begin{array}{l}\text { 직접관람 } \\
\text { 선호자 }\end{array}$ & $\mathrm{O}$ & $x$ & $x$ & $x$ & $x$ & $x$ & 1,622 & 16.06 \\
\hline 기타 & \multicolumn{6}{|c|}{ 위 4가지 유형에 해당하지 않는 나머지 } & 1,982 & 19.62 \\
\hline
\end{tabular}

자료: 「2019년 국민문화예술활동조사」통계자료(raw data) 기반 재구성

이렇듯 '기타' 영역에 속하는 사람들은 한두 가지 속성을 통해 규정하기 어려울 정도로 대단히 복잡다기한 속성을 지니고 있지만, 문화예술 향유 유형에서 다수를 차지하고 있는 [직접 관람]이나 [매체 관람]을 통한 문화예술 향유와는 다른 차원의 향유 방법을 가진 사람들로 평가할 수 있다. 또한 이와 같은 방식으로 응답자들을 구분했을 때는 각 범주에 속하는 사람들이 대략적으로 $20 \%$ 에 근접하기 때문에 극 히 소수의 사람들만 해당하는 향유 유형을 배제할 수 있다는 장점을 제공 한다.

\section{다. 문화예술 향유자 유형별 특성}

이와 같이 사후 해석적 분류에 따라 5가지 유형으로 구분된 예술향유자들은 우선 그들의 인구사회학적 특성에서 어떤 차이가 있는지 검토해 볼 필요가 있다. 다음으 로는 문화예술과 관련하여 향후 지출을 늘리고 싶은 영역이나, 문화예술행사를 관 람할 때 가장 중요한 기준 또는 어려움 등, 예술향유 방식에 있어 부가적인 특징들 의 비교가 필요하다.

\section{1) 유형별 인구사회학적 특성 비교}

인구사회학적 특성은 '2019년 국민문화예술활동조사'에서 적용된 측정 수준에 따라 구분하였다. 먼저 등간 또는 서열 척도 수준으로 측정된〈나이〉, 〈가구소득〉, 〈학력〉,〈동거 가구원 수〉, 그리고〈건강에 대한 인식〉은 각 예술향유자 집단의 평 
균으로 비교하였다. 여기서 〈나이〉와 〈동거 가구원 수〉를 제외한 나머지 변수들은 서열척도로 측정된 변수이지만 등간척도 형식으로 가정하고 평균값을 비교하였다.

〈표 3-30〉 예술향유자 유형별 인구사회학적 특성 비교1(평균 비교): 2019 국민문화예술활동조사

\begin{tabular}{|c|c|c|c|c|c|c|c|}
\hline & \multicolumn{5}{|c|}{ 유형구분 } & \multirow[b]{2}{*}{ 전체 평균 } & \multirow[b]{2}{*}{ 표준편차 } \\
\hline & $\begin{array}{l}\text { 완전 } \\
\text { 무관심자 }\end{array}$ & $\begin{array}{c}\text { 매체관람 } \\
\text { 선호자 }\end{array}$ & $\begin{array}{c}\text { 직접/매체 } \\
\text { 관람자 }\end{array}$ & $\begin{array}{l}\text { 직접관람 } \\
\text { 선호자 }\end{array}$ & 기타 & & \\
\hline 나이 & 52.63 & 52.72 & 38.73 & 38.63 & 42.55 & 45.85 & 17.67 \\
\hline 가구소득 & 4.75 & 4.71 & 5.72 & 5.75 & 5.43 & 5.22 & 2.08 \\
\hline 학력 & 4.00 & 3.99 & 5.02 & 5.02 & 4.85 & 4.51 & 1.34 \\
\hline 동거 가구원 수 & 2.66 & 2.60 & 3.00 & 3.04 & 2.82 & 2.80 & 1.239 \\
\hline 건강에 대한 인식 & 4.95 & 5.01 & 5.64 & 5.60 & 5.33 & 5.27 & 1.169 \\
\hline
\end{tabular}

자료: 2019 년 국민문화예술활동조사」 통계자료(raw data) 기반 재구성

우선 〈나이〉의 경우 ‘완전 무관심자'와 '매체 관람 선호자'의 연령이 전체 평균에 비해 대단히 높았으며, 12 개의 구간으로 측정된 〈가구소득>과 8 개의 구간으로 측정 된 〈학력〉의 경우에는 '직접/매체 관람자'와 '직접 관람 선호자'가 상대적으로 높은 수준을 나타냈다. 〈동거 가구원의 수〉와 〈건강에 대한 인식〉과 관련해서는 전체 평 균에 비해 특별히 매우 높거나 낮은 유형의 집단은 없는 것으로 나타났다.

이는 문화예술에 대해 완전 무관심하거나 매체를 통해서만 소비하는 사람들과 이 를 직접 관람의 형태를 통해 소비하는 사람들 사이에는 어느 정도의 세대 차이가 존재함을 말한다. 또한 사회적 계층을 나타내는 소득 및 학력 변수에서 직접 관람을 포함하는 유형의 향유자들 평균이 높다는 사실은 직접 관람을 위해서 어느 정도의 경제력과 문화적 관심이 필요하다는 사실을 함의하는 것으로 이해할 수 있다.

명목척도의 수준에서 측정된 〈시도〉, 〈혼인 상태〉, 〈성별〉의 경우 다음 몇 가지 특징이 나타난다. 우선 시도별 분포의 경우 '완전 무관심자'는 광주, 강원, 경북이 $30 \%$ 이상의 높은 비율을 나타냈다. 이는 전국 평균 $26.09 \%$ 와 비교해도 매우 높은 수준임을 알 수 있다. 또한 '매체 관람 선호자'의 경우 전북과 전남의 비중이 상대적 으로 높았으며, '직접/매체 관람자'의 경우 대전과 세종에서의 비중이 높게 나타났 다. '직접 관람 선호자'의 경우 전국 평균이 $16.06 \%$ 인데 비해 $20 \%$ 이상의 비율을 나타내는 지역이 많은 편이었다(ex. 대구, 인천, 광주, 울산). 시도 지역을 특별/광 
역시 지역과 도(道) 지역으로 분류했을 때, '직접/매체 관람자'와 '직접관람 선호자' 의 경우 특별/광역시 지역에서의 비율이 높았고, 반대로 '매체관람 선호자'의 경우 도(道) 지역에서의 비율이 높게 나타났다.

〈표 3-31〉 예술향유자 유형별 인구사회학적 특성 비교2(분포 비교): 2019 국민문화예술활동조사

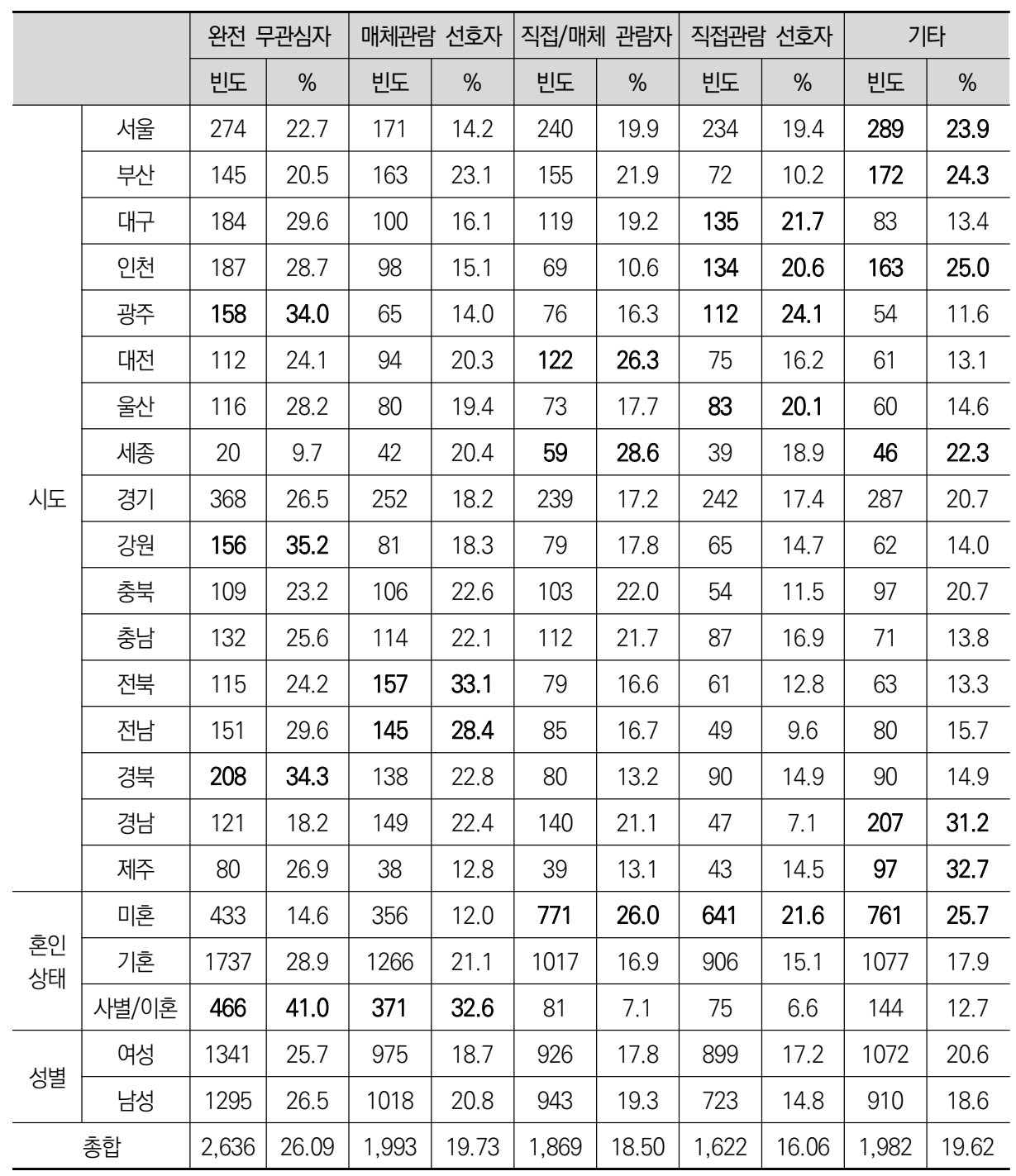

자료: 2019 년 국민문화예술활동조사」 통계자료(raw data) 기반 재구성 
〈혼인상태〉변수에서는 비교적 명확한 구분이 나타났는데, 미혼의 경우 '직접/매 체 관람자', '직접관람 선호자', '기타' 유형에서의 비중이 높았으며, 사별/이혼의 경 우 '완전 무관심자'와 '매체 관람 선호자'의 비중이 매우 높게 나타났다. 반면 〈혼인 상태〉에 있어 기혼자의 경우나 〈성별〉 변수의 경우에는 특별한 분포의 편향이 나타 나지 않은 것으로 보인다.

명목척도의 수준에서 측정된 3개 변수들의 경우 앞서 평균을 비교했던 〈나이〉나 〈가구소득〉, 〈학력〉 변수들에서 만큼 예술향유자 유형별 특성이 명확하게 드러나지 는 않았지만 다음 몇 가지 사실을 추론할 수 있다. 우선 지역의 경우 '직접/매체 관람자'와 '직접관람 선호자'들은 도(道) 지역보다는 특별/광역시 지역에서의 분포 율이 높다. 반면 '매체관람 선호자'의 경우 전남/전북을 비롯한 도 지역에서의 분포 율이 상대적으로 높게 나온 것을 알 수 있다. 물론 보다 확실한 주장을 위해서는 추가적인 조사와 분석이 필요하지만, 예술관련 시설의 분포나 지역별 접근성이 그 와 같은 차이와 관련된 것은 아닌지 조심스런 추론을 가능케 하는 부분이다. 또한 〈혼인상태〉에서도 미혼자들의 '직접/매체 관람자'와 '직접관람 선호자'의 비율이 높 게 나온 것은 여가시간의 절대량과 자유로운 사용 가능성과 관련되어 있을 수 있다.

\section{2) 문화예술 향유 방식에 있어 부가적 특성 비교}

예술 향유 방식에 있어 부가적 특성을 비교하기 위해 먼저 문화예술 관련 활동을 크게 〈구입 및 대여〉, 〈직접 관람〉, 〈기타(강습비, 학원비 등)〉 등 세 가지 영역으로 구분하고, 이를 다시 아홉 가지 세부 활동으로 분류하여 총 27 가지 예술 활동 대상 항목을 설정하였다. 〈표 3-32〉에서는 이들 27개 항목에 대해 '향후 지출을 늘리고 싶은 분야를 선택하게 한 후 응답의 분포를 제시하고 있다. 분석 결과 다음과 같은 몇 가지 특징을 발견할 수 있다.

첫째, 문화예술 활동의 세 가지 대분류 중에서는 문화예술 향유 유형과 상관없이 〈직접 관람〉에 대한 수요가 매우 강한 것으로 나타났다. 아홉 가지 예술 활동의 영 역을 모두 합치면 '직접/매체 관람자'와 '직접 관람 선호자' 유형에서는 3/4 이상의 수요가 이 영역에 집중되어 있으며, '완전 무관심자'와 '매체 관람 선호자' 집단에서 도 각각 $54.7 \%$ 와 $56.8 \%$ 의 수요가 이 영역에 몰려 있다. 그 중에서도 특히 '영화 
관람'에 대한 직접관람에 지출을 늘리고 싶다는 응답자들은 모든 문화예술 향유 유 형에서 절대적으로 큰 비중을 차지하고 있다.

둘째, 그 다음으로 큰 수요를 차지하고 있는 대분류는 문화예술 향유 유형에 따라 편차가 있다. '완전 무관심자'와 '매체 관람 선호자'의 경우 향후 지출을 늘리고 싶 은 특별한 항목이 없다고 응답한 비율이 매우 높은 반면, '직접/매체 관람자' 와 '직 접 관람 선호자' 집단에서는 〈구입 및 대여〉에 더 많은 지출을 원하는 것으로 나타 났다.

셋째, 향후 지출을 늘리고 싶은 항목에 관해서는 대체로 '완전 무관심자'와 '매체 관람 선호자' 그리고 '직접/매체 관람자'와 '직접 관람 선호자' 집단이 서로 유사한 선호 패턴이 보인 반면, '기타'에 해당하는 사람들은 나머지 향유자 유형 집단과는 상당히 차별적인 선호도를 나타내고 있다. 예를 들면 '기타' 유형의 향유자 경우 〈직접 관람〉에 대한 수요가 '직접/매체 관람자'나 '직접 관람 선호자' 만큼 높지 않 은 대신 〈구입 및 대여〉에 해당하는 항목에서는 다른 향유자 집단에 비해 압도적으 로 높은 수요를 나타내고 있다. 이는 '기타' 유형으로 분류된 문화예술 향유자의 실 제 예술향유 패턴이 매우 다양하고 차별적이라는 점과 무관하지 않은 것으로 보 인다.

〈표 3-32〉 문화예술과 관련하여 향후 지출을 늘리고 싶은 항목: 2019 국민문화예술활동조사

\begin{tabular}{|c|c|c|c|c|c|c|c|c|c|c|c|c|}
\hline \multirow[t]{2}{*}{ 분류 } & \multirow[t]{2}{*}{ 번호 } & \multirow[t]{2}{*}{ 문화예술 활동 종류 } & \multicolumn{2}{|c|}{$\begin{array}{l}\text { 완전 } \\
\text { 무관심자 }\end{array}$} & \multicolumn{2}{|c|}{$\begin{array}{c}\text { 매체관람 } \\
\text { 선호자 }\end{array}$} & \multicolumn{2}{|c|}{$\begin{array}{c}\text { 직접/매체 } \\
\text { 관람자 }\end{array}$} & \multicolumn{2}{|c|}{$\begin{array}{l}\text { 직접관람 } \\
\text { 선호자 }\end{array}$} & \multicolumn{2}{|c|}{ 기타 } \\
\hline & & & 빈도 & $\%$ & 빈도 & $\%$ & 빈도 & $\%$ & 빈도 & $\%$ & 빈도 & $\%$ \\
\hline \multirow{10}{*}{$\begin{array}{c}\text { 구입 } \\
\text { 및 } \\
\text { 대여 }\end{array}$} & 1 & 문학(독서 포함) & 65 & 2.5 & 42 & 2.1 & 66 & 3.5 & 54 & 3.3 & 96 & 4.8 \\
\hline & 2 & 미술(사진/서예/건축/디자인 포함) & 12 & 0.5 & 1 & 0.1 & 13 & 0.7 & 5 & 0.3 & 37 & 1.9 \\
\hline & 3 & 서양음악(클래식, 오페라, 서양악기 관련) & 2 & 0.1 & 3 & 0.2 & 3 & 0.2 & 4 & 0.2 & 30 & 1.5 \\
\hline & 4 & 전통예술(국악, 풍물, 민속극) & 11 & 0.4 & 6 & 0.3 & 4 & 0.2 & 2 & 0.1 & 26 & 1.3 \\
\hline & 5 & 연극 & 7 & 0.3 & 3 & 0.2 & 8 & 0.4 & 12 & 0.7 & 34 & 1.7 \\
\hline & 6 & 뮤지컬 & 21 & 0.8 & 12 & 0.6 & 23 & 1.2 & 11 & 0.7 & 43 & 2.2 \\
\hline & 7 & 무용(서양무용, 한국무용, 현대무용) & 4 & 0.2 & 2 & 0.1 & 2 & 0.1 & 1 & 0.1 & 13 & 0.7 \\
\hline & 8 & 영화 & 144 & 5.5 & 103 & 5.2 & 101 & 5.4 & 107 & 6.6 & 109 & 5.5 \\
\hline & 9 & 대중음악(가요콘서트) & 22 & 0.8 & 40 & 2.0 & 18 & 1.0 & 10 & 0.6 & 28 & 1.4 \\
\hline & & 소계 & 288 & 11.1 & 212 & 10.8 & 238 & 12.7 & 206 & 12.6 & 416 & 21.0 \\
\hline
\end{tabular}




\begin{tabular}{|c|c|c|c|c|c|c|c|c|c|c|c|c|}
\hline \multirow[t]{2}{*}{ 분류 } & \multirow[t]{2}{*}{ 번호 } & \multirow[t]{2}{*}{ 문화예술 활동 종류 } & \multicolumn{2}{|c|}{$\begin{array}{c}\text { 완전 } \\
\text { 무관심자 }\end{array}$} & \multicolumn{2}{|c|}{$\begin{array}{c}\text { 매체관람 } \\
\text { 선호자 }\end{array}$} & \multicolumn{2}{|c|}{$\begin{array}{l}\text { 직접/매체 } \\
\text { 관람자 }\end{array}$} & \multicolumn{2}{|c|}{$\begin{array}{l}\text { 직접관람 } \\
\text { 선호자 }\end{array}$} & \multicolumn{2}{|c|}{ 기타 } \\
\hline & & & 빈도 & $\%$ & 빈도 & $\%$ & 빈도 & $\%$ & 빈도 & $\%$ & 빈도 & $\%$ \\
\hline \multirow{10}{*}{$\begin{array}{l}\text { 직접 } \\
\text { 관람 }\end{array}$} & 10 & 문학행사(시화전, 도서전시회, 작가와의 대화) & 10 & 0.4 & 6 & 0.3 & 9 & 0.5 & 12 & 0.7 & 31 & 1.6 \\
\hline & 11 & 미술(사진/서예/건축/디자인 포함)전시회 & 14 & 0.5 & 14 & 0.7 & 23 & 1.2 & 17 & 1.0 & 54 & 2.7 \\
\hline & 12 & 서양음악(클래식, 오페라, 서양악기 관련) & 6 & 0.2 & 1 & 0.1 & 18 & 1.0 & 6 & 0.4 & 45 & 2.3 \\
\hline & 13 & 전통예술(국악, 풍물, 민속극) & 70 & 2.7 & 57 & 2.9 & 17 & 0.9 & 8 & 0.5 & 38 & 1.9 \\
\hline & 14 & 연극 & 50 & 1.9 & 39 & 2.0 & 72 & 3.9 & 67 & 4.1 & 79 & 4.0 \\
\hline & 15 & 뮤지컬 & 87 & 3.3 & 59 & 3.0 & 148 & 7.9 & 162 & 10.0 & 128 & 6.5 \\
\hline & 16 & 무용(서양무용, 한국무용, 현대무용) & 11 & 0.4 & 4 & 0.2 & 2 & 0.1 & 3 & 0.2 & 8 & 0.4 \\
\hline & 17 & 영화 & 1090 & 41.4 & 868 & 43.6 & 1049 & 56.1 & 902 & 55.6 & 752 & 37.9 \\
\hline & 18 & 대중음악(가요콘서트) & 104 & 3.9 & 79 & 4.0 & 97 & 5.2 & 94 & 5.8 & 80 & 4.0 \\
\hline & & 소계 & 1442 & 54.7 & 1127 & 56.8 & 1435 & 76.8 & 1271 & 78.3 & 1215 & 61.3 \\
\hline \multirow{11}{*}{$\begin{array}{c}\text { 기타 } \\
\text { (강습비, } \\
\text { 학원비 } \\
\text { 등) }\end{array}$} & 19 & 문학(글쓰기 포함) & 6 & 0.2 & 1 & 0.1 & 2 & 0.1 & 3 & 0.2 & 9 & 0.5 \\
\hline & 20 & 미술(사진/서예/건축/디자인 포함) & 5 & 0.2 & 2 & 0.1 & 5 & 0.3 & 3 & 0.2 & 21 & 1.1 \\
\hline & 21 & 서양음악(클래식, 오페라, 서양악기 관련) & 1 & 0.0 & 3 & 0.2 & 1 & 0.1 & 2 & 0.1 & 19 & 1.0 \\
\hline & 22 & 전통예술(국악, 풍물, 민속극) & 4 & 0.2 & 4 & 0.2 & 0 & 0.0 & 2 & 0.1 & 11 & 0.6 \\
\hline & 23 & 연극 & 1 & 0.0 & 0 & 0.0 & 3 & 0.2 & 0 & 0.0 & 5 & 0.3 \\
\hline & 24 & 뮤지컬 & 1 & 0.0 & 1 & 0.1 & 4 & 0.2 & 1 & 0.1 & 3 & 0.2 \\
\hline & 25 & 무용(서양무용, 한국무용, 현대무용) & 1 & 0.0 & 1 & 0.1 & 1 & 0.1 & 4 & 0.2 & 14 & 0.7 \\
\hline & 26 & 영화 & 14 & 0.5 & 15 & 0.8 & 13 & 0.7 & 13 & 0.8 & 21 & 1.1 \\
\hline & 27 & 대중음악(가요콘서트) & 13 & 0.5 & 13 & 0.7 & 7 & 0.4 & 4 & 0.2 & 18 & 0.9 \\
\hline & \multicolumn{2}{|r|}{ 소계 } & 46 & 1.6 & 40 & 2.3 & 36 & 2.1 & 32 & 1.9 & 121 & 6.4 \\
\hline & 28 & 해당사항 없음 & 860 & 32.6 & 614 & 30.8 & 160 & 8.6 & 113 & 7.0 & 230 & 11.6 \\
\hline & & 계 & 2636 & 100 & 1993 & 100 & 1869 & 100 & 1622 & 100 & 1982 & 100 \\
\hline
\end{tabular}

자료: $\ulcorner 2019$ 년 국민문화예술활동조사」통계자료(raw data) 기반 재구성

〈표 3-33〉에서는 문화예술 행사를 관람할 때 가장 중요한 기준과 가장 큰 어려움 이 무엇인가에 대한 답변을 각각 정리하고 있다. 우선 가장 중요한 기준의 경우 '완 전 무관심자'와 '매체 관람 선호자' 유형은 '접근성'을 높게 평가한 반면, '직접/매체 관람자', '직접 관람 선호자' 그리고 '기타' 유형의 향유자는 '문화예술 행사의 내용 및 수준'을 가장 중요시 했다. 
〈표 3-33〉 문화예술행사 관람 시, 기준과 어려움: 2019 국민문화예술활동조사

\begin{tabular}{|c|c|c|c|c|c|c|c|c|c|c|c|}
\hline & \multicolumn{2}{|c|}{$\begin{array}{c}\text { 완전 } \\
\text { 무관심자 }\end{array}$} & \multicolumn{2}{|c|}{$\begin{array}{c}\text { 매체관람 } \\
\text { 선호자 }\end{array}$} & \multicolumn{2}{|c|}{$\begin{array}{c}\text { 직접/매체 } \\
\text { 관람자 }\end{array}$} & \multicolumn{2}{|c|}{$\begin{array}{l}\text { 직접관람 } \\
\text { 선호자 }\end{array}$} & \multicolumn{2}{|c|}{ 기타 } \\
\hline & & 빈도 & $\%$ & 빈도 & $\%$ & 빈도 & $\%$ & 빈도 & $\%$ & 빈도 & $\%$ \\
\hline \multirow{10}{*}{$\begin{array}{c}\text { 가장 } \\
\text { 중요한 } \\
\text { 기준 }\end{array}$} & 문화예술행사의 내용 및 수준 & 767 & 29.1 & 581 & 29.2 & 786 & 42.1 & 662 & 40.8 & 719 & 36.3 \\
\hline & 관람 비용의 적절성 & 587 & 22.3 & 455 & 22.8 & 477 & 25.5 & 402 & 24.8 & 379 & 19.1 \\
\hline & 참가자(작가, 출연진)의 유명도 & 202 & 7.7 & 113 & 5.7 & 129 & 6.9 & 167 & 10.3 & 173 & 8.7 \\
\hline & 행사개최 장소의 유명도 & 60 & 2.3 & 39 & 2.0 & 49 & 2.6 & 56 & 3.5 & 83 & 4.2 \\
\hline & 교통의 편의성 & 316 & 12.0 & 202 & 10.1 & 149 & 8.0 & 99 & 6.1 & 209 & 10.5 \\
\hline & 편의시설 구비여부(놀이방 등) & 29 & 1.1 & 23 & 1.2 & 26 & 1.4 & 25 & 1.5 & 65 & 3.3 \\
\hline & 문화예술행사에 대한 전문가 의견, 언론보도 & 34 & 1.3 & 32 & 1.6 & 34 & 1.8 & 31 & 1.9 & 61 & 3.1 \\
\hline & 문화예술행사에 대한 주위 의견, 네티즌 의견 & 84 & 3.2 & 50 & 2.5 & 52 & 2.8 & 63 & 3.9 & 86 & 4.3 \\
\hline & 접근성(가깝다) & 529 & 20.1 & 493 & 24.7 & 163 & 8.7 & 112 & 6.9 & 203 & 10.2 \\
\hline & 기타 & 28 & 1.1 & 5 & 0.3 & 4 & 0.2 & 5 & 0.3 & 4 & 0.2 \\
\hline & 총합 & 2636 & 1 & 1993 & 1 & 1869 & 1 & 1622 & 1 & 1982 & 1 \\
\hline \multirow{9}{*}{$\begin{array}{c}\text { 가장 } \\
\text { 큰 } \\
\text { 어려움 }\end{array}$} & 비용이 많이 든다 & 493 & 18.7 & 373 & 18.7 & 601 & 32.2 & 458 & 28.2 & 466 & 23.5 \\
\hline & 시간이 좀처럼 나지 않는다 & 892 & 33.8 & 612 & 30.7 & 470 & 25.1 & 496 & 30.6 & 527 & 26.6 \\
\hline & 관심 있는 프로그램이 없다 & 472 & 17.9 & 325 & 16.3 & 248 & 13.3 & 257 & 15.8 & 290 & 14.6 \\
\hline & 교통이 불편하다 & 174 & 6.6 & 126 & 6.3 & 103 & 5.5 & 68 & 4.2 & 129 & 6.5 \\
\hline & 편의시설(놀이방 등)이 불편하다 & 42 & 1.6 & 28 & 1.4 & 31 & 1.7 & 30 & 1.8 & 76 & 3.8 \\
\hline & 관련정보가 부족하다 & 202 & 7.7 & 168 & 8.4 & 201 & 10.8 & 140 & 8.6 & 234 & 11.8 \\
\hline & 함께 관람할 사람이 없다 & 58 & 2.2 & 74 & 3.7 & 23 & 1.2 & 11 & 0.7 & 57 & 2.9 \\
\hline & 가까운 곳에 시설이 없다 & 259 & 9.8 & 268 & 13.4 & 178 & 9.5 & 147 & 9.1 & 188 & 9.5 \\
\hline & 기타 & 44 & 1.7 & 19 & 1.0 & 14 & 0.7 & 15 & 0.9 & 15 & 0.8 \\
\hline \multicolumn{2}{|r|}{ 총합 } & 2636 & 100 & 1993 & 100 & 1869 & 100 & 1622 & 100 & 1982 & 100 \\
\hline
\end{tabular}

자료: 2019 년 국민문화예술활동조사」 통계자료(raw data) 기반 재구성

가장 큰 어려움의 경우 ‘완전 무관심자'는 '시간이 없다'는 이유를 강조한 반면, '매체 관람 선호자'들은 (시간문제도 큰 어려움으로 생각한 경우가 많기는 했지만), 유독 '가까운 곳이 시설이 없다'는 이유를 상대적으로 더 많이 강조한 경향이 있다. 그에 비해 '직접/매체 관람자'는 많은 비용이 든다는 점을 어려움으로 가장 많이 선 택했고, '직접 관람 선호자' 그리고 '기타' 유형의 향유자는 시간과 비용의 문제를 비슷한 수준에서 큰 어려움이라고 제시했다. 
〈표 3-34〉 문화예술교육을 받고자할 때 가장 큰 어려움: 2019 국민문화예술활동조사

\begin{tabular}{c|c|c|c|c|c|c|c|c|c|c}
\hline \multirow{2}{*}{} & \multicolumn{2}{|c|}{ 완전 무관심자 } & \multicolumn{2}{|c|}{ 매체관람 선호자 } & \multicolumn{2}{|c|}{ 직접/매체 관람자 } & \multicolumn{2}{|c|}{ 적접관람 선호자 } & \multicolumn{2}{|c}{ 기타 } \\
\cline { 2 - 13 } & 빈도 & $\%$ & 빈도 & $\%$ & 빈도 & $\%$ & 빈도 & $\%$ & 빈도 & $\%$ \\
\hline 비용이 많이 든다 & 434 & 16.5 & 295 & 14.8 & 423 & 22.6 & 339 & 20.9 & 424 & 21.4 \\
\hline 시간이 좀처럼 나지 않는다 & 821 & 31.1 & 616 & 30.9 & 573 & 30.7 & 566 & 34.9 & 603 & 30.4 \\
\hline 관심 있는 강좌가 없다 & 688 & 26.1 & 478 & 24.0 & 439 & 23.5 & 383 & 23.6 & 340 & 17.2 \\
\hline 교통이 불편하다 & 86 & 3.3 & 94 & 4.7 & 39 & 2.1 & 20 & 1.2 & 86 & 4.3 \\
\hline 시설(편의시설)이 불편하다 & 52 & 2.0 & 32 & 1.6 & 39 & 2.1 & 36 & 2.2 & 82 & 4.1 \\
\hline 관련정보가 부족하다 & 195 & 7.4 & 182 & 9.1 & 178 & 9.5 & 118 & 7.3 & 217 & 10.9 \\
\hline 함께 배울 사람이 없다 & 72 & 2.7 & 74 & 3.7 & 30 & 1.6 & 38 & 2.3 & 69 & 3.5 \\
\hline 주변에 시설이 없다 & 242 & 9.2 & 205 & 10.3 & 143 & 7.7 & 115 & 7.1 & 148 & 7.5 \\
\hline 기타 & 46 & 1.7 & 17 & 0.9 & 5 & 0.3 & 7 & 0.4 & 13 & 0.7 \\
\hline 총합 & 2636 & 100 & 1993 & 100 & 1869 & 100 & 1622 & 100 & 1982 & 100 \\
\hline
\end{tabular}

자료:「2019년 국민문화예술활동조사」 통계자료(raw data) 기반 재구성

끝으로〈표 3-34〉에서는 문화예술 '교육'을 받고자 할 때 가장 큰 어려움이 무엇 인가에 대해 제시하고 있다. 여기에 나타난 특성은 다음 몇 가지로 요약할 수 있다. 첫째, 문화예술 관련 교육을 받으려 할 때 가장 큰 어려움은 모든 예술향유 유형에 서 공히 '시간 부족'의 문제로 나타났다. 이는 앞선 문화예술행사 관람 시 응답자가 제시한 가장 큰 어려움과도 비슷한 맥락으로 이해할 수 있다.

둘째, 두 번째로 빈번하게 제시된 문화예술 교육 참여의 어려움은 '기타'에 속하 는 향유자 유형을 제외하고는 동일하게 나타났다. 즉, '관심 있는 강좌가 없다'는 이유가 그것인데, 이는 앞의 '문화예술행사 관람 시의 어려움'에서 언급되었던 정도 와 비교해서 훨씬 더 크게 강조된 것으로 보인다.

셋째, 이번에도 '완전 무관심자'와 '매체 관람 선호자' 그리고 '직접/매체 관람자' 와 '직접 관람 선호자' 집단 사이에서는 가시적인 의견의 차이가 나타난다. 즉, '직 접/매체 관람자'와 '직접 관람 선호자' 집단의 경우 관심 있는 강좌가 없다는 이유와 함께 비용 문제를 비슷한 수준으로 언급한 반면, '완전 무관심자'와 '매체 관람 선호 자'의 경우에는 비용 문제를 강조하는 정도가 상대적으로 크지 않았다. 


\section{라. 시사점}

「2019 국민문화예술활동조사」에 제시된 6가지 예술향유 관련 변수를 기반으로 예술향유자들의 유형을 구분하고, 각 유형별 예술향유의 특성을 비교, 분석한 결과 다음 몇 가지 사실을 알 수 있었다. 첫째, 어떠한 기준을 적용하더라도 예술향유자 의 유형을 명확하게 구분하는 것은 쉽지 않다. 이는 기본적으로 문화예술 활동에 대해 전혀 무관심한 사람들(e.g., '완전 무관심자' (26.09\%))의 비율이 매우 높고 나 머지 절대 다수 역시 매체를 통하거나 현장에 나가 직접 관람하는 등, 일종의 제한 된 소비에만 국한되어 있기 때문이다. 또한 예술교육, 동호회, 자원봉사, 창작·실연 과 같은 보다 고차원적인 예술향유 활동의 경우 참여하는 사람들 수 자체가 매우 적고, 일일이 그 특성을 규정하기 어려울 정도로 다양한 조합의 예술향유자들이 현 실에 존재하기 때문이다. 물론 본문에 제시된 바와 같이 '완전 무관심자', '매체 관 람 선호자', '직접 관람 선호자' 등으로 분류한 것이 전혀 무의미하다고 할 수는 없 지만 문화예술향유 방식의 다양한 유형을 포괄하기에 충분한 분류로 보기는 어렵 다. 그러나 이를 다시 말하면, 예술향유자들의 경우 다양한 활동 영역에 걸쳐 중첩 적으로 참여하기도 하고, 이는 곧 활용 영역별 연계성과 전이의 가능성을 내포하고 있다고 해석할 수 있다.

둘째, 비록 충분한 수준의 유형 분류로 보기는 어렵지만 제시된 몇몇 예술향유자 유형 간에는 비교적 명확한 예술 활동에 대한 태도 및 접근 방식의 차이가 나타남이 주목된다. 앞서 언급한 바와 같이 '완전 무관심자' 및 '매체 관람 선호자'들의 경우 직접 관람을 즐기는 사람들('직접 관람 선호자', '직접/매체 관람자')과는 나이나 학 력, 가구소득뿐만 아니라 거주지와 혼인상태 등에서도 가시적인 차이가 나타났다.

또한 이들 집단 간에는 문화예술 활동의 향유에 있어 주로 관심을 보이는 분야나 충분한 예술향유를 하지 못하는 이유, 관람을 결정할 때의 중요한 기준 등에서도 상당한 차이를 보인다. 이는 단지 제한된 기준만을 적용하여 분류한 예술향유자의 유형이라도 각 유형 집단 간에는 의미 있는 수준에서 예술 활동에 대한 태도 및 선 택의 차이를 나타낼 수 있음을 시사한다.

따라서 이들의 차이점의 근원을 살펴보기 위해서는 향유 걸림돌의 요소를 다각적 으로 접근하고, 이들이 예술향유에 참여(혹은 비참여)하는 다양한 동기 및 예술에 
대한 인식 등을 종합적으로 살펴봐야 함을 시사한다고 하겠다.

셋째, 앞서 제시한 첫 번째와 두 번째 사실을 종합해 보면, 결국 예술향유 활동에 대해 구체적 정책적 제언을 이끌어 내기 위해서는 예술활동의 동기와 효과, 그리고 시민들의 예술에 대한 인식에 대해 보다 포괄적이고 종합적인 파악이 필요하다고 하겠다. 앞서「2019 국민문화예술활동조사」의 여섯 가지 변수를 가지고 예술향유 자의 유형을 명확하게 분류하기 어려웠던 이유는 단지 겉으로 드러난 특정 예술관 련 활동 경험만을 기준으로 분류를 시도했기 때문일 수도 있다.

예를 들어 '매체를 통한 관람' 대신 '직접 관람만을 선호'하는 사람들은 어떤 동기 나 이유로 그러한 선호를 갖게 되었는지, 또한 다수의 자원봉사 활동을 경험한 사람 들의 경우 어떠한 경로나 목적으로 그러한 경험을 갖게 되었는지 보다 구체적인 원 인을 파악할 수 있는 조사가 필요하다는 것이다. 그러한 조사를 바탕으로 예술향유 에 대한 분류를 시도하고 예술향유자 유형 간의 특징을 비교한다면 문화예술 향유 와 관련된 정책의 주요 대상자들에 대해 더 폭넓고 구체적으로 이해할 수 있을 것 이다.

\section{3. 실태조사 현황 및 향유유형 분석의 시사점}

\section{가. 향유 동기에 대한 파악 부재: 문화예술 활동 결과 중심}

앞의 3개의 국내 실태조사 분석에서 나타나는 공통점은 예술향유와 관련하여 그 동기를 파악할 수 있는 항목이 부재하다는 점이다. 실태조사 모두 '문화예술 활동에 관한 만족도'는 조사하고 있는 반면, 문화예술 활동에 대한 동기를 파악하기 위한 항목은 포함되어 있지 있다. 다만 「국민여가활동조사」의 경우, 여가의 목적을 파악 하기 위한 질문57)이 포함되어 있기는 하나, 「국민여가활동조사」 목적 자체가 '여 가' 수요의 활동실태를 분석하기 위한 조사이기 때문에 이를 예술향유와 직접적으 로 관련된 동기 혹은 목적이라고 보기는 어렵다. 이와 함께 예술향유에 대한 인식을 파악하고자 하는 항목도 삭제되었다. 1994년「문화향수실태조사: 2,000명 대상」

57) 건강, 즐거움, 마음의 안정과 휴식, 대인 관계·교제, 스트레스 해소, 자기 계발, 자기만족, 시간보내기, 가족과의 시간, 기타로 구성되었다. 
는 ‘문화에 대한 이해’를 처음으로 조사항목에 포함하여 조사가 진행된 바 있으나, 이는 2000년까지 유지되다가58) 이후 조사부터는 삭제되었다. 앞서 2019년 「국민 문화예술활동」의 기초 데이터를 기반으로 향유자특성 분석을 시도한 것에서도 '동 기'의 추적을 통해 다양한 향유활동 영역의 포착이 필요할 수 있음을 지적하였다.

그러나 예술향유와 관련한 현재 실태조사는 말 그대로 현재의 실태를 파악하기 위한 조사로만 시행되고 있으며, 예술이 가진 역할 및 가치 등과 연계하여 해석할 수 있는 항목인 동기·목적·인식 등과 관련한 항목은 없는 상태다. '현재' 예술향유 의 결과인 '만족도'에만 중점을 두고 시행되는 실태조사에서는 예술 환경 변화에 따 라 예술을 바라보는 국민들의 인식 및 동기 변화의 시계열적 추적이 불가능한 셈이 다. 이러한 현재의 예술향유 동기에 대한 정보 부재는 결국 예술향유 '과정'을 통한 인과관계 및 상관관계를 파악하기 어려울뿐더러 정책적 차원에서도 예술향유 진작 을 위한 다각적인 접근 방식을 모색하는데 근본적인 한계를 가지고 있다 하겠다.

\section{나. 문화예술 ‘참여’에 대한 모호한 정의: 장르 중심의 항목 제시}

일반적으로 향유는 관람과 참여로 구분되며, 국내 실태조사 역시 대부분 향유를 크게 '관람활동'과 '참여활동' 으로 구분하여 조사를 시행하였다. 하지만 3개의 실태 조사에 제시한 용어 개념 및 정의를 보면 문화예술 '참여' 활동에 대한 내용 및 범위 가 조사마다 상이함을 알 수 있다. 물론 참여의 경우, 상대적으로 시장형성이 충분 하지 않기 때문에 예술참여자를 적극적으로 분리하지 않음도 이유가 될 수 있겠으 나(나보리·나은 2019: 324), '직접 관람'이 아닌 '직접 참여하는 활동'으로서의 참 여의 정의가 매우 평면적으로 제시되어 있다는 것이 현 실태조사가 가진 한계로 보 인다. 이렇게 제한된 활동만을 나열하는 것이 조사대상자에게는 의미가 매우 한정 적이거나 불분명할 수밖에 없으며, 조사 결과 또한 한정적일 수밖에 없을 것이다.

「국민여가활동조사」의 경우, 문화행사, 문학, 미술, 음악, 전통예술, 사진, 무용 등 장르로만 제시되어 있어 이는 구체적으로 어떠한 참여 활동을 의미하는 것인지 는 명확하지 않다. 「국민문화예술활동조사」의 경우, 문화예술활동에 대한 정의를 비교적 설명과 함께 자세하게 제시하고는 있으나, 이 역시 문학, 미술, 음악, 전통예

58) 1994년, 1997년, 2000년까지 3회만 포함되었다. 
술, 연극, 뮤지컬, 무용, 영화, 대중음악 등의 장르를 기반으로 제시하고 있고, 참여 형태 및 층위에 대한 구분도 없이 그 결과를 장르별 참여율, 만족도, 의향으로만 보 여주고 있다.「서울시민 문화향유 실태조사」역시 문화예술 참여를 취미활동(창작, 연주, 전시 공유 등)으로 포괄하여 모호하게 정의하고 있다.

예술향유의 형태가 기존 관람 위주에서 점차 직접적인 참여 및 창작 단계로 확대 및 다변화되고 있으며, 참여형 예술향유의 범위도 전자매체를 포함, 예술공유, 예술 학습, 예술창작 및 공유 등을 포함하여 다양한 활동을 통해 이루어지고 있다. 하지 만 이러한 단편적 접근 및 관점에서의 ‘참여'에 대한 조사항목은 변화하는 예술 환 경에 조응하는 다양한 참여의 양태와 층위를 파악하는 데에는 한계가 발생할 수밖 에 없다.

\section{다. 예술향유 환경 변화 고려 미흡: 디지털 환경 변화 반영의 한계}

미디어와 기술 환경 변화는 급속하게 예술 향유의 방식을 변화시키고 있다. 디지 털 기술과 결합한 예술향유 방식은 관람과 참여의 방식을 완전히 바꾸어 놓고 있으 며, 국민들은 이전과는 다른 새로운 경험을 마주하고 있다. 하지만 실태조사에서는 이러한 디지털 예술향유 환경 변화가 고려되지 않고 있으며, 매회 거의 유사한 설문 항목을 기반으로 조사가 시행되고 있다. 〈서울시민 문화향유 실태조사〉의 경우, 2018년 조사에서 처음으로 일상생활에서의 매체를 통한 문화예술활동 항목을 추가 하기는 하였으나, 이는 TV, 라디오, $\mathrm{PC} /$ 노트북, 스마트폰 등의 기기를 통한 문화향 유(예: 드라마, 음악, 영화, 연극 등)를 조사하기 위한 항목에 그치고 있다. 「국민문 화예술활동조사」 역시 유사하게 매체를 이용한 문화예술행사 관람 경험을 조사하고 있으나, $\mathrm{TV}$, 라디오, $\mathrm{PC} /$ 노트북, 비디오/DVD/CD 플레이어 등의 매체를 통한 관 람경험을 조사하고 있기에59), 디지털 매체 및 콘텐츠와 관련한 예술향유 변화를 파 악하기에는 아직까지 미흡하다. 〈국민여가활동조사〉의 경우, 스마트기기를 활용한 여가활동에 관한 조사 항목이 있기는 하나, 이는 모두 스마트기기를 통한 1차적인 직접 여가 활동(예: 방송시청, 인터넷 강의, 게임, 웹툰, 음악 감상 등)만 해당되며,

59) 2019년부터 OT를 통한 관람 경험 문항이 추가되기는 하였으나, 이는 관람 경험 여부(있다 / 없다)에만 그치고 있다. 
스마트기기를 통한 예술향유와 연관된 활동(예: 공연 티켓 구매 등)은 포함되지 않 아 이 역시 스마트기기를 통한 여가 및 예술향유 활동 변화 등을 파악하기에는 부족 하다 할 수 있다.

따라서 단순하게 디지털 매체를 통한 예술향유의 실태를 파악하는 것을 넘어 디 지털 환경변화와 함께 고급예술 중심에서 다양한 예술향유의 범주 및 양태가 어떻 게 변화하고 있는지를 반영하기 위한 접근이 필요할 것이다. 디지털 기술 발전과 함께 갈수록 다변화되어 가는 예술향유의 실제적 측면을 이해하기 위해서는 보다 세밀한 조사 설계가 필요하다. 


\section{제2절 시민의 예술향유에 관한 인식 및 활동 양태}

\section{1. 시민 예술향유 인식 및 예술향유활동 설문조사}

\section{가. 조사개요}

1) 조사 목적

국내 일반 시만의 예술향유에 대한 인식 및 예술향유활동에 관한 객관적 자료를 수집하여, 관련 결과 분석을 통해 정책시사점 도출을 위해 조사를 수행하였다.

2) 조사 설계

〈표 3-35〉 2020 시민 예술향유 인식 및 예술향유활동 조사 개요

\begin{tabular}{c|l}
\hline 구분 & \multicolumn{1}{|c}{ 내용 } \\
\hline 조사 방법 & 구조화된 설문지를 활용한 온라인 조사 \\
\hline 표본수 & 1,000명 \\
\hline 모집단 & 전국 17개 시도에 거주하는 만15세 이상 일반 시민 \\
\hline 표집 방법 & 지역x성x연령별 비례 할당 \\
\hline 조사 기간 & 2020년 7월 30일 8월 6일 \\
\hline 조사수행기관 & (주글로벌 리서치 \\
\hline
\end{tabular}

\section{3) 조사 영역}

조사영역의 구성은 앞서 제1절에서 기존 실태조사를 기반으로 분석한 예술향유 실태와 특징에서 도출된 시사점을 바탕으로 설계하였다. 크게 4개 영역으로 구분하 여 설문을 구성하였으며, 기존 조사에 포함되지 못했던 영역을 포함하여 각각 예술 에 대한 인식(범주, 가치, 관심도), 예술관람 실태(동기, 매개, 효과 및 외적·내적 걸 림돌), 예술참여 실태(참여여부, 동기, 효과, 외적-내적 걸림돌), 마지막으로 예술지 
원에 관한 정책인식(정책인지도, 경험, 정부지원 충분성 인식, 정책수요)이다.

〈표 3-36〉 2020 시민 예술향유 인식 및 예술향유활동 조사 영역

\begin{tabular}{|c|c|}
\hline 구분 & 내용 \\
\hline 예술에 대한 인식 & $\begin{array}{l}\text { - 예술 범주에 대한 인식 } \\
\text { - 예술 가치에 대한 인식 } \\
\text { - 개인의 관심도 }\end{array}$ \\
\hline $\begin{array}{c}\text { 예술 관람 실태 } \\
\text { (온/오프라인) }\end{array}$ & $\begin{array}{l}\text { - 직접 관람 여부 및 횟수 } \\
\text { - 온라인 관람 여부 및 매체 } \\
\text { - 직접 관람/온라인 관람별 향유 활동 구성 요소(동기, 매개, 효과) } \\
\text { - 직접 관람/온라인 관람별 향유 활동 외적/물리적·내적/심리적 걸림돌 }\end{array}$ \\
\hline 예술 참여 실태 & $\begin{array}{l}\text { - 예술 향유 활동 참여 여부 } \\
\text { - 예술교육 활동 참여경로/동기/효과/걸림돌(외적, 내적) } \\
\text { - 예술창작 활동 참여경로/동기/효과/걸림돌(외적, 내적) } \\
\text { - 예술동호회 활동 참여경로/동기/효과/걸림돌(외적, 내적) } \\
\text { - 예술자원봉사/기부 활동 참여경로/동기/효과/걸림돌(외적, 내적) }\end{array}$ \\
\hline 예술 지원 정책 인식 & $\begin{array}{l}\text { - 정부 지원 정책 인지도 및 경험 정책 } \\
\text { - 정부 지원 충분성 } \\
\text { - 필요 정부 지원 }\end{array}$ \\
\hline
\end{tabular}

\section{4) 응답자 특성}

〈표 3-37〉 2020 시민 예술향유 인식 및 예술향유활동 조사: 응답자 특성

\begin{tabular}{|c|c|c|c|}
\hline & & 사례수 & 비율\% \\
\hline & 전체 & (1000) & 100.0 \\
\hline \multirow{2}{*}{ 성별 } & 남자 & (508) & 50.8 \\
\hline & 여자 & (492) & 49.2 \\
\hline \multirow{6}{*}{ 연령 } & 만 15 19세 & (68) & 6.8 \\
\hline & 만 20 29세 & (178) & 17.8 \\
\hline & 만 30 39세 & (188) & 18.8 \\
\hline & 만 40 49세 & (209) & 20.9 \\
\hline & 만 50 59세 & (212) & 21.2 \\
\hline & 만 60세 69세 & (145) & 14.5 \\
\hline \multirow{4}{*}{ 지역 } & 수도권 & (508) & 50.8 \\
\hline & - 서울 & (195) & 19.5 \\
\hline & - 인천경기 & (313) & 31.3 \\
\hline & 비수도권 & (492) & 49.2 \\
\hline
\end{tabular}




\begin{tabular}{|c|c|c|c|}
\hline & & 사례수 & 비율\% \\
\hline \multirow{3}{*}{ 지역규모 } & 대도시의 동 & (448) & 44.8 \\
\hline & 일반시의 동 & (445) & 44.5 \\
\hline & 읍면부 & (107) & 10.7 \\
\hline \multirow{2}{*}{ 최종학력 } & 고졸 이하 & (250) & 25.0 \\
\hline & 대재 이상 & (750) & 75.0 \\
\hline \multirow{5}{*}{ 가구원 } & 1인 가구 & (133) & 13.3 \\
\hline & 2인 가족(부부/커플) & (137) & 13.7 \\
\hline & 부모와 거주 & (310) & 31.0 \\
\hline & 자녀와 거주 & $(401)$ & 40.1 \\
\hline & 기타 & (19) & 1.9 \\
\hline \multirow{4}{*}{$\begin{array}{c}\text { 월평균 } \\
\text { 가구 소득 }\end{array}$} & 200만원 미만 & (141) & 14.1 \\
\hline & 200 400만원 미만 & (352) & 35.2 \\
\hline & 400 600만원 미만 & (295) & 29.5 \\
\hline & 600만원 이상 & (212) & 21.2 \\
\hline \multirow{6}{*}{ 직업 } & 사무전문직 & (466) & 46.6 \\
\hline & 판매노무직 & (176) & 17.6 \\
\hline & 주부 & (133) & 13.3 \\
\hline & 학생 & (119) & 11.9 \\
\hline & 무직/취업주부/퇴직 & (99) & 9.9 \\
\hline & 기타 & (7) & 0.7 \\
\hline \multirow{3}{*}{$\begin{array}{l}\text { 예술 } \\
\text { 관심도 }\end{array}$} & 관심있다 & (513) & 51.3 \\
\hline & 보통 & (356) & 35.6 \\
\hline & 관심없다 & (131) & 13.1 \\
\hline \multirow{3}{*}{$\begin{array}{l}\text { 직접관람 } \\
\text { 경험 }\end{array}$} & 무관람(G1) & (297) & 29.7 \\
\hline & 직관 저관여(G2) & (551) & 55.1 \\
\hline & 직관 고관여(G3) & (152) & 15.2 \\
\hline \multirow{2}{*}{$\begin{array}{l}\text { 온라인 매체 } \\
\text { 관람 경험 }\end{array}$} & 있다(G4) & (616) & 61.6 \\
\hline & 없다 & (384) & 38.4 \\
\hline \multirow{2}{*}{$\begin{array}{l}\text { 예술향유 } \\
\text { 활동 경험 }\end{array}$} & 있다(G5) & (388) & 38.8 \\
\hline & 없다 & (612) & 61.2 \\
\hline \multirow{3}{*}{$\begin{array}{l}\text { 예술향유 } \\
\text { 지원 정책 }\end{array}$} & 인지 \& 경험 & (549) & 54.9 \\
\hline & 인지 \& 비경험 & (270) & 27.0 \\
\hline & 비인지 & (181) & 18.1 \\
\hline \multirow{3}{*}{$\begin{array}{l}\text { 정부지원 } \\
\text { 충분도 }\end{array}$} & 충분 & (195) & 19.5 \\
\hline & 보통 & (586) & 58.6 \\
\hline & 부족 & (219) & 21.9 \\
\hline
\end{tabular}




\section{나. 조사결과60)}

1) 예술에 대한 인식

(1) 예술향유활동 범주 인식

설문문항으로 제시된 16 개 예술향유활동 중 '영화관 영화관람'과 '공연장 공연 관람'을 $62 \%$ 의 응답자가 예술향유 활동으로 인식하였다. 다음으로 '인터넷 영상 공 연/전시/영화 보기', ‘전시장 그림·조형물 감상', '예술교육 참여' 등의 순으로 높게 인식되고 있다. 반면 ‘웹툰, 웹소설 보기’, '예술 관련 동영상 편집 업로드', '예술관 련 기부/자원봉사' ‘동네 공방 생활용품 만들기' 등은 예술향유활동으로의 인식이 낮은 편이었다.

[그림 3-2] 예술향유활동 범주 인식: 2020 시민 예술향유 인식 및 예술향유활동 조사

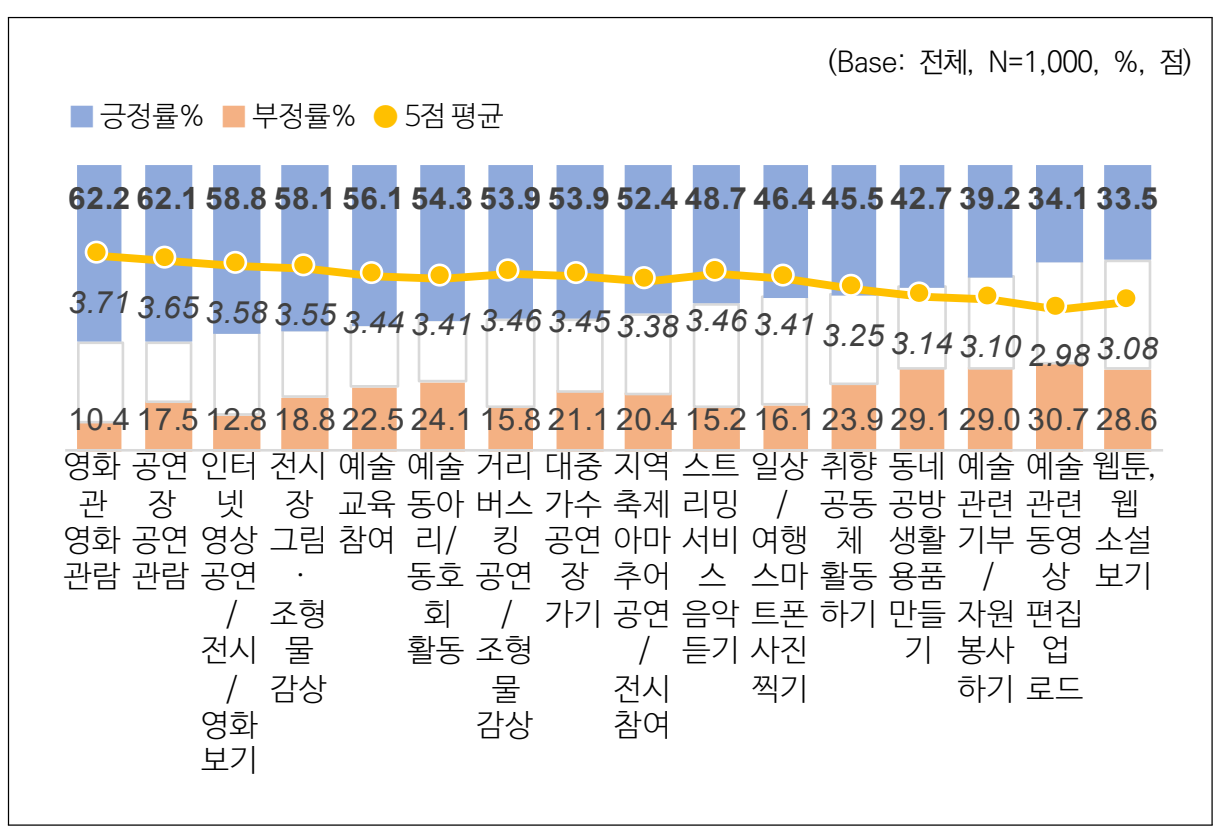

60) 조사항목 별로 결과를 기술하되, 모든 설문에 대한 분석 보다는 주목되는 부분 및 시사점 도출에 필요한 영역 중심으로 제시한다. 
〈표 3-38〉 응답자 특성별 예술향유활동 범주 인식(상위 8개 긍정률 \%): 2020 시민 예술향유 인식 및 예술향유활동 조사

\begin{tabular}{|c|c|c|c|c|c|c|c|c|c|c|}
\hline & & 사례수 & $\begin{array}{l}\text { 영화과 } \\
\text { 영화 } \\
\text { 관람 }\end{array}$ & $\begin{array}{l}\text { 공연장 } \\
\text { 공연 } \\
\text { 관람 }\end{array}$ & $\begin{array}{l}\text { 인티넷영상 } \\
\text { 공연/전시/ } \\
\text { 영화보기 }\end{array}$ & $\begin{array}{l}\text { 전시장 } \\
\text { 그림. } \\
\text { 조형물 } \\
\text { 감상 }\end{array}$ & $\begin{array}{l}\text { 예술 } \\
\text { 교육 } \\
\text { 참여 }\end{array}$ & $\begin{array}{l}\text { 예술 } \\
\text { 동아리/ } \\
\text { 동호회 } \\
\text { 활동 }\end{array}$ & \begin{tabular}{|c} 
거리버스킹 \\
공연/ \\
조형물 \\
감상 \\
\end{tabular} & $\begin{array}{c}\text { 대중 } \\
\text { 가수 } \\
\text { 공연장 } \\
\text { 가기 }\end{array}$ \\
\hline & 전체 & (1000) & 62.2 & 62.1 & 58.8 & 58.1 & 56.1 & 54.3 & 53.9 & 53.9 \\
\hline \multirow{2}{*}{ 성별 } & 남자 & (508) & 61.0 & 56.3 & 54.7 & 52.8 & 51.6 & 49.4 & 49.6 & 48.4 \\
\hline & 여자 & (492) & 63.4 & 68.1 & 63.0 & 63.6 & 60.8 & 59.3 & 58.3 & 59.6 \\
\hline \multirow{6}{*}{ 연령 } & 만 15 19세 & (68) & 86.8 & 69.1 & 75.0 & 63.2 & 55.9 & 58.8 & 58.8 & 66.2 \\
\hline & 만 20 29세 & (178) & 70.8 & 69.1 & 65.7 & 62.9 & 58.4 & 56.7 & 58.4 & 60.7 \\
\hline & 만 30 39세 & (188) & 64.4 & 59.6 & 62.2 & 55.9 & 56.4 & 56.9 & 55.9 & 57.4 \\
\hline & 만 40 49세 & (209) & 52.6 & 57.4 & 49.3 & 56.0 & 52.6 & 45.9 & 48.3 & 46.9 \\
\hline & 만 50 59세 & (212) & 57.1 & 59.4 & 59.0 & 56.6 & 56.6 & 54.7 & 54.7 & 48.1 \\
\hline & 만 60세 69세 & $(145)$ & 58.6 & 64.1 & 51.7 & 57.9 & 57.2 & 57.2 & 50.3 & 53.8 \\
\hline \multirow{4}{*}{ 지역 } & 수도권 & (508) & 62.2 & 63.8 & 57.1 & 59.6 & 56.9 & 55.9 & 52.6 & 55.9 \\
\hline & - 서울 & (195) & 64.1 & 67.7 & 54.4 & 65.1 & 58.5 & 64.1 & 54.9 & 59.0 \\
\hline & - 인천경기 & (313) & 61.0 & 61.3 & 58.8 & 56.2 & 55.9 & 50.8 & 51.1 & 54.0 \\
\hline & 비수도권 & (492) & 62.2 & 60.4 & 60.6 & 56.5 & 55.3 & 52.6 & 55.3 & 51.8 \\
\hline \multirow{3}{*}{ 지역규모 } & 대도시의 동 & (448) & 64.5 & 65.8 & 57.8 & 62.9 & 58.0 & 58.5 & 56.3 & 55.1 \\
\hline & 일반시의 동 & (445) & 60.4 & 59.6 & 59.8 & 55.5 & 55.1 & 52.1 & 51.9 & 51.5 \\
\hline & 읍면부 & (107) & 59.8 & 57.0 & 58.9 & 48.6 & 52.3 & 45.8 & 52.3 & 58.9 \\
\hline \multirow{2}{*}{ 최종학력 } & 고졸 이하 & (250) & 60.8 & 59.2 & 58.0 & 52.8 & 51.6 & 50.4 & 51.2 & 50.8 \\
\hline & 대재 이상 & (750) & 62.7 & 63.1 & 59.1 & 59.9 & 57.6 & 55.6 & 54.8 & 54.9 \\
\hline \multirow{5}{*}{ 가구원 } & 1인 가구 & (133) & 64.7 & 62.4 & 63.2 & 60.2 & 57.9 & 53.4 & 53.4 & 56.4 \\
\hline & 2인 가족(부부/커플) & (137) & 55.5 & 62.0 & 54.7 & 52.6 & 54.0 & 56.2 & 55.5 & 48.9 \\
\hline & 부모와 거주 & (310) & 70.0 & 64.2 & 62.3 & 61.9 & 56.8 & 55.5 & 55.5 & 58.4 \\
\hline & 자녀와 거주 & $(401)$ & 58.1 & 60.1 & 56.1 & 55.6 & 55.6 & 52.9 & 51.9 & 50.9 \\
\hline & 기타 & (19) & 52.6 & 68.4 & 57.9 & 73.7 & 57.9 & 57.9 & 63.2 & 63.2 \\
\hline \multirow{4}{*}{$\begin{array}{c}\text { 월평균 } \\
\text { 가구 소득 }\end{array}$} & 200만원 미만 & $(141)$ & 53.2 & 53.9 & 56.0 & 54.6 & 48.2 & 51.8 & 46.1 & 49.6 \\
\hline & 200 400만원 미만 & (352) & 61.9 & 63.9 & 56.0 & 56.3 & 58.0 & 52.8 & 53.1 & 54.8 \\
\hline & 400 600만원 미만 & (295) & 63.4 & 61.0 & 62.4 & 58.0 & 54.9 & 55.9 & 56.6 & 54.2 \\
\hline & 600만원 이상 & (212) & 67.0 & 66.0 & 60.4 & 63.7 & 59.9 & 56.1 & 56.6 & 54.7 \\
\hline \multirow{6}{*}{ 직업 } & 사무전문직 & $(466)$ & 63.5 & 63.1 & 57.5 & 60.9 & 58.8 & 57.1 & 54.5 & 55.4 \\
\hline & 판매노무직 & (176) & 53.4 & 54.5 & 51.7 & 45.5 & 48.3 & 46.0 & 46.0 & 46.6 \\
\hline & 주부 & (133) & 57.1 & 60.2 & 64.7 & 59.4 & 58.6 & 55.6 & 57.1 & 51.9 \\
\hline & 학생 & (119) & 83.2 & 68.9 & 72.3 & 61.3 & 56.3 & 56.3 & 58.8 & 63.9 \\
\hline & 무직/취업주부/퇴직 & (99) & 55.6 & 67.7 & 55.6 & 63.6 & 57.6 & 54.5 & 57.6 & 53.5 \\
\hline & 기타 & (7) & 28.6 & 28.6 & 28.6 & 28.6 & 0.0 & 14.3 & 14.3 & 14.3 \\
\hline
\end{tabular}




\begin{tabular}{|c|c|c|c|c|c|c|c|c|c|c|}
\hline & & 사례수 & $\begin{array}{l}\text { 영화관 } \\
\text { 영화 } \\
\text { 관람 }\end{array}$ & $\begin{array}{l}\text { 공연장 } \\
\text { 공연 } \\
\text { 관람 }\end{array}$ & $\begin{array}{l}\text { 인터넛영상 } \\
\text { 공연/전시/ } \\
\text { 영화보기 }\end{array}$ & $\begin{array}{l}\text { 전시장 } \\
\text { 그림. } \\
\text { 조형물 } \\
\text { 감상 }\end{array}$ & $\begin{array}{l}\text { 예술 } \\
\text { 교육 } \\
\text { 참여 }\end{array}$ & $\begin{array}{l}\text { 예술 } \\
\text { 동아리/ } \\
\text { 동호회 } \\
\text { 활동 }\end{array}$ & \begin{tabular}{|c|} 
거리버스킹 \\
공연/ \\
조형물 \\
감상
\end{tabular} & $\begin{array}{c}\text { 대중 } \\
\text { 가수 } \\
\text { 공연장 } \\
\text { 가기 }\end{array}$ \\
\hline \multirow{3}{*}{$\begin{array}{l}\text { 예술 } \\
\text { 관심도 }\end{array}$} & 관심있다 & (513) & 75.6 & 77.6 & 73.1 & 72.3 & 69.4 & 67.3 & 67.1 & 66.5 \\
\hline & 보통 & (356) & 53.7 & 50.6 & 48.9 & 46.3 & 45.2 & 43.5 & 44.1 & 46.6 \\
\hline & 관심없다 & (131) & 32.8 & 32.8 & 29.8 & 34.4 & 33.6 & 32.8 & 29.0 & 24.4 \\
\hline \multirow{3}{*}{$\begin{array}{c}\text { 직접관람 } \\
\text { 경험 }\end{array}$} & 무관람(G1) & (297) & 43.8 & 43.4 & 45.5 & 44.1 & 44.4 & 42.4 & 38.4 & 38.4 \\
\hline & 직관 저관여(G2) & (551) & 68.4 & 66.2 & 64.4 & 61.3 & 59.2 & 57.2 & 58.3 & 57.9 \\
\hline & 직관 고관여(G3) & (152) & 75.7 & 83.6 & 64.5 & 73.7 & 67.8 & 67.1 & 68.4 & 69.7 \\
\hline \multirow{2}{*}{$\begin{array}{c}\text { 온라인 매체 } \\
\text { 관람 경험 }\end{array}$} & 있다(G4) & (616) & 69.0 & 67.9 & 69.0 & 64.6 & 61.9 & 59.7 & 60.7 & 59.3 \\
\hline & 없다 & (384) & 51.3 & 52.9 & 42.4 & 47.7 & 46.9 & 45.6 & 43.0 & 45.3 \\
\hline \multirow{2}{*}{$\begin{array}{l}\text { 예술향유 } \\
\text { 활동 경험 }\end{array}$} & 있다(G5) & (388) & 69.1 & 70.6 & 64.2 & 62.4 & 60.8 & 60.3 & 60.3 & 59.0 \\
\hline & 없다 & (612) & 57.8 & 56.7 & 55.4 & 55.4 & 53.1 & 50.5 & 49.8 & 50.7 \\
\hline \multirow{3}{*}{$\begin{array}{l}\text { 예술향유 } \\
\text { 지원 정책 }\end{array}$} & 인지 \& 경험 & (549) & 71.0 & 70.5 & 66.5 & 65.0 & 61.6 & 59.0 & 59.6 & 60.5 \\
\hline & 인지 \& 비경험 & (270) & 60.7 & 62.6 & 57.4 & 60.4 & 56.3 & 55.6 & 58.1 & 53.7 \\
\hline & 비인지 & (181) & 37.6 & 35.9 & 37.6 & 33.7 & 39.2 & 38.1 & 30.4 & 34.3 \\
\hline \multirow{3}{*}{$\begin{array}{l}\text { 정부지원 } \\
\text { 충분도 }\end{array}$} & 충분 & (195) & 71.3 & 68.2 & 66.7 & 64.6 & 60.0 & 62.1 & 61.5 & 64.1 \\
\hline & 보통 & (586) & 59.2 & 60.9 & 56.3 & 56.5 & 54.8 & 53.8 & 51.0 & 52.2 \\
\hline & 부족 & (219) & 62.1 & 59.8 & 58.4 & 56.6 & 56.2 & 48.9 & 54.8 & 49.3 \\
\hline
\end{tabular}

〈표 3-39〉 응답자 특성별 예술향유활동 범주 인식(하위 8개, 긍정률 \%): 2020 시민 예술향유 인식 및 예술향유활동 조사

\begin{tabular}{|c|c|c|c|c|c|c|c|c|c|c|}
\hline & & 사례수 & $\begin{array}{c}\text { 지역축제 } \\
\text { 아마추어 } \\
\text { 공연/전시 } \\
\text { 참여 }\end{array}$ & $\begin{array}{c}\text { 스트리밍 } \\
\text { 서비스 } \\
\text { 음악 } \\
\text { 듣기 }\end{array}$ & $\begin{array}{l}\text { 일상/여행 } \\
\text { 스마트폰 } \\
\text { 사진찍기 }\end{array}$ & $\begin{array}{l}\text { 취향 } \\
\text { 공동체 } \\
\text { 활동 } \\
\text { 하기 }\end{array}$ & $\begin{array}{l}\text { 동네 } \\
\text { 공방 } \\
\text { 생활 } \\
\text { 용품 } \\
\text { 만들기 }\end{array}$ & $\begin{array}{c}\text { 예술관련 } \\
\text { 기뷔/ } \\
\text { 자원봉사 } \\
\text { 하기 }\end{array}$ & $\begin{array}{l}\text { 예술관련 } \\
\text { 동영상 } \\
\text { 편집 } \\
\text { 업로드 } \\
\text { 하기 }\end{array}$ & $\begin{array}{l}\text { 웽툰, } \\
\text { 웹소설 } \\
\text { 보기 }\end{array}$ \\
\hline & 전체 & (1000) & 52.4 & 48.7 & 46.4 & 45.5 & 42.7 & 39.2 & 34.1 & 33.5 \\
\hline \multirow{2}{*}{ 성별 } & 남자 & (508) & 46.9 & 49.6 & 44.3 & 41.5 & 39.2 & 36.0 & 32.1 & 32.9 \\
\hline & 여자 & (492) & 58.1 & 47.8 & 48.6 & 49.6 & 46.3 & 42.5 & 36.2 & 34.1 \\
\hline \multirow{6}{*}{ 연령 } & 만 15 19세 & (68) & 45.6 & 73.5 & 63.2 & 51.5 & 52.9 & 38.2 & 41.2 & 57.4 \\
\hline & 만 20 29세 & (178) & 56.2 & 60.7 & 53.9 & 49.4 & 46.1 & 46.6 & 44.4 & 47.8 \\
\hline & 만 30 39세 & (188) & 53.7 & 52.1 & 48.4 & 45.7 & 45.7 & 41.5 & 36.2 & 39.9 \\
\hline & 만 40 49세 & (209) & 49.8 & 39.2 & 34.9 & 43.5 & 39.7 & 33.5 & 29.7 & 27.8 \\
\hline & 만 50 59세 & (212) & 53.3 & 38.7 & 37.3 & 42.0 & 38.7 & 36.3 & 28.3 & 23.1 \\
\hline & 만 60세 69세 & (145) & 51.7 & 46.2 & 56.6 & 45.5 & 40.0 & 40.0 & 30.3 & 20.0 \\
\hline
\end{tabular}




\begin{tabular}{|c|c|c|c|c|c|c|c|c|c|c|}
\hline & & 사례수 & $\begin{array}{c}\text { 지역축제 } \\
\text { 아마추어 } \\
\text { 공연/전시 } \\
\text { 참여 }\end{array}$ & $\begin{array}{c}\text { 스트리밍 } \\
\text { 서비스 } \\
\text { 음악 } \\
\text { 듣기 }\end{array}$ & $\begin{array}{l}\text { 일상/여행 } \\
\text { 스마트폰 } \\
\text { 사진찍기 }\end{array}$ & $\begin{array}{l}\text { 취향 } \\
\text { 공동체 } \\
\text { 활동 } \\
\text { 하기 }\end{array}$ & $\begin{array}{l}\text { 동네 } \\
\text { 공방 } \\
\text { 생활 } \\
\text { 용품 } \\
\text { 만들기 }\end{array}$ & $\begin{array}{c}\text { 예술관련 } \\
\text { 기부/ } \\
\text { 자원봉사 } \\
\text { 하기 }\end{array}$ & $\begin{array}{c}\text { 예술관련 } \\
\text { 동영상 } \\
\text { 편집 } \\
\text { 업로도 } \\
\text { 하기 }\end{array}$ & $\begin{array}{l}\text { 웹툰, } \\
\text { 웹소설 } \\
\text { 보기 }\end{array}$ \\
\hline \multirow{4}{*}{ 지역 } & 수도권 & (508) & 52.2 & 46.3 & 45.9 & 46.5 & 43.5 & 41.7 & 31.9 & 31.9 \\
\hline & - 서울 & (195) & 59.5 & 47.7 & 53.3 & 50.3 & 49.2 & 46.2 & 35.9 & 32.8 \\
\hline & - 인천경기 & (313) & 47.6 & 45.4 & 41.2 & 44.1 & 39.9 & 39.0 & 29.4 & 31.3 \\
\hline & 비수도권 & (492) & 52.6 & 51.2 & 47.0 & 44.5 & 41.9 & 36.6 & 36.4 & 35.2 \\
\hline \multirow{3}{*}{ 지역규모 } & 대도시의 동 & (448) & 56.5 & 48.7 & 48.2 & 46.4 & 46.0 & 42.4 & 35.7 & 34.8 \\
\hline & 일반시의 동 & (445) & 47.0 & 48.5 & 43.8 & 45.6 & 40.2 & 36.4 & 32.6 & 32.1 \\
\hline & 읍면부 & $(107)$ & 57.9 & 49.5 & 49.5 & 41.1 & 39.3 & 37.4 & 33.6 & 33.6 \\
\hline \multirow{2}{*}{ 최종학력 } & 고졸 이하 & (250) & 48.0 & 44.4 & 44.4 & 39.2 & 41.6 & 32.8 & 31.2 & 28.8 \\
\hline & 대재 이상 & (750) & 53.9 & 50.1 & 47.1 & 47.6 & 43.1 & 41.3 & 35.1 & 35.1 \\
\hline \multirow{5}{*}{ 가구원 } & 1인 가구 & (133) & 48.1 & 54.1 & 39.8 & 45.9 & 44.4 & 40.6 & 33.1 & 38.3 \\
\hline & 2인 가족(부부/커플) & (137) & 54.7 & 37.2 & 41.6 & 37.2 & 37.2 & 36.5 & 32.1 & 24.8 \\
\hline & 부모와 거주 & (310) & 51.6 & 57.7 & 51.6 & 48.4 & 46.5 & 41.0 & 40.0 & 41.3 \\
\hline & 자녀와 거주 & $(401)$ & 53.1 & 43.9 & 46.4 & 45.6 & 40.9 & 38.2 & 30.4 & 28.4 \\
\hline & 기타 & (19) & 63.2 & 47.4 & 42.1 & 52.6 & 47.4 & 42.1 & 36.8 & 42.1 \\
\hline \multirow{4}{*}{$\begin{array}{c}\text { 월평균 } \\
\text { 가구 소득 }\end{array}$} & 200만원 미만 & $(141)$ & 45.4 & 49.6 & 39.7 & 41.8 & 38.3 & 34.0 & 32.6 & 35.5 \\
\hline & 200 400만원 미만 & (352) & 51.7 & 47.4 & 45.2 & 44.0 & 44.3 & 36.9 & 35.5 & 33.5 \\
\hline & 400 600만원 미만 & (295) & 53.6 & 46.8 & 48.1 & 46.8 & 42.7 & 42.0 & 35.6 & 28.8 \\
\hline & 600 만원 이상 & (212) & 56.6 & 52.8 & 50.5 & 48.6 & 42.9 & 42.5 & 30.7 & 38.7 \\
\hline \multirow{6}{*}{ 직업 } & 사무전문직 & $(466)$ & 54.5 & 46.8 & 44.0 & 47.4 & 44.6 & 44.2 & 35.0 & 31.5 \\
\hline & 판매노무직 & (176) & 45.5 & 42.0 & 41.5 & 39.8 & 38.6 & 33.0 & 23.9 & 30.1 \\
\hline & 주부 & (133) & 57.9 & 44.4 & 47.4 & 42.9 & 42.1 & 33.1 & 36.8 & 25.6 \\
\hline & 학생 & $(119)$ & 51.3 & 74.8 & 66.4 & 54.6 & 47.9 & 42.0 & 42.9 & 58.8 \\
\hline & 무직/취업주부/퇴직 & (99) & 52.5 & 44.4 & 42.4 & 42.4 & 38.4 & 34.3 & 36.4 & 28.3 \\
\hline & 기타 & (7) & 0.0 & 42.9 & 28.6 & 0.0 & 0.0 & 0.0 & 0.0 & 42.9 \\
\hline \multirow{3}{*}{$\begin{array}{l}\text { 예술 } \\
\text { 관심도 }\end{array}$} & 관심있다 & (513) & 65.9 & 62.8 & 59.5 & 60.8 & 53.8 & 52.2 & 45.4 & 44.4 \\
\hline & 보통 & (356) & 41.9 & 36.8 & 36.5 & 33.7 & 34.0 & 27.8 & 26.1 & 23.9 \\
\hline & 관심없다 & (131) & 28.2 & 26.0 & 22.1 & 17.6 & 22.9 & 19.1 & 11.5 & 16.8 \\
\hline \multirow{3}{*}{$\begin{array}{l}\text { 직접관람 } \\
\text { 경험 }\end{array}$} & 무관람(G1) & $(297)$ & 37.4 & 37.7 & 32.7 & 31.3 & 32.0 & 23.9 & 25.3 & 21.9 \\
\hline & 직관 저관여(G2) & $(551)$ & 56.1 & 52.1 & 51.4 & 49.9 & 45.6 & 43.9 & 36.1 & 36.5 \\
\hline & 직관 고관여(G3) & (152) & 68.4 & 57.9 & 55.3 & 57.2 & 53.3 & 52.0 & 44.1 & 45.4 \\
\hline \multirow{2}{*}{$\begin{array}{l}\text { 온라인 매체 } \\
\text { 관람 경험 }\end{array}$} & 있다(G4) & (616) & 58.9 & 56.3 & 53.9 & 53.7 & 49.0 & 45.9 & 39.1 & 41.9 \\
\hline & 없다 & (384) & 41.9 & 36.5 & 34.4 & 32.3 & 32.6 & 28.4 & 26.0 & 20.1 \\
\hline
\end{tabular}




\begin{tabular}{|c|c|c|c|c|c|c|c|c|c|c|}
\hline & & 사례수 & $\begin{array}{c}\text { 지역축제 } \\
\text { 아마추어 } \\
\text { 공연/전시 } \\
\text { 참여 }\end{array}$ & $\begin{array}{l}\text { 스트리밍 } \\
\text { 서비스 } \\
\text { 음악 } \\
\text { 듣기 }\end{array}$ & $\begin{array}{l}\text { 일상/여행 } \\
\text { 스마트폰 } \\
\text { 사진찍기 }\end{array}$ & $\begin{array}{l}\text { 취향 } \\
\text { 공동체 } \\
\text { 활동 } \\
\text { 하기 }\end{array}$ & $\begin{array}{l}\text { 동네 } \\
\text { 공방 } \\
\text { 생활 } \\
\text { 용품 } \\
\text { 만들기 }\end{array}$ & $\begin{array}{c}\text { 예술관련 } \\
\text { 기부/ } \\
\text { 자원봉사 } \\
\text { 하기 }\end{array}$ & $\begin{array}{c}\text { 예술관련 } \\
\text { 동영상 } \\
\text { 편집 } \\
\text { 업로드 } \\
\text { 하기 }\end{array}$ & $\begin{array}{l}\text { 웹툰, } \\
\text { 웹소설 } \\
\text { 보기 }\end{array}$ \\
\hline \multirow{2}{*}{$\begin{array}{l}\text { 예술향유 } \\
\text { 활동 경험 }\end{array}$} & 있다(G5) & (388) & 59.5 & 55.2 & 56.2 & 52.3 & 49.2 & 47.9 & 39.7 & 41.8 \\
\hline & 없다 & (612) & 47.9 & 44.6 & 40.2 & 41.2 & 38.6 & 33.7 & 30.6 & 28.3 \\
\hline \multirow{3}{*}{$\begin{array}{l}\text { 예술향유 } \\
\text { 지원 정책 }\end{array}$} & 인지 \& 경험 & (549) & 59.6 & 55.6 & 54.5 & 53.6 & 47.5 & 46.4 & 40.1 & 40.8 \\
\hline & 인지 \& 비경험 & (270) & 51.5 & 45.9 & 38.5 & 43.3 & 44.8 & 35.2 & 31.9 & 28.9 \\
\hline & 비인지 & (181) & 32.0 & 32.0 & 33.7 & 24.3 & 24.9 & 23.2 & 19.3 & 18.2 \\
\hline \multirow{3}{*}{$\begin{array}{l}\text { 정부지원 } \\
\text { 충분도 }\end{array}$} & 충분 & (195) & 63.6 & 60.5 & 60.0 & 52.3 & 45.6 & 45.6 & 43.6 & 46.7 \\
\hline & 보통 & (586) & 50.2 & 45.2 & 42.0 & 44.7 & 42.3 & 38.9 & 32.8 & 29.9 \\
\hline & 부족 & (219) & 48.4 & 47.5 & 46.1 & 41.6 & 41.1 & 34.2 & 29.2 & 31.5 \\
\hline
\end{tabular}

연령별로는 10 대와 20 대가 타 연령대보다 예술향유활동 범주 인식이 높은 특성 을 보이며, 지역별로는 서울 거주자가 타 지역 거주자 대비 높은 특성을 보였다.

직접관람 경험이 많을수록, 온라인 매체 관람 경험이 있는 자, 예술향유활동 경험 자가 예술향유활동 범주에 대한 확장적 인식이 높은 특성을 보였다.

(2) 예술의 가치에 대한 인식

예술의 가치 인식은 사회적 가치와 개인적 가치를 함께 질문하였고, '개인의 삶을 즐겁게 해준다'가 긍정률 $80 \%$ 로 가장 높았다. 다음으로 '사회를 문화적으로 풍요롭 게 한다' $75 \%$, '개인의 삶을 행복하게 해준다' $73 \%$, '평소 생각하지 못한 다른 사람 과 다른 문화를 이해하게 해 준다' $71 \%$ 순이었다. 한편, '사회의 경제적 발전에 도 움을 준다'는 54\%로 예술의 가치로 낮게 인식되고 있음이 나타났다. 
[그림 3-3] 예술의 가치에 대한 인식: 2020 시민 예술향유 인식 및 예술향유활동 조사

\begin{tabular}{|c|c|c|c|c|c|c|c|}
\hline & & & & & \multicolumn{3}{|c|}{ (Base: 전체, $\mathrm{N}=1,000, \%$, 점) } \\
\hline 긍정률\% & 6 부정률 & $\%$ 5점픙 & 평균 & & & & \\
\hline 80.0 & $\begin{array}{c}75.1 \\
0\end{array}$ & $\begin{array}{c}73.4 \\
0\end{array}$ & $\begin{array}{c}71.0 \\
0\end{array}$ & 69.5 & 67.9 & 62.4 & 54.1 \\
\hline 4.03 & 3.97 & 3.92 & 3.90 & 3.86 & 3.79 & 3.73 & 3.60 \\
\hline 3.2 & 5.0 & 5.1 & 4.7 & 7.8 & 7.5 & 6.5 & 7.4 \\
\hline $\begin{array}{l}\text { 개인의 } \\
\text { 삶을 } \\
\text { 즐겁게 } \\
\text { 해 준다 }\end{array}$ & $\begin{array}{c}\text { 사회를 } \\
\text { 문화적으 } \\
\text { 로 } \\
\text { 풍요롭게 } \\
\text { 해준다 }\end{array}$ & $\begin{array}{c}\text { 개인의 } \\
\text { 삶을 } \\
\text { 행복하게 } \\
\text { 해 준다 }\end{array}$ & $\begin{array}{c}\text { 평소 생각 } \\
\text { 하지 못한 } \\
\text { 다른 사람 } \\
\quad \text { 과 } \\
\text { 다른 문화 } \\
\text { 를 이해하 } \\
\text { 게 해 준다 }\end{array}$ & $\begin{array}{c}\text { 개인의 } \\
\text { 삶을 } \\
\text { 풍요롭게 } \\
\text { 해 준다 }\end{array}$ & $\begin{array}{c}\text { 개인의 } \\
\text { 자신감과 } \\
\text { 자존감을 } \\
\text { 높여준다 }\end{array}$ & $\begin{array}{c}\text { 사회의 } \\
\text { 공동체 } \\
\text { 형성에 } \\
\text { 기여한다 }\end{array}$ & $\begin{array}{c}\text { 사회의 } \\
\text { 경제적 } \\
\text { 발전에 } \\
\text { 도움을 } \\
\text { 준다 }\end{array}$ \\
\hline
\end{tabular}

(3) 예술에 대한 개인 관심도

예술에 대한 개인 관심도는 5점 척도 평균 3.48점, 관심률 $51 \%$, 무관심률 $13 \%$ 로 응답되었다.

[그림 3-4] 예술에 대한 개인 관심도: 2020 시민 예술향유 인식 및 예술향유활동 조사

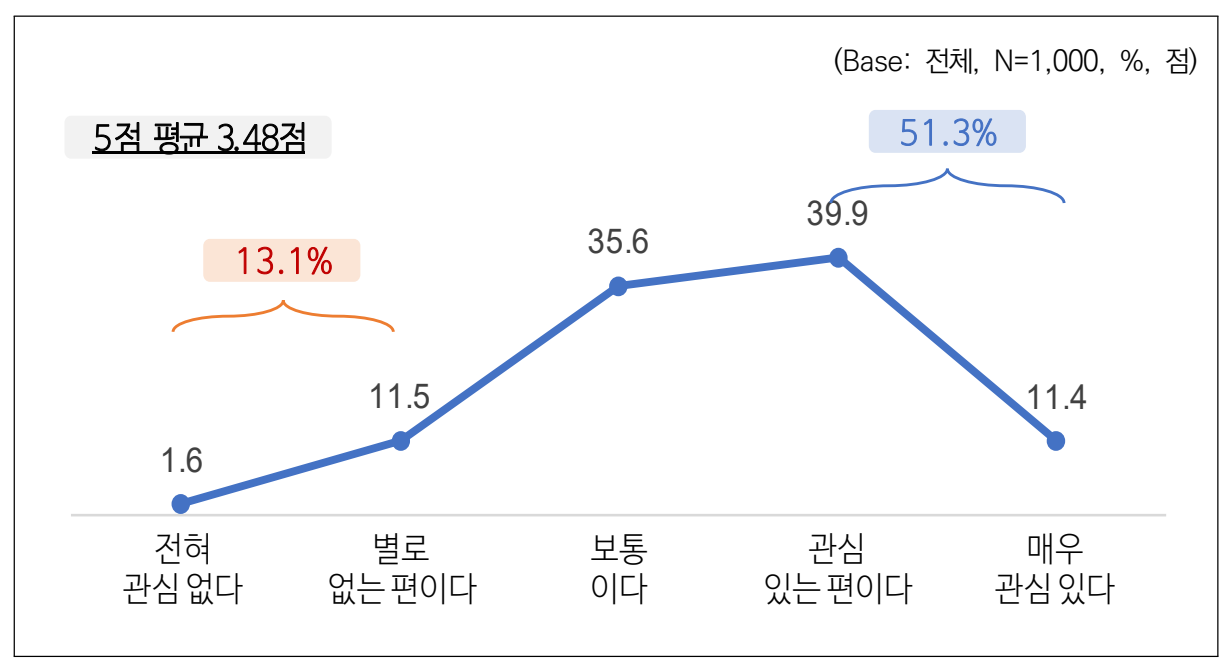


남자보다는 여자의 예술 관심이 높고, 10 대와 20 대가 상대적으로 관심이 높은 반면 40대가 가장 낮은 관심 수준을 보였다. 지역적으로 수도권과 비수도권은 큰 차이가 없고 다만 서울이 높은 관심도를 보였다. 예술 관심도는 거주 지역 규모, 월 평균 가구 소득과 비례하는 경향을 보였다. 그룹별 특성으로 보면, 직접 관람 고관 여 그룹(G3), 예술향유 활동 경험 그룹(G5), 온라인 매체 관람 경험 그룹(G4), 직접 관람 저관여 그룹(G2), 직접 관람 비경험 그룹(G1) 순으로 예술 관심도가 높았다.

(4) 예술에 대한 개인 차원의 효능감

예술에 대한 개인 차원의 효능감은 '예술적 활동에 참여/관람하는 것이 편안하다' 가 $65 \%$ 로 가장 높게 나타났다. 다음으로 '창작-연주활동, 그림·악기 등을 배우는 과정에서 발생하는 어려움은 극복할 수 있다고 생각한다'가 $38 \%$, '그림, 노래, 춤, 사진 등을 통해 내 기분과 생각을 표현하는 것이 어렵다고 느껴지지 않는다'가 $33 \%$ 로 나타났다.

[그림 3-5] 예술에 대한 개인 차원의 효능감: 2020 시민 예술향유 인식 및 예술향유활동 조사

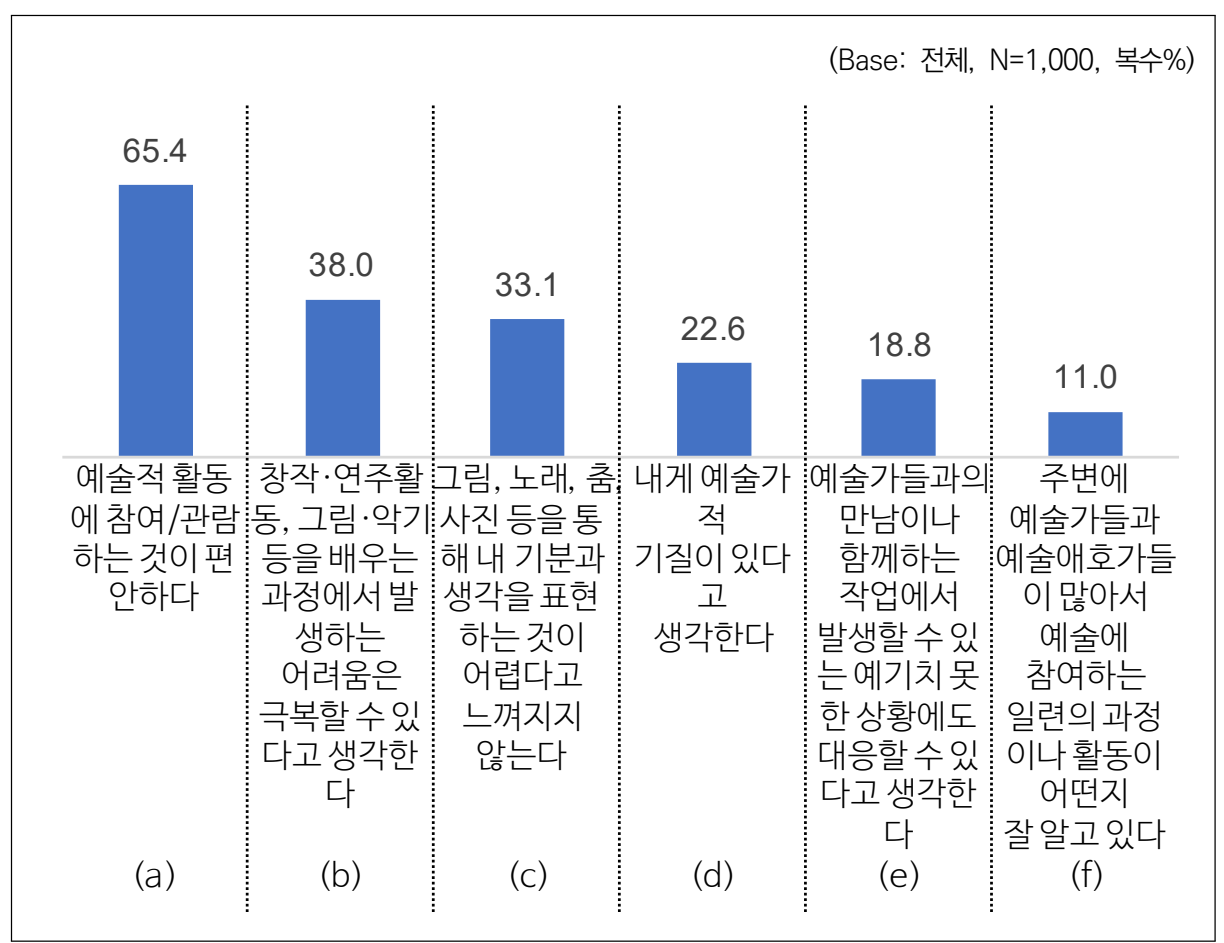


(5) 환경변화에 따른 예술인식 변화

최근 급속한 기술혁신 등의 환경변화가 개인(예술가 포함)의 예술활동에 '긍정적 영향을 줄 것이다' $51 \%$, '부정적 영향을 줄 것이다' $13 \%$ 로 긍정적 영향을 예상하고 있다.

[그림 3-6] 환경변화에 따른 예술인식 변화: 2020 시민 예술향유 인식 및 예술향유활동 조사

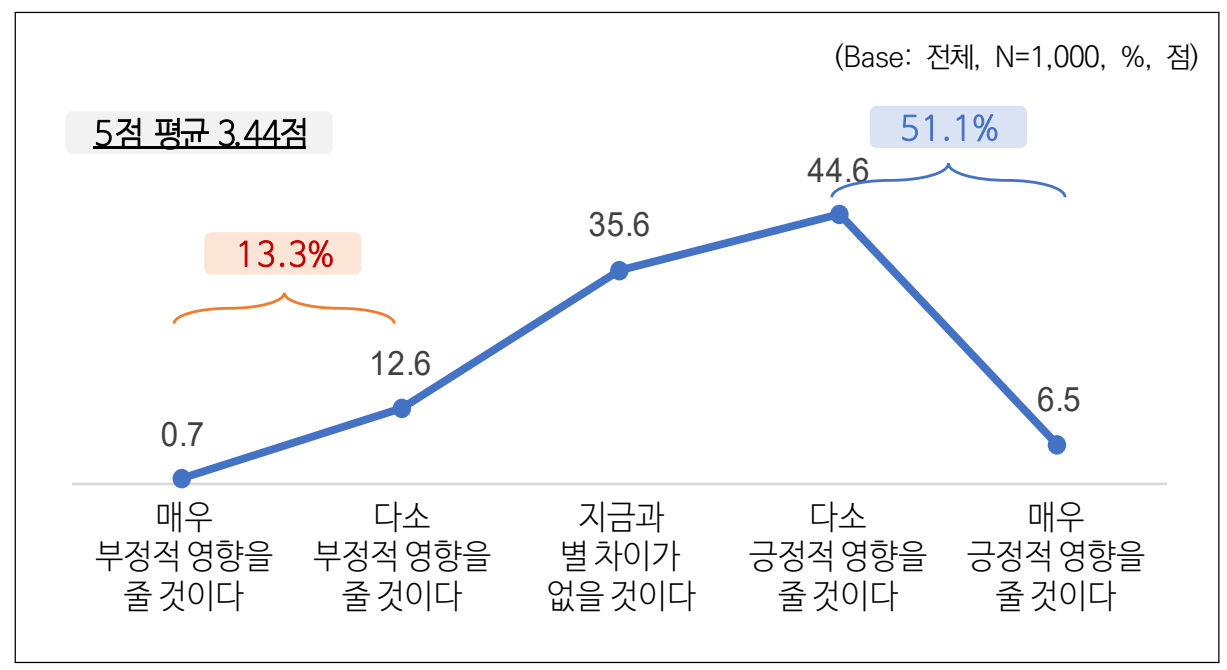

연령별로 10대의 긍정 인식이 높게 나타났다. 10대와 20대는 상대적으로 긍정적 인데 반해 40대와 50대는 상대적으로 부정적으로 인식하고 있다. 직접관람 경험이 많을수록 긍정적으로 인식하는 경향을 보인다. 직접 관람 고관여 그룹(G3), 예술향 유 활동 경험 그룹(G5), 온라인 매체 관람 경험 그룹(G4), 직접 관람 저관여 그룹 (G2), 직접 관람 비경험 그룹(G1) 순으로 긍정적으로 인식하고 있다.

〈표 3-40〉 응답자 특성별 환경변화에 따른 예술인식 변화: 2020 시민 예술향유 인식 및 예술향유활동 조사

\begin{tabular}{c|c|c|c|c|c|c}
\hline \multicolumn{2}{c|}{} & 사례수 & $\begin{array}{c}\text { 부정 영향 } \\
(1+(2))\end{array}$ & $\begin{array}{c}\text { 차이 없음 } \\
\text { (3) }\end{array}$ & $\begin{array}{c}\text { 긍정적 영향 } \\
(4)+(5)\end{array}$ & $\begin{array}{c}\text { 5점 } \\
\text { 평균 }\end{array}$ \\
\hline \multirow{2}{*}{ 선체 } & $(1000)$ & 13.3 & 35.6 & 51.1 & 3.44 \\
\hline \multirow{2}{*}{ 성별 } & 남자 & $(508)$ & 13.4 & 35.4 & 51.2 & 3.42 \\
\cline { 2 - 8 } & 여자 & $(492)$ & 13.2 & 35.8 & 51.0 & 3.45 \\
\hline
\end{tabular}




\begin{tabular}{|c|c|c|c|c|c|c|}
\hline & & 사례수 & $\begin{array}{c}\text { 부정 영향 } \\
\text { (1)+(2) }\end{array}$ & $\begin{array}{c}\text { 차이 없음 } \\
\text { (3) }\end{array}$ & $\begin{array}{c}\text { 긍정적 영향 } \\
\text { (4)+(5) }\end{array}$ & $\begin{array}{l}\text { 5점 } \\
\text { 평균 }\end{array}$ \\
\hline \multirow{6}{*}{ 연령 } & 만 15 19세 & (68) & 8.8 & 25.0 & 66.2 & 3.65 \\
\hline & 만 20 29세 & (178) & 11.2 & 33.1 & 55.6 & 3.57 \\
\hline & 만 30 39세 & (188) & 13.3 & 35.1 & 51.6 & 3.41 \\
\hline & 만 40 49세 & (209) & 15.3 & 39.7 & 45.0 & 3.34 \\
\hline & 만 50 59세 & (212) & 14.6 & 35.4 & 50.0 & 3.39 \\
\hline & 만 60세 69세 & (145) & 13.1 & 38.6 & 48.3 & 3.40 \\
\hline \multirow{4}{*}{ 지역 } & 수도권 & (508) & 11.8 & 35.8 & 52.4 & 3.45 \\
\hline & - 서울 & (195) & 13.3 & 32.3 & 54.4 & 3.45 \\
\hline & - 인천경기 & (313) & 10.9 & 38.0 & 51.1 & 3.46 \\
\hline & 비수도권 & (492) & 14.8 & 35.4 & 49.8 & 3.42 \\
\hline \multirow{3}{*}{ 지역규모 } & 대도시의 동 & (448) & 10.0 & 36.6 & 53.3 & 3.48 \\
\hline & 일반시의 동 & (445) & 16.4 & 34.2 & 49.4 & 3.40 \\
\hline & 읍면부 & (107) & 14.0 & 37.4 & 48.6 & 3.39 \\
\hline \multirow{2}{*}{ 최종학력 } & 고졸 이하 & (250) & 12.0 & 42.0 & 46.0 & 3.39 \\
\hline & 대재 이상 & (750) & 13.7 & 33.5 & 52.8 & 3.45 \\
\hline \multirow{5}{*}{ 가구원 } & 1인 가구 & (133) & 15.0 & 34.6 & 50.4 & 3.41 \\
\hline & 2인 가족(부부/커플) & (137) & 12.4 & 44.5 & 43.1 & 3.36 \\
\hline & 부모와 거주 & (310) & 12.9 & 31.3 & 55.8 & 3.50 \\
\hline & 자녀와 거주 & (401) & 13.2 & 36.7 & 50.1 & 3.42 \\
\hline & 기타 & (19) & 15.8 & 26.3 & 57.9 & 3.37 \\
\hline \multirow{4}{*}{$\begin{array}{c}\text { 월평균 } \\
\text { 가구 소득 }\end{array}$} & 200만원 미만 & (141) & 16.3 & 36.2 & 47.5 & 3.35 \\
\hline & 200 400만원 미만 & (352) & 11.4 & 38.4 & 50.3 & 3.47 \\
\hline & 400 600만원 미만 & (295) & 11.9 & 33.2 & 54.9 & 3.48 \\
\hline & 600 만원 이상 & (212) & 16.5 & 34.0 & 49.5 & 3.38 \\
\hline \multirow{6}{*}{ 직업 } & 사무전문직 & (466) & 14.2 & 33.5 & 52.4 & 3.44 \\
\hline & 판매노무직 & (176) & 9.1 & 41.5 & 49.4 & 3.46 \\
\hline & 주부 & (133) & 12.8 & 44.4 & 42.9 & 3.38 \\
\hline & 학생 & (119) & 8.4 & 24.4 & 67.2 & 3.69 \\
\hline & 무직/취업주부/퇴직 & (99) & 20.2 & 37.4 & 42.4 & 3.23 \\
\hline & 기타 & (7) & 57.1 & 28.6 & 14.3 & 2.43 \\
\hline \multirow{3}{*}{$\begin{array}{l}\text { 예술 } \\
\text { 관심도 }\end{array}$} & 관심있다 & (513) & 14.4 & 17.0 & 68.6 & 3.65 \\
\hline & 보통 & (356) & 9.6 & 54.8 & 35.7 & 3.28 \\
\hline & 관심없다 & (131) & 19.1 & 56.5 & 24.4 & 3.02 \\
\hline
\end{tabular}




\begin{tabular}{|c|c|c|c|c|c|c|}
\hline & & 사례수 & $\begin{array}{c}\text { 부정 영향 } \\
\text { (1)+(2) }\end{array}$ & $\begin{array}{c}\text { 차이 없음 } \\
\text { (3) }\end{array}$ & $\begin{array}{l}\text { 긍정적 영향 } \\
\text { (4)+(5)) }\end{array}$ & $\begin{array}{l}\text { 5점 } \\
\text { 평균 }\end{array}$ \\
\hline \multirow{3}{*}{$\begin{array}{c}\text { 직접관람 } \\
\text { 경험 }\end{array}$} & 무관람(G1) & (297) & 12.5 & 51.9 & 35.7 & 3.25 \\
\hline & 직관 저관여(G2) & (551) & 13.8 & 30.3 & 55.9 & 3.48 \\
\hline & 직관 고관여(G3) & (152) & 13.2 & 23.0 & 63.8 & 3.66 \\
\hline \multirow{2}{*}{$\begin{array}{l}\text { 온라인 매체 } \\
\text { 관람 경험 }\end{array}$} & 있다(G4) & (616) & 12.5 & 27.8 & 59.7 & 3.56 \\
\hline & 없다 & (384) & 14.6 & 48.2 & 37.2 & 3.24 \\
\hline \multirow{2}{*}{$\begin{array}{l}\text { 예술향유 } \\
\text { 활동 경험 }\end{array}$} & 있다(G5) & (388) & 11.6 & 27.3 & 61.1 & 3.60 \\
\hline & 없다 & (612) & 14.4 & 40.8 & 44.8 & 3.33 \\
\hline \multirow{3}{*}{$\begin{array}{l}\text { 예술향유 } \\
\text { 지원 정책 }\end{array}$} & 인지 \& 경험 & (549) & 12.6 & 27.3 & 60.1 & 3.57 \\
\hline & 인지 \& 비경험 & (270) & 15.2 & 34.4 & 50.4 & 3.37 \\
\hline & 비인지 & (181) & 12.7 & 62.4 & 24.9 & 3.12 \\
\hline \multirow{3}{*}{$\begin{array}{l}\text { 정부지원 } \\
\text { 충분도 }\end{array}$} & 충분 & (195) & 10.3 & 20.5 & 69.2 & 3.75 \\
\hline & 보통 & (586) & 11.8 & 41.0 & 47.3 & 3.40 \\
\hline & |부족 & (219) & 20.1 & 34.7 & 45.2 & 3.26 \\
\hline
\end{tabular}

\section{2) 예술관람 실태}

(1) 직접 관람 실태

(가) 직접 관람 경험 및 관람 빈도

2019년 직접 관람 경험률은 70\%이며, 직접 관람 경험자 중 6회 이하가 $78 \%$, 7 회 이상이 $22 \%$ 로 나타났다.

[그림 3-7] 2019년 직접 관람 경험 및 관람 빈도: 2020 시민 예술향유 인식 및 예술향유활동 조사

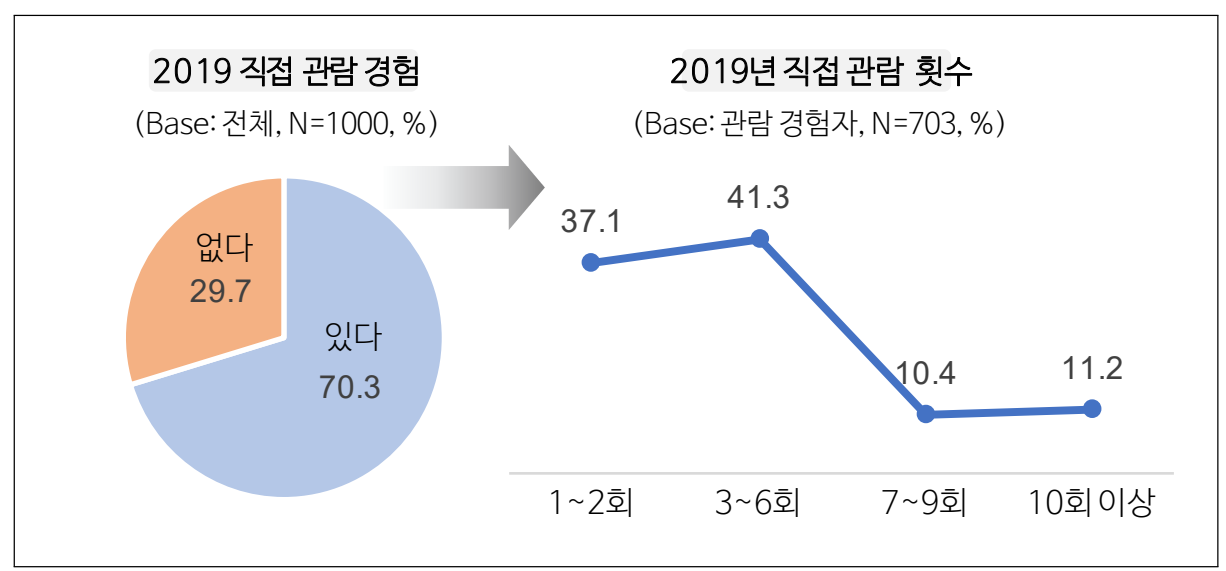


직접 관람 경험률은 남자보다 여자가 높고, 30 대 이하가 40 대 이상보다 관람률이 높고 관람 횟수는 20 30대가 많은 것으로 나타났다. 지역별로는 서울이 인천/경기 및 비수도권 지역보다 높은 관람률을 보이며 관람자의 관람 횟수도 더 많은 것으로 나타났다. 거주지의 지역 규모가 클수록 관람률이 높고 관람 횟수도 많다. 월평균 가구 소득 400 만원 미만 가구보다 400 만원 이상 가구가 높은 관람률과 높은 관람 횟수를 보인다. 그룹별로 보면 예술향유 활동 경험자(G5)와 온라인 매체 관람 경험 자(G4)가 직접 관람 경험률도 높게 나타났다.

(나) 직접 관람 예술 장르

직접 관람 예술 장르는 영화가 $83 \%$ 로 압도적으로 많고, 다음으로 전시회 $47 \%$, 대중 예술 $32 \%$, 연극 $28 \%$, 뮤지컬 $28 \%$, 음악 $23 \%$ 순으로 나타났다.

[그림 3-8] 2019년 직접 관람 장르: 2020 시민 예술향유 인식 및 예술향유활동 조사

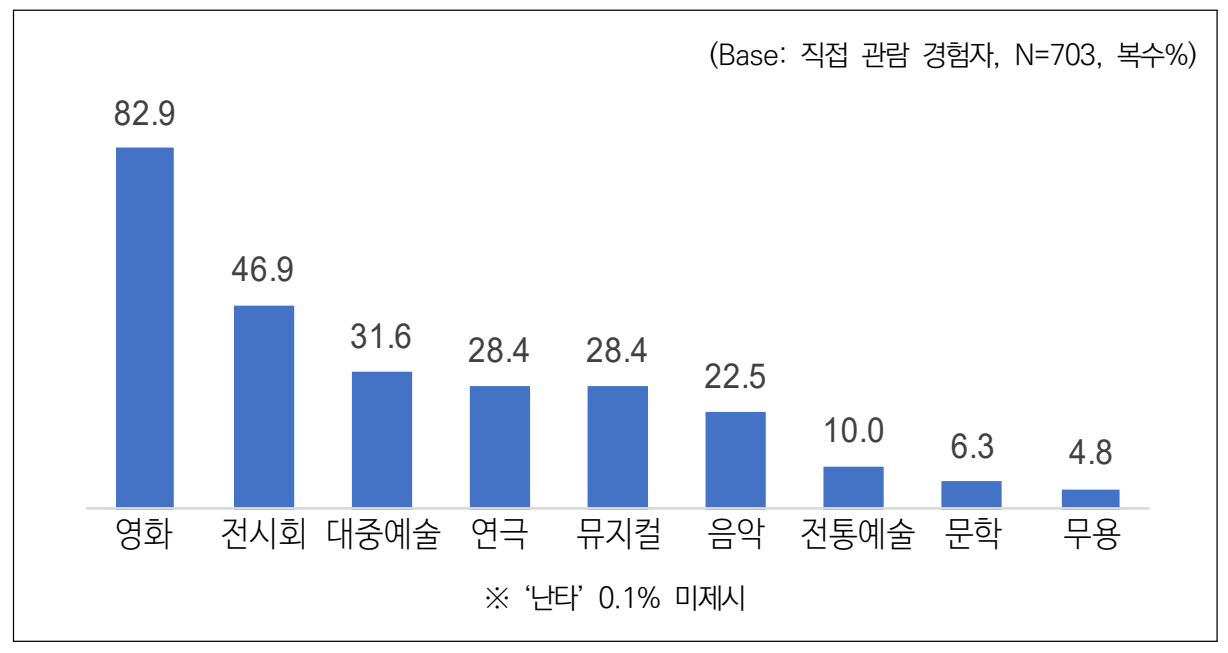

상대적으로 10 대는 대중예술과 연극, 무용 관람 경험이 많았으며. 20 대와 30 대 는 뮤지컬, 50 대는 영화, 60 대는 전시회와 전통 예술 관람 경험이 많았다. 수도권이 비수도권 대비 뮤지컬 관람 경험이 많고, 서울은 뮤지컬, 연극, 음악 관람 경험이 많았다. 읍면부 거주자는 도시 거주자 대비 전통예술과 문학 관람 경험이 많았다.

월평균 가구 소득이 높을수록 다양한 장르의 관람 경험이 높았으며 특히 월평균 
가구 소득 600 만원 이상 가구에서 관람 경험률이 높았다. 예술향유 활동 경험이 있 거나 온라인 매체 관람 경험이 있는 집단이 그렇지 않은 집단 대비 다양한 장르의 관람 경험을 보인다.

\section{(다) 직접 관람 동기}

직접 관람자의 직접 관람 동기는 본인의 즐거움, 다음으로 '마음의 안정과 휴식', '지인과의 시간 보내기' 순으로 나타났다. 연령별 직접 관람 동기는 상대적으로 10 대는 지인과의 시간 보내기 위해, 20 대는 본인의 즐거움 때문에, 30 대는 스트레스 해소를 위해, 40 대는 지인과의 시간 보내기 위해, 60 대는 예술에 대한 이해를 넓히 기 위해 직접 관람하는 것으로 나타났다.

직접 관람 고관여자의 직접 관람 동기는 본인의 즐거움, 스트레스 해소 그리고 예술에 대한 이해를 넓히기 위함 등에서 저관여자보다 높게 응답되었다.

[그림 3-9] 직접 관람 동기: 2020 시민 예술향유 인식 및 예술향유활동 조사

\begin{tabular}{|c|c|c|c|c|c|}
\hline \multirow[b]{2}{*}{63.2} & \multirow[b]{3}{*}{50.6} & \multirow{3}{*}{37.6} & \multicolumn{3}{|c|}{ (Base: 직접 관람 경험자, $\mathrm{N}=703$, 복수\%) } \\
\hline & & & \multicolumn{3}{|r|}{ 1+2순위\% } \\
\hline & & & \multirow{2}{*}{27.3} & \multicolumn{2}{|r|}{ ㄴ순위\% } \\
\hline \multirow{2}{*}{42.5} & \multirow[b]{2}{*}{24.5} & \multirow[b]{2}{*}{16.2} & & \multirow{2}{*}{$\begin{array}{c}12.1 \\
4.0\end{array}$} & \multirow{2}{*}{7.0} \\
\hline & & & 7.8 & & \\
\hline \multirow{6}{*}{$\begin{array}{c}\text { 내가 즐겁고 } \\
\text { 재미있기 } \\
\text { 때문에 }\end{array}$} & 마음의 & 가족, 친구, & 스트레스를 & 예술에 & 늘 \\
\hline & 안정과 & 지인과의 & 해소하기 & 대해좀더 & 하던 것이라 \\
\hline & 휴식을 위해서 & 시간을 & 위해서 & 많이 알고 & 습관적으로 \\
\hline & & 보내기 위해서 & & 이해하고 & \\
\hline & & & & 싶어서 & \\
\hline & & 1+2순위 기준 & $5 \%$ 미만 미제 & & \\
\hline
\end{tabular}


〈표 3-41〉 응답자 특성별 직접 관람 동기(중복응답 \%): 2020 시민 예술향유 인식 및 예술향유활동 조사

\begin{tabular}{|c|c|c|c|c|c|c|c|c|}
\hline & & 사례수 & $\begin{array}{c}\text { 내가 즐겁고 } \\
\text { 재미있기 } \\
\text { 때문에 }\end{array}$ & $\begin{array}{l}\text { 마음의 } \\
\text { 안정과 } \\
\text { 휴식을 } \\
\text { 위해서 }\end{array}$ & $\begin{array}{c}\text { 가족, 친구, } \\
\text { 지인과의 } \\
\text { 시간을 } \\
\text { 보내기 } \\
\text { 위해서 }\end{array}$ & $\begin{array}{l}\text { 스트레스 } \\
\text { 해소를 } \\
\text { 위해 }\end{array}$ & $\begin{array}{l}\text { 예술에 대해 } \\
\text { 좀 더 } \\
\text { 많이 알고 } \\
\text { 이해하고 } \\
\text { 싶어서 }\end{array}$ & $\begin{array}{l}\text { 늘 하던 } \\
\text { 것이라 } \\
\text { 습관적으로 }\end{array}$ \\
\hline & 전체 & (703) & 63.2 & 50.6 & 37.6 & 27.3 & 12.1 & 7.0 \\
\hline \multirow{2}{*}{ 성별 } & 남자 & (349) & 59.9 & 54.4 & 37.2 & 25.8 & 12.0 & 8.0 \\
\hline & 여자 & (354) & 66.4 & 46.9 & 37.9 & 28.8 & 12.1 & 5.9 \\
\hline \multirow{6}{*}{ 연령 } & 만 15 19세 & (49) & 57.1 & 44.9 & 42.9 & 30.6 & 8.2 & 8.2 \\
\hline & 만 20 29세 & (134) & 70.1 & 45.5 & 32.1 & 29.9 & 10.4 & 10.4 \\
\hline & 만 30 39세 & (139) & 59.0 & 47.5 & 35.3 & 34.5 & 12.9 & 9.4 \\
\hline & 만 40 49세 & (137) & 59.1 & 54.7 & 43.1 & 23.4 & 12.4 & 3.6 \\
\hline & 만 50 59세 & (146) & 65.8 & 54.8 & 41.8 & 19.9 & 8.2 & 7.5 \\
\hline & 만 60세 69세 & (98) & 64.3 & 53.1 & 31.6 & 28.6 & 20.4 & 2.0 \\
\hline \multirow{4}{*}{ 지역 } & 수도권 & (360) & 63.3 & 50.3 & 35.8 & 27.5 & 11.1 & 10.0 \\
\hline & - 서울 & (152) & 65.8 & 48.7 & 36.2 & 23.7 & 10.5 & 13.2 \\
\hline & - 인천경기 & (208) & 61.5 & 51.4 & 35.6 & 30.3 & 11.5 & 7.7 \\
\hline & 비수도권 & (343) & 63.0 & 51.0 & 39.4 & 27.1 & 13.1 & 3.8 \\
\hline \multirow{3}{*}{ 지역규모 } & 대도시의 동 & (333) & 66.4 & 46.5 & 36.6 & 27.6 & 12.0 & 9.0 \\
\hline & 일반시의 동 & (294) & 59.9 & 56.1 & 38.4 & 27.2 & 11.2 & 4.8 \\
\hline & 읍면부 & (76) & 61.8 & 47.4 & 38.2 & 26.3 & 15.8 & 6.6 \\
\hline \multirow{2}{*}{ 최종학력 } & 고졸 이하 & (144) & 66.7 & 49.3 & 34.7 & 34.0 & 6.9 & 6.9 \\
\hline & 대재 이상 & (559) & 62.3 & 51.0 & 38.3 & 25.6 & 13.4 & 7.0 \\
\hline \multirow{5}{*}{ 가구원 } & 1인 가구 & (86) & 70.9 & 46.5 & 32.6 & 24.4 & 12.8 & 10.5 \\
\hline & 2인 가족(부부/커플) & (92) & 66.3 & 52.2 & 38.0 & 23.9 & 9.8 & 8.7 \\
\hline & 부모와 거주 & (219) & 66.7 & 46.6 & 32.9 & 33.3 & 10.5 & 6.4 \\
\hline & 자녀와 거주 & (293) & 56.3 & 54.6 & 41.6 & 25.6 & 14.0 & 6.1 \\
\hline & 기타 & (13) & 84.6 & 46.2 & 53.8 & 7.7 & 7.7 & 0.0 \\
\hline \multirow{4}{*}{$\begin{array}{c}\text { 월평균 } \\
\text { 가구 소득 }\end{array}$} & 200만원 미만 & (87) & 64.4 & 41.4 & 39.1 & 33.3 & 10.3 & 8.0 \\
\hline & 200 400만원 미만 & (229) & 65.5 & 51.1 & 42.8 & 22.7 & 9.6 & 7.0 \\
\hline & 400 600만원 미만 & (224) & 60.7 & 50.9 & 34.4 & 32.6 & 11.6 & 6.7 \\
\hline & 600만원 이상 & (163) & 62.6 & 54.6 & 33.7 & 23.3 & 17.2 & 6.7 \\
\hline \multirow{6}{*}{ 직업 } & 사무전문직 & (350) & 63.1 & 51.1 & 34.9 & 26.3 & 14.9 & 8.0 \\
\hline & 판매노무직 & (118) & 66.1 & 56.8 & 34.7 & 26.3 & 11.0 & 3.4 \\
\hline & 주부 & (84) & 58.3 & 50.0 & 47.6 & 29.8 & 7.1 & 6.0 \\
\hline & 학생 & (85) & 64.7 & 48.2 & 41.2 & 25.9 & 8.2 & 7.1 \\
\hline & 무직/취업주부/퇴직 & (62) & 64.5 & 40.3 & 37.1 & 35.5 & 8.1 & 9.7 \\
\hline & 기타 & (4) & 25.0 & 50.0 & 75.0 & 0.0 & 50.0 & 0.0 \\
\hline
\end{tabular}




\begin{tabular}{|c|c|c|c|c|c|c|c|c|}
\hline & & 사례수 & $\begin{array}{c}\text { 내가 즐ㄱㅓㅓㄱㄱ } \\
\text { 재미있기 } \\
\text { 때문에 }\end{array}$ & $\begin{array}{l}\text { 마음의 } \\
\text { 안정과 } \\
\text { 휴식을 } \\
\text { 위해서 }\end{array}$ & $\begin{array}{l}\text { 가족, 칙구, } \\
\text { 지인과의 } \\
\text { 시간을 } \\
\text { 보내기 } \\
\text { 위해서 }\end{array}$ & $\begin{array}{l}\text { 스트레스 } \\
\text { 해소를 } \\
\text { 위해 }\end{array}$ & $\begin{array}{c}\text { 예술에 대해 } \\
\text { 좀 더 } \\
\text { 많이 알고 } \\
\text { 이해하고 } \\
\text { 싶어서 }\end{array}$ & $\begin{array}{l}\text { 늘 하던 } \\
\text { 것이라 } \\
\text { 습관적으로 }\end{array}$ \\
\hline \multirow{3}{*}{$\begin{array}{l}\text { 예술 } \\
\text { 관심도 }\end{array}$} & 관심있다 & (449) & 65.3 & 51.7 & 32.3 & 27.4 & 14.9 & 5.8 \\
\hline & 보통 & (210) & 61.9 & 49.5 & 44.8 & 29.0 & 5.7 & 7.6 \\
\hline & 관심없다 & (44) & 47.7 & 45.5 & 56.8 & 18.2 & 13.6 & 15.9 \\
\hline \multirow{2}{*}{$\begin{array}{c}\text { 직접관람 } \\
\text { 경험 }\end{array}$} & 직관 저관여(G2) & (551) & 60.3 & 53.5 & 39.0 & 26.1 & 10.9 & 7.6 \\
\hline & 직관 고관여(G3) & (152) & 73.7 & 40.1 & 32.2 & 31.6 & 16.4 & 4.6 \\
\hline \multirow{2}{*}{$\begin{array}{l}\text { 온라인 매체 } \\
\text { 관람 경험 }\end{array}$} & 있다(G4) & (527) & 64.3 & 50.3 & 36.1 & 26.8 & 13.3 & 6.8 \\
\hline & 없다 & (176) & 59.7 & 51.7 & 42.0 & 29.0 & 8.5 & 7.4 \\
\hline \multirow{2}{*}{$\begin{array}{l}\text { 예술향유 } \\
\text { 활동 경험 }\end{array}$} & 있다(G5) & (341) & 59.5 & 51.3 & 34.0 & 24.0 & 18.8 & 9.7 \\
\hline & 없다 & (362) & 66.6 & 50.0 & 40.9 & 30.4 & 5.8 & 4.4 \\
\hline \multirow{3}{*}{$\begin{array}{l}\text { 예술향유 } \\
\text { 지원 정책 }\end{array}$} & 인지 \& 경험 & $(464)$ & 64.7 & 50.4 & 34.9 & 26.3 & 14.0 & 7.5 \\
\hline & 인지 \& 비경험 & $(176)$ & 61.9 & 49.4 & 47.7 & 27.3 & 8.0 & 3.4 \\
\hline & 비인지 & (63) & 55.6 & 55.6 & 28.6 & 34.9 & 9.5 & 12.7 \\
\hline \multirow{3}{*}{$\begin{array}{l}\text { 정부지원 } \\
\text { 충분도 }\end{array}$} & 충분 & (156) & 60.9 & 51.9 & 32.1 & 28.2 & 13.5 & 10.3 \\
\hline & 보통 & (394) & 63.7 & 51.3 & 39.3 & 24.4 & 11.7 & 7.1 \\
\hline & 부족 & (153) & 64.1 & 47.7 & 38.6 & 34.0 & 11.8 & 3.3 \\
\hline
\end{tabular}

라) 직접 관람 결정 방법

직접 관람 경험자의 $48 \%$ 가 본인 의향에 따라 직접 관람을 결정하는 반면 $10 \%$ 는 타인의 권유에 따라 결정하는 것으로 나타났다.

[그림 3-10] 직접 관람 결정 방법: 2020 시민 예술향유 인식 및 예술향유활동 조사

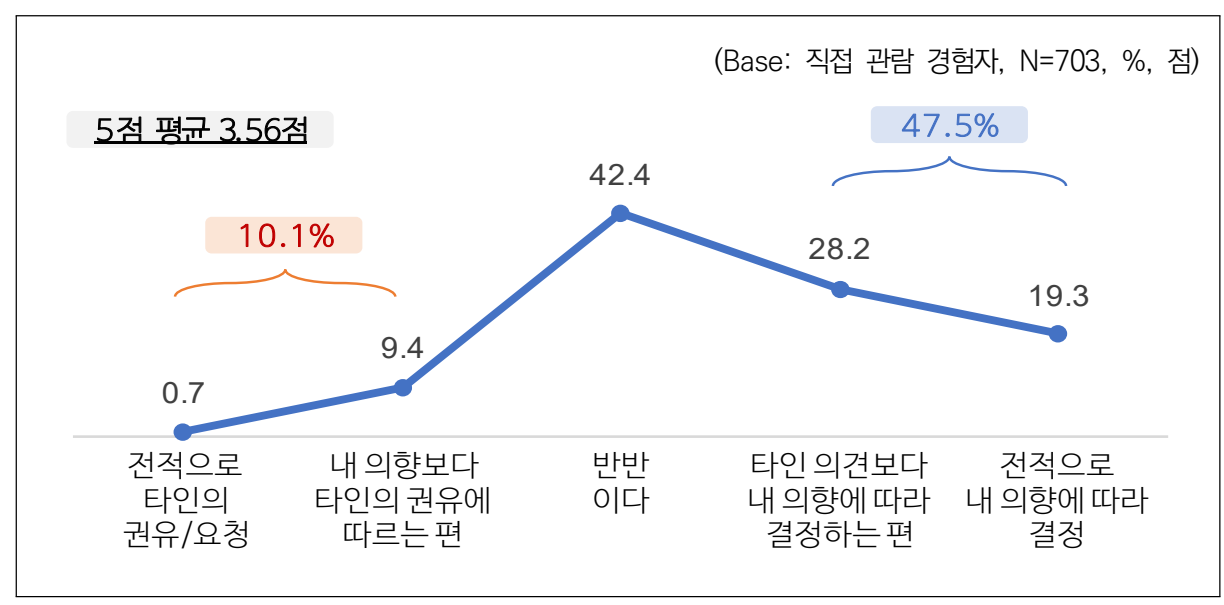


성별로는 여자보다 남자가 타인 중심으로 결정하는 경우가 많았다. 연령대별로는 10 대는 상대적으로 타인 중심 결정이 많았고, 20 대, 30대 그리고 60 대는 본인 중 심 결정이 많았다. 예술에 대한 관심이 높을수록 본인 중심으로 결정하는 경향을 보이며, 직관 고관여자가 저관여자 보다 본인 중심으로 결정하는 것으로 나타났다.

\section{(iㅏ) 직접 관람 후 인식/효과}

직접 관람 후 효과는 '삶이 조금 더 풍요로워지는 것 같다'가 $61.0 \%$ 로 가장 많았 으며, 다음으로 '타인의 생각이나 문화에 대한 공감 증대', '작품 관련 정보 관심 증 대' 순으로 응답되었다. 연령별로 10 30대는 상대적으로 '작품 관련 정보 관심 증 대'와 '경험의 타인 공유'가 높았고, 40 대는 '공감 증대', 50 대는 '삶의 풍요'와 '공 감 증대', 60 대는 '삶의 풍요'와 '나만의 관점/생각'이 상대적으로 높았다. 직접 관 람 고관여자는 상대적으로 '삶의 풍요'가 높았고, 저관여자는 '유사 활동 직접 참여 의향이 높았다.

[그림 3-11] 직접 관람 후 인식/효과: 2020 시민 예술향유 인식 및 예술향유활동 조사

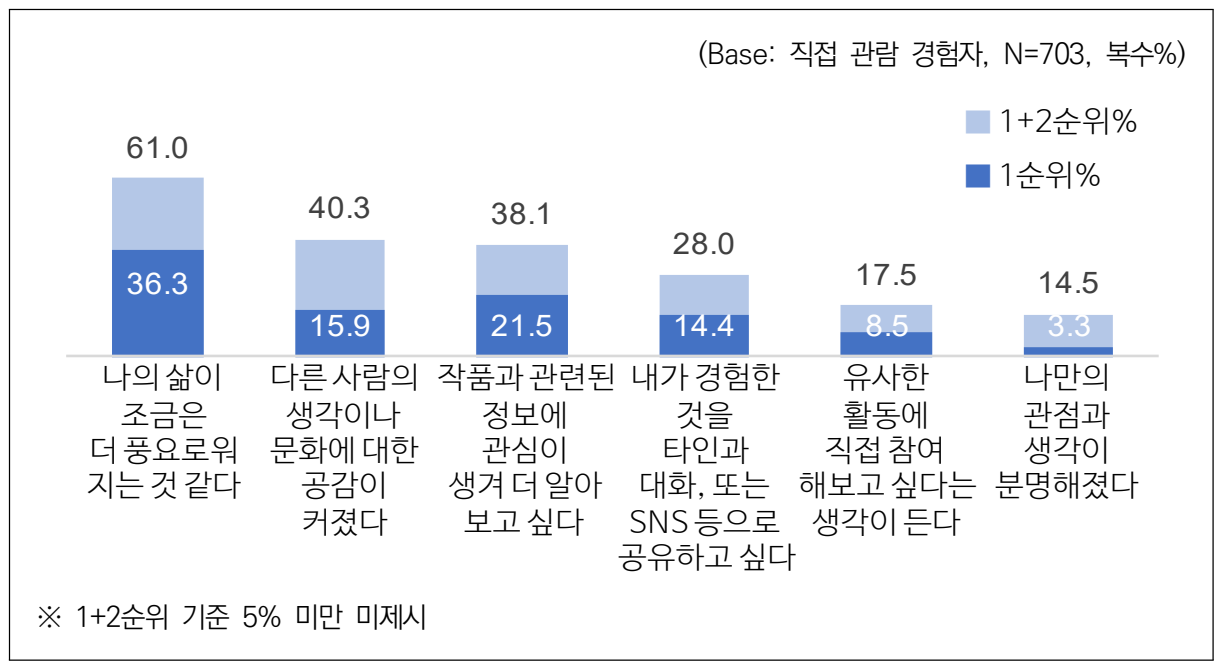

(바 직접 관람 걸림돌-외적·물리적 측면

직접 관람의 외적·물리적 걸림돌은 '경제적 부담'이 $57.2 \%$ 로 가장 높았고, 다음 으로 '시간 부족', '접근성 및 교통 불편', '정보 부족' 순으로 나타났다. 
[그림 3-12] 직접 관람 외적·물리적 걸림돌: 2020 시민 예술향유 인식 및 예술향유활동 조사

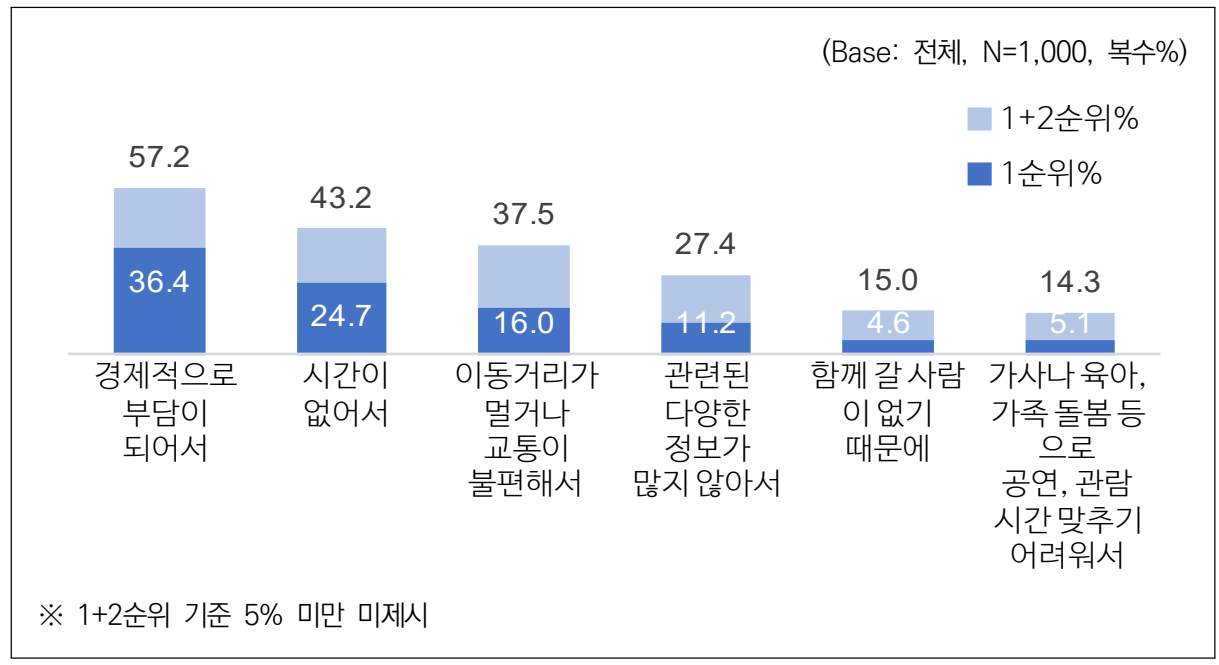

직접 관람 경험이 없는 사람은 직접 관람 경험자 대비 '시간 부족'을 외적·물리적 걸림돌로 더 많이 응답했다. 남자는 '시간 부족'을, 여자는 '경제적 부담'과 '접근성 및 교통 불편' 그리고 '가사로 시간 맞추기 어려움'을 상대적으로 더 많이 응답했다. 연령별로는 10 대는 '시간 부족', 20 대는 '경제적 부담' 40 대는 '시간 부족'과 '가사 부담', 60대는 ‘접근성 및 교통 불편’을 상대적으로 많이 응답했다.

〈표 3-42〉 응답자 특성별 직접 관람 외적·물리적 걸림돌(중복응답 \%): 2020 시민 예술향유 인식 및 예술향유활동 조사

\begin{tabular}{|c|c|c|c|c|c|c|c|c|}
\hline & & 사례수 & $\begin{array}{l}\text { 경제적 } \\
\text { 부담 }\end{array}$ & $\begin{array}{l}\text { 시간 } \\
\text { 없어서 }\end{array}$ & $\begin{array}{l}\text { 멀거나 } \\
\text { 교통이 } \\
\text { 불편해서 }\end{array}$ & $\begin{array}{l}\text { 정보가 } \\
\text { 많지 } \\
\text { 않아서 }\end{array}$ & $\begin{array}{l}\text { 동반할 } \\
\text { 사람이 } \\
\text { 없어서 }\end{array}$ & $\begin{array}{l}\text { 가사 등으로 } \\
\text { 시간 맞추기 } \\
\text { 어려워서 }\end{array}$ \\
\hline \multicolumn{2}{|r|}{ 전체 } & (1000) & 57.2 & 43.2 & 37.5 & 27.4 & 15.0 & 14.3 \\
\hline \multirow{2}{*}{ 성별 } & 남자 & (508) & 53.1 & 51.0 & 32.3 & 28.5 & 17.9 & 10.6 \\
\hline & 여자 & (492) & 61.4 & 35.2 & 42.9 & 26.2 & 12.0 & 18.1 \\
\hline \multirow{6}{*}{ 연령 } & 만 15 19세 & (68) & 58.8 & 64.7 & 33.8 & 19.1 & 10.3 & 7.4 \\
\hline & 만 20 29세 & (178) & 62.4 & 44.9 & 37.6 & 24.2 & 17.4 & 9.0 \\
\hline & 만 30 39세 & (188) & 60.6 & 30.9 & 36.2 & 31.4 & 16.5 & 17.6 \\
\hline & 만 40 49세 & (209) & 57.9 & 48.3 & 30.1 & 24.9 & 11.5 & 22.0 \\
\hline & 만 50 59세 & (212) & 52.4 & 45.3 & 39.2 & 31.1 & 15.1 & 12.3 \\
\hline & 만 60세 69세 & (145) & 51.7 & 36.6 & 49.0 & 28.3 & 17.2 & 11.7 \\
\hline
\end{tabular}




\begin{tabular}{|c|c|c|c|c|c|c|c|c|}
\hline & & 사례수 & $\begin{array}{c}\text { 경제적 } \\
\text { 부담 }\end{array}$ & $\begin{array}{l}\text { 시간 } \\
\text { 없어서 }\end{array}$ & $\begin{array}{c}\text { 멀거나 } \\
\text { 교통이 } \\
\text { 불편해서 }\end{array}$ & $\begin{array}{l}\text { 정보가 } \\
\text { 많지 } \\
\text { 않아서 }\end{array}$ & $\begin{array}{l}\text { 동반할 } \\
\text { 사람이 } \\
\text { 없어서 }\end{array}$ & $\begin{array}{c}\text { 가사 등으로 } \\
\text { 시간 맞추기 } \\
\text { 어려워서 }\end{array}$ \\
\hline \multirow{4}{*}{ 지역 } & 수도권 & (508) & 58.5 & 45.9 & 35.4 & 26.4 & 13.4 & 16.1 \\
\hline & - 서울 & (195) & 58.5 & 44.6 & 26.7 & 32.8 & 15.4 & 16.9 \\
\hline & - 인천경기 & (313) & 58.5 & 46.6 & 40.9 & 22.4 & 12.1 & 15.7 \\
\hline & 비수도권 & (492) & 55.9 & 40.4 & 39.6 & 28.5 & 16.7 & 12.4 \\
\hline \multirow{3}{*}{ 지역규모 } & 대도시의 동 & (448) & 58.3 & 44.4 & 32.1 & 30.4 & 17.0 & 12.7 \\
\hline & 일반시의 동 & $(445)$ & 56.0 & 43.6 & 41.3 & 24.9 & 13.5 & 15.7 \\
\hline & 읍면부 & (107) & 57.9 & 36.4 & 43.9 & 25.2 & 13.1 & 15.0 \\
\hline \multirow{2}{*}{ 최종학력 } & 고졸 이하 & (250) & 60.0 & 45.6 & 36.0 & 22.4 & 18.0 & 12.8 \\
\hline & 대재 이상 & $(750)$ & 56.3 & 42.4 & 38.0 & 29.1 & 14.0 & 14.8 \\
\hline \multirow{5}{*}{ 가구원 } & 1인 가구 & (133) & 56.4 & 44.4 & 32.3 & 31.6 & 20.3 & 9.0 \\
\hline & 2인 가족(부부/커플) & (137) & 57.7 & 29.9 & 40.1 & 35.0 & 15.3 & 16.1 \\
\hline & 부모와 거주 & (310) & 62.6 & 45.8 & 39.4 & 21.6 & 18.1 & 6.8 \\
\hline & 자녀와 거주 & $(401)$ & 52.9 & 45.1 & 36.9 & 27.4 & 11.2 & 21.7 \\
\hline & 기타 & (19) & 63.2 & 47.4 & 36.8 & 36.8 & 5.3 & 5.3 \\
\hline \multirow{4}{*}{$\begin{array}{c}\text { 월평균 } \\
\text { 가구 소득 }\end{array}$} & 200만원 미만 & (141) & 70.9 & 34.0 & 42.6 & 20.6 & 15.6 & 9.2 \\
\hline & 200 400만원 미만 & (352) & 60.8 & 40.1 & 35.5 & 27.0 & 17.6 & 14.2 \\
\hline & 400 600만원 미만 & (295) & 58.0 & 42.7 & 37.3 & 26.8 & 14.2 & 15.6 \\
\hline & 600만원 이상 & (212) & 41.0 & 55.2 & 37.7 & 33.5 & 11.3 & 16.0 \\
\hline \multirow{6}{*}{ 직업 } & 사무전문직 & $(466)$ & 55.8 & 47.2 & 35.6 & 29.0 & 13.9 & 13.1 \\
\hline & 판매노무직 & (176) & 53.4 & 49.4 & 30.1 & 27.3 & 16.5 & 15.9 \\
\hline & 주부 & (133) & 51.9 & 24.1 & 51.1 & 30.8 & 14.3 & 26.3 \\
\hline & 학생 & (119) & 62.2 & 57.1 & 36.1 & 20.2 & 10.9 & 7.6 \\
\hline & 무직/취업주부/퇴직 & (99) & 70.7 & 21.2 & 44.4 & 25.3 & 23.2 & 9.1 \\
\hline & 기타 & (7) & 71.4 & 57.1 & 14.3 & 14.3 & 14.3 & 14.3 \\
\hline \multirow{3}{*}{$\begin{array}{l}\text { 예술 } \\
\text { 관심도 }\end{array}$} & 관심있다 & (513) & 55.6 & 41.1 & 42.9 & 28.5 & 12.9 & 14.6 \\
\hline & 보통 & (356) & 59.6 & 42.1 & 33.7 & 27.8 & 18.0 & 14.0 \\
\hline & 관심없다 & (131) & 57.3 & 54.2 & 26.7 & 22.1 & 15.3 & 13.7 \\
\hline \multirow{3}{*}{$\begin{array}{l}\text { 직접관람 } \\
\text { 경험 }\end{array}$} & 무관람(G1) & (297) & 57.2 & 50.2 & 31.0 & 25.9 & 15.5 & 12.1 \\
\hline & 직관 저관여(G2) & (551) & 57.0 & 39.0 & 40.5 & 28.7 & 15.4 & 15.1 \\
\hline & 직관 고관여(G3) & (152) & 57.9 & 44.7 & 39.5 & 25.7 & 12.5 & 15.8 \\
\hline \multirow{2}{*}{$\begin{array}{l}\text { 온라인 매체 } \\
\text { 관람 경험 }\end{array}$} & 있다(G4) & (616) & 55.8 & 40.3 & 39.9 & 27.6 & 15.1 & 15.7 \\
\hline & 없다 & (384) & 59.4 & 47.9 & 33.6 & 27.1 & 14.8 & 12.0 \\
\hline \multirow{2}{*}{$\begin{array}{c}\text { 예술향유 } \\
\text { 활동 경험 }\end{array}$} & 있다(G5) & (388) & 51.8 & 41.0 & 39.2 & 30.4 & 16.5 & 16.2 \\
\hline & 없다 & (612) & 60.6 & 44.6 & 36.4 & 25.5 & 14.1 & 13.1 \\
\hline \multirow{3}{*}{$\begin{array}{l}\text { 예술향유 } \\
\text { 지원 정책 }\end{array}$} & 인지 \& 경험 & (549) & 57.0 & 41.2 & 41.0 & 28.1 & 13.5 & 14.2 \\
\hline & 인지 \& 비경험 & (270) & 60.0 & 45.2 & 35.2 & 24.8 & 14.4 & 15.9 \\
\hline & 비인지 & $(181)$ & 53.6 & 46.4 & 30.4 & 29.3 & 20.4 & 12.2 \\
\hline
\end{tabular}




\begin{tabular}{|c|c|c|c|c|c|c|c|c|}
\hline & & 사례수 & $\begin{array}{c}\text { 경제적 } \\
\text { 부담 }\end{array}$ & $\begin{array}{l}\text { 시간 } \\
\text { 없어서 }\end{array}$ & $\begin{array}{c}\text { 멀거나 } \\
\text { 교통이 } \\
\text { 불편해서 }\end{array}$ & $\begin{array}{l}\text { 정보가 } \\
\text { 많지 } \\
\text { 않아서 }\end{array}$ & $\begin{array}{l}\text { 동반할 } \\
\text { 사람이 } \\
\text { 없어서 }\end{array}$ & $\begin{array}{l}\text { 가사 등으로 } \\
\text { 시간 맞추기 } \\
\text { 어려워서 }\end{array}$ \\
\hline \multirow{3}{*}{$\begin{array}{l}\text { 정부지원 } \\
\text { 충분도 }\end{array}$} & 충분 & (195) & 50.3 & 46.7 & 41.5 & 25.6 & 13.8 & 16.4 \\
\hline & 보통 & (586) & 58.2 & 43.5 & 35.3 & 26.3 & 17.1 & 14.5 \\
\hline & 부족 & (219) & 60.7 & 39.3 & 39.7 & 32.0 & 10.5 & 11.9 \\
\hline
\end{tabular}

사 직접 관람 걸림돌 - 내적·심리적 측면

전체 응답자 중 내적·심리적 걸림돌로 가장 많이 지적한 사항은 '예술에 대한 기 초지식이나 경험이 부족해서'로 $61.9 \%$ 에 달했다. 무관심자 뿐 아니라 예술향유 활 동을 하는 이들 역시 예술에 대한 심리적 부담감이 내적 제약요인이 작동하고 있음 을 의미한다고 볼 수 있다. 직접 관람자 경우 역시, 내적·심리적 걸림돌은 '예술 기 초 지식 및 경험 부족'이 가장 높았지만, 무관심자의 경우 ‘필요성 인식 부족'이 가 장 높게 나타났다.

[그림 3-13] 직접 관람 내적-심리적 걸림돌: 2020 시민 예술향유 인식 및 예술향유활동 조사

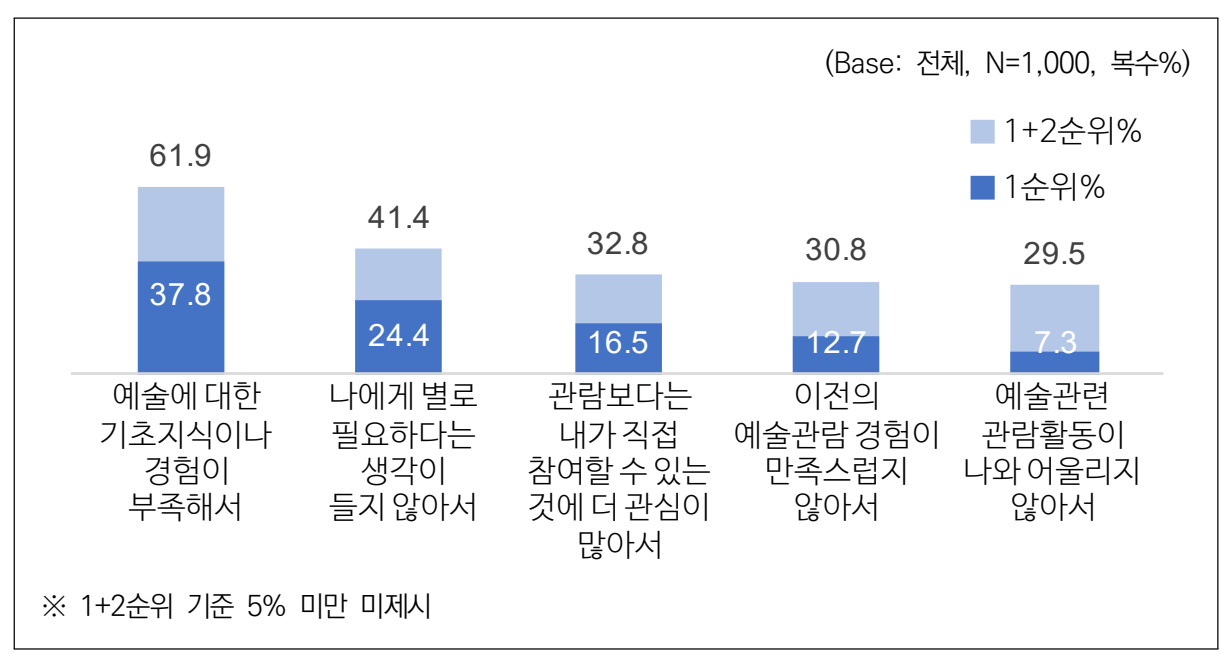

직접 관람 경험이 없는 사람은 직접 관람 경험자 대비 '필요성 인식 부족'과 '나와 어울리지 않는다'는 것을 내적·심리적 걸림돌로 더 많이 응답했다. 남자는 '필요성 인식 부족'을, 여자는 '기초지식/경험 부족'을 상대적으로 더 많이 응답했다. 
〈표 3-43〉 응답자 특성별 직접 관람 내적-심리적 걸림돌(중복응답 \%): 2020 시민 예술향유 인식 및 예술향유활동 조사

\begin{tabular}{|c|c|c|c|c|c|c|c|}
\hline & & 사례수 & $\begin{array}{c}\text { 예술기초지식 } \\
\text { /경험부족 }\end{array}$ & $\begin{array}{c}\text { 별로 필요하다 } \\
\text { 생각하지 } \\
\text { 않아서 }\end{array}$ & $\begin{array}{c}\text { 직접 참여할 } \\
\text { 수얐근게에관미 } \\
\text { 더 많아서 }\end{array}$ & $\begin{array}{c}\text { 이전 경험이 } \\
\text { 만족스럽지 } \\
\text { 않아서 }\end{array}$ & $\begin{array}{c}\text { 나와 } \\
\text { 어울리지 } \\
\text { 않아서 }\end{array}$ \\
\hline \multicolumn{2}{|r|}{ 전체 } & (1000) & 61.9 & 41.4 & 32.8 & 30.8 & 29.5 \\
\hline \multirow{2}{*}{ 성별 } & 남자 & (508) & 59.8 & 43.9 & 31.7 & 30.5 & 30.9 \\
\hline & 여자 & (492) & 64.0 & 38.8 & 33.9 & 31.1 & 28.0 \\
\hline \multirow{6}{*}{ 연령 } & 만 15 19세 & (68) & 61.8 & 35.3 & 41.2 & 26.5 & 32.4 \\
\hline & 만 20 29세 & (178) & 62.4 & 42.7 & 36.0 & 26.4 & 29.8 \\
\hline & 만 30 39세 & (188) & 62.2 & 37.8 & 36.7 & 34.0 & 24.5 \\
\hline & 만 40 49세 & (209) & 59.3 & 49.3 & 26.3 & 29.2 & 34.0 \\
\hline & 만 50 59세 & (212) & 61.8 & 42.0 & 30.7 & 32.1 & 28.8 \\
\hline & 만 60세 69세 & (145) & 64.8 & 35.2 & 32.4 & 34.5 & 29.0 \\
\hline \multirow{4}{*}{ 지역 } & 수도권 & (508) & 61.2 & 38.8 & 33.9 & 32.9 & 30.7 \\
\hline & - 서울 & (195) & 52.8 & 39.5 & 34.4 & 38.5 & 33.3 \\
\hline & - 인천경기 & (313) & 66.5 & 38.3 & 33.5 & 29.4 & 29.1 \\
\hline & 비수도권 & (492) & 62.6 & 44.1 & 31.7 & 28.7 & 28.3 \\
\hline \multirow{3}{*}{ 지역규모 } & 대도시의 동 & (448) & 57.8 & 41.3 & 31.7 & 34.6 & 31.7 \\
\hline & 일반시의 동 & (445) & 64.5 & 41.6 & 32.4 & 28.1 & 29.2 \\
\hline & 읍면부 & (107) & 68.2 & 41.1 & 39.3 & 26.2 & 21.5 \\
\hline \multirow{2}{*}{ 최종학력 } & 고졸 이하 & (250) & 60.4 & 46.0 & 31.2 & 28.8 & 30.8 \\
\hline & 대재 이상 & (750) & 62.4 & 39.9 & 33.3 & 31.5 & 29.1 \\
\hline \multirow{5}{*}{ 가구원 } & 1인 가구 & (133) & 60.2 & 47.4 & 30.1 & 30.1 & 26.3 \\
\hline & 2인 가족(부부/커플) & (137) & 67.9 & 38.0 & 33.6 & 33.6 & 24.8 \\
\hline & 부모와 거주 & (310) & 60.6 & 40.3 & 33.9 & 28.1 & 33.2 \\
\hline & 자녀와 거주 & (401) & 61.1 & 40.9 & 32.9 & 32.7 & 29.4 \\
\hline & 기타 & (19) & 68.4 & 52.6 & 26.3 & 21.1 & 26.3 \\
\hline \multirow{4}{*}{$\begin{array}{l}\text { 월평균 } \\
\text { 가구 소득 }\end{array}$} & 200만원 미만 & (141) & 63.1 & 48.9 & 29.8 & 27.7 & 24.1 \\
\hline & 200 400만원 미만 & (352) & 59.7 & 42.6 & 31.3 & 32.4 & 31.5 \\
\hline & 400 600만원 미만 & (295) & 66.1 & 38.3 & 32.9 & 30.5 & 28.5 \\
\hline & 600만원 이상 & (212) & 59.0 & 38.7 & 37.3 & 30.7 & 31.1 \\
\hline \multirow{6}{*}{ 직업 } & 사무전문직 & (466) & 61.8 & 38.6 & 33.3 & 35.4 & 27.3 \\
\hline & 판매노무직 & (176) & 56.3 & 46.0 & 33.0 & 30.1 & 30.1 \\
\hline & 주부 & (133) & 70.7 & 42.9 & 31.6 & 24.1 & 30.1 \\
\hline & 학생 & (119) & 60.5 & 38.7 & 43.7 & 22.7 & 31.1 \\
\hline & |무직/취업주부/퇴직 & (99) & 62.6 & 46.5 & 21.2 & 27.3 & 37.4 \\
\hline & 기타 & (7) & 57.1 & 57.1 & 0.0 & 57.1 & 14.3 \\
\hline
\end{tabular}




\begin{tabular}{|c|c|c|c|c|c|c|c|}
\hline & & 사례수 & $\begin{array}{c}\text { 예술기초지식 } \\
\text { /경험부족 }\end{array}$ & $\begin{array}{c}\text { 별로 필요하다 } \\
\text { 생각하지 } \\
\text { 않아서 }\end{array}$ & $\begin{array}{c}\text { 직접 참여할 } \\
\text { 수얐는게에쐔미 } \\
\text { 더 많아어 }\end{array}$ & $\begin{array}{c}\text { 이전 경험이 } \\
\text { 만족스럽지 } \\
\text { 않아서 }\end{array}$ & $\begin{array}{c}\text { 나와 } \\
\text { 어울리지 } \\
\text { 않아서 }\end{array}$ \\
\hline \multirow{3}{*}{$\begin{array}{l}\text { 예술 } \\
\text { 관심도 }\end{array}$} & 관심있다 & (513) & 65.3 & 31.4 & 39.8 & 35.5 & 22.6 \\
\hline & 보통 & (356) & 62.6 & 45.5 & 28.4 & 27.5 & 34.6 \\
\hline & 관심없다 & $(131)$ & 46.6 & 69.5 & 17.6 & 21.4 & 42.7 \\
\hline \multirow{3}{*}{$\begin{array}{l}\text { 직접관람 } \\
\text { 경험 }\end{array}$} & 무관람(G1) & (297) & 54.9 & 54.9 & 28.6 & 21.5 & 37.0 \\
\hline & 직관 저관여(G2) & (551) & 65.7 & 35.9 & 35.0 & 33.0 & 26.5 \\
\hline & 직관 고관여(G3) & (152) & 61.8 & 34.9 & 32.9 & 40.8 & 25.7 \\
\hline \multirow{2}{*}{$\begin{array}{l}\text { 온라인 매체 } \\
\text { 관람 경험 }\end{array}$} & 있다(G4) & $(616)$ & 64.3 & 37.3 & 35.7 & 34.4 & 24.2 \\
\hline & 없다 & (384) & 58.1 & 47.9 & 28.1 & 25.0 & 38.0 \\
\hline \multirow{2}{*}{$\begin{array}{l}\text { 예술향유 } \\
\text { 활동 경험 }\end{array}$} & 있다(G5) & (388) & 60.3 & 28.9 & 46.4 & 37.6 & 23.5 \\
\hline & 없다 & (612) & 62.9 & 49.3 & 24.2 & 26.5 & 33.3 \\
\hline \multirow{3}{*}{$\begin{array}{l}\text { 예술향유 } \\
\text { 지원 정책 }\end{array}$} & 인지 \& 경험 & (549) & 64.8 & 34.2 & 37.3 & 33.5 & 26.6 \\
\hline & 인지 \& 비경험 & (270) & 64.8 & 48.1 & 23.3 & 27.0 & 32.2 \\
\hline & 비인지 & (181) & 48.6 & 53.0 & 33.1 & 28.2 & 34.3 \\
\hline \multirow{3}{*}{$\begin{array}{l}\text { 정부지원 } \\
\text { 충분도 }\end{array}$} & 충분 & (195) & 64.6 & 37.9 & 33.3 & 33.8 & 28.2 \\
\hline & 보통 & (586) & 58.5 & 43.5 & 33.8 & 30.4 & 30.9 \\
\hline & 부족 & (219) & 68.5 & 38.8 & 29.7 & 29.2 & 26.9 \\
\hline
\end{tabular}

(2) 온라인 매체 관람 실태

(가) 온라인 매체 관람 경험 및 경험 매체

2019년 온라인 매체를 통한 관람 경험률은 $62 \%$ 였으며, 관람 매체는 스마트 기

기 $74 \%$, PC/노트북 65\%인데 반해 디지털TV는 $26 \%$ 수준으로 나타났다.

[그림 3-14] 2019년 온라인 매체 관람 경험 및 경험 매체: 2020 시민 예술향유 인식 및 예술향유활동 조사

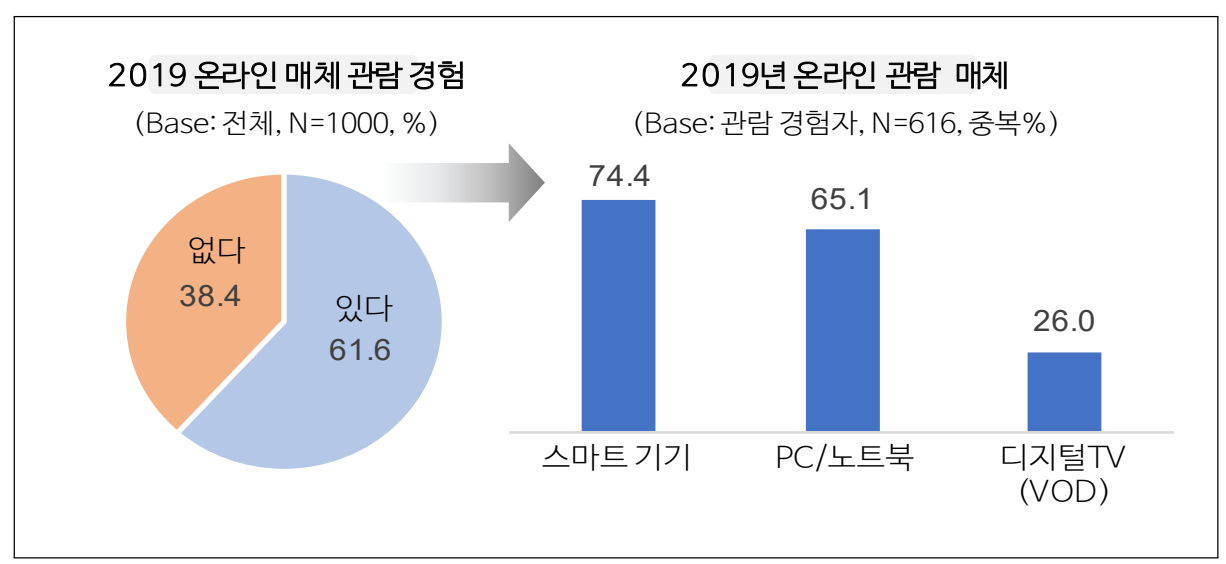


10 대와 20 대가 온라인 매체 경험이 높고, 연령이 높을수록 온라인 매체 관람 경 험률이 낮아지는 경향을 보인다. 상대적으로 남자는 PC/노트북을, 여자는 스마트기 기를 더 많이 이용하는 것으로 응답했다. 수도권보다 비수도권의 온라인 관람 경험 이 높고 거주지 지역 규모가 작을수록 온라인 관람 경험이 높아지는 경향을 보인다. 직접관람 무경험자는 온라인 매체 관람 경험률도 낮게 나타났고, 직접관람 횟수가 많을수록 온라인 관람 경험률도 높은 것으로 나타났다.

〈표 3-44〉 2019년 온라인 매체 관람 경험 및 경험 매체: 2020 시민 예술향유 인식 및 예술향유활동 조사

\begin{tabular}{|c|c|c|c|c|c|c|c|}
\hline & & \multicolumn{2}{|c|}{ 온라인 매체 관람 } & \multicolumn{4}{|c|}{ 온라인 관람 매체 } \\
\hline & & 사례수 & 경험률 & 사례수 & 스마트기기 & $\mathrm{PC} /$ 노트북 & $\begin{array}{c}\text { 디지털TV } \\
\text { (VOD) }\end{array}$ \\
\hline & 전체 & (1000) & 61.6 & (616) & 74.4 & 65.1 & 26.0 \\
\hline \multirow{2}{*}{ 성별 } & 남자 & $(508)$ & 60.4 & (307) & 70.4 & 71.0 & 25.4 \\
\hline & 여자 & (492) & 62.8 & (309) & 78.3 & 59.2 & 26.5 \\
\hline \multirow{6}{*}{ 연령 } & 만 15 19세 & (68) & 77.9 & (53) & 90.6 & 73.6 & 24.5 \\
\hline & 만 20 29세 & (178) & 67.4 & (120) & 80.8 & 64.2 & 19.2 \\
\hline & 만 30 39세 & (188) & 63.8 & (120) & 80.0 & 60.8 & 21.7 \\
\hline & 만 40 49세 & (209) & 55.0 & (115) & 68.7 & 58.3 & 28.7 \\
\hline & 만 50 59세 & (212) & 59.9 & (127) & 73.2 & 72.4 & 26.8 \\
\hline & 만 60세 69세 & $(145)$ & 55.9 & (81) & 55.6 & 65.4 & 38.3 \\
\hline \multirow{4}{*}{ 지역 } & 수도권 & (508) & 59.6 & (303) & 75.6 & 64.4 & 27.4 \\
\hline & - 서울 & (195) & 61.0 & (119) & 78.2 & 60.5 & 29.4 \\
\hline & - 인천경기 & (313) & 58.8 & (184) & 73.9 & 66.8 & 26.1 \\
\hline & 비수도권 & (492) & 63.6 & (313) & 73.2 & 65.8 & 24.6 \\
\hline \multirow{3}{*}{ 지역규모 } & 대도시의 동 & (448) & 59.2 & (265) & 75.8 & 63.4 & 27.5 \\
\hline & 일반시의 동 & (445) & 62.9 & $(280)$ & 73.9 & 66.4 & 22.5 \\
\hline & 읍면부 & (107) & 66.4 & (71) & 70.4 & 66.2 & 33.8 \\
\hline \multirow{2}{*}{ 최종학력 } & 고졸 이하 & (250) & 54.0 & (135) & 77.0 & 65.9 & 24.4 \\
\hline & 대재 이상 & (750) & 64.1 & $(481)$ & 73.6 & 64.9 & 26.4 \\
\hline \multirow{5}{*}{ 가구원 } & 1인 가구 & (133) & 55.6 & (74) & 75.7 & 71.6 & 16.2 \\
\hline & 2인 가족(부부/커플) & (137) & 58.4 & (80) & 68.8 & 66.3 & 32.5 \\
\hline & 부모와 거주 & (310) & 62.9 & (195) & 80.5 & 66.2 & 21.5 \\
\hline & 자녀와 거주 & (401) & 63.8 & (256) & 71.5 & 62.1 & 29.7 \\
\hline & 기타 & (19) & 57.9 & (11) & 63.6 & 63.6 & 36.4 \\
\hline
\end{tabular}




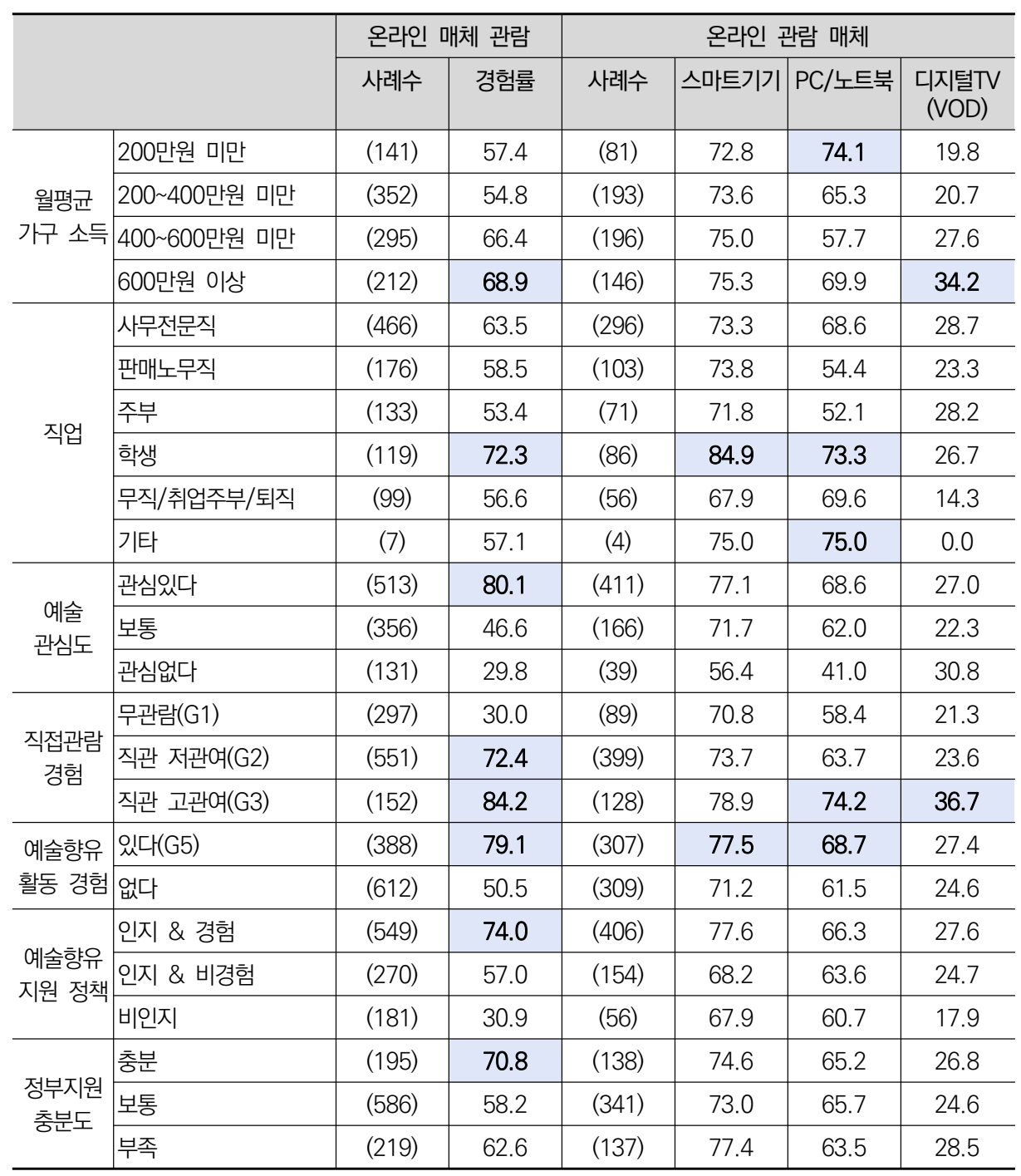

\section{(나) 온라인 매체 관람 동기}

온라인 매체 관람자의 관람 동기는 '본인의 즐거움'이 67.2\%로 가장 많았고, 다 음으로 '마음의 안정과 휴식', '스트레스 해소'가 높게 나타났다. 
[그림 3-15] 온라인 매체 관람 동기: 2020 시민 예술향유 인식 및 예술향유활동 조사

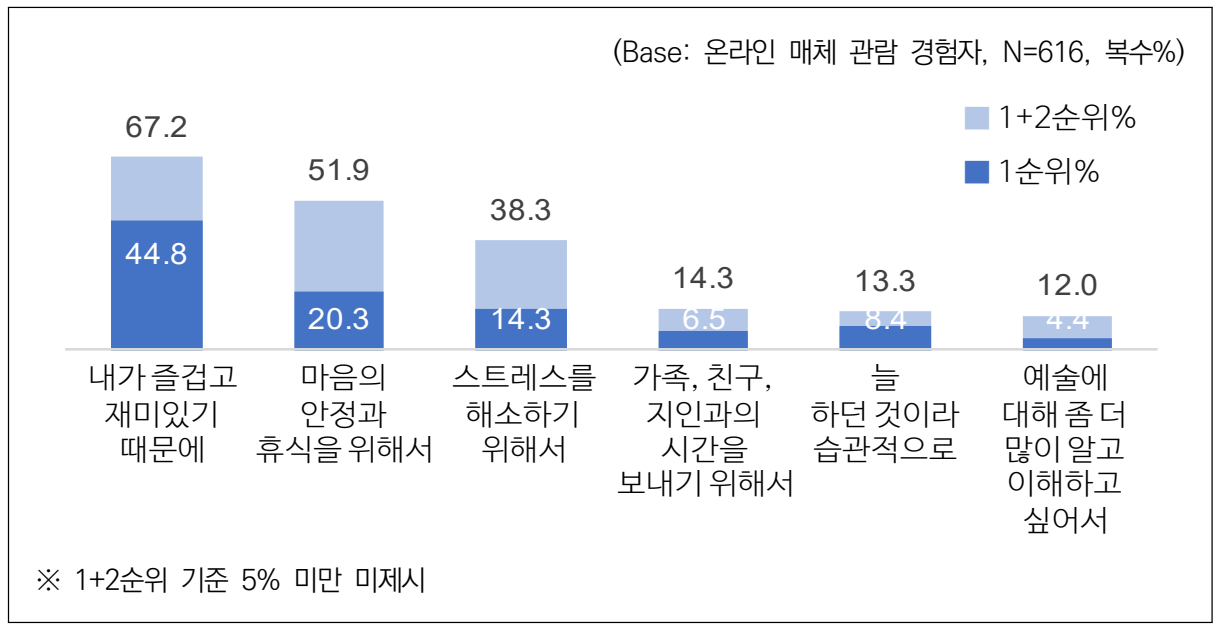

10대는 본인의 즐거움 때문에, 20대는 습관적으로, 30대는 스트레스 해소를 상 대적으로 많이 응답했다. 상대적으로 남자는 ‘마음의 안정과 휴식을 위해', 여자는 '본인의 즐거움' 때문에 온라인 매체 관람을 하는 것으로 응답했다.

〈표 3-45〉 응답자 특성별 온라인 매체 관람 동기(중복응답 \%): 2020 시민 예술향유 인식 및 예술향유활동 조사

\begin{tabular}{|c|c|c|c|c|c|c|c|c|}
\hline & & 사례수 & $\begin{array}{c}\text { 내가 즐겁고 } \\
\text { 재미있기 } \\
\text { 때문에 }\end{array}$ & $\begin{array}{l}\text { 마음의 안정과 } \\
\text { 휴식을 위해서 }\end{array}$ & $\begin{array}{c}\text { 스트레스 } \\
\text { 해소를 위해 }\end{array}$ & $\begin{array}{l}\text { 가족, 친구, } \\
\text { 지인과의 } \\
\text { 시간을 보내기 } \\
\text { 위해서 }\end{array}$ & $\begin{array}{l}\text { 늘 하던 } \\
\text { 것이라 } \\
\text { 습관적으로 }\end{array}$ & \begin{tabular}{|c} 
예술에 대해 \\
좀더민이얄고 \\
이해하고 \\
싶어서
\end{tabular} \\
\hline \multicolumn{2}{|r|}{ 전체 } & (616) & 67.2 & 51.9 & 38.3 & 14.3 & 13.3 & 12.0 \\
\hline \multirow{2}{*}{ 성별 } & 남자 & (307) & 62.5 & 56.7 & 37.1 & 12.7 & 14.7 & 12.7 \\
\hline & 여자 & (309) & 71.8 & 47.2 & 39.5 & 15.9 & 12.0 & 11.3 \\
\hline \multirow{6}{*}{ 연령 } & 만 15 19세 & (53) & 79.2 & 43.4 & 41.5 & 11.3 & 15.1 & 5.7 \\
\hline & 만 20 29세 & (120) & 68.3 & 48.3 & 37.5 & 11.7 & 19.2 & 10.0 \\
\hline & 만 30 39세 & (120) & 59.2 & 54.2 & 46.7 & 11.7 & 14.2 & 12.5 \\
\hline & 만 40 49세 & (115) & 67.8 & 49.6 & 40.9 & 19.1 & 8.7 & 11.3 \\
\hline & 만 50 59세 & (127) & 70.1 & 55.1 & 37.0 & 15.7 & 8.7 & 11.0 \\
\hline & 만 60세 69세 & (81) & 64.2 & 58.0 & 23.5 & 14.8 & 16.0 & 21.0 \\
\hline \multirow{4}{*}{ 지역 } & 수도권 & (303) & 66.3 & 51.2 & 41.6 & 11.6 & 15.2 & 11.6 \\
\hline & - 서울 & (119) & 73.1 & 46.2 & 38.7 & 8.4 & 18.5 & 10.1 \\
\hline & - 인천경기 & (184) & 62.0 & 54.3 & 43.5 & 13.6 & 13.0 & 12.5 \\
\hline & 비수도권 & (313) & 68.1 & 52.7 & 35.1 & 16.9 & 11.5 & 12.5 \\
\hline
\end{tabular}




\begin{tabular}{|c|c|c|c|c|c|c|c|c|}
\hline & & 사례수 & $\begin{array}{c}\text { 내가 즐겁고 } \\
\text { 재미있기 } \\
\text { 때문에 }\end{array}$ & $\begin{array}{l}\text { 마음의 안정과 } \\
\text { 휴식을 위해서 }\end{array}$ & $\begin{array}{c}\text { 스트레스 } \\
\text { 해소를 위해 }\end{array}$ & $\begin{array}{c}\text { 가족, 친구, } \\
\text { 지인과의 } \\
\text { 시간을 보내기 } \\
\text { 위해서 }\end{array}$ & $\begin{array}{c}\text { 늘 하던 } \\
\text { 것이라 } \\
\text { 습관적으로 }\end{array}$ & $\begin{array}{c}\text { 예술에 대해 } \\
\text { 좀더민이일고 } \\
\text { 이해하고 } \\
\text { 싶어서 }\end{array}$ \\
\hline \multirow{3}{*}{ 지역규모 } & 대도시의 동 & (265) & 69.8 & 49.8 & 38.9 & 12.1 & 14.3 & 10.9 \\
\hline & 일반시의 동 & (280) & 64.6 & 52.1 & 40.4 & 13.9 & 13.2 & 13.2 \\
\hline & 읍면부 & (71) & 67.6 & 59.2 & 28.2 & 23.9 & 9.9 & 11.3 \\
\hline \multirow{2}{*}{ 최종학력 } & 고졸 이하 & (135) & 73.3 & 55.6 & 36.3 & 10.4 & 14.1 & 8.1 \\
\hline & 대재 이상 & (481) & 65.5 & 50.9 & 38.9 & 15.4 & 13.1 & 13.1 \\
\hline \multirow{5}{*}{ 가구원 } & 1인 가구 & (74) & 79.7 & 37.8 & 40.5 & 8.1 & 13.5 & 14.9 \\
\hline & 2인 가족(부부/커플) & (80) & 60.0 & 60.0 & 23.8 & 25.0 & 16.3 & 13.8 \\
\hline & 부모와 거주 & (195) & 72.3 & 50.3 & 38.5 & 10.8 & 15.9 & 9.2 \\
\hline & 자녀와 거주 & (256) & 61.3 & 55.5 & 42.6 & 15.6 & 10.2 & 12.9 \\
\hline & 기타 & (11) & 81.8 & 36.4 & 27.3 & 9.1 & 18.2 & 9.1 \\
\hline \multirow{4}{*}{$\begin{array}{c}\text { 월평균 } \\
\text { 가구 소득 }\end{array}$} & 200만원 미만 & (81) & 82.7 & 34.6 & 39.5 & 11.1 & 19.8 & 9.9 \\
\hline & 200 400만원 미만 & (193) & 66.3 & 51.3 & 34.7 & 14.0 & 15.5 & 14.5 \\
\hline & 400 600만원 미만 & (196) & 67.3 & 53.1 & 37.8 & 14.3 & 11.7 & 12.8 \\
\hline & 600만원 이상 & (146) & 59.6 & 61.0 & 43.2 & 16.4 & 8.9 & 8.9 \\
\hline \multirow{6}{*}{ 직업 } & 사무전문직 & (296) & 63.2 & 56.4 & 41.6 & 13.2 & 10.5 & 12.2 \\
\hline & 판매노무직 & (103) & 68.9 & 43.7 & 37.9 & 16.5 & 12.6 & 17.5 \\
\hline & 주부 & (71) & 67.6 & 52.1 & 33.8 & 21.1 & 15.5 & 9.9 \\
\hline & 학생 & (86) & 75.6 & 46.5 & 37.2 & 10.5 & 20.9 & 8.1 \\
\hline & 무직/취업주부/퇴직 & (56) & 69.6 & 53.6 & 28.6 & 12.5 & 16.1 & 10.7 \\
\hline & 기타 & (4) & 100.0 & 25.0 & 50.0 & 25.0 & 0.0 & 0.0 \\
\hline \multirow{3}{*}{$\begin{array}{l}\text { 예술 } \\
\text { 관심도 }\end{array}$} & 관심있다 & (411) & 66.9 & 53.3 & 38.2 & 13.4 & 10.7 & 14.6 \\
\hline & 보통 & (166) & 68.7 & 49.4 & 40.4 & 14.5 & 18.7 & 6.0 \\
\hline & 관심없다 & (39) & 64.1 & 48.7 & 30.8 & 23.1 & 17.9 & 10.3 \\
\hline \multirow{3}{*}{$\begin{array}{l}\text { 직접관람 } \\
\text { 경험 }\end{array}$} & 무관람(G1) & (89) & 70.8 & 43.8 & 34.8 & 18.0 & 20.2 & 10.1 \\
\hline & 직관 저관여(G2) & (399) & 64.2 & 54.6 & 38.6 & 15.3 & 11.5 & 12.0 \\
\hline & 직관 고관여(G3) & (128) & 74.2 & 49.2 & 39.8 & 8.6 & 14.1 & 13.3 \\
\hline \multirow{2}{*}{$\begin{array}{l}\text { 예술향유 } \\
\text { 활동 경험 }\end{array}$} & 있다(G5) & (307) & 63.2 & 53.4 & 34.5 & 14.7 & 14.3 & 16.0 \\
\hline & 없다 & (309) & 71.2 & 50.5 & 42.1 & 13.9 & 12.3 & 8.1 \\
\hline \multirow{3}{*}{$\begin{array}{l}\text { 예술향유 } \\
\text { 지원 정책 }\end{array}$} & 인지 \& 경험 & (406) & 66.5 & 52.2 & 37.7 & 14.0 & 13.1 & 13.8 \\
\hline & 인지 \& 비경험 & (154) & 72.1 & 52.6 & 39.6 & 13.0 & 12.3 & 7.1 \\
\hline & 비인지 & (56) & 58.9 & 48.2 & 39.3 & 19.6 & 17.9 & 12.5 \\
\hline \multirow{3}{*}{$\begin{array}{l}\text { 정부지원 } \\
\text { 충분도 }\end{array}$} & 충분 & (138) & 67.4 & 54.3 & 33.3 & 17.4 & 13.0 & 13.0 \\
\hline & 보통 & (341) & 67.4 & 51.3 & 41.6 & 12.0 & 14.1 & 11.4 \\
\hline & 부족 & (137) & 66.4 & 51.1 & 35.0 & 16.8 & 11.7 & 12.4 \\
\hline
\end{tabular}


(다) 온라인 매체 관람 후 인식/효과

온라인 매체 관람 후 효과는 '삶이 조금 더 풍요로워지는 것 같다'가 가장 많았으 며, 다음으로 '작품 관련 정보 관심 증대', '타인의 생각이나 문화에 대한 공감 증대' 순으로 응답되었다.

[그림 3-16] 온라인 매체 관람 후 인식/효과: 2020 시민 예술향유 인식 및 예술향유활동 조사

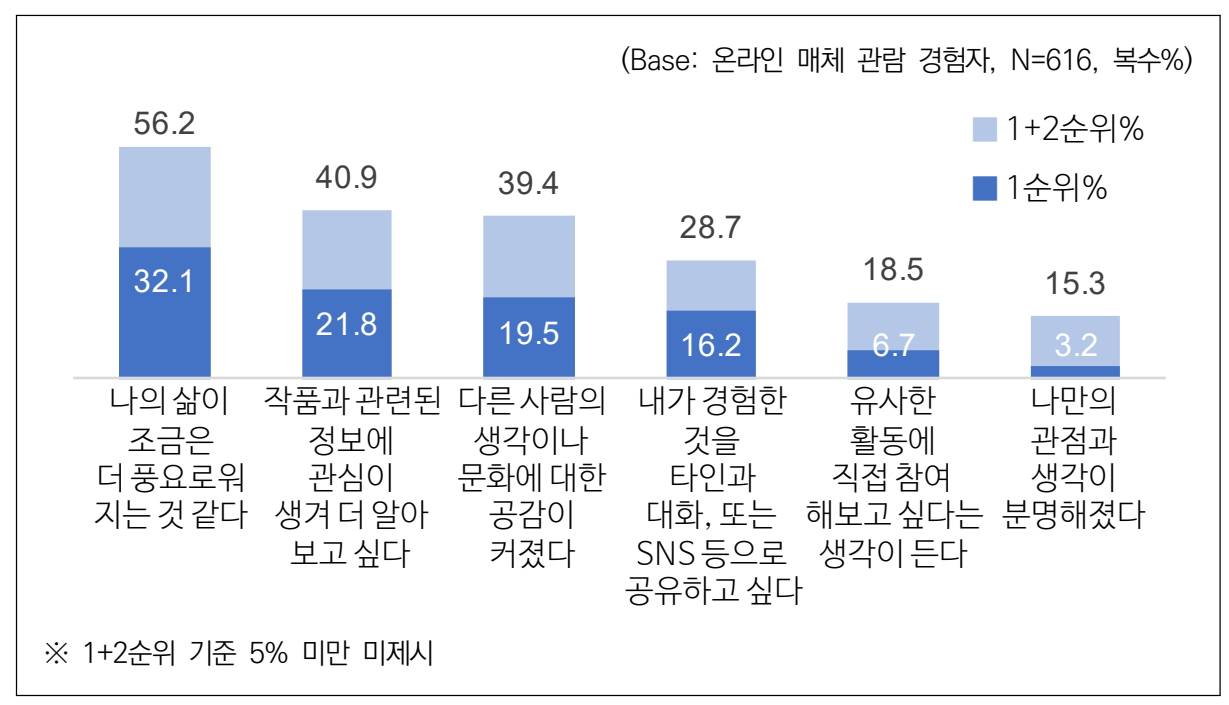

연령별로 10 30대는 상대적으로 ‘작품 관련 정보 관심 증대’와 '경험의 타인 공 유'가 높았고, 40대는 '공감 증대', 50 60대는 '삶의 풍요'와 '공감 증대'가 상대적 으로 높았다.

라 온라인 매체 관람 걸림돌 - 외적·물리적 측면

온라인 관람의 외적·물리적 걸림돌은 '관련 정보 부족', '시간 부족', '경제적 부 담'이 높게 나타났다. 
[그림 3-17] 온라인 매체 관람 외적·물리적 걸림돌: 2020 시민 예술향유 인식 및 예술향유활동 조사

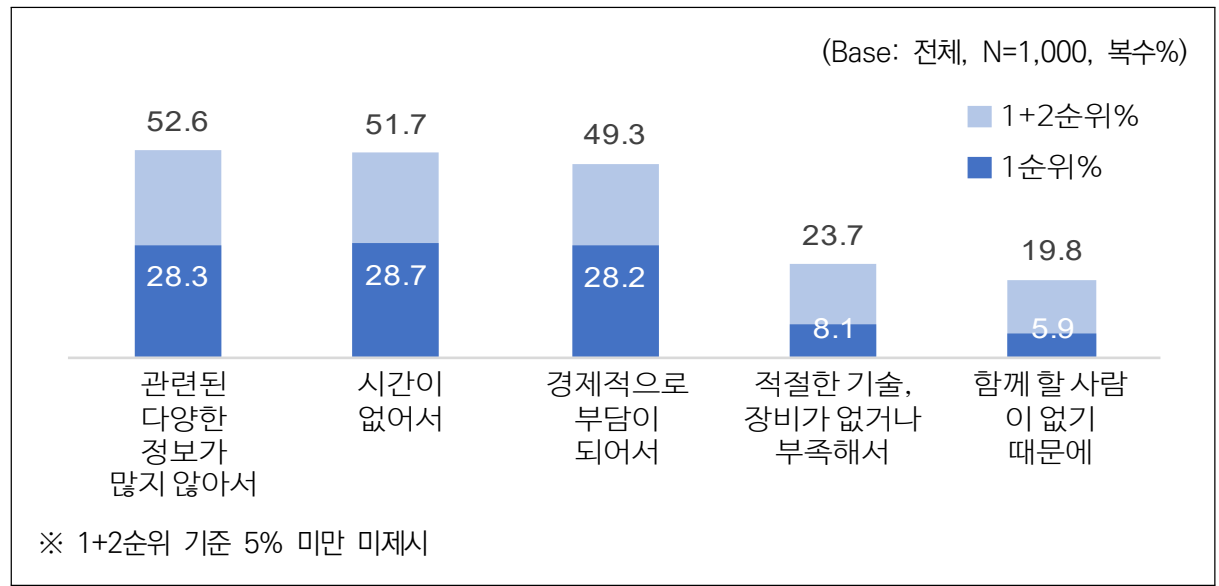

온라인 관람 경험 유무에 따른 외적·물리적 걸림돌은 차이가 없다. 남자는 '시간 부족'을, 여자는 '정보 부족'과 '기술/장비 부족'을 상대적으로 더 많이 응답했다. 10 대는 '시간 부족', 20 대는 '경제적 부담', 30대는 '함께할 사람이 없어서', 40 대 는 '시간 부족'을 상대적으로 많이 응답했다.

(마) 온라인 매체 관람 걸림돌 - 내적·심리적 측면

온라인 관람의 내적·심리적 걸림돌은 '예술 기초 지식 및 경험 부족' '직접 관람 대비 예술성 낮음' '필요성 인식 부족'이 높게 나타났다.

[그림 3-18] 온라인 매체 관람 내적-심리적 걸림돌: 2020 시민 예술향유 인식 및 예술향유활동 조사

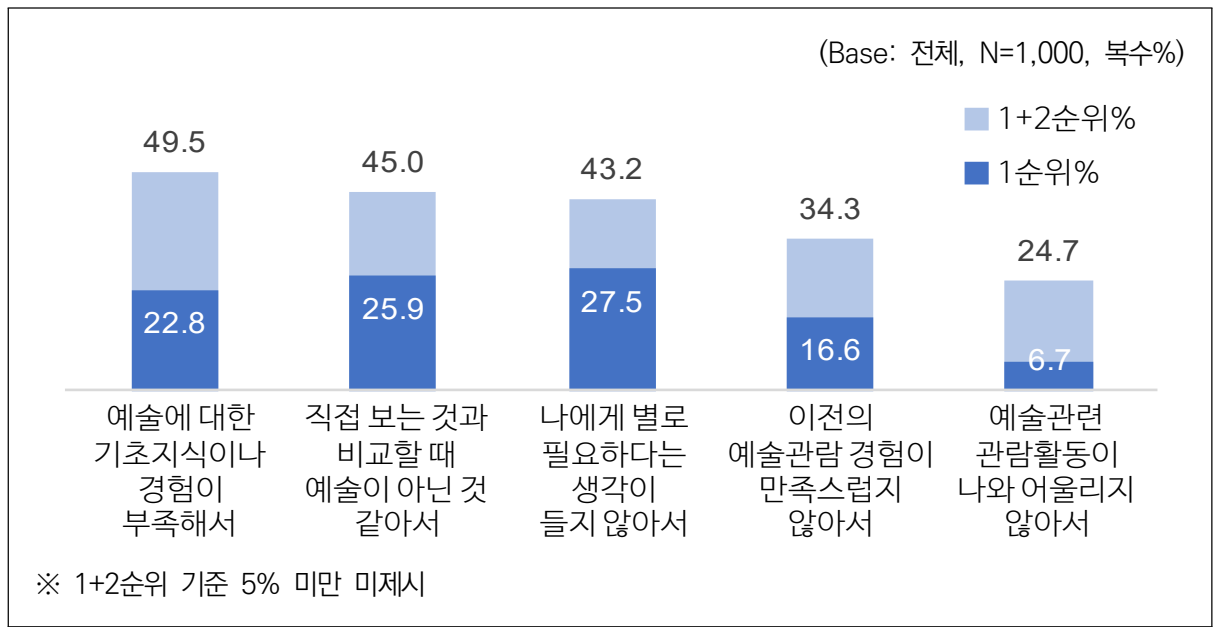


온라인 관람 경험이 없는 사람은 경험자 대비 '필요성 인식 부족'과 '나와 어울리 지 않는다'는 것을 내적·심리적 걸림돌로 더 많이 응답했다. 남자보다 여자는 '직접 관람 대비 예술성 낮음'을 상대적으로 더 많이 응답했다.

(바) 온라인 매체 관람의 장점 인식

온라인 매체 관람의 장점으로 ‘시간, 물리적 접근성 자유로움’이 $52 \%$ 로 가장 많 았고, 다음으로 '본인 선택 여지'와 '경제적 비용 부담 적음'으로 나타났다. 온라인 매체 관람 경험자는 비경험자 대비 '시간, 물리적 접근성'을 많이 응답했다.

[그림 3-19] 온라인 매체 관람의 장점 인식: 2020 시민 예술향유 인식 및 예술향유활동 조사

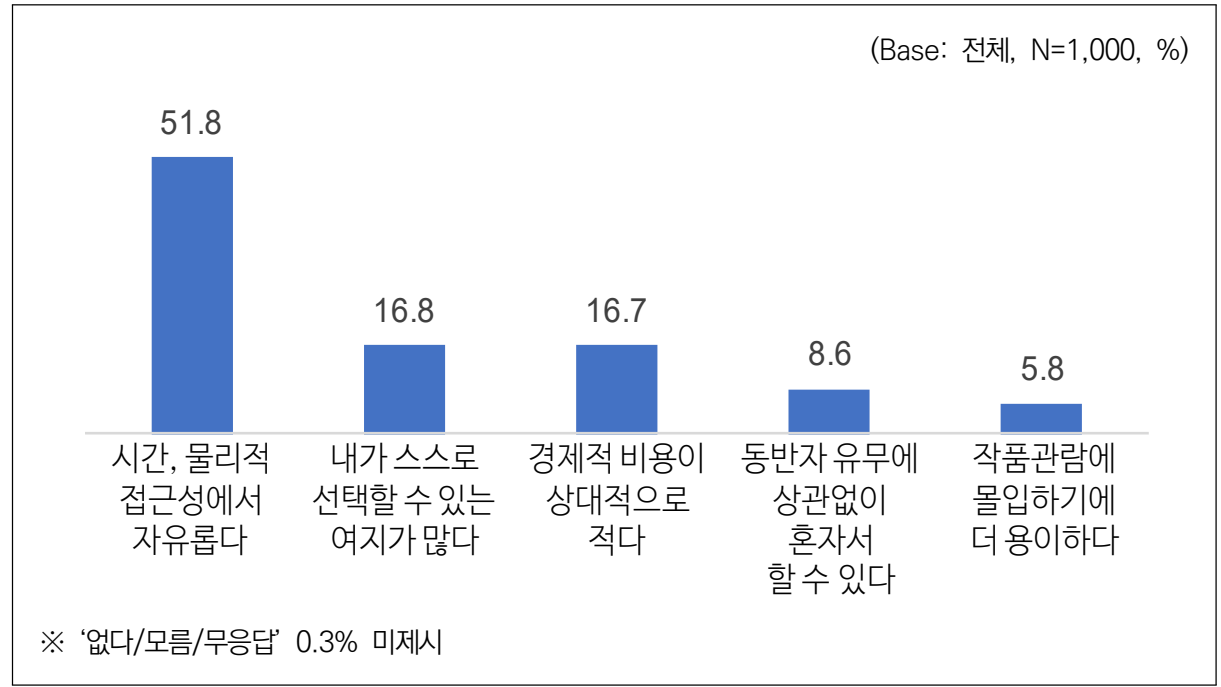

3) 예술 참여활동 실태

(1) 예술 참여활동 영역별 경험

예술 참여활동 경험률은 '예술 교육' $19 \%$, '예술 동호회' $18.4 \%$, '예술 자원봉사 /기부' $18.2 \%$, '예술 창작' $16.3 \%$ 순으로 나타났다. 
[그림 3-20] 예술 참여활동 경험률: 2020 시민 예술향유 인식 및 예술향유활동 조사

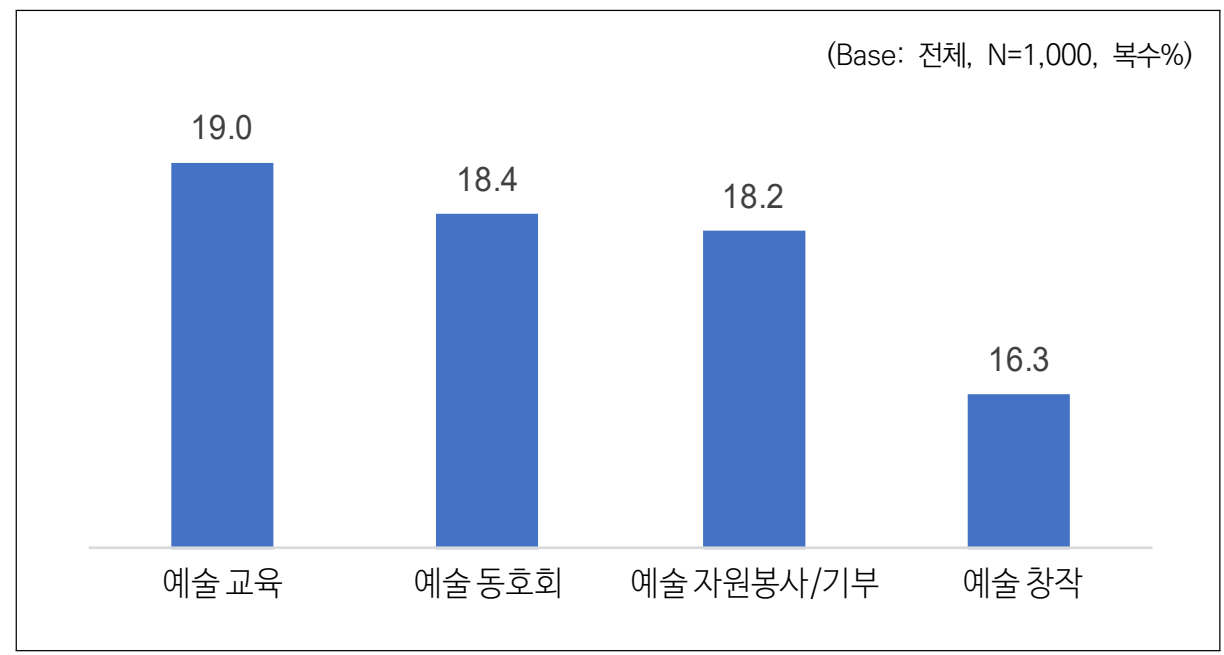

10 대는 상대적으로 예술 교육, 예술 창작, 예술 자원봉사/기부 활동 경험률이 높 고, 20대는 예술 창작 활동이, 60대는 예술 동호회 활동이 상대적으로 높았다. 읍면 부 거주자가 도시 거주자 대비 예술 교육과 예술 자원봉사/기부 활동 경험률이 높 았다.

(2) 예술 참여활동 비교

(가) 참여 경로

예술동호회와 예술자원봉사/기부는 상대적으로 오프라인으로 참여하고 있고, 예 술교육과 예술창작은 온라인 참여가 상대적으로 많은 것으로 나타났다.

〈표 3-46〉 예술참여 활동별 활동 참여 경로: 2020 시민 예술향유 인식 및 예술향유활동 조사

\begin{tabular}{c|c|c|c|c|c|c}
\hline & 사례수 & 오프라인 & 둘 다 & 온라인 & 오프라인 & 온라인 \\
\hline 예술교육 & $(190)$ & 48.4 & 16.8 & 34.7 & 65.3 & 51.6 \\
\hline 예술창작 & $(163)$ & 52.1 & 16.0 & 31.9 & 68.1 & 47.9 \\
\hline 예술동호회 & $(184)$ & 65.8 & 8.7 & 25.5 & 74.5 & 34.2 \\
\hline 예술자원봉사/기부 & $(182)$ & 58.8 & 12.6 & 28.6 & 71.4 & 41.2 \\
\hline
\end{tabular}




\section{(나) 참여 동기}

예술교육, 예술창작, 예술동호회의 참여 동기로는 '즐거움/재미’가 가장 높았으 며, 예술자원봉사/기부 참여 동기는 '직접 참여의 의미'가 가장 높았다.

예술자원봉사/기부는 ‘사회적 의미’도 동기로 높게 나타났다.

〈표 3-47〉 예술참여 활동별 활동 참여 동기(중복응답 \%): 2020 시민 예술향유 인식 및 예술향유활동 조사

\begin{tabular}{c|c|c|c|c|c|c|c}
\hline & 사례수 & $\begin{array}{c}\text { 즐겁고 } \\
\text { 재미있기 } \\
\text { 때문에 }\end{array}$ & $\begin{array}{c}\text { 직접 참여 } \\
\text { 해 볼 수 } \\
\text { 있는 것이 } \\
\text { 좋아서 }\end{array}$ & $\begin{array}{c}\text { 임 있는 } \\
\text { 예술에 대해 } \\
\text { 알고 이해 } \\
\text { 하고 싶어서 }\end{array}$ & $\begin{array}{c}\text { 새트레스 } \\
\text { 호를 위해 }\end{array}$ & $\begin{array}{c}\text { 가족, 친구, } \\
\text { 지인광 } \\
\text { 사난을 보내기 } \\
\text { 위해서 }\end{array}$ & $\begin{array}{c}\text { 사회적으로 } \\
\text { 의미 있는 } \\
\text { 일을 하고 } \\
\text { 싶어서 }\end{array}$ \\
\hline 예술교육 & $(190)$ & 60.0 & 53.2 & 31.1 & 28.9 & 19.5 & 7.4 \\
\hline 예술창작 & $(163)$ & 56.4 & 41.7 & 34.4 & 31.3 & 25.4 & 10.4 \\
\hline 예술동호회 & $(184)$ & 54.3 & 39.7 & 28.3 & 38.6 & 32.6 & 6.5 \\
\hline 예술자원봉사/기부 & $(182)$ & 42.3 & 43.4 & 26.4 & 25.8 & 26.4 & 34.6 \\
\hline
\end{tabular}

\section{(다) 활동 후 인식/효과}

예술교육 활동의 효과는 '공감 증대’ 였으며, 예술창작, 예술동호회, 예술자원봉사 /기부 활동의 효과는 '삶의 풍요'로 나타났다.

〈표 3-48〉 예술참여 활동별 활동 후 인식/효과(중복응답 \%):

2020 시민 예술향유 인식 및 예술향유활동 조사

\begin{tabular}{|c|c|c|c|c|c|c|c|}
\hline & 사례수 & $\begin{array}{l}\text { 타인의 } \\
\text { 생각이나 } \\
\text { 문화에 } \\
\text { 대한 공감 } \\
\text { 이 커졌다 }\end{array}$ & $\begin{array}{c}\text { 나의 삼이 } \\
\text { 조금은 } \\
\text { 풍요로워 } \\
\text { 지는 것 } \\
\text { 같다 }\end{array}$ & $\begin{array}{c}\text { 내 경험을 } \\
\text { 타인과 대화 } \\
\text { 또는 SNS } \\
\text { 등으로 공유 } \\
\text { 하고 싶다 }\end{array}$ & $\begin{array}{c}\text { 유사한 } \\
\text { 활동에 } \\
\text { 직접 참여 } \\
\text { 해보고 싶다 }\end{array}$ & $\begin{array}{c}\text { 작품 관련 } \\
\text { 정보에 } \\
\text { 관심이 생겨 } \\
\text { 더 알아보고 } \\
\quad \text { 싶다 }\end{array}$ & $\begin{array}{c}\text { 나만의 } \\
\text { 관점과 } \\
\text { 생각이 } \\
\text { 분명해 } \\
\text { 졌다 }\end{array}$ \\
\hline 예술교육 & (190) & 46.3 & 43.2 & 37.4 & 34.7 & 26.3 & 12.1 \\
\hline 예술창작 & (163) & 35.6 & 46.6 & 36.2 & 35.0 & 30.7 & 16.0 \\
\hline 예술동호회 & (184) & 39.1 & 45.7 & 38.0 & 36.4 & 31.0 & 9.8 \\
\hline 예술자원봉사/기부 & (182) & 41.2 & 47.3 & 35.7 & 37.9 & 19.2 & 18.7 \\
\hline
\end{tabular}

(라) 활동 참여 외적·물리적 걸림돌

예술교육과 예술자원봉사/기부의 외적·물리적 걸림돌은 '시간 부족'이며 예술창 작과 예술동호회의 물리적 걸림돌은 '경제적 부담' 으로 나타났다. 
〈표 3-49〉 예술참여 활동별 활동 참여 외적·물리적 걸림돌(중복응답 \%): 2020 시민 예술향유 인식 및 예술향유활동 조사

\begin{tabular}{c|c|c|c|c|c|c}
\hline & 사례수 & $\begin{array}{c}\text { 시간 } \\
\text { 없어서 }\end{array}$ & $\begin{array}{c}\text { 경제적 } \\
\text { 부담 }\end{array}$ & $\begin{array}{c}\text { 정보가 } \\
\text { 많지 않아서 }\end{array}$ & $\begin{array}{c}\text { 함께 하ㅁㅏㅏㅁㅇㅣ 없어서 } \\
\text { 예술교육 }\end{array}$ & $\begin{array}{c}\text { 기술, 장비 } \\
\text { 부족 }\end{array}$ \\
\hline 예술창작 & $(1,000)$ & 55.7 & 54.7 & 45.1 & 25.4 & 16.9 \\
\hline 예술동호회 & $(1,000)$ & 51.8 & 56.9 & 43.6 & 25.7 & 20.5 \\
\hline 예술자원봉사/기부 & $(1,000)$ & 52.5 & 51.7 & 49.4 & 30.4 & 14.7 \\
\hline
\end{tabular}

(마) 활동 참여 내적·심리적 걸림돌

예술교육, 예술창작, 예술자원봉사/기부의 내적·심리적 걸림돌은 '예술에 대한 기초지식/경험 부족'이었으며, 예술동호회의 심리적 걸림돌은 ‘필요성 인식 부족’이 었다.

〈표 3-50〉 예술참여 활동별 활동 참여 내적·심리적 걸림돌(중복응답 \%): 2020 시민 예술향유 인식 및 예술향유활동 조사

\begin{tabular}{c|c|c|c|c|c|c}
\hline & 사례수 & $\begin{array}{c}\text { 예술기초지식 } \\
\text { /경험 부록 }\end{array}$ & $\begin{array}{c}\text { 보ㄹㅗㅗ릴요하다 } \\
\text { 생각하지 } \\
\text { 않아서 }\end{array}$ & $\begin{array}{c}\text { 직접 참여 } \\
\text { 보다 관람이 } \\
\text { 더 좋아서 }\end{array}$ & $\begin{array}{c}\text { 이전 경험이 } \\
\text { 만족스럽지 } \\
\text { 않아서 }\end{array}$ & $\begin{array}{c}\text { 나와 어울리지 } \\
\text { 않아서 }\end{array}$ \\
\hline 예술교육 & $(1,000)$ & 51.5 & 48.8 & 47.8 & 25.5 & 24.4 \\
\hline 예술창작 & $(1,000)$ & 52.1 & 47.1 & 47.3 & 25.5 & 26.4 \\
\hline 예술동호회 & $(1,000)$ & 47.6 & 48.8 & 45.6 & 27.4 & 29.0 \\
\hline 예술자원봉사/기부 & $(1,000)$ & 51.6 & 45.2 & 39.6 & 27.9 & 33.8 \\
\hline
\end{tabular}

4) 예술향유에 관한 정책 인식

(1) 예술향유활동 지원 정책 인지 및 경험

(ㄱ) 지원 정책 인지도

예술향유활동 지원 정책 중 ‘문화가 있는 날 할인’ 인지도가 $72 \%$ 로 가장 높았으 며, 다음으로 '무료 관람 제도'(51\%), '문화바우처 지원'(49\%) 순으로 나타났다. 그 러나 다른 한편, 예술향유활동 지원 정책을 전혀 모르는 응답자는 $18 \%$ 수준으로 나타났다. 
[그림 3-21] 예술향유활동 지원 정책 인지도: 2020 시민 예술향유 인식 및 예술향유활동 조사

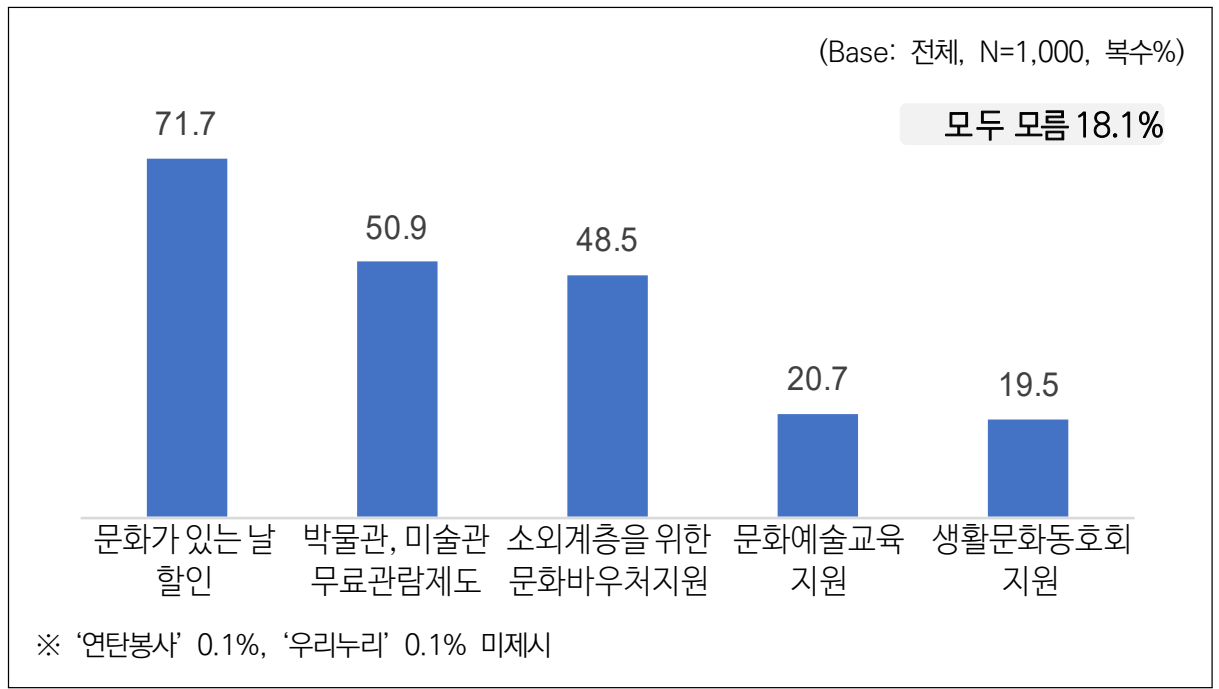

연령별로는 10 대와 40대는 '문화바우처 지원'을, 50대는 '문화예술교육 지원'과 '생활문화 동호회 지원'을, 60대는 '문화바우처 지원'과 '생활문화 동호회 지원'을 상대적으로 많이 알고 있었다. 수도권 대비 비수도권 거주자가 '무료 관람 제도'와 '생활문화 동호회 지원'을 더 많이 알고 있었다.

〈표 3-51〉 응답자 특성별 예술향유활동 지원 정책 인지도:

2020 시민 예술향유 인식 및 예술향유활동 조사

\begin{tabular}{|c|c|c|c|c|c|c|c|c|}
\hline & & 사례수 & $\begin{array}{c}\text { 문화가 } \\
\text { 있는 날 } \\
\text { 할인 }\end{array}$ & $\begin{array}{c}\text { 무료 } \\
\text { 관람제도 }\end{array}$ & $\begin{array}{l}\text { 문화 } \\
\text { 바우처 } \\
\text { 지원 }\end{array}$ & $\begin{array}{l}\text { 문화예술 } \\
\text { 교육지원 }\end{array}$ & $\begin{array}{c}\text { 생활문화 } \\
\text { 동호회 } \\
\text { 지원 }\end{array}$ & $\begin{array}{l}\text { 모두 } \\
\text { 모름 }\end{array}$ \\
\hline \multicolumn{2}{|r|}{ 전체 } & (1000) & 71.7 & 50.9 & 48.5 & 20.7 & 19.5 & 18.1 \\
\hline \multirow{2}{*}{ 성별 } & 남자 & (508) & 67.7 & 46.5 & 44.9 & 18.1 & 17.1 & 20.7 \\
\hline & 여자 & (492) & 75.8 & 55.5 & 52.2 & 23.4 & 22.0 & 15.4 \\
\hline \multirow{6}{*}{ 연령 } & 만 15 19세 & (68) & 72.1 & 51.5 & 55.9 & 20.6 & 8.8 & 11.8 \\
\hline & 만 20 29세 & (178) & 75.8 & 52.2 & 33.1 & 18.5 & 15.2 & 15.2 \\
\hline & 만 30 39세 & (188) & 71.8 & 45.2 & 42.0 & 16.5 & 12.2 & 18.6 \\
\hline & 만 40 49세 & (209) & 67.5 & 50.7 & 55.5 & 15.8 & 17.2 & 20.6 \\
\hline & 만 50 59세 & (212) & 71.2 & 52.4 & 52.8 & 29.7 & 29.2 & 17.9 \\
\hline & 만 60세 69세 & (145) & 73.1 & 54.5 & 55.9 & 22.8 & 28.3 & 20.7 \\
\hline
\end{tabular}




\begin{tabular}{|c|c|c|c|c|c|c|c|c|}
\hline & & 사례수 & $\begin{array}{c}\text { 문화가 } \\
\text { 있는 날 } \\
\text { 할인 }\end{array}$ & $\begin{array}{c}\text { 무료 } \\
\text { 관람제도 }\end{array}$ & $\begin{array}{l}\text { 문화 } \\
\text { 바우처 } \\
\text { 지원 }\end{array}$ & $\begin{array}{l}\text { 문화예술 } \\
\text { 교육지원 }\end{array}$ & $\begin{array}{l}\text { 생활문화 } \\
\text { 동호회 } \\
\text { 지원 }\end{array}$ & $\begin{array}{l}\text { 모두 } \\
\text { 모름 }\end{array}$ \\
\hline \multirow{4}{*}{ 지역 } & 수도권 & (508) & 72.2 & 47.6 & 46.1 & 18.3 & 16.9 & 19.3 \\
\hline & - 서울 & (195) & 73.3 & 44.6 & 44.1 & 17.9 & 16.4 & 16.9 \\
\hline & - 인천경기 & (313) & 71.6 & 49.5 & 47.3 & 18.5 & 17.3 & 20.8 \\
\hline & 비수도권 & (492) & 71.1 & 54.3 & 51.0 & 23.2 & 22.2 & 16.9 \\
\hline \multirow{3}{*}{ 지역규모 } & 대도시의 동 & (448) & 72.8 & 47.8 & 46.0 & 18.1 & 17.0 & 18.3 \\
\hline & 일반시의 동 & (445) & 70.6 & 51.9 & 48.5 & 19.3 & 19.8 & 18.2 \\
\hline & 읍면부 & (107) & 72.0 & 59.8 & 58.9 & 37.4 & 29.0 & 16.8 \\
\hline \multirow{2}{*}{ 최종학력 } & 고졸 이하 & (250) & 62.0 & 44.0 & 47.6 & 21.2 & 16.4 & 22.8 \\
\hline & 대재 이상 & (750) & 74.9 & 53.2 & 48.8 & 20.5 & 20.5 & 16.5 \\
\hline \multirow{5}{*}{ 가구원 } & 1인 가구 & (133) & 64.7 & 51.1 & 44.4 & 16.5 & 17.3 & 21.1 \\
\hline & 2인 가족(부부/커플) & (137) & 69.3 & 46.7 & 49.6 & 22.6 & 25.5 & 21.2 \\
\hline & 부모와 거주 & (310) & 74.5 & 48.7 & 43.2 & 18.1 & 12.3 & 16.1 \\
\hline & 자녀와 거주 & (401) & 72.1 & 53.4 & 53.6 & 22.9 & 23.7 & 18.2 \\
\hline & 기타 & (19) & 84.2 & 63.2 & 47.4 & 31.6 & 21.1 & 5.3 \\
\hline \multirow{4}{*}{$\begin{array}{c}\text { 월평균 } \\
\text { 가구 소득 }\end{array}$} & 200만원 미만 & (141) & 67.4 & 47.5 & 56.7 & 25.5 & 18.4 & 17.7 \\
\hline & 200 400만원 미만 & (352) & 67.3 & 48.3 & 46.9 & 16.2 & 17.6 & 21.3 \\
\hline & 400 600만원 미만 & (295) & 73.2 & 51.9 & 46.4 & 20.3 & 19.7 & 16.9 \\
\hline & 600만원 이상 & (212) & 79.7 & 56.1 & 48.6 & 25.5 & 23.1 & 14.6 \\
\hline \multirow{6}{*}{ 직업 } & 사무전문직 & (466) & 74.2 & 53.4 & 49.6 & 21.0 & 19.3 & 17.0 \\
\hline & 판매노무직 & (176) & 63.6 & 46.6 & 48.3 & 21.6 & 24.4 & 23.9 \\
\hline & 주부 & (133) & 73.7 & 49.6 & 49.6 & 23.3 & 24.8 & 15.8 \\
\hline & 학생 & (119) & 77.3 & 51.3 & 48.7 & 17.6 & 9.2 & 10.9 \\
\hline & 무직/취업주부/퇴직 & (99) & 64.6 & 47.5 & 42.4 & 17.2 & 16.2 & 24.2 \\
\hline & 기타 & (7) & 71.4 & 57.1 & 42.9 & 28.6 & 28.6 & 28.6 \\
\hline \multirow{3}{*}{$\begin{array}{c}\text { 예술 } \\
\text { 관심도 }\end{array}$} & 관심있다 & (513) & 84.4 & 65.1 & 59.1 & 28.8 & 25.0 & 7.2 \\
\hline & 보통 & (356) & 63.5 & 40.7 & 40.4 & 13.2 & 15.7 & 25.3 \\
\hline & 관심없다 & (131) & 44.3 & 22.9 & 29.0 & 9.2 & 8.4 & 41.2 \\
\hline \multirow{3}{*}{$\begin{array}{l}\text { 직접관람 } \\
\text { 경험 }\end{array}$} & 무관람(G1) & (297) & 47.5 & 29.6 & 33.3 & 9.1 & 10.4 & 39.7 \\
\hline & 직관 저관여(G2) & (551) & 78.0 & 56.8 & 53.0 & 25.6 & 22.9 & 10.9 \\
\hline & 직관 고관여(G3) & (152) & 96.1 & 71.1 & 61.8 & 25.7 & 25.0 & 2.0 \\
\hline \multirow{2}{*}{$\begin{array}{c}\text { 온라인 매체 } \\
\text { 관람 경험 }\end{array}$} & 있다(G4) & (616) & 81.3 & 61.7 & 57.1 & 26.9 & 24.4 & 9.1 \\
\hline & 없다 & (384) & 56.3 & 33.6 & 34.6 & 10.7 & 11.7 & 32.6 \\
\hline \multirow{2}{*}{$\begin{array}{l}\text { 예술향유 } \\
\text { 활동 경험 }\end{array}$} & 있다(G5) & (388) & 79.4 & 66.5 & 54.4 & 34.3 & 32.2 & 7.5 \\
\hline & 없다 & (612) & 66.8 & 41.0 & 44.8 & 12.1 & 11.4 & 24.8 \\
\hline
\end{tabular}




\begin{tabular}{|c|c|c|c|c|c|c|c|c|}
\hline & & 사례수 & $\begin{array}{c}\text { 문화가 } \\
\text { 있는 날 } \\
\text { 할인 }\end{array}$ & $\begin{array}{c}\text { 무료 } \\
\text { 관람제도 }\end{array}$ & $\begin{array}{l}\text { 문화 } \\
\text { 바우처 } \\
\text { 지원 }\end{array}$ & $\begin{array}{l}\text { 문화예술 } \\
\text { 교육지원 }\end{array}$ & $\begin{array}{c}\text { 생활문화 } \\
\text { 동호회 } \\
\text { 지원 }\end{array}$ & $\begin{array}{l}\text { 모두 } \\
\text { 모름 }\end{array}$ \\
\hline \multirow{3}{*}{$\begin{array}{l}\text { 예술향유 } \\
\text { 지원 정책 }\end{array}$} & 인지 \& 경험 & (549) & 90.0 & 69.6 & 61.4 & 28.8 & 27.0 & 0.0 \\
\hline & 인지 \& 비경험 & (270) & 82.6 & 47.0 & 54.8 & 18.1 & 17.4 & 0.0 \\
\hline & 비인지 & (181) & 0.0 & 0.0 & 0.0 & 0.0 & 0.0 & 100.0 \\
\hline \multirow{3}{*}{$\begin{array}{l}\text { 정부지원 } \\
\text { 충분도 }\end{array}$} & 충분 & (195) & 84.6 & 67.7 & 61.5 & 36.9 & 35.9 & 9.2 \\
\hline & 보통 & (586) & 68.8 & 43.9 & 44.5 & 16.6 & 16.0 & 21.5 \\
\hline & 부족 & (219) & 68.0 & 54.8 & 47.5 & 17.4 & 14.2 & 16.9 \\
\hline
\end{tabular}

(나) 지원 정책 인지 및 경험률

예술향유활동 지원 정책 중 ‘문화가 있는 날 할인’이 $43 \%$ 로 가장 높은 경험률을 보였으며 다음으로 '무료 관람 제도' $30 \%$ )가 높았다. '문화바우처 지원' 정책은 인 지도 대비 경험률이 $16 \%$ 로 타 지원 정책보다 낮은 경험률을 보였다.

[그림 3-22] 예술향유활동 지원 정책 인지 및 경험률: 2020 시민 예술향유 인식 및 예술향유활동 조사

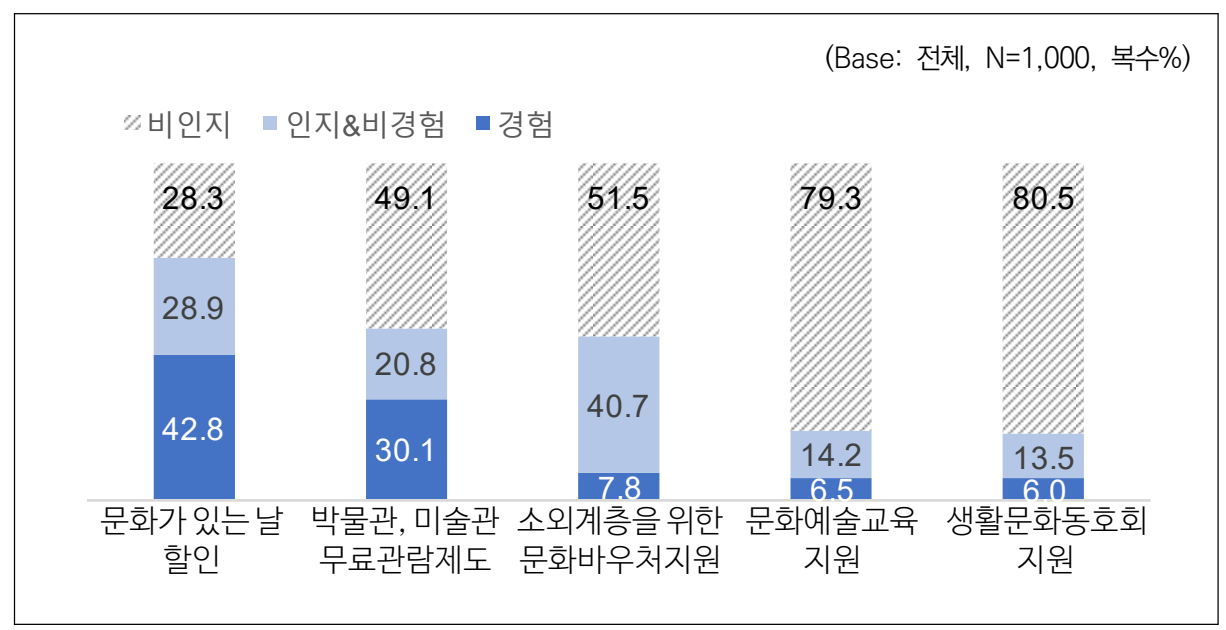

'문화가 있는 날' '무료 관람 제도' '문화바우처 지원' 등 주요 세 정책에 대해 남성보다 여성이 높은 인지도와 경험률을 보인다. 연령대로는 10 대와 20 대에서 이 용률이 높은 편이고, 30대는 인지도가 낮은 수준이다. 특히 ‘문화바우처 지원' (통합 문화이용권)의 경우 200 만원 미만 가구에서 높은 인지도와 경험률을 보이고 있다. 
〈표 3-52〉 응답자 특성별 예술향유활동 지원 정책 인지 및 경험률:

2020 시민 예술향유 인식 및 예술향유활동 조사

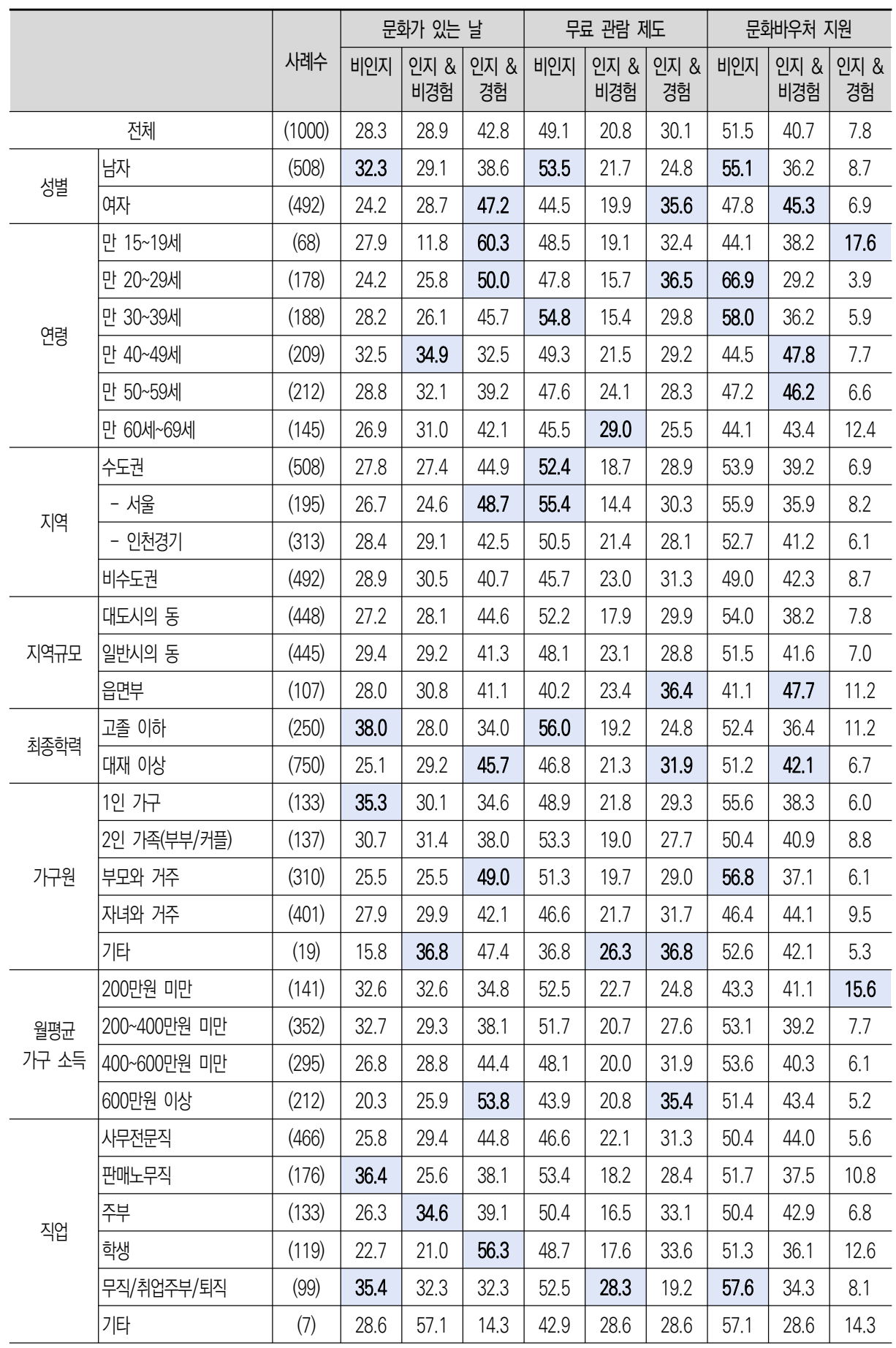




\begin{tabular}{|c|c|c|c|c|c|c|c|c|c|c|c|}
\hline & & \multirow[b]{2}{*}{ 사례수 } & \multicolumn{3}{|c|}{ 문화가 있는 날 } & \multicolumn{3}{|c|}{ 무료 관람 제도 } & \multicolumn{3}{|c|}{ 문화바우처 지원 } \\
\hline & & & 비인지 & $\begin{array}{l}\text { 인지 \& } \\
\text { 비경험 }\end{array}$ & $\begin{array}{c}\text { 인지 \& } \\
\text { 경험 }\end{array}$ & 비인지 & $\begin{array}{l}\text { 인지 \& } \\
\text { 비경험 }\end{array}$ & $\begin{array}{c}\text { 인지 \& } \\
\text { 경험 }\end{array}$ & 비인지 & $\begin{array}{l}\text { 인지 \& } \\
\text { 비경험 }\end{array}$ & $\begin{array}{l}\text { 인지 \& } \\
\text { 경험 }\end{array}$ \\
\hline \multirow{3}{*}{$\begin{array}{c}\text { 예술 } \\
\text { 관심도 }\end{array}$} & 관심있다 & (513) & 15.6 & 26.5 & 57.9 & 34.9 & 21.6 & 43.5 & 40.9 & 49.9 & 9.2 \\
\hline & 보통 & (356) & 36.5 & 33.4 & 30.1 & 59.3 & 22.2 & 18.5 & 59.6 & 33.4 & 7.0 \\
\hline & 관심없다 & (131) & 55.7 & 26.0 & 18.3 & 77.1 & 13.7 & 9.2 & 71.0 & 24.4 & 4.6 \\
\hline \multirow{3}{*}{$\begin{array}{c}\text { 직접관람 } \\
\text { 경험 }\end{array}$} & 무관람(G1) & (297) & 52.5 & 27.9 & 19.5 & 70.4 & 18.2 & 11.4 & 66.7 & 27.3 & 6.1 \\
\hline & 직관 저관여(G2) & (551) & 22.0 & 32.5 & 45.6 & 43.2 & 21.1 & 35.8 & 47.0 & 44.6 & 8.3 \\
\hline & 직관 고관여(G3) & (152) & 3.9 & 17.8 & 78.3 & 28.9 & 25.0 & 46.1 & 38.2 & 52.6 & 9.2 \\
\hline \multirow{2}{*}{$\begin{array}{l}\text { 온라인 매체 } \\
\text { 관람 경험 }\end{array}$} & 있다(G4) & (616) & 18.7 & 27.4 & 53.9 & 38.3 & 23.1 & 38.6 & 42.9 & 47.4 & 9.7 \\
\hline & 없다 & (384) & 43.8 & 31.3 & 25.0 & 66.4 & 17.2 & 16.4 & 65.4 & 29.9 & 4.7 \\
\hline \multirow{2}{*}{$\begin{array}{l}\text { 예술향유 } \\
\text { 활동 경험 }\end{array}$} & 있다(G5) & (388) & 20.6 & 19.6 & 59.8 & 33.5 & 22.4 & 44.1 & 45.6 & 40.5 & 13.9 \\
\hline & 없다 & (612) & 33.2 & 34.8 & 32.0 & 59.0 & 19.8 & 21.2 & 55.2 & 40.8 & 3.9 \\
\hline \multirow{3}{*}{$\begin{array}{c}\text { 예술향유 } \\
\text { 지원 정책 }\end{array}$} & 인지 \& 경험 & (549) & 10.0 & 12.0 & 78.0 & 30.4 & 14.8 & 54.8 & 38.6 & 47.2 & 14.2 \\
\hline & 인지 \& 비경험 & (270) & 17.4 & 82.6 & 0.0 & 53.0 & 47.0 & 0.0 & 45.2 & 54.8 & 0.0 \\
\hline & 비인지 & (181) & 100.0 & 0.0 & 0.0 & 100.0 & 0.0 & 0.0 & 100.0 & 0.0 & 0.0 \\
\hline \multirow{3}{*}{$\begin{array}{c}\text { 정부지원 } \\
\text { 충분도 }\end{array}$} & 충분 & (195) & 15.4 & 32.3 & 52.3 & 32.3 & 24.1 & 43.6 & 38.5 & 48.7 & 12.8 \\
\hline & 보통 & (586) & 31.2 & 29.4 & 39.4 & 56.1 & 19.3 & 24.6 & 55.5 & 39.1 & 5.5 \\
\hline & 부족 & (219) & 32.0 & 24.7 & 43.4 & 45.2 & 21.9 & 32.9 & 52.5 & 37.9 & 9.6 \\
\hline
\end{tabular}

'문화예술교육 지원' 과 '생활문화동호회 지원' 은 50세 이상, 비수도권, 읍면부 등 에서 상대적으로 높은 인지도와 경험률을 보이는 것으로 나타났다.

(2) 예술향유활동 정책 지원 충분성 인식

예술향유활동 정책 지원이 충분하다는 의견은 $20 \%$, 부족하다는 의견은 $22 \%$ 로 약간 부족한 것으로 인식하고 있음이 나타났다. 
[그림 3-23] 예술향유활동 정책 지원 충분성 인식: 2020 시민 예술향유 인식 및 예술향유활동 조사

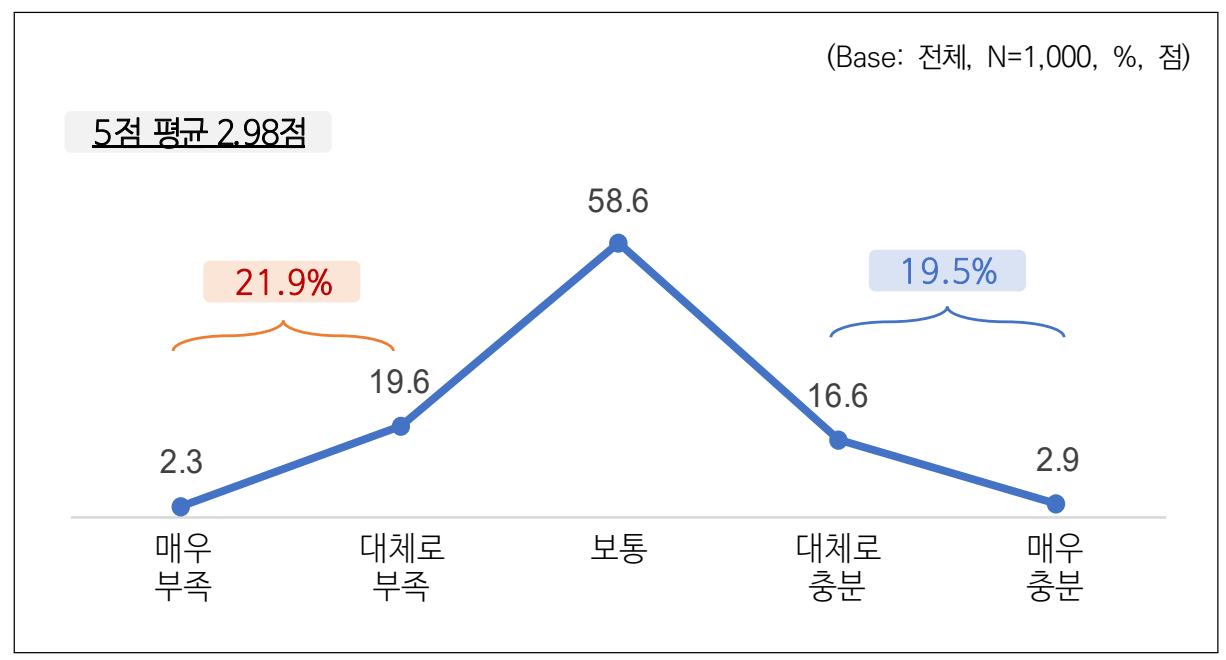

그러나 지역별로 보면 수도권 거주자는 ‘보통이다’라는 의견이 상대적으로 많은 반면 비수도권 거주자는 '부족하다’는 의견을 많이 보였다. 또한 도시의 동 거주자 대비 읍면부 거주자가 ‘부족하다’는 의견이 대체적으로 높았다. 월평균 가구 소득이 낮을수록 '부족하다'는 의견이 증가하고 ‘충분하다'는 의견은 감소하는 경향을 보이 고 있음이 확인된다.

(3) 필요 예술향유활동 정부 지원

예술향유활동 정부 지원으로 필요한 정책은 '관람 비용 할인'(54\%), '무료관람 확 대'(51\%), '거주지 문화시설 확충'(46\%) 순으로 나타났다. 
[그림 3-24] 필요 예술향유활동 정부 지원: 2020 시민 예술향유 인식 및 예술향유활동 조사

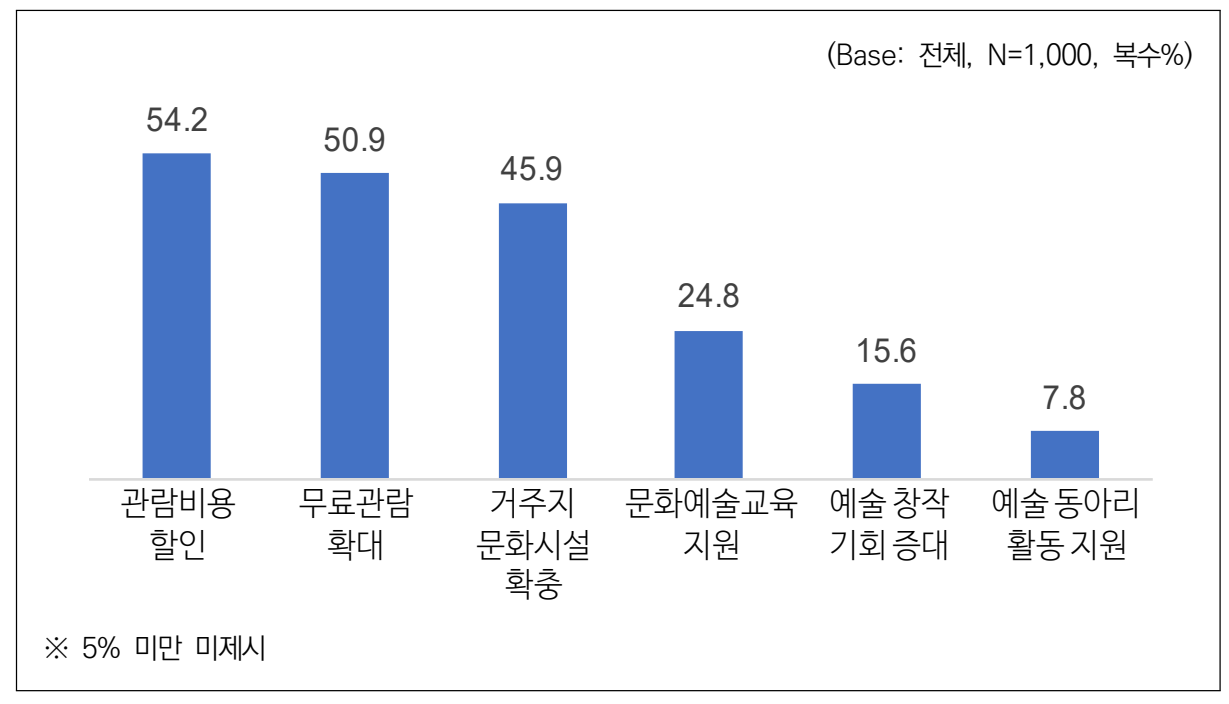

남자는 상대적으로 '무료관람 확대’를, 여자는 '거주지 문화시설 확충’을 더 많이 응답하였다. 연령별로 10대는 '관람비용 할인'을, 20대는 '거주지 문화시설 확충' 을, 40 50대는 ‘무료 관람 확대’를 상대적으로 더 많이 응답하였다. 읍면부 거주자 는 도시의 동 거주자 대비 '거주지 문화시설 확충'을 더 많이 응답하였다.

\section{2. 시민 예술향유 인식 및 예술향유활동 FGI}

\section{가. 조사개요}

1) 조사목적

문화예술 향유자의 예술 인식과 향유 양태의 심층적 분석을 위해 집단별 심층면 담을 실시하였다. 
2) 조사개요

〈표 3-53〉 시민 예술향유 인식 및 예술향유활동 FGI 개요

\begin{tabular}{c|l}
\hline 구분 & \multicolumn{1}{c}{ 내용 } \\
\hline 조사 방법 & FGI (그룹별 심층 면접) \\
\hline 표본수 & 전체 24명, 그룹별 4 6명 \\
\hline 모집단 & 서울 포함 수도권 거주 만15세 이상 일반 시민 \\
\hline 표집 방법 & 선정 질문지를 이용한 개별 컨택 \\
\hline 조사 기간 & 2020년 8월 5일 8월 10일 \\
\hline 조사수행기관 & (주) 글로벌리서치 \\
\hline
\end{tabular}

3) 인터뷰 대상 그룹별 구성 및 선별 기준

〈표 3-54〉시민 예술향유 인식 및 예술향유활동 FGI: 그룹별 구성 및 선별 기준

\begin{tabular}{c|l}
\hline 구분 & \multicolumn{1}{c}{ 그룹 특징 } \\
\hline 직접관람 $(\mathrm{G} 2+\mathrm{G} 3)$ & $\begin{array}{l}\text { - 고관여: 최근 1년 기준 장르별 3개 이상 직관람 경험 7회 이상 } \\
\text { - 저관여: 최근 1년 기준 직관람 경험 6회 이하 }\end{array}$ \\
\hline 온라인매체 주이용자 $(\mathrm{G} 4)$ & 최근 1년 기준 문화예술향유 경험 중 온라인 매체 이용 주이용자 \\
\hline 예술향유 참여활동 경험자 (G5) & 창작·실연, 교육, 동호회, 자원봉사·기부 경험자 \\
\hline 무관심자 (G1) & 최근 1년 이내 직관 및 온라인 이용 문화예술 향유 경험 없음 \\
\hline
\end{tabular}

관람 경험의 기간선정에 있어 최근 코로나19 상황을 고려하여 온라인 매체 관람 이 급증할 것으로 예상되고 그 영향에 관한 심도깊은 파악을 위해 온라인 설문조사 의 기준과 달리 최근 1 년간으로 설정하였다.

\section{4) 조사영역}

조사영역은 온라인 설문조사 조사영역을 기준으로 하되, 질적 인터뷰의 특성 및 효과를 배가하기 위해 조사 영역별 순서와 세부 질문 등을 일부 수정, 보완하여 진 행하였다. 그룹별 공통질문과 세부질문을 구분하여 접근하였다. 
〈표 3-55〉 시민 예술향유 인식 및 예술향유활동 FGI: 조사영역

\begin{tabular}{|c|c|c|}
\hline & 구분 & 내용 \\
\hline $\begin{array}{l}\text { 공통질문 } 1 \\
\text { (G1 G5) }\end{array}$ & 예술에 대한 인식 & $\begin{array}{l}\text { - ‘예술’에 대한 인식 (이미지) 예술 범주에 대한 인식 } \\
\text { - 현재 여가/취미활동에서의 예술향유 현황 및 비중 } \\
\text { - 개인의 관심 정도와 이유 } \\
\text { - 예술 및 예술향유활동 범주에 관한 인식 } \\
\text { - 예술의 가치에 관한 인식(개인적, 사회적) } \\
\text { - 환경변화에 따른 예술 변화 } \\
\text { - 예술에 대한 개인의 효능감 }\end{array}$ \\
\hline \multirow{2}{*}{$\begin{array}{c}\text { 그룹별 특성에 } \\
\text { 맞춰 항목 선택하여 } \\
\text { 진행 }\end{array}$} & $\begin{array}{l}\text { 예술 관람 실태 } \\
\text { (온/오프라인) }\end{array}$ & $\begin{array}{l}\text { - 직접 관람 여부 및 횟수 } \\
\text { - 온라인 관람 여부 및 매체 } \\
\text { - 직접 관람/온라인 관람별 향유 활동 구성 요소 } \\
\text { (경로/동기, 매개, 효과) } \\
\text { - 직접 관람/온라인 관람별 향유활동 걸림돌(외적·내적 측면) }\end{array}$ \\
\hline & $\begin{array}{c}\text { 예술 참여활동 } \\
\text { 실태 }\end{array}$ & $\begin{array}{l}\text { - 예술향유 참여활동(창작·실연, 교육, 동호회, 자봉/기부) 여부, } \\
\text { 빈도 } \\
\text { - 예술향유 참여활동의 걸림돌(외적·내적) } \\
\text { - 예술향유 참여활동의 경로/매개/동기/효과 } \\
\text { - 향후 지속 참여 의향 }\end{array}$ \\
\hline $\begin{array}{l}\text { 공통질문 } 2 \\
\text { (G1 G5) }\end{array}$ & $\begin{array}{l}\text { 예술 지원 } \\
\text { 정책 인식 }\end{array}$ & $\begin{array}{l}\text { - 정부 지원 정책 인지도 및 경험 정책 } \\
\text { - 정부 지원 수요 }\end{array}$ \\
\hline
\end{tabular}

\section{5) 그룹별 참여자}

〈표 3-56〉 G1 예술향유 무관심자: 2020 시민 예술향유 인식 및 예술향유활동 FGI

\begin{tabular}{|c|c|c|c|c|c|c|}
\hline 연번 & 이름 & 연령 & 성별 & 직업 & 가구소득 & $\begin{array}{l}\text { 문화예술향유 } \\
\text { 월평균 지출액 }\end{array}$ \\
\hline 1 & 주○○ & 25 & 남 & 대학생 & 월 800만원 & - \\
\hline 2 & 장○○ & 35 & 남 & 사무직 & 월 1000만원 & - \\
\hline 3 & 김이 & 25 & 여 & 사무직 & 월 600만원 & - \\
\hline 4 & 송○○ & 31 & 여 & 사무직 & 월 1000만원 & - \\
\hline 5 & 박○○ & 41 & 여 & 사무직 & 월 500만원 & - \\
\hline
\end{tabular}


〈표 3-57〉 G2·G3 예술향유 직접관람 저·고관여자: 2020 시민 예술향유 인식 및 예술향유활동 FGI

\begin{tabular}{|c|c|c|c|c|c|c|c|}
\hline 연번 & 구분 & 이름 & 연령 & 성별 & 직업 & 가구소득 & $\begin{array}{l}\text { 문화예술향유 } \\
\text { 월평균 지출액 }\end{array}$ \\
\hline 1 & 고관여자 & 0100 & 24 & 남 & 대학생 & - & 5만원 \\
\hline 2 & 고관여자 & 김○○ & 58 & 남 & 사무직 & - & 6만원 \\
\hline 3 & 고관여자 & 김○○ & 16 & 여 & 학생 & - & 10만원 \\
\hline 4 & 고관여자 & 임00 & 23 & 여 & 대학생 & - & 20만원 \\
\hline 5 & 고관여자 & 박ㅇ & 32 & 여 & 사무직 & - & 10만원 \\
\hline 6 & 저관여자 & 김00 & 30 & 남 & 사무직 & - & 5만원 \\
\hline 7 & 저관여자 & 강○○ & 40 & 남 & 사무직 & - & 5만원 \\
\hline 8 & 저관여자 & 노○○ & 26 & 여 & 사무직 & - & 5만원 \\
\hline 9 & 저관여자 & 강ㅇ & 28 & 여 & 사무직 & - & 5만원 \\
\hline
\end{tabular}

〈표 3-58〉 G4 온라인 매체 주이용자: 2020 시민 예술향유 인식 및 예술향유활동 FGI

\begin{tabular}{c|c|c|c|c|c|c}
\hline 연번 & 이름 & 연령 & 성별 & 직업 & 가구소득 & $\begin{array}{c}\text { 문화예술향유 } \\
\text { 월평균 지출액 }\end{array}$ \\
\hline 1 & 공 & 29 & 남 & 사무직 & 월 1000만원 & 30 만원 \\
\hline 2 & 김Oᄋ & 33 & 남 & 사무직 & 월 650만원 & 30 만원 \\
\hline 3 & 안ㅇ & 50 & 남 & 사무직 & 월 450만원 & 15 만원 \\
\hline 4 & 종 & 33 & 여 & 사무직 & 월 700만원 & 10 만원 \\
\hline 5 & 송ㅇ & 41 & 여 & 전업주부 & 월 750만원 & 25만원 \\
\hline
\end{tabular}

〈표 3-59〉 G5 예술향유활동 참여 경험자: 2020 시민 예술향유 인식 및 예술향유활동 FGI

\begin{tabular}{|c|c|c|c|c|c|c|}
\hline 연번 & 이름 & 연령 & 성별 & 직업 & 가구소득 & $\begin{array}{l}\text { 문화예술향유 } \\
\text { 월평균 지출액 }\end{array}$ \\
\hline 1 & 김OO & 25 & 남 & 대학생 & 월 300만원 & 15만원 \\
\hline 2 & 황○○ & 32 & 남 & 사무직 & 월 700만원 & 10만원 \\
\hline 3 & 안○○ & 47 & 남 & 전문직 & - & 20 30만원 \\
\hline 4 & 신00 & 39 & 여 & 전업주부 & 월 700만원 & 10만원 \\
\hline 5 & 최○○ & 45 & 여 & 자영업 & 월 700만원 & 3만원 \\
\hline
\end{tabular}




\section{나. 조사결과61)}

1) 예술향유활동에 대한 관심과 가치

(1) 예술향유활동 관심도 및 (비)향유동기

‘예술'에 대한 평소 관심도, 전체 여가생활 중에서 예술향유활동의 비중, 그리고 '예술향유(비)활동의 동기(계기)'를 묻는 질문에 대해 FGI 참여자들은 활동정도에 따라 대비되는 답변을 제시하였다. 직접 관람자 그룹(고관여+저관여), 온라인 주이 용자그룹, 참여활동 경험자들은 대부분 예술에 대한 관심도가 높고, 전체 여가 중에 서 예술향유 비중도 높은 편으로 나타났으며, 향유 동기에 있어 즐거움, 삶의 질 등 을 꼽았다.

반면, 무관심 그룹의 경우 평소 예술에 대한 관심 자체가 희박하다고 응답했다. 무관심 그룹 참여자 중에는 '시기적 무관심자(과거에는 향유했으나 현실적 문제로 인해 하지 않는)'도 있었지만, '원래 무관심자'의 경우 공통적으로 '어렸을 적 관련 경험을 거의 하지 않아서 익숙해지거나, 관심을 가질 기회가 없었다'는 의견이 제시 되었다. 이들의 경우 ‘예술향유활동을 하지 않는 이유'에 있어 재미와 흥미가 없다 는 의견 외에도 시간과 돈을 투자해도 그에 상응하는 만족감, 즐거움이 없다는 '기 회비용’ 관점에서 예술향유를 인식하는 경향도 보였다.

〈표 3-60〉 FGI 참여자 특성별 예술향유 관심도 및 동기

\begin{tabular}{|c|c|}
\hline 구분 & 그룹 특징 \\
\hline 직접관람 & $\begin{array}{l}\text { - 전체 참여자 중 절반 정도가 여가 중 예술향유활동의 비중이 높다고 응답, 향유활동 } \\
\text { 자체에 대한 관심은 대부분 가지고 있음 } \\
\text { - 관심, 호기심, 경험의 가치, 심리적 불안감 해소 등이 예술을 통해 얻는 주된 효과이 } \\
\text { 며 그룹별 차이는 크지 않음 }\end{array}$ \\
\hline 온라인매체 주이용자 & $\begin{array}{l}\text { - 전체 참여자 중 절반 이상이 여가 중 예술향유활동의 비중이 높다고 응답, 향유활동 } \\
\text { 자체에 대한 관심은 대부분 가지고 있음 } \\
\text { - 관심, 삶의 질 향상, 즐거움 추구, 감명 등이 예술을 통해 얻는 주된 효과 }\end{array}$ \\
\hline $\begin{array}{c}\text { 예술향유 } \\
\text { 참여활동 경험자 }\end{array}$ & $\begin{array}{l}\text { - 참여하고 있는 예술 활동으로는 도슨트 봉사, 국악 동호회, 목공 교육, 합창 동아리, } \\
\text { 음악 창작 등으로 다양했음 } \\
\text { - 여가 중 예술향유의 비중도 최소 } 30 \text { 에서 최대 } 80 \text { 으로 비중이 높은 편 }\end{array}$ \\
\hline
\end{tabular}

61) 아래 조사결과에서는 조사항목별 순차 기술보다는, 질문 항목별 그룹별 응답 차이점과 공통점 중심으로 분석한다. 이후 개별 인터뷰 실제 스크리트 인용문 활용은 이어지는 제 3 절에서 필요에 따라 제시한다. 


\begin{tabular}{c|c}
\hline 구분 & 그룹 특징 \\
\hline & - 전체 참여자의 다수가 평소 예술에 관심이 없었음. 이들은 여가 시간에 맛집 탐방, \\
& 운동, 정보 검색을 목적으로 한 스마트폰, 유튜브 시청 등을 주로 함 \\
무관심자 & - 원래 무관심자와 시기적 특성 무관심자로 나님. 전자는 접할 기회가 별로 없었거나 \\
& 재미, 보람을 별로 못 느낌. 후자는 어렸을 때 좋아했으나 현실적 문제에 부딪히며 \\
& 점점 관심을 놓음 \\
\hline
\end{tabular}

(2) '예술' 연상 이미지

“'예술’이라는 단어를 들으면 어떤 것(사물, 이미지, 형용사, 단어 등)이 떠오르는 가"라는 질문을 FGI 참여자에게 던졌을 때, 고관여자와 무관심자 간의 차이점은 명 확하게 드러난 편이었다. 직접 관람자(고관여+저관여자)와 온라인 주이용자에게는 모두 일상적 휴식이면서도 동시에 돈이 필요한 직업 등 예술에 대한 전통적 이미지 는 물론 개인적 차원에서 느끼는 정서적 반영이 포착되었다. 참여활동자일수록 예 술에 대한 이미지는 긍정적이고 고차원적이었으며, 무관심자일수록 거리감 있는 이 미지를 제시했다. 이를 통해 예술향유 경험의 정도나 관심 뿐 아니라 참여에서의 주체적 개입 정도에 따라 '예술'에 대한 대비되는 이미지나 인상을 가지고 있음이 확인되었다.

〈표 3-61〉 FGI 참여자 특성별 예술향유 연상 이미지

\begin{tabular}{|c|c|c|}
\hline \multicolumn{2}{|c|}{ 구분 } & 연상 이미지 \\
\hline \multirow{2}{*}{$\begin{array}{l}\text { 직접 } \\
\text { 관람 }\end{array}$} & 저관여 & $\begin{array}{l}\text { - 재력, 타임머신(과거와 현재를 이어주는, 과거의 음악을 지금도 들을 수 있는) } \\
\text { - 순수, 감성적이고 안정감을 줄 수 있는 것 }\end{array}$ \\
\hline & 고관여 & $\begin{array}{l}\text { - 여유, 낭만이나 휴식 } \\
\text { - 바쁜 일상에서 벗어날 수 있는 매개체, 그림이나 음악으로 여유를 즐기는 것 }\end{array}$ \\
\hline \multicolumn{2}{|c|}{ 온라인매체 주이용자 } & $\begin{array}{l}\text { - 돈 } \\
\text { - 사람에게 필수요소 } \\
\text { - 감동을 주는, 정신적 치유 } \\
\text { - 예술인에게는 그들만의 리그, 나 같은 이는 관람객 }\end{array}$ \\
\hline \multicolumn{2}{|c|}{$\begin{array}{l}\text { 예술향유 } \\
\text { 참여활동 경험자 }\end{array}$} & $\begin{array}{l}\text { - 창작, 신이 주신 선물, 음악, 미술 } \\
\text { - 아름다움, 즐겁다, } \\
\text { - 제일 쉬운 취미 활동(영화나 악기 연주 등 제일 많이 한다) } \\
\text { - 가난하다, 난해하다, 4차원, 고집 }\end{array}$ \\
\hline \multicolumn{2}{|c|}{ 무관심자 } & $\begin{array}{l}\text { - 어렵다, 복잡하다(단순 여가 생활로 즐기기에는 어려운 분야 같다) } \\
\text { - 거리감이 있다, 관심 없다(그런가 보다) } \\
\text { - 인간의 내재적인 욕망을 표현하는 방식 } \\
\text { - 논리가 들어있지 않은(추상적인 느낌) }\end{array}$ \\
\hline
\end{tabular}


(3) 예술의 가치 (개인적 가치/ 사회적 가치)

'예술이 개인적 차원, 그리고 사회적 차원에서 어떤 의미를 가질 수 있는지'를 질 문했을 때, FGI 참여자들 대부분 개인적, 사회적 차원에서의 가치를 긍정적으로 답 변했지만, 무관심자 그룹의 경우 개인적인 측면에서 타 활동 대비 예술의 가치에 대한 인식정도가 확연히 대비되었다.

개인적 가치는 주로 즐거움, 자극, 편안함으로 직접관람과 온라인 주이용자에서 유사한 답변이 나왔고, 참여활동자의 경우는 대리만족의 충만감과 다양성, 표현하 는 것에 대한 즐거움 등 보다 적극적인 인식을 하고 있는 점이 나타났다. 사회적 가치의 경우 공공의 복지/국위선양과 사회안정과 통합, 방향제시 차원으로 그룹 내 유사하게 나타났다. 주목되는 지점은 예술향유에 많이 개입하는 참여자 뿐 아니라 무관심 그룹의 경우도 예술의 사회적 가치에 대해서는 긍정적으로 인식하고 있다는 점이다. 이러한 측면은 한편으로 예술의 사회적 가치에 대해서 대부분 합의하고 있 는 것처럼 표면적으로 보일 수는 있으나, 개인의 경험, 관심정도 등에 따라서 실질 적으로 인식하는 예술의 가치는 다를 수 있다고 해석할 수 있다.

〈표 3-62〉 FGI 참여자 특성별 예술의 가치(개인/사회적) 인식

\begin{tabular}{|c|c|c|}
\hline 구분 & 개인적 가치 & 사회적 가치 \\
\hline 직접관람 & $\begin{array}{l}\text { - 삶의 자극제 } \\
\text { - 자주 접해보지 않은 영역 } \\
\text { - 알고 싶은 것 } \\
\text { - [-]거리감이 있는 }\end{array}$ & $\begin{array}{l}\text { - 공공의 복지 } \\
\text { - 친목의 자리 } \\
\text { - 다가가기 어려운 } \\
\text { - 취미를 강요하는 느낌(하지 않으면 도태 } \\
\quad \text { 된 사람이다, 아웃사이더다) }\end{array}$ \\
\hline $\begin{array}{c}\text { 온라인매체 } \\
\text { 주이용자 }\end{array}$ & $\begin{array}{l}\text { - 즐거움, 일상의 스트레스 해소 } \\
\text { - 가장 가치 있는 소비 } \\
\text { - 친구 같은(흔하게 접할 수 있고, 마음이 } \\
\text { 편안해져서) } \\
\text { - 감동(마음 속에서 우러나오는 감동, 아티 } \\
\text { 스트의 노력이 보여서) } \\
\text { - 상상할 수 있는 }\end{array}$ & $\begin{array}{l}\text { - 선진국의 척도 } \\
\text { - 국위선양의 기능 } \\
\text { - 사회 안정에 도움이 되는(사회적 생존과 } \\
\quad \text { 정의 스트레스 해소) } \\
\text { - 사회적 통합(빈부격차가 있지만 상호동질 } \\
\quad \text { 감 부여) }\end{array}$ \\
\hline $\begin{array}{c}\text { 예술향유 } \\
\text { 참여활동 경험자 }\end{array}$ & $\begin{array}{l}\text { - 가족들과 보내는 행복한 시간 } \\
\text { - 삶을 윤택하게 해주는 윤활유 } \\
\text { - 대리만족 } \\
\text { - 다른 세계, 다양한 사람들을 만남 } \\
\text { - 표현(나의 감정이나 생각을 표현) } \\
\text { - [-]실용적이지 않은 } \\
\text { - 내가 좋아서 시간과 에너지 투자 }\end{array}$ & $\begin{array}{l}\text { - 긴장을 이완시키는 역할 } \\
\text { - 사람을 하나로, 뭉치게 하는 역할 } \\
\text { - 삶의 재미를 느끼게 해주는 역할 } \\
\text { - 시대를 표현하는 역할 } \\
\text { - 방향을 제시하는 역할(예술가들이 자기만 } \\
\quad \text { 의 것들을 추구해서 활동했던 것들이 세 } \\
\quad \text { 대를 거쳐 반영됨) }\end{array}$ \\
\hline
\end{tabular}




\begin{tabular}{c|l|c}
\hline 구분 & 개인적 가치 & 사회적 가치 \\
\hline & - 순수한 여가(목적이 있는 활동과 다르게 & \\
& 진짜 좋아서 하는) & - 평화를 이루는 하나의 도구 \\
& $-[-]$ 불편함(어려움) & - 하나의 산업 영역으로 엄청난 일자리 창 \\
무관심자 & $-[-]$ 현실적으로 누리기 어려운 & 출 가능성 \\
& $-[-]$ 시간이 아까움(책은 독해 능력 향상에 & - 일상을 쉬어가는 기능/리프레시 \\
& 도움이 되지만, TV나 영화는 그런거랑 & - 인간관계 형성에 있어서 필요한 존재 \\
& 관련이 없음) 차라리 잠, 투자, 건강, 투 & (공감대 형성싱) \\
& 자 등에 관심을 갖겠다. & \\
\hline
\end{tabular}

(4) 효능감

예술향유활동에 있어 관람, 창작/실연 등 일련의 예술향유 관련 활동에 있어 본 인들이 얼마나 편안하게 느끼는지, 예술교육이나 활동에서 마주할 수 있는 위기나 난관 등에 주체적으로 개입, 극복할 수 있는 자신감 등에 관한 질문에 있어 전체 참여자 중 효능감을 높게 느끼는 이들은 참여활동 경험자 > 직접관람 고관여자 > 저관여자, 온라인매체 주이용자 > 무관심자 순으로 나타났다.

그렇게 생각하는 계기 혹은 동기 등 배경에 대한 답변에 따르면, 주변 예술관련 종사자 유무 및 어린 시절 경험 등이 개인의 효능감에 영향을 미치고, 효능감은 예 술향유 활동의 깊이와 적극성에 영향을 준 것으로 파악되었다. 예술과 관련된 경험 은 물론 가족이나 지인 중 예술가나 관련 활동을 하는 이들과 접촉하면서 성장한 경우 효능감에 대해 긍정적으로 응답하였다.

〈표 3-63〉 FGI 참여자 특성별 예술향유 효능감

\begin{tabular}{c|c}
\hline 구분 & 효능감 \\
\hline \multirow{5}{*}{ 직접관람 } & - 예술향유 및 관련 활동에 불편함을 느끼는 참여자는 없음. 개인의 성장 환경, 가치관 \\
& 등에 따라 효능감에 차이를 보이며 저관여, 고관여 그룹간 차이가 존재함 \\
& - 특히 고관여자의 경우 부모님이나 친구 등 주변 인물의 영향으로 예술영역에 대한 \\
& 관심이 높은 편 \\
& - 고관여 그룹은 저관여 대비 향유 측면에서의 어려움은 노력으로 극복할 수 있으며, \\
& 예술 영역에서의 기질도 어느 정도 보유하고 있다고 인식 \\
& - 저관여 그룹이 상대적으로 좀 더 예술에 대한 거리감을 갖고 있음 \\
\hline & - 예술향유 및 관련 활동에 불편함을 느끼는 참여자는 없음 \\
& - 특히 향유 측면에서의 어려움은 노력으로 극복할 수 있으며 그 도전에 의의가 있다는 \\
& 의견롸, 아인매체 주이용용아역엑에서는 타고난 재능과 기질이 중요하다는 의견 차이가 두드러짐 \\
& - 예술 활동/과정에 대해서는 주변에 예술영역 종사자 및 관련자들이 있는지의 여부와 \\
& 그 영향력에서 차이를 보임
\end{tabular}




\begin{tabular}{|c|c|}
\hline 구분 & 효능감 \\
\hline $\begin{array}{c}\text { 예술향유 } \\
\text { 참여활동 경험자 }\end{array}$ & $\begin{array}{l}\text { - 예술향유 및 관련 활동에 대한 불편함을 대부분 느끼지 않았음. 어렸을 때부터 친숙 } \\
\text { 하다는 의견 존재 } \\
\text { - 반면 예술가적 기질이나 재능에 대해서는 이견을 보이며 재능을 알아볼 기회가 경제 } \\
\text { 적 여건으로 주어지지 않았다는 의견이 있음 } \\
\text { - 또한 주변에 예술가 및 관련 종사자들의 여부 및 영향력의 차이는 사람에 따라 상이 } \\
\text { 했음 }\end{array}$ \\
\hline 무관심자 & $\begin{array}{l}\text { - 예술향유 및 관련 활동에 대해 불편함을 느끼는 이유로는 이해의 어려움이 주였음 } \\
\text { - 특히 향유 측면에서의 어려움에 대해서는 대다수가 노력으로 극복할 수 없다고 한 } \\
\text { 것이 두드러지며, 타고난 재능이 있어야 한다고 생각함 } \\
\text { - 예술 활동ㄱ과정에 대해서는 주변에 예술영역 종사자 및 관련자들이 없어서 잘 모른다 } \\
\text { 는 응답자가 다수였음 } \\
\text { - 예술활동에 참여하는 것이 편안하지 않다는 응답자가 다수였으나, 여건이 되면 예술 } \\
\text { 향유를 좋아한다는 응답도 존재함 }\end{array}$ \\
\hline
\end{tabular}

\section{2) 예술향유 활동 현황}

(1) 예술향유 활동의 동기와 효과

직접관람자 중 저관여, 고관여 그룹 모두 예술향유활동(직관람)을 통해 '삶의 질 향상 효과를 얻는 것으로 응답했다. 저관여 그룹이 예술향유를 접촉함으로써 얻는 '현장의 에너지'적 측면을 중요시한 반면, 고관여 그룹은 현장감을 강조하되 '지적 인 자극을 통한 시각/관점 확대의 의미'로 접근하는 경향이 나타났다. 온라인을 통 한 관람의 경우 예술향유의 편리성과 편의성을 향상시키는 반면 중독성(미드 등)과 현장감에 대한 갈증이나 니즈를 불러일으키기도 한다는 응답이 제시되었다.

특히 참여활동에 대한 효과에 있어 다른 예술향유활동과 달리 성취감, 소속감을 언급한 것이 두드러지며, 참여활동자의 경우 대부분 직접관람으로부터의 전이가 나 타났다고 응답했다.

〈표 3-64〉 FGI 참여자 특성별 예술향유활동 동기 및 효과

\begin{tabular}{c|c}
\hline 구분 & 예술향유 활동의 계기와 효과 \\
\hline & - (동기) 직접관람을 하는 이유는 '현장감' \\
& - (효과) 직접관람을 통해 얻는 효과에서 저관여자들은 삶의 에너지, 대화 주제, 관람 \\
& 과 관련된 기분 등을 표현하는 반면 고관여자들은 사고의 깊이, 지적인 자극 등을 \\
& 언급함 \\
& 직접관람 \\
& (매개) 직접관람을 하게 만드는 매개체로 참여자들 모두가 자신의 관심도, 흥미, 선 \\
& 훌어 이벤트 초대, 대중성, 접근성 등의 외적인 영향이 큰 영향을 미침 \\
\hline
\end{tabular}




\begin{tabular}{|c|c|}
\hline 구분 & 예술향유 활동의 계기와 효과 \\
\hline $\begin{array}{c}\text { 온라인 매체 } \\
\text { 주이용자 }\end{array}$ & $\begin{array}{l}\text { - (효과) 온라인 관람을 통해 얻는 효과는 편리함. 반면 직접관람을 통해 얻는 효과로 } \\
\text { 현장감, 감명, 아쉬움 등 언급 } \\
\text { - (매개) 온라인 관람을 하게 만드는 매개체로 한 달 무료 체험, 지인 추천, 리뷰나 } \\
\text { 랭킹, 알고리즘, 라이브 인터뷰 등의 외적인 영향 존재 } \\
\text { - (매개) 직접관람 매개체는 초대권, 광고 문구 등 외적인 영향에 더해 내가 좋아하는 } \\
\quad \text { 아티스트, 어떤 배우, 어디서 하는지 등의 내적인 영향도 중요 }\end{array}$ \\
\hline $\begin{array}{c}\text { 예술향유 } \\
\text { 참여활동 경험자 }\end{array}$ & $\begin{array}{l}\text { - (동기) 참여활동의 계기는 직업적으로 일을 해봐서, 정말 좋아하는 일을 하고 싶어 } \\
\text { 서, 좋아하는 일을 직업이 아닌 취미로 하기 위해서 등임. 특히 좋아하지만 직업적 } \\
\text { 으로 돈이 안 되어 취미로 한다는 의견이 많았음 } \\
\text { - (효과) 향유활동에 비해 참여활동의 효과는 성취감, 일원이 된다는 기분, 진정한 예 } \\
\text { 술 활동에의 뿌듯함이 있음 } \\
\text { - 직접관람에서 참여 활동으로의 전이는 활발한 편 }\end{array}$ \\
\hline
\end{tabular}

(2) 예술향유 활동에서의 걸림돌(애로사항)

고관여자일수록 직접관람에 대한 돈, 시간, 정보 등의 외적요소인 걸림돌이 커지 며, 참여활동자에게는 외적요소가 걸림돌의 대부분이었다. 무관심자 경우 예술향유 에 대한 거리감, 필요성, 공감성 등을 언급하는 등 내적·심리적 요인이 가장 큰 걸림 돌로 나타났으며, 온라인 매체 관람은 현장감과 몰입감의 부족이 가장 큰 걸림돌이 었다. 무관심 그룹을 제외한 참여자 대부분이 걸림돌이 사라진다면 예술향유를 더 많이 할 것이라고 응답하였다.

〈표 3-65〉 FGI 참여자 특성별 예술향유활동 걸림돌

\begin{tabular}{|c|c|}
\hline 구분 & 예술향유 활동에서의 걸림돌(애로사항) \\
\hline 직접관람 & $\begin{array}{l}\text { - 직접관람을 할 때의 걸림돌 요소로 '기회비용', '시간' 또는 '정보의 부족' 등이 공통적 } \\
\text { 으로 제시됨 } \\
\text { - 그 밖에 저관여 그룹은 내적요소(필요성, 공감성, 이해도)의 걸림돌도 존재 } \\
\text { - 고관여 그룹은 내적 요소의 걸림돌은 적은 반면, 상대적으로 더 많은 예술향유를 위한 } \\
\text { 외적요소(시간, 비용)의 걸림돌 요소가 존재 }\end{array}$ \\
\hline $\begin{array}{l}\text { 온라인 매체 } \\
\text { 관람 주이용자 }\end{array}$ & $\begin{array}{l}\text { - 온라인 매체 관람을 할 때의 장점은 편리함, 신속함, 저렴한 비용, 다회차 관람, 편의 } \\
\text { 성 등이 있으나, 공통적인 걸림돌 요소는 특히 몰입도 및 현장감 부족임. 그 밖에 방 } \\
\text { 해요소 존재, 가격 차별화, 눈속임 등도 존재 }\end{array}$ \\
\hline $\begin{array}{c}\text { 예술향유 } \\
\text { 참여활동 경험자 }\end{array}$ & $\begin{array}{l}\text { - 참여활동 경험자 중 참여활동 비중이 낮고, 직접관람이 높은 이들은 참여활동에 대한 } \\
\text { 시간이 많이 나지 않는다고 응답함 } \\
\text { - 걸림돌로는 시간 제약, 정보 부족(누가 알려주지 않는 이상 혼자 찾아야 해서 어려움), } \\
\text { 공간 대여 제약, 금전적인 이유가 존재함 }\end{array}$ \\
\hline 무관심자 & $\begin{array}{l}\text { - 외적인 측면으로는 시간, 비용 등 } \\
\text { - 심리적 측면으로는 필요성 부족, 기초지식의 부족 언급 }\end{array}$ \\
\hline
\end{tabular}


(3) 온라인 관람 등 기술적 변화가 예술향유에 미치는 영향

최근 코로나19 확산 등으로 급작스럽게 온라인 향유가 확산되는 현 상황에서 고 +저관여자들 및 온라인 주이용자, 참여활동자 모두 온라인 매체를 통한 예술관람이 나 활동은 '대체재’라기 보다 '보완재’에 가까움에 대부분 동의했다. 참여활동자 그 룹에 있어서는 관람 외에도 예술창작/실연이나 교육 등 참여활동에 있어서도 기술 변화와 온라인 기반 활동을 활용하고 있음이 나타났다.

향후 온라인 매체 비중이 증가될 것이라는 전망에는 대부분의 참여자가 동의했으 나, 온라인 주이용자의 경우 현장감, 입체감 확대를 통한 직접관람과의 격차 축소가 필요할 것이라는 의견을 제시했다. 반면 무관심자의 경우 기술적 변화가 본인에게 영향을 미치지 않을 것이라는 의견과, 자신과 맞는 것이 나타난다면 관심이 갈 수 있다는 의견으로 나뉘었다.

〈표 3-66〉 FGI 참여자 특성별 기술변화 및 예술향유 영향 인식

\begin{tabular}{|c|c|}
\hline 구분 & 기술적 변화가 예술향유에 미치는 영향 \\
\hline 직접관람 & $\begin{array}{l}\text { - 시간적, 공간적 제약이 해소된다 } \\
\text { - 보완재의 개념으로 온라인 매체를 찾게 된다 } \\
\text { - 경제적 부담이 적다 } \\
\text { - 디지털을 잘 모르면 정보 등을 제공받기 힘들다. 기술적 부분이 중요하다 } \\
\text { - 오프라인을 향유할 수 없을 때, 집, 출퇴근 중 스마트폰을 이용한 관람이 많다 }\end{array}$ \\
\hline $\begin{array}{c}\text { 온라인 매체 } \\
\text { 주이용자 }\end{array}$ & $\begin{array}{l}\text { - 가수 공연은 VR/AR을 이용해 이미 사용되고 있다(위치, 음향, 시선) } \\
\text { - 오프라인 시장이 줄어들 것이다(코로나와 온라인 매체의 증가-넷플릭스, 왓챠, 씨즌 } \\
\text { 등) } \\
\text { - 오프라인에서 느끼는 감동의 격차를 줄여줄 기술적인 것이 생기면 온라인 비중이 } \\
\text { 더 늘어날 것이다, 집에서도 현장을 입체적으로 즐길 수 있는 기술 혁신이 일어난다 } \\
\text { 면 일부 공연은 대체 가능할 것이다 } \\
\text { - 코로나 유지 및 기술 혁신 상황에서는 온라인 비중이 더 높아질 것이다 }\end{array}$ \\
\hline $\begin{array}{c}\text { 예술향유 } \\
\text { 참여활동 경험자 }\end{array}$ & $\begin{array}{l}\text { - 온라인 매체 관람이 늘어날 것이다. 참여활동 방식도 점진적으로 온라인을 이용한 } \\
\text { 방식이 증가할 것이다 } \\
\text { - 지금도 기술의 변화가 영향을 많이 미치고 있다. 실제로도 유튜브에서 많이 예술활 } \\
\text { 동을 배우고 있다 } \\
\text { - Al가 창작은 못하지만, 현장에서 일손이 되어 사람 인력이 줄어들 것이다 }\end{array}$ \\
\hline 무관심자 & $\begin{array}{l}\text { - 예술을 접하는 경로가 집에서도 가능해 질 것이다 } \\
\text { - 오프라인에서 온라인으로 비중이 높아질 것이다 } \\
\text { - 사람들이 그 장소에 가지 않더라도 쉽게 접할 수 있는 환경이 될 것이다 } \\
\text { - 온라인을 통해 배우고 표현하는 비중이 높아질 것이다(ex. 신곡 발표, 팬 미팅) } \\
\text { - 단체 소속 예술가 뿐 아니라 개인 활동을 하는 사람들도 많아질 것이다 } \\
\text { - 그러나 심리적 요인이 가장 큰 문제라 이후 기술 변화를 통한 온라인 매체 기능이 } \\
\text { 강화되어도 예술향유를 하지 않을 가능성이 크다 }\end{array}$ \\
\hline
\end{tabular}




\section{3) 예술 범주에 대한 인식}

예술의 범주에 관한 인식을 살펴보기 위해 '특정장소기반 관람 vs. 일상적 향유 (장소)', '고급 vs. 대중예술(장르)', '전문 vs. 아마추어 예술(전문/비전문)', '관람 vs. 참여활동' 등의 기준을 중심으로 예시문을 제시하여 '예술'로 포함할 수 있는지 에 대한 동의정도를 질문하였다.

인터뷰 참여자 대부분이 이미 예술범주에 대한 인식이 폭넓은 편이었고, 참여활 동경험자의 예술범주는 타 그룹과 달리 '참여'적 측면이 강조되었다. 그룹 간이 아 닌 각 그룹 내에서 게임이나 동영상 편집 등을 예술로 볼 것인지에 관한 의견이 나 뉘는 측면도 있었지만, 향후 기술적 요인의 중요도가 커진다고 가정할 때 예술범주 로 포용될 수 있다는 예상도 제시되었다.

주목되는 부분은 무관심자의 경우 탈장소적 관람이나 대중예술 중 일부장르(만화 /웹툰), 게임 등은 예술이라 보기 어렵다는 전통적 예술관점을 드러냈으며, 직접관 람자와 예술향유참여활동 경험자들은 대부분 탈장소적 관람, 아마추어 예술, 대중 예술장르의 폭넓은 수용 등 예술의 범주를 넓게 이해하는 경향을 나타냈다.

〈표 3-67〉 FGI 참여자 특성별 예술의 범주에 대한 인식

\begin{tabular}{|c|c|}
\hline 구분 & 예술범주에 대한 인식 \\
\hline 직접관람 & $\begin{array}{l}\text { - 상대적으로 고관여 그룹이 '독서', '만화나 웹툰 보기', '예술관련 동영상 편집'을 예술 } \\
\text { 이 아닌 것으로 분류하며, 전통적인 예술 관점을 나타냄 }\end{array}$ \\
\hline $\begin{array}{l}\text { 온라인 매체 } \\
\text { 주이용자 }\end{array}$ & $\begin{array}{l}\text { - ‘독서나 글쓰기', ‘전국노래자랑 대회 참여’, ‘만회나 웹툰 보기', ‘예술 관련 동영상 } \\
\text { 편집해서 SNS 올리기’ 등은 예술이 아닌 것으로 분류하는 경향 }\end{array}$ \\
\hline $\begin{array}{l}\text { 예술향유 } \\
\text { 참여활동 경험자 }\end{array}$ & $\begin{array}{l}\text { - 예술을 볼 때 감정이 동요되는 것 외에도 자신의 끼나 창의성 발휘, 창작물의 유무, } \\
\text { 관심사에 따라 활동하는 것 등으로 봄 } \\
\text { - '독서나 글쓰기'는 예술일 수도 있고 아닐수도 있음 } \\
\text { - 예술은 어떤 경지에 이르는 수준은 있어야 함. 아마추어 수준에서 할 수 있는 최상의 } \\
\text { 결과 }\end{array}$ \\
\hline 무관심자 & $\begin{array}{l}\text { - '거리 버스킹이나 지하철역 전시', '만화나 웹툰 보기', '게임' 은 예술이 아닌 것으로 } \\
\text { 분류하는 경향 }\end{array}$ \\
\hline
\end{tabular}

\section{4) 예술향유 확대를 위해 지원 가능한 정부 정책}

직접관람자의 경우 예술향유의 물리적 제한을 감소시킬 수 있는 바우처 등의 비 용 지원을 선호하였고, 예술향유 관심도 제고를 위해서 어렸을 때부터 가정 및 학교 
에서의 예술교육 기회 제공이 필수적임을 강조했다. 이는 참여활동자 그룹에서도 유사했다. 또한 일상적으로 예술을 접할 수 있는 기회가 많아져야 한다는 의견도 있었다.

정부정책 수요 관련 질문에 관해 온라인 매체 주이용자는 비용적 측면의 대안을 주로 제시하는 특성이 나타났으며, 참여활동 경험자는 참여활동을 위한 공간/교육 지원 확대를 강조한 것이 특징적이었다. 반면, 무관심자는 실생활에서의 경제적, 시 간적 여유의 확보를 위한 지원을 언급했다.

〈표 3-68〉 FGI 참여자 특성별 예술향유 확대를 위한 정책수요

\begin{tabular}{c|c}
\hline 구분 & 예술향유 확대를 위한 정부정책 \\
\hline 직접관람 & $\begin{array}{c}- \text { 무료관람, 바우처 등, 예체능교육의 초등학생부터 실시, 예술품 건축품 등 일상에서 } \\
\text { 도 쉽게 대중예술에 접할 수 있도록 선진국 벤치마킹 }\end{array}$ \\
\hline $\begin{array}{c}\text { 온라인 매체 } \\
\text { 주이용자 }\end{array}$ & $\begin{array}{c}- \text { 경연에 대한 진입장벽 낮추기(ex.과거의 사랑티켓), 세금 감면, 공연 비용 인하, 문화 } \\
\text { 바우처, 문화예술 지출비 공제, 긴급재난지원금처럼 문화시설 이용료 감면의 날 }\end{array}$ \\
\hline 예술향유 & $\begin{array}{c}- \text { 자금 지원(공연장 대관), 예체능 교육에서의 참여활동 확대, 일반인도 참여할 수 있는 } \\
\text { 교육 프로그램 지원, 공간문제 해결 }\end{array}$ \\
\hline 참여활동 경험자 & $\begin{array}{c}\text { 예술적 측면의 접근보다 경제적인 여건을 해결해주어야 함(수입), 경제적, 시간적 여 } \\
\text { 유가 있어야, 공연장, 전시회장의 확대 및 콘서트 가격의 인하, 근무시간 줄이기 }\end{array}$ \\
\hline 무관심자 & \multicolumn{2}{|l}{}
\end{tabular}

\section{3. 예술향유 인식 및 양태 분석의 종합 시사점}

앞서 제시된 예술향유에 대한 인식 및 예술향유 활동의 다양한 양태 변화 분석을 위한 온라인 설문조사와 심층 분석을 위해 수행된 FGI 결과로부터 도출된 시사점은 다음과 같다. 이들은 이어지는 제4장과 제 5 장에서의 지원사업 분석은 물론 향후 예 술향유정책의 방향성을 탐색하는데 주요한 논의와 관점를 담지하고 있다는 점에서 주목될 필요가 있다.62)

\section{가. 예술향유 범주에 관한 인식 확장: 기존 예술향유 정책지원과의 간극 존재}

온라인 설문조사에서 예술향유 활동 범주에 대한 인식은 여전히 '관람' 중심의 활

62) 각각의 시사점 분석에 있어 $\mathrm{FGI}$ 녹취록 중 일부 발언 인용을 활용하였음을 밝힌다. 
동, 즉, 영화관람, 공연관람, 전시감상에 대한 인식이 높은 편으로 나타났다. 하지만 이와 함께 주목해야 할 부분은 온라인 매체를 통한 예술향유 활동과 관람 이외의 활동도 예술향유 활동 범주에 포함시켜 폭넓게 인식되고 있다는 점이다. 인터넷 영 상공연/전시/영화와 스트리밍 음악듣기 등의 온라인 매체를 통한 활동도 상위 순위 에 집계되었으며, 관람 외에 예술교육, 동아리, 취향공동체, 공방 제작, 기부와 자원 봉사 등 ‘참여', '창작', '공동체 활동' 등도 상대적으로 낮은 순위이기는 하나 예술 향유 활동의 범주로서 인식되고 있는 것으로 나타났다.

FGI에서도 유사하게 예술향유 활동에 대한 인식이 폭넓게 나타났다. 직접관람자 그룹, 온라인 매체 주이용자 그룹, 예술참여 활동 경험자 그룹 등 모든 그룹에서 예 술향유 활동에 대한 범주를 대부분 다양한 활동으로 인식하고 있으며, 특히 예술 참여활동 경험자 그룹의 경우에는 다른 그룹에 비해 '공유' 및 '참여적' 측면에서의 향유 활동을 강조하였다. 무경험자 그룹 역시 아래 답변과 같이 예술향유 활동을 일상에서의 활동 등을 포함한 다양한 범위 내에서 인식하고 있음을 알 수 있다.

" 진로나 직장이랑 직접적으로 일하는 것과 상관없으면 그냥 자기가 좋아해서 하는 건 다 예술인 것 같아요.(...) 작품으로 그림을 그리는 거나 실력의 차이만 있을 뿐 같은 것 같고, 공연을 보러가는 것도 예술의 전당을 가거나 여길(아마추어 공연) 가는 거나 본질은 똑같고 대회도 가수가 노래하나, 내가 TV 나와서 노래하나 다 예술일 것 같아요.(..) 예술관련 동 영상 편집해서 SNS 등에 올리기 같은 경우는 똑같이 어떤 동영상을 보더라고 절대 관심이 없으면 안하잖아요. 관심 있는 사람이나 능동적으로 하는 거지. 그래서 예술인 것 같아요"

(무관심자, 여, 30대, 송OO)

"자기 개인 취향을 표현하거나 다른 취향을 감상하는 것도 다 예술이라고 생각해요"

(무관심자, 남, 30대, 장O)

“(...) 메이크업이든 집 꾸미기든 그것도 넓은 의미에서 예술이라고 봐요"

(무관심자, 여, 40대, 박OO)

응답자들은 온라인상의 활동, 대중예술, 일상에서의 활동 등을 모두 포괄하여 이 러한 활동 전부를 예술향유 활동이라고 인식하고 있을 만큼 예술향유라고 생각하는 활동 범위는 상당히 넓고 다양했다. 이러한 예술향유 범주에 대한 인식은 예술향유 고관여자와 무관심 그룹 간에 큰 차이가 없는 것으로 나타났으며, 관심 유무에 관계 
없이 예술향유 활동 범주나 즐기는 방식에 대해 확장된 인식을 가지고 있음을 알 수 있다. 이처럼 예술향유를 바라보는 사람들의 인식은 전통적인 시설/공간 기반 '관람 위주의 예술향유를 넘어 온라인 매체 수용, 여가와 취미생활, 참여와 창작 활동 등이 예술향유와 맞물리며 보다 다원화되고 복합적인 양상으로 인식되고 있음 을 보여준다. 그렇다면 과연 현재 예술향유 지원정책상에서는 이처럼 다양화된 사 람들의 예술향유에 대한 인식이 반영되고 있는 것인가? 사실상 앞서 지속적으로 지 적되었다시피, 예술향유 지원정책은 여전히 주로 '관람' 위주의 향유 진작을 위한 방향성에 머물러 있으며, 이러한 다양화된 향유활동에 대해 적극적인 반영은 여전 히 미진한 것으로 나타나고 있다.

이러한 예술향유라는 개념의 다양화와 다원화는 향후 예술향유 정책지원에 있어 '예술'과 '예술 향유'라는 범주 자체를 과연 어떻게 설정해야 하는가에 대한 문제를 제시해주는 주요한 관점이라 할 수 있다. 따라서 '관람'이라는 단순한 활동에 치중 되어 시행되어오던 대부분의 예술향유 지원정책에서 '예술향유' 개념 자체가 시급 하게 재정립되지 않는다면, 시대적·사회적·기술적 변화에 따라 급속도로 변화하는 사람들의 예술에 대한 니즈, 수요, 태도, 인식 등이 반영되지 않는 의미 없는 정책으 로 남을 수밖에 없을 것이다.

\section{나. 예술향유 걸림돌 파악: 세분화된 예술향유 지원 접근 부재}

본 연구에서는 예술향유 활동에 있어서의 걸림돌(애로사항)을 외적·물리적 측면 과 내적·심리적 측면에서 조사하였다. 온라인 설문조사 결과, 예술향유 경험자별로 향유 활동에 대한 애로사항(걸림돌) 중 외적·물리적 측면에서의 요인을 상위 3순위 까지 정리한 결과는 다음과 같다. 무엇보다 전체 응답자 그룹에 걸쳐 향유활동을 어렵게 하는 요소로는 경제적 부담이 가장 많은 것으로 나타났으며, 다음으로 시간 과 정보 부족 등이 주요 요인으로 꼽혔다. 
〈표 3-69〉 예술향유 경험자별 외적·물리적 걸림돌: 2020 시민 예술향유 인식 및 예술향유활동 조사

\begin{tabular}{c|c|c|c|c}
\hline \multicolumn{2}{|c|}{ 구분 } & 1순위 & 2순위 & 3순위 \\
\hline 관람 & 직접 관람 & 경제적 부담 & 시간 부족 & 접근성 \\
\hline 온라인 & 온라인 매체 & 정보 부족 & 시간 부족 & 경제적 부담 \\
\hline \multirow{4}{*}{ 참여 활동 } & 예술교육 & 시간 부족 & 경제적 부담 & 정보 부족 \\
\cline { 2 - 5 } & 예술창작 & 경제적 부담 & 시간 부족 & 정보 부족 \\
\cline { 2 - 6 } & 예술동호회 & 경제적 부담 & 시간 부족 & 정보 부족 \\
\cline { 2 - 6 } & 예술자원봉사/기부 & 시간 부족 & 경제적 부담 & 정보 부족 \\
\hline
\end{tabular}

이와 함께 예술향유 경험자별로 향유 활동에 대한 애로사항(걸림돌) 중 내적·심리 적 측면에서의 요인을 상위 3순위까지 정리한 결과는 다음과 같다. 예술에 대한 지 식과 경험 부족이 가장 큰 걸림돌로 작용하고 있음을 알 수 있다.

〈표 3-70〉 예술향유 경험자별 내적-심리적 걸림돌: 2020 시민 예술향유 인식 및 예술향유활동 조사

\begin{tabular}{|c|c|c|c|c|}
\hline \multicolumn{2}{|c|}{ 구분 } & 1순위 & 2순위 & 3순위 \\
\hline 관람 & 직접 관람 & $\begin{array}{c}\text { 예술 지식 및 } \\
\text { 경험 부족 }\end{array}$ & 필요성 인식 부족 & $\begin{array}{c}\text { 관람보다 } \\
\text { 참여에 관심 }\end{array}$ \\
\hline 온라인 & 온라인 매체 & $\begin{array}{c}\text { 예술 지식 및 } \\
\text { 경험 부족 }\end{array}$ & 직접 보는 것과 비교됨 & 필요성 인식 부족 \\
\hline \multirow{4}{*}{ 참여 활동 } & 예술교육 & $\begin{array}{l}\text { 예술 지식 및 } \\
\text { 경험 부족 }\end{array}$ & 필요성 인식 부족 & $\begin{array}{c}\text { 참여보다 } \\
\text { 관람에 관심 }\end{array}$ \\
\hline & 예술창작 & $\begin{array}{l}\text { 예술 지식 및 } \\
\text { 경험 부족 }\end{array}$ & $\begin{array}{c}\text { 참여보다 } \\
\text { 관람에 관심 }\end{array}$ & 필요성 인식 부족 \\
\hline & 예술동호회 & 필요성 인식 부족 & $\begin{array}{l}\text { 예술 지식 및 } \\
\text { 경험 부족 }\end{array}$ & $\begin{array}{l}\text { 참여보다 } \\
\text { 관람에 관심 }\end{array}$ \\
\hline & 예술자원봉사/기부 & $\begin{array}{l}\text { 예술 지식 및 } \\
\text { 경험 부족 }\end{array}$ & 필요성 인식 부족 & $\begin{array}{c}\text { 참여보다 } \\
\text { 관람에 관심 }\end{array}$ \\
\hline
\end{tabular}

FGI 참여자들 역시 '경제적 이유', '시간', '정보 부족' 등의 요인이 전체 그룹에 걸쳐 유사하게 지적되었다. 이 중 직접 관람 고관여자와 예술참여 활동 경험자 그룹 은 주로 내적·심리적 요인보다는 외적·물리적 요소, 즉 시간, 비용, 정보 등이 걸림 돌로서 작용한다고 응답하였다. 더불어 이러한 문제가 해결된다면 더 많은 예술향 유를 할 것이라는 긍정적인 반응을 보였다.

반면 직접 관람 저관여자 그룹의 경우, 외적·물리적 요소뿐만 아니라 예술에 대 
한 지식 부족과 같은 요인들이 걸림돌로 작용하고 있으며, 아래 답변에서와 같이 이들에게는 제대로 예술을 향유하기 위해서는 기본적인 지식을 갖추는 것이 중요한 조건이라고 인식하고 있다.

"저는 예술 향유를 하러 직접 관람 갔을 때 얻고 싶은 기대치가 있는데 그 기대치를 스스로 못 얻게 되면 가지 않아요. 뮤지컬 갔다가 온 사람이 대박이었다라고 해도 저는 잘 몰라서 가도 대박이지 않을 거 같으면 안 가지요."

(저관여자, 남, 20대, 이OO)

"무용 보면서 많이 느겼는데 제가 무용에 대한 지식이 없거든요. 처음에 보러 갔을 때 이상 한 옷 입은 사람이 이상한 춤추는 것으로 밖에 안 보여서 공감이 안 되었거든요. 그래서 지식이 어느 정도 있어야 한다고 생각해요."

(저관여자, 여, 20대, 강OO)

"저는 음악이나 다른 것은 괜찮은데 미술은 지식이 있어야...시대배경이나 작가 의도, 어떤 예술을 표현하려고 했는지 어느 정도 알아야 그 그림을 보면서 이게 이렇게 연결 된다고 느끼는데, 잘 모르고 그냥 보면 그냥 다 비슷한 그림으로 느껴져서 알고 보는 것이 더 도움 이 될 거 같아요."

(저관여자, 여, 20대, 노OO)

무경험자 그룹 역시 예술향유에 대한 거리감이나 지식의 부족 등 내적인 요인들 이 걸림돌로 작용하고 있음을 알 수 있다.

"그런 게 어렸을 때부터 자연스럽게 인식이 박힌 사람들이 좀 더 자연스럽게 보는 것 같더 라고요. 저는 어렸을 때부터 그냥 그런 기회가 별로 없었고, 공대를 다니고 하다 보니까 주위 환경 자체가 별로 그런 쪽에 접할 수 있는 기회가 없었기 때문에..."

(무경험자, 남, 20대, 주OO)

“그냥 그 분야가 너무 어렵게만 느겨져서 쉽게 접근할 수 없는 그런 느낌이 있어서(...) 예술 은 제가 직관적으로 보기에 느낄 수 없는, 뭔가 제가 기본적인 지식이라도 있어야지 그것을 이해할 수 있는 그런 분야인 것 같아요"

(무경험자, 여, 20대, 김OO)

"보면 저만 관심이 없는 것 같더라고요. 친구들도 대학교까지는 별로 안 그랬는데 직장인이 되다 보니까 다 그런걸 보러 다니고 이런 거에 투자 많이 하는데. 저는 좀 돈이 아까운 것 
같아서...그거랑 그만큼 공부를 많이 해야 하는데 하기가 귀찮아요. 그래서 누가 보여준다 그러면 가긴 가는데, 제가 찾아보고 가지는 않은 거 같아요."

(무경험자, 여, 30대, 송OO)

앞서 저관여자들의 경우, 예술향유를 함에 있어 그에 대한 어느 정도 기대치를 가지고 있으나, 이전 자신의 경험에 비추어볼 때 본인이 가진 예술에 대한 지식 및 이해 정도가 그에 미치지 못한다고 인식하고 있다. 다시 말하면, 이러한 요소를 걸 림돌로 인지한다는 것 자체가 곧 예술에 대해 더 잘 알고자 하는 욕구를 내재하고 있음으로 해석할 수 있다.

이에 반해 무관심자(무경험자)의 경우는 예술향유를 하기 위해서는 반드시 지식 이 필요하다는 것은 인식하고 있으나, 본인들이 아닌 예술에 대한 높은 지식과 이해 를 갖춘 사람들만이 접할 수 있는 영역으로 구분 짓고 있다는 것이 두 그룹 간의 차이점이라 할 수 있다. 이는 예술에 대해 떠오르는 이미지를 묘사하는 데에서도 확인되는데, 무관심자 그룹의 응답자들은 예술을 '어려움, '불편함', '현실적으로 누리기 어려운 존재' 등 부정적인 이미지로 설명하고 있다. 이들에게 예술향유란 '제대로 공부'해야 하고, '기본적인 지식'이 있어야만 할 수 있는 것이라는 관념이 자리 잡고 있으며, 심지어 한 응답자에게는 예술이란 '다 이해해야 한다는 압박감' 이 동반된 대상이 되기도 한다.

이처럼 예술향유 집단별로 내적-외적 걸림돌 요인들이 작용하고 있으며, 특히 무 관심자 그룹의 경우에는 예술에 대한 문화자본의 부재가 예술에 대한 부정적 이미 지 및 수용에 대한 저항으로까지 이어지고 있음을 알 수 있다. 이러한 결과와 결부 시켜 예술향유 정책 영역에 줄 수 있는 시사점은 과연 예술향유 지원정책의 역할은 어떻게 이러한 내적·외적 요인들을 세분화하여, 물리적·심리적 장벽을 낮출 수 있 을지에 대한 고려가 필요하다고 하겠다.

물론 이러한 걸림돌 요인들이 본 연구를 통해 새롭게 도출된 것은 아니며, 지속적 으로 제기되어 온 문제이기도 하다. 그러나 본 설문 결과를 통해 분명하게 확인된 바는 예술향유 정도에 따라 걸림돌이 상이하게 존재하며, 그 정도에 따라 세분화되 고 구체적인 접근이 요구된다는 것이다. 예술향유 경험 정도가 높은 사람들에게는 정보 접근성을 높여주고, 재정적 지원을 통해 지속적으로 예술향유 활동이 행해지 
도록 유도하는 전략이 필요하다는 것을 시사하고 있다. 더불어 예술향유 무경험자/ 무관심자의 경우, 문화자본 부재에 대한 자발적 인지가 얼마나 예술향유에 대한 시 도조차 어렵게 만드는 요인으로 작용하고 있는지를 여실히 보여주고 있다.

따라서 관객개발 차원에서 예술향유 지원정책은 예술향유 활동 정도에 따라 어떻 게 경제적 부담이나 정보 부족의 문제를 보완할 수 있을지, 그리고 어떻게 심리적 거리감이나 수용의 저항을 완화시켜줄 수 있을지에 대한 보다 세밀한 접근과 고민 이 필요하다.

\section{다. 기술 환경변화에 따른 예술향유 양상 변화: 예술향유 지원의 범주와 개념적 변화 필요}

온라인 설문조사 결과, 최근 급속한 미디어 및 온라인 환경변화가 예술활동에 긍 정적인 영향을 줄 것이라는 인식이 $50 \%$ 이상으로 높게 나타났으며, 부정적 영향은 $13 \%$ 에 불과했다. 특히 예술향유 경험이 많은 그룹일수록 긍정적으로 인식하는 것 으로 나타났다. 온라인 설문 응답자 중 온라인 매체 관람률은 $62 \%$ 였으며, 그 중 스 마트 기기를 통한 경험 비중이 가장 높았다. 연령이 낮을수록 온라인 매체 경험이 높으며, 지역 규모가 작을수록 온라인 관람 경험이 높은 경향을 보였다. 또한 직접 관람하는 횟수가 높은 고관여자일수록 온라인 향유 경험 또한 높은 것으로 나타났 고, 예술 참여활동 경험자 그룹에서는 온라인 비중이 예술교육과 창작 활동에서 높 게 나타났다. 온라인 매체가 가지는 장점으로는 '시간-물리적 접근성'이 $52 \%$ 로 가 장 높았으며, 다음으로 '선택에 대한 주체성'과 '경제적 비용 부담 적음' 순으로 나 타났다.

FGI에서도 다양한 방식으로 온라인 매체를 통한 예술향유 활동이 행해지고 있음 을 알 수 있다. 최근에는 특히 코로나19로 인해 온라인 매체를 통한 예술향유가 증 가하고 있음이 확인되었고, 최근 1 년간 유튜브, 넷플릭스, 왓차, 오디오북 등의 온 라인 매체를 통해 영화, 콘서트, 뮤지컬, 무용, 디지털 출판물 등의 다양한 콘텐츠를 접해온 것으로 나타났다. 온라인 매체를 이용하는 데 있어 장점으로 꼽은 요인들로 는 ‘비용 절감', '추천 등의 정보 탐색 용이성', '(육아 등으로 인해) 시간 선택의 유 연성', '편한 환경에서의 감상' 등을 제시하였고, 온라인 매체를 선택하는데 어려운 요인으로는 '현장감', '몰입감', '관객과의 상호작용', '집중력 부재' 등이 지적되었 
다. 이러한 기술 환경 발전은 온라인 매체를 통한 예술향유 활동에 상당한 변화를 미치고 있으며, 현재 제기되는 기술적인 문제들이 어느 정도 해소된다면 온라인 매 체를 통한 예술향유 방식 비중 또한 늘어날 것이라고 응답하였다.

"100\%는 못 채우겠지만 VR이나 AR을 이용해서 가수들 공연은 실제로 그렇게 많이 응용 되어서 한다고 알고 있거든요. 프로야구처럼 어디 객석에 앉아 있는 것과 똑같은 위치에서 음향이나 시선 같은 거, 그걸 응용하면 $100 \%$ 까지는 아니지만 지금보다 이렇게 보는 것보 다 기술적으로 발전되면 더 즐길 수 있을 것 같아요(...) 덧붙이면 오프라인에 비용, 시간, 에너지를 투자해서 가는데 온라인에서 느낌 감동이 그 격차를 줄여줄 수 있는 기술적인 것 이 더 생기면 온라인 향유 비중이 더 늘 수 있을 것 같아요"

(온라인매체 주 이용자, 여, 40대, 송OO)

"저는 원래 온라인을 잘 사용 안하다보니 전체적으로 향유 기회가 줄었다고 생각을 하는데, 코로나 때문에 디지털 시대에 익숙해져 있다고 생각이 들기는 했어요. 수업도 인터넷으로 다 하는데, 그걸 모르면 도태되고 그걸 잘 알아야지 정보도 찾기 쉽고. 어디서 공연을 무료 로 한다면 디지털을 잘 모르면 누리지 못하다 보니깐 이제는 이런 것도 잘 알아야겠다고 생각한 것 같아요."

(예술관람 고관여자, 남, 20대, 이OO)

"온라인 기술혁신이 어느 정도 오프라인하고 가까워지느냐인데 사운드도 그렇고 입체적으 로 보는거, $4 \mathrm{D}$ 이런 것으로 기술발전이 되어서 오프라인에 가까워지고 있는데, 그게 많이 가까워질수록 사람들이 더 온라인을 선호하겠지요."

(온라인매체 주 이용자, 남, 50대, 안OO)

온라인 매체는 관람 형태의 예술향유뿐만 아니라 예술교육, 자원봉사, 창작 영역 에까지 영향을 주고 있는데, 이러한 변화는 아래 답변에서도 확인되듯이 응답자들 에게 다양한 방식의 예술향유 활동 기회를 제공해 주는 수단으로서 역할을 할 수 있을 것으로 보인다.

"저는 가서 봉사도 해보고 배워도 보는데 언택트 시대는 그것도 대체할 수 있을 것 같아요. 교육이나 나눔 분야도 원거리로, VR을 도입하면 만나지 않아도 눈앞에 있는 것처럼 전수도 가능하고 그런 영역까지 확장할 수 있을 것 같아요(...) 저는 배우는 거 좋아하는데 배우는 것도 화상이나 가상현실을 통해 진짜 앞에 그 선생님이 나를 티칭해주는 것처럼 교육도 온 라인으로 배우게 될 것 같아요"

(온라인매체 주 이용자, 남, 30대, 김OO) 
"기술적인 게 지금도 엄청나게 영향을 미치고 있다고 생각하는 게 예술활동이나 참여를 하 려면 배우는 과정이나 익숙해지는 과정에서 실제로 많이 유튜브나 이런 데서 배우고 있거든 요. 그렇게 하고 나면 이게 내가 좋아하는 건가 해볼 만한 건가, 아니면 누군가와 같이 할 수 있는 건가 알 수 있으니 매우 영향이 큰 것 같아요."

(예술참여 활동 경험자, 남, 40 대, 안OO)

이러한 기술 발전으로 인한 환경 변화는 예술향유의 방식과 개념에도 영향을 미 치고 있음을 알 수 있다. 응답자들은 이러한 변화를 긍정적으로 바라보고 있으며, 보다 영역을 확장하여 교육 및 창작에까지 온라인 매체를 활용하고자 한다. 하지만 정작 예술향유 정책상에서는 이러한 기술적 변화를 반영하기 위한 그간의 고민이 있었는지를 되짚어 볼 필요가 있다.

특히 온라인 매체를 통한 예술향유 방식은 앞서 기술한 설문조사 결과에도 나타 났듯이, 연령이 높을수록 경험이 높으며 지역 규모가 작을수록 온라인 관람 경험이 높은 경향을 보이는 것으로 나타났다. 이는 디지털 리터러시에 익숙한 낮은 연령 대상의 예술향유는 앞으로 이러한 온라인 매체를 적극적으로 활용하여 세대적 확장 을 고민해야 함을 시사하고 있다. 또한 예술향유 인프라가 충분히 구축되지 않은 소규모 지역의 경우, 기존 관람 위주의 찾아가는 형태의 예술향유 지원정책에서 필 수적이었던 장소성에 대한 개념을 탈피하여 가상공간을 통한 예술향유 방식 확대에 대한 가능성을 열어두어야 함을 의미한다 하겠다.

물론 신기술 및 온라인 매체 활용을 통한 예술향유가 향후 현재의 방식을 완전히 대체할 수는 없을 것이며, ‘보완재’로서 중요한 역할을 할 수 있을 것이라고 전망되 고 있다. 그럼에도 중요한 점은 앞으로 이러한 디지털 기술 변화는 예술향유 방식에 있어 물리적 제약을 넘어 새로운 양태의 예술향유를 가능케 해줄 것이며, 온라인을 통해 예술을 접하는 경우 이것이 다시 오프라인 활동으로 연결되어 예술향유 활동 의 확산을 가져다줄 수 있다는 점에서 시대적 변화에 따른 예술향유 정책의 범주와 개념의 재정비가 요구되는 지점이라 하겠다.

따라서 기존 공간, 관람, 장르 중심의 향유 정책에서 디지털 기술 기반의 다양한 온라인 예술향유 양태를 포용할 수 있는 방향성으로의 재정비가 필요하며, 이러한 예술향유의 범주와 양태의 변화를 반영할 수 있는 정책적 접근이 반드시 동반되어 야 할 것이다. 


\section{라. 예술향유자의 내적 요소로서 예술향유 가치 인식 변화를 위한 정책지원 관점 필요}

예술향유는 주체적 맥락에서 향유자 개인의 향유 동기나 목적, 예술의 가치에 대 한 인식이나 기대정도, 예술과 관련된 효능감 등과 연관되어 있다. 온라인 설문조사 를 통해 예술에 대해 인식하는 가치를 조사한 결과를 상위 4순위까지 살펴보면, 1 순위는 '개인 삶의 즐거움', 2 순위는 '사회를 문화적으로 풍요롭게 함', 3순위는 '개 인 삶의 행복', 마지막 4순위는 '다른 문화에 대한 이해'로 나타났다. 이처럼 응답자 들은 예술의 가치를 '즐거움' '행복'과 같은 개인적 차원에서 인식할 뿐만 아니라 '사회의 풍요로움', '다양성 이해'와 같은 사회적 차원과도 연계하여 인식하고 있음 을 알 수 있다.

FGI에서도 예술이 가진 가치에 대해 사회적 차원에서 유사한 결과를 보이고 있 다. 사회적 가치 측면에서 응답자들은 대부분 예술은 '통합', '공공', '사회적 관계 맺기', '사회 안정' 등의 역할을 하고 있다고 응답하였다. 예술향유 무관심자 그룹 응답자들조차도 예술의 가치에 대해 사회적 차원에서는 상당히 긍정적으로 인식하 고 있으며, 구체적으로는 평화, 일자리 창출, 국위선양의 영역까지 연결시켜 예술이 가진 가치를 설명하였다.

이에 반해 흥미로운 지점은 개인적 가치 차원에서 나타나는 예술향유 경험자 그 룹과 무관심자 그룹 간의 차이라 할 수 있다. 예술향유 경험자들의 경우, 예술이 가 진 개인적 가치를 위의 온라인 설문조사 결과와 유사하게 개인적 '즐거움' '행복', '삶의 자극제', '편안함' 등으로 인식하고 있으며, 특히 예술향유 참여활동 경험자들 의 경우 예술향유를 통해 대리만족을 하거나, 다양성과 개인적 표현의 영역으로까 지 확장시켜 보다 적극적 차원에서 예술이 주는 개인적 가치를 인식하고 있음을 알 수 있다. 하지만 무관심자 그룹의 경우, 개인적 차원에서의 예술은 '어려움' '불편 함', '거리감', '관심 없는 분야' 등으로 받아들이고 있으며, 투자, 재테크, 건강, 휴 식 등 예술이 아닌 더 관심을 가질 다른 대상이 많기 때문에 예술의 가치나 필요성 은 중요한 고려 대상이 아닌 것으로 나타났다.

"이것도 고정관념인 것 같은데, 만약 책을 보면 집중도에도 도움이 된다고 생각하고, 책을 빨리 읽으면 자료나 공부하는데 빨리 읽는 능력도 생겨서 좋다고 생각하거든요. 독해력도 생기고. 그런데 TV나 영화는 전혀 그런 거랑 관련이 없는 거 같아서 이 생각이 어렸을 때부 
터 커서 안 보게 되는 것 같아요.”

(무관심자, 여, 30대, 송OO)

무관심자 그룹과는 달리, 예술향유 경험자들을 대상으로 그 동기를 묻는 온라인 설문에서도 '즐거움' 혹은 '재미'와 같은 개인적 차원의 요인들은 확연하게 나타난 다. 예술향유 경험에 대한 동기를 묻는 온라인 설문 결과, 아래 표가 보여주듯이 '즐 거움과 재미'가 예술향유 활동을 하게 하는 가장 중요한 동기임을 알 수 있다.

〈표 3-71〉 예술향유 경험자별 예술향유의 경험동기: 2020 시민 예술향유 인식 및 예술향유활동 조사

\begin{tabular}{c|c|c|c|c}
\hline \multicolumn{2}{|c|}{ 구분 } & 1순위 & 2순위 & 3순위 \\
\hline 관람 & 직접 관람 & 즐거움과 재미 & 마음의 안정과 휴식 & 관계맺기 \\
\hline 온라인 & 온라인 매체 & 즐거움과 재미 & 마음의 안정과 휴식 & 스트레스 해소 \\
\hline \multirow{4}{*}{ 참여 활동 } & 예술교육 & 즐거움과 재미 & 직접 참여 선호 & 예술에 대한 이해 \\
\cline { 2 - 6 } & 예술창작 & 즐거움과 재미 & 직접 참여 선호 & 예술에 대한 이해 \\
\cline { 2 - 5 } & 예술동호회 & 즐거움과 재미 & 직접 참여 선호 & 스트레스 해소 \\
\cline { 2 - 5 } & 예술자원봉사/기부 & 직접 참여 선호 & 즐거움과 재미 & 사회적으로 의미 추구 \\
\hline
\end{tabular}

이처럼 예술이 지닌 사회적 가치에 대해서는 예술향유 경험 유무와 관계없이 대 체적으로 긍정적으로 인식하고 있는 반면, 개인적 가치에 대해서는 차이가 존재하 고 있음을 알 수 있다. 예술향유에 관심이 없는 그룹의 응답자들은 개념적으로는 예술이란 사회적으로 가치 있고 좋은 것임은 인식하고 있지만, 정작 개인차원에서 는 자신의 삶과는 관련 없는 거리감이 있는 대상으로서 인식하고 있는 것이다. 이들 에게는 예술이란 타 그룹의 응답자들이 언급한 '즐거움'이나 ‘행복감'과 같은 가치 가 적용되지 않으며, 이러한 요소들을 제공해주는 대상으로서 역할을 하지 못하고 있다.

덧붙여서 예술을 바라보는 주체적 관점에서 '나'와 결부된 예술의 인식을 확인할 수 있는 '예술에 대한 개인 효능감'에 관한 조사 결과에서도 그 차이는 유사하게 나 타난다. 개인의 예술에 대한 효능감을 알아보기 위한 질문으로 예술 관람이나 예술 관련 활동에 대해 어색하거나 불편한지, 창작-연주 활동이나 그림, 악기 등을 배우 는 과정에서 발생하는 어려움을 극복할 수 있는지, 예술가적 기질이 있다고 생각하 는지, 예술가와의 만남이나 작업에서 발생하는 예기치 않은 상황에 충분히 대응할 
수 있는지, 주변 예술가나 애호가가 많아 예술 참여에 대한 과정이나 활동에 대해 잘 알고 있는지 등을 물어보았다.

FGI 결과, 개인과 결부된 예술에 대한 효능감은 참여활동 경험자 > 직접 관람 고관여자 > 저관여자, 온라인 매체 주 이용자 > 무관심자 그룹 순으로 나타났으며, 주변에 예술관련 종사자가 있는지 유무와 어린 시절의 예술향유 경험 유무가 개인 의 효능감에 큰 영향을 미치는 것으로 나타났다. 이는 아래 예술참여 활동 경험자 그룹과 무관심자 그룹의 주요 답변에서도 분명하게 확인된다. 예술참여 활동 경험 자 그룹은 아래와 같이 예술 관람이나 관련 활동을 어릴 때부터 해왔기 때문에 예술 향유 활동에 매우 친숙하며, 주변에 예술가 및 관련 종사자들과 현재도 교류하며 예술에 대한 개인적인 주체성을 확실하게 피력하고 있다.

"(예술 관람이나 예술 관련 활동에 대해) 어릴 때부터 접했으니까 그런 것들도 있고, 그 외 에 예술이라는 게 주관적이라서 관람이 어색하고 불편한 게 딱히 없을 것 같아요(...) 저는 주위에 음악이나 미술 하는 분들이 많아서 같이 참여도 해봤던 적도 많고 해서 대충 어떻게 돌아가는지 알 것 같아요."

(예술참여 활동 경험자, 남, 30대, 황OO)

"(예술 관람이나 예술 관련 활동에 대해) 예술 관람은 너무 많이 해서 예술 관람은 어떤 흐름 같은 것을 이해하기 때문에 여기에 가서 내가 어떻게 행동해야 되고, 어떤 식으로 관 람을 해야 되고, 그런 거를 알고 있어서 그런지 어색하거나 불편하거나 그런 건 없는 것 같아요."

(예술참여 활동 경험자, 여, 30대, 신OO)

"(주변 예술가나 애호가가 많아 예술 참여에 대한 과정이나 활동에 대해 잘 알고 있는지에 대해) 어릴 때 친구들도 같은 음악 쪽에서 만난 친구들도 많고, 그 친구들하고 만나서 아직 까지도 이야기하고 그러니까 좋아하는 사람들 많죠."

(예술참여 활동 경험자, 남, 40대, 안OO)

반면 무관심자 그룹은 예술에 대한 이해 및 지식 부족이 개인적 효능감에 영향을 미치고 있으며, 대부분 향유 측면의 어려움을 노력으로 극복할 수 없다고 인식하고 있다. 
"(예술 관람이나 예술 관련 활동에 대해) 불편해요. 어떤 게 관전 포인트인지 잘 모르겠어 요. 미술 작품을 보면 어딜 보라는 거고 뭐가 중요한 건지 그런 걸 캐치하기가 어려워요."

(무관심자, 남, 20대, 주OO)

"(예술 관람이나 예술 관련 활동에 대해) 마음의 차이인 것 같아요. 잘 모르기 때문에 저 스스로 어색한 것 같아요. 저는 그냥 어색한 것 같아요."

(무관심자, 여, 30대, 송OO)

"(창작·연주 활동이나 그림, 악기 등을 배우는 과정에서 발생하는 어려움을 극복할 수 있을 지에 대해) 딱히 좋아하지도 않고, 좋아하면 배우고 싶고 알고 싶은 거잖아요. 그런 걸 느껴 본 적이 없고 아예 좋아하지도 않고."

(무관심자, 여, 30대, 송OO)

"(예술가와의 만남이나 작업에서 발생하는 예기치 않은 상황에 충분히 대응할 수 있는지에 대해) 예기치 못한 상황이라면 저도 대응을 잘 못할 것 같은데. 그냥 나와 다른 부류라고 생각이 들면 제가 부자연스러워지는 것 같아요."

(무관심자, 남, 20대, 주OO)

“(주변 예술가나 애호가가 많아 예술 참여에 대한 과정이나 활동에 대해 잘 알고 있는지에 대해) 해당이 안 돼요. 주변에 없어요."

(무관심자, 여, 20대, 김OO)

이처럼 예술이 무엇인가에 대해 사회적인 가치는 전반적으로 동의하고 있음에도, 동기, 가치 인식, 효능감과 같은 개인적이고 주체적인 맥락에서는 예술향유 활동 정 도에 따라 간극이 존재하고 있음을 알 수 있다. 따라서 이러한 내적 동기 및 가치 인식 차원의 차이가 시사하는 바는 과연 예술향유 정책상에서 시민들에게 개인적 차원의 예술향유에 대한 가치 인식 변화를 가져다 줄 수 있는 방안은 무엇이 있을지 에 대한 논의가 필요하다는 것이다. 특히 무관심 그룹의 경우, 예술은 즐겁고 재미 있고 편한 대상이 아니라, 어렵고 불편한 대상이라고 인식하는 데에는 그간 예술계 가 가지고 있는 수월성을 추구하고자 하는 엘리트적 관점이 어느 정도 이러한 그룹 의 인식에 영향을 미쳤음을 부인할 수 없을 것이다.

그럼에도 불구하고 본 조사에서 나타났듯이, 대부분 예술향유 경험자들이 예술을 통해 ‘즐거움'과 ‘행복'이라는 가치를 추구하고 있다는 사실에 비추어 볼 때, 예술이 
란 특정 집단만이 누리고 특별한 목적을 위해 향유하는 대상이 아니라 개인의 일상 과 밀접하게 맞닿아 있는 것임을 의미한다고 볼 수 있다. 따라서 예술에 대해 부정 적인 인식을 가지고 있는 사람들에게 조금이라도 일상에서 그 장벽을 낮출 수 있는 기회를 제공하여 그간 예술에 관심이 없던 사람들의 인식을 전환하는 것이 중요하 며, 특히 온라인 매체 활용 등을 통해 예술향유 기회가 확장되고 다양화되는 현 시 대에서 예술향유에 관심을 갖지 않던 사람들의 내적인 장벽 완화를 위해 외적인 매 개를 활용할 수 있는 방안에 대해 보다 심도 있는 고려가 필요할 것으로 보인다. 여기에서 의미하는 바는 전혀 예술향유에 관심 없는 사람들을 억지로 향유자로 전 환해야 함을 의미하는 것이 아니라, 환경적 제약 및 내적인 장벽으로 인해 그간 예 술향유 기회를 갖지 못했던 사람들을 대상으로 새로운 미디어 및 매체를 활용하여 예술향유 저변 확대를 위한 고민을 해야 함을 의미하는 것이다.

아래 인터뷰 답변에서도 확인할 수 있듯이, 무관심자 그룹 응답자들의 경우, 예술 향유라는 것이 아직 익숙하지는 않지만 언젠가는 하고 싶은 혹은 해야 할 필요성 자체는 인식하고 있음을 알 수 있다.

“지금은 대학원도 다니고 바쁘니까 그런데, 예를 들어서 주부가 된다거나 제가 50세의 저 를 상상해봤을 때 일만 하는 건 너무 슬플 것 같아서 관심을 억지로라도 가지면서 즐길 것 같아요."

(무관심자, 여, 30대, 송O0)

"저는 과거에 관심을 아예 안 두지 않아서 관심을 가질 것 같고. 그리고 점점 예술이라는 영역이 다른 거랑 융합이 돼서 저희에게 더 쉽게 닿아올 거라는 생각이 점점 그래요. 지금 도 많이 닿아왔고(...) 지금은 그렇지 않은데, 언제가 될지 모르겠지만 그렇게 멀지 않을 것 같다는 생각이 들어요."

(무관심자, 남, 30대, 장OO)

따라서 이들이 예술에 보다 익숙하도록 하기 위해서는 단순히 관람료 인하, 무료 관람 확대와 같은 기존 사업방식은 큰 효과를 거두기 어려울 것이며, 이들이 예술에 대해 가지고 있는 부정적인 개인적 가치 및 효능감을 긍정적인 인식으로 전환하고 보다 '재미'와 '익숙함'의 대상으로의 예술향유를 경험할 수 있도록 현 예술향유 정 책상에서 어떤 것들이 개선될 수 있을지를 다각적으로 고민해야 할 것이다. 


\section{마. 정부정책 인식 및 의견: 인지도 제고 및 지원제도 다각화}

현재 정부에서 시행하고 있는 예술향유 정책에 대한 인식과 경험에 대해 알아보 기 위한 온라인 설문조사에서 ‘문화가 있는 날 할인’이 가장 인지도 및 경험률이 높 은 것으로 나타났으며, 다음으로 '박물관·미술관 무료 관람 제도', '문화바우처 지 원 순으로 나타났다. 반면 설문조사에서 제시된 예술향유 지원정책 모두를 모른다 는 응답자도 $18 \%$ 에 달하는 것으로 나타났다. 예술향유 활동 지원정책이 충분하다 는 의견이 $19.5 \%$, 부족하다는 의견은 $21.9 \%$ 로 약간 높게 나타났으며, 나머지 보통 이라는 의견이 $58.6 \%$ 로 가장 많이 차지함으로써, 전체적으로 약간 부족한 편으로 인식하고 있음을 알 수 있다.

FGI에서도 정부의 향유지원 정책에 대한 인지도는 대체적으로 낮은 것으로 보인 다. 예를 들어, '문화가 있는 날 할인' 제도는 알고 있으나, 정작 정부에서 시행하는 제도가 아닌 특정 영화관에서 시행하는 행사로 인식하기도 했다.

이처럼 온라인 설문조사 및 FGI 결과를 비추어볼 때, 현재 정부가 시행하고 있는 예술향유 정책 중에서 '문화가 있는 날 할인'을 제외하고는 지원제도에 대한 인지도 가 높은 편은 아니기에, 예술향유를 위한 지원정책에 대한 인식과 공감을 얻을 수 있도록 홍보를 강화하는 것이 필요할 것으로 보인다. 지원정책 자체를 아예 모르기 때문에 예술향유 기회를 가지지 못하는 사람들도 분명이 존재할 것이므로, 한 번도 기회를 갖지 못한 사람들이 계속 인지조차 못하는 상황이 지속되지 않도록 이러한 간극을 좁힐 수 있는 홍보 방안을 고민해야 할 것이다. 이와 함께 예술향유 확대를 위해 필요한 정부 지원 정책에 대해서는 온라인 설문조사 결과, '관람 비용 할인'이 $54 \%$ 로 가장 높게 나타났으며, 다음으로 '무료관람 확대', '문화시설 확충' 순으로 나타났다. 상대적으로 예술교육, 창작, 동아리 지원영역과 관련한 답변은 낮게 나타 났다.

FGI에서도 대부분의 응답자들은 '관람료(공연료) 인하', '문화바우처 제공', '세금 공제' 등 주로 향유활동에 대한 경제적 부담을 줄일 수 있는 금전적 측면의 지원을 제안하였다. 이 중 참여활동 중심의 응답자들의 경우에는, '공간 대여 지원', '예술 교육 확대', '교육 프로그램 확대' 등과 같이 예술활동 자체에 초점을 둔 의견을 제 시하기도 하였다. 
온라인 설문조사 및 FGI 참여자들의 희망하는 정책 지원에 대한 답변에서 공통적 으로 알 수 있는 점은 이들은 주로 비용 차원에서의 관람료 절감 및 바우처 제공 등 직접 지원 형태의 지원 방식을 선호하고 있으며, 관람 위주, 시설 등 인프라 중심 으로 접근하여 제안하고 있다는 점이다. 이러한 결과는 사실상 대부분의 응답자들 역시 예술향유에 대해 가지고 있는 인식이 특정 '공간'에서 행해지는 '관람' 위주의 형태에 치우쳐 있으며, 상대적으로 '창작'이나 ‘참여'와 같은 향유활동에 대한 인식 은 아직도 미흡하다는 것을 방증해주고 있다 하겠다.

따라서 이러한 사실에 비추어볼 때, 이들이 선호하는 할인 티켓 제공 등과 같은 단기적인 지원 제도도 물론 필요하겠지만, 장기적으로는 보다 근본적으로 시민들의 예술향유에 대한 인식 변화를 위한 지원 제도 또한 동반되어야 할 것이다. 이를 통 해 현재 관람 위주의 인식에 머물러있는 시민들이 다양한 예술향유의 범주를 이해 하고, 관람 형태에서 벗어나 확장된 영역, 즉 참여 및 창작 활동까지 인식과 활동을 포괄한 보다 다양한 예술향유 활동이 이루어지도록 해야 할 필요가 있다.

〈표 3-72〉 시민 예술향유 인식 및 예술향유활동 조사(설문조사 및 FGI)의 종합시사점

예술향유 인식 및 향유활동 양태조사 종합시사점

가. 예술향유 범주에 대한 인식 확장: 예술향유 정책과의 간극 존재

나. 예술향유의 걸림돌 파악: 세분화된 예술향유 정책적 접근 필요

다. 기술적 환경변화에 따른 예술향유 양상 변화: 예술향유 정책의 범주와 개념 재정비

라. 예술향유자의 내적 요소: 예술향유 가치 인식 변화를 위한 정책적 노력

마. 정부 정책에 대한 인식 및 의견: 인지도 제고 및 지원제도의 다각화 

예술향유정책 분석 및 방향 연구

제4장

예술향유정책 전개과정 및

정책지원 구조 



\section{제1절 예술향유정책의 전개과정과 특징}

\section{1. 예술향유정책의 전개과정}

국내 예술정책 논의에 있어 '예술향유정책' 영역이 특정한 학술적 혹은 정책적 기 준에 의거하여 명확하게 존재하는 것은 아니다. 다만 예술정책의 궁극적 목적이 예 술을 통해 국민의 삶의 질 제고에 기여하는 것이라 한다면, 예술정책 내에서 창작과 향유, 유통(매개) 영역 간 선순환 구조를 지원함으로써, 많은 이들이 예술을 통해 행복한 삶을 영위할 수 있도록 하는 데 있다고 하겠다. 이런 관점을 채택할 때, 예술 정책의 세부적 목표는 창작영역과 향유, 그리고 이 둘을 매개하는 영역 등 3개 영역 간 가치사슬 관점에서의 예술생태계 활성화를 모색하되, 궁극적으로 이것이 '국민 의 삶의 제고'라는 대의적 목적에 부합하도록 할 필요가 있다.63) 그러나 국내 예술 정책의 역사적 전개과정을 살펴보면 초기 예술정책은 전문예술인과 단체, 시설 지 원 등 ‘창작지원'에 주된 방점을 두었다가 서서히 ‘향유지원'의 중요성을 인식하고 포용해 온 것으로 보인다. 그 과정에서 '향유'지원은 보다 포괄적인 개념과 관점인 '문화복지'라는 차원에서 접근되어 온 것이 특징적이다. 이어지는 논의에서는 예술 정책이 처음 시작되었던 1970년대부터 현재까지 예술정책에서 '향유' 관련 지원정 책의 흐름을 살펴보고자 한다. 이를 통해 향유를 바라보는 정책적 관점이 어떻게 변화되어 왔는지, 그리고 이러한 정책 관점의 변화가 '문화복지'의 담론적 프레임 속에서 어떻게 긴밀히 연계되면서 진행되어 왔는지를 살펴보기로 한다.

63) 이는 예술정책이 창작, 향유 등 2 개 영역으로만 배타적으로 구성된다는 의미는 아니다. 창작과 향유를 매개하는 중간영역으로서의 유통 등을 고려하지 않을 수 없기 때문이다. 


\section{가. 발아기(1972 1987)}

\section{- 1970년대 박정희 정부 시기(제3, 4공화국)}

국내 예술정책은 1972년 「문화예술진흥법」제정과 1973년 문예진흥기금을 통 한 지원을 시작점으로 발전해 온 것으로 일반적으로 논의된다. 해당시기 예술에 대 한 국가 지원이 처음으로 시작된 것은 맞지만, 예술지원을 창작과 향유로 구분하고, '예술향유'에 대한 정책적 이해 혹은 관점이 명확하게 있었던 시기로 보기는 어렵 다. 창작을 위한 기초적 인프라 조차 일천했던 당시 상황에서 초기 예술정책은 전문 예술인이나 관련 협.단체 지원 혹은 문화시설 건립 등 인프라 구축에 상대적으로 집중된 지원이 이뤼졌다.

더욱이 유신정권시기로, 예술지원의 주요목적은 "문화유산의 보존·계승과 전통문화 의 계발을 통한 민족주체성 확립"에 초점이 맞춰져 있었다(양건열 외 2002:214).64) 예술지원에 있어서도 '주체적 민족사관의 정립'이 강조되었고, '문화유산의 보존과 계승'과 ‘민족예술에 대한 긍지와 자부심'을 느낄 수 있는 창작 및 발표 지원이 강조 되었다. ${ }^{65)}$ 예술지원의 경우 별도의 대규모 시설 건립이 아닌 이상 주로 '문예진흥 기금'을 통해 이루어졌다. 그러나 이 역시 정권의 정당성 획득과 직결된 국학연구 및 전통예술과 문화재 보호, 혹은 국공립 기관 및 시설 운영 및 국가차원의 대규모 예술행사 개최 등에 상대적으로 집중된 특징이 나타났다(오명석 1998: 122).66)

이러한 가운데, 1973 년 「제 1 차 문예중흥 5개년 계획」에서 '국민의 문화수준 향 상'이 정책목표 중 하나로 제시된 것이 주목된다. 그러나 여기서의 '국민'은 문화예 술활동의 주체보다는, '의식개조의 대상'이거나 혹은 낮은 수준의 문화의식을 향상 할 필요가 있는 수동적 '객체'로서 전제하고 있었던 것으로 보인다.

64) 이 시기의 문화예술정책은 외연적으로는 민족문화 창달 등이 강조되었지만, 실질적으로는 군사정권의 체 제유지를 위해 적극 동원되었던 바, 이데올로기적 기능을 수행했다고 평가된다(오명석 1998: 122).

65) 1973년 발표한 11 차 문예중흥 5개년 계획 에 따르면, 5년간 총 경비 485.4억 중 민족사관정립은 $70.2 \%$, 예술진흥 $12.1 \%$, 대중문화 $8.9 \%$, 기반조성 $6.0 \%$, 기타 $2.7 \%$ 로 압도적인 비중을 차지하고 있었다(한국문화예술위원회 2013: 40).

66) 1973년부터 1978년 까지 5년 동안의 문화예술진흥기금 총 67.9억 중 사업비는 42.2억이었고, 사업비 지원내역은 국학연구·전통예술 및 문화재 보호 $20.6 \%$, 문예단체·행사·시설지원 $21.3 \%$, 문학14.3\%, 출 판9.8\%, 영화9.5\%, 무용 2.3\% 등이었다(한국문화예술위원회 2013: 45). 
〈표 4-1〉1973년「제1차 문예중흥 5개년 계획」

\begin{tabular}{|c|c|c|}
\hline 정책기조 & 정책목표 & 정책수단 \\
\hline \multirow{4}{*}{$\begin{array}{c}\text { 전통문화를 계승하고 그 바탕위에 } \\
\text { 새로운 민족문화를 창조하여 } \\
\text { 문화중흥을 이룩한다 }\end{array}$} & 주체적 민족사관의 정립 & 문화유산 전승.계발 사업 \\
\hline & 새로운 민족예술의 창조 & 민족예술 창작지원사업 \\
\hline & 국민의 문화수준 향상 & $\begin{array}{c}\text { 예술의 생활화, 대중화 및 } \\
\text { 문예진흥기반 조성사업 }\end{array}$ \\
\hline & 문화한국의 국위선양 & 문화예술 국제교류 사업 \\
\hline
\end{tabular}

자료: 양건열 외 2002: 213 〈표 3-1〉 발췌, 수정보완

이는 당시 지방문화원들이 “향토문화계발” 보다는 “정부선전물의 배부와 전시, 홍보필름의 상영, 정부주관의 집회의 대행” 등을 주요사업으로 추진하고, 특히 10 월 유신 이후 “유신이념과 새마을운동이념을 계도하고 선전하는 역할"을 수행했다 는 점을 통해서도 확인된다(오명석 1998: 139).67) 이런 점에서「제1차 문예중흥 5개년 계획」의 정책수단으로 제시되었던 '예술의 생활화'는 당시 국가주의적 관점 에서 정치화된 예술을 통한 국민들의 의식계도를 의미했던 것이라고 보인다.

\section{- 1980년대 전두환 정부(제5공화국)}

제5공화국 시기와 중첩되는 1980 년대에는 경제성장의 결실이 조금씩 가시화되 면서 소득증가에 따라 예술수요가 조금씩 높아지기 시작했던 때였다. 그러나 전반 적으로 공연·전시 시설 등 물리적 인프라가 여전히 부족하고 도시와 지역 간 접근성 격차가 컸다. 따라서 인프라 부족 해결, 혹은 접근성 격차 해소 등을 위한 전국적인 대규모 문화시설 조성과 지방문화 육성 등 기초인프라 마련에 특히 주력했던 것이 특징이었다(양건열 외 2002: 224). 전두환 정부의 출범이 정치적 정통성에 문제가 있었음에도 불구하고, 1980년대에는 '문화예술'과 '삶의 질'을 연계하는 정책 인식 이 나타났음이 확인된다(정갑영 2006: 227-228).

67) 지방문화원은 1950 1960년대 사설문화원으로 존립하던 민간단체였다가 1962년 한국문화원연합회가 창 립되면서 박정희 정부에 의해 공인단체로 인정되었고, 이를 계기로 정부의 공식적 지원을 받게 되었다한 국문화원연합회 1974: 101). 오명석(1998: 139)은 당시 정부가 문화원에 대한 공식지원을 하게 된 것은 관변단체로서의 기능을 인정하였기 때문이었다고 지적한다. 
〈표 4-2〉1983년「제5차 경제·사회발전 5개년 수정계획」 중 문화부문계획

\begin{tabular}{c|c|c}
\hline 정책목표 & 주요시책 & 정책수단 \\
\hline \multirow{2}{*}{ 국민의 문화향수기회 확대 } & 문화창달의 기반 구축 & $\begin{array}{c}\text { 문화시설의 확충 } \\
\text { 지방문화 육성 }\end{array}$ \\
\hline \multirow{2}{*}{ 민족문화의 주체성 확립 } & 민족문화예술의 창달 & $\begin{array}{c}\text { 민족문화의 정통성 확보 } \\
\text { 전통문화예술의 보존·개발 } \\
\text { 문화예술 창작여건의 개선 }\end{array}$ \\
\hline \multirow{2}{*}{ 세계 속의 한국문화 위상 정립 } & 문화예술 국제교류 확대 & $\begin{array}{c}\text { 적극적인 해외 선양 } \\
\text { (86게임, 88올림픽 계기) }\end{array}$ \\
\cline { 2 - 2 } & 문화매체산업 육성 & (8)
\end{tabular}

자료: 양건열 외 2002: 218 〈표 3-3〉 발췌, 수정보완

당시 경제발전 5개년 계획 수정계획의 문화부문 계획은 “생활의 질을 향상시켜나가 는 데 있어서 문화예술의 진흥은 중요한 과제”라고 지목하는 한편68) “문화향수”라 는 공식적인 정책표현을 사용하고 있다(한국문화예술진흥원 1985: 28, 재인용). ${ }^{69)}$ 또한 대통령 국정연설(1983.01.18.)에서도 “문화권 신장”을 위해 “지역과 계층, 그 리고 세대 간의 문화적 격차 해소”가 필요하며, “문화발전의 혜택이 전국의 국민에 게 고루 돌아가도록 해야 할 것”이 언급되기도 한다.

문화권의 신장을 위하여 지역과 계층 그리고 세대 간의 문화적인 격차를 해소하는데 역점을 둠으로써 문화발전의 혜택이 전국의 모든 국민에게 고루고루 돌아가도록 해 나갈 것입니 다.70)

물론 개념과 논리의 언급이 곧바로 동일하게 정책으로 반영된 것을 의미하지는 않는다(정갑영 2006: 228).「제5차 경제·사회발전 5개년 수정계획」중 문화부문계 획을 좀 더 자세히 살펴보면 “국민의 문화향수기회 확대”라는 정책목표가 제시되었 으나, 주요 정책수단으로 대도시와 지방에서의 문화시설의 확충이 강조되었다. 즉,

68) 한국문화예술진흥원, 「문화예술진흥백서 1981-1985」, 28쪽(정갑영 2006: 228 재인용).

69) 현재로서 해방이후 1990년 말까지의 국내 문화정책의 변천과정을 상세히 기록한 것은 양건열 외(2002) 의 연구가 대표적이라 할 수 있다. 각 시기별 문화관련 정부계획 및 문서 등의 자료에 기반을 둔 분석이라 는 점을 고려할 때, 양건열 외(2002)의 분석상 “문화향수” 용어의 공식적 등장은 1983년 「제5차 경제·사 회발전 5 개년 수정계획 중, 문화부문계획에서다.

70) 1983년 1월 18일. 전두환 대통령 국정연설. 행안부 국가기록원 대통령기록관 연설기록 (CEA0003706) http://www.pa.go.kr/research/contents/speech/index03.jsp?spMode=view\&catid=c_pa0206 4\&artid=1311365 (최종접근: 2020.03.25) 
국민의 문화적 권리를 인식, 외연적으로 언급하기는 했지만, 실제 정책 접근은 상당 부분 지역의 ‘문화시설 건립’ 차원에서 구체화되었던 것이다. 이는 한편으로 시설설 립 등 인프라 구축을 국민의 문화향수 및 예술향유의 우선적 토대로 인식했던 것으 로 볼 수 있다. 동시에 다른 한편으로 서울을 제외한 지역에 있어 전문예술인들의 작품이 대중에게 선보일 수 있는 기초 인프라 격차 자체가 컸던 당시 상황에서 시설 조성 및 건립은 구체적인 문화권 신장을 위한 지원이기 보다는 창작지원 성격에 더 가까웠던 것으로 해석이 가능하다.

그럼에도 불구하고 전문예술인 지원 위주의 예술정책을 전개해왔던 이전 정부와 비교할 때 제5공화국 시기는 정책대상을 예술인에서 일반 국민으로 확대 설정하고, 국민의 삶의 질 향상을 위해 문화예술이 중요함을 강조했다는 점에서 큰 차이점을 보인다. 이런 맥락에서 예술정책 논의에 있어 '향유'지원에 대한 정책인식이 처음 발아된 시기였다고 해석할 수 있다.

\section{나. 태동기(1988 2003)}

\section{— 노태우 정부 시기(제6공화국: 1988 1993)}

제6공화국은 정치적 민주화에 이은 문화적 민주화에 관심을 보였다. 실제로 1990년에는 문화부가 최초로 신설되었고, 초대 문화부장관 이어령은 '국민의 문화 향수권' 및 문화민주화적 관점에서의 '문화보급방식의 혁신' 등을 강조하기도 했 다.71) 이 시기 예술정책의 큰 특징은 바로 "문화복지”라는 용어 및 개념이 처음으로 공식 등장하고, 그 연계선상에서 예술향유 관련 정책논의가 중첩되기 시작했다는 점이다.

당시 수립된「문화발전 10개년 계획(1990-1999)」은 "삶의 질을 추구하는 문화 복지의 실현”이라는 차원에서 “국민의 문화향수권과 참여권을 신장”을 강조하였다 (양건열 외 2002: 222; 문순덕·조현성 2016: 16). 또한 “문화복지국가”의 건설을

71) 당시 이어령 장관은 '문화향수권 신장'을 위한 방안으로 '문화가족운동과 문화사랑방 운동, 소외계층과 지역을 찾아가는 문화보급 방식의 혁신을 통해 전 국토를 문화공간화' 하겠다고 언급했다. 이상룡 (1990.01.15.) 이어령 문화부장관 문화정책 기본안 마련, 전 국토 문화공간화. $\mathrm{MBC}$ 기사. https://imnews.imbc.com/replay/1990/nwdesk/article/1830172_30435.html (최종접근: 2020.03.25) 
비전으로 제시하면서 "다가 올 새로운 시대는 국민의 모든 문화적 활동의 창조자이 자 수용자가 되어 보다 높은 삶의 가치를, 보다 풍요로운 삶의 질을 향유할 수 있는 시대”라고 언급했다(한국문화예술진흥원 문화발전연구소 1989).

이는 곧 '문화복지'라는 정책프레임 하에서 향유지원을 접근하되, 정책대상을 전 국민으로 설정하고 '보편적 관점에서 문화예술 활동에의 참여권’을 강조했던 것이라 볼 수 있다. 일례로 관객개발 차원에서 1991년 시작된 '사랑티켓' 사업은 이러한 정 책인식이 반영되어 추진되었던 것이라 할 수 있다.72) 또한 1988년 「문화예술 수용 및 향수능력 실태조사」가 처음 시작된 것(한국문화정책개발원 편집부 1988)과, 현 재 ‘복권기금 문화나눔’ 사업의 원형이라 할 수 있는 '찾아가는 문화활동’이라는 정 책사업이 당시 처음 시작되었다는 것 역시 당시 보편적 '문화복지'적 관점에서 '향유 지원 관련 정책인식이 연계되고 있었던 근거로 볼 수 있다(정갑영 2006: 232).73)

〈표 4-3〉1990년「문화발전 10개년 계획」

\begin{tabular}{|c|c|c|c|}
\hline & 기본방향 & 정책과제 & 추진전략 \\
\hline \multirow{5}{*}{$\begin{array}{l}\text { 문화복지국가 } \\
\text { 실현을 위한 } \\
\text { 다섯 가지 } \\
\text { 문화의 틀 구축 }\end{array}$} & $\begin{array}{l}\text { (1) 마음의 풍요를 지향하는 } \\
\text { '복지문화의 틀' }\end{array}$ & $\begin{array}{c}\text { 국민의 } \\
\text { 문화향수 확대 }\end{array}$ & $\begin{array}{c}\text { 문화환경 조성을 통한 } \\
\text { 문화창조와 수용여건을 } \\
\text { 개선하는 '지열효과' }\end{array}$ \\
\hline & (2) 갈등구조를 푸는 '화합의 틀' & $\begin{array}{l}\text { 문화창조력의 } \\
\quad \text { 제고 }\end{array}$ & $\begin{array}{c}\text { 문화의 자율성을 돕는 } \\
\text { '바람개비효과' }\end{array}$ \\
\hline & $\begin{array}{l}\text { (3) 환태평양시대를 주도하는 } \\
\text { '민족문화의 틀' }\end{array}$ & \multirow{2}{*}{$\begin{array}{l}\text { 국제 문화교류의 } \\
\text { 증진 }\end{array}$} & $\begin{array}{c}\text { 문화활동의 무대, 시장, 기술을 } \\
\text { 제공하는 '통발효과' }\end{array}$ \\
\hline & $\begin{array}{l}\text { (4) 후기 산업시대에 적응하는 } \\
\text { '개방문화의 틀' }\end{array}$ & & $\begin{array}{c}\text { 부정적 요인을 긍정적 문화로 } \\
\text { 발전시키는 '인화효과' }\end{array}$ \\
\hline & $\begin{array}{l}\text { (5) 남북한 협력시대를 준비하는 } \\
\text { '통일문화의 틀' }\end{array}$ & $\begin{array}{l}\text { 문화매개 } \\
\text { 기능의 확충 }\end{array}$ & $\begin{array}{c}\text { 다목적, 다기능 복합적 } \\
\text { 사업추진으로 이루는 } \\
\text { '메아리효과' }\end{array}$ \\
\hline
\end{tabular}

자료: 양건열 외 2002: 218 〈표 3-6〉 발췌, 수정보완

72) 사랑티켓 사업은 1991년 (연극,영화의해)부터 문예진흥기금을 재원으로 일반시민 대상의 관객개발을 목 표로 시작되었다가 이후 2006년 복권기금사업으로 편입되어 취약계층 지원으로 대상을 집중하였다가 2016년에 폐지되었다(문화체육관광부 2013: 159).

73)「문화예술 수용 및 향수능력 실태조사」는 우리에게 잘 알려진「문화향수실태조사」의 최초 버전으로 1988년 처음 표본조사로 시작되었다. 이후 1991년 통계청 승인통계로 인정되면서 「문화향수실태조사 로 명칭도 함께 변경되었다. 이후 18년간 지속된 「문화향수실태조사」는 2019년 「국민문화예술활동조사」 로 명칭이 다시 바뀌었다. 보다 자세한 사항은 통계청 설명자료를 참조할 것.

http://meta. narastat.kr/metasvc/svc/SvcMetaDcDtaPopup. do?orgld=113\&confmNo=113001 \&kosis $Y n=Y$ (최종접근: 2020.03.23) 
하지만 동일시기 '문화복지' 용어가 처음으로 등장했다는 그 자체는 의미가 있지 만, 이와 관련된 구체적 담론의 발전이나 혹은 이를 구현하기 위한 세밀하고 구체적 인 정책적 접근이 존재했다고 보기는 어렵다는 평가가 일반적이다(문순덕·조현성 2016; 양건열 외 2002; 정갑영 2006; 정광렬 외 2010; 조현성·연수현 2019).74) 외연적으로는 '문화복지’라는 개념적 틀 속에서 ‘향유자 정책지원이 필요하다는 인 식의 발현'이 주목되는 것은 사실이나, 세부 사업들의 경우 시설조성이나 건립 등 이전 정부에서 추진되었던 것을 상당부분 계승한 것 이상의 의미를 갖는다고 보기 어렵고, '문화복지' 자체에 대한 개념적 논의 역시 구체적으로 발전되지는 못했기 때문이다.

\section{— 김영삼 정부 시기(문민정부, 1993 1998)}

1993년 출범한 김영삼 정부 시기는 일반적으로 “문화복지”라는 포괄적 개념 하 에 “문화향수권” 논의가 보다 본격적으로 발전되었다는 평가를 받는다(문순덕·조현 성 2016: 16). '문화복지' 구현을 위해 한시적으로 '문화복지기획단'이 실제로 구성 되었고, '문화복지 중장기 실천계획'이 수립되는 등, '문화복지' 관련 정책 논의가 본격화되었기 때문이다(정광렬 외 2015: 15-16). 특히 1993년 발표한「문화창달 5개년 계획」에서 정책기조로 '창조계층에서 향수계층으로'를, 정책과제로 '문화복 지의 균점화'를 제시한 것은 이러한 변화를 반영한 것으로 보인다.

〈표 4-4〉1993년「문화창달 5개년 계획」

\begin{tabular}{|c|c|c|}
\hline 정책목표 & 정책기조 & 정책과제 \\
\hline \multirow{6}{*}{$\begin{array}{c}\text { 문화창달을 통해 국민들의 } \\
\text { 삶의 질을 향상시켜 선진 } \\
\text { 문화복지국가로 진입 }\end{array}$} & 규제에서 자율로 & 문화창조력 제고와 문화환경개선 \\
\hline & 중앙에서 지역으로 & 지역문화의 활성화 \\
\hline & \multirow{2}{*}{ 창조계층에서 향수계층으로 } & 문화복지의 균점화 \\
\hline & & 문화산업개발과 기업문화활성화 \\
\hline & 분단에서 통일로 & $\begin{array}{c}\text { 민족정기의 확립 } \\
\text { 한겨레문화의 조성 }\end{array}$ \\
\hline & 보다 넓은 세계로 & 우리문화의 세계와 \\
\hline
\end{tabular}

자료: 양건열 외 2002: 226 〈표 3-7〉 발췌, 수정보완

74)「문화발전 10개년 계획(1990-1999)」계획은 이후 문민정부(1993 1997)가 들어서면서「문화창달 5개 년 계획(1993-1997)」에 일부 흡수되기도 하였으나, 대부분 구체적 실행단계로 이어지지는 못했던 것으 로 알려져 있다(양건열 외 2002: 223) 
이러한 특성은 문화향수 혹은 예술향유를 바라보는 정책적 시각의 전환을 반영한 다고 해석이 가능하다. 즉, '국민의 문화향수 기회 확대' 논의가 이전과 같이 물리적 차원의 인프라 제공 등 '대규모 문화시설' 관점에 한정하여 접근하는 것이 아니라, 시 민의 입장에서 그들이 “일상에서 누릴 수 있는 문화예술활동 지원”에 방점을 두고 논 의하고 있기 때문이다(문순덕·조현성 2018: 16-19). 가령, '문화의집' 관련 설치근거 를 마련하고, 문화동호인 모임의 활성화, 현장 중심 문화체험 기회 확대 등을 주요 정책사업으로 추진했던 것은 용어로서만 존재하던 '문화복지' 개념을 담론적으로나 세부 사업차원에서도 구체화시키고자 시도했던 것이라 볼 수 있다. 더욱이 당시 '문화 복지'는 유네스코에서 제시된 ‘문화권' 개념을 반영하여 문화예술을 “인간이 향유해 야 할 권리”로서 이해될 필요가 있음이 강조되기도 하였다(정갑영 1996).75)

반면 다른 해석도 동시에 존재한다. 가령 심광현(1993)은 「문화창달 5개년 계획」 에서 제시되었던 ‘창조계층에서 향수계층으로'라는 정책기조가 담론적으로는 타당 한 방향성이나, 실질적인 예술지원이 여전히 “창작중심의 문화에 비중”이 두어져 있 는 한편, "고급예술문화 위주의 문화개념을 답습하고 있고 국민들의 자발적인 문화 창조와 향유보다는 고급지배문화를 위로부터 하달하고자 하는 관점”에 기반을 두고 있었다고 지적한다(심광현 1993: 27). 즉, 창조와 향유를 아우른 예술활동의 자발 적 주체로서 국민을 인식하기보다는 여전히 전문예술인에 의해 생산된 예술을 소비 하는 수동적 대상으로 인식하는 정책관점이 농후했다는 것이다.

정리하자면, 문민정부 당시 ‘문화복지’는 물질적 복지와 대비되는 문화적·정신적 차원의 복지로서 개념이 상대적으로 명쾌하게 제시되었다는 점에서 특징적이라 할 수 있다. '문화감수성 증진을 통한 삶의 질 향상'이란 목표 하에 모든 국민을 정책대 상으로 설정하되, 하드웨어 중심 인프라 확충이라는 정책 관점을 넘어서서 일상적 접근의 중요성을 강조하고 이를 반영한 구체적인 사업들이 추진되었다는 사실에서 주목된다. 그러나 정책 실제에서는 '문화' 혹은 '예술'의 개념 자체를 지배문화 혹은 소수의 전문예술가가 생산한 것으로 한정한 제약적 접근은 여전히 존재했던 것으로 보인다. 이로 인해 일반 국민을 예술생산과 향유의 적극적 주체로서 바라보기보다는 여전히 수동적 주체로 이해하는 정책적 접근이 강조되었던 시기였다고 할 수 있다.

75) http://www.arko.or.kr/zine/artspaper96_10/19961002.htm(최종접근: 2020.03.26) 
김대중 정부 시기(국민의 정부, 1998 2003)

$\mathrm{IMF}$ 구제금융으로 대표되는 경제위기로 인해 계층 양극화 문제가 심화되는 가운 데 집권한 ‘국민의 정부’ 시기에는 양극화 해소, 복지에 대한 정책적 관심이 급증하 던 때였다. 김대중 정부는 '창의적 문화복지국가'로 문화정책 목표를 제시하였다. 하지만 ‘문화복지’ 관련 담론적 논의의 확장이 두드러졌다고 보기는 어렵다. 1998 년 발표된「국민의 정부 새문화정책」을 살펴보면, 10 대 중점과제 중 하나로 '문화 복지의 실질적 구현'이 제시되어 있다, ‘창의성' 평생학습을 위한 문화기반 시설의 역할 확대, 문화프로그램 정보 확대, 문화자원봉사 육성 등의 지원을 강조했다. 이 는 곧 국민의 문화예술활동 혹은 향수기회 확대를 위한 노력이 시설, 인프라 중심 접근이 아닌 국민의 일상적 삶속에서 가능할 수 있도록 하는 정책적 접근을 강조했 던 것으로 이해할 수 있다.

〈표 4-5〉1998년「국민의 정부 새문화정책

\begin{tabular}{|c|c|c|}
\hline 정책목표 / 지향점 & 추진전략 & 10대 중점 과제 \\
\hline \multirow{3}{*}{$\begin{array}{c}\text { 창의적 } \\
\text { 문화복지국가의 건설 }\end{array}$} & $\begin{array}{c}\text { 문화의 세기를 } \\
\text { 대비하는 비전 제시 }\end{array}$ & \multirow{3}{*}{$\begin{array}{l}\text { 21세기 문화국가 실현을 위한 정책기반 구축 } \\
\text { 문화기반시설 확충과 운영개선 } \\
\text { 지식정보사회에 대비한 기반조성 } \\
\text { 창조적 예술활동을 위한 여건 조성 } \\
\text { 문화복지의 실질적 구현을 통한 삶의 질 향상 } \\
\text { 문화유산의 체계적 보호·계승·발전 } \\
\text { 문화산업의 획기적 발전체제 구축 } \\
\text { 문화기반 지역 간 균형발전 및 사회통합 추구 } \\
\text { 문화를 통한 민족통합 지향 } \\
\text { 문화정체성 기반 보편적 세계주의 지향 }\end{array}$} \\
\hline & $\begin{array}{l}\text { 문화를 국가발전의 } \\
\text { 핵심 동인으로 활용 }\end{array}$ & \\
\hline & $\begin{array}{c}\text { 주요분야 중심 } \\
\text { 거점적 사업 추진 }\end{array}$ & \\
\hline
\end{tabular}

자료: 양건열 외 2002: 226 〈표 3-8〉 발췌, 수정보완

그러나 담론적 논의와 정책 실제가 늘 동일한 궤를 이루는 것은 아니듯, 당시 문 화정책 전반은 국가발전의 새로운 동력으로서 '문화산업'에 대한 정책적 관심과 지 원에 집중되어 있었다. 반면 예술정책에서의 향유 지원 혹은 '문화복지' 관련 논의 는 크게 확장되지 못했다. 외연적으로는 “창의적 문화복지국가”, 즉 “창의성'과 '문 화복지'를 함께 강조하는 것으로 보였으나, 실질적으로는 문화산업 중심의 '창의성' 관련 정책지원이 특징적이었다는 평가도 이런 배경에서 이해될 수 있다(문순덕·조 현성 2016). 


\section{다. 전환기(2003 2013)}

— 노무현 정부 시기(참여정부: 2003 2008)

참여정부 시기는 예술정책 전반에 걸쳐 큰 변화와 전환이 일어났던 시기였다. 출 범 직후 발표된 문화정책 비전서「창의한국」 등을 통해 문화민주주의 정책기조가 강조되었고, 이는 '주체적인 시민들의 문화역량'에 대한 정책논의로 확장되었다. 결 과적으로 이는 곧 예술정책 논의에 있어 수요자 중심의 '문화향유권' 신장에 대한 공식적인 강조로 이어졌다. 이런 배경에서 특히 주목되는 당시의 변화는 '향유'의 토대로서 '문화예술교육'이 예술정책에서의 최우선 의제로 급부상했다는 점이다.76)

실제로 참여정부 출범 직후 문화예술교육 지원을 위한 문체부 내 TF 설치(2003), 문화예술교육지원법 제정(2004) 및 전담기관 설치(2005) 등 제도적 지원이 본격화 되었으며, 그 외에도 향유격차 해소를 위한 다양한 사업들이 추진되었다. 이로 인해 역설적으로 참여정부 시기 문화 및 예술정책의 방향성은 “수요자 중심성”을 강조하 고, “창작보다 향유지원에 치중한 것”으로 해석-평가되기도 한다(이규석 2017; 허 은영 외 2018: 16). 반면, 당시 예술정책의 우선적 정책목표로 '문화향유권' 신장이 설정·제시된 것은 사실이나 “이에 대한 기본적 관점이 상대적으로 불명확"했다는 분석도 있다(정광렬 외 2010: 24). 사실상 예술정책의 목표와 대상은 우수성 증진 에 초점을 두어왔고, 지원받은 우수한 예술이 보다 많은 국민에게 접근하는 효과는 상대적으로 낮은 편이었기 때문이다.

76)「새 예술정책」(문화관광부 2004b)보다 먼저 발표된 문화정책 비전서「창의한국」(문화관광부 2004a)에 서 제시된 27대 추진과제에서도 '문화예술교육을 통한 문화역량 강화'는 가장 첫 번째 과제로 제시되었다. 
〈표 4-6〉2004년「참여정부 새 예술정책 기본방향 및 14대 역점추진과제」

\begin{tabular}{|c|c|c|}
\hline 정책비전 & 4대 기본방향 & 14대 역점 추진 과제 \\
\hline \multirow{4}{*}{$\begin{array}{c}\text { 예술의 힘, } \\
\text { 미래를 창조합니다 }\end{array}$} & $\begin{array}{l}\text { 향유자 중심의 } \\
\text { 예술활동 강화 }\end{array}$ & $\begin{array}{l}\text { (1) 예술교육을 통한 문화향유능력 개발 } \\
\text { (2) 생활 속의 예술참여 활성화 } \\
\text { (3) 예술의 공공성 제고 }\end{array}$ \\
\hline & 예술의 창조성 증진 & $\begin{array}{l}\text { (4) 장르별 예술창작활동 지원확대 } \\
\text { (5) 새롭고 실험적인 예술활동 지원 } \\
\text { (6) 남북 및 국제예술교류를 통한 예술의 지평 확대 } \\
\text { (7) 국립예술시설·단체의 기능활성화 및 특화된 예술환경 조성 }\end{array}$ \\
\hline & 예술의 자생력 신장 & $\begin{array}{l}\text { (8) 예술인에 대한 사회적 예우 강화 } \\
\text { (9) 예술전문인력의 체계적 양성 및 재교육 } \\
\text { (10) 예술의 산업적 발전 지원 } \\
\text { (11) 개성있는 지역문화 진흥 }\end{array}$ \\
\hline & $\begin{array}{c}\text { 열린 예술행정체계 } \\
\text { 구축 }\end{array}$ & $\begin{array}{l}\text { (12) 예술지원시스템을 현장중심으로 전환 } \\
\text { (13) 예술재원의 안정적 확충과 효과적 활용 } \\
\text { (14) 예술진흥을 위한 법과 제도 개선 }\end{array}$ \\
\hline
\end{tabular}

자료: 문화관광부(2004b: 27)「4대 기본방향 및 14대 역점추진과제」 발췌 및 보완

그럼에도 불구하고 참여정부가 추진했던 예술향유 정책지원은 이전 정부와 차별 화된 차이점을 가졌다. 정책대상의 우선순위를 일반시민이 아닌 '취약계층(소외계 층)' 으로 특정화하였기 때문이다. 정부 출범 초기에는 '모두를 위한 예술' 즉 보편적 차원의 향유지원을 강조하였지만(문화관광부 2004a), 경제위기 이후 양극화가 지 속적으로 심화된 상황에서 정책의 우선대상을 '취약계층'으로 설정하고 이들의 문 화예술에 대한 접근성 제고를 위한 정책지원을 강화했다.

문화향유 기회의 양극화 등 ‘물리적 격차 해소'라는 취지하에 저소득층, 농어촌거 주자, 노인, 장애인, 군인, 다문화 가정 등의 구성원 등이 이른 바 '소외계층' 으로 지 칭되었고, 이들의 문화향유 기회확대가 향유지원의 우선순위로 강조되었다. 가령, 2004년 처음 시작된 ‘복권기금 문화나눔사업’이 대표적이다.77) 초기에는 ‘모두를 위 한 예술'을 지향했으나, 2007년 이후부터는 보다 집중적으로 “취약계층의 문화향수 권 시장”, 이들이 구조적으로 겪는 “문화양극화 해소” 가 정책적으로 강조되었다(조현

77) ‘복권기금 문화나눔’ 사업은 소외계층 문화순회(2004), 전통나눔(2004), 지방문예회관 특별프로그램 지원 (2004), 공공박물관-미술관 전시프로그램 지원(2004), 문학나눔(2005), 사랑티켓, 문화바우처(2005), 생 활문화공동체만들기(2009) 등의 세부사업으로 구성되어 진행되었다. 이 중 1991년 시작된 '사랑티켓'은 2006년 복권기금사업으로 편입됨으로써 기금 취지에 따라 2008년부터 지원대상을 문화혜택을 받지못하 는 어르신(65세이상), 아동·청소년(24세이하) 등 취약계층으로 한정하여 지원했다. 
성·연수현 2019: 48). 이는 이전까지 김영삼, 김대중 정부 시기의 '문화복지' 논의에 서 정책대상을 '일반국민' 으로 강조했던 것과는 명확한 차이로 이해할 수 있다.

참여정부 시기 예술향유 및 문화복지 관련 정책지원이 '취약계층(혹은 소외계층) 중심'이었다고 평가되는 배경은 당시 예술지원을 위한 재원에 ‘복권기금'이 공식적 으로 편제되었던 사실과 함께 복합적으로 이해될 필요가 있다. 주지하다시피 2000 년 초반 '문화예술진흥기금' 모금이 위헌으로 판정되어 모금이 중단되는 등 고갈위 기에 처했던 상황에서, 부족한 예술지원 재원의 대안 차원에서 '복권기금'이 유입되 었다. 그러나 기재부가 제시한 재원조성 '역진성' 논리에 따라 해당 기금이 '소외계 층' 대상으로만 사용되도록 용도가 규정되었고, 이는 복권기금을 재원으로 하는 모 든 사업의 정책대상이 '취약계층(혹은 소외계층)' 에만 한정되는 결과로 이어졌다. 당시 '소외계층 문화향유 기회 확대'를 정책목표로 새로 추진된 대표적인 사업들이 바로 '방방곡곡 문화공감'(2004년 ), '순회계층 문화순회사업'(2004년 ), '작은도 서관 조성사업'(2004년 ), '문화이용권 사업'(2005년 시범운영) 등이다.78)

그럼에도 불구하고 당시 참여정부의 모든 향유지원 정책이 '소외계층' 우선으로만 추진되었다고 보기는 어렵다. 일례로 '향유' 의 토대로 강조된 '문화예술교육'의 경우 초·중등학교를 중심으로 한 '학교문화예술교육' 지원은 보편적 성격이었다. 물론 사 회문화예술교육 활성화 차원에서 시도된 초기 사업들 중「복지기관 문화예술교육 지 원사업 등의 경우 지역아동센터의 아동, 장애인 및 노인 복지기관을 대상으로 이른 바 ‘소외계층' 중심으로 추진된 것은 사실이나, 이 역시 복권기금으로 충당된 사업이 었다. 더욱이 이들에 대한 예산 규모를 비교할 때, 당시 보편적 지원 성격에 가까운 학교문화예술교육 예산은 사회문화예술교육보다 많았다(최보연 외 2017: 43).

이러한 배경에서 참여정부 시기 예술향유에서의 ‘취약계층(소외계층) 중심성' 측 면은 사실상 정부 초기부터 예술정책 전반에 걸친 전략적 접근의 결과로 해석하기 보다는 당시 예술재원 부족을 복권기금이란 대안을 통해 해결하는 과정, 그리고 양 극화 심화 등에 대한 대안으로 '사업' 단위의 지원 확대라는 관점에서 이해하는 것 이 타당하다는 분석도 존재한다(정광렬 외 2015: 19-20).79)

78) ‘방방곡곡 문화공감’이나 ‘소외계층 순회사업’ 등은 ‘취약계층’ 대상 찾아가는 문화프로그램 성격으로 운영 되었고, 작은도서관 조성사업의 경우 역시 '문화취약'지역을 중심으로 노후 작은도서관 리모델링이나, 공 공건물 유휴공간을 활용한 생활밀착형 소규모 도서관 등 2012년까지 총 506개관이 조성되었다(문화체육 관광부 2013: 34). 


\section{이명박 정부 시기(2008 2013)}

이명박 정부는 참여정부와 달리 문화예술정책 관련 별도의 공개적인 중장기계획 을 수립하지는 않았다. 출범 당시 제시했던 문화비전에서는 '품격있는 문화국가 대 한민국'을 정책비전으로, 10 대 추진방향에 '문화예술의 가치 및 완성도 제고', '선택 과 집중을 통한 경쟁력 제고', ‘사회적 약자에 대한 문화향유 기회 확대’, ‘국가정책 수립 시 문화적 관점 반영’ 등이 포함되었다. 이후 정부는 예술지원체계의 재정비를 목표로 예술지원의 4대 지원방식을 '선택과 집중' , '간접지원' , '사후지원' ' 생활 속 예술'로 공표하였다(문화체육관광부 2013: 6).

국정기조로 '창조적 실용주의'를 표방했던 이명박 정부는 출범 초기부터 사회경 제정책 전반에 있어 친시장적 정책 및 '생산적 복지’라는 개념을 강조했던 것이 특 징적이다. 이로 인해 당초 문화복지 및 예술향유 지원 역시 이러한 궤를 따를 것으 로 예상되었다. 그러나 정부 출범 초기 금융위기와 신자유주의 정책에 대한 반발이 거세졌고, 이에 대응하는 차원에서 이른바 '친서민정책' 으로 국정기조가 급변하여, 결과적으로 '취약계층(소외계층)' 중심의 '문화복지' 지원이 강조되었다. 2012년「 문화예술진흥법」 개정을 통해 '문화복지'의 대상을 '취약계층'으로 명시한 것(제15 조의3 문화소외계층 대상 문화예술복지 증진 시책 강구)은 바로 이러한 지점을 명 확히 보여준다. 이는 결과적으로 '문화복지'의 개념과 정책대상의 범주를 '취약계 층' 중심으로 재편하는 방향으로 이어졌다.

〈표 4-7〉「이명박 정부 예술정책 3대 기본방향 및 9개 역점추진과제

\begin{tabular}{|c|c|c|c|}
\hline 정책목표 & 3 대 기본방향 & 9대 역점추진과제 & 4대 지원방안 \\
\hline \multirow{3}{*}{$\begin{array}{l}\text { 품격있는 } \\
\text { 문화국가 } \\
\text { 대한민국 }\end{array}$} & 예술창작역량 강화 & $\begin{array}{l}\text { (1) 예술인 창작지원 기반조성 } \\
\text { (2) 전략적 예술창작 지원 } \\
\text { (3) 예술의 해외교류를 통한 경쟁력 강화 }\end{array}$ & \multirow{3}{*}{$\begin{array}{l}\text { 선택과 집중 } \\
\text { 간접 지원 } \\
\text { 사후 지원 } \\
\text { 생활 속의 예술 }\end{array}$} \\
\hline & $\begin{array}{c}\text { 수요창출을 위한 } \\
\text { 예술정책 강화 }\end{array}$ & $\begin{array}{l}\text { (4) 문화예술교육을 통한 창조적 수요자 양성 } \\
\text { (5) 민간부문의 문화예술 수요 확충 } \\
\text { (6) 취약계층 등의 문화예술향유 확산 }\end{array}$ & \\
\hline & 예술의 자생력 제고 & $\begin{array}{l}\text { (7) 예술의 산업적 발전 연계 강화 } \\
\text { (8) 문화예술 인력의 체계적 양성 } \\
\text { (9) 예술진흥 재원의 다변화 }\end{array}$ & \\
\hline
\end{tabular}

자료: 문화관광부(2009), 「2008 문화정책백서」326쪽.〈표 4-1-1〉발췌, 수정

79) 정광렬 외(2015: 16)는 노무현 정부 초기 '문화예술교육’을 중심으로한 주체적 시민들의 문화역량 강화가 강조되다가, 양극화 문제가 주요한 사회의제로 부각되고 복권기금이 문예진흥기금으로 전입되면서 "전략 이 아닌 사업” 중심으로 취약계층 중심의 문화복지 지원이 추진되었다고 해석한다. 
물론 이명박 정부 시기 향유지원이 '취약계층(소외계층)' 대상 사업에만 한정된 것은 아니었다. '문화와 일상생활의 연계'가 강조되면서 '국공립 박물관 미술관의 무료관람'(2008년 ) 실시, '공공 도서관 개관시장 연장' 사업 확대가 추진되었고 이 들은 보편적 차원에서의 향유기반 확대 및 환경조성을 위한 지원 성격이 강했다(문 화체육관광부 2013).80)

그러나 양극화 심화 속에 정부 후반기였던 2011년 “친서민정책’을 공식적으로 표 방한 이후부터는 '사회적 약자에 대한 문화향유 기회 확대'라는 취지 하에 '문화바 우처' 예산을 전년 대비 5배 이상 증액하는 등 취약계층 중심 지원의 예산확대가 두드러졌다(조현성·연수현 2019: 50).81)

\section{라. 과도기 (2013년 이후 )}

\section{— 박근혜 정부 시기(2013 2017)}

‘문화융성'을 국정기조로 제시했던 박근혜 정부 시기에는 향유지원 대상에 대한 이중적 접근이 두드러졌다. 경제양극화 현상으로 인한 시민복지에 대한 관심에 따 라 '맞춤형 문화복지 확대’라는 취지 하에 ‘문화이용권'을 여행, 체육 영역까지 포괄 하는 '통합문화이용권' 으로 재편하는 등 취약계층 문화복지적 관점에서의 지원은 지속적으로 이어졌다.82) 통합문화이융권(문화누리카드)은 경제적 여건으로 인해 문 화예술활동에 제약을 받는 저소득층의 문화향유 기회 확대를 위해 전용이용권(문화 누리카드) 형식으로 문화예술, 여행, 체육활동을 지원하는 사업으로, 이용자의 자발 적 문화향유 욕구를 끌어내고, 이를 통해 정서적 행복감을 느낄 수 있도록 하는 '수 요자 중심'의 문화기본권' 보장 사업이라는 취지에서 추진되었다(문화체육관광부 2019: 101).

동시에 일상에서의 문화적 삶을 강조하면서 보편적 예술향유기회 확대를 위한 사

80) ‘공공도서관 개관시간 연장운영 지원사업’은 2006.11 국립중앙도서관 및 16 개 지역별 대표도서관 대상으 로 시범운영하다가 2007년 80개로 확대되었다. 이명박 정부 초기 2008년 117개에서, 2012년에는 참여 도서관이 357개로 증가했다(문화체육관광부 2013: 277).

81) '공정사회'가 정치적 화두로 부상했던 후반기에는 특히 취약계층을 구성하는 사회적 약자 중 노인, 장애인 에 대한 지원이 강조되기도 했다(정광렬 외 2015: 20).

82) 2015년 통합문화이용권은 세대 당 10 만원에서 개인당 5 만원으로 지원방식이 개선되었고, 기초생활보장 법 시행령 개정('15, 7월)에 따라 중위소득 $50 \%$ 까지 대상을 확대하였다. 
업들이 주요하게 추진되었다. 문화적 권리를 명시한「문화기본법」이 제정되었고, 관련 근거 조항에 따라 매월 마지막 수요일 문화혜택을 제공하는 '문화가 있는 날'(2014. 1. 29.)이 대표적인 사례라 할 수 있다. 또한 일반시민이 일상적 삶 속에 서 문화예술향유 기회 확대를 모색하기 위한 '생활문화진흥원(현 지역문화진흥원 2016)'이 설립되었고, 기초 단위 생활문화센터(2014 )가 조성되었다. 이들 사업들 은 당시 정부가 문화정책 기조로 제시했던 '문화융성'의 실현과 국민 개개인의 문화 예술적 체감을 통해 국민 개인의 행복이 증대되고, 이는 궁극적으로 국가 발전의 선순환 체계 형성에 기여할 수 있다는 배경에서 강조되었다.

[그림 4-1] 박근혜 정부 국정비전과 문화융성

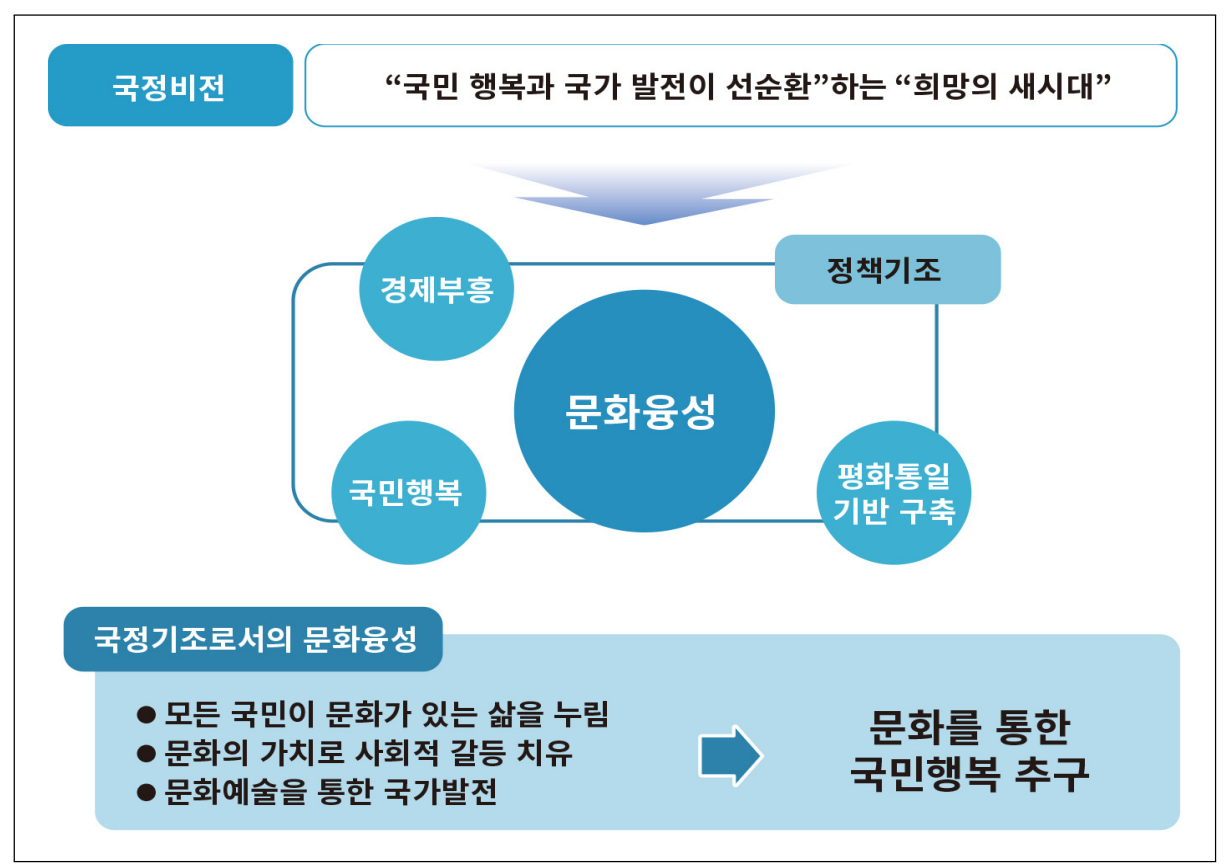

하지만 박근혜 정부 시기는 국정농단 및 블랙리스트 사태로 예술정책 전반에 왜 곡을 가져왔던 시기였다. 반정부적인 성향을 가진 예술계 인사를 공적 지원에서 체 계적으로 배제하는 등의 반국가적 행위로 인해 '예술지원의 생태계가 파괴되고 교 란'되었기 때문이다(새 예술정책 수립 TF·문화체육관광부 2018: 3). 


\section{문재인 정부 시기(2017 현재)}

문재인 정부는 출범 후「문화비전 2030」, 「새 예술정책」등의 연이은 발표를 통 해 무너진 예술정책에 대한 예술계 및 국민의 신뢰를 회복하고, 예술창작과 향유의 선순환이 가능한 예술 환경 조성을 통해 문화예술발전에 기여하겠다는 의지를 표명 하였다. 현 정부의 문화정책 비전서인 「문화비전 2030」은 문화정책 9대 의제를 제 시하는 가운데, '개인의 문화권리 확대’를 '문화권' 확산이란 차원에서 가장 최우선 과제로 지목하고 있다.

국민의 기본권으로서 문화의 권리를 사회의제로 확산하고, 노동중심에서 여가중심 사회로 전환하여 개인이 일상생활에서 자신이 원하는 문화를 즐기고, 문화향유자만이 아니라 생산 자로 활동할 수 있도록 문화정책의 방향을 새롭게 정립

「문화비전 2030」(새문화정책준비단·문화체육관광부 2018: 90)

'사람이 있는 문화, 예술이 있는 삶'이라는 비전 하에「새 예술정책」은 8대 전략 과제와 25개 실행과제 등을 아래와 같이 제시하고 있다(문화체육관광부 2018: 53).

〈표 4-8〉 문재인 정부「새 예술정책(2018-2022)」

\begin{tabular}{|c|c|c|}
\hline 정책목표/지향점 & \multicolumn{2}{|r|}{ 8대 전략과제 } \\
\hline \multirow{8}{*}{$\begin{array}{c}\text { 사람이 있는 문화, } \\
\text { 예술이 있는 삶 }\end{array}$} & 1 & 예술표현의 자유와 예술인인권을 보호하겠습니다. \\
\hline & 2 & 예술행정의 독립성 자율성을 높이겠습니다. \\
\hline & 3 & 예술 가치 창출과 발현에 중점을 둔 창작 지원을 하겠습니다. \\
\hline & 4 & 예술인의 삶을 지키는 예술인 복지를 펴겠습니다. \\
\hline & 5 & 모두에 열려있는 예술참여환경을 만들겠습니다. \\
\hline & 6 & 소수자가 예술로 어울려 사는 사회를 만들겠습니다. \\
\hline & 7 & 공정하고 활력 있는 예술시장 환경을 만들겠습니다. \\
\hline & 8 & 예술의 미래 가치를 키워가겠습니다. \\
\hline
\end{tabular}

자료: 새 예술정책 수립 TF·문화체육관광부 2018: 53-54 정리

「새 예술정책」은 그간 정부가 문화예술교육이나 통합문화이용권 등을 통해 지속 적인 예술향유지원 정책 차원에서 예산확대를 모색해 왔지만, "개인의 예술참여 역 량 증진이나 수요기반 확대에 있어서는 여전히 취약하다”고 지적한다. 향후 “문화예 술교육과 예술향유의 결합성”을 높이고, “자발적 예술향유와 참여가 가능한 사회 환 
경 조성에 중점”을 둘 것을 공표하기도 했다(문화체육관광부 2018: 52).

그러나 위의 8대 전략과제를 통해서 확인되는 바와 같이 문재인 정부의「새 예술 정책」이 제시하는 전체적 방향성은 이전 정부의 중대한 실책으로 파괴된 예술생태계 및 예술인 지원정책에 대한 신뢰회복에 초점이 맞춰져 있는 것이 사실이다. 예술인 에 대한 존중과 보호, 예술지원행정 체계의 독립성, 자율성 확보 등을 명시하고 있는 전략과제들은 예술지원체계의 공정성, 투명성, 독립성, 자율성 등의 가치를 재구현 하는 것이 문재인 정부 예술정책이 직면한 최우선 과제임을 시사한다고 하겠다.

그럼에도 불구하고「새 예술정책」에서 주목되는 것은 지금까지의 역대 정부 발간 문화정책 혹은 예술정책 중장기 계획이나 비전서와 달리 '예술향유' 혹은 '예술향유 지원정책'이 공식적으로 등장한다는 점이다. 이전의 경우 대부분 문화향유 혹은 추 상적 차원의 향유지원이란 표현은 존재했었다. 「새 예술정책」에서는 '예술향유'에 관한 개념적 정의나 규정을 제시하고 있지는 않지만, '예술향유', '예술향유자 지원' 등의 구체적 표현을 사용하면서 "차별없는 예술향유를 통한 문화적 권리의 증진에 중점을 두는 예술정책 수립”의 필요성을 강조하고 있다(새 예술정책 수립TF·문화체 육관광부 2018: 45).

이들 8대 전략과제 중 ‘향유' 관련 전략과제는 ‘모두에 열려있는 예술참여환경 조 성’이다. 세부실행과제로는 “문화예술교육을 통한 예술향유 역량강화”, “수요창출형 관객지원제도 도입”, “일상에서 누리는 예술향유 기반조성”이 제시되고 있으며, 제 안된 대표사업으로 수요자 맞춤형 생애주기별 문화예술교육 확대, 예술동아리 교육 지원 및 활성화, 세제지원을 통한 예술소비 활성화 등이 포함되어 있다. 이들 중 최 근 새롭게 도입되어 추진되고 있는 사업은 '문화비 소득공제'(2017년 7월 ) 다.83) 문화예술소비 확대를 위한 그간의 정책들이 주로 공급측면인 제작과 유통에 초점을 두었다면, 소득공제 지원은 향유자에게 직접 혜택을 제공한다는 점에서 다르다. 그 러나 근로소득 기준 7,000 만 원 이하 기준 적용 등 보편적 측면에서의 향유기반 확대라기보다는 상대적으로 경제적, 소비적 제약이 있는 계층에게 집중된 지원이라 할 수 있다.

83) 문화비 소득공제는 7,000만 원 이하 근로소득자에게 적용되는 것으로 신용카드 등으로 도서구입 및 공연 관람을 위해 사용한 금액을 추가공제(최대 100 만 원), 공제율은 $30 \%$ 로 적용하는 사업이다. 
〈표 4-9〉문재인정부「새 예술정책 수립 기본방향」

\section{2. 새 예술정책 수립의 기본방향}

$\square$ 예술지원체계혁신으로 예술현장과 국민의 신뢰를 회복하는 예술정책 수립

예술참여주체들의 권리를 보호하고 증진하는 예술정책 수립

“예술향유자의 경우 차별 없는 예술 향유를 통한 문화적 권리 증진에 중점을 두는 예술정책을 수립해야 함

- 기존의 예술향유지원정책이 문화이용권 사업과 같이 '접근성' 관점에서 물량적인 예술의 공급에 중점을 두었다면, 향유자로서의 문화적 리터러시를 길러 스스로 주체적이고 능동적인 예술참여주체로서 참여 할 수 있는 환경을 조성해야함

- 또한 접근성 확대는 지속되어야 하는 바, 예술 향유자들이 차별없이 일상에서 쉽게 예술을 향유할 수 있는 예술참여환경을 조성해야 함

- 특히 '보는 예술'이 아니라 ‘하는 예술'을 통한 참여 활동을 통해 예술 문화의 다양성 증진에 기여하고, 소수자 예술 활성화로 예술을 통한 사회통합이나 연대성이 증진될 수 있도록 해야 함"

$\square$ 예술지원체계를 수직적 전달체계에서 수평적 협력체계로 전환

$\square$ 공공과 민간이 상생하고 협력하는 공공성 구현의 예술정책 수립

$\square$ 예술생태계와 지속가능성을 높이는 예술 가치 존중의 예술정책 수립

$\square$ 예술가치의 확산으로 미래를 준비하는 예술정책 수립

자료: 새 예술정책 수립 TF·문화체육관광부 2018: 45 부분 발췌

하지만 이를 제외하고 문재인 정부의 향유지원은 일반시민 대상 사업의 경우 이 전 정부의 사업들(예, 문화가 있는 날, 생활문화활성화 등)을 대부분 지속하고 있는 반면, 소외계층 대상 사업에서는 예산 확대 등이 상대적으로 두드러진다. 가령, '통 합문화이용권'의 경우 정부 출범 첫 해였던 2017년에는 992억 원(2014년 732억 원, 2016년 785억 원), 2018년에는 1,299억 원으로 확대되는 상황이다. 1 인당 수 령액도 연도별로 상향되어 2017년 6만원, 2018년 7만원, 2019년 8만원, 2020년 9만원, 2021년에는 1 인당 10 만원까지 확대가 계획되어 있다.

정리하자면, '예술향유'와 관련하여 현재 문재인 정부 예술정책 논의의 가장 주요 한 특성은 '예술향유'라는 공식적 표현을 사용하는 등 예술정책에서의 향유지원이 주요한 영역 중 하나 임을 공표하고 있다는 점이라 하겠다. 더욱이 지금까지의 '복 지적' 관점에서 접근한 사업들이 개인의 예술참여 역량 개발과, 예술생태계 관점에 서의 수요기반 확대에 기여하지 못했다는 자체적 평가와 인식을 제시하고 있는 점 역시 주목할 만하다. 이러한 인식에도 불구하고 예술계 블랙리스트 사태에 대한 대 응적 차원에서 예술정책의 주된 논의가 주로 창작자의 권리 보호, 자율성과 독립성 
보호 등에 상대적으로 초점이 맞춰져 있는 것 또한 사실이다. 반면 향유지원에 있어 앞서 지적한 변화된 담론적 인식과는 달리 여전히 복지대상에 대한 사업확대 등에 만 주된 방점을 두고 있는 것을 볼 때, 향유지원의 새로운 목표 제시나 방향성 설정 등이 아직까지 명확하게 드러나고 있다고 보기는 어렵다.

〈표 4-10〉정부 시기별 예술향유정책 지원 목표, 대상 및 주요 정책수단

\begin{tabular}{|c|c|c|c|c|c|}
\hline \multicolumn{2}{|c|}{ 구분 } & 정책기조 & 주요 정책대상 & 주요 정책사업(수단) & 특성 \\
\hline \multirow{2}{*}{$\begin{array}{l}\text { 발 } \\
\text { 아 } \\
\text { 기 }\end{array}$} & 박정희 & $\begin{array}{c}\text { 문화유산의 보존·계승과 } \\
\text { 전통문화의 계발을 통한 } \\
\text { 민족주체성 확립 }\end{array}$ & 전 국민 & $\begin{array}{c}\text { 문화시설 건립, 확충 } \\
\text { 지방문화원 지원 }\end{array}$ & $\begin{array}{c}\text { 지방문화원- } \\
\text { 새마을운동 연계 }\end{array}$ \\
\hline & 전두환 & $\begin{array}{l}\text { 생활의 질 향상을 위한 } \\
\text { 문화예술진흥 }\end{array}$ & 전 국민 & 지역 문화시설 확충 & $\begin{array}{c}\text { 시설확충 등 } \\
\text { 인프라 지원 중심 }\end{array}$ \\
\hline \multirow{3}{*}{$\begin{array}{l}\text { 태 } \\
\text { 동 } \\
\text { 기 }\end{array}$} & 노태우 & $\begin{array}{l}\text { 삶의 질 향상을 위한 } \\
\text { 문화복지실현 }\end{array}$ & 전 국민 & $\begin{array}{c}\text { 찾아가는 문화활동(1986) } \\
\quad \text { 사랑티켓(1991) }\end{array}$ & $\begin{array}{c}\text { 문화복지 } \\
\text { 용어 처음 사용 }\end{array}$ \\
\hline & 김영삼 & $\begin{array}{l}\text { 문화창달을 통해 } \\
\text { 국민들의 삶의 질을 } \\
\text { 향상시켜 선진 } \\
\text { 문화복지국가로 진입 }\end{array}$ & 전 국민 & $\mid \begin{array}{c}\text { 문화의 집 설치근거 마련(1996) } \\
\text { 문화학교 및 문화동호인 모임 } \\
\text { 활성화 }\end{array}$ & $\begin{array}{c}\text { 정책목표로 } \\
\text { 문화복지 개념의 } \\
\text { 본격적 등장 }\end{array}$ \\
\hline & 김대중 & $\begin{array}{c}\text { 창의적 문화복지 } \\
\text { 국가 건설 }\end{array}$ & 전 국민 & 문화예술교육 사업시작(1999) & 창의성 강조 \\
\hline \multirow{2}{*}{$\begin{array}{l}\text { 전 } \\
\text { 환 } \\
\text { 기 }\end{array}$} & 노무현 & $\begin{array}{c}\text { 창의한국, } \\
\text { 예술의 힘 미래를 } \\
\text { 창조합니다 } \\
\end{array}$ & 취약계층 & $\begin{array}{l}\text { 문화예술교육 제도화(2005) } \\
\text { 작은도서관 조성사사업(2004) } \\
\text { 복권기금 문화나눔사업(2004) }\end{array}$ & $\begin{array}{l}\text { 취약계층 } \\
\text { 사업 중심 }\end{array}$ \\
\hline & 이명박 & 품격있는 문화국가 & 취약계층 & $\begin{array}{c}\text { 국공립박물관미술관무료관람 } \\
\text { (2008) } \\
\text { 예술나무운동(2012) }\end{array}$ & $\begin{array}{l}\text { 문화복지대상 } \\
\text { 취약계층으로 } \\
\text { 법제화 }\end{array}$ \\
\hline \multirow[b]{2}{*}{$\begin{array}{l}\text { 과 } \\
\text { 도 } \\
\text { 기 }\end{array}$} & 박근혜 & $\begin{array}{l}\text { 문화융성, } \\
\text { 문화가 있는 삶 }\end{array}$ & $\begin{array}{l}\text { 취약계층 } \\
\text { 일반시민 }\end{array}$ & $\begin{array}{l}\text { 문화가 있는 날 제정(2014) } \\
\text { 생활문화동호회활성화(2014) }\end{array}$ & $\begin{array}{l}\text { 일반시민 대상 } \\
\text { 향유지원 추진 }\end{array}$ \\
\hline & 문재인 & $\begin{array}{c}\text { 사람이 있는 문화 } \\
\text { 예술이 있는 삶 }\end{array}$ & $\begin{array}{l}\text { 취약계층 \& } \\
\text { 일반시민 }\end{array}$ & $\begin{array}{c}\text { 통합문화이용권 사업 중심 예산 } \\
\text { 확대 } \\
\text { 문화비 소득공제 } \\
\text { (2017년 7월 ) }\end{array}$ & $\begin{array}{c}\text { 투트랙 전략 } \\
\text { (예술향유 } \\
\text { 일상화 및 } \\
\text { 복지지원 확대) }\end{array}$ \\
\hline
\end{tabular}




\section{2. 예술향유정책의 특성 및 시사점}

\section{가. '문화향유권' 논의 속의 예술향유}

예술정책이 시작되었던 1970 년대부터 현재까지의 ‘향유' 지원 전개과정을 살펴 보면 '예술향유'라는 구체적 개념보다는 포괄적 개념인 '문화향유', 혹은 '문화향수 (향유)권' 신장이라는 틀 속에서 논의되어 왔다.

「문화기본법, 에 따른 '문화' 의 정의는 "문화예술, 생활양식, 공동체적 삶의 방식, 가치 체계, 전통 및 신념 등을 포함하는 사회나 사회 구성원의 고유한 정신적·물질 적·지적·감성적 특성의 총체”이다.84) ‘문화권' 역시 “성별, 종교, 인종, 세대, 지역, 정치적 견해, 사회적 신분, 경제적 지위나 신체적 조건 등에 관계없이 문화표현과 활동에서 차별을 받지 아니하고 자유롭게 문화를 창조하고 문화활동에 참여하며 문 화를 향유할 권리”로서 제시된다. 그렇다면 여기서의 '문화표현과 활동'의 영역은 일반 시민의 입장에서 접근할 때 어떻게 이해될 수 있을까? 현재 문체부가 소관하는 영역인 '문화예술', '콘텐츠', '관광', '체육' 그리고 '종교' 등이 포괄된다고 할 수 있다.

그간 문화예술정책 논의에서 '문화향유권 신장'을 지원한다는 의미는 보다 구체 적 차원에서 '예술영역'과 직결된 부분을 대체적으로 의미했다고 볼 수 있다. 초기 정책수단으로 활용되었던 '찾아가는 문화활동'이나 '문화의집' 등의 사업에서의 핵 심은 연극, 무용 등 구체적인 '예술작품’을 수요자에게 가까이 전달하는 방식이었 고, 현재에도 이들을 원형으로 삼는 사업들이 향유지원사업으로 추진되고 있다. 2000년대 중반 첫 시도되어 현재 '문화복지'의 핵심사업으로 일컬어지는 '통합이용 권' 정책사업 경우도 동일하다. 2017년 '관광', '체육' 으로 지원영역이 확대되었으 나, '문화' 영역만 놓고 볼 때, 공연(공연예술)이나 전시관람(시각예술) 혹은 도서(문 학) 등 주로 예술영역에 대한 향유기회 제공에 집중하고 있음이 확인된다.85)

84) 국가법령정보센터, 「문화기본법

http://www.law.go.kr/IsInfoP.do?urlMode=IsInfoP\&lsld=011953\#0000 (최종접근: 2020.04.20)

85) 하지만 통합이용권 이용률을 살펴보면 영화와 도서를 제외할 때 예술영역에서의 소비수준이 상당히 낮은 것으로 확인되고 있다. 이는 역설적으로 말하면 '경제적 격차' 해소만으로(비용지급) 예술영역에서의 수요 진작이 이뤄지기가 어렵다는 점, 더불어 그 이유로 인해 국가의 공적지원이 지속적으로 필요할 수밖에 없다는 점을 동시에 방증하는 지점이다. 
그렇다면 '문화향유' 논의가 '예술' 영역에 대한 향유기회 확대에 방점을 두고 진 행되어온 이유는 무엇일까? 이는 관광·체육과 달리 '예술'의 경우, 단순히 경제력 차이에 의해서만 접근성이 제약되는 것이 아니라, 교육(예술에 대한 경험과 지식, 이해 등)에 따른 구조적 격차가 주요하게 작동한다는 정책인식의 반영된 것이라고 해석할 수 있다. 참여정부 초기 발간된「창의한국」과「예술의 힘」에서 최우선과제 로 '문화예술교육'에 대한 공적지원이 강조된 후 현재까지 비약적으로 확대되어 온 것도 사실상 ‘단순한 경제적 격차 해소'만으로 문화향유의 확산이 이뤄질 수 없다는 정책인식의 반영이었다(최보연·김병주 2013). 경험재로서 기능하는 '예술'의 접근 성에 있어 사회경제적 계층과 교육이 복합적으로 결합되어 작동하는 구조적 문제를 근본적으로 해결하고자 하는 정책적 대응 차원에서 접근해야 한다는 정책인식의 공 유가 해당 정책지원의 근본적인 배경이었던 셈이다(김세훈 2004; 양현미 2004; 조 현성·최보연 2016; 최보연 외 2017).

이런 측면을 고려할 때 그간의 문화예술정책 논의가 문화향유와 예술향유가 서로 다른 것을 적시, 혹은 다른 영역을 지향한다고 전제했다고 보기는 어렵다. 오히려 '문화향유권 신장' 개념 하에 '예술'에 대한 향유자 접근성 강화 지원에 보다 중요한 방점을 놓고 발전되어 왔다고 해석하는 것이 타당한 것으로 보인다.

\section{나. '문화복지'와의 중첩 과정: ‘향유지원’ 목적과 대상의 혼란}

예술향유 지원을 위한 정책 발전을 살펴 보면, 1990 년대 초중반 이후 '문화복지' 개념과 중첩되어 오는 과정에서 발현된 독특한 특성이 나타난다. 즉, 예술향유를 '문화복지'라는 큰 개념 속에 편재하여 접근한 것이 그 첫 번째라면, 두 번째 특성은 '예술향유를 포괄한 문화복지'의 정책대상의 변화이다. 초기에는 전 국민으로 설정 했다가 '소외계층' 으로 특정하고, 이후 최근에는 일반시민과 소외계층에 대한 중요 성을 둘 다 강조하고 있기 때문이다.

전술한 바와 같이 '문화복지' 정책개념이 처음 대두되었던 초기에는 일부 소외계 층에 대한 지원도 진행하였지만 전반적으로 '전 국민' 대상의 '문화복지' 개념을 주 로 강조했었다. 이후 참여정부, 이명박 정부시기를 거치면서 '문화복지'의 주요 정 책 대상이 '취약계층 혹은 소외계층' 으로 특정화되고, 제도적 차원에서 경제적 취약 
계층 중심으로 고착화되었다. 이명박 정부 시기 '소외계층’ 정의 조항을「문화예술 진흥법」에 포함시킨 것은 바로 문화복지 정책대상의 특정화가 제도적 차원에서 이 뤄진 것을 의미했기 때문이다.86) 결과적으로 이러한 제도적 규정이 고착된 이후, '문화복지'가 마치 이들 계층만을 대상으로 삼는 정책으로 축소되어 이해되는 현상 으로 이어졌다.

문화복지 담론에서 '문화(예술) 향유기회 확대'가 개인의 '삶의 질 향상'과 직결된 다는 논의는 노태우 정부 이후부터 현재까지 일관되게 나타나는 지점이다. 그러나 '예 술에 대한 접근성'이 사회경제적 지위와 교육수준에 의해 구조적으로 제약될 수밖에 없다는 점을 고려할 때, '모든 이들이 삶의 질 향상을 위해 누려야 할 문화(예술)향유' 에 있어 이러한 격차와 간극을 상대적으로 더 강하게 경험할 수밖에 없는 정책대상(소 외계층, 취약계층)을 우선적으로 지원하고자 했던 접근전략은 그 자체로 필연적이었 던 것으로 보인다. 실제로 이들이 겪는 격차와 간극을 해소하기 위한 노력은 예술지원 의 공공성 관점에서 반드시 공적 개입이 필요한 영역이기 때문이다.

문제는 문화복지 논의가 특정대상 중심으로 축소되는 과정이 예술정책 논의에서 '예술향유' 지원 목적 자체를 “소외계층의 향유 격차 해소”에만 한정하는 구조로 작 동했다는 점에 있다. 예술에 대한 공적지원은 예술에 대한 접근성 제고를 위해서도 필요하지만, 예술계를 구성하는 창작, 유통·매개, 향유 등 다양한 영역 및 구성요소 들 간의 선순환적 연계가 순조롭게 이뤄질 수 있도록 지원하는 것 역시 포함될 수 있다. 더욱이 이러한 선순환적 연계에 대한 지원은 예술을 통해 국민의 삶의 질 제 고에 기여한다는 예술정책(지원)의 궁극적 지향을 감안할 때, 일종의 방법론 차원에 서 필요한 지점이기도 하다. 문제는 현재 향유지원이 '특정계층 중심의 격차해소' 에만 천착하는 것이 이러한 생태계 관점에서의 선순환적 연계에도 긍정적으로 기여 하기 어려울 뿐 아니라, 보편적 관점에서의 국민의 삶의 질 제고라는 대의적 명분에 있어서도 분산적, 산발적 접근에 그칠 가능성이 크다는 점이다. 그럼에도 '문화복 지' 개념적 논의 속에 편재되어 '예술향유' 지원이 진행되어 온 과정에서 '예술향유' 에 대한 공적지원의 목적 자체가 '소외계층의 예술향유기회 확대'에 주요하게 천착 되고, 정책대상 역시 특정계층 중심성이 강화되는 결과로 이어졌다고 하겠다.

86) ‘문화소외계층’으로 적시되어 있으나, 그 기준을 제시한 시행령을 살펴보면 기초생활수급자, 차상위계층 등 주로 경제적 취약계층에 집중되어 있다. 


\section{다. 담론은 ‘보편적 기회 확대’ 강조, 실행은 '선별적’ 접근}

이명박 정부 시기 '문화복지’의 정책대상을 '문화소외계층' 으로 제도적으로 한정 하였지만, 최근 '문화복지' 관련 개념적, 담론적 논의는 특정계층이 아닌 '전 국민의 보편적 문화권' 관점에서 접근, 진행되고 있다는 점이 주목된다(새문화정책준비단. 문화체육관광부 2018: 104-115). 특히 현 정부 들어 '포용적 혁신' 및 '포용국가' 실현을 강조하는 국정기조는 '복지' 관련 논의에서의 '포용' 관점 역시 강조하고 있 는 바, '문화복지' 관련 논의에도 유사한 정책적 강조가 담론적으로 진행되고 있는 것으로 볼 수 있다.

문제는 담론적 차원에서 '문화복지’의 '보편적' 접근 기회 확산을 강조하지만, 실 제 관련된 정책사업 대부분을 '소외계층'에 특정한 사업 중심으로 예산 확대를 추진 하는 등 향유지원 관련 정책에서의 담론과 정책실제 간 모순이 나타난다는 점이다. 일례로 문재인 정부 초기 발간된 「문화비전 2030」을 살펴보면 정책논의상에서 이 러한 간극에 대한 인식이 공유되고 있는 것으로 보인다.

최빈곤층과 깊은 오지에 해당하는 경우를 제외하면 문화소외는 계층-지역과 상관없이 불규 칙적으로 발생하고, ‘문화소외’라는 개념적 정의가 확산을 전제로 새로운 정의와 확대가 필 요하며, 이를 바탕으로 대상을 확장하는 정책의 확산이 필요함

「문화비전 2030」(새문화정책준비단·문화체육관광부 2018: 90)

그럼에도 불구하고 '전 국민 문화복지 확산' 의제의 세부실행방안을 살펴보면 (소 외계층 대상의) '통합문화이용권 제도의 개선과 확산'에 집중되어 있는 것이 확인된 다.87) 이는 또한 비전서뿐 아니라, 국정운영 계획이나 대통령 국정 공약에도 동일 하게 나타난다. 실제 국정운영 5개년 계획에 제시된 100대 과제 중 67번째 과제로 제시된 '지역과 일상에서 문화를 누리는 생활문화시대' 의 경우 세부실행과제로는 '국민 기초문화생활 보장을 위한 통합문화이용권의 연차별 확대(2021년부터 10만 원 지급)'가 제시되어 있다(국정자문위원회 2017: 103).88) 실제로 '통합문화이용

87)「문화비전 2030」에서 제시된 '전 국민에게 문화복지 확산' 의제와 관련된 추진과제는 모두 3가지로 '통합 문화이용권제도 개선과 확산', '생애주기별 문화복지 확산(청소년,직장인,중년세대 문화예술교육 지원)', '생활문화공간을 재편해 전 국민적 문화향유 확대'이다. 이들 중 예산 관점에서 가장 주목되는 사업은 '통 합문화이용권'으로 2020년 기준 총 1,033억이다.

88) 국정기획자문위원회(2017)「문재인정부 국정운영 5개년 계획」, 103쪽. 
권' 예산은 지난 2017년 698억, 2018년 821억, 2019년 915억에서 2020년 현재 기준 1,033 억으로 증대되었다. ${ }^{89)}$

담론적 차원에서는 문화복지의 보편적 확산을 이야기 하면서 정책실행 사업에 있 어 '소외계층' 중심 사업 확대에만 그 초점을 맞춰 온 이유는 무엇인가? 원인은 여 러 가지로 추정이 가능할 수 있을 것이다. '통합문화이용권'은 최종수혜자 대상 직 접지원 사업으로, 실질적인 사업실적 및 성과지표는 '지원받은 사람' 수와 이들의 '만족도'에 주된 초점이 맞춰져 있다(문화체육관광부 2020: 110-111).90) 또한 2017년 정부 교체 이후 1인당 수혜 금액 확대가 공약으로 제시된 가운데 금액 확대 역시 주요 실적으로 간주되고 있다. 다시 말하면 사람 수(카드 발급 건 수), 이들에 게 돌아가는 실질적 금액91) 등이 예술향유지원의 실적으로 대변되는 것이다. 현재 로서는 1 인당 금액 확대가 실질적인 문화향유에 어떠한 긍정적 영향으로 이뤼지는 지, 다양한 향유 영역에 있어 예술향유 관련 측면에는 어떠한 효과가 있는지에 관한 지점은 확인되지 못한 채, 카드 발급 건 수, 1 인당 수혜금액의 “숫자 늘리는 것” 그 자체가 정책지원의 목표로 제시되고, 그 자체가 성과로 대체되는 상황인 셈이다. 이 러한 측면은 수혜자 대상 현물지원 성격의 '통합이용권' 사업 예산 확대가 사실상 선거에서의 표심과 직결되는 정치적 포퓰리즘 접근의 산물이라는 비판이 제기되는 배경이기도 하다.92)

89) 2017년 698억 이후 증가율을 살펴보면 총 148\%에 달한다. 「2018년 문화체육관광부 예산·기금 운용계 획」(문화체육관광부 2018), 87쪽, 「2020년 문화체육관광부 예산·기금 운용계획안 사업설명자료 4권 (문 화체육관광부 2020), 105쪽.

90) 2020년 문화체육관광부 예산·기금 운용계획안 사업설명자료(문화체육관광부 2020: 110-111)에 따르 면, 문화누리카드(통합문화이용권)의 사업실적은 문화누리카드 발급 건수(2016년 1,450,801매 $\rightarrow 2017$ 년 1,523,532매 $\rightarrow$ 2018년 1,591,77매), 성과지표로는 문화누리카드 전액 미사용자 비율(\%) (2016년 $5.1 \% \rightarrow 2017$ 년 5.2\% $\rightarrow$ 2018년 5.7\% $\rightarrow$ 2019년 5.1\%(목표) $\rightarrow$ 2020년 4.5\%(목표)), 문화누리카 드 사용자 만족도(2016년 86.1\% $\rightarrow$ 2017년 83.2\% $\rightarrow$ 2018년 85.9\% $\rightarrow$ 2019년 86.4\%(목표) $\rightarrow$ 2020년 86.9\%(목표)로 제시되어 있다.

91) 2021년까지 10만원으로 1인당 지원금액 상향 조정이 향후 추진방향으로 제시되어 있다.

92) 다시 말하면, '통합이용권' 등으로 대변되는 현 향유지원 정책의 문제는 단순히 '소외계층' 중심 지원사업 자체에 있는 것이라기보다는, 이들 사업 중심으로 확대 해 오면서 '예술향유' 지원에 관한 정책인식이 확 장되지 못하고 좁은 의미의 '시혜적' 복지' 프레임 속에 갇혀 구속되었다는 데 있다. 


\section{라. 예술정책을 구성하는 핵심영역으로서 '예술향유' 재검토 필요}

예술향유정책 전개과정의 특성은 향후 예술정책을 구성하는 핵심 요소로서 '예술 향유'지원이 전제되고, 이를 위한 정책지원의 필요성이 보다 적극적으로 진행될 필 요가 있음을 시사한다.

첫째, 향후 예술향유 논의는 '예술정책'을 구성하는 핵심요소로서 전제하되, 기존 의 문화향유와 차별화된 '예술향유’ 개념에 집중하여 개진될 필요가 있다. 전술한 바와 같이 ‘문화향유' 가 ‘문화기본법’에 의거하여 개인의 삶의 양식이나 신념 등을 포괄한 종교, 젠더 및 체육과 스포츠 영역까지를 아우르는 종합적인 문화영역에서 의 표현과 활동에 관한 권리로 이해된다면, '예술향유'는 「문화예술진흥법」에 의거 한 '예술영역'에 집중된 표현과 활동에 대한 권리로 이해될 필요가 있다.

'예술향유'에 대한 정책적 지원은 '개인'의 차원에서 예술활동 및 표현에 대한 권 리를 보장하는 것을 기본적으로 포함해야 한다. 그러나 이러한 활동이 독립적 영역 이 아니라 창작과 매개(유통)을 아우르는 예술생태계 차원에서 유기적으로 접목되 는 영역으로 이해될 필요가 있다. 다만 이러한 생태계적 관점에서의 선순환적 연계 에 관한 고려는 '예술을 통한 풍성한 모든 이들의 삶'이 가능할 수 있도록 하는 예술 정책의 본연의 목적을 구현하기 위한 필연적인 방법론 차원에서 접근되어야 한다.

둘째, '예술향유'에 관한 입체적인 정책 인식과 이해가 필요하다. 현재 '문화복지' 관점에서 접근되는 향유지원의 상당부분은 ‘예술향유'에 대한 '전형적' 이해에 기반 을 두고 있음이 확인된다. 여기서의 '전형성'이란 '향유'를 '특정 공간'을 전제하거 나, 향유활동의 양태를 공연 및 전시 등을 '관람' 하는 것으로 전제하고 있다는 점에 서 발견된다. 일례로 현재 향유관련 지원 예산의 큰 부분을 차지하는 바우처형 사업 (예를 들어 통합문화이용권)이나 방문형 사업(예를 들어 방방곡곡 문화공감 사업)은 모두 특정 공간에 직접 가서 공연이나 전시를 관람하는 것을 전제로 한다.

물론 '공간' 기반 '관람'활동이 '예술향유활동'의 한 양태임은 분명하다. 서론에서 언급한 바와 같이 예술향유에서의 '향유(享有)'는 '누리어 가짐'이라는 적극적 의미 를 갖는다. 따라서 향유활동은 문화예술교육, 생활예술, 문화관련 자원봉사나 기부 등 예술영역에서의 다양한 활동을 폭넓게 포괄할 수 있다. 현재 이들 영역은 정책적 으로 '문화예술교육', '생활예술' , '기부' 등으로 세분화되어 접근되고 있는데, 마치 
‘향유’ 정책과는 별개의 영역으로 인식되고 있다. 그러나 향유활동은 관람 및 자발적 창작 행위는 물론 문화예술교육이나 생활예술, 자원봉사 및 기부 등의 활동까지를 포괄하는 다원적이고 입체적인 개념으로 이해될 수 있다.93) 이 같은 입체적 관점에 서의 개념규정은 향후 향유정책의 다원적 접근을 위해 필요한 전제로서 충분히 고 려될 필요성이 제기된다.

셋째, 예술향유의 환경 및 향유수요 다원화에 대한 대응을 고려할 필요가 있다. 지금까지의 '예술향유' 지원은 대부분 특정 계층이 가진 '향유기회에 대한 구조적 제약 및 격차 해소'를 중심으로 진행되어 왔다. 고질적인 '격차해소'가 예술향유 지 원의 주요한 부분인 것은 분명하나, 이와 동시에 예술계를 둘러싼 다양한 환경변화 및 향유수요의 다원화라는 측면도 함께 고려될 필요가 있다. 최근 기술혁신으로 인 한 예술창작 및 향유환경의 변화나, 주52시간제 도입 등 삶의 질 향상의 지표로 일 과 여가의 균형 등이 강조되는 가운데, 일반시민들의 예술향유 양태는 다원화되고 중층적으로 변화하고 있다(김혜인·김연진 외 2018). 이미 많은 연구에서는 일반 시 민들의 예술을 향유하는 방식이 특정 장소나 장르 중심의 수동적 관람을 넘어서서 활동의 층위가 다층화되고 입체화되고 있음이 반복적으로 지적되고 있으며(지역문 화진흥원 2019), 삶의 경로에 따라 활동형 여가 및 취미생활과 예술향유과 맞물리 는 복합적 수요 확대가 전망되고 있는 상황이다(김현경 외 2019). 향후 기술혁신 및 사회변화 등으로 인한 예술향유에 대한 수요가 더욱 다원화·복합화 될 전망임을 고려한다면, ‘예술향유'에 대한 입체적 이해를 전제로 '예술향유' 수요 다원화에 대 한 보다 적극적 관점에서의 정책적 접근과 고민이 필요하다.

넷째, ‘향유’지원의 정책대상 설정에 있어서의 유연한 관점이 필요하다. 지금까지 향유지원의 정책대상은 '향유활동'을 행사할 주체, 즉 '최종수혜자' 관점에 주로 한 정해왔다. 정책 발전과정 초기에는 시설건립 등 기초 환경조성에 집중하였지만, 이 후 문화복지 개념과 결합되면서 향유기회에 제약받는 '계층'에 대한 직접 지원 중심 으로 정책이 발전해왔기 때문이다. 이후 예술향유 지원에 있어서의 정책대상 관련 논의가 '전 국민' vs. '소외계층' 등으로 양분되어 진행되어 온 것 역시 예술향유 지 원에서의 정책대상이 '향유활동'을 행사할 실제 주체로서의 '최종수혜자'를 전제로

93) '예술향유'의 복합적이고 입체적인 개념과 의미에 관한 자세한 논의는 제2장 참조. 
해왔음을 방증한다.

물론 실제 '향유'활동을 하는 이들이 많아지고 이를 통해 향유저변 확대가 이뤼질 수도 있다. 하지만 이러한 관점에만 집중할 경우 ‘향유저변 확대’ 관련 의제는 ‘최종 수혜자’에 대한 '직접지원' 구조에 고착될 수밖에 없다. 하지만 통합문화이용권 사 례를 통해 반복적으로 확인되는 바와 같이 '직접지원' 만으로 새로운 수요개발 및 대응이나 향유저변 확대는 기대하기 힘들다. 예술향유에 대한 다원적 수요를 고려 하되 향유활동이 유발될 수 있는 환경조성 등, 다양한 간접지원 형태의 접근을 함께 고민하는 등 향유지원의 정책대상에 대한 보다 유연한 정책적 관점이 적용될 필요 가 있다.

〈표 4-11〉 예술향유정책의 특성 및 시사점

\begin{tabular}{|c|}
\hline $\begin{array}{c}\text { 예술향유정책 전개과정에서 } \\
\text { 나타난 특성 }\end{array}$ \\
\hline $\begin{array}{c}\text { '문화향유권' 논의 속의 } \\
\text { '예술향유' }\end{array}$ \\
\hline $\begin{array}{c}\text { 문화복지' 담론과의 } \\
\text { 중첩 과정에서 나타난 } \\
\text { ‘향유지원' 목적과 대상의 모호 }\end{array}$ \\
담론은 '보편성' 강조, \\
실행은 '선별적' 접근에 천착 \\
\hline 예술정책을 구성하는 핵심영역으로서 \\
'예술향유' 재검토 필요성 \\
\hline
\end{tabular}

\begin{tabular}{|c|c|}
\hline \multicolumn{2}{|c|}{ 시사점 } \\
\hline \multirow{5}{*}{$\begin{array}{c}\text { 예술정책을 구성하는 } \\
\text { 핵심영역으로서 } \\
\text { 예술향유 지원정책 }\end{array}$} & $\begin{array}{l}\text { 정책 개념으로서 } \\
\text { ‘예술향유' 구체화 }\end{array}$ \\
\hline & $\begin{array}{c}\text { 예술향유 지원목적 } \\
\text { 명확화 }\end{array}$ \\
\hline & $\begin{array}{c}\text { ‘예술향유’에 대한 입체적 } \\
\text { 정책인식 }\end{array}$ \\
\hline & $\begin{array}{c}\text { 예술향유의 환경변화 및 } \\
\text { 향유수요 다원화 고려 }\end{array}$ \\
\hline & $\begin{array}{c}\text { ‘향유’ 지원 정책대상 } \\
\text { 설정의 유연화 }\end{array}$ \\
\hline
\end{tabular}




\section{제2절 예산을 통해서 본 예술향유정책 지원구조}

\section{1. 문화체육관광부 예산구조}

중앙정부의 재정은 크게 예산과 기금으로 나눠지며, 문화체육관광부 재정은 일반 회계와 2 개의 특별회계, 6 개의 기금으로 구성된다. 2020 년 기준 문화체육관광부 예산 편성총액은 총 6 조 4,758 억 원으로 전년대비 $9.4 \%$ 증가한 수치다.

각 부문별로는 문화예술 2 조 1,213 억 원, 콘텐츠 9,650 억 원, 관광 1 조 3,491 억 원, 체육 1 조 6,961 억 원이며, 문화행정 일반은 3,488 억 원이다. '예술향유' 관련 지원이 귀속되는 '문화예술' 부문의 경우, 전년대비 $12.5 \%$ 가 증가하였으며, 전체 문화체육관광부 예산 총액 대비 $32.7 \%$ 를 차지한다.

〈표 4-12〉 2020년 문화체육관광부 예산 및 부문별 편성 내역

\begin{tabular}{c|c|c|c|c|c|c|c|c}
\hline \multirow{2}{*}{ 구분 } & \multicolumn{3}{|c|}{ 2019년 } & \multicolumn{2}{c|}{2020 년 } & \multicolumn{2}{c}{ (단위: 암 원, \%) } \\
\cline { 2 - 9 } & \multicolumn{2}{|c|}{ 본예산(A) } & \multicolumn{2}{|c|}{ 추경 } & \multicolumn{2}{|c}{ 예산(B) } & \multicolumn{2}{|c}{$(\mathrm{B}-\mathrm{A})$} \\
\hline 합계 & 59,233 & $100(\%)$ & 59,772 & $100(\%)$ & 64,803 & $100(\%)$ & 5,570 & 9.4 \\
\hline 문화예술 & 18,852 & $31.8(\%)$ & 18,868 & $31.6(\%)$ & 21,213 & $32.7(\%)$ & 2,361 & 12.5 \\
\hline 콘텐츠 & 8,292 & $14(\%)$ & 8,292 & $13.9(\%)$ & 9,650 & $14.9(\%)$ & 1,358 & 16.4 \\
\hline 관광 & 14,140 & $23.9(\%)$ & 14,540 & $24.3(\%)$ & 13,491 & $20.8(\%)$ & $\triangle 649$ & $\triangle 4.6$ \\
\hline 체육 & 14,647 & $24.7(\%)$ & 14,770 & $24.7(\%)$ & 16,961 & $26.2(\%)$ & 2,314 & 15.8 \\
\hline 문화행정 & 3,302 & $5.6(\%)$ & 3,302 & $5.5(\%)$ & 3,488 & $5.4(\%)$ & 186 & 5.6 \\
\hline
\end{tabular}

자료: 2020 년 문화체육관광부 예산·기금운용계획 개요」, 10쪽

$\lceil 2020$ 년도 문화체육관광부 예산·기금운용계획 개요」에 따른 당해 연도 문화예 술부문 내 중점편성내용은 아래와 같이 제시된다. 
〈표 4-13〉2020년 문화예술부문 중점 편성 내용

\begin{tabular}{c|l}
\hline 구분 & \multicolumn{1}{c}{ 중점 내용 } \\
\hline 예술에 전념할 수 있는 \\
창작 복지환경 조성 & - 예술인창작안전망 구축(518억 원) \\
\hline \multirow{3}{*}{$\begin{array}{c}\text { 예술인 창·취업 활성화를 통한 } \\
\text { 예술일자리 확대 }\end{array}$} & - 예술산업 선순환 생태계 조성(25억 원) \\
& - 박물관·미술관 청년인재 단기체험형 일자리지원(19억 원) \\
& - 전통문화창업지원 및 융합활성화(28억 원) \\
& - 이야기할머니 등 활동지원(105억 원) 등 \\
\hline & - 공공도서관 개관시장 연장(199억 원) \\
일상에서 쉽게 문화를 & - 문화도시조성(100억 원) \\
누릴 수 있는 환경조성 & - 문화예술교육 전용시설(52억 원) \\
& - 문화가있는 날(199억 원) \\
& - 공공박물관·미술관 실감형 체험관 조성(100억 원) \\
& - 2020년 연극의 해(21억 원) 등 \\
\hline 통합문화이용권 등 & - 통합문화이용권 지원(1,033억 원) \\
소외·취약계층 문화 향유기회 제고 & - 함께누리 지원사업(100억 원) \\
\hline
\end{tabular}

자료: 2020 년 문화체육관광부 예산·기금운용계획 개요」, 10 쪽.

현재 문화체육관광부 재정 구조상 '예술향유지원' 관련 재정은 크게 일반회계, 문 화예술진흥기금, 국민체육기금 등 세 줄기를 통해 지원되고 있다.

〈표 4-14〉 문화체육관광부 재정 구조(2020)

\begin{tabular}{|c|c|}
\hline 예산 & 기금 \\
\hline \multirow{2}{*}{ 일반회계 } & 문화예술진흥기금 \\
\hline & 영화발전기금 \\
\hline \multirow{2}{*}{ 국가균형발전특별회계 } & 지역신문발전기금 \\
\hline & 언론진흥기금 \\
\hline \multirow{2}{*}{$\begin{array}{c}\text { 아시아문화중심도시 } \\
\text { 조성특별회계 }\end{array}$} & 관광진흥개발기금 \\
\hline & 국민체육진흥기금 \\
\hline
\end{tabular}

\begin{tabular}{|c|}
\hline 문화예술부문 (향유*) \\
\hline 일반회계* \\
\hline 국가균형발전특별회계 \\
\hline 아시아문화도시조성특별회계 \\
\hline 문화예술진흥기금* \\
\hline 관광진흥개발기금 \\
\hline 국민체육기금* \\
\hline
\end{tabular}

자료: 「2020년 문화체육관광부 예산·기금운용계획 개요」, 17쪽. 


\section{2. 예술향유지원 예산구성94)}

2020년 예술향유지원의 총 지원규모는 일반회계, 문화예술진흥기금, 체육기금 등을 포괄하여 대략 3,409억 원 정도로 파악된다.95) 이들을 각 일반회계, 문화예술 진흥기금, 체육기금 등 3 개 예산 줄기별 세부적으로 살펴보면 다음과 같다.

〈표 4-15〉 예술향유 지원 예산 규모(2020)

(단위: 억 원, \%)

\begin{tabular}{|c|c|c|c|c|}
\hline \multicolumn{2}{|c|}{ 구분 } & \multicolumn{2}{|c|}{ 향유지원 예산규모 } & 전체 예산 \\
\hline \multirow{2}{*}{ 일반회계 } & 예술정책관 & $1,323.84$ & $38.8 \%$ & $3,789.65$ \\
\hline & 지역문화정책관 & 558.45 & $16.4 \%$ & $1,849.66$ \\
\hline \multicolumn{2}{|c|}{ 문화예술진흥기금 } & $1,433.03$ & $42.0 \%$ & $2,677.95$ \\
\hline \multicolumn{2}{|c|}{ 체육기금 } & 94.00 & $2.8 \%$ & $1,448.74$ \\
\hline \multicolumn{2}{|c|}{ 계 } & $3,409.32$ & $100.0 \%$ & - \\
\hline
\end{tabular}

자료:「2020년 문화체육관광부 예산·기금운용계획 개요」기준

\section{가. 일반회계}

문화체육관광부 일반회계에서 예술향유 지원은 예술정책관 및 지역문화정책관 예산으로 이뤄진다.96)

\section{1) 예술정책관}

2020년 기준 예술정책관 일반회계 총 예산은 약 3,790억 원 규모이다. 예산지원 분야는 크게 5개 영역으로 '문화예술단체 지원’ 약 952억(25.1\%), ‘공연 및 전통예 술 진흥기반 구축' 402억(10.6\%), '기초예술 역량 강화' 898억(23.7\%), '시각예술 진흥기반 구축' 241억(6.4\%), '문화예술교육 지원' 약 1,297억(34.2\%)이다.

94) 아래 제시되는 예산 분석은 「2020 문화체육관광부 예산·기금 운영계획,에 따른다.

95) 이는 아래 일반회계(예술정책관, 지역문화정책관 사업 중 예술향유 관련 사업), 문화예술진흥기금 중 예술 향유 관련 사업, 체육기금 내 ‘문화예술취약분야 육성’ 예산 내 일부 예술향유 관련 8개 사업 예산을 합한 수치다.

96) 제1장의 연구범위에서 언급한 바와 같이 문화정책관 관할 예산은 제외한다. 
〈표 4-16〉2020년 문체부 예술정책관 일반회계 예산 내역

(단위: 백만 원)

\begin{tabular}{|c|c|c|c|}
\hline & 구분 & 예산액 & 비중 \\
\hline \multicolumn{2}{|c|}{ 문화예술단체 지원 } & 95,152 & $25.1 \%$ \\
\hline & 문화예술단체 운영지원 & 85,740 & \\
\hline & 예술의 전당 지원 & 9,412 & \\
\hline \multicolumn{2}{|c|}{ 공연 및 전통예술 진흥기반 구축 } & 40,201 & $10.6 \%$ \\
\hline & 예술의전당 리모델링 & 3,922 & \\
\hline & 공연예술 진흥기반 조성 & 7,257 & \\
\hline & 문화예술인프라 구축 & 27,022 & \\
\hline & 공연예술 창작거점 조성 & 2,000 & \\
\hline \multicolumn{2}{|c|}{ 기초예술 역량 강화 } & 89,839 & $23.7 \%$ \\
\hline & 예술창작활동 지원 & 8,938 & \\
\hline & 예술인 창작안전망 구축 & 51,827 & \\
\hline & 함께누리 지원 & 10,021 & \\
\hline & 예술의산업화 추진 & 8,091 & \\
\hline & 한국문학번역원 지원 & 10,962 & \\
\hline \multicolumn{2}{|c|}{ 시각예술 진흥기반 구축 } & 24,113 & $6.4 \%$ \\
\hline & 디자인 및 공간문화 진흥 & 13,853 & \\
\hline & $\begin{array}{c}\text { 미술진흥기반 구축 } \\
\text { (*미술창작 및 향유지원 } 1,948, \text { 공공미술프로젝트 운영 1,176 포함) } \\
\end{array}$ & 10,260 & \\
\hline \multicolumn{2}{|c|}{ 문화예술교육 지원(1637) } & 129,660 & $34.2 \%$ \\
\hline & *문화예술교육 활성화 & 129,260 & $34.1 \%$ \\
\hline & 문화예술 ODA & 400 & \\
\hline 합계 & & 378,965 & $100.0 \%$ \\
\hline
\end{tabular}

자료: 「2020년 문화체육관광부 예산·기금운용계획 개요」, 27-31쪽

*예술향유 관련 예산항목에 해당(굵은글씨)

\section{口 예술정책관 일반회계 중 '예술향유' 관련 예산 규모: 약 1,324 억 원}

전체 약 3,790 억 원 중, 향유지원 예산은 1,324 억 원 규모로 전체 대비 $34.9 \%$ 에 해당한다. 이들은 '문화예술교육지원(문화예술 $\mathrm{ODA}$ 는 제외), 시각예술 진흥기반 구축 영역 내 ‘미술진흥기반 구축' 항목 중 일부사업으로 지원되는 '미술창작 및 향 유지원', ‘공공미술프로젝트 운영’을 포함한 수치다. 현재 예술정책관 일반회계 예 산상 '향유' 지원 예산은 '문화예술교육'을 중심으로 되어 있고, 시각예술에서의 일 부 지원이 포함되어 있다고 할 수 있다. 


\section{2) 지역문화정책관}

2020 년 기준 지역문화정책관의 일반회계 전체 규모는 약 1,850 억 원 규모이다. 예산지원 분야는 크게 3 개 영역으로 '지역문화정책 지원', '박물관 정책 활성화', ‘도서관 정보정책 체계 활성화' 등이다.

〈표 4-17〉2020년 문체부 지역문화정책관 일반회계 예산 내역

(단위: 백만 원)

\begin{tabular}{|c|c|c|c|}
\hline \multicolumn{2}{|c|}{ 구분 } & 예산액 & 비중 \\
\hline \multicolumn{2}{|c|}{ 지역문화정책 지원 } & 111,975 & $60.5 \%$ \\
\hline & $\begin{array}{c}\text { 지역문화진흥 } \\
\text { (*생활문화활성화 } 1,150, \text { 실버문화페스티발 } 850 \text { 포함) }\end{array}$ & 11,657 & $6.3 \%$ \\
\hline & *어르신 문화프로그램 운영 & 2,773 & $1.5 \%$ \\
\hline & *국민문화활동 지원 & 19,949 & $10.8 \%$ \\
\hline & 지역문화기반시설 구축 & 77,596 & $42.0 \%$ \\
\hline \multicolumn{2}{|c|}{ 박물관 정책 활성화 } & 60,834 & $32.9 \%$ \\
\hline & 박물관 미술관 진흥지원 & 21,976 & $11.9 \%$ \\
\hline & $\begin{array}{c}\text { *국민문화향유권 확대 } \\
\text { (국립박물관 미정리 유물등록 및 정비 제외 } 7,735 \text { ) }\end{array}$ & 38,858 & $21.0 \%$ \\
\hline \multicolumn{2}{|c|}{ 도서관 정보정책 체계 활성화 } & 12,157 & $6.6 \%$ \\
\hline & 도서관정책개발 및 서비스 환경 개선 & 11,618 & $34.1 \%$ \\
\hline & 해외 작은 도서관 조성지원 & 539 & $0.3 \%$ \\
\hline 합계 & & 184,966 & $100.0 \%$ \\
\hline
\end{tabular}

자료: 「2020년 문화체육관광부 예산·기금운용계획 개요」, 27-31쪽.

*예술향유 관련 예산항목에 해당(굵은글씨)

그러나 '지역문화정책 지원', '박물관 정책 활성화' 예산의 세부 항목을 살펴보면 '예술향유' 관련 사업예산이 포함되어 있음이 확인된다. 먼저 '지역문화정책 지원' 의 경우는 '지역문화진흥' 일환으로 생활문화활성화, 실버문화페스티발 사업 등이, ‘어르신 문화프로그램 운영' 역시 사업내용과 목적상 활동형 예술향유 지원 성격을 가지며, '국민문화 활동 지원' 관련 ‘문화가 있는 날' 이나 ‘여가친화기업 조성' 등은 예술향유 진작을 위한 환경 및 기반조성적 성격을 가지는 사업목적 및 성격을 가지 기 때문이다.

또한 '박물관 정책 활성화' 예산 중 '국민문화향유권 확대’ 의 경우 국공립 개관시 장 연장, 휴관없는 국립 박물관·미술관 사업, 국공립 문화시설 문화가 있는 주말프 
로그램 운영 등은 인력 지원적 성격을 가지기는 하나, 궁극적으로 일반시민의 관람 환경 조성을 위한 지원으로 볼 수 있다.

지역문화정책관 일반회계 중 '예술향유' 관련 예산 규모: 약 558억 원

지역문화정책관 관할의 '예술향유' 관련 예산은 대략 558억 규모에 이르며, 이는 전체 지역문화정책관 예산대비 $30.2 \%$ 에 해당한다. 세부항목은 아래와 같다.

〈표 4-18〉2020년 문체부 지역문화정책관 일반회계 예산 세부내역 중 향유사업

\begin{tabular}{|c|c|c|c|c|}
\hline & \multicolumn{2}{|c|}{ (단위: 백만 원, \% } \\
\hline \multicolumn{3}{|c|}{ 구분 } & 예산액 & 비중 \\
\hline \multicolumn{3}{|l|}{ 지역문화정책 지원 } & 111,975 & $60.5 \%$ \\
\hline \multirow{8}{*}{$\begin{array}{l}\text { 지역문화 } \\
\text { 진흥 }\end{array}$} & \multirow{8}{*}{11,657} & 지역문화역량강화 & 2,491 & \\
\hline & & 한국문화원연합회 지원 & 2,066 & \\
\hline & & 생활문화활성화 & 1,150 & $0.6 \%$ \\
\hline & & 지역문화활동가 지원 & 500 & \\
\hline & & 문화적 도시재생 & 0 & \\
\hline & & 문화도시 지정 및 평가관리 사업 & 100 & \\
\hline & & 실버문화페스티발 & 850 & $0.5 \%$ \\
\hline & & 지방문화원 원천 콘텐츠 발굴지원 & 4,500 & \\
\hline 어르신문화프로그램 & 2,273 & 어르신 문화프로그램 운영 & 2,773 & $1.5 \%$ \\
\hline \multirow{3}{*}{$\begin{array}{l}\text { 국민문화 } \\
\text { 활동 지원 }\end{array}$} & \multirow{3}{*}{19,949} & 문화가 있는 날 기획프로그램 운영 & 19,652 & \multirow{3}{*}{$10.8 \%$} \\
\hline & & 문화가 있는 날 종합안내센터 운영 & 200 & \\
\hline & & 여가친화기업 선정지원 & 97 & \\
\hline 지역문화기반시설 구축 & 77,596 & 지역문화기반시설 구축 & 77,596 & \\
\hline \multicolumn{3}{|l|}{ 박물관 정책 활성화 } & 60,834 & $32.9 \%$ \\
\hline \multirow{4}{*}{$\begin{array}{l}\text { 박물관 미술관 } \\
\text { 진흥지원 }\end{array}$} & \multirow{4}{*}{21,976} & 박물관운영활성화 & 7408 & \\
\hline & & 공사립박물관 소장 국가문화유산DB화 & 693 & \\
\hline & & 해외박물관한국실운영지원 & 2550 & \\
\hline & & 박물관미술관협력강화 & 11325 & \\
\hline \multirow{5}{*}{$\begin{array}{c}\text { 국민문화 } \\
\text { 향유권 확대 }\end{array}$} & \multirow{5}{*}{$\begin{array}{c}38,858 \\
(31,123)\end{array}$} & 국·공립 문화시설 개관시장 연장 & 23,208 & \multirow{5}{*}{$16.8 \%$} \\
\hline & & 국립박물관 미정리 유물등록 및 정리 & 7,735 & \\
\hline & & 휴관없는 국립박물관·미술관운영 & 6,195 & \\
\hline & & 국·공립 문화시설 문화가 있는 주말프로그램 운영 & 720 & \\
\hline & & 안전하고 편안한 관람환경조성 & 1,000 & \\
\hline
\end{tabular}




\begin{tabular}{|c|c|c|}
\hline 구분 & 예산액 & 비중 \\
\hline 도서관 정보정책 체계 활성화 & 12,157 & $6.6 \%$ \\
\hline 도서관정책개발 및 서비스 환경 개선 & 11,618 & \\
\hline 해외 작은 도서관 조성지원 & 539 & \\
\hline 예술향유사업 예산 합계 (굵은 표시 사업기준) & 55,845 & $30.2 \%$ \\
\hline 지역문화정책관 전체 예산합계 & 184,966 & $100 \%$ \\
\hline
\end{tabular}

자료:「2020년 문화체육관광부 예산·기금운용계획 개요, 32-34쪽.

\section{나. 문화예술진흥기금}

2020년 기준 문화예술진흥기금 중 사업비 기준 총 예산은 2,678억 원으로 전년 도 2,510 억 원 대비 $6.7 \%$ 증가된 수치다.

〈표 4-19〉2020년 문화예술진흥기금 예산

(단위: 백만 원, \%)

\begin{tabular}{|c|c|c|c|c|c|c|}
\hline & \multirow{3}{*}{$\begin{array}{l}\text { 구분 } \\
\text { 합계 }\end{array}$} & \multicolumn{2}{|c|}{ 2019년 예산 } & \multirow{3}{*}{$\begin{array}{c}\text { 2020년 } \\
\text { 예산(B) } \\
543,910\end{array}$} & \multirow{2}{*}{\multicolumn{2}{|c|}{$\begin{array}{c}\text { 증감 } \\
(B-A)\end{array}$}} \\
\hline & & \multirow{2}{*}{$\begin{array}{l}\text { 본예산(A) } \\
468,533\end{array}$} & \multirow{2}{*}{$\frac{\text { 추경(A) }}{468,533}$} & & & \\
\hline & & & & & 75,377 & $9.4 \%$ \\
\hline \multirow{2}{*}{ 총지출 } & 사업비 & 251,077 & 251,077 & 267,795 & 16,718 & $6.7 \%$ \\
\hline & 기금운영비 & 20,654 & 20,654 & 21,487 & 833 & $4.0 \%$ \\
\hline \multicolumn{2}{|r|}{ 내부거래 } & 5,000 & 5,000 & 5,000 & - & - \\
\hline \multicolumn{2}{|c|}{ 여유자금운용 } & 191,802 & 191,802 & 249,628 & 57,826 & \\
\hline
\end{tabular}

자료: 2020 년 문화체육관광부 예산·기금운용계획 개요」, 77쪽.

문화예술진흥기금을 통한 예술지원은 크게 세 분야로 나뉘는데, '예술창작역량강 화' 791 억(29.5\%), '지역문화예술진흥' 215 억(8.0\%), '예술향유기회확대' 1,672 억 (62.4\%)으로 구성된다. 
〈표 4-20〉2020년 문체부 문화예술진흥기금 예산 내역 (단위: 백만 원)

\begin{tabular}{|c|c|c|c|}
\hline & 구분 & 예산액 & 비중 \\
\hline \multicolumn{2}{|c|}{ 예술창작역량강화 } & 79,088 & $29.5 \%$ \\
\hline & 예술창작지원 & 44,548 & $17.0 \%$ \\
\hline & 예술인력육성 & 14,540 & $5.4 \%$ \\
\hline & 예술인생활안정자금(융자) & 19,000 & $7.1 \%$ \\
\hline \multicolumn{2}{|c|}{ 지역문화예술진흥 } & 21,528 & $8.0 \%$ \\
\hline & 지역문화예술지원 & 10,457 & $3.9 \%$ \\
\hline & 예술의 관광자원화 & 11,070 & $4.1 \%$ \\
\hline \multicolumn{2}{|c|}{ 예술향유기회확대(구[舊] 예술의 사회적 가치 확산)97) } & 167,180 & $62.4 \%$ \\
\hline & 예술정책 및 기부활성화 & 23,877 & $8.9 \%$ \\
\hline & *문화예술향유지원 & 143,303 & $53.5 \%$ \\
\hline 합계 & & 267,795 & $100 \%$ \\
\hline
\end{tabular}

자료: 「2020년 문화체육관광부 예산·기금운용계획 개요」, 77-80쪽.

*예술향유 관련 예산항목에 해당(굵은 글씨)

\section{문화예술진흥기금 사업비 예산 중 '예술향유' 예산: 약 1,433 억 원 규모}

문화예술진흥기금 사업 예산 중 '예술향유' 관련 예산을 '예술향유기회확대' 예산 항목에만 한정하되, '예술정책 및 기부활성화' 관련 사업 내역을 제외하고 산정하면 예술향유 사업 예산규모는 약 1,433 억 원으로 총 $53.5 \%$ 를 차지한다. 사업별 내역 은 다음과 같다. ${ }^{98)}$

97) 2018년까지 '예술향유기회확대' 예산명은 '예술의 사회적 가치확산'으로 해당 항목 내 '문화예술사회적 인식제고', ‘소외계층문화역량강화'로 구성되었다. 이것이 현재 전자는 '예술정책 및 기부활성화'로, 후자 는 '문화예술향유지원'으로 변경됨. 이는 복권기금 사업 변경과 연동된 것이다.

98) 제2장 예술향유 담론 및 이론적 논의에서 '기부'를 향유의 한 유형으로 볼 것임을 제안하였으나, 현재 국내 예술정책에서 '기부’를 ‘향유지원'으로 보지 않아 위의 예산논의에서는 제외하였다. 기부 관련 예산 (200억 원)을 포괄하면 전체 향유지원예산 지원 규모는 1,633 억 원이다. 
〈표 4-21〉 2020년 문화예술진흥기금 예산 세부내역 중 향유사업

(단위: 백만 원, \%)

\begin{tabular}{|c|c|c|c|c|}
\hline \multicolumn{3}{|c|}{ 구분 } & 예산액 & 비중 \\
\hline \multicolumn{3}{|l|}{ 예술창작역량강화 } & 111,975 & $29.5 \%$ \\
\hline \multirow{7}{*}{ 예술창작지원 } & \multirow{7}{*}{79,088} & 문학창작육성 & 2,988 & \multirow{7}{*}{$17.0 \%$} \\
\hline & & 시각예술창작육성 & 2,672 & \\
\hline & & 공연예술창작육성 & 26,655 & \\
\hline & & 국제예술교육지원 & 6,443 & \\
\hline & & 공연예술중장기창작지원 & 5,490 & \\
\hline & & 남북문화예술교육지원 & 300 & \\
\hline & & 청년예술가생애첫지원 & 1,000 & \\
\hline \multirow{2}{*}{ 예술인력육성 } & \multirow{2}{*}{14,082} & 차세대예술인력육성 & 3,000 & \multirow{2}{*}{$5.4 \%$} \\
\hline & & 현장예술인력육성 & 11,540 & \\
\hline 예술인생활안정자금 & 19,000 & 예술인생활안정자금(융자) & 19,000 & $7.1 \%$ \\
\hline \multicolumn{3}{|l|}{ 지역문화예술진흥 } & 21,527 & $8.0 \%$ \\
\hline \multirow{3}{*}{$\begin{array}{l}\text { 지역문화 } \\
\text { 예술지원 }\end{array}$} & \multirow{3}{*}{21,527} & 공연장상주단체육성지원 & 6,187 & \multirow{3}{*}{$3.9 \%$} \\
\hline & & 지역문화협의체 등 운영 & 270 & \\
\hline & & (신규)아르코공공예술사업 & 4,000 & \\
\hline \multirow{7}{*}{ 예술의 관광자원화 } & \multirow{7}{*}{11,070} & 전통예술지역브랜드상설공연 & 2,145 & \multirow{7}{*}{$4.1 \%$} \\
\hline & & 인류무형문화유산활용공연사업 & 1,099 & \\
\hline & & 문화공간활용전통공연사업 & 1,200 & \\
\hline & & 전통공연예술활동지원 & 2,585 & \\
\hline & & 공연예술 전략적 해외진출 지원 & 2,150 & \\
\hline & & 전통예술해외아트마켓참가/해외진출 & 1,210 & \\
\hline & & 지역명소활용공연지원 & 681 & \\
\hline \multicolumn{3}{|l|}{ 예술향유기회확대 } & 167,180 & $62.4 \%$ \\
\hline \multirow{4}{*}{$\begin{array}{l}\text { 예술정책 및 } \\
\text { 기부활성화 }\end{array}$} & \multirow{4}{*}{23,877} & 예술정책실행력제고 & 1,579 & \\
\hline & & 문화예술기부활성화 & 19,980 & \\
\hline & & 원로문예인복지지원 & 108 & \\
\hline & & 예술자료수집 및 디지털화 & 2,210 & \\
\hline \multirow{3}{*}{$\begin{array}{l}\text { 문화예술 } \\
\text { 향유지원* }\end{array}$} & \multirow{3}{*}{143,303} & 통합문화체육관광이용권* & 103,324 & \\
\hline & & 신나는예술여행* & 24,229 & \\
\hline & & 방방곡곡문화공감* & 15,750 & \\
\hline \multicolumn{3}{|c|}{ 예술향유사업 예산 합계 (굵은 표시 사업기준) } & 143,303 & $53.5 \%$ \\
\hline \multicolumn{3}{|c|}{ 문화예술진흥기금 사업비 합계 } & 267,795 & $100 \%$ \\
\hline
\end{tabular}

자료: 2020년 문화체육관광부 예산·기금운용계획 개요, 77-80쪽. 
문화예술진흥기금 사업 내 '예술향유' 지원은 2014년 이전까지 대부분 복권기금 사업에 의존되어 진행되었고, 복권기금 재원용도 지정으로 인해 '소외계층' 관련 사 업으로 구조화되어 있었다.

그러나 2014년 이후 기존 8개 내역사업이 5개로 변경되었고, 일부사업은 국고사 업으로 이전되었다. 덧붙여 여행이용권, 스포츠관람이용권 사업이 '통합문화이용권' 사업으로 흡수되었으며, 우수문학도서보급, 공공박물관·미술관전시프로그램, 장애 인 창작 및 표현지원활동 등이 국고사업으로 통합 이전되었다. 또한 이전까지 대표 적인 ‘소외계층’ 사업으로 일컬어지던 ‘방방곡곡문화나눔사업’과 ‘신나는예술여행' 사업은 2018년부터 복권기금이 아닌 '문화예술진흥기금' 으로 운영되고 있다.

〈표 4-22〉 복권기금 문화예술진흥기금 전출 내역(2014 2020)

\begin{tabular}{c|c|c|c|c|c|c|c}
\multicolumn{1}{|c|}{} & 2014 & 2015 & 2016 & 2017 & 2018 & 2019 & 2020 \\
\hline 통합 문화이용권 & 40,866 & 42,643 & - & - & 82,103 & 95,061 & 103,324 \\
\hline 공연나눔 & 19,234 & 19,278 & 36,119 & 36,119 & - & - & - \\
\hline 창작나눔 & 1,200 & 1,200 & 1,080 & 1,080 & - & - & - \\
\hline 예술인생활안정자금 원, \%) & - & - & - & - & - & 10,500 & 19,000 \\
\hline 복권기금 합계 & 61,300 & 63,121 & 37,199 & 37,199 & 82,103 & 105,561 & 122,324 \\
\hline
\end{tabular}

자료: http://www.bokgwon.go.kr/fund/02_01.jsp(최종접근: 2020.05.17)

현재 '문화예술진흥기금' 내 '문화예술향유지원' 은 3개의 사업 중심으로 단순화 되어 있으며, 이는 각각 통합문화이용권, 신나는 예술여행, 방방곡곡 문화공감이다. 이들 중 복권기금 재원 사업은 ‘통합문화이용권'이 유일하며, 그 외 '예술창작지원' 분야에서 2019년부터 신규사업으로 진행 중인 '예술인생활안정자금(융자)'사업 역 시 복권기금으로 지원된다.

2020년 기준 문화예술진흥기금 사업비 내 문예진흥기금과 복권기금 비중은 각각 54.3\%: 45.7\%이다. 2016 2017년 한때 문예진흥기금이 83.1 83.7\%까지 높아졌 으나, 2018년 이후 통합문화이용권 사업비 확장에 따른 기금 유입 확대로 현재는 엇비슷하게 유지되고 있다. 


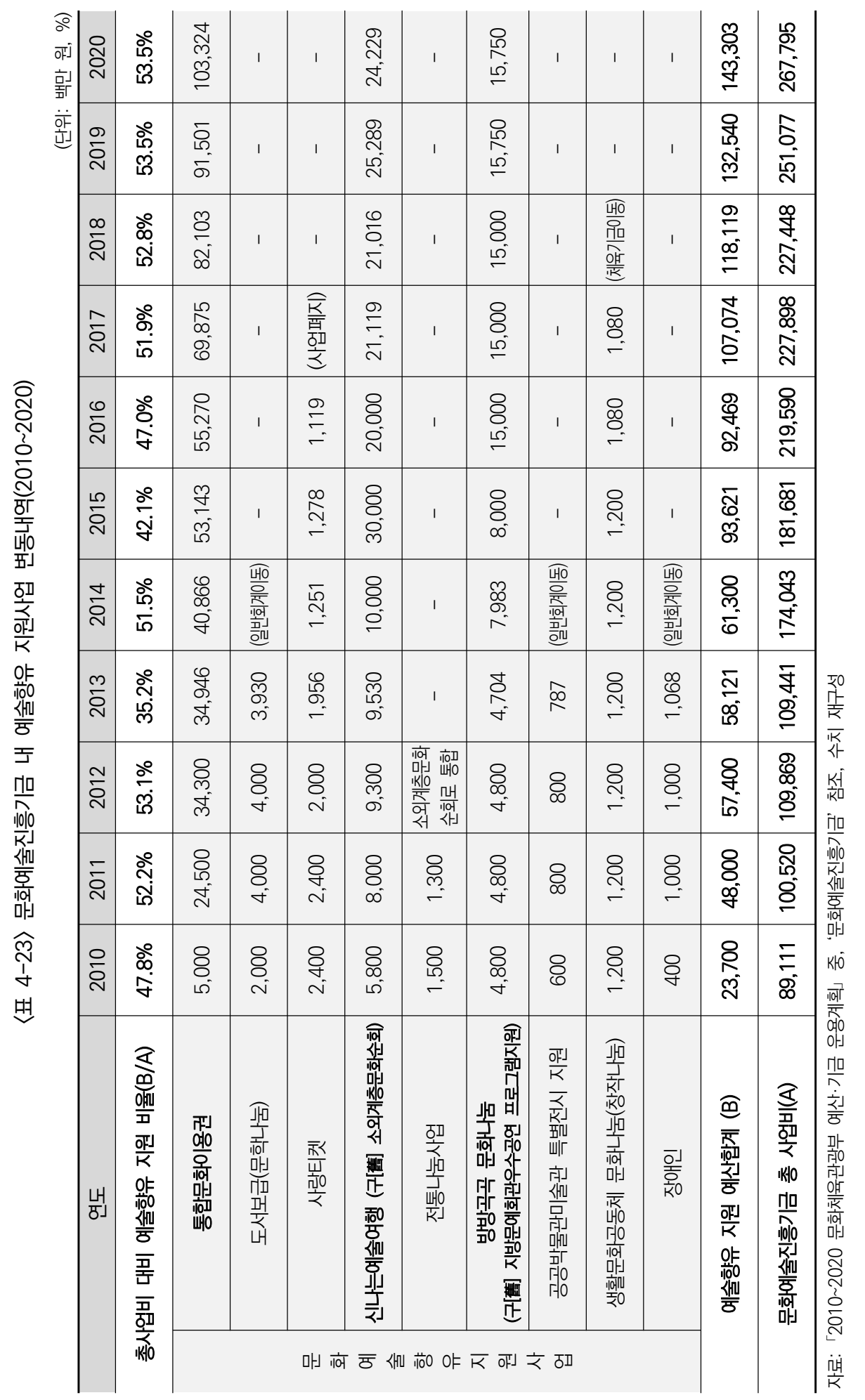



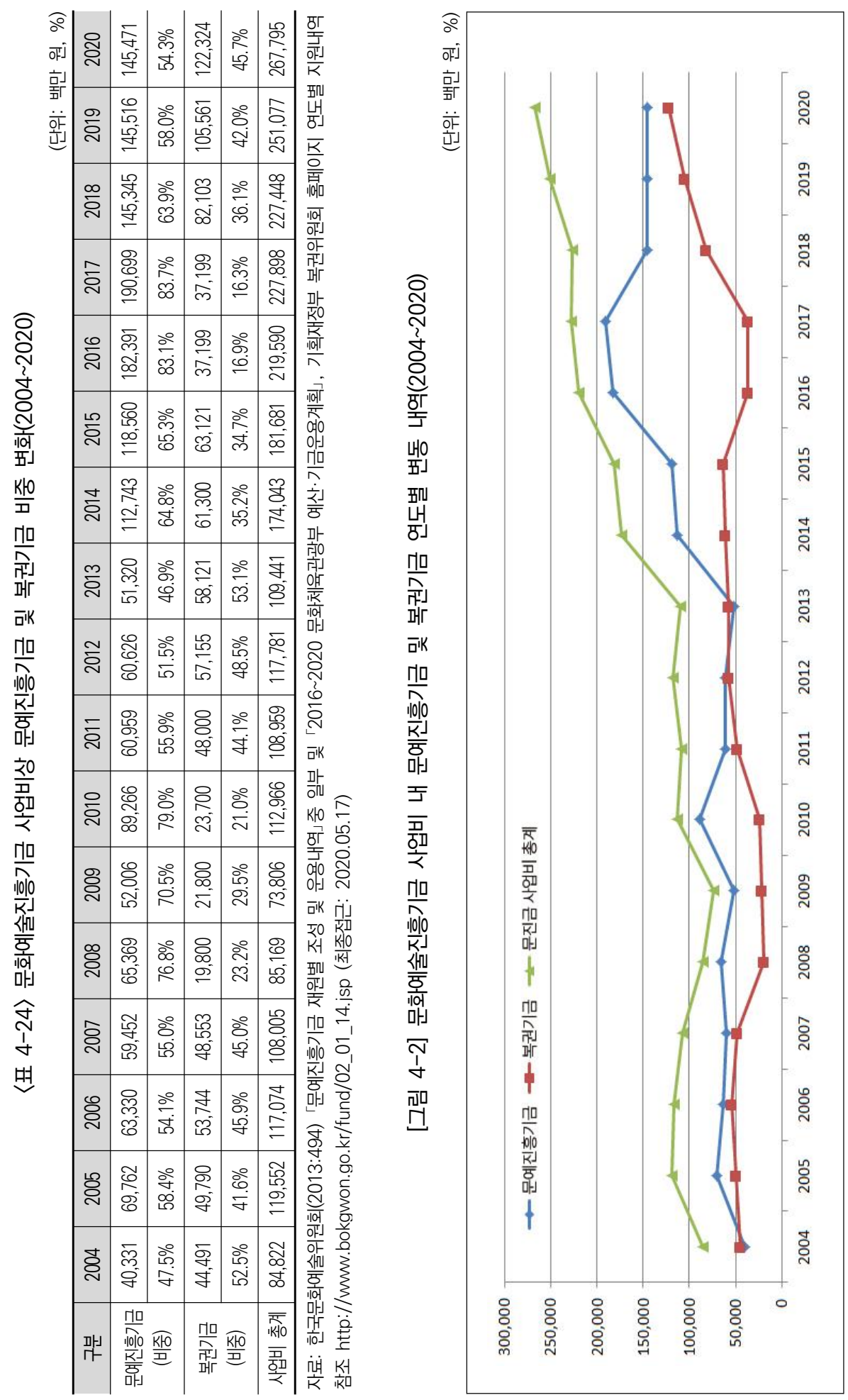


\section{다. 국민체육진흥기금}

2020 년 기준 국민체육진흥기금 사업비 기준 총 예산은 약 1 조 4,487 억 원으로 전년도 1 조 2,275 억 원 대비 $18 \%$ 증가된 수치다.

〈표 4-25〉2020년도 국민체육진흥기금 예산

(단위: 백만 원, \%)

\begin{tabular}{c|c|c|c|c|c}
\hline \multicolumn{2}{c|}{ 구분 } & $\begin{array}{c}\text { 2019년 예산 } \\
\text { 본예산(A) }\end{array}$ & $\begin{array}{c}\text { 2020년 } \\
\text { 예산(B) }\end{array}$ & \multicolumn{2}{|c}{$\begin{array}{c}\text { 증감 } \\
(\mathrm{B}-\mathrm{A})\end{array}$} \\
\hline \multirow{2}{*}{ 찹계 } & $2,349,294$ & $2,607,258$ & 257,964 & $11 \%$ \\
\hline \multirow{2}{*}{ 총출 } & 사업비 & $1,227,533$ & $1,448,748$ & 221,215 & $18 \%$ \\
\cline { 2 - 6 } & 운영비 & 29,244 & 29,115 & $\triangle 129$ & $\triangle 0.4 \%$ \\
\hline \multicolumn{2}{c|}{ 공공자금예치 } & 520,000 & 520,000 & & - \\
\hline \multicolumn{2}{c|}{ 공공기금전출금 } & 100,000 & 100,000 & & \\
\hline \multicolumn{2}{c|}{ 여유자금운용 } & 472,517 & 509,395 & 36,878 & $7.8 \%$ \\
\hline
\end{tabular}

자료: 「2020년 문화체육관광부 예산·기금운용계획 개요」, 97쪽.

표면적으로 국민체육진흥기금은 예술향유와 무관할 것으로 보이나, '생활체육육 성' 예산 내역 하에 세부예산항목인 '체육·문화예술사업의 지원' 관련하여 '문화예 술취약분야 육성' 사업이 총 150 억 원 규모로 지원되고 있다. 일례로 지난 2018년 부터 문화예술진흥기금 사업 중 하나인 '생활문화공동체만들기(창작나눔)' 지원사업 의 경우 '체육기금' 으로 진행되고 있다.

〈표 4-26〉 2020년 국민체육진흥기금 예산 내역 (단위: 백만 원)

\begin{tabular}{|c|c|c|c|}
\hline & 구분 & 예산액 & 비중 \\
\hline \multicolumn{2}{|c|}{ 생활체육육성 } & 645,041 & $44.5 \%$ \\
\hline & $\begin{array}{c}\text { 생활체육활성화 } \\
\text { (체육·문화예술사업의 지원-문화예술취약분야 육성 15,003 포함*) }\end{array}$ & 245,578 & $17.0 \%$ \\
\hline & 생활체육시설지원 & 365,279 & $25.2 \%$ \\
\hline & 학교체육육성 & 34,184 & $2.4 \%$ \\
\hline \multicolumn{2}{|c|}{ 전문체육 육성 } & 388,106 & $26.8 \%$ \\
\hline & 전문체육 육성 & 338,892 & $23.4 \%$ \\
\hline & 전문체육 육성기반 구축 & 32,595 & $2.2 \%$ \\
\hline & 체육인 복지사업 & 21,619 & $1.5 \%$ \\
\hline
\end{tabular}




\begin{tabular}{|c|c|c|c|}
\hline & 구분 & 예산액 & 비중 \\
\hline \multicolumn{2}{|c|}{ 스포츠산업육성 } & 216,094 & $14.9 \%$ \\
\hline & 스포츠산업연구및기술개발 & 12,973 & $0.9 \%$ \\
\hline & 기금조성기반시설지원 & 71,343 & $4.9 \%$ \\
\hline & 스포츠산업활성화 & 131,778 & $9.1 \%$ \\
\hline \multicolumn{2}{|c|}{ 국제스포츠역량강화 } & 216,094 & $5.9 \%$ \\
\hline & 국제스포츠교류활성화 & 12,973 & $5.9 \%$ \\
\hline \multicolumn{2}{|c|}{ 장애인체육육성 } & 71,343 & $6.3 \%$ \\
\hline & 장애인체육육성 & 131,778 & $6.3 \%$ \\
\hline 합계 & & $1,448,748$ & $100.0 \%$ \\
\hline
\end{tabular}

자료: 「2020년 문화체육관광부 예산·기금운용계획 개요」, 97-107쪽.

*세부예산항목인 '체육·문화사업의 지원(5161-307) 내에 '문화예술취약분야 육성' 항목이 존재

\section{口 국민체육진흥기금 사업비 예산 중 ‘예술향유' 관련 예산: 약 94억 원 규모}

문화체육 취약분야 육성의 경우, 총 16 개 세부사업이 진행되고 있는데 이중 예술 향유와 직간접적으로 관련된 사업은 모두 8개로 파악된다. 대표적으로 '생활문화공 동체만들기' 지원사업 외, 일반 시민들의 예술접근성 확대를 위한 '작은미술관 조성 및 운영지원' 등을 비롯하여 총 94억 원 규모다. 전체 국민체육진흥기금 사업비상 으로는 불과 $0.6 \%$ 에 불과하지만, '문화예술취약분야육성' 사업비(150억 원) 대비로 는 $62.7 \%$ 에 해당한다.

〈표 4-27〉2020년 체육기금 ‘체육·문화예술사업의 지원’(5161-307) 중 문화예술취약분야육성 사업내역

\begin{tabular}{|c|c|c|c|}
\hline \multicolumn{2}{|r|}{ 구분 } & 예산액 & 비중 \\
\hline \multirow{8}{*}{$\begin{array}{c}\text { 예술향유 } \\
\text { 관련 사업 } \\
(9,400 \text { 백만 원) }\end{array}$} & 생활문화공동체만들기 & 1,300 & $8.7 \%$ \\
\hline & 도서관 상주작가 지원 & 1,200 & $8.0 \%$ \\
\hline & 작가와 함께하는 문학서점 & 1,000 & $6.7 \%$ \\
\hline & 노인요양시설 전통예술 프로그램 지원 & 1,400 & $9.3 \%$ \\
\hline & 작은미술관 조성 및 운영지원 & 700 & $4.7 \%$ \\
\hline & 미술 전시공간 활성화지원 & 2,100 & $14.0 \%$ \\
\hline & 전시해설 인력지원 & 1,400 & $9.3 \%$ \\
\hline & 책읽어주는 문화봉사단 & 300 & $2.0 \%$ \\
\hline \multicolumn{2}{|c|}{ 장애인 문화예술진흥 } & 2,320 & $15.5 \%$ \\
\hline \multicolumn{2}{|c|}{ 발달장애인 특성화 교육프로그램 연구개발 } & 153 & $1.0 \%$ \\
\hline
\end{tabular}




\begin{tabular}{c|c|c}
\hline 구분 & 예산액 & 비중 \\
\hline 예술인 의료비 및 역량강화 지원 & 225 & $1.5 \%$ \\
\hline 원로예술인 공연지원 & 1,150 & $7.7 \%$ \\
\hline 한국미술담론 창출 & 270 & $1.8 \%$ \\
\hline 안녕 우리말 공연지원 & 50 & $0.3 \%$ \\
\hline 점자전문인력 양성환경 개선 & 135 & $0.9 \%$ \\
\hline 영세출판 및 경력자 재취업지원 & 1,300 & $8.7 \%$ \\
\hline 합계 & 15,003 & $100.0 \%$ \\
\hline
\end{tabular}

자료:「2020년 문화체육관광부 예산·기금운용계획 개요, 97-107쪽. 
예술향유정책 분석 및 방향 연구

제5장

예술향유정책 사업 분석 



\section{제1절 주요 지원사업 현황}

제4장에서 살펴 본 바와 같이 현재 국내 예술향유 관련 정책지원구조는 예산출처 뿐 아니라 문화체육관광부 내 주관 부처 역시 다원적임이 확인된다. 이를 고려하여 제5장에서 다루는 주요 지원사업 현황은 문화체육관광부 ‘예산항목별'로 접근하되, 각각 사업(지원목적), 예산, 수혜대상, 성과지표·실적을 중심으로 검토, 분석·제시 한다.

\section{1. 예산항목별 예술향유 지원사업}

\section{가. 일반회계 예술정책관}

1) 시각예술 진흥기반구축: 미술진흥기반구축

(1) 미술창작 및 향유 지원: 미술주간 운영

'미술창작 및 향유 지원' 예산으로 운영하는 '미술주간 운영' 은 매년 10 월 문화의 달을 계기로 미술에 대한 관심을 높이고자 진행하는 국내 최대 규모의 미술행사이 다. 미술주간 동안 국·공·사립미술관, 갤러리, 비영리 전시공간 등 전국 미술공간들 이 협력하여 다채로운 연계 행사와 참여 프로그램을 제공한다. 예술경영지원센터에 서 주관하며 2020년 사업 예산은 802백만 원이다. '미술주간 운영'은 미술향유 기 회 확대와 소비 증진을 목적으로 하며, 2019년이 5 회였으며 사업의 수혜대상은 대 국민과 미술계 종사자이다. 미술주간 동안에는 전문 인솔자와 전국의 다양한 전시 공간과 화랑을 방문하는 미술여행 프로그램, 미술주간 연계 프로그램 지원, 미술주 간 통합패스 운영, 대국민 참여 행사 등이 열린다(2019년 기준). 미술의 문턱을 낮 추고 관객들이 일상 속에서 미술을 가깝고 친숙하게 느낄 수 있게, 무료 입장 또는 
할인, 야간개장 혜택을 제공하거나, 작품을 직접 구매하는 경험을 할 수 있는 한국 국제아트페어(KIAF)와 작가미술장터를 개최한다. 2019년 미술주간 방문객 수는 약 64만 6천명으로 2018년보다 32.2\% 상승한 것으로 집계되었다. 2016년 약 23만 명, 2017년 약 30만 명, 2018년 약 49만 명으로 방문객수가 크게 증가한 것을 알 수 있다. 이는 미술주간이 국민이 향유하는 미술축제로 자리매김 하고 있으며 미술 을 일상에서 친근하게 즐기고 느끼는 사람들이 늘어나는 데 긍정적인 역할을 하고 있음을 시사한다. ${ }^{99)}$

(2) 미술창작 및 향유 지원: 작가미술장터 개설 지원

‘미술주간 운영' 외에 또 다른 '미술창작 및 향유 지원' 예산 사업인 '작가미술장 터'는 2 백만 원 이하의 중저가 미술품을 대상으로 하는 대안적이고 실험적인 성격 의 미술장터를 말한다.100) 2015년 시작된 사업으로 예술경영지원센터가 주관하며 2020년 예산은 846백만 원이다. 사업의 목적은 직거래 미술장터를 개설하여 미술 시장 진입장벽이 높은 작가들의 미술품 판로개척을 지원하고, 저렴한 가격에 미술 품을 소장할 수 있는 기회를 제공하여 미술품 향유 및 소장 문화를 만드는 것이다. 작품 판매 수익금 전액은 해당 작가에게 지급한다. 지원대상은 장터를 기획하고자 하는 민간단체나 기획자이며 수혜대상은 전 국민이다.

2019년에는 사업 5년차를 맞아 '유니온아트페어', '퍼폼', '그림도시', '팩(pack)', ‘아트 앳 홈’이 ‘작가미술장터'의 이름으로 3회 이상 행사를 계속할 정도로 자리를 잡았으며 미술시장 안에서 지속적으로 화두가 되고 있다.101) 2019년에는 특히 비 주류 장르의 마켓을 지원해 미술시장 저변을 확대하고자 했고, 비 수도권 장터의 비율을 확대해 지역의 미술시장을 활성화 하고자 했다. 2019년 기준 참여 작가수는 약 1,000 명, 관람객은 약 10 만 명, 판매 작품수는 3 만 3 천여 점이다. 1 차적으로는 작가들의 작품 판로개척을 지원하는 사업이지만 지난 5년 간 일반적인 문화공간 외 에도 번화가, 백화점, 커피숍, 폐건물 등에서 장터를 진행102)하면서 일상성과 탈장

99) 예술경영지원센터 보도자료, 2019.10.24. 미술로 좋은 날! 2019 미술주간 성료,

http://artweek.kr/news/02.php?admin_mode=read\&no=101\&make=\&search=\&type=\&page=1

100) 2020 〈작가미술장터 개설 지원〉 사업 공모요강

101) 2019 작가미술장터 도록 비평집, 4쪽.

102) 한겨레. 2017.06.29. 피맛골 모퉁이에 '불끈’ 솟아난 청년 미술장터, 
소성을 추구해 왔으며, 젊은 층을 중심으로 미술작품 향유와 구입에 대한 접근 장벽 을 낮추는 역할을 해온 측면이 있다.

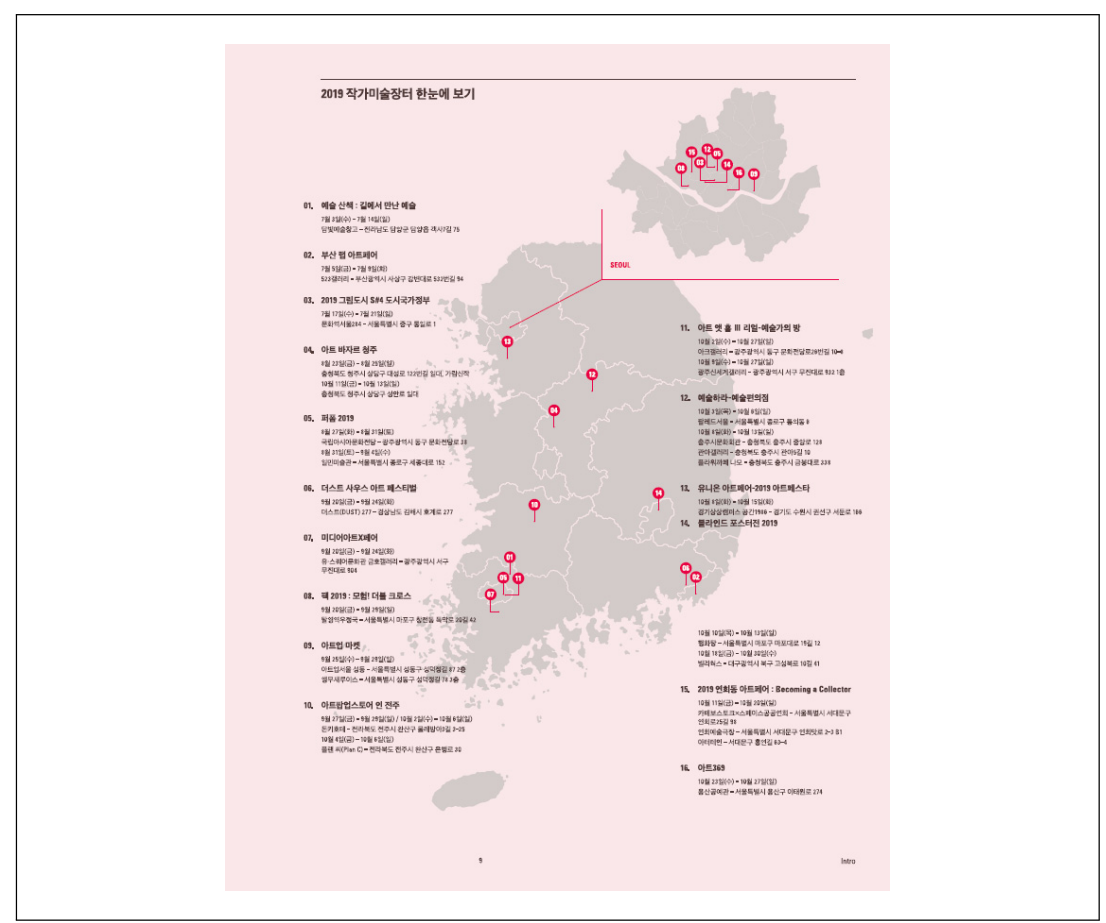

자료: 2019 작가미술장터 도록 비평집, 9쪽.

(3) 공공미술 프로젝트 운영: 마을미술 프로젝트

'공공미술 프로젝트 운영' 사업 예산으로 운영되는 '마을미술 프로젝트'는 주관기 관이 한국문화예술위원회에서 2019년 한국공예디자인문화진흥원으로 이관되었으 며 (재)아름다운맵에서 위탁 운영한다. 일상공간을 문화예술 공간으로 재창조하여 주민들의 문화 향수권을 신장하고 건강한 예술마을을 조성하는 것을 목적으로 한 다. 2019년까지 전국 110곳에서 사업이 진행되었다.103) 2020년 사업 예산은 1,122 백만 원이며 신규 공모는 435 백만 원 규모로 진행한다. 지자체와 사업수행단 체가 매칭하여 함께 제안하는 방식이다. 2009년 사업 시작 당시 예술뉴딜정책의 일환으로 추진되었기 때문에 예술가들의 일자리 창출 목적도 병행한다. 성과지표는

http://mww.hani.co.kr/arti/culture/music/800842.html

103) 2020 마을미술 프로젝트 지원 대상지 공모 
시각예술진흥사업 전체 수혜자 만족도로 산출하며, 앞으로 공공미술프로젝트 등 미 술을 매개로 한 사업을 통해 문화향유여건을 개선한다는 계획을 갖고 있다.

〈표 5-1〉 '시각예술 진흥기반구축' 중 예술향유 지원사업(2020)

\begin{tabular}{|c|c|c|c|c|c|c|}
\hline 세부사업명 & 내역사업명 & 운영기관 & 예산 & 목적 & 수혜대상 & 지표/실적 \\
\hline \multirow{3}{*}{$\begin{array}{c}\text { [311] } \\
\text { 미술진흥 } \\
\text { 기반구축 }\end{array}$} & $\begin{array}{l}\text { 미술창작 및 향유지원: } \\
\text { 미술주간 운영 }\end{array}$ & 예술경영지원센터 & 802 & $\begin{array}{c}\text { 국민의 미술향유 증진, } \\
\text { 미술문화 확산 }\end{array}$ & $\begin{array}{l}\text { 대국민 및 } \\
\text { 미술계 } \\
\text { 종사자 }\end{array}$ & 참여자수 \\
\hline & $\begin{array}{c}\text { 미술창작 및 향유지원: } \\
\text { 작가 미술장터 개설 } \\
\text { 지원 }\end{array}$ & 예술경영지원센터 & 846 & $\begin{array}{l}\text { 국민의 미술문화 향유, 미술품 } \\
\text { 소장문화 확산 유도, 판로개척 }\end{array}$ & 전국민 & 참여자수 \\
\hline & $\begin{array}{c}\text { 공공미술 프로젝트 } \\
\text { 운영: 마을미술 } \\
\text { 프로젝트 }\end{array}$ & $\begin{array}{l}\text { 한국공예디자인 } \\
\text { 문화진흥원 }\end{array}$ & 1,122 & $\begin{array}{l}\text { 일상공간을 문화예술공간으로 } \\
\text { 재창조, 주민들의 문화향수권 } \\
\text { 신장 및 건강한 예술마을 조성 }\end{array}$ & 전국민 & $\begin{array}{l}\text { 수혜자 } \\
\text { 만족도 }\end{array}$ \\
\hline
\end{tabular}

\section{2) 문화예술교육지원: 문화예술교육 활성화}

'문화예술교육지원: 문화예술교육 활성화' 예산은 4개의 세부 예산항목으로 나뉘 어 진다. 이들은 각각 '학교문화예술교육지원' , '사회문화예술교육지원', '지역문화 예술교육지원' , ‘문화예술교육 전문인력'이다. 각 세부 예산항목별로 진행되는 사업 을 살펴보면 다음과 같다.

\section{2-1) 학교 문화예술교육지원}

(1) 학교예술강사지원

'학교예술강사지원' 사업은 학생들에게는 예술현장과 공교육 연계를 통한 문화예 술교육 및 체험 기회의 확대로 문화적 감수성 및 인성·창의력 향상에 기여하고, 예 술인들에게는 창작활동과 병행 가능한 일자리를 창출하는 것을 목표로 한다. 2000 년에 국악 분야 '강사풀제'를 모태로 하는 예술인 일자리 창출 사업으로 시작되었 다. 예산은 2020 년 기준 총 54,779 백만 원(민간 경상 보조 48,966 백만 원, 지자체 보조 5,813 백만 원) 이다. 
〈표 5-2〉 학교예술강사지원 교급별 운영 현황(2019)

(단위: 개교)

\begin{tabular}{c|c|c|c|c|c|c}
\hline 구분 & 초등학교 & 중학교 & 고등학교 & 특수학교 & 대안학교 & 총계 \\
\hline 학교수 & 5,789 & 1,617 & 906 & 152 & 17 & 8,481 \\
\hline
\end{tabular}

자료: 한국문화예술교육진흥원, 「2019 국고 보조사업 실적보고서」

문체부와 교육부, 17 개 시·도 교육청과 지자체 협력을 통해 17 개 시·도 지역운영 기관(지역센터, 국악단체, 신규단체)을 통해 운영한다. 전국 초·중·고등학교, 특수학 교, 대안학교(교육부 인가)를 대상으로 국악, 연극, 영화, 무용, 만화·애니메이션, 공 예, 사진, 디자인 등 8 개 분야 예술 강사를 학교 수요에 맞춰 배치한다. 예술강사는 초·중·고등학교 정규 교육과정 내 기본교과, 선택교과(고등학교), 창의적 체험활동, 교육과정 외 토요동아리, 초등 돌봄교실 수업을 진행한다. 2019년에는 전국 17 개 시·도 8,481 개교(중복 포함 11,351 개교)에 8 개 분야별 예술강사 5,159 명을 파견 했다. 사업의 수혜대상인 학생 수는 추진실적에 명시하지 않는다.

〈표 5-3〉학교예술강사지원 운영 실적(2019)

\begin{tabular}{c|c|c|c}
\hline 분야 & 학교수 & 강사수 & 수업시수 \\
\hline 국악 & 4,674 & 2,072 & 600,486 \\
\hline 연극 & 1990 & 885 & 244,934 \\
\hline 영화 & 416 & 197 & 48,542 \\
\hline 무용 & 2,195 & 1,095 & 307,526 \\
\hline 만화/애니 & 799 & 364 & 93,414 \\
\hline 공예 & 621 & 278 & 64,538 \\
\hline 사진 & 287 & 98 & 22,212 \\
\hline 디자인 & 369 & 170 & 37,232 \\
\hline 계 & 11,351 & 5,159 & $1,418,884$ \\
\hline
\end{tabular}

자료: 한국문화예술교육진흥원, 「2019 국고 보조사업 실적보고서」

학교예술강사 지원사업의 성과지표는 파견 예술 강사수(사회 포함)으로 수혜대상 인 학생보다는 예술강사의 선발과 배치 중심으로 운영되는 '인력 연계형' 사업으로 볼 수 있다. 
〈표 5-4〉 학교예술강사지원 운영 실적(2016 2020)

\begin{tabular}{|c|c|c|c|c|c|c|c|c|c|}
\hline 성과지표 & 구분 & '16 & '17 & '18 & '19 & '20 & $\begin{array}{l}\text { ‘9목표치 } \\
\text { 산출근거 }\end{array}$ & $\begin{array}{c}\text { 측정산식 } \\
\text { (또는 측정방법) }\end{array}$ & $\begin{array}{c}\text { 자료수집방법 } \\
\text { (또는 자료출처) }\end{array}$ \\
\hline \multirow{3}{*}{$\begin{array}{c}\text { (2) 학교 등 } \\
\text { 파견 예술강사 } \\
\text { 수(명) }\end{array}$} & 목표 & 8,100 & 8,200 & 8,300 & 8,900 & 9,000 & \multirow{3}{*}{$\begin{array}{c}\text { 과거의 실적 및 추세를 } \\
\text { 감안 ‘최근 4년간 } \\
\text { ('16년' } 19 \text { 년) 평균 } \\
\text { 실적치인 } 8,418 \text { 명보다 } \\
\text { 상향된 } 8,900 \text { 명으로 } \\
\text { 목표치 설정 }\end{array}$} & \multirow{3}{*}{$\begin{array}{c}\text { 학교 및 사회 } \\
\text { 예술강사 수 합산 }\end{array}$} & \multirow{3}{*}{$\begin{array}{c}\text { 문화예술교육진 } \\
\text { 흥원 및 지자체 } \\
\text { 사업실적 }\end{array}$} \\
\hline & 실적 & 8,594 & 8,207 & 9,026 & - & - & & & \\
\hline & 달성도 & 106.1 & 100 & 108.7 & - & - & & & \\
\hline
\end{tabular}

\section{(2) 예술꽃씨앗학교 운영}

'예술꽃씨앗학교'는 농산어촌 등 문화소외지역의 전교생 400명 이하 소규모 학교 를 예술꽃 씨앗학교로 지정해 전교생 대상 문화예술교육을 집중 지원하는 사업이 다. 문화소외지역 학생들의 문화예술향유 기회를 확대하고 지역 내 문화예술교육 거점학교로 육성해 지역 문화예술 활성화에 기여하는 것을 목적으로 한다. 2008년 1 기를 시작으로 2020년 11 기를 모집했으며 예산은 3,200백만 원이다. 2020년에 는 15 개교를 신규로 선정해 1 기부터 누적 선정된 학교 수는 총 133 개교이다.

전교생의 문화감수성과 문화소양 증진을 위해 문화예술 분야와 학교 교육과정을 연계한 전교생 대상 문화예술교육 프로그램을 학교별로 최대 4년까지 지원한다. 2019년에는 7 기에서 10 기까지의 초등 35 개교, 중·고등 8 개교, 특수 1 개교, 총 44 개교를 지원했다.

〈표 5-5〉예술꽃 씨앗학교 추진실적(2016 2019)

\begin{tabular}{c|c|c|c|c|c}
\hline 구분 & $\begin{array}{c}\text { 7기 } \\
\text { ('16 선정) }\end{array}$ & $\begin{array}{c}\text { 8기 } \\
\text { ('17 선정) }\end{array}$ & $\begin{array}{c}\text { 9기 } \\
\text { ('18 선정) }\end{array}$ & $\begin{array}{c}10 \text { 기 } \\
\text { ('19 선정) }\end{array}$ & 합계 \\
\hline 지원예산 & 721백만 원* & 450백만 원 & 507백만 원 & 825백만 원 & 2,503백만 원 \\
\hline 학교 수 & 13 개교** & 8 개교 & 8 개교 & 15 개교 & 44개교 \\
\hline 전교생 & 1,844 & 1,012 & 782 & 1,441 & 5,079 명 \\
\hline 교육시간*** & 9,605 & 6,405 & 6,917 & 9,483 & 32,410 \\
\hline 참여인력**** & 109 & 56 & 70 & 97 & 332 명 \\
\hline
\end{tabular}

* 성과공유회 운영비 92백만 원 포함

** 7 기 학교 수의 경우 영춘초 사업 포기에 따라 기존 14 개교 $\rightarrow 13$ 개교로 변경

*** 교별 실적보고서 기준('20. 1. 기준), 교별 연간 평균 737시수 운영

**** 교육강사 및 씨앗가꿈이 수('20. 1. 기준) 
지역별로는 경남이 8 개교로 가장 많고 경기 6 개교, 충북, 전북, 경북 5 개교 순이 다. 분야별로는 음악예술 15 개교, 공연예술 10 개교, 시각예술 8 개교, 통합예술 11 개교로 다양한 분야의 문화예술교육이 진행되고 있음을 알 수 있다.

〈표 5-6〉예술꽃 씨앗학교 지역별, 분야별 운영 현황(2019)

\begin{tabular}{|c|c|c|c|c|c|c|c|c|c|c|c|c|c|c|c|c|c|c|}
\hline 지역 & 서울 & 부산 & 대구 & 광주 & 인천 & 대전 & 울산 & 세종 & 경기 & 강원 & 충북 & 충남 & 전북 & 전남 & 경북 & 경남 & 제주 & 합계 \\
\hline 학교수 & - & 1 & - & - & - & - & - & 1 & 6 & 4 & 5 & 4 & 5 & 4 & 5 & 8 & 1 & 44 \\
\hline \multicolumn{3}{|c|}{ 분야 } & \multicolumn{3}{|c|}{ 음악예술 } & \multicolumn{3}{|c|}{ 공연예술 } & \multicolumn{4}{|c|}{ 시각예술 } & \multicolumn{3}{|c|}{ 통합예술 } & \multicolumn{3}{|c|}{ 합계 } \\
\hline \multicolumn{2}{|c|}{ 학교 수 } & & \multicolumn{3}{|c|}{15} & \multicolumn{3}{|c|}{10} & \multicolumn{3}{|c|}{8} & & \multicolumn{3}{|c|}{11} & \multicolumn{3}{|c|}{44} \\
\hline
\end{tabular}

자료: 한국문화예술교육원, 「2019 국고보조사업 실적보고서

수혜대상은 '전국 400명 이하 초등학교 전교생' 으로 선정학교의 전교생 수를 실 적으로 산출한다. 교육강사 외에 씨앗가꿈이라는 문화 코디네이터 인력을 배치할 수 있으며, 학생들이 수동적으로 수업을 받는 것이 아니라 능동적으로 기획하고 참 여할 수 있는 프로그램을 진행하고자 하는 것이 특징이다. 학생외의 교사 그룹의 문화예술교육에 대한 이해도가 높아지고 학교 현장의 문화예술교육에 대한 공감대 를 형성하는 효과가 있는 것으로 평가하고 있으며, 문화소외지역의 소규모 학교만 을 대상으로 하기 때문에 선별적 복지형 사업의 성격도 갖고 있다.

(3) 유아 문화예술교육 지원

'유아 문화예술교육 지원' 사업은 생애주기 문화예술교육 지원의 일환으로 생애초 기의 맞춤형 문화예술교육을 확대하여 보편적 문화예술교육을 실현하고, 지역의 문 화시설과 자원을 토대로 지역 중심의 유아 문화예술교육 기반을 구축하는 것을 목 적으로 한다. 수혜대상인 유아 기준으로는 정서와 표현력 발달에 기여하고 지역 간 문화예술 수혜격차를 해소하고 문화예술 경험을 확대하는 것이 목표이다. 이외에도 영유아기에 질 높은 문화예술교육 경험을 통해 문화감수성을 증진한다는 목표도 제 시하고 있다. 2016년 시작한 사업으로 2019년부터 지자체로 사업이 이관되었으며 교육진흥원에서는 관리, 컨설팅 등의 업무를 맡고 있다. 2020년 운영 예산은 1,999 백만 원(교육진흥원 299 백만 원, 지자체 1,700 백만 원)이다. 
지역문화시설에서 고유 콘텐츠를 중심으로 누리과정과 차별화된 양질의 유아 문 화예술교육 프로그램을 개발해서 교육·문화적 여건이 취약한 지역의 유아시설에 보 급하는 방식이다. 수혜대상은 전국 유치원, 어린이집 3 5세 유아이며 2019년에는 58 개 프로그램으로 918 개 유아시설에서 20,521 명의 유아가 참여했다. 유아뿐만 아니라 유아 교사 대상의 연수프로그램도 진행해 1,944 명의 유아 교사가 참여했다. 지자체 이관 이후 참여 문화시설은 2018년 10개에서 58개로 수혜유아시설은 243 개로 918 개로 증가했다.

\section{2-2) 사회문화예술교육 활성화}

(1) 사회문화예술교육 지원

'사회문화예술교육 지원'은 사회·문화적 취약계층·지역주민 등에 문화예술의 향 유와 교육 기회를 제공하는 사업이다. 아동·청소년, 노인, 장애인 등의 문화적 소외 계층과 군장병, 재소자 등 특수계층을 대상으로 지속적인 문화예술교육 지원을 통 한 긍정적인 삶의 변화를 추구하고 지역사회 활력을 제고하고 문화 사각지대를 완 화하는 것을 목적으로 한다.

2020년 기준으로 '사회문화예술교육 지원'사업에서는 복지기관 문화예술교육 지 원, 부처 간 협력 문화예술교육 지원, 문화파출소 운영 지원, 직장인 문화예술교육 지원, 노인영상미디어 문화예술교육 지원, 사회적경제 활성화 시범사업 등을 운영 한다. 104) 2020년 예산은 26,571백만 원으로 ‘부처 간 협력 문화예술교육 지원’이 전체 예산의 40.3\%, '복지기관 문화예술교육 지원'이 30.3\%를 차지한다. '복지기관 문화예술교육 지원’은 2004년 아동복지시설 예술강사 지원 사업으로 시작되어 2006년 노인, 장애인으로 대상이 확대되었으며, '부처 간 협력 문화예술교육 지원' 사업은 ‘범 부처 협력 문화예술교육 지원’ 사업으로 2006년부터 군부대, 교정시설을 시작되어 협력부처와 기관이 추가되는 방식으로 확장되었다.

104) 문화소외지역을 찾아가는 농산어촌 이동형 문화예술교육(움직이는 예술정거장)과 고3 수험생 대상 문화 예술교육(학교문화예술교육 지원에 속하지만 사회문화예술교육 지원 예산으로 운영), 문화예술교육 명예 교사는 2019년까지만 진행되었다. 
〈표 5-7〉 사회문화예술교육 지원 예산 구성(2020)

\begin{tabular}{c|c|c}
\hline 사회문화예술교육 지원 & 예산(백만 원) & 비율(\%) \\
\hline 복지기관 문화예술교육 지원(아동, 노인, 장애인) & 8,064 & $30.3 \%$ \\
\hline 부처 간 협력 문화예술교육 지원 & 10,705 & $40.3 \%$ \\
\hline 사회문화예술교육 기반 지원(제도 운영, 연구 등) & 3,735 & $14.1 \%$ \\
\hline $\begin{array}{c}\text { 문화예술교육 모델개발 및 지역확산 } \\
\text { (문화파출소, 노인영상미디어, 직장인, 시범사업 등) }\end{array}$ & 3,036 & $11.4 \%$ \\
\hline 사업관리 & 1,031 & $3.9 \%$ \\
\hline 합계 & 26,571 & $100.0 \%$ \\
\hline
\end{tabular}

자료: 한국문화예술교육진흥원 2020년 예산서

‘복지기관 문화예술교육 지원' 사업과 '부처 간 협력 문화예술교육 지원’ 사업은 취 약계층 대상의 선별적 복지형 사업에 해당한다. 한편, 지역주민을 대상으로 하는 문 화파출소 조성 및 운영, 직장인 문화예술교육 지원(2019년 ), 노인영상미디어 문화 예술교육(2019년 )105) 등은 보편적 복지형 사업이라 할 수 있다. 이중 주민의 주체 성을 강조하고 주민동아리가 운영되는 '문화파출소'와 노인 미디어활동가, 노인영 상문화동호회를 활성화하고자 하는 '노인영상미디어' 사업은 활동 지원형에도 가깝 다. 2020 년에는 문화예술교육분야 사회적경제 활성화 지원사업(250백만 원)이 신 설되는 등 기존에는 취약계층 대상의 사업이 중심이었지만 '모델개발 및 지역확산' 이라는 이름으로 사회의 변화를 반영한 사업과 일반인 대상의 사업을 소규모로 신 설하는 추세이다. 대상기관, 시설과 연계해 사전수요조사를 실시하고 예술강사와 예술교육단체를 선발해 매칭하거나, 운영단체(기관)을 공모하는 방식으로 진행한다.

직접적인 지원대상은 예술강사와 교육운영단체, 시설 등이며 수혜대상은 아동·청 소년, 노인, 장애인, 군 장병, 교정시설 재소자 및 소년원학교 학생, 문화 소외지역 주민 및 일반시민 등으로 광범위하다. 사업 실적은 주로 수혜시설, 프로그램수, 참 여자수 등으로 집계한다. 2019년에는 1,792 개 시설에서 2,732개의 프로그램이 운 영되었으며, 39,456 명이 참여했다. 프로그램 수혜자수와 참여자 만족도, 복지기관 문화예술교육의 예술강사수는 문체부의 사업성과지표에 반영되며, 이는 '사회문화 예술교육 지원'사업 외에도 교육진흥원과 지자체 운영사업을 총괄하여 산출한다.

105) 지역미디어센터 인근에 거주하는 노인을 대상으로 하는 사업이다. 
〈표 5-8〉사회문화예술교육 지원사업 대상별 수혜자수(2019)

\begin{tabular}{c|c}
\hline 대상 & 수혜자수(명) \\
\hline 복지기관 문화예술교육 지원 & 12,523 \\
\hline 아동보호시설 & 2,654 \\
\hline 노인복지관 & 6,199 \\
\hline 장애인복지관 & 3,670 \\
\hline 부처 간 협력 문화예술교육 지원 & 18,260 \\
\hline 지역아동센터 & 10,511 \\
\hline 군부대 & 4,194 \\
\hline 소년원학교 & 321 \\
\hline 교정시설 & 821 \\
\hline 치료감호소 & 151 \\
\hline 학교밖청소년 & 895 \\
\hline 방과후청소년 & 329 \\
\hline 근로자 & 607 \\
\hline 북한이탈주민 & 130 \\
\hline 상이군경 & 301 \\
\hline 농산어촌 이동형 문화예술교육(사업 종료) & 2,461 \\
\hline 노인영상 시범사업 & 227 \\
\hline 직장인 문화예술교육 지원 & 283 \\
\hline 문화파출소 조성 및 운영 & 5,702 \\
\hline 합계 & 39,456 \\
\hline
\end{tabular}

자료: 한국문화예술교육진흥원, 「2019 국고 보조사업 실적보고서」, 정보공개자료-수혜자수,

https://mww.arte.or.kr/disclosure/data/Data_BoardList.do

(2) 문화예술기관 토요문화학교 운영·토요문화학교 예술감상교육

2개 사업 모두 ‘꿈다락 문화학교’라는 사업명으로 운영되며 아동·청소년과 가족 이 참여할 수 있는 학교 밖 주말 문화예술교육 프로그램을 운영·지원하는 사업이다. 주관처는 한국문화예술교육진흥원과 한국문화예술회관연합회이다. 미술관, 박물관, 문화예술회관 등 지역 내 문화기반시설과 공공시설을 활용해 양질의 문화예술 경험 을 제공하여 문화예술 소양을 함양하고 또래 간, 가족 간 문화예술을 통해 소통할 수 있는 여가 문화를 조성하며 일상 속 즐거움을 향유하고 삶의 질을 향상하는 것을 목적으로 한다. 예산은 한국문화예술교육진흥원을 기준으로 2012년 5,000백만 원 으로 사업을 시작해 2013년 3배 이상 증가한 이후 점점 줄어들고 있는 추세이다. 
〈표 5-9〉 꿈다락 토요문화학교 운영 현황(한국문화예술교육진흥원 운영사업 기준, 2012 2019)

\begin{tabular}{c|c|c|c}
\hline 연도 & 프로그램 수 & 참여자 수 & 지원예산 \\
\hline 2012 & 151개 & 9,886 명 & 5,000백만 원 \\
\hline 2013 & 537개 & 29,116 명 & 16,000백만 원 \\
\hline 2014 & 382개 & 23,164명 & 10,637백만 원 \\
\hline 2015 & 305개 & 17,568명 & 12,187백만 원 \\
\hline 2016 & 225개 & 11,290 명 & 7,687백만 원 \\
\hline 2017 & 184개 & 10,375 명 & 6,952 백만 원 \\
\hline 2018 & 168개 & 7,848 명 & 6,750 백만 원 \\
\hline 2019 & 81개 & 3,072 명 & 4,293 백만 원 \\
\hline
\end{tabular}

자료: 한국문화예술교육진흥원, https://www.arte.or.kr/business/society/saturdaycultureschool/intro/index.do

지원대상은 전국 미술관, 박물관, 도서관, 단체, 교육기관 등이며 수혜대상은 아 동·청소년 및 가족이다. 프로그램 분야는 건축, 공예, 놀이활동, 디자인, 무용, 문학, 미술, 사진, 여행, 연극뮤지컬, 영상미디어, 음악, 전통예술 등 문화예술 장르 전반 을 아우른다.

2019년에는 전국에서 100 개의 프로그램을 운영해 아동·청소년 및 가족 9,327 명이 참여했다. 2019년 진행한 만족도 조사에서 전반적인 만족도는 90.5점이었으 며 삶의 질 향상 88.3점, 프로그램 재이용 의향 88.7점, 타인 추천의향 88.4점으로 나타났다. 만족도 조사에서 '문화예술을 잘 이해하고 감동을 느끼게 되었다', '자유 시간에 문화예술활동이 많아졌다', '문화예술에 대한 관심이 많아졌다'와 같은 문항 을 포함하여 문화예술교육이 문화예술향유에 미치는 영향을 파악하려고 시도했 다.106)

106) https://uww.arte.or.kr/business/society/saturdaycultureschool/intro/index.do 
〈표 5-10〉 꿈다락 토요문화학교 추진실적(한국문화예술교육진흥원 운영사업, 2019)

(단위: 개소, 개, 명)

\begin{tabular}{c|c|c|c|c}
\hline 연번 & 구분 & 운영기관 & 프로그램 & 참여자 \\
\hline 1 & 국공립기관 연계 프로그램 & 7 & 11 & 456 \\
\hline 2 & 건축문화 프로그램 & 1 & 17 & 312 \\
\hline 3 & 가족오케스트라·합창 프로그램 & 6 & 6 & 384 \\
\hline 4 & 꼬마작곡가 프로그램 & 9 & 9 & 555 \\
\hline 5 & 어린이는 무엇을 믿는가 프로그램 & 3 & 3 & 62 \\
\hline 6 & 주말예술캠퍼스 프로그램 & 11 & 11 & 592 \\
\hline 7 & 일상의작가 프로그램 & 1 & 13 & 347 \\
\hline 8 & 드림아트랩 4.0 프로그램 & 4 & 11 & 364 \\
\hline 9 & 고3·수험생 문화예술교육 지원 & 1 & 10 & 5,705 \\
\hline 10 & 어린이는 무엇을 믿는가 아카이브전 & 1 & 1 & 200 \\
\hline 11 & (성과확산)기획워크숍 Free Play Fun & 1 & 8 & 350 \\
\hline & 합 계 & 45 & 100 & 9,327 \\
\hline
\end{tabular}

자료: 한국문화예술교육진흥원, 「2019 국고 보조사업 실적보고서」

한편, '토요문화학교 예술감상교육' 사업은 한국문화예술회관연합회에서 청소년 을 대상으로 운영한다. '청소년 문화예술 감상학교'라는 부제로 초·중·고 학생들에 게 학교 밖 문예회관을 기반으로 하는 감상교육 프로그램을 제공해 자발적 문화예 술 향유능력을 제고하고 청소년들의 문화예술 소양 및 정서를 함양하고, 감수성 및 소통능력 제고하는 목적으로 2013년부터 진행했으며 2020년 사업 예산은 1,900 백만 원이다.

문예회관이나 지역의 문화예술 기반을 고려한 음악, 미술, 공연 등 분야별 또는 세부 장르별 예술작품 감상교육이 중심이 된 프로그램이나 융·복합적 프로그램을 선정해 지원한다. ${ }^{107)}$ 문예회관의 공연, 전시 프로그램과 직접적으로 연계되는 문화 예술교육이라는 부분에서 관람형 예술향유활동과의 연계성이 높은 사업이다.

(3) 소외 아동청소년 오케스트라 교육(꿈의 오케스트라)

'꿈의 오케스트라'라는 사업명으로 진행되며 2010년 시작해 10년 이상 진행된 사업으로 2020년 예산은 4,000백만 원이다. 오케스트라 합주교육을 통해 소외 계

107) 한국문화예술회관연합회, https://www.kocaca.or.kr/Pages/Business/Business08.aspx 
층을 포함한 아동.청소년들의 문화예술교육 향유 기회를 확대하고 주체적 문화예술 활동 기회를 제공하고자 한다. 기존의 음악영재 발굴 교육이 아닌 창의성-사회성 함양을 위한 공동체 교육으로 상호학습과 협력을 이끌어내고, 아동·청소년의 건강 한 다면적 성장을 유도하고 나아가 가족과 지역사회의 긍정적 변화에 기여하는 것 을 목적으로 한다.

2020년 기준으로 지원 거점기관 47개, 자립 거점기관(7년차 이후) 23개가 운영 중이다. 수혜대상은 지역 내 취약계층 $60 \%$ 를 포함한 아동청소년으로. "소외 아동청 소년’이 사업명에 포함되어 있지만 완전한 선별적 복지형 사업이라기보다는 일반 아동청소년도 같이 참여하는 사업으로 볼 수 있다.

2019년 사업에는 거점기관 46개소에 음악감독, 교육강사, 코디네이터 등 교육인 력 500명, 수혜인원 2,804명이 참여했다. 특이사항은 문화예술교육 분야에서 총 366명 대상의 아동변화연구를 1단계('16 '18년)연구에 이어 2단계('19 '21년) 연 구를 종단으로 진행 중이라는 점이다.

〈표 5-11〉 소외 아동청소년 오케스트라 교육 운영 현황(2010 2020)

\begin{tabular}{c|c|c|c|c|c|c|c|c|c|c|c}
\hline 연도 구분 & 2010 & 2011 & 2012 & 2013 & 2014 & 2015 & 2016 & 2017 & 2018 & 2019 & 2020 \\
\hline $\begin{array}{c}\text { 지원 } \\
\text { 거점기관 수 }\end{array}$ & 8 개소 & 9 9개소 & 19 개소 & 30 개소 & 35 개소 & 39 개소 & 42 개소 & 43 개소 & 43 개소 & 46 개소 & 47 개소 \\
\hline $\begin{array}{c}\text { 자립 } \\
\text { 거점기관 수 }\end{array}$ & - & - & - & - & - & - & - & 3 3개소 & 11 개소 & 24 개소 & 28 개소 \\
\hline $\begin{array}{c}\text { 아동 수 } \\
\text { (명) }\end{array}$ & 470 & 425 & 979 & 1,521 & 1,920 & 2,111 & 2,421 & 2,206 & 2,439 & 2,804 & 2,800 \\
\hline $\begin{array}{c}\text { 교육 } \\
\text { 인력 수(명) }\end{array}$ & 80 & 98 & 191 & 325 & 365 & 375 & 428 & 420 & 512 & 500 & 500 \\
\hline
\end{tabular}

자료: 한국문화예술교육진흥원, https://www.arte.or.kr/business/society/orchestra/intro/index.do

(4) 문화예술치유 프로그램 지원

'문화예술치유 프로그램 지원'은 심리적 상처를 가진 대상에 특화된 문화예술치 유 프로그램을 지원하여 개인의 심리적 문제를 극복하고 사회적 역할을 회복할 수 있는 계기를 제공하는 것을 목적으로 한다. 2005년 시범사업으로 시작, 2011년 사 업을 중단했으나 2015년 재개했으며 2020년 사업예산은 2,280백만 원이다.

경찰청, 국방부, 법무부 등 6 개 부처와 협력하는 부처 협력형, 문화기반시설과 치 
매안심센터와 협력하는 치매 예방형, 지원 사각지대 대상(감정노동자, 난치병환자 등)의 기획형으로 구분하여 운영한다.

수혜대상은 학교폭력 피·가해 학생, 범죄 피해자, 군대 부적응 병사, 도박 중독자 및 가족, 게임과몰입 대상, 성-가정 폭력 피해자, 감정노동자, 미혼모자 등으로 타 사업에 비해 매우 구체적으로 세분화 되어 있는 것이 특징이다.

지원대상은 문화예술치유 전문 단체이며 2019년에는 114 개 시설에서 120 개 프 로그램이 운영되었으며 예술치료사 등 415 명의 인력과 1,320 명이 프로그램에 참 여했다. 유형별 사업의 효과분석연구, 만족도 조사도 병행해서 진행한다.

〈표 5-12〉 문화예술치유 프로그램 지원 사업 대상 및 추진실적(2019)

\begin{tabular}{|c|c|c|c|c|c|c|c|}
\hline 구분 & $\begin{array}{l}\text { 협력부처/기관 } \\
\text { 및 지원방식 }\end{array}$ & 대상시설 & 지원대상 & $\begin{array}{l}\text { 참여 } \\
\text { 시설 }\end{array}$ & $\begin{array}{l}\text { 프로 } \\
\text { 그램 }\end{array}$ & $\begin{array}{l}\text { 참여 } \\
\text { 인원 } \\
\end{array}$ & $\begin{array}{l}\text { 참여 } \\
\text { 인력 }\end{array}$ \\
\hline \multirow{6}{*}{$\begin{array}{l}\text { 부처/ } \\
\text { 기관 } \\
\text { 협력 }\end{array}$} & 경찰청 & $\begin{array}{c}\text { 경찰서 및 치안센터, } \\
\text { 문화파출소 }\end{array}$ & $\begin{array}{c}\text { 각종 범죄사건 } \\
\text { 발생 지역 거주 주민 }\end{array}$ & 10 & 10 & 104 & 36 \\
\hline & 교육부 & $\begin{array}{l}\text { wee프로젝트 } \\
\text { 관련 시설 }\end{array}$ & 학교 폭력 피·가해 학생 & 24 & 24 & 238 & 67 \\
\hline & 국방부 & 국군병원 등 & 군대부적응 병사 & 12 & 14 & 224 & 42 \\
\hline & 법무부 & 소년원학교 & 학교 부적응 학생 & 10 & 14 & 116 & 47 \\
\hline & $\begin{array}{l}\text { 사행산업통합 } \\
\text { 감독위원회 }\end{array}$ & 한국도박문제관리센터 & 도박중독자 및 가족 & 3 & 3 & 26 & 12 \\
\hline & 여성가족부 & 보호시설 & 성.가정폭력 피해자 & 9 & 9 & 94 & 39 \\
\hline \multirow{10}{*}{ 기획 } & \multirow{10}{*}{$\begin{array}{c}\text { 운영단체의 } \\
\text { 대상/시설 섭외 }\end{array}$} & 병원, 연합회 등 & 난치병환자 및 가족 & 5 & 5 & 69 & 23 \\
\hline & & $\begin{array}{l}\text { 고객대면, 공공서비스 } \\
\text { 영역 등 관련 시설 }\end{array}$ & 감정노동자 & 8 & 8 & 114 & 43 \\
\hline & & 한부모가족복지시설 & 미혼모자 & 2 & 2 & 34 & 10 \\
\hline & & 아동복지(양육)시설 & 가정 밖 아동 & 1 & 1 & 12 & 5 \\
\hline & & 사회복지관 & 발달장애 자녀를 둔 가족 & 1 & 1 & 8 & 4 \\
\hline & & 다문화가족지원센터 & 중도입국 청소년 & 1 & 1 & 10 & 5 \\
\hline & & 여성노숙인 요양시설 & 과거 여성노숙자 & 1 & 1 & 16 & 4 \\
\hline & & 중학교 & 사별가족 청소년 & 1 & 1 & 4 & 4 \\
\hline & & 관련 협회 & 자폐아동을 둔 어머니 & 1 & 1 & 3 & 4 \\
\hline & & 한부모 자조모임 & 한부모 모자 & 1 & 1 & 12 & 4 \\
\hline $\begin{array}{l}\text { 치매 } \\
\text { 예방 }\end{array}$ & \begin{tabular}{|c|} 
문화기반시설- \\
치매안심센터 협력
\end{tabular} & 문화기반시설 & $\begin{array}{l}\text { 경도인지장애 혹은 치매 } \\
\text { 위험이 있는 노인 및 가족 }\end{array}$ & 24 & 24 & 236 & 66 \\
\hline \multicolumn{4}{|c|}{ 총 계 } & 114 & 120 & 1,320 & 415 \\
\hline
\end{tabular}

자료: 한국문화예술교육진흥원, 「2019 국고 보조사업 실적보고서」 
(5) 생애전환 문화예술학교 운영

‘생애전환 문화예술학교 운영'사업은 은퇴로 생애전환기를 맞은 중년세대를 대상 으로 문화예술교육을 지원하여 은퇴 후의 인생을 준비할 수 있는 기회를 제공하는 사업이다. 50 64세의 중년 세대의 문화향유와 여가활동 기회를 확대하고 참여자의 관심사를 반영한 수요자 맞춤형 프로그램을 개발하고 운영해 신중년의 문화예술교 육 참여 장애요인을 제거하는 것을 목적으로 한다. '신중년'이라는 새로운 교육대상 에 초점을 맞춰 2018년부터 시작한 사업이며 2020년 사업예산은 1,000 백만 원으 로 2018년과 2019년의 420백만 원에서 2배 이상 증가했다.

2020년 '생애전환 문화예술교육 지원' 사업은 광역 단위 지역문화예술교육 지원 센터 중 8개 내외, '신중년 문화예술교육 지원' 사업은 기초자치단체에서 5 개 내외의 규모로 진행하며 공모는 지역문화진흥원에서 통합으로 진행했다. 수혜대상은 50 64세 중장년층 은퇴예정자와 퇴직자이다.

2019년에는 시범사업으로 진행되어 문화예술교육 세부 프로그램 23개(프로그램 연구개발 2건)가 운영되었으며 490명이 참여했다. 생애주기형 문화예술교육으로의 전환 기조를 반영한 사업으로 실제 시범사업 운영결과 신중년 대상 문화예술교육 프로그램의 높은 수요와 필요성이 확인된 것으로 나타났다.

〈표 5-13〉'생애전환 문화예술학교 운영'사업 추진실적(2019)

\begin{tabular}{|c|c|c|c|c|c|}
\hline \multicolumn{2}{|c|}{ 구 분 } & 센터명 & 사업명 & 프로그램(개) & 수혜자(명) \\
\hline 1 & \multirow{5}{*}{ 지역센터 } & 경남 & 생애전환 문화예술학교, 쓸만한교(敉) 시즌2 & 5 & 100 \\
\hline 2 & & 대전 & 생애전환 문화예술학교 꽃보다 작가 & 2 & 23 \\
\hline 3 & & 세종 & 생애전환 문화예술학교 & 2 & 35 \\
\hline 4 & & 인천 & 생애전환 문화예술학교 & 8 & 152 \\
\hline 5 & & 충남 & 생애전환 문화예술학교 이짝워뗘 & 3 & 37 \\
\hline 6 & \multirow{4}{*}{\multicolumn{2}{|c|}{$\begin{array}{l}\text { 한국문화예술 } \\
\text { 교육진흥원 }\end{array}$}} & $\begin{array}{c}\text { (상반기) 자연과 함께 한달 살아보기 } \\
\text { (하반기) 품격있는 고난으로 한달 살아보기 }\end{array}$ & 1 & 60 \\
\hline 7 & & & 신중년 관계재형성 문화예술교육 프로그램 연구개발 & 1 & 10 \\
\hline 8 & & & 신중년 디지털에이징 문화예술교육 프로그램 연구개발 & 1 & 10 \\
\hline 9 & & & 결과공유회| & - & 63 \\
\hline \multicolumn{4}{|r|}{ 합 계 } & 23 & 490 \\
\hline
\end{tabular}

자료: 한국문화예술교육진흥원, 「2019 국고 보조사업 실적보고서」 
(6) 예술동아리 교육 지원

'예술동아리 교육 지원'사업은 아마추어 예술동아리 대상 예술교육지원을 통해 지역주민의 자발적인 문화예술활동을 독려하고 예술동아리를 활성화하는 것을 목 적으로 한다. 2018년 시작한 사업으로 문화체육관광부와 지자체 매칭으로 운영하 며 2020년 사업 예산은 2,000백만 원이다. 예술활동 지원에 교육 지원이 접목된 형태로 예술동아리에 분야별로 문화예술강사를 매칭해주거나 동아리에서 지원을 받아 자체 매칭하는 방식으로 지원한다. 2019년 사업에는 10 개의 광역지자체가 참 여했으며, 1,128 개 동아리에서 10,448 명이 참여했으며, 1,038 명의 강사가 매칭되 었다.

〈표 5-14〉 예술동아리 교육 지원 사업 운영 현황(2019)

\begin{tabular}{c|c|c|c|c|c}
\hline 구분 & 운영기관 & 동아리 (개) & 동아리 회원(명) & 강사(명) & 코디 네이터(명) \\
\hline 강원 & 강릉문화원 & 153 & 1,582 & 132 & 13 \\
\hline 경남 & 경남문화예술진흥원 & 19 & 217 & 76 & 7 \\
\hline 광주 & 광주문화재단 & 33 & 330 & 33 & 5 \\
\hline 대구 & 대구문화재단 & 84 & 1,278 & 67 & 12 \\
\hline 부산 & 부산문화재단 & 28 & 300 & 20 & - \\
\hline 세종 & 세종시문화재단 & 55 & 506 & 55 & 10 \\
\hline 인천 & 인천문화재단 & 82 & 800 & 82 & 8 \\
\hline 전북 & 전북문화관광재단 & 57 & 576 & 54 & 13 \\
\hline 충남 & 충남문화재단 & 30 & 359 & 32 & 4 \\
\hline 충북 & 충북문화재단 & 587 & 4,500 & 487 & 29 \\
\hline & 총 계 & 1,128 & 10,448 & 1,038 & 101 \\
\hline
\end{tabular}

자료: https://mww.arte.or.kr/business/society/circles/intro/index.do

(7) 문예회관 문화예술교육 프로그램 지원

'문예회관 문화예술교육 프로그램 지원' 사업은 문예회관에서 문화예술교육 프로 그램을 직접 기획하고 실행해 지역민들의 문화예술 향유 기회를 확대하기 위해 운 영하는 사업이다. 한국문화예술회관연합회의 주관으로 2013년부터 진행되었으며 2020 년 예산은 1,500 백만 원이다. 문예회관의 주 기능 중 하나인 교육기능을 확대 해 문예회관의 활성화에 기여하고, 지역주민들에게 문화예술 활동에 참여 할 수 있 는 기회와 교육을 제공함으로서 문화예술 역량을 강화하고, 문화감수성을 증진하여 
문화예술 애호가의 저변을 확대하고자 하는 목표가 있다. 지역과 문예회관별 특성 을 반영해 차별화 한 체험형 또는 감상형 예술교육프로그램을 공모를 통해 선정해 서 지원한다. 수혜대상은 해당 프로그램을 수강하는 지역주민이다.108) 2019년 운 영실적은 프로그램 수 65개, 참여자수 2,107 명이다.

(8) 창의예술교육랩 지원

2019년 시작한 사업으로 교육진흥원에서 시범사업으로 운영하다 2020년부터 지자체 보조 사업으로 운영하며 예산은 1,100 백만 원이다. 문화예술교육 현장의 프 로그램 심화와 다각화 요구에 부응하고 4차 산업혁명 등에 따른 교육법 변화의 필 요성에 따라, 통합 문화예술교육과 융·복합 문화예술교육 콘텐츠를 개발하고 미래 문화예술교육을 이끌어 갈 젊은 예술교육자를 양성하는 것을 목표로 한다. 지역 문 화자원을 바탕으로 지역 내 문화예술교육 인력, 기관이 협력해 사회변화와 관련한 현장에서 활용 가능한 다양한 양질의 지역형 문화예술교육 콘텐츠를 개발하고 보급 하는 내용이다. 2019년 시범사업에는 부산, 대전, 대구, 강원, 제주 총 5 개 시도가 참여했다.

(9) 문화예술 직업체험 교육 프로그램 지원

2020년 신규사업으로 '기술 입은 문화예술교육'이라는 사업명으로 한국문화예술 회관연합회에서 주관하며 사업 예산은 3,000백만 원이다. 공연예술을 중심으로 한 기술탐구와 예술창작이 융합된 문화예술교육을 통해 청소년의 예술적 상상력과 창 의력을 함양시키고자 하는 사업이다. 문예회관을 기반으로 다양한 직업군에 대한 진로 탐색 기회도 제공해 창의·융합형 미래 인재를 키우고자 한다. 융복합프로그램 운영이 가능한 단체와 문예회관의 매칭형과, 문예회관 기획형으로 구분하여 공모를 진행하며 수혜대상은 초중고 재학생 및 해당 연령대의 청소년이다.109)

108) 한국문화예술회관연합회, https://uww.kocaca.or.kr/Pages/Business/Business07.aspx

109) 한국문화예술회관연합회, https://uww.kocaca.or.kr/Pages/Business/Business27.aspx 


\section{2-3) 지역문화예술교육 지원}

(1) 지역문화예술교육 기반구축

문체부의 지자체 보조 사업으로 17 개 광역문화예술교육지원센터에서 직접 추진 하며 2020년 예산은 총 13,045 백만 원이다. 지역밀착형 문화예술교육을 통해 지역 주민의 문화예술 향유를 제고하고 지역의 문화자원과 환경 특성을 반영한 다양한 문화예술교육 기획을 통해 지역 주민의 문화예술 소양 함양과 건강한 여가문화 조 성에 기여하고자 한다. '꿈다락 토요문화학교(지역)'와 '지역 특성화 문화예술교육 프로그램' 으로 구성된다. 공모 유형은 광역지자체별로 자유롭게 구성하여 운영한다.

〈표 5-15〉 지역문화예술교육 기반구축 사업 구성-경기문화예술교육지원센터(2020)

\begin{tabular}{|c|c|c|c|c|c|}
\hline & 구분 & 공모유형 & 지원내용 & 교육대상 & 지원한도 \\
\hline \multirow{5}{*}{$\begin{array}{l}\text { 지역 } \\
\text { 문화 } \\
\text { 예술 } \\
\text { 교육 } \\
\text { 기반 } \\
\text { 구축 }\end{array}$} & \multirow{3}{*}{$\begin{array}{c}\text { 꿈다락 } \\
\text { 토요문화학교 }\end{array}$} & 일반공모 & $\begin{array}{c}\text { 주말 문화예술교육 프로그램 } \\
\text { 운영 지원 }\end{array}$ & \multirow{3}{*}{$\begin{array}{c}\text { 학령기 어린이, } \\
\text { 청소년 및 } \\
\text { 그 가족 }\end{array}$} & $\begin{array}{c}\text { 최고 } \\
\text { 2천만 원 }\end{array}$ \\
\hline & & $\begin{array}{l}\text { 기획공모 } \\
\text { (연구형) } \\
\end{array}$ & 경력단체 프로그램 개발 지원 & & $\begin{array}{c}\text { 정액 } \\
5 \text { 백만 원 } \\
\end{array}$ \\
\hline & & $\begin{array}{l}\text { 기획공모 } \\
\text { (성장형) }\end{array}$ & 진입단체 성장 지원 & & $\begin{array}{c}\text { 정액 } \\
5 \text { 백만 원 }\end{array}$ \\
\hline & \multirow{2}{*}{\begin{tabular}{|c|} 
지역특성화 \\
문화예술교육
\end{tabular}} & 일반공모 & $\begin{array}{c}\text { 지역 밀착형 문화예술교육 } \\
\text { 프로그램 운영 지원 }\end{array}$ & 성인 & $\begin{array}{c}\text { 최고 } \\
\text { 2천만 원 }\end{array}$ \\
\hline & & $\begin{array}{l}\text { 기획공모 } \\
\text { (거점지원) }\end{array}$ & $\begin{array}{l}\text { 지역 거점 문화예술교육 } \\
\text { 공간 운영 지원 }\end{array}$ & \begin{tabular}{|c} 
지역주민 \\
(연령제한 없음)
\end{tabular} & $\begin{array}{c}\text { 정액 } \\
\text { 3천5백만 원 }\end{array}$ \\
\hline
\end{tabular}

자료: 경기문화재단 지원공고, https://mww.ggcf.or.kr/pages/board/view.asp?MU_IDX=18\&BOARD=500\& BOARD_CATE=\&BOARD_IDX=14551\&pageStatus=V\&searchBoard $=500$

지원대상은 지역 내 문화예술교육 프로그램 기획이 가능한 문화예술 기관과 단체 이며 공모를 통해 선정한다. 수혜대상은 학령기 아동·청소년과 가족(꿈다락), 성인, 지역주민(지특)이다. 보편적 복지형 사업으로 일반인 대상의 문화예술교육은 지역 특성화 문화예술교육 사업을 운영하는 광역 단위에서 더 광범위하게 이뤄지고 있다 고 볼 수 있다.

(2) 문화예술교육전용시설 지원

'문화예술교육전용시설 지원’사업은 ‘꿈꾸는 예술터'라는 사업명으로 운영되며 2020년 사업 예산은 5,200백만 원이다. 지역 생활권 단위 유휴공간을 활용해 지속 
가능한 지역문화예술교육 플랫폼을 마련하고 지역 문화예술교육의 선순환 생태계 를 조성하며 지역 아동·청소년과 주민이 예술(교육)가와 함께 다양한 양질의 문화예 술교육 프로그램을 체험하고 창작활동을 할 수 있는 창조적인 교육 공간을 조성하 는 것을 목적으로 한다. 2020년에는 충북 청주, 강원 강릉, 경남 밀양, 전북 장수, 부산 북구의 5 개소를 선정했으며, 2018년 시범사업으로 선정된 2개소 중 전북 전 주(팔복예술공장)는 작년 10 월 개소했으며 경기 성남은 2020년 개소할 예정이다.

\section{2-4) 전문인력 지원}

(1) 문화예술교육 전문인력 양성

'문화예술 전문인력 양성' 사업에서는 예술강사, 기획자 등 문화예술교육 전문인 력과 관계자를 대상으로 연수 프로그램을 운영한다. 2020년 사업 예산은 1,900 백 만 원으로 교육진흥원에서 직접 운영하며 예술가의 직업역량을 강화하고 수요자 맞 춤형 문화예술교육의 질적 제고를 위한 문화예술교육 전문인력의 역량제고 연수와 활동을 지원한다.

사업 진행명은 ‘아르떼 아카데미’이며 현장 활동에 필요한 실무교육과 문화예술 교육 전문성을 높이는 단계별 연수, 온라인 연수, 자율 연수로 구성된다. 수혜대상 은 예술강사, 문화예술교육사, 교원, 기획자, 행정인력, 예비 인력 등이다. 문화예술 교육 및 매개 인력을 양성하고 전문성과 역량을 강화하는 기반형 사업으로 볼 수 있다.

(2) 문화예술교육사 인턴십 지원

2019년 시작된 신규 사업으로 16개 광역지자체(세종 제외)에서 진행하며 2020 년 사업 예산은 2,000 백만 원이다. 청년 문화예술교육사들이 예술현장에서 요구되 는 프로그램 기획과 운영 등 실무 경험을 쌍을 수 있는 기회를 제공하는 사업이다. 수혜대상은 문화예술교육 자격증 소지자(나이 및 경력 제한 있음)이며 지역 문화시 설에서 근무하며 6 10개월 동안 인건비를 지원 받고 문화예술교육 프로그램을 기 획하고 운영한다. 청년 문화예술교육사를 문화시설에 배치해 프로그램을 운영함으 로써 지역주민의 문화예술 향유 기회를 확대하는 인력 연계형 사업에 가깝다. 2020 년에는 102 개 문화시설에서 각 1 명씩 102 명의 문화예술교육사가 근무한다. 
〈표 5-16〉 문화예술교육사 인턴십 지원 지역별 운영안(2020)

\begin{tabular}{c|c|c|c}
\hline 지역 & 문화시설/문화예술교육사 수 & 지역 & 문화시설/문화예술교육사 수 \\
\hline 서울 & 6개소 6명 & 강원 & 6개소 6명 \\
\hline 부산 & 7개소 7명 & 충북 & 7개소 7명 \\
\hline 대구 & 7개소 7명 & 충남 & 7개소 7명 \\
\hline 인천 & 7개소 7명 & 전북 & 8개소 8명 \\
\hline 광주 & 7개소 7명 & 전남 & 6개소 6명 \\
\hline 대전 & 5개소 5명 & 경북 & 7개소 7명 \\
\hline 울산 & 6개소 6명 & 경남 & 7개소 7명 \\
\hline 경기 & 6개소 6명 & 제주 \\
\hline 총계 & \multicolumn{3}{|c}{ 3개소 3매송 102 명 } \\
\hline
\end{tabular}

자료: 한국문화예술교육진흥원, https://mww.arte.or.kr/business/society/cultureartInternship/intro/index.do 


\begin{tabular}{|c|c|c|c|c|c|c|c|c|}
\hline 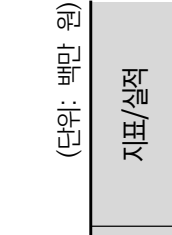 & 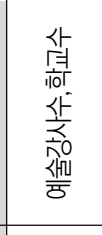 & 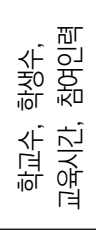 & 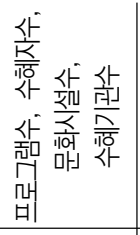 & 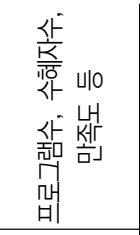 & 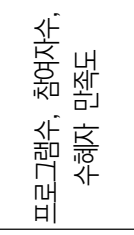 & 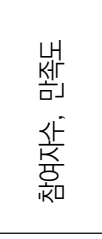 & 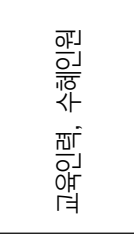 & 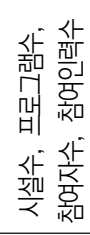 \\
\hline 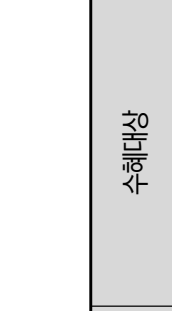 & 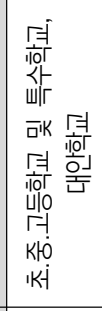 & 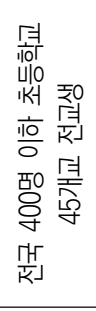 & 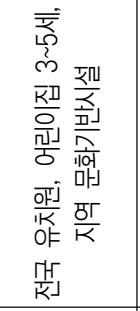 & 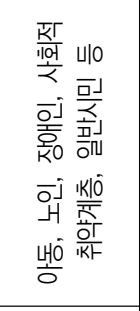 & 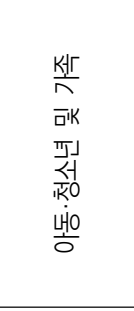 & 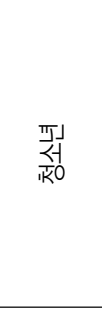 & 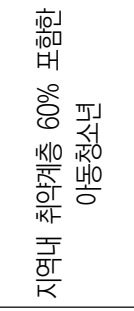 & 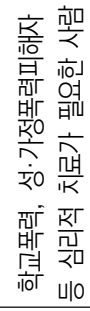 \\
\hline $\begin{array}{l}\text { 자 } \\
\text { 마 }\end{array}$ & 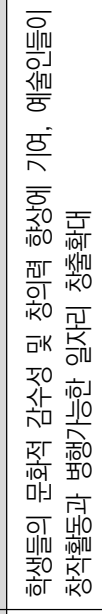 & 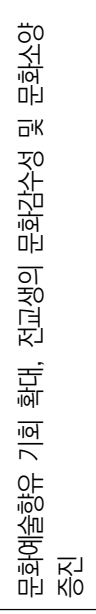 & 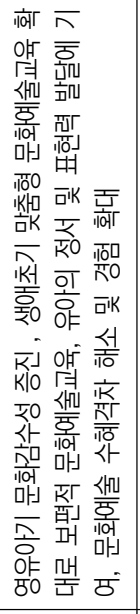 & 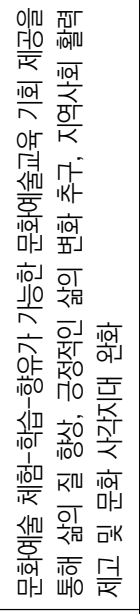 & 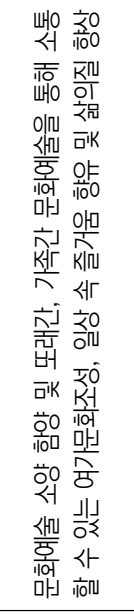 & 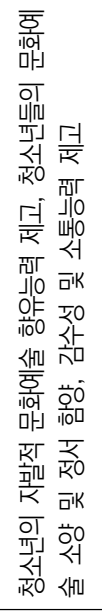 & 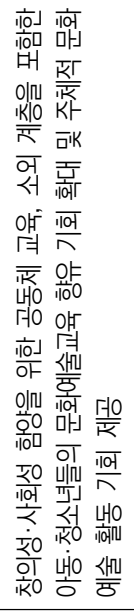 & 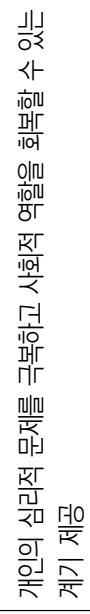 \\
\hline$\frac{\grave{2}}{\bar{\delta}}$ & 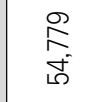 & 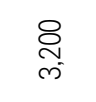 & $\stackrel{\text { S্ }}{=}$ & 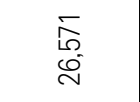 & 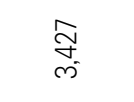 & \& & $\underset{\forall}{8}$ & $\begin{array}{l}\stackrel{D}{\sim} \\
\underset{\sim}{v}\end{array}$ \\
\hline $\begin{array}{l}\frac{\bar{y}\rfloor}{\bar{n}} \\
\text { 이 } \\
\text { 아 }\end{array}$ & 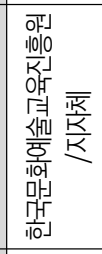 & 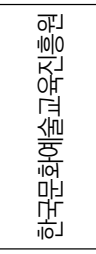 & 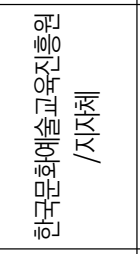 & 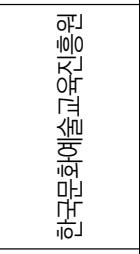 & 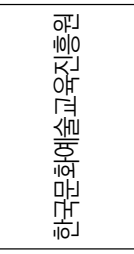 & 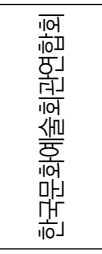 & 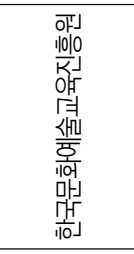 & 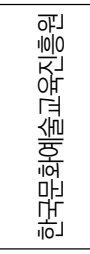 \\
\hline 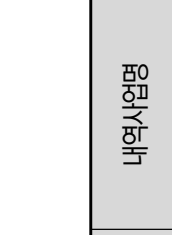 & 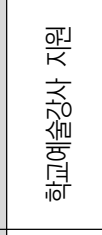 & 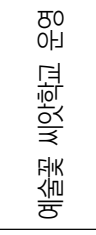 & 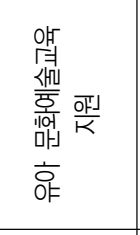 & 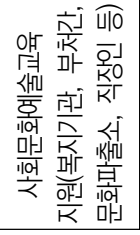 & 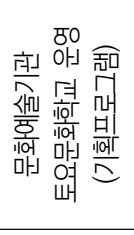 & 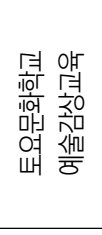 & 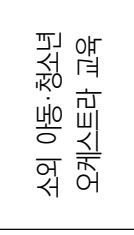 & 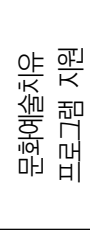 \\
\hline 맥 & \multicolumn{3}{|c|}{$\frac{\text { 뎐 }}{100}$} & \multicolumn{5}{|c|}{$\frac{\text { 柇 }}{\chi}$} \\
\hline 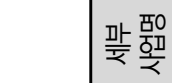 & \multicolumn{8}{|c|}{ 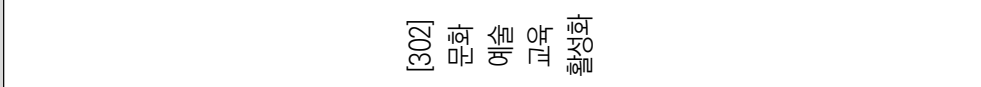 } \\
\hline
\end{tabular}




\begin{tabular}{|c|c|c|c|c|c|c|c|c|c|}
\hline $\begin{array}{l}\frac{\mathrm{E} \Gamma}{\mathrm{K}} \\
\frac{\mathrm{MU}}{\mathrm{K}} \\
\mathrm{k}\end{array}$ & 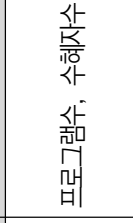 & & 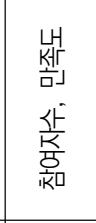 & & 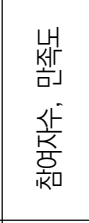 & 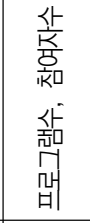 & & & 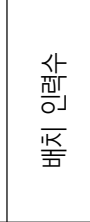 \\
\hline 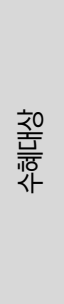 & 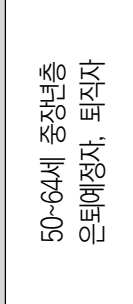 & $\begin{array}{l}\overline{\bar{a}} \\
\frac{k}{K \Gamma} \\
\frac{\mathrm{B}}{\mathrm{K}}\end{array}$ & 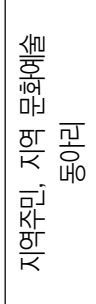 & 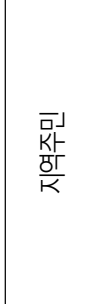 & 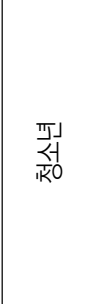 & $\begin{array}{l}\overline{\vec{a}\lrcorner} \\
\frac{\mathrm{k} \vdash}{\mathrm{B}}\end{array}$ & $\begin{array}{l}\overline{\vec{a}} \\
\mathrm{k} \vdash \\
\frac{\mathrm{B}}{\mathrm{K}}\end{array}$ & 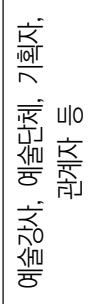 & 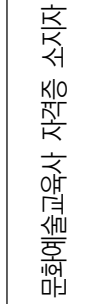 \\
\hline $\begin{array}{l}\text { 丝 } \\
\text { ㄷ }\end{array}$ & 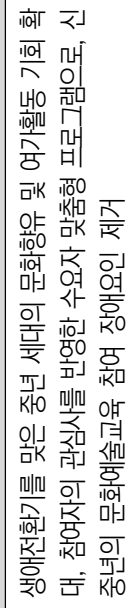 & 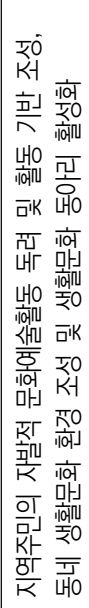 & 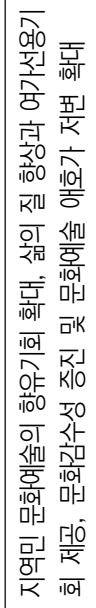 & 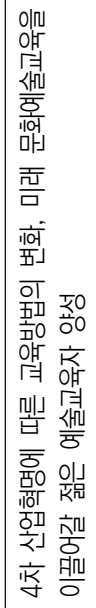 & 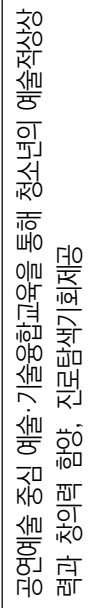 & 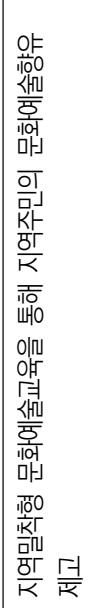 & 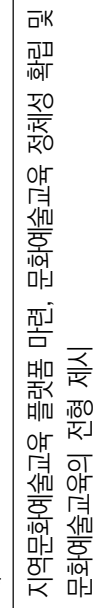 & 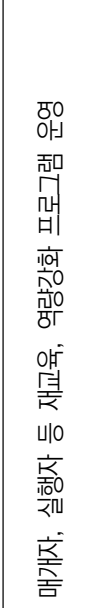 & 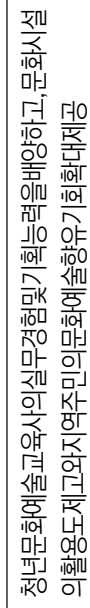 \\
\hline$\frac{\grave{\nwarrow}}{\bar{\delta}}$ & 8 & ষ্ণ & $\stackrel{8}{8}$ & $\stackrel{8}{\stackrel{0}{=}}$ & $\begin{array}{l}8 \\
\text { m. }\end{array}$ & 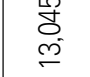 & $\begin{array}{l}\stackrel{\mathrm{N}}{8} \\
\text { ద' }\end{array}$ & ৪্. & $\underset{\text { i }}{8}$ \\
\hline $\begin{array}{l}\frac{\bar{y}\rfloor}{\bar{L}} \\
\text { 어 } \\
\text { 이 }\end{array}$ & 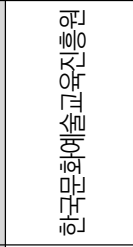 & 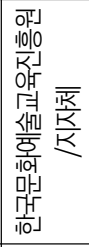 & 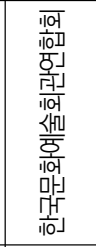 & 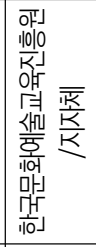 & 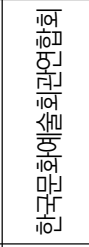 & 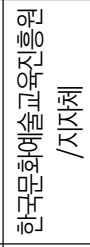 & 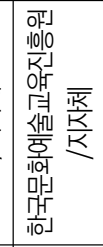 & 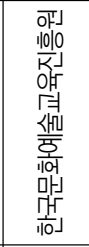 & 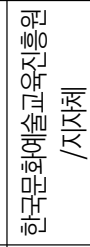 \\
\hline 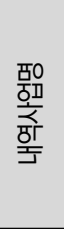 & 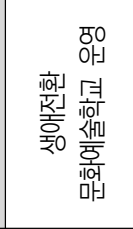 & 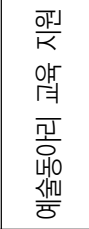 & 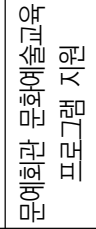 & 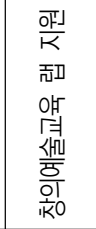 & 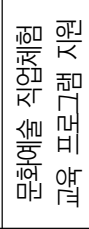 & 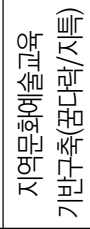 & 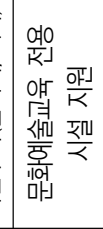 & 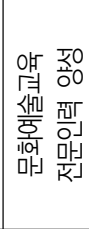 & 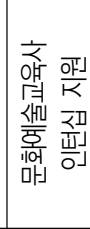 \\
\hline 만 & & & & & & \multicolumn{2}{|c|}{$\frac{\delta \Gamma}{K}$} & \multicolumn{2}{|c|}{$\frac{\mathrm{d} \Gamma}{\mathrm{d} \Gamma} \frac{\mathrm{oF}\lrcorner}{\mathrm{K}}$} \\
\hline
\end{tabular}




\section{나. 일반회계 지역문화정책관}

1) 박물관 정책 활성화: 국민문화향유권 확대

(1) 국·공립 문화시설 개관시간 연장

문체부에서 ‘국민문화권향유 확대' 예산으로 직접 진행하는 사업이며 평일 낮 시 간대 문화시설 이용이 어려운 이용자들에게 박물관·도서관·미술관 등의 이용 시간 을 야간시간까지 연장해 문화서비스를 제공함으로써 대국민 문화 향유권을 증대하 고 관련분야 전문 인력 일자리를 창출하는 것을 목적으로 한다. 전체 예산은 23,208 백만 원이며, 지자체 보조로 진행하는 '공공도서관 개관시간 연장 지원' 예 산이 19,895 백만 원으로 가장 많은 비중을 차지한다. '공공도서관 개관시간 연장 지원'은 2006년 시범사업 이후 2008년 1월부터 전국 117 개 도서관에서 참여했으 며, 이용자 증가와 함께 2016년 483개, 2017년 512개, 2018년 525개로 확대되는 추세이다. 국립박물관과 국립현대미술관은 2007년부터 야간개장을 하고 있다.

지원대상은 공공도서관, 국립박물관, 국립미술관이며 수혜대상은 해당 시설을 이 용하는 일반 국민이다. 성과지표는 야간 이용자수로 잡고 있으며 2018년 기준으로 약 380,000 명이 이용한 것으로 집계되었다. 관련 일자리 창출수도 실적으로 집계 한다. 국민들의 문화향유 욕구 해소에 기여하면서 야간 운영을 위한 인력을 채용함 으로서 일자리 창출에도 기여하는 것으로 평가된다.

〈표 5-18〉 국·공립 문화시설 개관시간 연장 사업 성과지표(2016 2020)

\begin{tabular}{|c|c|c|c|c|c|c|c|c|}
\hline 성과지표 & 구분 & '16 & '17 & '18 & '19 & '20 & $\begin{array}{c}\text { 측정산식 } \\
\text { (또는 측정방법) }\end{array}$ & $\begin{array}{l}\text { 자료수집방법 } \\
\text { (또는 자료출처) }\end{array}$ \\
\hline \multirow{3}{*}{$\begin{array}{c}\text { 국립 문화시설 } \\
\text { (박물관·미술관. } \\
\text { 도서관) 야간 } \\
\text { 이용자 수(천명) }\end{array}$} & 목표 & 395 & 396 & 471 & 404 & - & \multirow{3}{*}{$\begin{array}{c}\text { 국립박물관-미술관 } \\
\text { 국립중앙도서관 } \\
\text { 야간 이용자 수 } \\
\text { 집계 }\end{array}$} & \multirow{3}{*}{$\begin{array}{l}\text { 이용자 수 } \\
\text { 집계자료 }\end{array}$} \\
\hline & 실적 & 358 & 462 & 380 & - & - & & \\
\hline & 달성도 & 90.6 & 117 & 80.7 & - & - & & \\
\hline
\end{tabular}

(2) 휴관없는 국립박물관·미술관 운영

문체부 소속 국립박물관-미술관을 주 7일 개관함으로써 국민문화 향유기회를 확 대하고 관련 일자리 창출에 기여하는 것을 목적으로 한다. 전체 예산은 6,195 백만 원으로 국립중앙박물관(서울 본관 및 소속 지방 3 개관: 경주·광주·전주) 국립민속박 
물관, 대한민국역사박물관, 국립한글박물관, 국립현대미술관(서울관)이 해당되며, 휴관일 근무 인력의 인건비와 프로그램 운영비를 지원한다. 휴관 없는 운영과 더불 어 다양한 교육·문화프로그램을 개발하여 내·외국인 관람객 추가 유치에도 도움을 얻고자 한다. 성과지표는 기존 휴관일 관람객수로, 2018년 기준 실적은 기존 휴관 일 관람인원 905,202명이며 일자리창출은 144 명이다.

〈표 5-19〉 국·공립 문화시설 개관시간 연장 사업 성과지표(2016 2020)

\begin{tabular}{c|c|c|c|c|c|c|c|c|c}
\hline 성과지표 & 구분 & '16 & '17 & '18 & '19 & '20 & $\begin{array}{c}\text { '19목표치 } \\
\text { 산출근거 }\end{array}$ & $\begin{array}{c}\text { 측정산식 } \\
\text { (또는 측정방법) }\end{array}$ & $\begin{array}{c}\text { 자료수집방법 } \\
\text { (또는 자료출처) }\end{array}$ \\
\hline $\begin{array}{c}\text { 휴관 없는 } \\
\begin{array}{c}\text { 국립박물관·미술관 } \\
\text { 기존 휴관일 } \\
\text { 관람객수(천명) }\end{array}\end{array}$ & 목표 & - & 신규 & 158 & - & - & & $\begin{array}{c}\text { 주7일제 시행성덕 } \\
\text { 곡립박물관·미술관 } \\
\text { 기존 휴관일* } \\
\text { 관람객 수 집계 }\end{array}$ & $\begin{array}{c}\text { 이용자 수 } \\
\text { 집계자료 }\end{array}$ \\
\hline
\end{tabular}

\section{국공립 박물관·미술관 무료관람정책110)}

- 국민 문화향수 기회 확대를 목적으로 2008년 5월 12월 국립박물관.미술관 무료관람 시범 시행

- 2018년 총람 기준 박물관 전체의 평균 $44 \%$, 미술관 전체의 평균 $45.1 \%$ 가 무료관람정책을 시행중임

- 2018년 기준 박물관·미술관 수 증가, 박물관·미술관의 사회적 기능에 대한 논의 확대, 국민여가활동 규모 확대 등 사회문화적 환경 변화와 관련된 정책 운영 재점검이 필요한 시점

- 대국민 대상 조사 결과 $(1,000$ 명) 무료관람제도가 방문에 대한 관심을 높이는데 기여한다는 의견이 $35.3 \%$ 로 가장 높았으며, 방문빈도를 높이는데 기여한다는 의견 $33.3 \%$, 문화활동 선택 시 상대적 우 위(21.8\%), 큰 영향 없다는 의견은 가장 낮게 나타남

- 정부의 국립 박물관 미술관 대상 상설전시 무료관람제도가 지속되어야 한다는 응답은 $93.2 \%$ 임

- 정책 목표였던 '국민문화향유 기회 확대' 및 '소외계층 접근성 개선'에 대한 긍정적인 평가를 내릴 수 있고 방문 의향 및 방문 동기에 긍정적인 영향을 미쳐, 간접적 형태의 방문 유발 효과가 있음

- 문화복지가 아닌 문화향유의 관점, 소외계층을 위한 정책에서 포용적인 관람 문화형성을 위해 '관람정 책'으로 정책 모델을 재설계해야 한다는 의견

자료: 연구원 내부자료

(3) 국·공립 문화시설 문화가 있는 주말 프로그램 운영

지역 생활기반의 도서관과 박물관의 특색을 고려한 문화프로그램을 구성해 지역 주민들의 문화향유기회를 확대하고, 자발적이고 자생적인 문화예술공동체 협력을 통해 지역민의 지속적 문화체험 기회를 확대하는 것을 목적으로 하는 사업이다. 2020년 사업 예산은 720백만 원으로 '국·공립 문화시설 문화가 있는 주말 프로그 램 운영'(120백만 원)과 ‘도서관·박물관 1관 1단 사업'(600백만 원)으로 구성된다.

110) 문체부 예산 항목으로 분류되어 있지 않으나 주요 향유 정책 중 하나로 추진되고 있어 별도로 소개한다. 
2018년 기준 국립지방박물관 13 개관에서 839회의 주말 문화예술프로그램을 운 영해 233,684 명이 참가했다. '도서관·박물관 1 관 1 단 사업'을 통해서는 지역주민 이 쉽게 접근할 수 있는 도서관·박물관 공간을 활용해 문화예술 활동에 관심이 많거 나 재능 있는 지역 주민들이 직접 참여할 수 있도록 문화예술 커뮤니티(동호회)를 구성하고 공연과 전시를 할 수 있도록 지원한다. 2016년부터 시작된 사업으로 2018년에는 15 개 지역 70개관이 참여했으며, 국립박물관에서는 66회 프로그램을 운영해 8,144 명이 참가했다. 교육 지원과 활동 지원이 결합된 사업으로 볼 수 있다.

〈표 5-20〉 '박물관 정책 활성화’ 중 예술향유 지원사업(2020)

\begin{tabular}{|c|c|c|c|c|c|c|}
\hline \multirow{2}{*}{$\begin{array}{c}\text { 세부 } \\
\text { 사업명 }\end{array}$} & \multicolumn{6}{|r|}{ (단위: 백만 원) } \\
\hline & 내역사업명 & 운영기관 & 예산 & 목적 & $\begin{array}{l}\text { 수혜 } \\
\text { 대상 }\end{array}$ & 지표/실적 \\
\hline \multirow{3}{*}{$\begin{array}{l}\text { [301] } \\
\text { 국민문화 } \\
\text { 향유권 } \\
\text { 확대 }\end{array}$} & $\begin{array}{l}\text { 국·공립 문화시설 } \\
\text { 개관시간 연장 }\end{array}$ & $\begin{array}{l}\text { 문화체육 } \\
\text { 관광부 }\end{array}$ & 23,208 & $\begin{array}{c}\text { 대국민 문화 향유권 증대, } \\
\text { 관련분야 전문인력 } \\
\text { 일자리 창출 }\end{array}$ & $\begin{array}{l}\text { 일반 } \\
\text { 국민 }\end{array}$ & 야간 이용자수 \\
\hline & $\begin{array}{c}\text { 휴관없는 } \\
\text { 국립박물관·미술관 운영 } \\
\end{array}$ & $\begin{array}{l}\text { 문화체육 } \\
\text { 관광부 }\end{array}$ & 6,195 & $\begin{array}{l}\text { 국민문화 향유기회 확대, } \\
\text { 관련 일자리 창출 }\end{array}$ & $\begin{array}{l}\text { 일반 } \\
\text { 국민 }\end{array}$ & $\begin{array}{l}\text { 기존휴관일 } \\
\text { 관람객수 }\end{array}$ \\
\hline & $\begin{array}{l}\text { 국·공립 문화시설 문화가 } \\
\text { 있는 주말 프로그램 운영 }\end{array}$ & $\begin{array}{l}\text { 문화체육 } \\
\text { 관광부 }\end{array}$ & 720 & $\begin{array}{c}\text { 지역민의 지속적 문화체험 } \\
\text { 기회 제공 }\end{array}$ & 전국민 & 참여자수 \\
\hline
\end{tabular}

2) 지역문화 진흥: 지역문화 진흥

(1) 생활문화 활성화: 생활문화센터 활성화 지원

'생활문화센터 활성화 지원'사업은 지역주민을 위해 조성한 맞춤형 문화공간이 활발히 운영될 수 있도록 지원해, 지역주민의 문화향유 기회 확대와 중앙과 지역 간 문화격차 해소, 지역의 생활문화 활동 거점 형성의 계기를 마련하고자 하는 사업 이다. 지역문화진흥원에서 주관하며 2020년 예산은 650백만 원이다. 생활문화센터 는 문화예술활동을 하고자 하는 지역주민이라면 누구나 자유롭게 이용할 수 있는 생활문화공간을 말하며, 연습·발표 공간, 주민 커뮤니티 공간, 북까페, 공연장 등으 로 구성된다. 생활문화센터 조성사업은 2014년부터 시작되었으며, 현재 전국에 132 개소가 운영중이며 59개소가 조성중이다(2020년 5월 기준). 사업내용은 공간 조성 컨설팅 지원, 프로그램 지원, 운영자 역량강화 및 네트워킹 지원, 연구 및 아카 이빙 지원으로 구성된다. 
(2) 생활문화 활성화: 문화자원봉사활성화

'문화자원봉사활성화’사업은 문화자원봉사를 통한 문화 복지 기반 강화 및 문화 향유 기회 확대를 목적으로 한다. 한국문화원연합회에서 '문화품앗e'111) 웹사이트 를 운영하며 활동처와 봉사자를 연결해주는 역할을 한다. '문화품앗e'는 문체부의 문화체육자원봉사 활성화 정책의 일환으로 만들어진 문화체육자원봉사의 수요-공 급 매칭시스템이다. 전 연령대의 시민이 회원으로 가입할 수 있으며 가입자수는 2019 년 기준 58,380 명, 활동처는 1,658 곳이다. '꿈나눔 문화봉사단'을 통해 지역 별 맞춤형 문화자원봉사 대표 프로그램을 개발(10개, 8천만 원)하고 운영한다. 성과 지표는 매칭수로 잡고 있으며, 2019년 기준 매칭수는 총 12,030건이었다(한국문화 원연합회 내부자료)

(3) 실버문화페스티벌

실버문화페스티벌은 2015년 시작되었으며 한국문화원연합회에서 주관하며 2020년 사업예산은 850백만 원이다. 아마추어 예술가로 활동하는 어르신들의 문 화생활 참여 기회를 확대하고 어르신들의 건강한 여가활동과 문화향유 증진을 통한 삶의 질 향상을 목표로 한다. 전체 프로그램은 샤이니스타를 찾아라(본선 25개 팀 규모), 어른이 행복무대(40개 프로그램), 문화나눔 한마당으로 구분되며 어르신들이 양악, 국악, 무용, 연극 등 분야에서 모든 연령대의 관람객을 대상으로 노래, 악기연 주, 춤, 연기 등의 실연을 하거나 체험행사 등에 참여한다. 112) 2019년 행사는 국립 중앙박물관 극장 용(샤이니스타를 찾아라)과 서울어린이대공원 일대에서 열렸다. 전국의 60세 이상 어르신으로 구성된 문화단체, 동아리, 개인 단위가 참가할 수 있 으며, 직접지원 대상은 어르신 동아리의 소속 기관(문화원, 문화의집, 노인종합복지 관) 등이다.

111) 문화품앗e 웹사이트, https://csv.culture.go.kr/frt/main.do

112) 2019 실버문화페스티벌 웹사이트, http://www.silverfestival.co.kr 


\section{3) 지역문화 진흥: 어르신 문화프로그램 운영}

‘어르신 문화프로그램 운영'113)사업은 2005년 ‘땡땡땡! 실버문화학교'라는 명칭 의 시범사업으로 시작되었다. 2008년 '지방문화원 어르신문화학교'로 사업명이 변 경되고 2009년 재원이 복권기금에서 국고보조금으로 전환되었으며 2014년부터 '어르신 문화프로그램'으로 운영하고 있다. '어르신문화예술교육 지원', '어르신 문 화예술동아리 지원', '어르신과 청년 협력프로그램', '찾아가는 문화로 청춘' 4개의 프로그램으로 구성되어 있으며 한국문화원연합회에서 주관한다. 2020년 예산은 2,773백만 원으로 2019년 예산(3,273백만 원)대비 감소했다.

〈표 5-21〉 어르신 문화프로그램 운영 사업 구성(2020)

\begin{tabular}{|c|c|c|}
\hline 단위사업명 & 주요내용 & 지원대상 \\
\hline 어르신문화예술교육 지원 & 문화예술교육을 통한 활기찬 노년 생활의 시작 & \multirow{4}{*}{$\begin{array}{l}\text { 문화시설 및 } \\
\text { 문화예술단체 }\end{array}$} \\
\hline 어르신문화예술동아리 지원 & 문화예술동아리 활동을 통한 즐거운 경험의 시작 & \\
\hline 찾아가는 문화로 청춘 & 야외에서 펼쳐지는 아마추어 어르신들의 문화예술 공연 & \\
\hline 어르신\&협력프로젝트 & 문화예술을 매개로 어르신과 타 세대 간의 생활 속 관계 맺기 & \\
\hline
\end{tabular}

어르신들에게 문화예술을 접할 수 있는 기회를 제공하여 적극적이고 주체적인 문 화예술 활동을 통해 개인적, 사회적, 성취감을 추구할 수 있도록 지원하는 것을 목 표로 한다. 사회적 소속감과 안정감을 주는 어르신들의 동아리 활동을 지원하고 공 연 봉사활동을 통해 지역사회 공헌활동으로 연계하고자 한다. 동아리는 보통 10 명 내외로 구성되며 접근 장벽이 낮고 비용 부담이 적은 민요나 공예 분야 동아리가 많다. 야외 공연으로 진행되는 '찾아가는 문화로 청춘'은 어르신 공연자와 관람자 모두 일상생활 속에서 문화예술을 향유할 기회를 제공한다. 기존의 전시장, 공연장 을 벗어나 진행되기 때문에 탈 장소성이 강하다. 수혜대상은 60세 이상 전 국민이 며, 성과 지표는 참여자의 만족도로 측정한다. 2019년 사업에는 258개 시설에서 311 개 프로그램(교육164개, 동아리89개, 찾아가는 34개, 어르신\&협력 24개)에 10,039 명의 어르신이 참여했으며, 어르신 대상 종합 만족도는 89.5점으로 측정되 었다. 사업의 성과로 프로그램에 참여한 어르신의 주중 평균 여가시간은 4시간 59

113) http://seniorculture.or.kr/ 
분으로, 일반 어르신보다 30 분 정도 높게 나타났다. 삶의 질 측면에서 주관적인 심 리상태를 포괄적으로 파악하는 행복온도는 일반 어르신 $\left(67.4^{\circ} \mathrm{C}\right)$ 보다 $12.8^{\circ} \mathrm{C}$ 높은 $80.2^{\circ} \mathrm{C}$ 로 조사되었다. 114 ) 행복온도의 개념은 2015 년 사업평가 및 만족도조사에서 부터 사용되었다.

[그림 5-1] 어르신문화프로그램 운영 및 행복온도 조사 결과(2019)

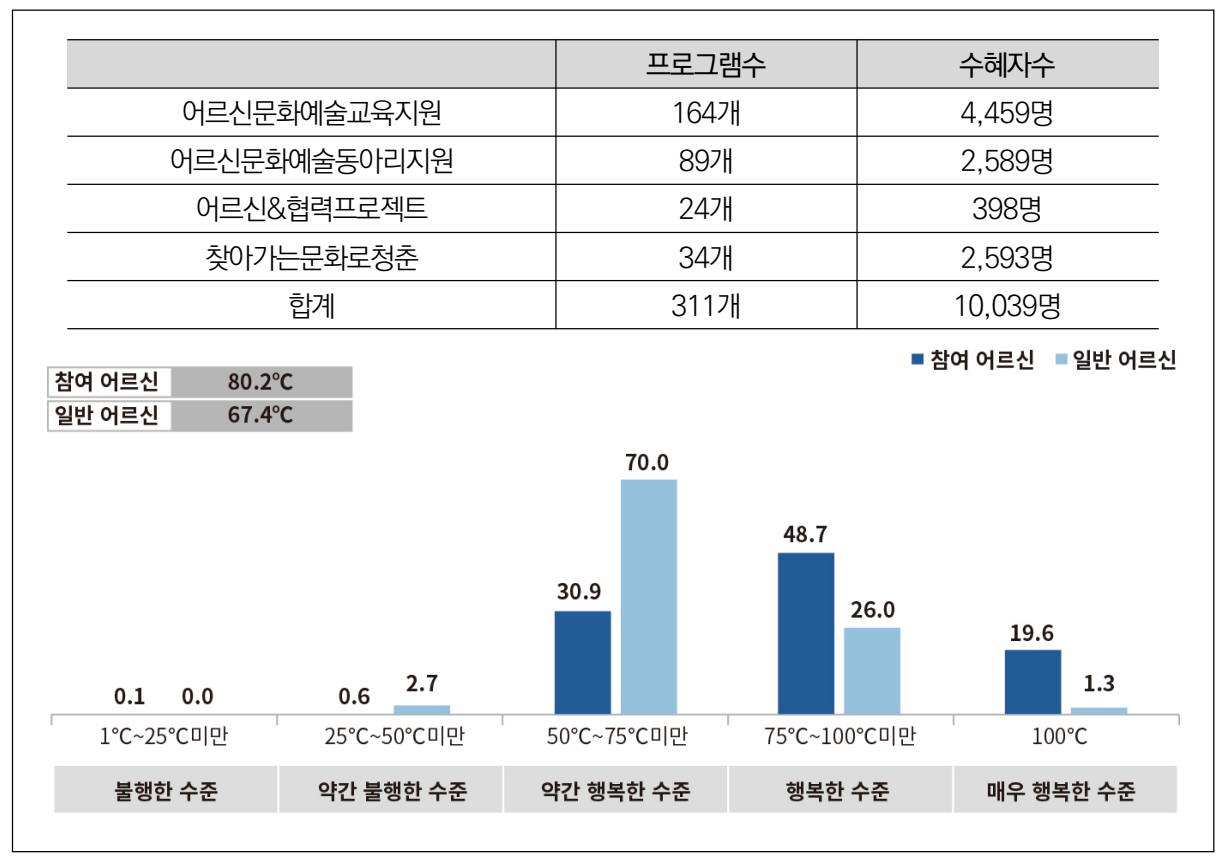

자료: 한국문화원연합회, 「2019년 어르신문화프로그램 사업평가 및 만족도 조사

4) 지역문화 진흥: 국민문화활동지원

(1) 문화가 있는 날 종합안내센터 운영

'문화가 있는 날'은 매달 마지막 수요일과 그 주간에 국민 모두가 일상에서 문화 를 더 쉽게 접할 수 있도록 문체부가 지정한 날이다. 전 국민의 일상생활 속 문화향 유 기회 확대를 목표로 2014년 1월부터 시행되었으며 2015년부터 기존 문화시설 의 할인 혜택과 함께 다양한 기획 프로그램으로 확대 운영하고 있다. 2017년부터는 평일에 진행하는 행사에 국민들이 참여하기 힘든 현실을 고려해 매달 마지막 수요

114) 한국문화원연합회 보도자료 2019.12.20. 참여 어르신 종합만족도 평가 3년 연속 상승 
일에서 주말까지 확대 운영 중이다. 2016년 ‘문화가 있는 날 사업추진단’이 구성되 었으며, 2018년부터는 지역문화진흥원에서 이관 받아 관련 사업을 주관하고 있다.

‘문화가 있는 날 종합안내센터 운영'사업 예산은 총 200 백만 원으로 목표는 문 화가 있는 날 사업, 혜택 등에 대한 통합 정보를 제공하고 홍보하여 국민의 문화 향유 기회를 확대하는 데 있다. 문화가 있는 날 누리집을 운영 관리하면서 문화가 있는 날 월별 참여 시설과 프로그램 정보를 제공하며 수혜대상은 전국민이다.

〈표 5-22〉 문화가 있는 날 혜택

- 전국 국·공립 도서관의 야간 개방 확대 및 문화프로그램 운영

- 경복궁, 창덕궁, 덕수궁, 창경궁 등 조선 4대 궁궐과 종묘, 조선왕릉 무료 개방

- 전국 주요 영화상영관의 영화 관람료 특별 할인

- 자녀(초등학생 이하)와 부모 동반 입장 시 프로농구, 프로배구 관람료 특별 할인

- 전국 주요 전시관람 문화시설 무료 또는 할인

- 국립극장 및 국립국악원 특별공연 무료, 정동극장, 예술의 전당 등

- 주요 공연관람시설 할인

자료: 지역문화진흥원 웹사이트, http://mww.rcda.or.kr/business/business8_new.asp

사업의 성과지표와 실적은 인지도와 참여율로 보고 있으며 2015년 인지도 $45.2 \%$, 참여율 $37.2 \%$ 에서 2018년 인지도 $68.9 \%$, 참여율 $59.8 \%$ 로 지속적으로 상 승했다. 문체부는 향후 문화가 있는 날 사업을 통해 공급자 중심에서 수요자 중심. 체험형 정책으로 전환하고자 하며, 기업과 학교 등 생활밀접기관과 협력해 국민들 의 실질적 참여기회를 확대한다는 계획을 밝히고 있다.

〈표 5-23〉 문화가 있는 날 사업 성과지표(2016 2020)

\begin{tabular}{|c|c|c|c|c|c|c|c|c|c|}
\hline 성과지표 & 구분 & '16 & '17 & '18 & '19 & '20 & $\begin{array}{l}\text { '20목표치 } \\
\text { 산출근거 }\end{array}$ & $\begin{array}{c}\text { 측정산식 } \\
\text { (또는 측정방법) }\end{array}$ & $\begin{array}{l}\text { 자료수집방법 } \\
\text { (또는 자료출처) }\end{array}$ \\
\hline \multirow{3}{*}{$\begin{array}{l}\text { 문화가 있는 날 } \\
\text { 국민참여율 } \\
\text { (단위: \% ) }\end{array}$} & 목표 & 신규 & 44.5 & 50.9 & 51.1 & 60.0 & \multirow{3}{*}{ 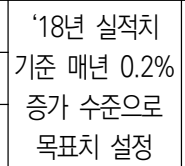 } & \multirow{3}{*}{$\begin{array}{l}\text { 일반 국민대상 } \\
\text { 문화가 있는 날 } \\
\text { 인지자 중 } \\
\text { 참여여부 집계 }\end{array}$} & \multirow{3}{*}{$\begin{array}{c}\text { 조사 } \\
\text { 결과보고서 }\end{array}$} \\
\hline & 실적 & 43.3 & 50.7 & 59.8 & - & & & & \\
\hline & 달성도 & & $113.9 \%$ & $117.5 \%$ & - & & & & \\
\hline
\end{tabular}

자료: 문화체육관광부 사업설명자료 
(2) 문화가 있는 날 기획프로그램 운영지원

'문화가 있는 날 기획프로그램 운영지원' 사업은 예산은 총 19,652 백만 원으로 전 국민이 일상생활 속에서 문화향유 기회를 확대하는 것을 목표로 한다. 주관기관인 지역문화진흥원에서 공모 형태로 직접 운영하는 기획프로그램은 지역문화 콘텐츠 특성화, 청춘마이크(청년문화우리 포함), 직장 문화배달, 동동동 문화놀이터, 생활 문화 동호회 활성화, 동네책방 문화사랑방 총 6개이다.115) 기존의 '지역특화프로그 램'은 2018년부터 문체부의 지자체 보조 사업으로 분류되었고, '지역문화 콘텐츠 특성화’사업만 지역문화진흥원에서 직접 운영한다. 한국문화예술회관연합회에서 운 영하던 '동동동 문화놀이터'는 2018년 지역문화진흥원으로 이관되었다. 초기에 기 획프로그램으로 운영했던 소셜 다이닝, 대학 동아리 지원, 군부대 지원 사업은 폐지 되고 2019년 청년문화우리, 동네책방 문화사랑방이 신설되는 등 세부 프로그램 유 형의 변화가 많았다.

〈표 5-24〉 문화가 있는 날 기획프로그램 운영지원사업 현황(2019 2020)

\begin{tabular}{|c|c|c|c|c|c|}
\hline \multirow{3}{*}{ 구분 } & \multirow{3}{*}{ 프로그램 } & \multicolumn{4}{|c|}{ 예산 및 지원규모 } \\
\hline & & \multicolumn{2}{|c|}{ ‘19년 현황 } & \multicolumn{2}{|c|}{ '20년 계획 } \\
\hline & & 예산 & 지원규모 & 예산 & 지원규모 \\
\hline \multirow{2}{*}{$\begin{array}{l}\text { 지역 참여 } \\
\text { 활성화 }\end{array}$} & 지역특화 프로그램 & 2,000 & 28개 지자체 & 1,800 & 30개(내외) 지자체 \\
\hline & 지역문화콘텐츠 특성화 사업 & 2,200 & 34개 단체 & 3,000 & 42개 단체 \\
\hline \multicolumn{2}{|c|}{ 참여예술가 지원(청춘마이크) } & 4,700 & 250팀, 1천명 & 6,700 & 410팀, 1.6천명 \\
\hline \multicolumn{2}{|c|}{$\begin{array}{c}\text { 참여문화시설 지원(도서관, 박물관, 미술관, } \\
\text { 문예회관, 문화원 등) }\end{array}$} & 4,050 & 470개 시설 & 2,850 & 300개 시설 \\
\hline \multirow{3}{*}{$\begin{array}{c}\text { 생활 속 } \\
\text { 문화 활동 } \\
\text { 및 향유 지원 }\end{array}$} & $\begin{array}{c}\text { 생활문화운동 지원 } \\
\text { (생활문화동호회 활성화) }\end{array}$ & 2,000 & $\begin{array}{c}\text { 70개 단체, } \\
\text { 1,550개 동호회 }\end{array}$ & 1,900 & $\begin{array}{c}\text { 63개 단체, } \\
1,400 \text { 개 동호회 }\end{array}$ \\
\hline & $\begin{array}{l}\text { 직장으로 찾아가는 문화행사 } \\
\text { (직장 문화배달 사업) }\end{array}$ & 700 & 120개 기업 & 600 & 100 개 기업 \\
\hline & $\begin{array}{l}\text { 유아동시설 찾아가는 문화행사 } \\
\text { (동동동 문화놀이터) }\end{array}$ & 800 & 200개 시설 & 700 & 175 개 시설 \\
\hline \multirow{3}{*}{$\begin{array}{c}\text { 민간프로그램 } \\
\text { 참여 및 } \\
\text { 마케팅 지원 }\end{array}$} & $\begin{array}{c}\text { 민간참여 사업자 마케팅 지원 } \\
\text { 및 정책 홍보 등 }\end{array}$ & 1,489 & $\begin{array}{l}\text { 온라인 간접광고 } \\
\text { 기업 제휴 마케팅 } \\
\text { 집콘 및 홍보 등 }\end{array}$ & 1,419 & $\begin{array}{l}\text { 온라인 간접광고 } \\
\text { 기업 제휴 마케팅 } \\
\text { 집콘 및 홍보 등 }\end{array}$ \\
\hline & 독서문화 진흥(도깨비 책방) & 500 & 2만8천명 & 200 & 1만1천명 \\
\hline & $\begin{array}{c}\text { 동네서점 연계 문화프로그램 } \\
\text { (동네책방 문화사랑방) }\end{array}$ & 400 & 30개 서점 & 400 & 30개 서점 \\
\hline 운영비 & 수용비, 여비 등 & 83 & - & 83 & - \\
\hline \multicolumn{2}{|r|}{ 합 계 } & 18,922 & & 19,652 & \\
\hline
\end{tabular}

자료: 문체부 사업설명자료 및 연구자 재구성

115) '문화가 있는 날 기획프로그램 운영지원' 예산으로 운영하는 '생활문화 동호회 활성화’는 별도로 다룬다. 
한국문화원연합회, 한국문화예술회관연합회, 한국박물관협회, 한국사립미술관협 회, 한국문화의집협회, 어린이와작은도서관협회, 한국도서관문화진흥원 7개 기관은 ‘참여문화시설 지원’프로그램을 주관하여 시설별로 기획사업을 별도로 운영한다.

〈표 5-25〉 문화가 있는 날 ‘참여문화시설 지원’ 프로그램 운영 실적(2019. 11)

\begin{tabular}{|c|c|c|c|c|c|}
\hline 지원 사업명 & 운영기관 & 사업내용 & 기관(팀)수 & 운영횟수 & 참여인원 \\
\hline $\begin{array}{c}\text { 지방문화원 } \\
\text { 문화가 있는 날 }\end{array}$ & 한국문화원연합회 & $\begin{array}{c}\text { 주민 주도형 문화예술체험 } \\
\text { 프로그램 개발, 운영 }\end{array}$ & 63팀 & 388회 & 69,548 명 \\
\hline $\begin{array}{l}\text { 지역문화예술회관 } \\
\text { 문화가 있는 날 } \\
\text { '공연산책' }\end{array}$ & $\begin{array}{c}\text { 한국문화예술회관 } \\
\text { 연합회 }\end{array}$ & $\begin{array}{c}\text { 지역 문예회관 등 } \\
\text { 문화시설에서의 지역 밀착 } \\
\text { 맞춤형 공연프로그램개최 }\end{array}$ & 206개 & 939회 & 244,322명 \\
\hline $\begin{array}{c}\text { 박물관 } \\
\text { 문화가 있는 날 } \\
\end{array}$ & $\begin{array}{c}\text { (사) } \\
\text { 한국박물관협회 }\end{array}$ & \begin{tabular}{|l|} 
박물관 고유 콘텐츠와 연계된 \\
교육·문화예술프로그램 진행
\end{tabular} & 205팀 & 1,580회 & 49,119명 \\
\hline $\begin{array}{c}\text { 미술관 } \\
\text { 문화가 있는 날 }\end{array}$ & \begin{tabular}{|c|} 
(사)한국사립미술관 \\
협회
\end{tabular} & \begin{tabular}{|c|} 
지역 특성에 맞는 고유의 예술 \\
콘텐츠와 아티스트, 전시, \\
소장작품 등과 연계한 대상 \\
특화 예술체험 프로그램 제공
\end{tabular} & 159 개소 & 804회 & 17,280명 \\
\hline $\begin{array}{c}\text { (공공)도서관 } \\
\text { 문화가 있는 날 }\end{array}$ & $\begin{array}{l}\text { 한국도서관문화 } \\
\text { 진흥원 }\end{array}$ & \begin{tabular}{|c} 
지역 주민 누구나 쉽게 이용할 \\
수 있는 공공도서관을 활용해 \\
지역 문화 예술 접근성 향상과 \\
이용률 제고
\end{tabular} & 135개 & 188회 & 22,209명 \\
\hline $\begin{array}{l}\text { 작은도서관 문 } \\
\text { 화가 있는 날 }\end{array}$ & $\begin{array}{c}\text { 어린이와 } \\
\text { 작은도서관협회 }\end{array}$ & $\begin{array}{c}\text { 작은도서관에 맞는 문화 } \\
\text { 프로그램 발굴 }\end{array}$ & 470팀 & 3,920회 & 100,548명 \\
\hline
\end{tabular}

자료: 문화가 있는 날 웹사이트, 현황은 2019년 11월 기준

기획프로그램 중 ‘청춘마이크’ 의 경우 국민 문화향유 공간 발굴을 통한 대국민 문 화 향유 기반 활성화를 목적으로 하며, 전문예술가로 성장하려는 청년의 성장 발판 을 마련하기 위해 공연비와 경비를 직접 지급하는 일자리 창출과 신진 예술가 육성 지원사업의 성격도 강하다. 버스킹 공연이기 때문에 공연 장소는 유동인구가 많은 야외에서 주로 진행한다. '직장 문화배달' 은 예술위의 '신나는 예술여행'을 직장인 대상으로 한정한 방문형 사업이며 회사 로비, 강당, 야외 등 정식 공연장이 아닌 일 상의 장소에서 진행한다. '동동동 문화놀이터'는 유아 대상의 방문형 사업으로 연극 프로그램이 50\%에 달한다. 116) 유아 외에도 가족과 지역주민도 초청할 수 있도록 대상을 확대했다. '동네책방 문화사랑방'은 지역주민의 문화 향유 공간 확대를 목표

116) 지역문화진흥원(2020), 「2019년 문화가 있는 날 성과평가 및 이용자 분석연구」, 37쪽. 
로 하며, 2019 년에는 복합형 $42.5 \%$, 강연 $17.5 \%$, 창작·체험 $17.5 \%$, 낭독·독서 $15 \%$, 공연·상영회 $7.5 \%$ 등 다양한 유형의 프로그램을 진행했다. 2020년 사업에서 는 '직장 문화배달' 프로그램에서 문화소외지역, 지방 이전 기업 등 근로사각지대를 우선 배려하고, ‘동동동 문화놀이터'는 수혜처의 요구를 고려해 공연팀을 배정하는 방향으로 개선해 운영한다.

〈표 5-26〉 문화가 있는 날 기획프로그램-지역문화진흥원 주관 사업 내용

\begin{tabular}{|c|c|c|}
\hline 사업명 & 목표 & 내용 \\
\hline 청춘마이크 & $\begin{array}{l}\text { 열정과 재능이 넘치는 대한민국 젊은 예술가 } \\
\text { 들에게 '문화가 있는 날' 무대에 설 기회를 마 } \\
\text { 련하여 청년들의 꿈을 키우고 전문성을 가진 } \\
\text { 예술가로 성장할 수 있도록 지원 }\end{array}$ & $\begin{array}{l}\text { 만 19 34세 청년예술가를 대상으로 학력, 경 } \\
\text { 력, 수상 이력에 관계없이 공모 · 선정하여 공 } \\
\text { 연 경비 및 운영시스템을 지원 }\end{array}$ \\
\hline $\begin{array}{l}\text { 지역(청년) } \\
\text { 문화우리 }\end{array}$ & $\begin{array}{l}\text { 청년 주도 문화 활동 지원을 통한 지역 청년 } \\
\text { 문화 활성화 계기를 마련하고 지역 문화 가치 } \\
\text { 창출에 기반을 구축 }\end{array}$ & $\begin{array}{l}\text { 지역 현안 및 자원을 중심으로 청년들이 자율 } \\
\text { 기획 프로그램 운영(청춘마이크 예산 활용) }\end{array}$ \\
\hline $\begin{array}{c}\text { 지역문화 } \\
\text { 콘텐츠 특성화 }\end{array}$ & $\begin{array}{l}\text { 지역 고유의 특성을 활용한 문화 프로그램을 } \\
\text { 발굴하고 국민 문화향유 기회를 제공 }\end{array}$ & $\begin{array}{l}\text { 지역 문화예술 기획자와 예술가, 지역민 등 다 } \\
\text { 양한 주체 간 협력을 통해 지역의 유·무형적 } \\
\text { 콘텐츠를 활용한 다채로운 문화 프로그램 운 } \\
\text { 영 }\end{array}$ \\
\hline $\begin{array}{c}\text { 직장 } \\
\text { 문화배달 }\end{array}$ & $\begin{array}{l}\text { 근로자의 문화가 있는 삶 실현 및 직장의 사회 } \\
\text { 문화적 책임의식을 증대 }\end{array}$ & $\begin{array}{l}\text { 근무지로 직접 찾아가 문화예술 체험 기회를 } \\
\text { 제공하는 직장인 맞춤 프로그램 }\end{array}$ \\
\hline $\begin{array}{l}\text { 동동동 } \\
\text { 문화놀이터 }\end{array}$ & $\begin{array}{l}\text { 아이들이 다양한 문화 프로그램을 통해 예술 } \\
\text { 적 표현과 감상의 즐거움을 경험하고 미래의 } \\
\text { 문화예술 시민으로 성장 }\end{array}$ & $\begin{array}{l}\text { 전국(洞) 영유아(童) 시설을 대상으로 문화가 } \\
\text { 있는 날 찾아가는(動) 문화예술 및 예술체험 } \\
\text { 지원 }\end{array}$ \\
\hline $\begin{array}{l}\text { 동네책방 } \\
\text { 문화사랑방 }\end{array}$ & $\begin{array}{l}\text { 지역주민들이 동네책방을 거점으로 문화공동 } \\
\text { 체를 형성하는 과정을 지원하여 지역을 바꾸 } \\
\text { 는 서점의 역할을 확대 }\end{array}$ & $\begin{array}{l}\text { 문화가 있는 날에 동네책방에서 주민들이 책 } \\
\text { 을 매개로 관계를 형성하는 문화활동 }\end{array}$ \\
\hline
\end{tabular}

자료: 문화가 있는 날 웹사이트 기획사업

문화가 있는 날 기획프로그램 운영지원 사업 중 ‘민간참여 사업자 마케팅 및 캠페 인 지원'사업은 민간 문화예술 사업자의 '문화가 있는 날' 홍보마케팅을 지원하여 국민들의 참여를 유도하고 문화접근성 증대를 통한 문화예술 시장 활성화를 목표로 한다. 해당 예산으로 문화계 인사들과 함께 다양한 일상의 공간을 찾아가 음악 또는 강연을 하는 '집들이 콘서트(집콘)' 프로그램을 운영한다. 2019년 1월 기준 133 개 팀이 참여하고 37 개 장소에서 운영되었으며 3,386명이 오프라인에서 관람했다. 이 외에 '도깨비 책방'은 공연, 전시, 영화 관람권과 지역서점 도서구입 영수증을 책으 
로 교환해주는 사업으로 2020년 예산은 200백만 원이다. 한국서점조합연합회에서 주관하며 시민들의 독서문화 조성, 지역서점 이용 확대 및 문화예술 관련 소비 활성 화를 목표로 한다. 2017년 2월 영세 출판사를 돕고, 경기불황으로 인한 문화예술시 장의 소비 활성화를 위해 '문화가 있는 날'에 진행했으며, 2019년 11월 기준으로 26개소(오프라인)에서 운영되어 101,612명이 참여했다.

2019년 지역문화진흥원에서 주관한 기획프로그램에는 총 447개의 단체가 선정 되어 2,336회 프로그램을 운영했으며, 총 38.7만 명이 참여한 것으로 추산된다. 기 획프로그램을 통해 주요 문화시설이 집중되어 있는 수도권과 실질적인 참여 기회가 적은 비수도권의 향유 격차를 해소해나간다는 계획이다.

〈표 5-27〉 문화가 있는 날 기획프로그램 운영: 지역문화진흥원 운영 결과(2019)

\begin{tabular}{|c|c|c|c|c|c|c|c|c|}
\hline \multirow{2}{*}{$\begin{array}{l}\text { 평가 } \\
\text { 대상 }\end{array}$} & \multirow{2}{*}{$\begin{array}{l}\text { 사업 } \\
\text { 기간 }\end{array}$} & \multirow{2}{*}{$\begin{array}{l}\text { 지원규모 } \\
\text { (사업예산) }\end{array}$} & \multicolumn{4}{|c|}{ 지원 내용 } & \multirow[b]{2}{*}{ 참여인원 } & \multirow[b]{2}{*}{ 비고 } \\
\hline & & & $\begin{array}{l}\text { 참여 } \\
\text { 단체수 }\end{array}$ & $\begin{array}{l}\text { 평균 } \\
\text { 지원액 }\end{array}$ & 운영회차 & $\begin{array}{l}\text { 단체당 } \\
\text { 회수 }\end{array}$ & & \\
\hline \multirow{2}{*}{$\begin{array}{l}\text { 청춘 } \\
\text { 마이크 }\end{array}$} & \multirow{2}{*}{ '19.4 12월 } & \multirow{2}{*}{$\begin{array}{l}\text { 2,134백만 원 } \\
\text { (4,230백만 원) }\end{array}$} & \multirow{2}{*}{$\begin{array}{c}284 \text { 팀 } \\
\text { (주관사 } 8+ \\
\text { 예술단체 276) }\end{array}$} & \multirow{2}{*}{ 773만원 } & \begin{tabular}{|c|}
1,545 회 \\
276 개 단체기준
\end{tabular} & \multirow{2}{*}{ 5회 } & \multirow{2}{*}{ 약 17.6만명 } & \multirow{2}{*}{$\begin{array}{c}\text { (주관단체) 팀당 } \\
1.6 ~ 4.5 \text { 억 원 지원 } \\
\text { (예술단체) 팀당 } \\
350 ~ 1,050 \text { 만원 지원 }\end{array}$} \\
\hline & & & & & \begin{tabular}{|c|}
425 회 \\
8개 주관사 기준
\end{tabular} & & & \\
\hline $\begin{array}{l}\text { 청년문화 } \\
\text { 우리 }\end{array}$ & '19.6 11월 & $\begin{array}{l}\text { 210백만 원 } \\
\text { (470백만 원) }\end{array}$ & $\begin{array}{c}\text { 7팀 } \\
\text { (기획자) }\end{array}$ & 3,000 만원 & 29회 & $\begin{array}{l}3.7 \text { 회 } \\
\text { (평균) }\end{array}$ & 약 0.4 만명 & $\begin{array}{c}\text { 월별프로그램 운영: 29회 } \\
\text { 월별활동: 81회 }\end{array}$ \\
\hline $\begin{array}{l}\text { 지역문화 } \\
\text { 콘텐츠 } \\
\text { 특성화 }\end{array}$ & '19.4 11월 & $\begin{array}{l}\text { 1,800백만 원 } \\
\text { (2,200백만 원) }\end{array}$ & $\begin{array}{c}\text { 33팀 } \\
\text { (예술단체) }\end{array}$ & 5,455만원 & 208회 & $\begin{array}{l}6.3 \text { 회 } \\
\text { (평균) }\end{array}$ & 약 15.6만명 & \\
\hline $\begin{array}{c}\text { 동동동 } \\
\text { 문화놀이터 }\end{array}$ & '19.4 12월 & $\begin{array}{l}\text { 606백만 원 } \\
\text { (800백만 원) }\end{array}$ & $\begin{array}{c}\text { 40팀 } \\
\text { (예술단체) }\end{array}$ & 1,516만원 & 201회 & 5회 & 약 2.7만명 & 수혜처 200개소 \\
\hline $\begin{array}{c}\text { 직장 } \\
\text { 문화배달 }\end{array}$ & '19.3 11월 & $\begin{array}{l}\text { 543백만 원 } \\
\text { (700백만 원) }\end{array}$ & $\begin{array}{c}\text { 43팀 } \\
\text { (예술단체) }\end{array}$ & 1,263만원 & 130회 & 3회 & 약 1.8만명 & 수혜처 129개소 \\
\hline $\begin{array}{l}\text { 동네책방 } \\
\text { 문화사랑방 }\end{array}$ & '19.5 11월 & $\begin{array}{l}\text { 270백만 원 } \\
\text { (400백만 원) }\end{array}$ & $\begin{array}{l}\text { 40팀 } \\
\text { (서점) }\end{array}$ & 675만원 & 223회 & $\begin{array}{l}5.6 \text { 회 } \\
\text { (평균) }\end{array}$ & 약 0.5만명 & \\
\hline \multicolumn{2}{|c|}{ 종합 } & $\begin{array}{l}5,563 \text { 백만 원 } \\
\text { (8,800백만 원) }\end{array}$ & 총 447팀 & $\begin{array}{c}\text { 평균 } \\
2,114 \text { 만원 }\end{array}$ & 총 2,336회 & $\begin{array}{c}\text { 평균 } \\
4.8 \text { 회 }\end{array}$ & 총 38.7만명 & \\
\hline
\end{tabular}

자료: 지역문화진흥원(2020), 「2019 문화가 있는 날 성과평가 및 이용자 분석연구」, 12쪽. 
(3) 문화가 있는 날 기획프로그램 운영지원: 생활문화동호회 활성화 지원

지역문화진흥원에서 '문화가 있는 날 기획프로그램 운영지원' 예산으로 진행하는 '생활문화동호회 활성화 지원' 은 주민 주도형 생활문화 협력 기반 조성, 일상 속 생 활문화 다양성 지원, 지역 문제해결형 생활문화 활동을 위한 담론 형성을 목표로 한다. 지역 문화주체로서의 성장과 문화공동체 형성을 독려한다. 생활문화동호회의 형성, 발표 및 교류, 확장을 단계별로 지원하고 공연, 전시, 체험 프로그램 등으로 구성된 전국생활문화축제를 연 1 회 개최한다.

[그림 5-2] 생활문화동호회 지원사업의 목적과 지원방식

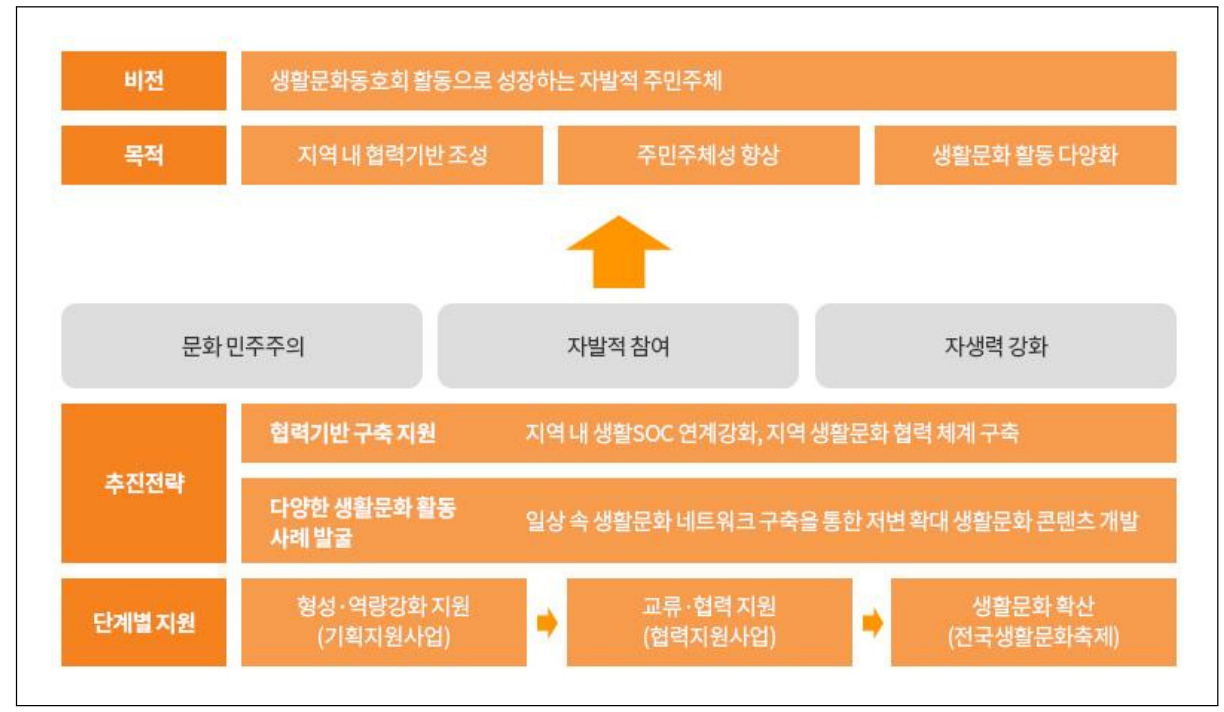

자료: 지역문화진흥원 http://mww.rcda.or.kr/business/business3_new.asp

수혜대상은 전 국민이며 문화재단, 생활문화 유관 기관 및 시설, 단체117)에서 지 원을 신청할 수 있다. 2020년 사업 예산은 1,900 백만 원이며 사업의 성과는 동호 회수와 관객 수(발표 및 교류 지원 기준)로 제시되고 있다.

117) http://www.rcda.or.kr/business/business3_new.asp 
〈표 5-28〉 생활문화동호회 지원 사업 연도별 실적(2018 2014)

\begin{tabular}{|c|c|c|c|c|c|c|}
\hline \multirow{2}{*}{ 연도 } & \multicolumn{4}{|c|}{ 지역 생활문화동호회 활성화 지원 중 발표 및 교류 지원 } & \multicolumn{2}{|c|}{ 전국생활문화축제 } \\
\hline & 지원단체수 & 지원규모 & 참가규모 & 관객수 & 동호회수 & 회원수 \\
\hline 2018 & 86개 & 1,155,000천원 & 동호회 1,840팀 & 70,700명 & 147팀 & 1,218 명 \\
\hline 2017 & 56개 & 728,106천원 & 동호회 1,450팀 & 665,819명 & 105팀 & 1,004명 \\
\hline 2016 & 55개 & 678,170 천원 & 동호회 1,364팀 & 54,175명 & 125팀 & 1,481 명 \\
\hline 2015 & 45개 & 868,940천원 & 동호회 1,586팀 & 415,786명 & 132팀 & 1232명 \\
\hline 2014 & 7개 & 260,000천원 & 동호회 663팀 & 134,105명 & 55팀 & 540명 \\
\hline 누적 & 163개 & $2,535,126$ 천원 & 동호회 5,063팀 & 동호회 5,063팀 & 564팀 & 5,475 명 \\
\hline
\end{tabular}

자료: 지역문화진흥원 http://www.rcda.or.kr/business/business3_new.asp

(4) 여가 기반 조성: 여가친화기업 선정·지원

'여가친화기업 선정·지원' 사업은 지역문화진흥원에서 주관하며 예산은 97백만 원이다. 여가와 일을 조화롭게 영위할 수 있는 업무 환경을 조성하고 근로자의 삶의 질 향상을 통한 행복한 사회 조성을 목적으로 한다. 여가친화기업 인증제도는 근로 자가 일과 여가생활을 조화롭게 병행할 수 있도록 모범적으로 지원·운영하는 기업 을 선정하여 인증하고 지원하는 제도이다. 신규 인증 후 3년간 유효하고 이후 2년 연장된다. 대기업·중견기업·중소기업·공기업 및 지방공기업을 대상으로 하며 선정 기업에는 정부포상(문화체육관광부·지역문화진흥원 표창), 기업문화 홍보, 문화예 술 향유 기회(공연, 전시 등)를 부여한다. 수혜대상은 여가친화기업 근로자이며 2019년 여가친화기업 모집시에는 선택사항이긴 하지만 근로자 대상의 수요조사 결 과를 제출하도록 했다. 설문의 지원받고 싶은 여가활동에 '문화예술 관람 및 향유 기회확대'가 있으며, 강좌 중심의 체험 기회 확대 수요도 조사에 포함되었다. 
[그림 5-3] 여가친화기업 인증 신청용 근로자 대상의 수요조사 항목(2019)

5. 귀하가 소속한 사업장이 ‘여가친화기업’ 인증을 받는다면, 이를 통해 개인적으로 지원 또는 제공받고 싶은 여가활동은 무엇입니까?

\begin{tabular}{|c|c|c|c|c|}
\hline \multicolumn{2}{|c|}{$\begin{array}{l}\text { 문화예술 관람 및 향유 기회 확대 } \\
\text { (선호 장르 선택: } 3 \text { 개까지 중복선택 가능) }\end{array}$} & \multirow{2}{*}{$\begin{array}{l}\text { 문화예술 체험 기회 확대(간헐적/주기적 강좌) } \\
\text { (선호 장르 선택: } 5 \text { 개까지 중복선택 가능) } \\
\text { (1) 서양음악(클래식, 서양악기 등) }\end{array}$} & \multicolumn{2}{|c|}{$\begin{array}{c}\text { 기타: 인문학, 생활기술 또는 적정기술 등 } \\
\text { (선호 분야 선택: } 5 \text { 개까지 중복선택 가능) }\end{array}$} \\
\hline (1) 전통예술 공연 & (2) 뮤지컬·연극 공연 & & (1) 인문학 강연 & (2) 역사·문화재 교육 \\
\hline (3) 미술 전시 & (4) 대중예술 공연 & (2) 전통음악(국악, 풍물 등) & \multicolumn{2}{|l|}{ (3) 언어교육/강습 } \\
\hline \multicolumn{2}{|c|}{ (5) 음악(클래식, 월드뮤직 등) 공연 } & (3) 대중음악(K-Pop, 밴드 등) & (4) 캘리그라피/POP & (5) 꽃꽃이 \\
\hline \multirow{10}{*}{\multicolumn{2}{|c|}{$※$ 기타 (그 외 지원받고 싶은 장르) }} & (4) 서양무용(댄스스퐃, 발레, 현대무용 등) & (6) 퀼트, 뜨개질, 미싱 & (7) 요리 \\
\hline & & (5) 한국무용 & (8) 바리스타 & (9) 다도 \\
\hline & & (6) 대중무용(K-Pop, 치어리딩 등) & (10) 여행 & (11) 건축/인테리어 \\
\hline & & (7) 미술(회화, 조소 등) 8 (8) 사진 & \multicolumn{2}{|c|}{ (12) 과학 관련 활동(별자리, 발명 등) } \\
\hline & & \begin{tabular}{|l|l|} 
(9) 디자인 & (10) 서예 \\
\end{tabular} & \multicolumn{2}{|c|}{ (13) 생태/환경 관련 활동 } \\
\hline & & (11) 공예(목공, 가죽, 도자, 새활용/업사이클링 등) & \multicolumn{2}{|c|}{ (14) 봉사활동/재능기부 } \\
\hline & & (12) 문학(독서, 시·소설 창작 등) & \multirow{4}{*}{\multicolumn{2}{|c|}{ ※ 기타 (그 외 지원받고 싶은 분야) }} \\
\hline & & \begin{tabular}{|l|l|} 
(13) 연극 & (14) 뮤지컬 \\
\end{tabular} & & \\
\hline & & (15) 영상·영화제작 및 감상 & & \\
\hline & & ※ 기타 (그 외 지원받고 싶은 장르) & & \\
\hline
\end{tabular}

자료: 2019 여가친화인증기업 정책 개발을 위한 수요조사(근로자용)

여가친화기업은 문화가 있는 날 '직장 문화배달' 프로그램 신청시 우대하며, 2019년 인증 시에는 '직장 문화배달'과 한국예술인복지재단의 예술인파견지원 사 업 참여기업에 가점을 주었다.118) 2019년 12월 기준으로 총 154 개 기업이 인증을 받았으며 중소기업이 $42.8 \%$ 로 가장 많다.

〈표 5-29〉 여가친화기업 선정 현황(2012 2019)

(‘19년 12월 기준)

\begin{tabular}{c|c|c|c|c|c|c|c|c|c}
\hline 군도 & 계 & 2012 & 2013 & 2014 & 2015 & 2016 & 2017 & 2018 & 2019 \\
\hline 계 & 154 & 10 & 4 & 14 & 15 & 17 & 19 & 31 & 44 \\
\hline 공기업 & 31 & - & - & - & 2 & 3 & 8 & 7 & 11 \\
\hline 대기업 & 29 & 3 & - & 2 & 1 & 2 & 2 & 11 & 10 \\
\hline 중견기업 & 28 & - & 1 & 6 & 4 & 2 & - & 5 & 8 \\
\hline 중소기업 & 66 & 7 & 3 & 6 & 8 & 10 & 9 & 8 & 15 \\
\hline
\end{tabular}

자료: 지역문화진흥원(2020), 「2020 문화가 있는 날 공모사업 설명회 자료」, 49쪽.

118) 2019 여가친화기업 모집 안내, https://uww.mcst.go.kr/kor/s_notice/notice/noticeView.jsp?pSeq=14176 
〈표 5-30〉 ‘지역문화 진흥' 중 예술향유 지원사업(2020)

(단위: 백만 원)

\begin{tabular}{|c|c|c|c|c|c|c|c|}
\hline $\begin{array}{l}\text { 세부 } \\
\text { 사업명 }\end{array}$ & \multicolumn{2}{|c|}{ 내역사업명 } & 수행기관 & 예산 & 목적 & $\begin{array}{l}\text { 수혜 } \\
\text { 대상 }\end{array}$ & $\begin{array}{l}\text { 지표/ } \\
\text { 실적 }\end{array}$ \\
\hline \multirow{3}{*}{$\begin{array}{l}{[300]} \\
\text { 지역문화 } \\
\text { 진흥 }\end{array}$} & \multirow{2}{*}{$\begin{array}{c}\text { 생활문화 } \\
\text { 활성화 }\end{array}$} & $\begin{array}{l}\text { 생활문화센터 } \\
\text { 활성화 지원 }\end{array}$ & 지역문화진흥원 & 650 & $\begin{array}{l}\text { 지역주민의 문화향유 기회 } \\
\text { 확대 }\end{array}$ & 지역주민 & \\
\hline & & $\begin{array}{l}\text { 문화자원봉사 } \\
\text { 활성화 } \\
\text { (문화품앗e) }\end{array}$ & $\begin{array}{l}\text { 한국문화원 } \\
\text { 연합회 }\end{array}$ & 500 & $\begin{array}{l}\text { 문화자원봉사를 통한 문화 } \\
\text { 복지 기반 강화 및 문화 } \\
\text { 향유 기회 확대 }\end{array}$ & 전국민 & 매칭수 \\
\hline & \multicolumn{2}{|c|}{ 실버문화페스티벌 } & $\begin{array}{l}\text { 한국문화원 } \\
\text { 연합회 }\end{array}$ & 850 & $\begin{array}{l}\text { 아마추어 예술가로 활동 } \\
\text { 하는 어르신들의 문화생활 } \\
\text { 참여 기회 확대, 어르신들의 } \\
\text { 건강한 여가활동과 문화 } \\
\text { 향유 증진을 통한 삶의 질 } \\
\text { 향상 }\end{array}$ & \begin{tabular}{|c|} 
60세 이상 \\
어르신
\end{tabular} & 참여자수 \\
\hline $\begin{array}{c}\text { [306] } \\
\text { 어르신 } \\
\text { 문화 } \\
\text { 프로그램 } \\
\text { 운영 }\end{array}$ & \multicolumn{2}{|c|}{ 어르신문화프로그램 } & $\begin{array}{l}\text { 한국문화원 } \\
\text { 연합회 }\end{array}$ & 2,773 & $\begin{array}{l}\text { 어르신 커뮤니티 형성을 } \\
\text { 통한 사회적 소속감 및 } \\
\text { 안정감 증대 }\end{array}$ & \begin{tabular}{|} 
60세 이상 \\
어르신
\end{tabular} & $\begin{array}{l}\text { 참여자 } \\
\text { 만족도 }\end{array}$ \\
\hline \multirow{5}{*}{$\begin{array}{l}\text { [307] } \\
\text { 국민문화 } \\
\text { 활동지원 }\end{array}$} & \multicolumn{2}{|c|}{$\begin{array}{l}\text { 문화가 있는 날 } \\
\text { 종합안내센터 운영 }\end{array}$} & 지역문화진흥원 & 200 & 국민 문화향유기회 확대 & 전국민 & $\begin{array}{l}\text { 인지율, } \\
\text { 참여율 }\end{array}$ \\
\hline & \multirow{3}{*}{$\begin{array}{l}\text { 문화가 } \\
\text { 있는 날 } \\
\text { 기획 } \\
\text { 프로그램 } \\
\text { 운영지원 } \\
\text { (운영비 } \\
\text { 제외) }\end{array}$} & $\begin{array}{l}\text { 지역특화 } \\
\text { 프로그램 }\end{array}$ & 지자체 & 1,800 & $\begin{array}{l}\text { 문화시설이 부족한 지역민 } \\
\text { 또는 그 지역 방문객에게 } \\
\text { 참여형 문화예술 참여 기회 } \\
\text { 제공 }\end{array}$ & 지역주민 & \\
\hline & & $\begin{array}{l}\text { 기획프로그램 } \\
\text { (동호회 제외) }\end{array}$ & \begin{tabular}{|c|} 
지역문화진흥원 \\
/참여시설
\end{tabular} & 15,869 & $\begin{array}{l}\text { 전 국민의 일상생활 속 문화 } \\
\text { 향유 기회 확대 }\end{array}$ & 전국민 & 참여자수 \\
\hline & & $\begin{array}{c}\text { 생활문화동호회 } \\
\text { 활성화 }\end{array}$ & 지역문화진흥원 & 1,900 & $\begin{array}{l}\text { 주민 주도형 생활문화 협력 } \\
\text { 기반 조성. 지역별·세대별 } \\
\text { 수요에 부응하는 일상 속 } \\
\text { 생활문화 다양성 지원 }\end{array}$ & 전국민 & $\begin{array}{l}\text { 동호회수/ } \\
\text { 회원수 }\end{array}$ \\
\hline & \multicolumn{2}{|c|}{$\begin{array}{c}\text { 여가 기반 조성: } \\
\text { 여가친화기업선정·지원 }\end{array}$} & 지역문화진흥원 & 97 & $\begin{array}{l}\text { 근로자 여가향유기회 제공, } \\
\text { 삶의 질 향상을 통한 보다 } \\
\text { 행복한 사회 조성 }\end{array}$ & $\begin{array}{l}\text { 소속 } \\
\text { 근로자 }\end{array}$ & $\begin{array}{l}\text { 인증 } \\
\text { 기업수 }\end{array}$ \\
\hline
\end{tabular}




\section{다. 문화예술진흥기금 및 체육진흥기금}

1) 문화예술진흥기금: 예술향유기회확대(문화예술향유지원)

(1) 통합문화(체육관광)이용권 사업

‘통합문화이용권' 은 경제적인 사정으로 문화생활이 어려운 소외계층에게 문화 향 유 비용을 지원해 실질적인 문화예술 향유를 증진하고, 문화예술·여행·체육 활동기 회를 제공해 문화 격차를 완화하고 삶의 질을 향상시키는 것을 목표로 한다. 기초생 활수급자 및 차상위계층 대상으로 선불카드(문화누리카드)를 발급하는 방식이기 때 문에 개인의 의사와 취향에 따라 선택해서 사용할 수 있다.

2005년 복권기금을 활용한 시범사업으로 시작했으며 2011년 기존의 온라인 포 인트제에서 카드 발급 방식으로 변경되었다. 2014년에는 여행 및 스포츠 관람 이용 권과 일원화되었고 2016년과 2017년에는 통합문화이용권의 서비스 범위 확대와 체육·기금, 관광기금의 전입으로 문예진흥기금으로 운영 되는 등 재원과 사업 운영 에 많은 변화를 겪어왔다. 2018년부터는 문예진흥기금 고갈로 인한 안정적인 재원 확보와 경제적 소외계층을 지원하는 복권기금의 취지에 가장 부합하는 사업이라는 측면에서 다시 복권기금으로 운영중이다. 2020년 사업의 개인당 연간 지원금은 9 만원이며 운영비를 포함한 사업의 총 예산은 155,794 백만 원(복권기금 103,324 백 만 원, 문예진흥기금 6,300 백만 원, 지방비 46,170 백만 원)이다.

수혜대상은 문화소외계층 중에서도 경제적 취약계층으로 한정해 6세 이상의 기 초생활수급자와 차상위 계층을 지원한다. 초기에는 개인당 포인트로 지급하다가 2011년 카드 발급방식이 도입된 이후 세대 기준으로 지급되었다. 2014년 여행, 스 포츠 관람 이용권과 통합된 이후 2015년 다시 개인 기준으로 변경되었다. 2015년 부터는 청소년 추가발급 연령을 10 19세에서 6 19세(학령기 아동 추가)로 확대 했다. 향유 지원사업 중 거의 유일하게 수혜대상과 직접 지원 대상이 동일한 사업 이다. 
- 2005: 문화부/예술위 문화바우처 시범사업 추진(복권기금 4억, 5개 주관처 운영)

- 2006: 전국 단위로 확대 운영(1인당 연간 3,000포인트, 3 만원 상당)

- 2007: 1 인당 연간 5,000포인트(5만원 상당)로 지원액 상승

- 2011: 카드 발급 방식 도입(연간 5만원, 세대 기준으로 변경), 기획사업 병행

- 2013: 문화, 여행, 스포츠 관람 이용권 일원화 추진

- 2014: 통합문화(체육관광)이용권사업으로 개편

- 2015: 개인 기준으로 변경, 청소년 추가발급연령 확대, 동일 세대 내 지원금 합산, 본인 충전금 기능 도입

- 2016: 기획사업(문화더누리) 폐지

- 2016 2017: 문예진흥기금 사업으로 추진

- 2017: 1인당 연간 6만원으로 증액

- 2018: 복권기금으로 추진, 1 인당 연간 7만원 증액

- 2019: 1 인당 연간 8만원으로 증액

- 2020: 1인당 연간 9만원으로 증액

문화누리카드는 문화, 여행, 스포츠 관련 업종에서 이용 가능하며, 가맹점 수는 2020 년 6월 기준 문화 분야 11,638 개, 여행 분야 8,099 개, 체육 분야 3,920 개이 다. 온·오프라인 신규 가맹점은 17 개 시·도 지역주관처와 예술위에서 직접 발굴한 다. 문화누리카드 사용자 수요조사를 토대로 2019년도에는 OTT 플랫폼(왓챠플레 이, 웨이브, 넷플릭스, 유튜브), 웹툰(카카오페이지, 밀리의서재, 리디북스) 등을 신 규 가맹점으로 발굴했다. 부가서비스인 나눔티켓은 공연이나 전시를 주관하는 문화 예술단체가 기부한 무료 또는 할인티켓을 문화누리카드 이용자에게 제공하는 제도 이다. 전체 회원수는 2019 년 기준 약 2 만 명이며 티켓 예매 회원은 4,027 명, 신규 작품 수는 785 개, 참여단체 수는 158 개이다.

2014 년 통합문화이용권으로 개편 된 이후 영화 분야 이용금액은 $28.8 \%$ 에서 2019년 $19.1 \%$ 로 감소했으며, 문화체험은 $0.3 \%$ 에서 $7.3 \%$ 로 증가했다. 공연은 2014년부터 1 2\% 사이를 오가고 있으며, 전시는 0.1 0.2\%에 불과하다 2019년 $0.8 \%$ 로 증가했다. 지원금 소진 후 금액을 충전해 사용하는 본인 비용 충전자수는 2018년 대비 2019년 2.2배 증가했으며, 전체 카드 발급자수 대비 본인 비용 충전 자수도 2018년 5.3\%에서 2019년 11.2\%로 크게 증가했다. 
〈표 5-32〉 통합문화이용권 분야별 이용금액 비율(2014 2019)

(단위: 백만 원, \%)

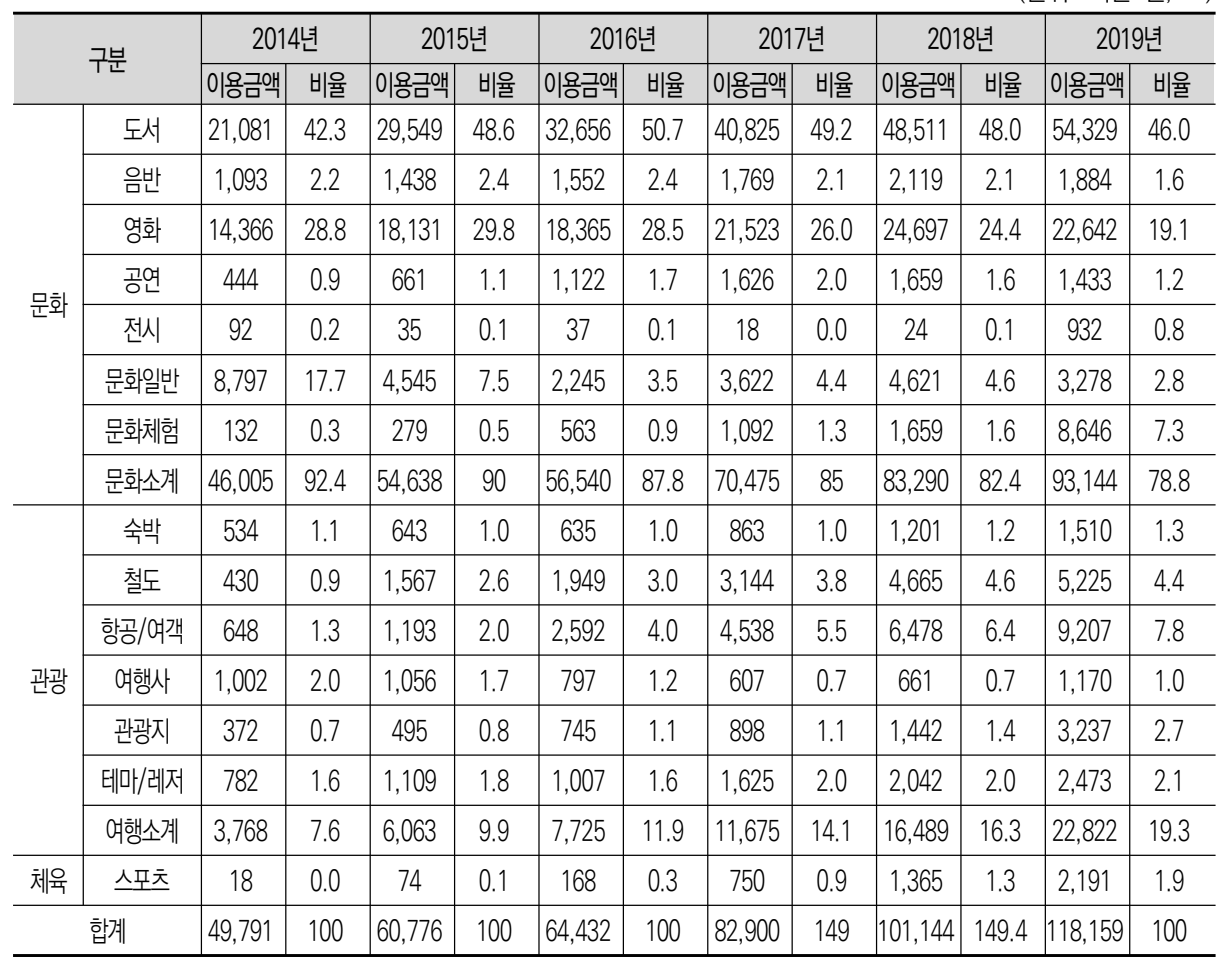

사업의 성과지표는 문화누리카드 이용 활성화 수준을 보는 정량 지표인 전액 미사 용자 비율(\%)과 이용자 만족도이다. 이용자 만족도 조사에서는 '행복', '즐거움'과 같 은 감정의 변화도 측정하고 있다. 2019년 지방자치단체 합동평가에는 문화누리카드 의 발급률와 이용률을 모두 평가하였으나, 2020년에는 예산 집행률로 일원화했다.

〈표 5-33〉 통합문화이용권 성과지표 및 연도별 변화추이(2016 2020)

(단위: \%)

\begin{tabular}{|c|c|c|c|c|c|c|}
\hline 지표항목 & & 2016 & 2017 & 2018 & 2019 & 2020 \\
\hline \multirow{3}{*}{ 전액 미사용자 비율 } & 목표 & - & - & - & 4.8 & 4.5 \\
\hline & 실적 & 6.1 & 5.2 & 5.7 & 4.9 & - \\
\hline & 달성도 & - & - & - & - & - \\
\hline \multirow{3}{*}{$\begin{array}{l}\text { 사용자 만족도 } \\
\text { (단위: 점) }\end{array}$} & 목표 & 86.8 & 86.6 & 83.7 & 86.4 & 87.3 \\
\hline & 실적 & 86.1 & 83.2 & 85.9 & 86.8 & - \\
\hline & 달성도 & $99.2 \%$ & $96.1 \%$ & $102.6 \%$ & $100.5 \%$ & - \\
\hline
\end{tabular}

자료: 문체부 사업설명자료, 예술위 내부자료 
〈표 5-34〉 통합문화이용권 이용자 만족도 조사 결과(2018 2019)

\begin{tabular}{|c|c|c|c|c|c|}
\hline \multirow[b]{2}{*}{ 구분 } & \multirow{2}{*}{$\begin{array}{l}\text { 전체 } \\
\text { 만족도 }\end{array}$} & \multicolumn{4}{|c|}{ 정서적·사회적 효과성 } \\
\hline & & $\begin{array}{c}\text { 이전보다 } \\
\text { 행복하다고 생각 }\end{array}$ & $\begin{array}{c}\text { 이전보다 } \\
\text { 생활이 활기차짐 }\end{array}$ & $\begin{array}{c}\text { 다른 사람과 어울리는 } \\
\text { 것이 즐거워짐 }\end{array}$ & $\begin{array}{c}\text { 사람을 만나는 것이 } \\
\text { 부담스럽지 않음 }\end{array}$ \\
\hline 2018 & 85.9 & 81.5 & 77.4 & 70.2 & 69.0 \\
\hline 2019 & 86.8 & 81.0 & 78.8 & 73.7 & 71.2 \\
\hline
\end{tabular}

자료: 예술위 내부자료

(2) 신나는 예술여행

2004년 복권기금을 재원으로 '소외계층 문화순회사업’을 시작한 '신나는 예술여 행'은 2014년부터 한국문화예술회관연합회에서 한국문화예술위원회로 주관처가 변경되었고, 2018년부터는 재원이 복권기금에서 문예진흥기금으로 변경되면서 대 상이 소외계층에서 일반 국민으로 조금씩 확장되는 추세이다. 이에 따라 최근에는 '소외계층'을 뺀 '신나는 예술여행' 으로만 사업명을 표기하고 있다. 관련 예산은 2014년부터 정부 국정과제((109-4)지역 특성에 맞는 문화도시·문화마을 조성 및 지역 문화격차 해소)로 확대되면서 100억 원에서 2016년 200억 원으로 2배로 증 가했으며, 2020년 사업 예산은 242억 원이다.

문화 인프라가 부족한 지역을 찾아가 다양한 문화예술 향유 및 참여 프로그램을 제공해 문화 향유권을 신장하고 문화 양극화 해소에 기여하는 초기의 사업 목적 외 에도 역량 있는 예술단체가 공연장 외의 다양한 시설과 야외장소를 직접 찾아가 예 술 프로그램을 제공함으로써 온 국민이 수준 높은 예술을 즐길 수 있도록 하고, 예 술단체에게 작품 발표 기회를 주고 창작 환경을 조성한다는 최근의 사업방향 전환 이 반영된 목표를 나란히 제시하고 있다. 수혜자의 만족도 제고를 위해 지원 대상을 생애주기별(아동기, 청소년기, 성인기, 노년기)과 특수계층으로 세분화하고 순회처 와 예술단체를 선정한 후 매칭해 공연 프로그램을 제공하는 방식으로 운영한다.

지원대상은 문화예술관련 법인 및 단체 또는 문화예술분야를 중점으로 활동하는 사회적 경제조직이며, 특정 장소에서만 접할 수 있던 공연을 전국 어디에서든 국민 이 향유할 수 있도록 기획한 공연을 지원하기 때문에 탈장소성이 강한 사업이라고 볼 수 있다. 2020년 사업은 매칭형(100억), 기획형(64억 5천), 청년형(67억 5천)으 로 구분하여 공모를 진행했다. 매칭형과 기획형은 예산이 삭감된 반면 청년형 예산 
은 2019년 30억 원에서 67억 5천만 원으로 2배 이상 증가했다. 매칭형은 아동, 청소년, 노인, 장애인 대상의 교육, 복지 의료시설, 일반인 대상은 교정시설, 군부대 와 같은 소외지역 외에 역사, 산업단지, 문화원 등 다중이용시설도 포함된다. 기획 형은 문화향유에 대한 수요가 있으나 자발적으로 신청하기 어려운 시설과 지역을 예술단체가 직접 발굴하여 찾아가는 방식이다. 청년형은 사업참여자 전체를 청년으 로 한정하며 일거리 창출형과 사회문제 해결형으로 구분한다. 장르는 연극, 무용, 음악, 전통예술, 다원예술과 같은 공연예술 뿐 아니라 문학, 시각예술, 문화일반까 지 포괄한다.119) 참여 예술단체를 소개하는 '프로그램북'(신나는 예술여행 2020년 선정프로그램) 기준으로 보면 프로그램의 주요 관객층은 아동, 청소년, 일반, 노인, 장애인으로 구분한다. 주요 수혜대상은 사회적·경제적·지리적 문화소외계층이며 직 접지원대상은 예술단체 및 예술인이다.

〈표 5-35〉 신나는 예술여행의 사업유형과 분야(2020)

\begin{tabular}{|c|c|c|c|c|c|c|c|c|c|}
\hline 신나는예술여행 & 2020 예산 & 문학 & $\begin{array}{l}\text { 시각 } \\
\text { 예술 }\end{array}$ & 연극 & 무용 & 음악 & $\begin{array}{l}\text { 전통 } \\
\text { 예술 }\end{array}$ & $\begin{array}{l}\text { 다원 } \\
\text { 예술 }\end{array}$ & $\begin{array}{l}\text { 문화 } \\
\text { 일반 }\end{array}$ \\
\hline 매칭형 & 100억 원 & & & & 0 & 0 & O & O & O \\
\hline 기획형 & 64억 5천만 원 & 0 & 0 & & & 0 & 0 & 0 & 0 \\
\hline 청년형 & 67억 5천만 원 & & 0 & 0 & 0 & 0 & 0 & 0 & 0 \\
\hline
\end{tabular}

자료: 신나는 예술여행 공모 안내, https://mww.arko.or.kr/m1_01/m2_01/m3_01/m4_02.do?mode=view\& page $=4 \&$ cid $=1602587 \&$ sf_icon_category=cw00000019

2019년에는 368개 예술단체가 참여해 8,348회 프로그램이 개최되었으며 988,311 명의 관객이 관람했다. 문체부의 사업 성과지표는 '예산 대비 참여 관객수'와 '참여 사회적 경제 조직수’이며, 2018년 기준 34개 단체가 참여했고 38,770명이 관람했 다. 전체 예술단체수나 프로그램수가 아닌 사회적 경제 조직수만을 지표에 반영하 는 점이 특징이다.

119) 2020 신나는 예술여행 공모 안내, https://www.arko.or.kr/m1_01/m2_01/m3_01/m4_02. do?mode=view\&page=\&cid=1602587\&sf_icon_category=cw00000019 
〈표 5-36〉 신나는 예술여행 사업 성과지표(2016 2020)

\begin{tabular}{c|c|c|c|c|c|c}
\hline & & 16 & 17 & 18 & 19 & 20 \\
\hline \multirow{3}{*}{$\begin{array}{c}\text { 참여 사회적 경제 조직수 } \\
\text { (단위: 개) }\end{array}$} & 목표 & - & - & - & 50 & 74 \\
\cline { 2 - 7 } & 실적 & 17 & 26 & 34 & - & - \\
\cline { 2 - 7 } & 달성도 & - & - & - & - & - \\
\hline \multirow{3}{*}{$\begin{array}{c}\text { 예산 대비 참여관객 수 } \\
\text { (단위: 명) }\end{array}$} & 목표 & - & - & - & 35,448 & 49,857 \\
\cline { 2 - 8 } & 실적 & 38,978 & 41,353 & 38,770 & - & - \\
\cline { 2 - 8 } & 달성도 & - & - & - & - & - \\
\hline
\end{tabular}

(3) 방방곡곡 문화공감

한국문화예술회관연합회에서 주관하는 ‘방방곡곡 문화공감’ 지원사업은 2004년 복권기금 문화나눔사업(지방 문예회관 특별공연프로그램 지원)으로 시작되었으며 2014년에는 기존의 지방 문예회관 특별프로그램 지원(복권기금), 국립예술단과 함 께하는 방방곡곡 문화공감(국고)을 통합해 '문예회관과 함께하는 방방곡곡 문화공 감'(복권기금)으로 사업명을 변경하고 복권기금으로 재원을 일원화했다. 2018년부 터는 복권기금 문화나눔사업에서 제외되어 문예진흥기금 사업으로 운영중이며 사 업 예산은 15,750 백만 원이다.

〈표 5-37〉 방방곡곡 문화공감 사업 유형

\begin{tabular}{|c|c|c|}
\hline 지원유형 & 주요내용 & 지원방식 \\
\hline $\begin{array}{c}\text { 민간예술단체 우수공연 } \\
\text { 프로그램 }\end{array}$ & $\begin{array}{l}\text { 작품성 및 대중성 등에서 검증된 민간 예술단체의 우수 공 } \\
\text { 연 프로그램을 선정하여 지역문예회관에서 유치한 우수공연 } \\
\text { 에 대해 초청경비 일부 지원 }\end{array}$ & \multirow{2}{*}{$\begin{array}{l}\text { 해당자치단체의 } \\
\text { 재정자립도 따라 } \\
\text { 차등지원 }\end{array}$} \\
\hline $\begin{array}{c}\text { 국공립예술단체 우수공연 } \\
\text { 프로그램 }\end{array}$ & $\begin{array}{l}\text { 국공립예술단체의 전막공연 등 우수 공연 프로그램을 선정 } \\
\text { 하여 지역문예회관에서 유치한 우수공연에 대해 초청경비 } \\
\text { 일부 지원 }\end{array}$ & \\
\hline $\begin{array}{c}\text { 문예회관 } \\
\text { 기획·제작프로그램 }\end{array}$ & $\begin{array}{l}\text { 문예회관을 중심축으로 지역 예술단체 및 주민 등이 참여하 } \\
\text { 여 지역문화의 특성을 반영할 수 있는 공연, 전시, 특별 기 } \\
\text { 획프로그램을 기획. 제작 운영할 수 있도록 운영경비 일부 } \\
\text { 지원 }\end{array}$ & $\begin{array}{c}\text { 프로그램 특성에 따라 } \\
\text { 선정심사 시 } \\
\text { 지원 금액 결정 }\end{array}$ \\
\hline
\end{tabular}

자료: 한국문화예술회관연합회 웹사이트, https://mww.kocaca.or.kr/Pages/Business/Business01.aspx 
지역 문예회관의 시설 특성을 활용하여 문화소외지역 주민에게 다양한 문화예술 프로그램을 제공함으로써 문화 향유권 신장 및 문화 양극화 해소에 기여하는 것을 목적으로 한다. 지역주민의 예술향유뿐만 아니라 지역 특성에 맞는 기획 공연 제작 과 창작·유통 역량 강화를 통해 지역 문예회관의 운영도 활성화하고자 한다.

'방방곡곡 문화공감' 은 민간 예술단체 우수공연 프로그램, 국·공립 예술단체 우수 공연 프로그램, 문예회관 기획·제작 프로그램으로 구성되며, 공모를 통해 예술단체 의 프로그램을 선정하고 문예회관이 다시 프로그램을 신청하는 방식이다. 서울 지 역 문예회관은 지원대상에서 제외되다가, 2018년부터 '문예회관 기획·제작 프로그 램'만 신청할 수 있다. 직접지원대상은 문예회관과 공연단체이며 간접수혜대상은 지역주민이다. 지방 문예회관을 중심으로 지원한다는 점에서 지리적인 제약 요인을 기준으로 한다는 것을 알 수 있으며, 지자체의 재정자립도에 따라 차등 지원하고 소외계층을 초대하는 등 경제적인 요인도 고려한다.

사업실적으로 2019년 지원기관수는 511개, 지원작품 수는 285개이며 프로그램 진행횟수는 2,139 회이다. 수혜인원은 700,690 명에 소외계층은 190,581 명으로 $27 \%$ 이다.

〈표 5-38〉 방방곡곡 문화공감 지역별 수혜자수(소외계층포함, 2019)

\begin{tabular}{|c|c|c|c|}
\hline 지역 & 수혜자수(소외계층) & 지역 & 수혜자수(소외계층) \\
\hline 강원 & 78,334명(14,625명) & 세종 & 1,305명(394명) \\
\hline 경기 & 108,286명(28,988명) & 울산 & 12,842명(2,934명) \\
\hline 경남 & 59,245명(17,812명) & 인천 & 20,570명(4,197명) \\
\hline 경북 & 70,742명(20,087명) & 전남 & 49,478명(16,012명) \\
\hline 광주 & 13,506명(2,162명) & 전북 & 48,945명(10,427명) \\
\hline 대구 & 63.711명(12,222명) & 제주 & 14,609명(4,366명) \\
\hline 대전 & 8,483명(1,574명) & 충남 & 47,972명(21,156명) \\
\hline 부산 & 45,460명(15,186명) & 충북 & 32,775명(12,932명) \\
\hline 서울 & 20,927명(5,507명) & 대구경북지회 & 3,500명 \\
\hline & 계 & \multicolumn{2}{|c|}{ 700,690명(190,581명) } \\
\hline
\end{tabular}

자료: 2019 문예회관과 함께하는 방방곡곡 문화공감 사업 결과보고서, 40쪽. 
〈표 5-39〉 '예술향유기회확대’ 중 예술향유 지원사업(2002)

(단위: 백만 원)

\begin{tabular}{c|c|c|c|c|c|c}
\hline $\begin{array}{c}\text { 세부 } \\
\text { 사업명 }\end{array}$ & 내역사업명 & 운영기관 & 예산 & 목적 & 수혜대상 & 지표/실적 \\
\hline \multirow{2}{*}[301]{} & $\begin{array}{c}\text { 통합문화이용권 } \\
\text { (문화누리카드) }\end{array}$ & $\begin{array}{c}\text { 한국문화예술 } \\
\text { 위원회 }\end{array}$ & 103,324 & $\begin{array}{c}\text { 문화격차 완화 및 삶의질 } \\
\text { 향상, 소외계층에게 문화 } \\
\text { 향유 비용 지원 }\end{array}$ & $\begin{array}{c}\text { 기초생환수급자 및 } \\
\text { 차상위계층 }\end{array}$ & $\begin{array}{c}\text { 예산 집행률 } \\
\text { (전액 미사용 비율) }\end{array}$ \\
\cline { 2 - 7 } \\
$\begin{array}{c}\text { 문화예술 } \\
\text { 향유지원 }\end{array}$ & $\begin{array}{c}\text { 신나는 } \\
\text { 예술여행 }\end{array}$ & $\begin{array}{c}\text { 한국문화예술 } \\
\text { 위원회 }\end{array}$ & 24,229 & $\begin{array}{c}\text { 문화 향유권 신장 및 } \\
\text { 문화 양극화 해소 }\end{array}$ & $\begin{array}{c}\text { 사회적.경제적·지리 } \\
\text { 적 문화소외계층 }\end{array}$ & $\begin{array}{c}\text { 예산 대비 참여 } \\
\text { 관객수, 참여 } \\
\text { 사회적 경제 조직수 }\end{array}$ \\
\cline { 2 - 7 } & $\begin{array}{c}\text { 방방곡곡 } \\
\text { 문화공감 }\end{array}$ & $\begin{array}{c}\text { 한국문화예술 } \\
\text { 회관연합회 }\end{array}$ & 15,750 & $\begin{array}{c}\text { 문화 향유권 신장 및 } \\
\text { 문화 양극화 해소 }\end{array}$ & $\begin{array}{c}\text { 사회적.경제적·지리 } \\
\text { 적 문화소외계층 }\end{array}$ & 참여관객수 \\
\hline
\end{tabular}

\section{2) 국민체육진흥기금: 생활체육활성화(체육·문화예술사업의 지원)}

(1) 문화예술 취약 분야 육성: 작은미술관 조성 및 운영지원

'작은미술관' 은 생활권 내 미술공간이 없는 지역의 공공 유휴공간을 활용하여 조 성한 소규모 미술관을 말한다. 한국문화예술위원회에서 주관하며, 국민체육진흥기 금 ‘문화예술 취약 분야 육성' 사업 예산 중 700백만 원을 사용한다. 2015년 시범 사업으로 시작해 2018년까지 15개소가 조성되었고, 2019년 1개, 2020년 2개가 신규 선정되었다. ${ }^{120)}$ 사업의 목적은 시각예술 공간이 절실한 지역 내 공공 유휴공 간을 작은미술관으로 조성·운영하도록 지원하여, 전국 곳곳에 미술문화가 도달할 수 있는 기반을 마련함으로써 국민의 시각예술향유기회를 확대하고자 하는 것이다. 사업은 신규조성(2개), 지속운영(4개), 전시활성화 지원(8개)으로 구성된다. 수혜대 상은 시각예술 소외지역 국민이며, 지원대상은 대상지 내 공공 유휴공간을 보유·운 영하는 중앙부처, 지자체 혹은 공공기관과 협약을 체결한 지역문화재단, 문화예술 분야 비영리법인, 사회적기업, 소셜벤처, 협동조합이다. 시각예술분야의 향유 기회 확대 목적과 함께 미술관이 없는 문화소외 지역주민의 지리적 접근성을 확대하는 선별적 복지형 성격이 있는 사업이다.

120) 한국문화예술위원회 2019, 2020 사업 지원심의 결과 공지를 확인했으며 지난 2년간 신규 조성 지원신 청이 저조했으나 2020년 공모에서는 8건으로 증가한 것이 확인되었다. 
(2) 문화예술 취약 분야 육성: 전시공간 활성화 지원

‘전시공간 활성화 지원’ 또한 국민체육진흥기금으로 운영하는 사업으로 한국문화 예술회관연합회에서 주관하며 예산은 2,100 백 원이다. 수도권에 집중된 전시프로 그램을 지역으로 확산하여 지역 유휴 전시공간의 가동률을 높이고, 지역주민에게 전시관람 기회를 주어 시각예술분야의 문화 향유 기회를 확대하는 것을 목적으로 한다. 지역 유휴 전시공간에 알맞은 전시프로그램을 매칭하고 경비를 지원한다. 전 시프로그램을 제공하는 기관, 단체 등과 문예회관, 생활문화센터 등 지역 내 전시공 간제공자를 매칭하는 형태로 운영한다. 수혜대상은 지역주민으로 다양한 전시프로 그램을 공급해 전시향유 기반시설의 편차를 해소하고자 한다.

(3) 문화예술 취약 분야 육성: 전시해설 인력 지원

한국문화예술회관연합회 주관 사업으로 미술전시에 대한 일반 관람객의 접근성 을 향상시키고, 작가들에게 창작활동을 병행할 수 있는 일자리을 지원하여 자생적 창작환경을 조성하고자 하는 2020 년 신규사업이다. 사업 예산은 1,400 백만 원이며 지원규모는 75 개 기관(2020년 기준)이다. 지원대상은 전시기관과 전시해설사로 미 술관, 문예회관 등에서 전시해설사를 고용할 경우 인건비(지원금 7:자부담3)를 지원 하는 방식으로 운영한다. 전시해설사로는 미술 전공 졸업생, 졸업예정자, 야간대학 원 재학생 또는 미술 작가, 미술 해설 경력자 등을 고용할 수 있다. 수도권 이외 지역의 전시기관은 자부담 비율(8:2)을 낮추는 방식으로 문화소외지역을 배려한다. 전시공간에 도슨트를 배치해 수혜대상인 일반 관람객의 미술에 대한 이해도를 높여 미술전시에 쉽게 접근할 수 있게 한다.

(4) 문화예술 취약 분야 육성: 작가와 함께하는 작은 서점 지원 2018년부터 진행중인 사업으로 (사)한국작가회의에서 주관하며 사업 예산은 1,000 백만 원이다. 문학 소비와 수요자를 확대해 작은서점을 활성화하는 것을 목적 으로 하는 한편 문학작가들의 일자리 창출 목적도 크다. 지원대상은 문학거점서점, 작은서점, 문학작가이며 수혜대상은 일반 참여시민이다. 작은서점과 문학작가가 매 칭해서 신청할 수 있으며 작가에게는 인건비를, 서점에는 문학 프로그램 운영비를 지원한다. 2018년에는 문학거점서점과 작은서점을 포함해 45개소, 2019년에는 23개소를 선정해 지원했다. 
〈표 5-40〉작가와 함께하는 작은 서점 지원사업 내용(2020)

\begin{tabular}{|c|c|c|c|}
\hline 구분 & 대상 & 항목 & 지원규모 \\
\hline \multirow{4}{*}{$\begin{array}{c}\text { 2020년 } \\
\text { 작가와 } \\
\text { 함께하는 } \\
\text { 작은서점 } \\
\text { 지원사업 }\end{array}$} & 문학거점서점 & 문학 프로그램 운영비 및 대관료 지원 & 80만원 $\times$ 7개월 \\
\hline & 작은서점 & 문학 프로그램 운영비 및 대관료 지원 & 70만원 × 7개월 \\
\hline & 상주문학작가 & $\begin{array}{c}\text { 인건비 지원 } \\
\text { * 기관부담 4대보험료 별도지원 }\end{array}$ & 200만원 $\times$ 7개월 \\
\hline & 파견문학작가 & 사례비 지원 & 30만원 $\times 2$ 회 $\times$ 7개월 \\
\hline
\end{tabular}

자료: 한국작가회의 웹사이트, 2020년 작가와 함께하는 작은서점 지원사업 신청 공고

(5) 문화예술 취약 분야 육성: 도서관 상주작가 지원

한국문화예술위원회에서 주관하며 문인에게 일자리와 안정적인 창작 여건 제공 을 통해 해당 지역의 문학 수요를 확대하는 목적의 사업으로 예산은 1,200 백만 원 이다. 2017년부터 시작되었으며 전국의 공공도서관에 문인이 상주하며 지역 주민 또는 아동·청소년을 대상으로 문학 향유를 돕는 문학 프로그램 운영할 수 있도록 지원한다. 신청 도서관에 상주작가의 인건비(월 2백만 원)와 프로그램 운영비를 지 원한다. ${ }^{121)}$ 지원대상은 공공도서관과 문학작가이며 수혜대상은 도서관 이용 국민 이다. 2017년에는 33개소, 2018년에는 35개소, 2019년에는 31개소가 참여했다.

121) 2020년 도서관 상주작가 지원사업 공모안내, https://www.arko.or.kr/m1_01/m2_01/m3_01/m4 _02.do?mode=view\&page=2\&cid=1602904\&sf_icon_category=cw00000019 
[그림 5-4] 도서관 상주작가 지원사업 참여 도서관(2019)

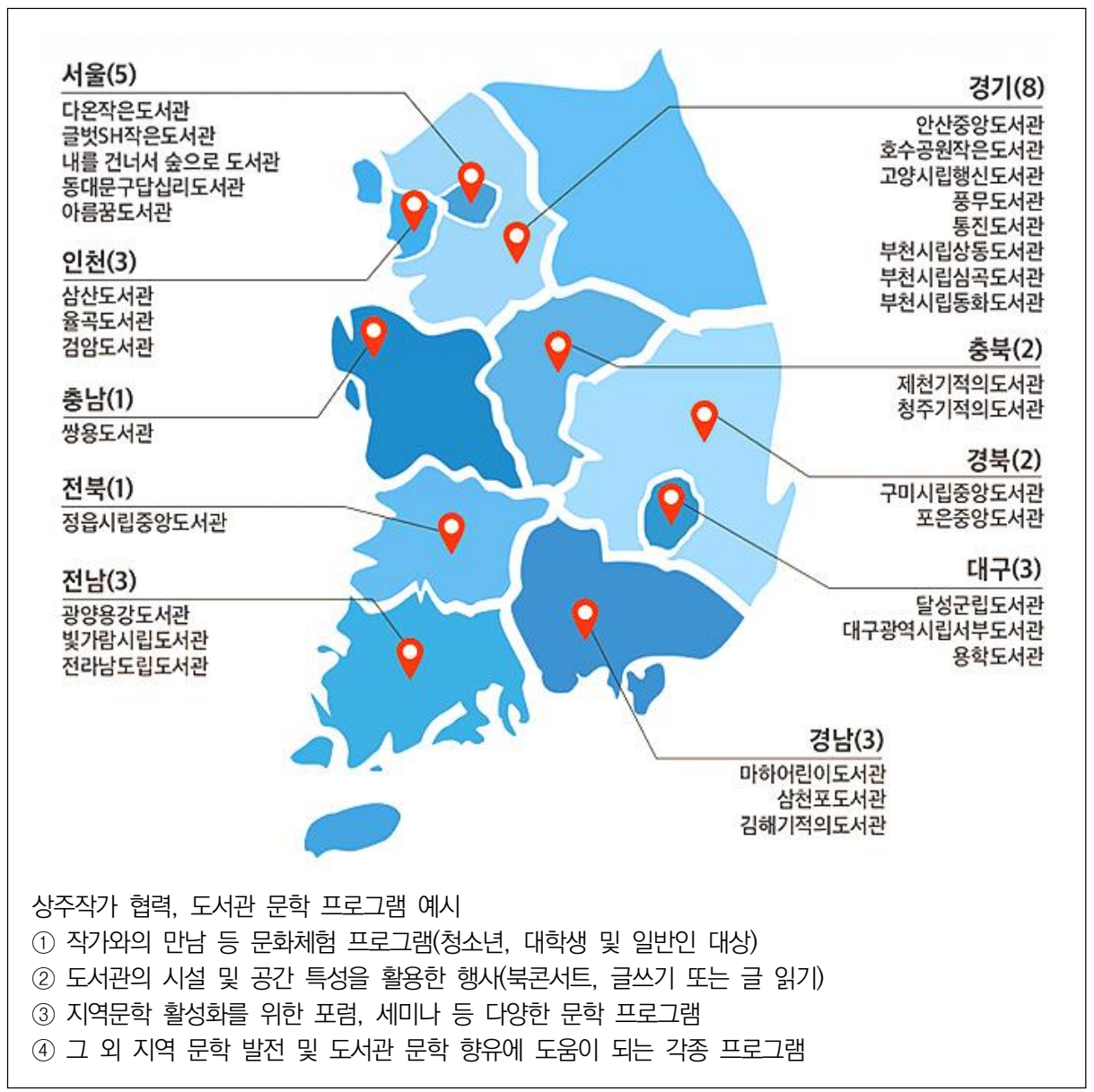

자료: 한국문화예술위원회, 주요사업안내, 2020년 도서관 상주작가 지원사업 공모안내

(6) 문화예술 취약 분야 육성: 노인요양시설 전통예술 프로그램 지원

전통공연예술진흥재단에서 주관하는 '노인요양시설 전통예술 프로그램 지원'사 업 또한 '문화예술 취약 분야 육성' 사업 예산으로 운영한다. 2018년부터 진행했으 며, 2020 년 예산은 1,400 백만 원이다. 사업의 목적은 전통예술프로그램을 통한 노 인복지 향상 및 전통예술 활성화이다.

장기요양기관 인증서를 보유한 요양원에서 신청할 수 있고 프로그램에 적합한 환 경을 갖춘 시설 60 개를 선정해 시설당 10 회 내외의 전통공연예술 프로그램을 진행 한다. 전통예술 프로그램 운영단체는 20 곳을 선정하며 회별로 1 시간 내외 프로그램 
으로 노인요양시설에 방문하여 공연한다. 2020년에는 노인요양공동생활가정을 대 상으로 전통예술 치유 연계형 프로그램을 개발하는 시범사업을 지자체와 연계해 운 영하는 등 전통예술의 사회적 기능 측면으로 확장하고 있다. 수혜대상은 노인요양 원 입소 노인 약 12,000 명, 노인요양공동생활가정 입소 노인 약 900 명, 주야간보 호서비스 이용노인 약 2,000명이다.122) 대표적인 방문형 사업인 '신나는 예술여행' 에서 대상(노인요양시설)과 분야(전통공연예술)가 한정된 유형이라 볼 수 있다.

(7) 문화예술 취약 분야 육성: 책 읽어주는 문화봉사단

'문화예술 취약 분야 육성' 예산 300백만 원으로 한국출판문화산업진흥원에서 운 영한다. 50세 이상의 예비 실버 세대와 실버 세대가 문화소외 계층에게 책 읽어주 기 문화 봉사활동을 통해 문화복지 수혜자에서 재능기부자로 사회와 소통하고 문화 를 향유하는 기회를 제공하고자 한다. 지역별로 10 개의 주관처를 선정해 전국 200 명 규모의 봉사단을 모집한다. 지역별로 전국 지역아동센터, 요양 어르신 및 장애 인, 다문화가정 등 소외계층 시설을 중심으로 방문한다.123) 수혜 규모는 총 33,600 여 명 $(12$ 회 주활동 $\times 200$ 명 $\times 14$ 명 이상)이며, 봉사단에는 회당 3 만원의 활동비를 지급한다.

(8) 문화예술 취약 분야 육성: 생활문화공동체만들기

'생활문화공동체만들기' 사업은 복권기금 문화나눔 사업으로 2009년 시작되어 한 국문화예술교육진흥원에서 운영하다, 2014년 한국문화원연합회로 이관되었으며, 2017년부터 지역문화진흥원(당시 생활문화진흥원)에서 운영한다. 재원은 2017년 까지 문예진흥기금 소외계층문화역량강화 예산(1,080백만 원)으로 운영되다가 2018년부터 국민체육진흥기금 ‘문화예술 취약 분야 육성' 예산으로 운영되고 있다.

'생활문화공동체만들기' 사업은 생활 속 문화예술 활동을 통해 지역의 문화·사회 적 격차를 해소하고, 공동체를 회복하여 건강한 지역문화를 만들고자 한다. 공동체 단위의 지원사업이지만 공동체를 통한 개개인의 삶의 문화적·사회적 가치 발견과 확산을 목표로 한다. 생활문화공동체란 '주민들이 일상생활 속에서 문화를 매개로

122) e나라도움 보조사업 상세현황, https://opn.gosims.go.kr/opn/ih/ih001/getlH001004QView.do 123) 독서in-책읽어주는 문화봉사단, https://www.readin.or.kr/home/volunteerlntro/contents.do 
한 자발적인 생활문화 활동을 통해, 주민 스스로 문화적인 삶을 향유하고, 이러한 활동을 중심으로 그들의 삶의 품격과 행복온도를 높여나가는 공동체'를 말한다.124) 주민 주도의 마을공동체 형성을 위한 일반 지원사업과 공동체 확산을 위한 지역네 트워크 지원사업을 중심으로 한다. 생활문화를 매개로 한 마을공동체 활동과 주민 참여 프로그램 운영비를 지원하며, 지원대상은 주민조직(공동체) 및 문화예술 단체, 기관, 시설이다. 선정된 단체는 3년까지 연속지원을 받을 수 있으며 지역협력네트 워크는 최대 2년까지 지원한다.

〈표 5-41〉 생활문화공동체 지원사업 구성

\begin{tabular}{|c|c|c|c|}
\hline & 연속지원 & 신규지원 & 지역협력네트워크지원 \\
\hline \multirow[t]{2}{*}{ 지원대상 } & \multirow[t]{2}{*}{$\begin{array}{c}\text { 2019년 동사업을 추진한 } \\
\text { 1년차(7개) 2년차 (28개) 총 } \\
\text { 35개 단체 }\end{array}$} & $\begin{array}{l}\text { 마을단위 주민조직 및 } \\
\text { 문화예술 단체·기관·시설 }\end{array}$ & $\begin{array}{c}\text { 생활문화공동체만들기 지원사업의 } \\
\text { 경험이 있는 주민조직 및 멘토 } \\
\text { 마을의 역량을 갖춘 주민조직, } \\
\text { 문화예술 단체·기관·시설 } \\
\text { (교류마을 2곳 이상 필수) }\end{array}$ \\
\hline & & \multicolumn{2}{|c|}{$※$ 고유번호증 또는 사업자등록증 보유 단체만 지원가능 } \\
\hline 지원내용 & $\begin{array}{l}\text { 2년차: 생활문화공동체 성장 } \\
\text { 및 일상화를 위한 지원 } \\
\text { 3년차: 생활문화공동체 자생력 } \\
\text { 및 지속력 확대 활동 지원 }\end{array}$ & $\begin{array}{c}\text { 마을을 기반의 공동체 형성을 } \\
\text { 위한 주민 주도의 다양한 } \\
\text { 생활문화 활동 }\end{array}$ & $\begin{array}{c}\text { 인근 마을의 공동체 발굴 및 } \\
\text { 확산을 지원 } \\
\text { 인근 마을 공동체 간의 협력, 동반 } \\
\text { 성장을 위한 활동 및 프로그램 }\end{array}$ \\
\hline 지원기간 & 최대 3년까지 지원 가능 & 최대 3년까지 지원 가능 & 최대 2년까지 지원 가능 \\
\hline 지원규모 & 15백 40백만 원 & 15백 25백만 원 & 20백 25백만 원 \\
\hline 선정규모 & 18개소 내외 & 22개소 내외 & 7개소 내외 \\
\hline
\end{tabular}

사업 진행에 있어서 민주성, 공공성, 주체성, 일상성을 중요하게 고려하며, 행복 온도(삶의 만족도)를 성과로 제시하는 점이 특징이다. 2017 생활문화공동체만들기 성과평가보고서에 따르면 사업참여 마을의 행복온도(삶의 만족도)는 $78^{\circ} \mathrm{C}$ 로 일반 마을의 $68.3^{\circ} \mathrm{C}$ 보다 $9.7^{\circ} \mathrm{C}$ 높은 것으로 나타났다.

124) 지역문화진흥원 웹사이트 사업안내, http://www.rcda.or.kr/business/business4_new.asp 
(1) 민주성: 모든 개인의 의견이 존중되며, 모든 사람들이 참여할 수 있는 수평적인 논의체계를 구성 해야함

(2) 공공성: 몇몇 주민의 사적 이익을 추구하거나, 보편적 복지차원의 접근방식의 활동은 제외하며 반드시 모든 주민을 위한 공공성을 포함해야함

(3) 주체성: 주민들이 단순 관객이나, 프로그램의 혜택만 받는 수혜자가 아닌 주체적으로 활동에 대한 의 견을 제시하고, 직접 기획하며, 프로그램을 만들어가는 과정에도 직접 참여할 수 있도록 사업계획을 설계해야함. 단발성 행사, 단순 관람형 교육 등 나열식 프로그램은 지원 제외함

(4) 일상성: 마을의 범위를 걸어서 10-15분 거리의 범위로 한정하며, 일상생활에서 마주칠 수 있는 거리 에서 일상적인 활동으로 주민들과 공동체 활동을 추진해야함 ※ 전담인력 및 핵심인력은 반드시 마을에 거주하거나, 생활기반을 가지고 있어야 함

〈표 5-43〉'생활체육 활성화' 중 예술향유 지원사업(2020)

(단위: 백만 원)

\begin{tabular}{|c|c|c|c|c|c|c|c|}
\hline $\begin{array}{l}\text { 세부 } \\
\text { 사업명 }\end{array}$ & & 내역사업명 & 운영기관 & 예산 & 목적 & 수혜대상 & 지표/실적 \\
\hline \multirow{8}{*}{$\begin{array}{l}\text { [307] } \\
\text { 체육·문화 } \\
\text { 예술사업 } \\
\text { 의 지원 }\end{array}$} & \multirow{8}{*}{$\begin{array}{l}\text { 문화 } \\
\text { 예술 } \\
\text { 취약 } \\
\text { 분야 } \\
\text { 육성 }\end{array}$} & $\begin{array}{l}\text { 작은미술관 조성 } \\
\text { 및 운영지원 }\end{array}$ & $\begin{array}{l}\text { 한국문화예술 } \\
\quad \text { 위원회 }\end{array}$ & 700 & $\begin{array}{c}\text { 국민의 시각예술 향유기회 } \\
\text { 확대 }\end{array}$ & $\begin{array}{c}\text { 시각예술 } \\
\text { 소외지역 국민 }\end{array}$ & \\
\hline & & $\begin{array}{l}\text { 전시공간 활성화 } \\
\text { 지원 사업 }\end{array}$ & $\begin{array}{l}\text { 한국문화예술 } \\
\text { 회관연합회 }\end{array}$ & 2,100 & $\begin{array}{c}\text { 전시 향유 기반시설 } \\
\text { 편차해소, 수도권에 집중된 } \\
\text { 전시프로그램을 지역으로 } \\
\text { 확산, 전시 관람기회 확대 }\end{array}$ & 지역주민 & $\begin{array}{l}\text { 전시공간, } \\
\text { 전시프로그램 }\end{array}$ \\
\hline & & $\begin{array}{l}\text { 전시해설 } \\
\text { 인력 지원 }\end{array}$ & $\begin{array}{l}\text { 한국문화예술 } \\
\text { 회관연합회 }\end{array}$ & 1,400 & $\begin{array}{c}\text { 일반 관람객들의 미술전시 } \\
\text { 접근성 낮은 실태 해소, 전업 } \\
\text { 작가 창작활동 병행 일자리 } \\
\text { 지원 }\end{array}$ & 전시 관람객 & \\
\hline & & \begin{tabular}{|l} 
작가와 함께하는 \\
작은서점 지원
\end{tabular} & $\begin{array}{l}\text { (사)한국작가 } \\
\quad \text { 회의 }\end{array}$ & 1,000 & $\begin{array}{c}\text { 문학소비·수요자확대, } \\
\text { 작은서점 활성화, 일자리 } \\
\text { 창출 }\end{array}$ & $\begin{array}{l}\text { 문학작가, } \\
\text { 일반 시민 }\end{array}$ & \\
\hline & & $\begin{array}{c}\text { 도서관 상주작가 } \\
\text { 지원 }\end{array}$ & $\begin{array}{l}\text { 한국문화예술 } \\
\text { 위원회 }\end{array}$ & 1,200 & $\begin{array}{c}\text { 문인 일자리 창출, 지역문학 } \\
\text { 수요자 확대 }\end{array}$ & $\begin{array}{l}\text { 도서관 이용 } \\
\text { 국민 }\end{array}$ & \\
\hline & & $\begin{array}{l}\text { 노인요양시설 } \\
\text { 전통예술 } \\
\text { 프로그램 지원 }\end{array}$ & $\begin{array}{l}\text { (재)전통공연 } \\
\text { 예술진흥재단 }\end{array}$ & 1,400 & $\begin{array}{l}\text { 노인복지 향상 및 } \\
\text { 전통예술 활성화 }\end{array}$ & $\begin{array}{l}\text { 노인요양원, } \\
\text { 보호시설 등 } \\
\text { 노인 }\end{array}$ & - \\
\hline & & $\begin{array}{l}\text { 책 읽어주는 } \\
\text { 문화봉사단 }\end{array}$ & $\begin{array}{l}\text { 한국출판문화 } \\
\text { 산업진흥원 }\end{array}$ & 300 & $\begin{array}{l}\text { 문화소외계층에게 책 } \\
\text { 읽어주기 활동을 통해 } \\
\text { 문화향유 기회 제공 }\end{array}$ & $\begin{array}{l}\text { 50대 이상 } \\
\text { (예비) } \\
\text { 실버세대 }\end{array}$ & \\
\hline & & $\begin{array}{c}\text { 생활문화공동체 } \\
\text { 만들기 }\end{array}$ & $\begin{array}{l}\text { 지역문화 } \\
\text { 진흥원 }\end{array}$ & 1,300 & $\begin{array}{c}\text { 지역관계망 형성 및 } \\
\text { 지역문화발전도모, } \\
\text { 개개인의삶의 } \\
\text { 문화적·사회적가치발견 및 } \\
\text { 확산을 통한 삶의질 제고 }\end{array}$ & 지역주민 & \\
\hline
\end{tabular}




\section{2. 사업목적과 내용에 따른 (유형) 분석125)}

앞서 문화체육관광부의 예술향유 지원사업을 목적, 예산, 수혜대상, 성과지표·실 적을 중심으로 살펴보았다. 주지하다시피 이들 일련의 향유지원 사업들의 태생 및 정책내용의 구성, 그리고 사업수행 구조 등은 ‘예술정책'이란 거시적·총체적 관점에 서 '향유' 지원 필요성에 대한 종합적이고 포괄적인 정책비전이나 체계 하에서 이뤼 진 것은 아니었다. 세밀한 정책설계에 기반을 둔 것이기 보다는 그 때 그 때 정책적 수요와 필요에 의해 '단위사업' 중심으로 향유지원사업들이 구조화되어 왔기 때문 이다. 이러한 그간의 맥락을 고려한다면, 이들 사업을 포괄적 관점에서 배타적 기준 설정에 의해 종합적으로 유형화한다는 것은 거의 불가능에 가깝다. 그럼에도 불구 하고, 현재 이러한 예술향유 지원사업들의 성격 및 문제점들을 한 눈에 조망해보기 위해 본 연구에서는 일부 유형 분류를 시도해보았다.126)

우선 본 연구에서 이들 사업 유형분류 시도에 있어 주요하게 적용된 기준은 '정책 적 관점에서의 사업 목적', 그리고 '정책의 공급자 관점에서 수혜자를 지원하는 사 업의 내용'이다. 이에 따라 사업 목적에 따른 보편적 복지형와 선별적 복지형 2가지 유형, 그리고 사업 내용에 따른 교육지원형과 활동지원형 등 2 가지 유형으로의 1 차 적 구분이 가능할 수 있다.

우선 정책 사업의 목적에 따라 살펴보면 보편적 복지형, 그리고 선별적 복지형으 로 구분하여 볼 수 있다.127) 보편적 복지형 사업은 불특정 일반 국민을 대상으로 하는 문화예술향유 기회 확대와 삶의 질 향상을 목표로 내세우는 캠페인형 사업과 예술향유 관련 물리적인 기초 인프라를 확보하고 연계하는 공간기반형과 인력배치 형 사업을 말한다. 특히 '문화가 있는 날'과 같은 캠페인형 사업은 기존의 공연장, 전시장을 벗어난 거리, 건물 로비, 공원 등 탈장소성을 추구하며 전 국민을 수혜대 상으로 보고 향유활동을 확산하고자 하는 의도를 표방한다. 주로 무료 및 할인 정책

125) 유형별 지원사업 세부 분석에서의 예산자료는 국가보조금 기준 e나라도움에서 확인된 사업별 계획상 예산액 수치 중심으로 하였다. 이에 앞서 재정 지원구조 분석에서 제시된 문체부 예산기금운용 계획상에 제시된 수치와 차이가 있음을 밝힌다.

126) 이들 분류는 본 연구에서 진행한 '분류 및 구분 시도'에 한정된 것으로 현재 중앙주도 예술향유지원사업 의 완결된 유형 분석으로 해석될 수는 없음을 밝힌다.

127) 정책사업 목적에서의 ‘보편적' '선별적’을 구분한 이유는 해당사업 태생 당시 표방된 ‘정책목적’이 명확 했다는 점에 주목했다. 
을 통해 진입장벽을 낮추고 캠페인성 사업을 통해 문화예술을 접한 국민들이 예술 향유자와 애호가로 거듭날 수 있게 하는 잠재적인 수요 확대 목적을 담고 있다.

선별적 복지형 사업은 기존의 복권기금 문화나눔 예산으로 진행되었던 한국문화 예술위원회의 '문화예술향유지원'사업으로 경제적 취약계층만 한정해서 문화예술분 야의 진입장벽을 낮추기 위해 수혜대상을 직접적으로 지원하는 '바우처형' 사업과 경제적 제약보다는 지리적, 사회적 접근성에 제약을 받는 문화소외계층을 대상으로 이들이 위치한 곳으로 직접 '찾아가서' 공연 중심의 관람 기회를 제공하는 '방문형' 으로 구분된다. 현재는 '바우처형'사업만 복권기금으로 운영되며 '방문형'사업은 2018년부터 복권기금에서 문화예술기금으로 재원이 바뀌면서 사업의 성격도 선별 적 복지형 사업에서 일반 시민 대상의 보편적 복지형이 혼재되어 있는 양상을 보이 고 있다.

다음으로 정책 사업의 내용 중심으로 살펴보면, 교육지원형과 활동지원형으로 구 분하여 볼 수 있다. 128) 교육 지원형 사업은 문체부의 세부사업 '문화예술교육 활성 화'에 속하는 사업들로 생애주기형 문화예술교육을 통해 개인의 취향을 개발하고 예술향유의 토대를 형성한다는 궁극적인 목적을 지닌다. 학교문화예술교육, 사회문 화예술교육, 지역문화예술교육, 인력 양성과 같은 기존의 지원사업 분류 체계가 유 형에도 적용되었다. 교육 지원형 사업은 문화예술교육의 특성상 교육, 체험, 감상, 활동, 발표 등 다양한 향유 유형을 포괄한다는 특징이 있다.

활동 지원형 사업은 개인의 능동적 향유 활동을 진작하고 지역연계를 통한 사회 적 가치 확산을 목적으로 하는 사업 유형이다. 교육 프로그램을 통해 형성된 소규모 의 모임이나 취미로 규모가 있는 동호회에 참여해 창작 활동을 하며 공연이나 전시 발표를 하고 공동체와 지역사회참여로 이어지는 활동의 형태별로 구분하였다. 동호 회 활동을 지원하는 사업은 중앙 단위보다는 광역지자체나 기초지자체에서 주로 이 뤄지기 때문에 사업의 가짓수는 많지 않으나, 교육 지원형이나 보편적 복지형 사업 내에서도 다양하게 동아리, 동호회 등의 참여 활동을 지원하는 내용이 포함되어 있 다. 창작 및 발표형은 동호회 등의 단위가 모여 네트워킹을 하며 축제 형식의 발표 회나 전시회를 하는 유형으로 사업으로 단일 사업으로 분류되기 보다는 동호회 활

128) 교육지원형 사업과 활동지원형 사업들은 각각 보편적 복지 성격 및 선별적 복지의 성격을 동시에 가지고 있기도 함을 유념할 필요가 있다. 
동형이나 교육 지원형, 기타 지역문화 사업에 포함되어 진행되는 경우가 많다.

예산 지원규모 별로 살펴보면 사업수는 많지 않지만 지원규모가 큰 통합문화이용 권이 포함된 선별적 복지형이 144,703 백만 원이며, 다음으로는 교육 지원형이 128,901 백만 원, 보편적 복지형은 57,909 백만 원이다. 활동 지원형 사업의 예산은 7,623백만 원으로 유형별로 예산 규모에는 차이가 있다.129)

〈표 5-44〉 예술향유 지원사업 유형 분류(2020)

(단위: 백만 원)

\begin{tabular}{|c|c|c|c|c|c|}
\hline 구분 & & |부유형 및 사업내용 & 대상 & 지원목적 & 예산 \\
\hline \multirow{3}{*}{$\begin{array}{l}\text { 보편적 } \\
\text { 복지형 }\end{array}$} & 캠페인형 & $\begin{array}{l}\text {-특정일, 기간을 활용한 전 국민 향 } \\
\text { 유 기회 확대를 통한 인식 제고 } \\
\text {-문화시설기반 및 탈장소적 향유 프 } \\
\text { 로그램 공급 }\end{array}$ & \multirow{3}{*}{ 일반시민 } & \multirow{3}{*}{$\begin{array}{l}\text {-범국민 예술향유활동 } \\
\text { 확산관람형 향유 및 } \\
\text { 일상적 향유) } \\
\text {-예술향유 관련 물리 } \\
\text { 적 기초인프라 확보 }\end{array}$} & \multirow{3}{*}{57,909} \\
\hline & 공간기반형 & $\begin{array}{l}\text { 공간과 장소를 활용한 지리적, 심리 } \\
\text { 적 제약을 해소하는 일상적 향유 } \\
\text { 제공 }\end{array}$ & & & \\
\hline & 인력 연계형 & $\begin{array}{l}\text { 시간적 제약 해소와 공간 활용을 통 } \\
\text { 한 예술향유를 위한 인건비 지원 }\end{array}$ & & & \\
\hline \multirow{2}{*}{$\begin{array}{l}\text { 선별적 } \\
\text { 복지형 }\end{array}$} & 바우처형 & $\begin{array}{l}\text { 향유를 위한 비용 직접 지원(통합문 } \\
\text { 화이용권) }\end{array}$ & $\begin{array}{l}\text { 경제적 } \\
\text { 취약계층 }\end{array}$ & $\begin{array}{l}\text { 기초생활수급자와 차 } \\
\text { 상위 계층의 접근성 제 } \\
\text { 약요소 해소 }\end{array}$ & \multirow[t]{2}{*}{144,703} \\
\hline & 방문형 & $\begin{array}{l}\text { 문화소외지역을 직접 찾아가서 문화 } \\
\text { 예술관람 기회 제공 }\end{array}$ & $\begin{array}{c}\text { 지리적 사회적 } \\
\text { 취약계층 } \\
\end{array}$ & $\begin{array}{l}\text { 지리적, 물리적 접근 } \\
\text { 제약요소 해소 }\end{array}$ & \\
\hline \multirow{4}{*}{$\begin{array}{l}\text { 교육 } \\
\text { 지원형 }\end{array}$} & $\begin{array}{c}\text { 학교문화예술교육 } \\
\text { 활성화 }\end{array}$ & $\begin{array}{l}\text { 어린이집, 유치원, 초중고 교육과정 } \\
\text { 내에서의 예술교육 기회 제공 }\end{array}$ & \multirow{4}{*}{$\begin{array}{l}\text { 일반시민 } \\
+ \text { +취약계층 } \\
\text { 투트랙 }\end{array}$} & \multirow{4}{*}{$\begin{array}{l}\text { 개인의 기초 예술향유 } \\
\text { 선호 및 취향 개발 }\end{array}$} & \multirow{4}{*}{128,901} \\
\hline & $\begin{array}{c}\text { 사회문화예술교육 } \\
\text { 활성화 }\end{array}$ & $\begin{array}{l}\text { 사회적 취약계층과 일반 시민 대상의 } \\
\text { 문화예술교육경험 제공 }\end{array}$ & & & \\
\hline & $\begin{array}{c}\text { 지역문화예술교육 } \\
\text { 지원 }\end{array}$ & $\begin{array}{l}\text { 지역문화예술교육 기반 조성 및 지역 } \\
\text { 자원활용 교육 활성화 }\end{array}$ & & & \\
\hline & 인력 지원 & 전문인력 연수 및 인력 활용 & & & \\
\hline \multirow{3}{*}{$\begin{array}{l}\text { 활동 } \\
\text { 지원형 }\end{array}$} & 동호회 활동형 & 자발적인 문화예술참여 활동 지원 & \multirow{3}{*}{ 일반시민 } & \multirow{3}{*}{$\begin{array}{l}\text {-개인의 능동적 향유 } \\
\text { 진작, 향유활동 저변 } \\
\text { 확대 } \\
\text {-지역연계를 통한 사 } \\
\text { 회적 가치 확산 }\end{array}$} & \multirow{3}{*}{7,623} \\
\hline & 창작 및 발표형 & 창작, 전시, 실연 기회 제공 & & & \\
\hline & 지역사회연계형 & 문화자원봉사 및 공동체 활동 지원 & & & \\
\hline \multicolumn{5}{|c|}{ 합계 } & 339,136 \\
\hline
\end{tabular}

129) 사업 분류와 예산은 e나라도움을 기준이며, 문체부 직접사업은 2020년 예산기금운용계획을 기준이다. 


\section{가. 보편적 복지형}

보편적 복지형 사업은 크게 캠페인형, 공간기반형, 인력연계형 3가지로 구분할 수 있다. 캠페인형은 다시 인식 제고형과 프로그램 공급형으로 분류가 되는데, 인식 제고형은 특정한 날이나 특정 기간 동안 행사를 개최하거나 무료관람이나 할인형의 혜택을 제공하는 사업으로 문화가 있는 날, 미술창작 및 향유지원 사업 중 '미술주 간 운영'와 같은 유형이다. 문체부에서 운영하는 여가친화기업제도도 캠페인의 성 격이 있다고 보아, '여가친화기업선정지원'사업도 포함시켰다. 프로그램 공급형은 매월 마지막주 수요일 '문화가 있는 날'과 그 주말, 10 월 초 미술주간과 같은 특정 기간에 문화예술 향유 프로그램을 국민들에게 공급하는 유형의 사업으로 문화가 있 는 날 기획프로그램 운영 지원, 국·공립 문화시설 문화가 있는 주말 프로그램 운영, 미술창작 및 향유지원 사업 중 '작가 미술장터 개설 지원'사업이 속한다.

공간기반형 사업에는 시각미술 분야의 지리적 제약을 해소하기 위한 작은미술관 조성 및 운영지원, 전시공간 활성화 지원 사업, 특정 공간은 아니지만 장소성과 일 상성이 강한 사업으로 공공미술 프로젝트를 운영하는 '마을미술 프로젝트'사업을 포함시켰다.

보편적 복지형 사업 중에는 국민체육진흥기금 '문화예술 취약 분야 육성' 예산 사 업이 다수를 차지하는데 사업명에는 취약 분야로 명시되어 있지만 완전한 복지형 사업은 아니며, 유사한 형태의 인력 연계형 사업을 다수 운영하고 있는 것으로 나타 났다. 대부분 문화시설이나 공간에 작가, 예술인 등의 인력을 상주하게 하거나 파견 해 대상 시설을 이용하는 시민들이 문화예술을 체험할 수 있게 하는 유형의 사업으 로 전시해설 인력 지원, 작가와 함께하는 작은서점 지원, 도서관 상주작가 지원이 해당하며 해당 분야 예술인의 일자리 창출 목적도 겸한다. 문체부에서 주관하는 국. 공립 문화시설 개관시간 연장, 휴관없는 국립박물관.미술관 운영 사업 또한 야간개 장과 휴일개장을 위해 추가 근무인력의 인건비를 지원한다. 보편적 복지형 사업 예 산 총액은 57,909 백만 원이다. 


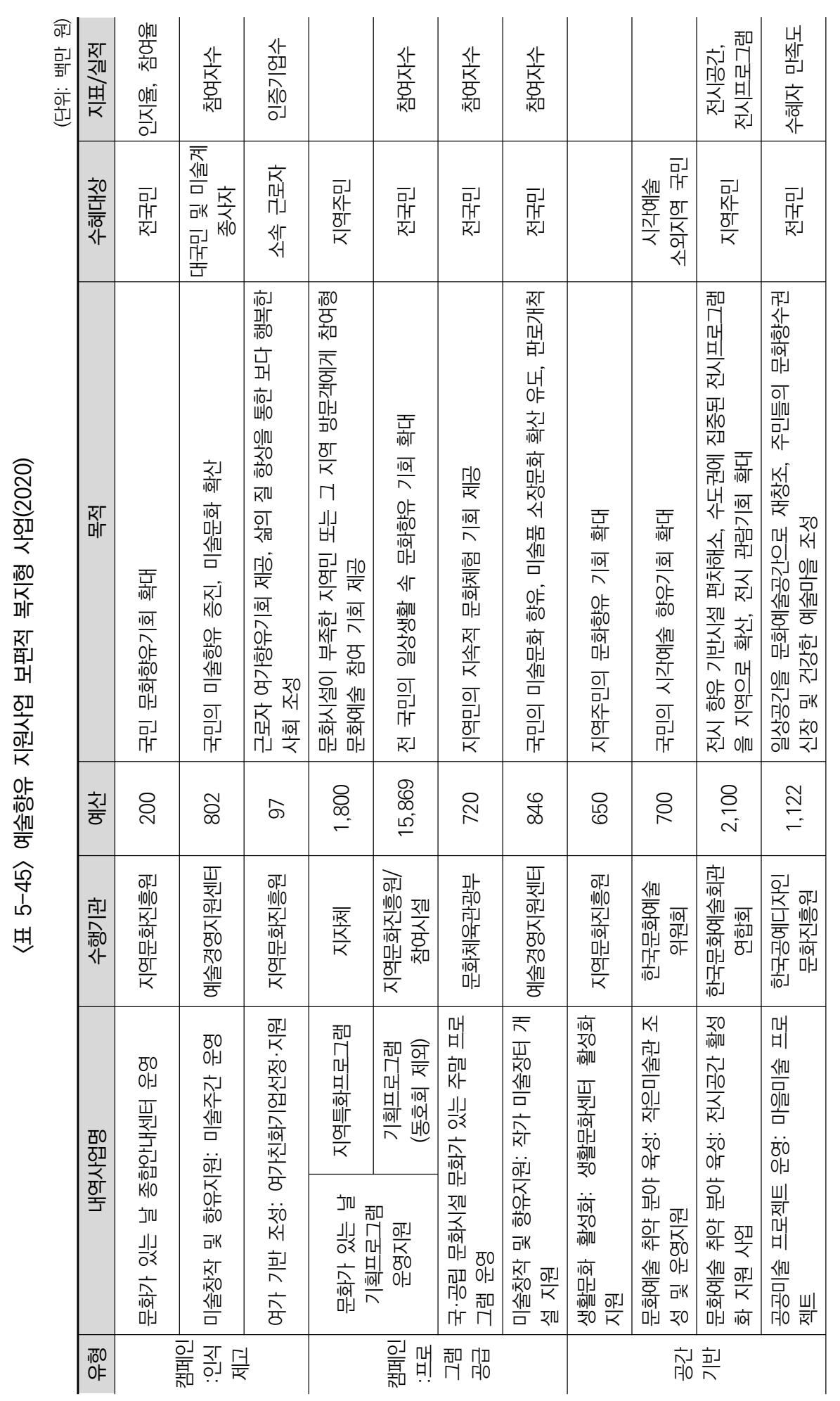




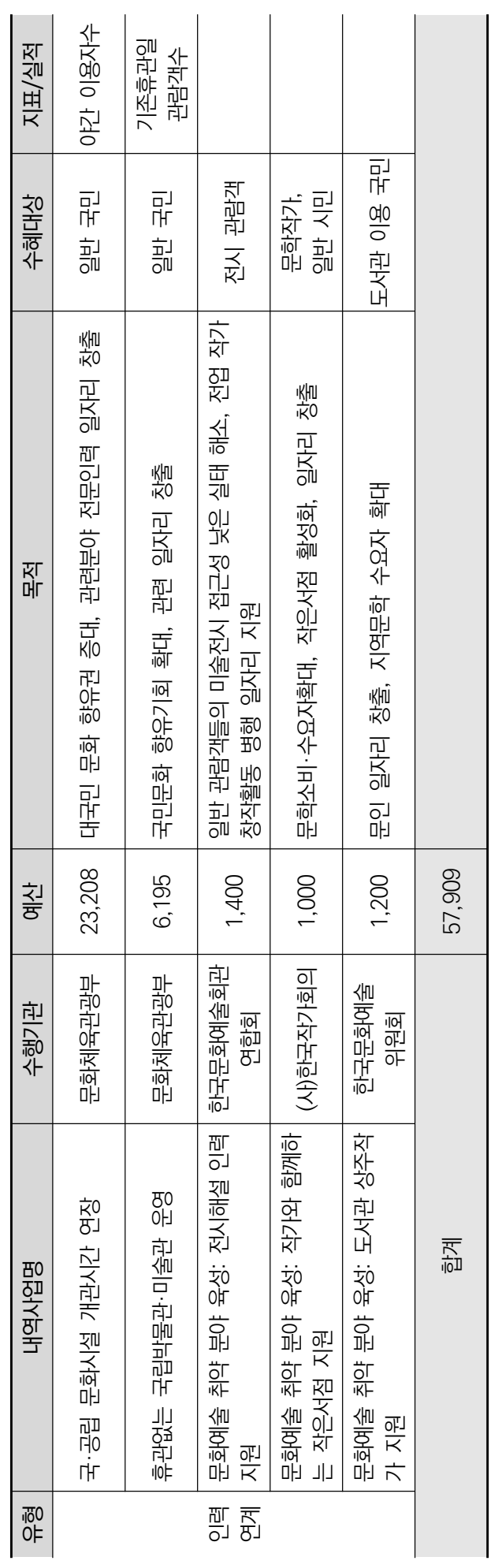




\section{나. 선별적 복지형}

선별적 복지형 사업은 크게 바우처형과 방문형, 2가지 유형으로 구분된다. 첫째 는 바우처형으로 복권기금으로 운영하는 통합문화이용권 사업이 이에 해당한다. 경 제적 소외 계층을 대상으로 직접 지원금을 지급하는 사업은 바우처형이 유일하다. 방문형 사업으로는 '방방곡곡 문화공감'과 ‘신나는 예술여행'이 해당되며, 이들 사 업은 대표적으로 복권기금 문화나눔 사업으로 운영될 당시에는 '신나는 예술여행' 사업명에 '소외계층'이라는 단어가 있을 정도로 문화복지사업의 성격이 강했으나, 2018년부터 두 사업 모두 문화예술진흥기금으로 운영되기 시작하면서 일반인으로 수혜대상이 점차 확대되고 있으며, 지역 문예회관 활성화라든가 예술단체 지원을 통한 창작 활성화와 같은 사업의 2 차적인 목적도 강조되는 상황이다. 선별형 복지형 사업 예산 규모는 144,703 백만 원이다.

〈표 5-46〉 예술향유 지원사업 선별적 복지형 사업(2020)

\begin{tabular}{|c|c|c|c|c|c|c|}
\hline 구분 & 내역사업명 & 운영기관 & 예산 & 목적 & 수혜대상 & $\begin{array}{c}\text { (단위: 백만 원) } \\
\text { 지표/실적 }\end{array}$ \\
\hline $\begin{array}{l}\text { 바 } \\
\text { 우 } \\
\text { 처 } \\
\text { 형 }\end{array}$ & $\begin{array}{l}\text { 통합문화이용권 } \\
\text { (문화누리카드) }\end{array}$ & $\begin{array}{c}\text { 한국문화예술 } \\
\text { 위원회 }\end{array}$ & 103,324 & $\begin{array}{c}\text { 문화격차 완화 및 } \\
\text { 삶의질 향상, } \\
\text { 소외계층에게 문화 } \\
\text { 향유 비용 지원 }\end{array}$ & $\begin{array}{c}\text { 기초생활수급자 및 } \\
\text { 차상위계층 }\end{array}$ & \begin{tabular}{|c} 
지원액, 이용건수, \\
예산 집행률
\end{tabular} \\
\hline \multirow{3}{*}{$\begin{array}{l}\text { 방 } \\
\text { 문 } \\
\text { 형 }\end{array}$} & $\begin{array}{l}\text { 방방곡곡 } \\
\text { 문화공감 }\end{array}$ & $\begin{array}{l}\text { 한국문화예술 } \\
\text { 회관연합회 }\end{array}$ & 15,750 & $\begin{array}{c}\text { 문화 향유권 신장 및 } \\
\text { 문화 양극화 해소 }\end{array}$ & $\begin{array}{l}\text { 사회적·경제적·지리 } \\
\text { 적 문화소외계층 }\end{array}$ & 참여관객수 \\
\hline & $\begin{array}{l}\text { 신나는 } \\
\text { 예술여행 }\end{array}$ & $\begin{array}{l}\text { 한국문화예술 } \\
\quad \text { 위원회 }\end{array}$ & 24,229 & $\begin{array}{c}\text { 문화 향유권 신장 및 } \\
\text { 문화 양극화 해소 }\end{array}$ & $\begin{array}{l}\text { 사회적·경제적·지리 } \\
\text { 적 문화소외계층 }\end{array}$ & \begin{tabular}{|c} 
예산 대비 참여 \\
관객수, 참여 \\
사회적 경제 \\
조직수
\end{tabular} \\
\hline & $\begin{array}{c}\text { 문화예술 취약 분야 } \\
\text { 육성: 노인요양시설 } \\
\text { 전통예술 프로그램 } \\
\text { 지원 }\end{array}$ & \begin{tabular}{|c} 
(재)전통공연예 \\
술진흥재단
\end{tabular} & 1,400 & $\begin{array}{l}\text { 노인복지 향상 및 } \\
\text { 전통예술 활성화 }\end{array}$ & $\begin{array}{c}\text { 노인요양원, } \\
\text { 보호시설 등 노인 }\end{array}$ & - \\
\hline \multicolumn{3}{|c|}{ 합계 } & 144,703 & & & \\
\hline
\end{tabular}




\section{다. 교육 지원형}

교육 지원형 사업은 크게 학교문화예술교육 활성화, 사회문화예술교육 활성화, 지역문화예술교육 지원, 인력 지원으로 구분한다. 이는 지원대상이나 목적에 따른 분류라기보다는 사업을 주관하는 한국문화예술교육진흥원의 사업 분류 체계에 가 깝다.

개별사업 내에서는 아동, 노인, 장애인, 일반시민 등으로 수혜대상이 세분화 된 다. 다수의 사업을 한국문화예술교육진흥원에서 주관하고 있으며 한국문화예술회관 연합회에서 주관하는 사업은 3 개이다. 학교문화예술교육 활성화 사업은 전국 초. 중·고등학교 등의 재학생과 유치원, 어린이집 유아를 대상으로 운영하며 예술강사 를 파견하는 방식이다. 예술꽃 씨앗학교 운영 사업은 문화소외지역 학교를 대상으 로 학교 단위에서 주체적으로 프로그램을 구성해 운영한다. 사회문화예술교육 활성 화 사업에는 기존의 복지기관 문화예술교육 지원사업, 부처 간 협력 지원사업, 꿈다 락 토요문화학교 외에도 생애주기형으로 새롭게 개발한 직장인, 실버세대 등을 대 상으로 한 신규 사업들이 포함되어 있다. 지역문화예술교육 지원사업은 지역 문화 예술교육 기반 구축을 위해 지역에서 자율적으로 프로그램을 운영하고 전용시설을 구축하는 사업이며, 인력 지원사업은 전문인력들의 재교육을 위한 연수와 문화예술 교육사 자격증 소지자를 활용한 인력 연계형 사업이 포함된다. 추진실적이나 성과 지표로는 주로 예술강사수, 참여자수, 참여자 만족도 등을 측정하며, 교육 지원형 예산의 총합은 128,901 백만 원이다. 


\begin{tabular}{|c|c|c|c|c|c|c|c|c|}
\hline 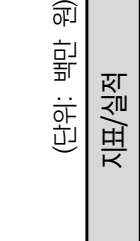 & 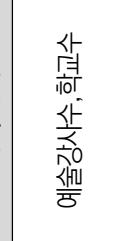 & 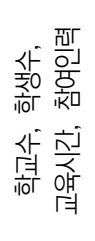 & 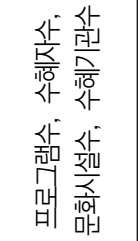 & 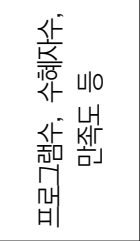 & 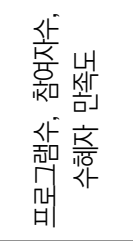 & 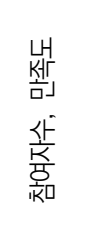 & 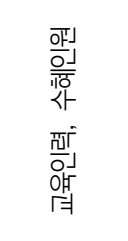 & 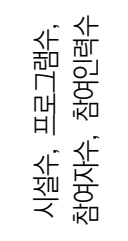 \\
\hline 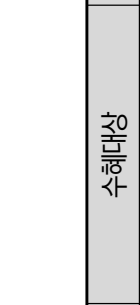 & 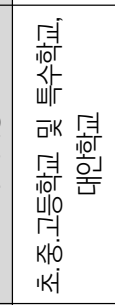 & 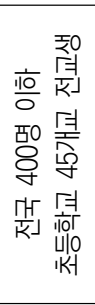 & 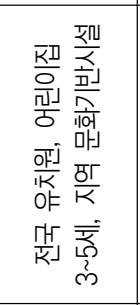 & 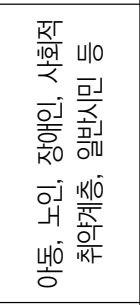 & 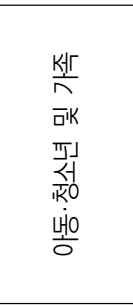 & 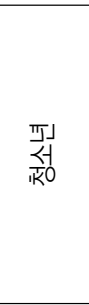 & 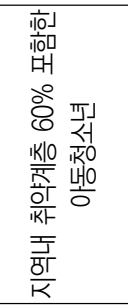 & 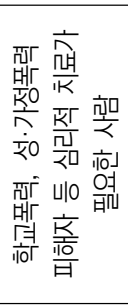 \\
\hline $\begin{array}{l}\text { E厂 } \\
\text { प्र }\end{array}$ & 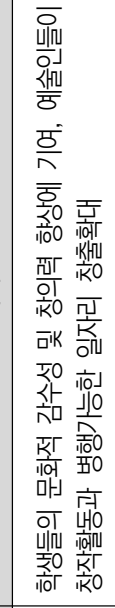 & 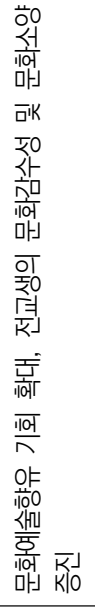 & 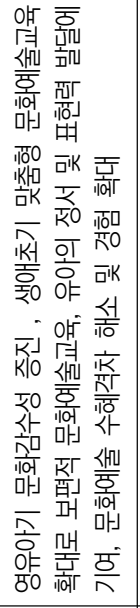 & 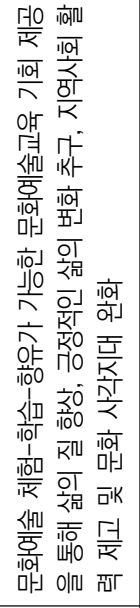 & 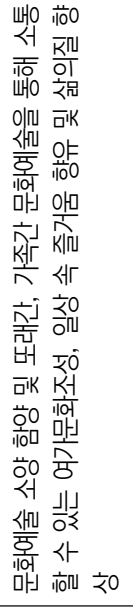 & 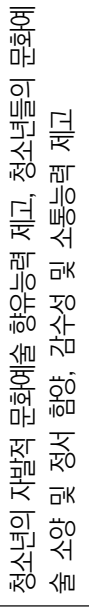 & 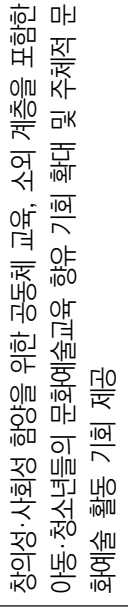 & 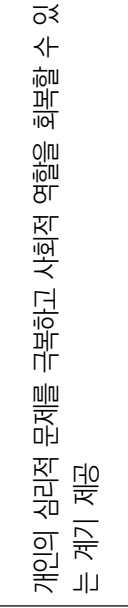 \\
\hline$\frac{\grave{\bigsqcup}}{\bar{J}}$ & 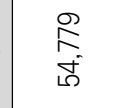 & 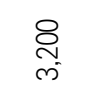 & 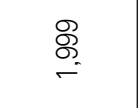 & $\begin{array}{l}\overline{1} \\
0 \\
0 \\
0\end{array}$ & 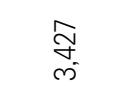 & $\stackrel{8}{8}$ & $\begin{array}{l}8 \\
8 \\
+\end{array}$ & $\begin{array}{l}\stackrel{8}{N} \\
\text { N }\end{array}$ \\
\hline $\begin{array}{l}\frac{\bar{c}\rfloor}{\bar{n}} \\
\text { 이 } \\
\text { 아 }\end{array}$ & 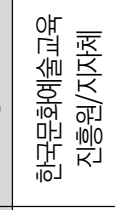 & 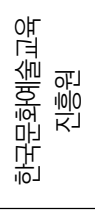 & 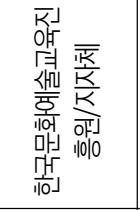 & 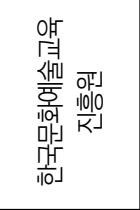 & 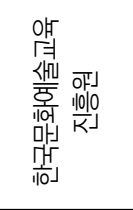 & 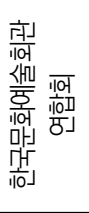 & 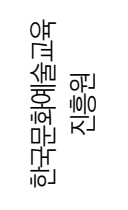 & 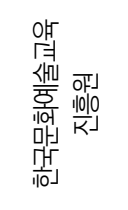 \\
\hline 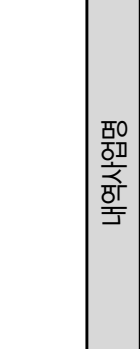 & 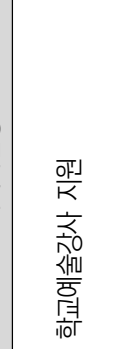 & 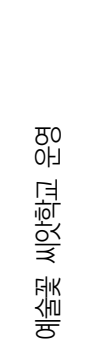 & 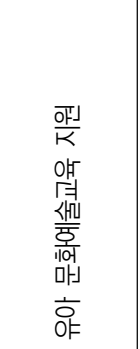 & 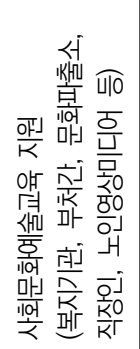 & 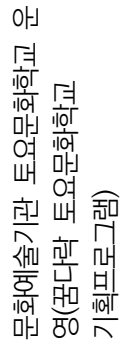 & 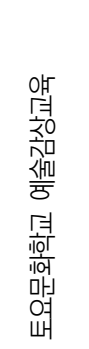 & 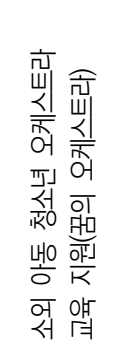 & 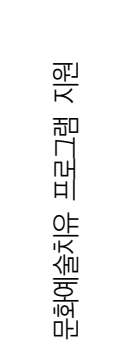 \\
\hline $\begin{array}{l}\text { 100 } \\
\text { OF }\end{array}$ & \multicolumn{3}{|c|}{ 110厂 뎨 } & \multicolumn{5}{|c|}{ 之 $\bar{c}$} \\
\hline
\end{tabular}




\begin{tabular}{|c|c|c|c|c|c|c|c|c|c|c|}
\hline 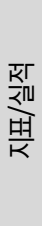 & 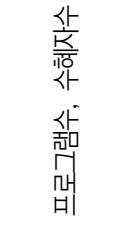 & & 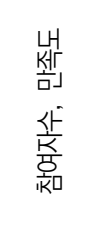 & & 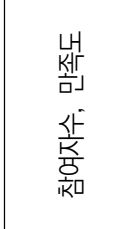 & 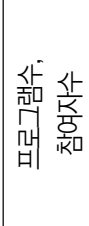 & & & 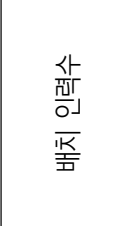 & \\
\hline 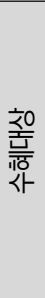 & 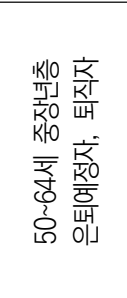 & 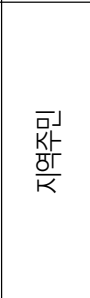 & 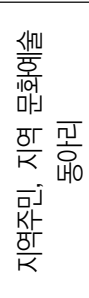 & 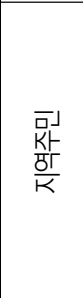 & 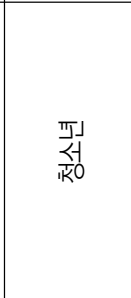 & 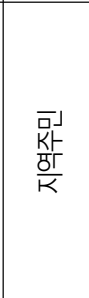 & $\begin{array}{l}\text { ज्ञ } \\
\text { KF } \\
\frac{\mathrm{DI}}{\mathrm{K}}\end{array}$ & 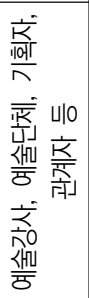 & 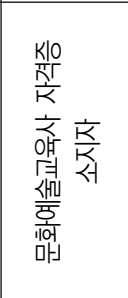 & \\
\hline $\begin{array}{l}\text { 지 } \\
\text { 마 }\end{array}$ & 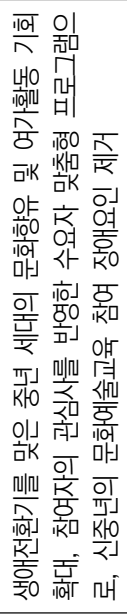 & 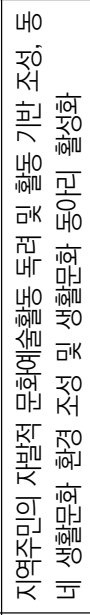 & 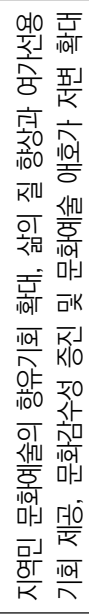 & 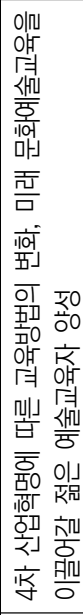 & 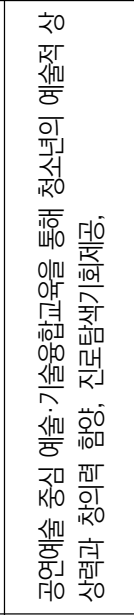 & 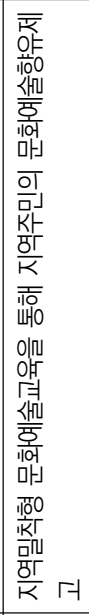 & 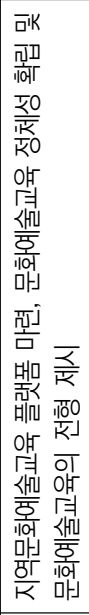 & 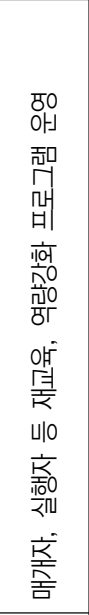 & 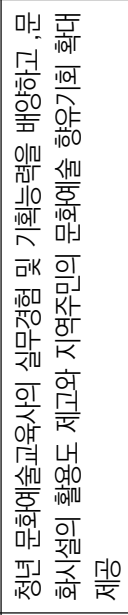 & \\
\hline$\frac{\grave{\lfloor}}{\bar{\delta}}$ & $\stackrel{8}{8}$ & ৪) & $\stackrel{8}{\stackrel{8}{\circ}}$ & $\stackrel{8}{\circ}$ & $\begin{array}{l}8 \\
\text { m }\end{array}$ & $\begin{array}{l}\text { Sơ } \\
\text { M. }\end{array}$ & 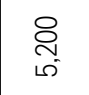 & $\underset{-}{\stackrel{8}{-}}$ & ষ্ণ & 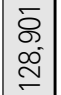 \\
\hline 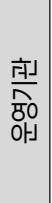 & 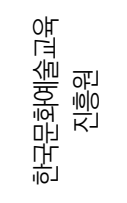 & 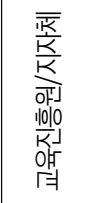 & 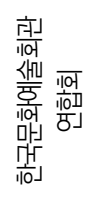 & 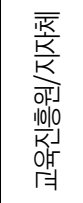 & 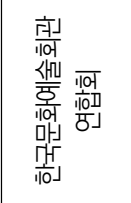 & 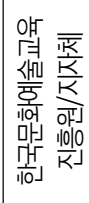 & 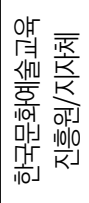 & 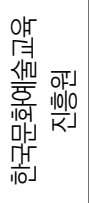 & 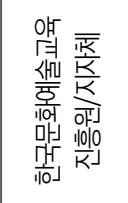 & \\
\hline 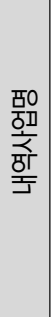 & 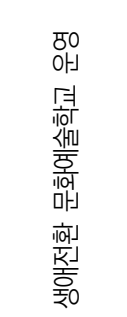 & 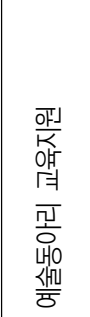 & 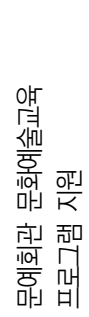 & 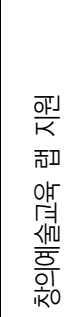 & 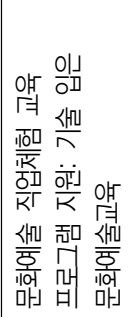 & 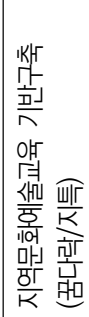 & 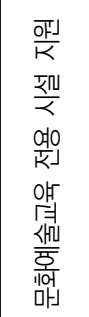 & 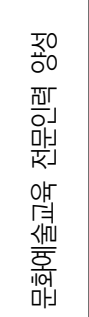 & 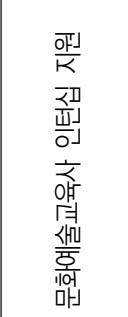 & $\begin{array}{l}\overline{\bar{F}} \\
\frac{1}{101}\end{array}$ \\
\hline d] & & & & & & & & $\bar{\alpha}\lrcorner \pi$ & $\bar{k}$ 아」 & \\
\hline
\end{tabular}




\section{라. 활동 지원형}

활동 지원형 사업은 크게 동호회 활동형, 창작 및 발표형, 지역사회 연계형 3가지 로 구분한다. 동호회 활동형에는 '문화가 있는 날 기획프로그램 운영' 사업 중 생활 문화 동호회 활성화 사업과 한국문화원연합회의 '어르신 문화 프로그램' 사업이 해 당한다. 어르신 문화 프로그램은 교육형, 동호회 활동형, 발표형, 지역사회연계형이 모두 결합된 형태로 세부사업을 운영하지만 동호회를 중심으로 하는 사업이 많아 동호회형에 포함시켰다. 창작 및 발표형에는 실버문화페스티벌만 포함되어 있으나 실제로는 생활문화 동호회 활성화 지원 사업이나 교육형 사업, 보편적 복지형 사업 인 문화가 있는 날 기획프로그램 등에서도 창작과 발표 활동을 병행한다. 지역사회 연계형은 개인 혹은 모임 단위로 문화예술분야의 봉사활동을 하거나 지역사회활동 에 참여하는 유형으로 '문화자원봉사 활성화', '생활문화공동체 만들기', '책 읽어주 는 문화봉사단'이 이에 속한다. 활동지원형 사업의 특징은 전 국민(시민, 지역주민) 을 대상으로 하며 향유자 개인의 자발성과 주체성, 지역과 사회문제와 연결하여 공 동체성을 강조한다는 점이다. 전 국민을 대상으로 하지만 중앙 단위의 지원사업은 어르신을 대상으로 하는 사업의 비중이 높다. 전체 예산 규모는 7,623백만 원이다. 
〈표 5-48〉 예술향유 지원사업 활동 지원형 사업(2020)

(단위: 백만 원)

\begin{tabular}{|c|c|c|c|c|c|c|}
\hline 유형 & 내역사업명 & 운영기관 & 예산 & 목적 & 수혜대상 & 지표/실적 \\
\hline \multirow{2}{*}{$\begin{array}{l}\text { 동 } \\
\text { 호 } \\
\text { 회 } \\
\text { 형 }\end{array}$} & $\begin{array}{l}\text { 문화가 있는 날 기획 } \\
\text { 프로그램 운영지원: } \\
\text { 생활문화동호회 활성화 }\end{array}$ & $\begin{array}{l}\text { 지역문화 } \\
\text { 진흥원 }\end{array}$ & 1,900 & $\begin{array}{l}\text { 주민 주도형 생활문화 협력 } \\
\text { 기반 조성. 지역별·세대별 } \\
\text { 수요에 부응하는 일상 속 생 } \\
\text { 활문화 다양성 지원 }\end{array}$ & 전국민 & $\begin{array}{l}\text { 동호회수/ } \\
\text { 회원수 }\end{array}$ \\
\hline & 어르신문화프로그램 & $\begin{array}{c}\text { 한국문화원 } \\
\text { 연합회 }\end{array}$ & 2,773 & $\begin{array}{l}\text { 어르신 커뮤니티 형성을 } \\
\text { 통한 사회적 소속감 및 } \\
\text { 안정감 증대 }\end{array}$ & $\begin{array}{l}\text { 60세 } \\
\text { 이상 } \\
\text { 어르신 }\end{array}$ & $\begin{array}{l}\text { 참여자 } \\
\text { 만족도 }\end{array}$ \\
\hline $\begin{array}{l}\text { 창 } \\
\text { 작/ } \\
\text { 발 } \\
\text { 표 } \\
\text { 형 }\end{array}$ & 실버문화페스티벌 & $\begin{array}{c}\text { 한국문화원 } \\
\text { 연합회 }\end{array}$ & 850 & $\begin{array}{l}\text { 아마추어 예술가로 활동하는 } \\
\text { 어르신들의 문화생활 참여 } \\
\text { 기회 확대, 어르신들의 건강 } \\
\text { 한 여가활동과 문화향유 } \\
\text { 증진을 통한 삶의 질 향상 }\end{array}$ & $\begin{array}{l}\text { 60세 } \\
\text { 이상 } \\
\text { 어르신 }\end{array}$ & 참여자수 \\
\hline \multirow{3}{*}{$\begin{array}{l}\text { 지 } \\
\text { 역 } \\
\text { 사 } \\
\text { 회 } \\
\text { 연 } \\
\text { 계 } \\
\text { 형 }\end{array}$} & $\begin{array}{l}\text { 생활문화 활성화: } \\
\text { 문화자원봉사활성화 } \\
\text { (문화품앗e) }\end{array}$ & $\begin{array}{c}\text { 한국문화원 } \\
\text { 연합회 }\end{array}$ & 500 & $\begin{array}{l}\text { 문화자원봉사를 통한 문화 } \\
\text { 복지 기반 강화 및 문화 향 } \\
\text { 유 기회 확대 }\end{array}$ & 전국민 & 매칭수 \\
\hline & $\begin{array}{l}\text { 문화예술 취약 분야 } \\
\text { 육성: 책 읽어주는 } \\
\text { 문화봉사단 }\end{array}$ & $\begin{array}{c}\text { 한국출판문화 } \\
\text { 산업진흥원 }\end{array}$ & 300 & $\begin{array}{l}\text { 문화소외계층에게 책 읽어 } \\
\text { 주기 활동을 통해 문화향유 } \\
\text { 기회 제공 }\end{array}$ & $\begin{array}{c}\text { 50대 } \\
\text { 이상 } \\
\text { (예비) } \\
\text { 실버세대 }\end{array}$ & \\
\hline & $\begin{array}{l}\text { 문화예술 취약 분야 } \\
\text { 육성: 생활문화공동체 } \\
\text { 만들기 }\end{array}$ & $\begin{array}{c}\text { 지역문화 } \\
\text { 진흥원 }\end{array}$ & 1,300 & $\begin{array}{l}\text { 지역관계망 형성 및 지역 } \\
\text { 문화발전도모, 개개인의 삶 } \\
\text { 의 문화적·사회적가치발견 } \\
\text { 및 확산을 통한 삶의질 제고 }\end{array}$ & 지역주민 & \\
\hline \multicolumn{3}{|c|}{ 합계 } & 7,623 & & & \\
\hline
\end{tabular}




\section{제2절 예술향유 지원사업 특성 및 시사점}

\section{1. 시혜적인 공급형 사업 진행과 수동적 대상으로 인식되는 향유자}

문화체육관광부에서 진행하는 예술향유 지원사업의 목적은 대부분 '국민의 문화 예술향유 기회 확대를 통한 삶의 질 향상`으로 수렴된다. 향유의 대상인 국민의 수 요가 있어서 사업을 추진하기보다는, 향유 기회 확대라는 정책적 목적 하에 중앙에 서 사업을 기획하는 방식이다보니 수요자 맞춤형으로 운영하는 데는 한계가 있었 다. 특히 문화복지형 성격이 강한 지원사업들은 사업 규모 전체를 놓고 보면 프로그 램수가 많고 분야가 다양해 보이지만, 1 개의 기관이나 시설을 기준으로는 1 2개의 프로그램만 운영되는 것이기 때문에 수혜대상자 프로그램을 직접 선택할 수 없는 경우가 많다. 사전에 수요조사를 하기도 하지만, 복지 차원으로 진행되는 사업들에 서는 향유자를 시혜 대상으로 보고 향유를 수동적인 행위로 전제하는 선입견이 여 전히 남아 있는 것으로 보인다.

현재 수요자가 직접 선택해서 향유할 수 있는 유형의 지원사업은 통합문화이용 권, 문화가 있는 날 할인 혜택, 일부 보편적 복지형 사업이 있다. 특히 선택적 복지 형의 방문형 사업은 기관이나 시설 대상으로 (주로 담당자) 수요 조사를 거쳐 예술 단체의 기존 프로그램을 매칭하는 형태로 운영하다보니, 현실적으로 개인의 수요를 일일이 반영하기는 어렵다. 일부 복지기관을 중심으로 사업이 집중적으로 진행되면 서 오히려 공급은 넘치지만 막상 개인이 원하는 프로그램은 없고 때로는 원치 않는 행사와 프로그램에 관객이나 수강생으로 동원되어 자리를 채워야 하는 일도 발생한 다. 교육 지원형 사업도 방문형 사업과 유사하게 수요조사와 매칭, 프로그램 지원 신청 등의 절차를 거치지만, 취약계층대상 사업과 마찬가지로 선택의 폭이 좁은 편 이거나 이미 공급자 중심으로 선정되어 있는 프로그램을 받아야 한다. 일반 시민 대상 프로그램은 소수의 프로그램 중에서 치열한 선착순 접수 과정을 통과한 일부 
인원만이 혜택을 누릴 수 있다. 또한 일회성으로 한 달에 1 회 혹은 연간 1 개의 프로 그램만 진행되는 경우가 많아 개개인의 시간과 장소 등에 따라 참여에 제약이 생길 수밖에 없다. 사실상 지원사업을 통해서는 자신이 직접 자신의 취향과 선호도에 따 라 자발적으로 프로그램을 선택하고 때론 비용을 지불하고, 이를 위해 시간을 내고 해당 장소에 방문해 직접 체험하고 느끼는 향유의 과정을 제대로 경험해 볼 수 있는 기회는 많지 않은 셈이다.

공급형으로 예술향유 지원사업들이 운영되면서 그 과정에서 접하게 되는 콘텐츠 가 제한적이라는 문제도 발생한다. 내용이 길거나 어렵지 않고, 접근성이 좋은 콘텐 츠들이 대중들에게 다가가기 쉬운 장점이 있는 반면 다양하고 수준 높은 문화예술 장르를 접하는 데는 한계가 있다. '방방곡곡 문화공감'을 통해 지방문예회관에서도 일부 예술단체들의 인기 레퍼토리가 반복적으로 재생되는 한편에는, 여전히 이것을 접해본 적이 없는 취약계층, 무관심 일반 시민들도 많다는 점도 딜레마이다.

지원사업의 운영 방향과 목적이 그렇다보니 개인의 즐거움과 행복감이라는 향유 의 동기와 효과에 대한 고민도 상대적으로 부족해 보인다. 사회적인 문제를 지원사 업을 통해 해결하려는 시도들은 있으나 개인 차원에서 주체적으로 하는 향유활동의 관점으로 접근하는 부분은 미흡하다고 볼 수 있다. 담당자 인터뷰를 통해서도 정책 적 담론은 사회 문제의 해결 등 '사회' 관점에서는 앞서 가는데, 그 안에서 실제로 즐기는 '개인의 주체성'에 대한 고민은 약화되어 이에 대한 성찰이 필요하다는 의견 이 있었다. 예술에 과도하게 사회적인 역할을 요구하는 것이 담론적으로 확산되는 상황에서 예술은 일차적으로 개인이 즐겨야 하는 것이라는 부분을 놓치고 가는 것 이 염려된다는 것이다. '교육 지원형' 사업에서는 일부 교육에 따른 개인의 변화를 목적으로 언급하고 있는데, 이는 문화감수성·창의력·문화소양·표현력·소통능력 함 양·긍정적인 삶의 변화 등이다. 사업 목적에 수혜자의 주체성을 언급한 사업으로는 '꿈의 오케스트라'(주체적 문화예술 활동 기회 제공)가 유일했고, 문화예술치유 프 로그램 지원은 '개인의 심리적 문제를 극복하고 사회적 역할을 회복할 수 있는 계기 제공'을 목적으로 했다. '활동 지원형' 사업들은 개개인의 삶의 문화적·사회적 가치 발견, 사회에서의 소속감과 안정감을 목적으로 하는 등 개인 자체가 아니라 사회와 연결된 개인에 초점이 맞춰져 있다. 개인의 즐거움과 사회 문제 해결이라는 목적 간의 균형감을 확보해 나가는 것을 향후 중요한 과제로 삼아야 할 것으로 보인다. 
전반적으로는 다수의 사업들이 성과지표가 참가자수, 프로그램수와 같은 '숫자' 로만 되어 있어, 사업의 양적인 확대에 치중하면서 사업의 질적 점검 부분이 부족했 다. 일회성 방문과 사업 운영으로 횟수는 늘어났지만, 수혜자 입장에서의 변화라든 가 지속성이 없었다. 사업성과 관점에서 참여자수는 포기할 수 없는 지표이기도 하 다. 실적으로 확인되고 기록되는 수치는 차년도 예산확보의 근거로 사용되기 때문 이다. 정량적인 수치 외에도 프로젝트가 지속적으로 이어질 수 있도록 정성적 측면 에서의 프로그램 개발이나 시도가 필요하며, 이러한 노력이 성과지표로 잡힐 수 있 어야 한다.

\section{2. 향유를 표방하는 사업 목적의 주객전도 경향성}

\section{가. 명목은 향유 지원, 내용은 창작 지원 대체재}

‘선택적 복지형'으로 분류한 '신나는 예술여행'과 ‘방방곡곡 문화공감' 지원사업 은 문화예술진흥기금의 '문화예술향유지원(구 소외계층문화순회: 2019년부터 예산 명 변경)' 예산을 재원으로 하고 ‘문화 향유권 신장 및 문화 양극화 해소'를 사업 목표로 내세운 대표적인 방문형 지원사업이지만, 사업에 참여하는 예술단체들에게 는 창작지원의 대체사업처럼 인식된다.

‘신나는 예술여행' 은 통합문화이용권을 제외하고는 단일 예산 규모도 가장 큰 사 업 중 하나로, 공연예술단체 사이에서는 사업에 선정되면 1년간 단체를 안정적으로 운영하는 데 도움이 되어서 매년 신청하는 사업 중 하나이다. 새로운 작품을 창작하 기보다는 기존에 단체에서 하던 작품을 일부 변형해서 수행할 수 있기 때문이다. 사업에 참여하는 예술단체 입장에서는 예술위의 창작산실과 같은 지원 사업에서 탈 락할 경우 2순위로 신청하는 사업에 해당한다. 성과지표에서 '예산 대비 관객수'와 함께 '참여 사회적 경제 조직수’를 보는 것에서도 이 사업을 예술단체의 지원으로 보는 관점이 드러난다. '방방곡곡 문화공감’도 ‘민간 및 국공립우수공연 프로그램 유통 지원', ‘문예회관 제작·기획 프로그램 지원’이라는 사업 분류에서 알 수 있듯이 사실상 향유보다는 창작과 유통 지원사업의 성격이 강하다. 사업 수혜대상은 간접 적으로는 지역주민이긴 하지만, 직접적인 1 차 수혜자는 공연 콘텐츠를 공급 받는 
지역문예회관과 레퍼토리를 유통할 수 있는 공연단체들이다.

전국의 문예회관을 순회하는 '방방곡곡 문화공감'의 경우 지역별 공연 장소나 관 객의 차이가 크지는 않지만 '신나는 예술여행' 은 방문 장소와 대상별로 차이가 매우 큰 사업이다. 그러나 대상별 문화격차해소를 위한 접근 방식에 대한 고민은 충분히 반영되어 있다고 보기 어렵다. 실질적으로 예술단체 지원사업이라는 측면이 강하게 작동되면서, 해당 수요층만을 위한 프로그램을 별도로 개발하기보다는 원래 단체에 서 하고자 했던 작품을 그대로 혹은 약간만 변형해서 가져가는 경향이 강하기 때문 이다. 선정단체들도 창작지원으로 인식하기 때문에 수요층에 대한 고민을 충분히 하지 않다 보니, 수요층에 대한 사전 리서치를 기반으로 하는 작업은 거의 없는 편 이다. 물론 수요층 파악에 투자할 만한 시간과 경제적인 여유가 없는 단체들의 사정 도 감안하지 않을 수 없다. 향후 취약계층 대상 방문형 향유지원사업의 취지를 살릴 수 있는 방식으로의 사업의 전환과 개선이 필요한 지점이다.

문화가 있는 날 기획프로그램 중 ‘청춘마이크'의 경우 국민 문화향유 공간 발굴을 통한 대국민 문화 향유 기반 활성화를 목적으로 하는 '보편적 복지형' 성격의 사업 이지만, 전문예술가로 성장하려는 청년의 성장 발판을 마련하기 위해 공연 기회를 제공하고 공연비와 관련비용을 직접 지급하는 신진 예술가 지원 사업의 성격도 강 하다. 예술가 입장에서는 성장의 기회를 잡는다는 면에서 거리 등 열악한 환경에서 의 공연을 감내해야 하는 면도 있다. 특히 예술향유 지원사업에 참여하는 예술가들 은 국민들의 예술향유를 위해 도구로 사용된다는 인식을 가질 수 있으므로, 그간 부족했던 향유와 창작 지원의 연계와 선순환의 관점에서 절충해 나갈 필요가 있다.

\section{나. 향유 확대와 일자리 확대의 병행}

일반 국민 대상 향유 지원사업의 한 유형으로 예술계 인력의 일자리 창출 목적을 병행하는 사업이 다수 진행 중인데, 이러한 인력 배치형 사업들은 향유를 1 차적인 목표로 내세우지만 일자리 창출이라는 성과지표가 숨어있거나, 일자리 창출이 사실 상 궁극적인 목표인 경우가 많다.

대표적인 사업이 국악인들의 일자리 창출을 목표로 시작되었던 학교 예술강사 지 원사업이다. 사업 목표에 '예술인들이 창작활동과 병행가능한 일자리 창출 확대'가 
포함되어 있고, 성과지표도 학생수가 아닌 예술강사수로 산출한다. 절대적인 양적 확대를 통해 학교 현장에서 학생들이 받은 혜택과 효과를 부인할 수는 없겠지만, 만약 문화예술교육 예산이 갑자기 사라지고 사업이 중단된다고 할 때, 가장 안타까 워하고 반대할 집단이 수혜대상인 학생일지, 아니면 교육을 공급해왔던 예술강사일 지를 상상해 볼 필요가 있다. 사실상 수혜자들이 아쉬워하고 사업의 존재 의미를 강조하고 지지해줘야 하는데, 공급자들만 아쉬워하게 될 상황이 눈앞에 그려진다면 정책사업의 재검토가 필요하다. 일자리 창출을 병행하는 예술향유 지원사업의 접근 방식에 대한 고민이 새롭게 이뤄져야 할 필요가 있다는 것이다.

박물관, 미술관, 도서관과 같은 '국공립 문화시설의 개관시간 연장'과 '휴관 없는 운영 사업'도 대국민 문화향유 기회 확대와 함께 관련 분야 전문 인력의 일자리 창출 을 목적으로 설정하고, 예산도 해당 인력의 추가근무시간에 대한 인건비로 책정되어 있다. 이렇듯 예술가를 문화시설에 배치하거나 매칭하고 인건비를 지급하는 사업들 은 대부분 국민들의 향유 기회 확대는 부수적인 목표이고 관련 분야 인력의 일자리 창출이 주된 목표이다. '도서관 상주작가 지원사업’은 선정 작가에게 월 급여를 주는 '문인 일자리 창출' 사업으로 예술향유 지원사업으로 분류하기 애매하지만, 수혜대 상에는 도서관 이용 국민을 제시하고 있다. '전업 작가의 창작활동 병행 일자리 지 원'을 목적으로 제시한 '전시해설 인력 지원' 사업도 유사한 성격을 지닌다.

물론 국민의 향유기회 확대를 위해 예술계 내부의 인력 지원이 필연적일 수밖에 없다. 여기서 주요하게 보아야 할 지점은 향유기회 확대를 사업목적으로 내세울 때, 인력지원 관련 부분은 해당 목적을 구현하기 위한 '수단'에 해당한다는 점이다. 이들 사업들은 예술가도 지원하고 국민들에게 향유 기회도 제공하는 사업이라고 볼 수도 있다. 그러나 다른 한편으로 인력창출과 관련된 부분이 성과지표로 제시되어 있다는 지점은, 사실상 일자리 창출 목적의 사업에 참여하는 예술가들을 활용해 향유정책처 럼 보이게 한 것으로 해석될 여지도 있다. 왜냐하면 해당 사업에 있어 '인력창출' 이 외에 궁극적 사업목적인 '향유' 확대를 위한 어떠한 정책적 노력이 부가적으로 주요 하게 다뤄지는지 보여지지 않기 때문이다. 이로 인해 명목상 수혜대상은 전 국민이 고 목표에는 ‘향유 기회 확대’가 포함되어 있지만, 예술향유 지원사업으로 직관적으 로 인지하기에는 어려운 성격의 사업으로 해석될 수밖에 없는 셈이다. 


\section{3. 복잡한 예산구조 및 유사사업 진행}

문체부의 예산 단위별로 예술향유 지원사업을 분석해 본 결과, 일반회계, 문예진 흥기금(복권기금 포함), 국민체육진흥기금 등 다양한 재원이 사용된다. 특히 문예진 흥기금을 재원으로 하는 예술향유 지원사업의 예산 규모가 가장 큰데, 앞서 살펴보 았듯이 해당 사업들은 복권기금의 전입과 문예진흥기금 고갈이라는 복합적 요인이 작용하며 복잡한 재원의 변화과정을 겪었다. 한편에서는 예술위에서 향유지원사업 을 하는 것에 대한 비판적 시각도 존재한다. 사업 담당자는 방문형 사업 성격의 최 근 변화는 지난 몇 년 간 담론적 차원에서 일반 국민으로의 수혜대상 확대가 논의되 는 과정인 것은 사실이나, 필요에 의한 재원변경이 함께 진행된 것이지, 담론이나 정책지향 변화를 위해 재원변화가 후차적으로 이뤄진 것은 아니라고 인식한다. 방 문형 사업들이 더 이상 복권기금을 재원으로 하지 않기 때문에 일반 국민 대상으로 가는 것이 맞는지, 재원과 관계없이 취약계층대상 사업에 더욱 집중해야 하는지에 대한 예술위의 역할과 함께 명확한 방향설정이 필요한 시점이다.

또 다른 특징은 현재 예술향유 지원으로 구분되는 사업 중에 국민체육진흥기금으 로 진행되는 사업의 수가 상당히 많다는 점이다. '문화 예술 취약 분야 육성' 사업의 경우, 사업간 성격을 분류하기 쉽지 않다. '도서관 상주작가 지원'과 '작가와 함께하 는 작은 서점 지원' 처럼 운영기관은 다르지만 '문학 작가의 일자리 창출'을 목적으 로 하는 사업이 있다. 기존 복권기금으로 운영되던 '생활문화공동체만들기' 사업도 해당 기금으로 추진되고 있는 것을 보면 재원 조달이 어려워진 사업도 기금 사업에 부차적으로 포함시킨 것으로 추정된다. '문화 예술 취약 분야 육성'사업에 속해 있 지만 상위 사업명은 ‘생활체육 활성화/체육문화예술사업의 지원’이란 점에서도 재 원과 세부사업의 성격이 정합적이라 보기 어렵다. 이는 국민체육진흥기금으로 운영 되는 예술향유 지원사업의 성격을 명확히 하고 재분류할 필요가 있음을 시사한다.

사업을 주관하고 있는 기관별로 살펴보면 유사한 유형의 사업이 진행되고 있음을 알 수 있다. '신나는 예술여행'과 같은 방문형 사업의 경우, '문화예술 취약분야 육 성' 예산으로 운영되는 '노인요양시설 전통예술 프로그램 지원' '동동동 문화놀이 터', ‘직장 문화배달'과 같은 ‘문화가 있는 날 기획프로그램' 등은 비슷한 성격을 지 닌다. 운영기관들은 개별적으로 사업을 진행하기 때문에, 취약계층대상 사업의 경 
우 방문하는 아동, 노인, 장애인 복지시설과 지역이 중복되기도 한다. 문화예술교육 지원사업은 대부분 한국문화예술교육진흥원에서 운영하지만, 문예회관을 기반으로 하는 사업은 한국문화예술회관연합회에서 주관한다.

중앙에서 진행하는 사업의 경우 유사한 유형의 사업을 하나로 통합하여 1 개의 기 관에서 운영하는 것이 효과적일 수 있으나, 각각의 사업마다 재원이 다르거나 운영 기관이 여러 개로 나뉘어져 있는 현실적 문제 등이 상존하는 것도 사실이다. 향유 관련 사업을 운영하는 기관의 수(數)를 보더라도 문체부 직접 운영사업을 제외하고 10 개가 넘는 것으로 파악된다. 2000년부터는 중앙 6개 사업(인생나눔교실, 무지개 다리, 문화이모작, 지역문화콘텐츠 특성화, 지역문화전문인력배치지원, 신중년문화 예술교육지원)을 묶어, 문체부, 지역문화진흥원, 한국문화예술교육진흥원에서 '지역 문화 생태계 구축 통합운영'사업으로 공모를 진행하는 큰 변화가 있었다. 내부적으 로 중앙 단위 동호회 지원사업도 지역문화진흥원으로의 통합을 검토 중이다. 이러 한 시도를 통해 운영기간 간 유사사업의 조정과 수요자 중심의 통합 운영의 향후 가능성을 점쳐볼 수 있을 것으로 기대된다.

\section{4. 중앙과 지역의 역할 분담의 모호성}

‘활동 지원형’ 사업 중 동호회 지원사업의 경우 중앙 단위 사업의 비중이 높지는 않지만 지역문화진흥원과 문화예술교육진흥원에서 진행하고 있다. 생활문화센터, 문화예술교육 전용 시설 조성과 같은 사업은 기반 시설을 확충하는 측면과 중앙 차 원에서 지자체와 매칭하여 진행하는 것이 의미 있는 사업이지만, 동아리 활동 자체 를 지원하는 것은 지역에서 해야 할 일이라는 인식이 많다. '활동 지원형'사업의 수 가 많지 않고 예산의 비율이 상대적으로 매우 낮은 것도 문체부 예산 사업으로만 한정해서 분석했기 때문이다. 만약 광역이나 기초 지자체 단위로 내려가면 활동지 원형 예산의 비중이 훨씬 높아질 것으로 예상된다. 일반적으로 지역의 동호회 지원, 지역 축제 지원 등 전체 향유관련 예산의 규모가 창작지원 예산보다 크다. 향유 관 련 예산의 비율은 중앙 $20 \%$, 지역 $80 \%$ 정도로 추정된다. 현재 지역밀착형으로 가 야 유의미한 생활문화형 사업은 중앙 주도가 아닌 지역으로 내리고, 중앙의 정책적 
역할에 대한 논의가 진행 중이다. 그리고 생활문화동호회 활성화 사업, 생활문화공 동체만들기 사업 등은 출구전략과 지원중단 시기에 대한 논의가 필요한 상황이다. 전반적으로 지역주민들의 직접적인 향유활동에 대한 지원은 지역에서 담당하고, 중 앙의 정책은 기본적인 환경조성으로 선회해서 접근해야 한다는 것이 중론이다.

새로운 향유 정책의 대상과 사업모델을 연구하고 개발하는 R\&D역할도 중앙에서 담당해야 하는 부분으로 보인다. 관련 연구와 시범사업 진행 후 중앙에서 운영하는 기간과 지역에 이관하는 방식까지 고려해 전략적으로 접근해야 한다. 문화예술교육 분야의 경우 중앙에서 직접 운영하던 사업들을 광역 단위로 사업들을 차츰 이관하 고 있다. 교육진흥원에서는 일반인의 관심, 인지도, 인식이 낮은 점을 고려해, 문화 예술교육을 통해 개인의 삶과 사회가 어떻게 달라지고, 문화예술을 향유하는 소비 자로 이어질 수 있을지를 지속적으로 연구하고, 이야기하고, 인식을 바꾸는 캠페인 활동을 지속적으로 담당해 줄 필요가 있다. 지역문화진흥원의 경우 '생활문화' 관련 일반 사람들이 그 중요성과 의미를 인식할 수 있는 캠페인을 해야 한다는 요청을 많이 받고 있다는 점을 감안했을 때, 인식제고나 홍보 관련 캠페인 주도를 어디서 담당할지 중앙과 지역의 역할 구분 차원에서 검토해보아야 할 지점이다.

아직까지는 중앙에서 해야 할 당위성이 있는 사업도 존재하는 것을 보인다. '신나 는 예술여행'의 경우, 장기적으로는 수요자 맞춤형 지원 측면에서 광역 단위에서 하 는 것이 효율적이겠지만, 광역단위로 가면 주로 지역에서 활동하는 단체로 한정되 어 자원의 편차가 생길 수밖에 없는 문제도 상존하고 있기 때문이다. 예술단체들이 수도권에 집중되어 있기 때문에 이들이 전국 단위로 활동지역을 선택할 수 있는 창 구를 열어주는 차원에서 중앙의 역할이 필요할 수 있을 것으로 보인다.

\section{5. 사회 변화 반영 및 향유 정책 대상의 다변화 시도}

문화가 있는 날 직장 문화배달, 생애전환 문화예술교육 지원 등 비교적 최근에 시작된 예술향유 지원사업들을 보면, 문화복지 차원의 소외계층에서 일반시민으로 의 대상 확대와 변화가 감지된다. 특히 문재인 정부 국정과제에 '생애주기별 문화예 술교육 확대'가 포함되면서 신중년 등을 대상으로 한 사업이 모델 개발 차원에서 
시범사업으로 진행되기 시작했다. '책 읽어주는 문화봉사단' 또한 50대 이상 실버세 대를 대상으로 하는 등 사회에서 주목하고 있는 신중년 대상의 사업이 집중적으로 진행되고 있다. 사업 모델을 개발해서 적용한 결과 참여자들의 반응이 좋았고 수요 가 있고 필요성을 공감하고 있음이 확인된 점에서 신규 대상 설정은 유의미했던 것 으로 보인다. '직장인' 또한 그동안 향유 지원의 사각지대에 있었으나, 워라밸 등의 트렌드에 맞춰 점심시간을 활용한 공연, 직장인 동호회 활동 지원, 여가친화기업 인 증 등 직장인의 라이프스타일을 반영한 지원사업들이 진행되고 있다.

통합문화이용권 사업의 경우 지원금으로 넷플릭스, 왓챠 등 OTT서비스 이용이 가능해졌으며, 이로 인해 온라인 사용처 이용 비율이 지속적으로 증가하고 있다. 내 부적으로는 수혜를 받기만 하는 것이 아니라 기여하고 싶다는 욕구도 있는 것으로 보고 지원금의 기부금 사용 가능 여부를 검토해보는 등 기존과는 다른 사고와 접근 이 시도되고 있다.

'어르신 문화프로그램 지원'은 60세 이상 어르신, 베이비부머 세대들이 은퇴 후 문화예술로 인생2막을 구축할 수 있는 방향을 제시한다. 사업담당자는 2005년 시 범사업으로 시작해 15년째 지속하면서 당시에는 '어르신'을 문화 수혜자로 인식했 으나, 시대가 변함에 따라 누적된 경험을 토대로 새로운 문화예술에 기여할 수 있는 문화적 '주체자'로 인식하고 사업 개편을 계획하고 있다고 밝혔다. 15년을 거치면서 기존의 교육형, 동호회형 사업 외에도 세대 간의 갈등을 해소하고 신기술을 활용해 어르신과 청년이 협력하는 등 사회문제와 트렌드를 접목한 사업으로 진화하고 있 다. 교육 분야를 중심으로는 4 차 산업혁명 시대에 대비해 신기술을 반영한 새로운 유형의 프로그램을 개발하거나, 예술과 기술의 융합형 교육도 새롭게 시도되고 있 는 것을 알 수 있다. 사업의 목표 측면에서도 ‘긍정적인 삶의 변화 추구’라는 개인 차원의 목표를 내세우는 변화가 감지되고 있으며, 이는 향유지원사업 전반으로 점 차 확대될 필요가 있을 것으로 보인다. 


\section{6. 일상성 vs. 특수성, 무료 vs. 유료의 딜레마}

예술향유 지원사업은 수혜자의 입장에서는 무료관람, 야간개장, 할인 혜택 제공 등으로 정규 문화시설에 대한 관람의 접근성을 높이는 사업과 정식 공연장이나 전 시장이 아닌 거리나 로비 같은 일상의 공간에서 진행하거나, 지리적 접근성을 높이 기 위해 오지와 소외계층을 직접 찾아가는 유형의 사업으로 구분된다. '방방곡곡 문 화공감'과 '신나는 예술여행' 은 비슷한 방문형 사업이다. '방방곡곡 문화공감' 은 지 방문예회관의 정식 공연장에서 진행되고, '신나는 예술여행'은 공연장 외의 (주로 복지)시설과 야외 장소로 직접 찾아간다는 점에서 차이가 있다. 대부분의 방문형 사 업을 비롯한 예술향유 지원사업은 일상적 공간에서 예술을 향유할 기회를 준다는 취지에서 해당 시설의 공간이나 야외에서 진행되기 때문에, 일상 공간에서 공연하 기 위해 축약된 무대 등이 실제 공연의 특별한 경험으로 읽혀지지 않는 아이러니로 작동하기도 한다. 공연 관람은 특별한 날에 하는 것이고, 일상적인 공간이 아닌 무 대에서 보는 공연을 예술이라고 인식하기 때문이다. 정책에서 일상적 차원의 예술 을 강조하기는 하지만, 수요자도 똑같이 일상성을 중요하게 느끼고 가치를 부여한 다고 보기는 어렵다. 정식 공연장이 아닌 곳에서 무료로 제공되는 약식의 예술을 반복적으로 접하면서 감동보다는 오히려 예술에 대한 반감이 생길 수도 있기 때문 에, 정식 공연장에서 수준 높은 공연을 한 번 접하는 것이 더 효과적일 수도 있는 것이다.

예술향유에 대한 경험을 무료로 할 수 제도(기회)가 많은 것 또한 딜레마 중 하나 이다. 특히 교육 지원형의 문화예술교육 사업은 대부분 무료로 진행된다. 수혜자들 에게 무료가 당연하다는 인식이 생기면 향후에 유사한 활동에 비용을 내기 꺼려하 는 문화가 자리 잡을 수 있다. 민간에서 운영하는 유사한 형태의 유료 프로그램을 고사시킬 수 있는 위험도 있다. 장기적으로는 예술향유 지원사업을 통해 잠재적 관 객을 개발하고 무료 향유자를 유료 향유자로 변화시킬 수 있는 전략적인 접근이 필 요하다. 물론 무료의 장점은 충분히 많다. 국공립 박물관, 미술관 무료 관람을 통해 한두 번 시설에 들어와 봤다가 이후 자연스럽게 드나들면서 다른 유료 기획전시에 관심을 갖고 보게 될 수도 있다. 무료관람으로 경제적인 요인에 의한 진입 장벽이 사라지고 언제든 마음만 먹으면 들어올 수 있는 곳이라는 인식이 생기는 것은 바람 
직하고, 어린 시절부터 경험한 아이들이 성인이 되었을 때 그 자녀에게까지 미치게 될 파급력을 생각하면 장기적으로 저변 확대에도 기여한다고 볼 수 있다. 무료 운영 의 취지가 보편적 복지 차원에서 접근성 확대를 위한 것이라면, 앞으로는 유료 관객 개발과 접목하면서 갈 수 있는 방식을 고민해봐야 한다. 무료로 향유한 경험이 차곡 차곡 쌓여 능동적이고 주체적으로 향유하는 유료 관객을 견인해 내고, 예술생태계 창작활성화의 선순환을 만들어 낼 수 있을 것이다.

〈표 5-49〉 예술향유 지원사업 분석 시사점(종합)

예술향유 지원사업 분석 시사점(종합)

1. 시혜적인 공급형 사업 진행과 수동적 대상으로 인식되는 향유자

2. 향유를 표방하는 사업 목적의 주객전도 경향성(향유+창작, 향유+일자리창출)

3. 복잡한 예산구조 및 재원출처 문제와 기관별 유사중복사업

4. 중앙과 지역의 역할분담의 모호성

5. 사회변화 반영 및 향유 정책 대상의 다변화 시도

6. 일상성 vs 특수성, 무료 vs 유료 딜레마 
예술향유정책 분석 및 방향 연구

\section{제6장}

예술향유정책 방향 



\section{제1절 예술향유정책 가치정향 명확화}

\section{1. 예술향유 개념 정립을 위한 기본 원칙}

향후 예술향유정책의 가치정향 명확화를 위해서는 '예술향유'의 정책적 개념에 대한 정립이 가장 우선적으로 필요한 것으로 보인다. 앞서 제2장에서 논의한 '예술 향유' 관련 최근의 이론적 논의를 반영하되, 동시에 제 3 장에서의 일반 시민의 '예술 향유'에 관한 인식 및 양태 분석, 더불어 제4장 및 제5장에서 다룬 현재 예술향유 지원정책의 문제점 및 시사점 분석에 기초할 때, 향후 예술지원에서의 '예술향유' 개념 정립은 연구결과를 토대로 도출된 아래와 같은 다섯 가지의 주요관점을 기본 원칙으로 삼을 수 있다.

\section{가. ‘예술’에 대한 확장적 이해 전제}

'예술향유'를 정책적으로 논함에 있어 향후 개념 정립은 '예술'에 대한 확장적 이 해를 바탕으로 이뤄질 필요가 있다. 이때 새로운 '예술' 개념 설정에 있어 주요 요소 는 정의규정 기준의 '유연성'과 범주의 '개방성'을 들 수 있다. 이러한 유연적, 개방 적 관점을 적용함에 있어 '예술'에 대한 이해가 '작품' 중심의 결과물 중심 정의가 아닌 '과정', 즉 프로세스 중심으로 '예술을 이해하는 관점' 또한 필수적일 것으로 보인다.

서론에서도 언급한 바와 같이 현재 예술정책 및 문화정책 관련 일반적 논의에서 여전히 '예술'의 정의는 「문화예술진흥법」에 의거하여 진행된다. 하지만「문화예술 진흥법」에서의 '문화예술'에 대한 정의는 법제도적 성격상, 그 정의의 정책적 적용 대상 설정을 위한 행정적 규정 이상으로 보기 어렵다. 총 13 개의 세부 '장르' 중심 으로만 제시된 현재의 정의는 예술창작 관점에서의 적용뿐 아니라, 향유자의 입장 
에서도 한계가 노정된다. 장르별 다원화 및 장르 간 융복합화는 물론이거니와, 기술 혁신에 따른 새로운 예술형식과 유형이 발현되고 있고, 기술혁신에 따른 대중예술 과의 중첩이 활발히 일어나고 있는 지점은 '예술'에 대한 이해와 폭이 지속적으로 넓어지고 확장되고 있음을 방증한다. 따라서 향후 '예술'에 대한 확장적 이해는 이 러한 정의규정의 ‘유연성'과 범주의 '개방성' 요소를 고려하되, 결과를 포함하지만 예술이 창작되고 향유되는 '과정' 차원에서의 개념 역시 포용하여 재설정될 필요가 있다.

\section{나. '향유자’ 관점의 접근, 주체적-적극적·즐거운 권리로서의 ‘향유'}

두 번째로 중요한 것은 ‘향유' 개념설정을 반드시 '향유자’ 관점에서 출발.접근하 되, 이들의 주체성 및 적극적 권리가 포용된 의미로 상정될 필요가 있다는 점이다. 표준국어대사전에 의거, 이미 '향유(享有)' 단어는 그 자체로 '적극적·소유적 의미' 를 내포하고 있으며, 이를 바탕으로 개인이 예술활동을 함에 있어 기본적이자 적극 적 권리, 스스로 참여하는 가운데 주체성을 발현할 수 있는 개념으로서 해석될 수 있다. 이렇듯 좋은 단어를 이미 가지고 있음에도 불구하고, 그간 정책 논의에서는 향유자를 수동적으로 대상화할 수 있는 언어적 뉘앙스가 농후한 공급자 관점에서의 ‘향수’라는 표현을 관성적으로 견지해왔다. 따라서 향후 ‘예술향유'의 개념적 정의 및 관련 논의는 ‘향유(享有) = 누리어 가짐’이라는 단어 고유의 취지를 십분 되살리 는 방향으로 정립될 필요가 있다.

더불어 이때 주요한 지점은 ‘예술향유활동’이 향유자 입장에서 ‘흥미롭고', '재미 나고', '신나는' 요소를 느낄 수 있는 영역으로서도 인식될 필요가 있다는 점이다. 물론 수용자의 재미와 즐거움을 최우선적으로 강조하는 대중예술과 달리, 순수예술 의 경우 장르별 관습 등 사전지식이 요청되는 경우도 많고, 어려서부터 지속적이고 반복적인 경험을 통해 이러한 지식과 경험의 교차적 축적이 요청되는 것이 특징적 인 것도 실증적 측면임을 부인하긴 어렵다. 그러나 문제는 변화하는 예술에 대한 인식이나 범주의 확장성 등을 고려하지 않고 엘리트주의적 관점에서의 '예술' 정의 에만 천착할 경우, 예술은 우리가 '즐길 수 있는 것' 으로 인식되기보다는 늘 '공부해 야 하는', 혹은 경험적으로나 지식적으로 '나와는 거리가 먼 당신' 으로 치부될 수밖 
에 없다. 예술관람 혹은 예술교육이나 동호회 활동이 내가 흥미와 재미를 느낄 수 있고, 점진적으로 일회성이 아닌 반복적인 활동으로 이어질 수 있기 위해서는 이러 한 활동들 속에 향유자가 흥미와 관심, 재미를 느낄 수 있는 요소들이 함께 포진되 어야 한다. 이는 단순히 예술가(기관 혹은 단체) 입장에서 작품의 질을 제쳐두고 향 유자의 말초적 관심이나 흥미를 유발시키는 방식을 고민해야한다는 의미가 아니라, 향유자가 예술을 창작하는 과정에 함께 참여하고 협업할 수 있는 기회나 방식 등을 적극적으로 고민하는 것이 필요하다는 의미다. 이를 통해 향유자는 자신들이 이전 에 책이나 수동적인 활동에서 경험하지 못한 적극적 주체자, 참여자로서의 '즐거움' 과 '재미'를 느낄 수 있기 때문이다.

\section{다. ‘향유' 활동영역의 다원적 입체성 고려}

세 번째로 '향유' 개념 정립에 있어 관련 활동영역을 다원적, 입체적으로 이해해 야 한다. 현재 예술향유 관련 ‘활동’을 정책적으로 이해하는 방식은 「국민문화예술 활동조사(구[舊], 문화향수실태조사)」에서 제시된 바와 같이 전통적 의미에서 접근 하는 특정 시설에서의 '관람(attendance)' 중심으로 구조화되어 있다. 물론 '참여' 라는 분류 하에 개인의 창작·실연의 경우가 파악되고 있지만, 그 정의가 모호하게 제시되어 있는 상황(행사참여)이다. 그 외 조사영역으로 '학교 이외의 교육경험', '동호회', '자원봉사' 활동 등이 파악되고는 있지만, 이들이 넓은 의미에서의 '참여' 영역으로 포섭되어 규정되는 상황은 아니다. 향후 ‘향유활동'의 영역은 관람 뿐 아 니라 참여로 구분은 하되, 창작·실연, 교육(과거뿐 아니라 현재의 경험까지 포용), 동호회, '자원봉사' 및 '기부'의 영역까지 포괄하여 입체적으로 이해될 필요가 있다. 관람의 경우, 현재「국민문화예술활동조사」에서의 경우처럼, 전통적인 시설이나 공 간을 방문하는 것만으로 전제할 것이 아니라 온라인 매체로의 관람이나 거리예술 혹은 일상 차원에서 예술관람(거리예술이나 마을예술축제참여 등)까지 포용하는 방 식으로 '관람'의 범주와 범위를 확장적으로 이해할 필요가 있다.

이때 가장 유의해야 하는 지점은 관람 및 참여의 양태를 다양하게 세부적으로 이 해함에 있어서 이들 영역을 상호 배타적이거나, 혹은 ‘단계적', ‘발전적' 관점으로 바라보지 않아야 한다는 점이다. 가령 향유활동에 있어 관람이 직접 창작에 참여하 
는 형태보다 상대적으로 타인의 예술창작 과정이나 작품을 '수용하는 성격 (receptive)'을 가진다고 볼 수는 있지만, 이를 곧바로 '관람'이 '창작.실연'과 단순 비교하여 ‘수동적(passive)'이라고 보기는 어렵다. 이미 앞서 FGI 분석을 통해서도 살펴본 바와 같이 시즌 티켓 구매자 등 헤비유저라던가, 혹은 자신이 관람한 공연. 전시 관련 개인비평이나 정보 공유를 적극적으로 하는 이른바 '관람활동의 고관여 자'가 혼자만의 창작활동이나 동호회 활동에만 집중하는 향유자에 비교하여 '수동 적 행동 양태를 나타내는 것이라 볼 수는 없기 때문이다.

[그림 6-1] 예술 ‘향유활동'의 다원적 입체성

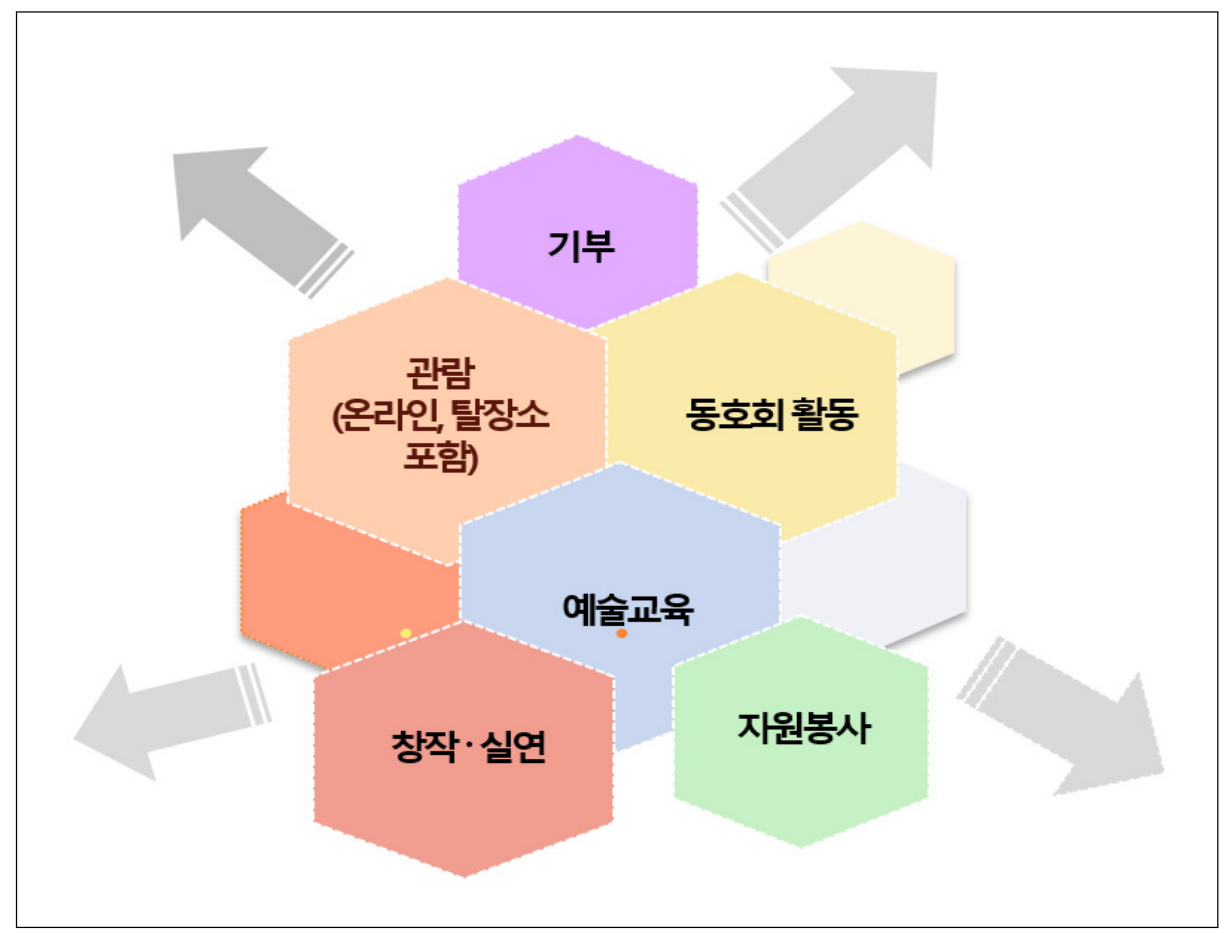

종합하자면 향유활동의 영역을 크게 관람형과 참여형으로 볼 수 있다, (1) '관람형 (attendance)'영역은 전통적 관람형과 참여적 관람형으로, (2) '참여형(participation)' 영역은 매개된 경험형(교육), 창작·실연형(공동창작 및 개인창작 포함), 일상예술형(동 호회), 자원봉사·기부형 등으로 볼 수 있다.130) 현재 실태조사 등에 반영된 영역은 이

130) 제2장에서 다룬 예술향유 관련 이론적 논의, 그리고 최근 정책담론의 흐름 분석에서 도출된 시사점을 
들 중 '관람형'에서의 ‘전통적 관람형'에서 오프라인의 경우는 특정 전문시설만을 기반 으로 하는 관람과 매체 관람에 한정된다. '참여형'의 경우는 기존 실태조사에서 '참여' 의 용어를 암묵적으로 '행사'에 참여하여 창작물을 선보이거나 혹은 실연하는 경우에만 한정한 것을 넘어서서 향유자의 주체성과 능동성이 상대적으로 보다 결부되어 있는 '참 여적 속성'을 가진 영역을 중심으로 재구성하였다.

\section{[그림 6-2] 예술 ‘향유활동’의 다원적 영역(안)}

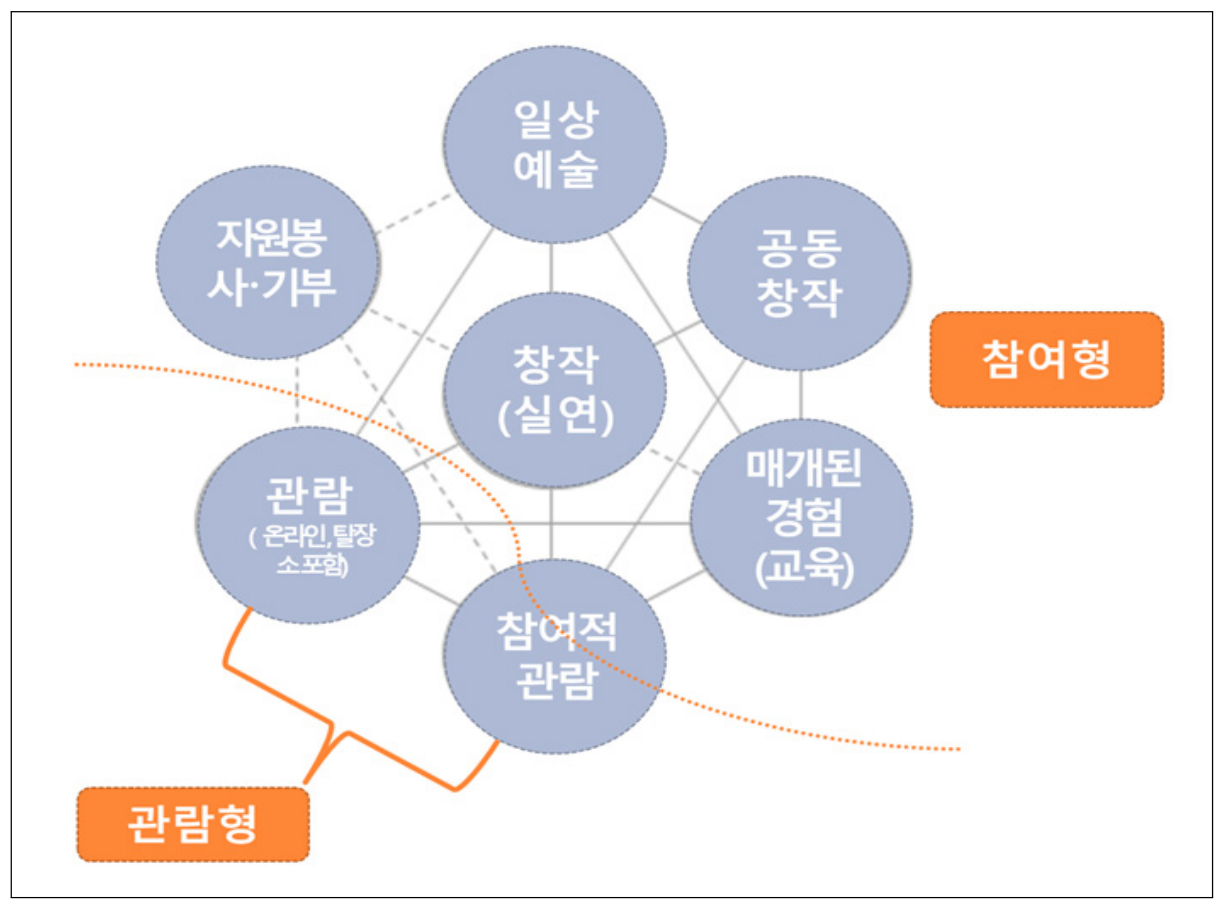

그러나 제시된 향유활동 영역을 이해함에 있어 몇 가지 유의할 지점이 있다. 이들 은 모두 독자적 속성을 가지면서도, 동시에 타 영역과 중첩되거나 상호 연계·전이될 수 있는 있는 영역들이기 때문이다. ${ }^{131)}$ 또한 각각의 영역 내에서 향유자의 주체적 활동과 적극성이 단계적으로 발현될 수 있는 것이며(저관여 $\rightarrow$ 고관여, 소극적 $\rightarrow$ 적극

기반으로 재구성하여 제안한 향유활동 영역(안)임을 유의할 필요가 있다. ‘참여적 관람'과 '참여형’에서 중복되는 '참여'의 용어는 'Participatory' 혹은 'Participation'의 개념이나 현재로서 관람과 참여가 중 첩되는 현상이 발현되고 있음을 반영한 것으로 이해할 수 있겠다.

131) 제2장의 이론적 논의 외에도, 제3장의 $\mathrm{FGI}$ 를 통해서도 확인된 사안이다. 
적), 이후 각 영역 간 활동의 전이 혹은 확장도 발생할 수 있는 것으로 바라보아야 할 것이다. 더불어 앞서 제2장 이론적 논의에서 지적한 바와 같이 향후 향유활동의 영역이 다양한 방식과 형식으로 전개될 수 있는 바, 5 개 영역에 한정하지 않고 추후 새로운 영역의 포용성을 담지한 방식으로 영역 제시를 하는 것이 타당할 것으로 보 인다. 또한 각 영역의 구분 기준 역시 상호배타적으로 설정하기보다는, 상호 간 전 이와 연계가 가능할 수 있음을 전제로 바라볼 것을 제언한다. ${ }^{132)}$

〈표 6-1〉예술향유 양태유형 분류 - 수정(안)

\begin{tabular}{|c|c|c|c|c|}
\hline \multicolumn{2}{|c|}{ 구분 } & \multirow{2}{*}{$\begin{array}{l}\text { 향유양태, 활동의 예시 } \\
\text { 예술의 창작이나 재현, 프로그램 등을 보거나 듣는 유형 } \\
\text { (오프라인, 온라인 매체기반 포용) }\end{array}$} & \multicolumn{2}{|c|}{ 특성화 요인 } \\
\hline \multirow[b]{2}{*}{ 관람형 } & $\begin{array}{l}\text { 전통적 } \\
\text { 관람형 }\end{array}$ & & & \multirow{4}{*}{ 내적요소 } \\
\hline & $\begin{array}{l}\text { 참여적 } \\
\text { 관람형 }\end{array}$ & $\begin{array}{l}\text { 관람 대상의 예술적 활동이나 작업, 작품에 대해 자신의 } \\
\text { 해석이나 의도를 부여하며 교감하거나 관람 차원의 참여 } \\
\text { 확동에 응하는 향유 유형. 예를 드ㅇㅓㅓ 자신의 예술 향유 } \\
\text { 콘텐츠를 수집하거나 목록화하는 활동, 이머시브 공연의 } \\
\text { 놘람활동, 커뮤니티 아트에 참여 등을 들 수 있음 }\end{array}$ & 주체성 & \\
\hline \multirow{2}{*}{\multicolumn{2}{|c|}{$\begin{array}{l}\text { 매개된 경험형 } \\
\text { (교육) }\end{array}$}} & \multirow{2}{*}{ 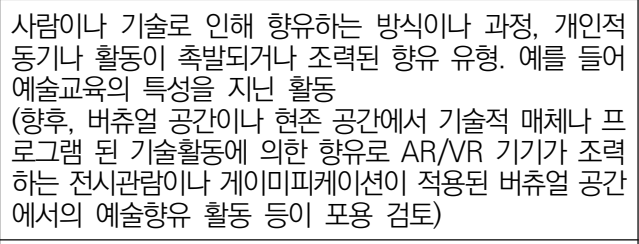 } & $\begin{array}{l}\text { 창작(표현)의 } \\
\text { 권한 }\end{array}$ & \\
\hline & & & 사회지향성 & \\
\hline \multirow{4}{*}{$\begin{array}{c}\text { 창작 } \\
\text { (실연) } \\
\text { 형 }\end{array}$} & \multirow{2}{*}{$\begin{array}{l}\text { 공동 } \\
\text { 창작형 }\end{array}$} & \multirow{2}{*}{$\begin{array}{l}\text { 창작 주체(예술가 등)에 의해 초대된 향유로 창작과 표현 } \\
\text { 에 대한 권한의 일부를 부여받은 예술 활동. 창작의 과정 } \\
\text { 은 물론 결과물에 대한 자신의 기여를 인지할 수 있는 유 } \\
\text { 형임 }\end{array}$} & 빈도 & \multirow{4}{*}{ 외적 요소 } \\
\hline & & & 장소성 & \\
\hline & \multirow[t]{2}{*}{$\begin{array}{l}\text { 개인 } \\
\text { 창작형 }\end{array}$} & \multirow{2}{*}{ 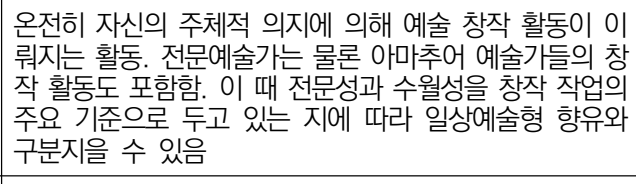 } & 매개여부 & \\
\hline & & & \multirow{3}{*}{$\begin{array}{l}\text { 기대영향 } \\
\text { (목적성) }\end{array}$} & \\
\hline \multicolumn{2}{|c|}{$\begin{array}{l}\text { 일상예술형 } \\
\text { (동호회) }\end{array}$} & $\begin{array}{l}\text { 예술적 감성과 예술적 표현, 예술적 훈련이 일상에서 루 } \\
\text { 틴하게 이뤼지는 자발적 유형의 활동. 예를들어 악기 연 } \\
\text { 읍이나 시의 습작, 일상 드로잉, 동호회 활동 등을 들 수 } \\
\text { 있음 }\end{array}$ & & J \\
\hline \multicolumn{2}{|c|}{ 자원봉사/기부형 } & $\begin{array}{l}\text { 예술작품의 보존이나 예술환동의 지속성을 지지하고 지원 } \\
\text { 하는 활동. 예를 들어 기부나 예술기관에서의 도슨트 자 } \\
\text { 원봉사, 시설 등을 찾은 나눔 연주 등을 들 수 있음 }\end{array}$ & & \\
\hline
\end{tabular}

132) 향후 실태조사에서의 반영을 위해서는 여기서 제시된 내용을 고려하되, 현실적인 지점을 함께 검토하여 자세한 적용(안)을 도출할 필요가 있을 것이다. 


\section{라. 창작과 향유 간 중첩적 연계성}

네 번째로 창작과 향유가 배타적으로 대척점에 있는 것이 아닌, 중첩적 속성을 가질 수 있다는 점을 반드시 고려할 필요가 있다. 앞서 제시한 향유활동 영역 논의 에 따르면 ‘향유' 개념 속에는 '창작'이 별개로 분리된 영역이 아닌 중첩된 영역으로 위치될 수 있음이 포착된다. 이미 온라인 설문조사 및 FGI 결과 분석을 통해 일반 시민의 입장에서 예술을 접하고, 누리고, 즐기는 예술향유활동은 이후 아마추어 활 동을 넘어서서 직업적 전문예술가로서 창작행위까지 연계·발전될 수 있음이 확인되 었기 때문이다. 물론 모든 시민의 예술향유활동이 '창작' 영역을 반드시 포용할 필 요는 없을 것이나, 그 가능성 자체를 배제할 이유도 없다는 의미로 해석될 필요가 있다.

이는 기존 예술지원정책 일부 논의에서 지속적으로 지목되어 온 "창작 vs. 향유 지원 간 불균형” 논의가 이제는 층위를 달리하여 전개될 필요성이 있음을 동시에 시사한다. 기존 논의는 '전문가'인 예술가에 의한 '창작지원'에 예술지원의 무게중 심이 상대적으로 더 주요하게 놓아져야 한다는 관점을 암묵적으로 견지하는 성격이 농후하다. 담론적 차원에서 그간 '문화민주주의' 대의하에 전문예술가와 일반 시민 모두가 예술생산 주체로서 인정받아야 한다고 강조해 왔으면서도, 일부에서 향유지 원사업이 창작지원을 구축(驅逐)한다는 관점의 비판적 논의는 사실상 논리적으로도 상호 모순적으로 해석될 여지가 있다. 앞서 언급한대로 향유지원에 대한 총체적 비 전이 부재한 상황에서 단위사업별로 다소 무분별하게 전개된 정책접근방식에서의 문제에 오히려 향후 비판적 논의의 초점이 맞춰질 필요가 있다.

이런 점에서 향후 '예술향유' 개념정립의 방향성은 '예술가를 포함한 모든 시민' 의 입장에서 예술을 접하고, 누리고, 즐기는 예술향유활동이 이후 아마추어 활동을 넘어서서 직업적 전문예술가로서의 창작행위까지 연계·발전될 수 있는 가능성까지 포함하는 관점에서 이뤄질 필요가 있다.

\section{마. 정책용어로서의 ‘문화향유’와의 지향점 및 차별성 기준 제시}

다섯 번째로 정책개념으로서의 '문화향유'와의 차별성의 기준을 제시하는 것이 필요하다. 국내 정책논의에서의 개념 정립은 필연적으로 제도적 정의와 결부되어 
개진되는 양상을 보인다. 이미 「문화기본법」을 통해 포괄적 개념으로서의 ‘문화’ 가 제시된 바 있고, '문화’의 영역 중 일부로 '예술'이 포함된 것임을 감안할 때, 문화향 유는 예술분야를 포함한 스포츠, 관광, 종교, 젠더 등을 비롯한 개인의 다양한 가치 관 및 삶의 양식을 포괄한 넓은 의미의 문화활동으로 상정하되, '예술향유'의 경우 '프로세스로서의 '예술', 더불어 예술양식과 범주의 확장성, 유연성, 개방성을 반영 한 '예술' 영역에서 이뤄지는 다양한 활동들로 이해할 필요가 있다. 다만 이때 '예술 향유'에서의 개념 규정은 향후「문화예술진흥법」의 ‘문화예술' 관련 정의 규정의 변 화를 전제한다. ${ }^{133)}$

〈표 6-2〉 문화향유와 예술향유 개념 정의(안)

\begin{tabular}{|c|c|c|}
\hline 구분 & 문화향유(文化享有) & 예술향유(藝術享有) \\
\hline 제도적 근거 & $\begin{array}{c}\text { 「문화기본법 } \\
\text { (법률 제12134호, 2013.12.30. 제정) }\end{array}$ & $\begin{array}{c}\text { 「문화예술진흥법」 } \\
\text { (법률 제16595호, 2019.11.26. 일부개정) }\end{array}$ \\
\hline $\begin{array}{l}\text { 현행 문화, } \\
\text { 예술의 } \\
\text { 영역별 정의 }\end{array}$ & $\begin{array}{l}\text { 제3조(정의) 이 법에서 “문화”란 문화예술, } \\
\text { 생활 양식, 공동체적 삶의 방식, 가치 체 } \\
\text { 계, 전통 및 신념 등을 포함하는 사회나 사 } \\
\text { 회 구성원의 고유한 정신적·물질적·지적· } \\
\text { 감성적 특성의 총체를 말한다. }\end{array}$ & $\begin{array}{l}\text { 제1장 제2조(정의)에 따르면 “문화예술”이란 “문 } \\
\text { 학, 미술(응용미술을 포함한다), 음악, 무용, 연극, } \\
\text { 영화, 연예, 국악, 사진, 건축, 어문, 출판 및 만 } \\
\text { 화”를 말한다. }\end{array}$ \\
\hline $\begin{array}{l}\text { 개념규정 } \\
\text { (예시) }\end{array}$ & $\begin{array}{l}\text { 문화향유(文化享有)란 문화다앙성에 의거 } \\
\text { 하여 개인의 다양한 삶의 양식과 가치관이 } \\
\text { 반영된 문화예술, 생활양식, 가치 ,체계, } \\
\text { 전통, 신념을 포함한 사회나 사회구성원의 } \\
\text { 고유한 정신적 개인의 정신적·물질적·지적. } \\
\text { 감성적 특성을 투영된 활동을 말한다 }\end{array}$ & $\begin{array}{l}\text { (향후 진흥법 개정 필요) } \\
\text { 유연적 확장성, 개방성을 포용한 예술정의에 의거 } \\
\text { 하여, 개인이 자신의 주체적 적극적 권리로서 행 } \\
\text { 하는 예술영역과 관련된 일련의 활동으로 관람, } \\
\text { 창작·실연, 교육, 동호회활동, 자원봉사 및 기부 } \\
\text { 등을 포함한다. }\end{array}$ \\
\hline 공통점 & \multicolumn{2}{|c|}{$\begin{array}{l}\text { 누리어 즐김이라는 ‘향유(享有)' 용어 고유의 의미를 전제로 개인의 적극적 권리, 주체성 등의 } \\
\text { 요소를 반영 }\end{array}$} \\
\hline
\end{tabular}

자료: 국가법령정보센터(http://law.go.kr 최종접근: 2020.05.14) 및 연구진 재구성

전술한 논의를 토대로 '예술향유' 개념 정립을 위한 5가지 주요 관점 및 예술향유 활동의 개념적 정의(안)을 제시하면 아래 그림과 같다.

133) 그러나 유의해야하는 지점은 상기 구분은 본 연구의 연구결과에 따라 제시된 것이기에 절대적 기준으로 오해되어서는 안 된다는 점이다. 문화향유, 예술향유의 중첩성 및 차별성에 대한 보다 심도 깊은 연구 및 검토를 통해 향후 정책적 관점에서의 문화향유 및 예술향유의 지향점과 차별성은 더욱 정치하게 제시 될 필요가 있을 것이다. 
[그림 6-3] '예술향유' 개념 정립을 위한 기본원칙 및 예술향유 개념 정의(안)

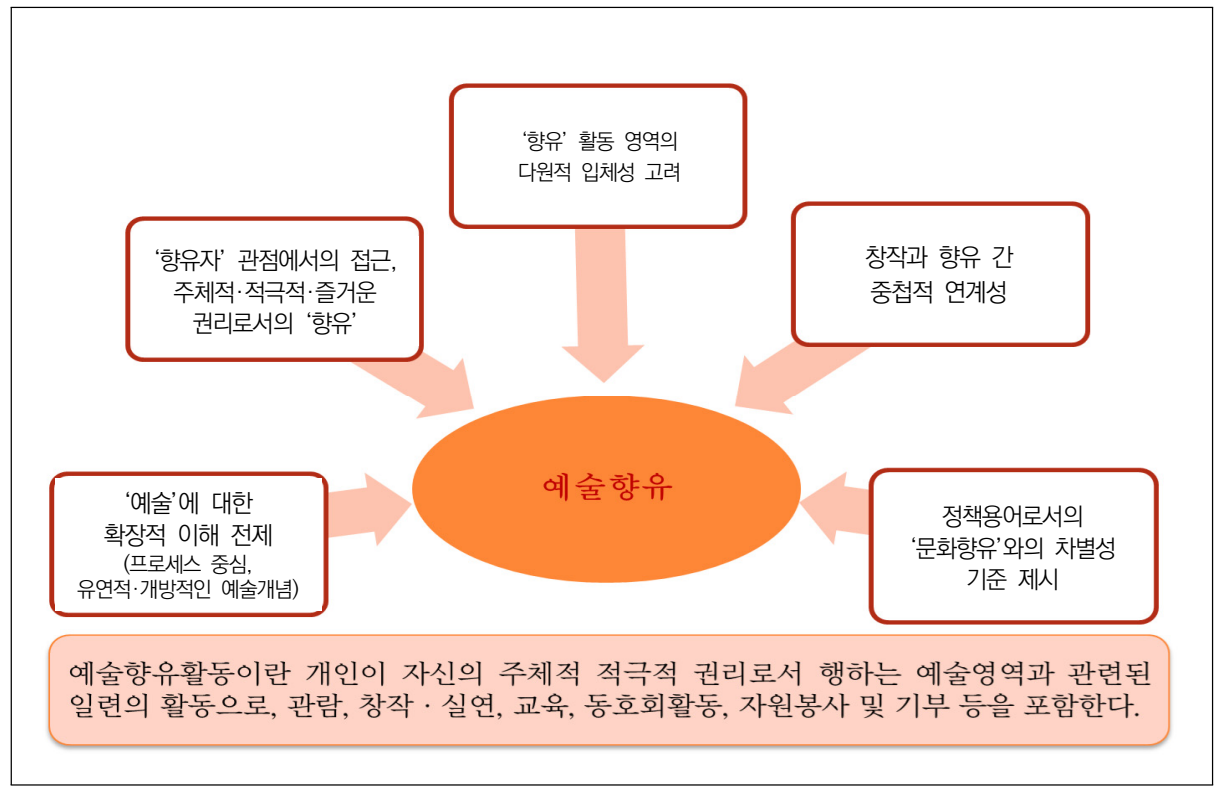

\section{2. 예술향유정책 설정의 기본방향}

앞서 제시한 5가지 관점에서의 예술향유 개념 정립과 함께 향후 예술향유 관련 정책 지원은 거시적 관점에서의 예술지원 정책 내 확고한 영역으로서 그 위상이 견 고하게 다져질 필요가 있다. 한국문화예술위원회, 한국문화예술교육진흥원, 지역문 화진흥원뿐 아니라, 미술관 박물관 등 예술기관에서의 사업담당자들은 모두 예술지 원에서 ‘향유'에 대한 지원은 필수적인 영역임을 강조하고 있다. 예술지원의 궁극적 목적이 국민의 향유기회 확대를 통해 그들의 삶이 예술을 매개로 보다 풍요로워 지 는 삶의 질 향상에 있음을 고려할 때, 향유 관련 정책지원은 예술정책 내 필연적인 구성요소로 인식되어야 한다.

주지하다시피「문화기본법」 제4조(국민의 권리)는 “모든 국민은 성별, 종교, 인 종, 세대, 지역, 정치적 견해, 사회적 신분, 경제적 지위나 신체적 조건 등에 관계없 이 문화 표현과 활동에서 차별을 받지 아니하고 자유롭게 문화를 창조하고 문화 활 동에 참여하며 문화를 향유할 권리(이하 “문화권”이라 한다)를 가진다<개정 2017. 
11.28. ”라고 규정하고 있다. 동 법의 ‘문화’ 관련 정의 속에 ‘(문화)예술’이 포함된 바, 동 조항에서 문화를 예술로 치환하여 해석해도 무방하다고 할 수 있다. 즉, 예술 가뿐 아니라 이들을 포함한 모든 국민을 대상으로 이들이 개인적 차원에서 성별, 종교, 인종, 세대, 지역, 정치적 견해, 사회적 신분, 경제적 지위나 신체적(정신적) 조건에 관계없이 "예술표현과 활동에서 차별을 받지 아니하고 자유롭게 예술을 창 조하고 예술활동에 참여하며, 예술을 향유할 권리”가 존재하는 것이다.

〈표 6-3〉 예술향유권(예시)

\begin{tabular}{|c|c|}
\hline & 개념적 규정(예시) \\
\hline $\begin{array}{l}\text { 예술향유권 } \\
\text { (藝術享有權) }\end{array}$ & $\begin{array}{l}\text { 모든 국민은 성별, 종교, 인종, 세대, 지역, 정치적 견해, 사회적 신분, 경제적 지위나 } \\
\text { 심신의 조건134) 등에 관계없이 예술표현과 활동에서 차별을 받지 아니하고 자유롭게 } \\
\text { 예술을 창조하고 예술활동에 참여하며, 예술을 향유할 권리(이하 '예술향유권'이라 한 } \\
\text { 다)를 가진다. }\end{array}$ \\
\hline
\end{tabular}

자료: 국가법령정보센터(http://law.go.kr 최종접근: 2020.05.14) 및 연구진 재구성

온라인 설문조사 결과 및 FGI 결과에서 나타나듯이 예술이 우리 사회를 풍요롭게 한다는 사회적 가치에 대한 동의를 비록 많은 이들이 공감하고 있기는 하나, 다른 한편으로 여전히 '예술향유’와 관련된 물리적 제약 뿐 아니라 심리적 제약 역시 경 험하고 있음이 확인된다. 보다 많은 이들이 예술향유를 통해 삶을 보다 풍요롭게 할 수 있는 기회를 평등하게 누릴 수 있으려면, 이를 위한 정책지원은 필연적일 수 밖에 없으며, 이는 곧 예술지원에 있어 핵심목표로 설정해야 하는 이유가 된다.

이런 관점에서 향후 예술정책 논의는 전문 예술가 및 기관.단체 중심의 창작지원 과 모든 국민을 정책대상으로 이들의 적극적, 주체적 예술향유활동에의 참여를 독 려할 수 있는 ‘향유' 지원을 예술정책을 구성하는 핵심영역으로 설정, 예술지원을 구 성하는 또 다른 중요한 축임을 명확히 할 필요가 있다. 동시에 '향유' 지원을 창작의 부차적인 영역이나 수세적 관점에서 접근, 옹호하는 것이 아니라, ‘향유'에 대한 지 원 자체가 예술지원의 본질적 당위임을 좀 더 적극적으로 옹호하고 강조해야 할 것 이다. 이를 통해 일부에서 제기되는 '창작 vs. 향유' 지원 간 불균형 비판에 얽매이 기 보다는 거시적 관점에서 창작지원과 향유지원 간의 선순환적 균형을 모색하기

134) 원문에는 신체적 조건만이 제시되나, 장애의 경우 신체뿐 아니라 정신을 포괄함으로 '신체적 조건'을 '심신의 조건'으로 치환하여 제시한다. 
위한 다양한 방법론적 고민에 집중하는 것이 보다 진취적이고 생산적인 예술지원 담론 형성과 사회적 합의 획득, 더 나아가 지속가능한 국민의 예술향유권 실현을 위해 보다 유용할 것으로 판단된다. 이를 가능케 하기 위해서는 우선 현재 예술정책 분야 내 '예술향유'와 관련된 법, 제도를 '향유자' 관점에서 재점검 하는 한편, 이들 에 있어 국민들의 적극적이고 주체적인 '예술향유' 권리가 보다 적극적으로 반영되 는 정책 방식을 적극 모색할 필요가 있다. 


\section{제2절 예술향유정책 방향과 과제}

\section{1. 보편적 국민 예술향유 진작을 위한 정책 환경 조성}

현재 예술지원 관점에서 진행되고 있는 중앙단위의 예술향유지원은 앞서 지적한 것처럼 특정 정책의제 혹은 재원변경 등 환경변화에 따라 단위사업 중심으로 구조 화되어 온 특성을 가진다.135) 그로 인해 향유지원 사업별 목적과 대상의 모호성 뿐 아니라, 국민의 입장에서 ‘예술향유’라는 것을 정책적 관점에서 어떤 방식으로 이해 할 것인가에 관한 논의는 심도 깊게 진행되지 못한 채 전개된 그간의 과정은 결국 향유지원 사업들의 목적과 대상의 모호성 등의 문제를 배태할 수밖에 없던 것으로 보인다.

더욱이 '향유' 지원의 성격을 가진 개별 단위사업들의 경우 궁극 정책목표를 '국 민 향유기회 확대’로 제시하기는 하지만, 해당 사업에서의 ‘향유' 기회 확대를 구체 적으로 어떻게 이해하고 있는지는 모호하다. '만족도', ‘참여자 수 증대' 등을 넘어 서는 정책적 고민이 충분히 발현되지 못했던 이러한 문제는 공급자 관점에서 접근 하여 ‘향유’를 평면적으로 이해했던 정책인식의 문제와 맞닿아 있다고 볼 수 있다.

따라서 향후 예술향유지원 정책의 새로운 방향성을 모색함에 있어 무엇보다 국민 의 입장에서 그들이 실제 예술활동과 결합하여 경험하는 '향유'를 복합적으로 이해 하는 한편, 이를 정책적으로 지원하기 위한 고민이 보다 입체적으로 진행될 필요가 있다고 하겠다. '향유'를 바라보는 정책인식의 입체화와 관련 정책인식의 제고를 위 해서는 다음과 같은 전략들이 필요하다.

135) 제4장 및 제5장의 정책 전개과정과 지원사업 분석 시사점 참조. 


\section{가. 문화예술진흥법」개정 추진}

'예술향유'에 대한 입체적이고 다원적인 정책인식을 확보하기 위해서는 먼저 예 술지원의 모법으로 기능하고 있는 「문화예술진흥법」에 반영된 예술 및 향유 관련 인식의 변화가 필요할 것으로 사료된다. 해당 법 조항에 제시된 '예술'에 대한 정의 는 앞서 지적한 것처럼 시대변화에 부응하지 못하는 '예술'에 관한 고루한 정책인식 뿐 아니라, 예술정책에서의 ‘향유’지원이 마치 소외계층을 위한 부차적 영역인 것으 로 간주되는 오해의 여지가 잔존함을 간과하기 어렵다.

최근「문화예술진흥법 정비를 위한 사전연구」에서는 '문화예술'의 정의가 현재 “장르별 열거식 나열”로 일관된 문제를 복합적으로 지적·논의하는 한편(양혜원 외 2020: 117), 향후 예술의 개념과 범주가 지속적으로 변화하고 있음을 고려하여 예 술의 “새로운 유형이나 활동의 형식이 법적 보호영역에 포함”될 수 있도록 재검토 될 필요가 있음을 강조하기도 했다(양혜원 외 2020: 131).「문화예술진흥법」 자체 가 가진 다양하고 복잡다기한 문제를 고려할 때, 향후 동법의 개정은 추진될 가능성 이 농후하다고 예견되는 상황이다. 이 때「문화예술진흥법」 개정안 논의에는 반드 시 예술에 대한 정의가 확장적 차원에서 제시되고, 미래 환경변화로 인한 새로운 예술양식과 유형이 포용될 수 있는 가능성이 반드시 전제될 필요가 있을 것으로 보 인다.

아울러 정책 실제에서「문화예술진흥법」이 예술분야에 대한 정부지원 일체를 포 괄하는 일종의 모법으로서의 기능을 수행하고 있는 점을 고려할 때, 향후 개정(안) 에는 예술지원에 있어 주요한 창작지원과 향유지원과 관련된 섹션이 법령 내 별도 의 '장'으로 공식 마련되어 이에 대한 국민의 권리가 명확히 제시될 필요가 있을 것 으로 사료된다. 이때 '예술향유권(가칭)'과 관련된 논의는 앞서 제시한 예술향유 지 원 필요성 논의에서 제시한 정의(안)을 토대로 개진될 수 있을 것이다. 이를 통해 '소외계층'을 위한 향유지원만 언급되는 것이 아니라, 예술지원 전반에서 '향유'지 원이 예술정책의 핵심영역임을 명확히 할 필요가 있다. 
〈표 6-4〉「문화예술진흥법」개정을 위한 정비-정의(안) 예시

\begin{tabular}{|l|l|}
\hline \multicolumn{1}{|c|}{ 현재 조항 } & \multicolumn{1}{|c|}{ 주요쟁점 } \\
\hline 제2조 (정의) (1)이 법에서 사용하는 용어의 뜻은 & \\
다음과 같다. & (1) 문화예술진흥법 규율범위: 문화예술 vs. 예술 \\
1. "문화예술”이란 문학, 미술(응용미술을 포 & (2) '문화예술'의 정의방식: 열거규정 vs. 일반조항+예시규정 \\
함한다), 음악, 무용, 연극, 영화, 연예(演 & (3) 열거된 장르 및 부문 간 개념적, 범주적 위계관계 불명확 \\
藝), 국악, 사진, 건축, 어문(語文), 출판 & 성 및 비체계성 \\
및 만화를 말한다. &
\end{tabular}

\section{[정의(안) 예시]}

제2조(정의) ‘문화예술’이란 인상, 견문, 경험, 직관, 상상력을 근거로 한 개인 또는 집단의 심미적, 창조적 표현활동과 그 결과물에 관련된 것으로서 다음 각목의 어느 하나에 해당하는 것을 포함한다.

가. 문학예술: 연어로 된 시, 소설, 수필, 희곡 등

나. 공연예술: 무대 등과 같은 공객된 장소에서 이루어지는 연극, 무용, 음악 등

다. 시각예술: 시각적 감각에 기반한 미술, 설치, 서예, 사진, 공예, 디자인, 건축, 미디어아트 등

라. 전통예술: 과거로부터 이어져 내려오는 전통문학예술, 전통시각예술, 전통공연예술 등

마. 이 밖에 둘 이상의 예술형식이나 분야가 혼합되거나(융복합예술), 다양한 형태의 미디어를 활용하거나 (영화, 대중예술, 멀티미디어예술), 디지털기술을 활용하거나(디지털아트), 실험성과 다양성을 추구하는 예술(다양성예술) 등

자료: 양혜원 외(2020), 『문화예술진흥법 정비를 위한 사전연구』, 131쪽.

이러한 정책인식의 변화는 이미 진행 중인 상황이다. 앞서 언급한「문화예술진흥 법 정비를 위한 사전연구」(양혜원 외 2020)에서는 동 법령의 장 구성을 '창작활성 화, '향유와 참여증진', '기반조성' 등 세 개의 섹션으로 구분하여 재편하는 방향으 로 제시한 바 있다. 또한 가장 핵심적인 '문화예술'의 정의 역시 기존의 장르별 열거 규정 및 장르 간 층위의 비체계성을 수정, 보완할 것을 제언하기도 하였다. 136)

〈표 6-5〉「문화예술진흥법」 개정을 위한 정비(안)

\begin{tabular}{|c|c|c|c|}
\hline \multicolumn{2}{|r|}{ 기존 } & \multicolumn{2}{|r|}{ 변경(안) } \\
\hline $\begin{array}{l}\text { 제1장 } \\
\text { 총칙 }\end{array}$ & $\begin{array}{l}\text { 제1조(목적) } \\
\text { 제2조(정의) } \\
\text { 제3조(시책과 권장) } \\
\text { 제4조의2(문화시설에 관한 실태조사 및 } \\
\text { 통계작성 등) }\end{array}$ & $\begin{array}{l}\text { 제1장 } \\
\text { 총칙 }\end{array}$ & $\begin{array}{l}\text { 제1조(목적) } \\
\text { 제2조(정의) } \\
\text { 제3조(기본원리) 또는 (기본원칙) } \\
\text { 제4조(국가와 지자체의 책무) } \\
\text { 제5조(다른법률과의 관계) } \\
\text { 제6조(문화예술진흥 기본계회) } \\
\text { 제7조(문화예술진흥 시행계획) }\end{array}$ \\
\hline
\end{tabular}

136) 이 연구에서는 「문화예술진흥법」을 기존 명칭을 그대로 유지하되 내부 법령 체계 등을 대폭 수정하는 방안과 함께, 예술분야를 관장하는 모법으로서 「예술진흥기본법」명칭까지 재편하는 (안)을 함께 제시하 고 있다. 다만 연구결과에서는 1 안 중심의 의견을 제시한 바, '문화예술'의 정의에서 '문화예술’이란 용 어를 그대로 제시하지만, 그 정의에 있어서 확장된 관점에서의 ‘예술’에 대한 이해를 반영하고 있다. 


\begin{tabular}{|c|c|c|c|}
\hline \multicolumn{2}{|r|}{ 기존 } & \multicolumn{2}{|r|}{ 변경(안) } \\
\hline $\begin{array}{l}\text { 제2장 } \\
\text { 문화예술 } \\
\text { 공간의 } \\
\text { 설치 }\end{array}$ & $\begin{array}{l}\text { 제5조(문화예술 공간의 설치 권장) } \\
\text { 제6조(전문인력 양성) } \\
\text { 제7조(전문예술법인·단체의 지정·육성) } \\
\text { 제9조(건축물에 대한 미술작품의 설치 등) }\end{array}$ & $\begin{array}{l}\text { 제2장 } \\
\text { 문화예술 } \\
\text { 활동 및 } \\
\text { 창작 } \\
\text { 활성화 }\end{array}$ & $\begin{array}{l}\text { 제8조(예술표현 및 활동의 자유 보장) } \\
\text { 제9조(예술창작 지원) } \\
\text { 제10조(창작여건 증진 지원) } \\
\text { 제11조(전문예술법인·단체의 지정·육성) } \\
\text { 제12조(장려금 지급 등) } \\
\text { 제13조(국제문화교류 지원) }\end{array}$ \\
\hline $\begin{array}{l}\text { 제3장 } \\
\text { 문화예술 } \\
\text { 복지의 } \\
\text { 증진 }\end{array}$ & $\begin{array}{l}\text { 제11조(장려금 지급 등) } \\
\text { 제12조(문화강좌 설치) } \\
\text { 제13조(학교 등의 문화예술 진흥) } \\
\text { 제14조(문화산업의 육성·지원) } \\
\text { 제15조(도서·문화 전용 상품권 인증제도) } \\
\text { 제15조의2(장애인 문화예술 활동의 지원) } \\
\text { 제15조의3(문화소외계층의 문화예술복지 } \\
\quad \text { 증진 시책 강구) } \\
\text { 제15조의4(문화이용권의 지급 및 관리) }\end{array}$ & $\begin{array}{l}\text { 제3장 } \\
\text { 문화예술 } \\
\text { 향유와 } \\
\text { 참여 증진 }\end{array}$ & $\begin{array}{l}\text { 제14조(문화향유 및 참여 증진) } \\
\text { 제15조(문화예술교육 지원) } \\
\text { 제16조(장애인 문화예술활동의 지원) } \\
\text { 제17조(문화소외계층의 문화복지 증진) } \\
\text { 제18조(소수집단의 문화적 표현 보장) } \\
\text { 제19조(문화이용권 지급 및 관리) }\end{array}$ \\
\hline $\begin{array}{l}\text { 제4장 } \\
\text { 문화예술 } \\
\text { 진흥기금 }\end{array}$ & $\begin{array}{l}\text { 제16조(기금의 설치 등) } \\
\text { 제17조(문화예술진흥기금의 조성) } \\
\text { 제18조(문화예술기금의 용도) }\end{array}$ & $\begin{array}{l}\text { 제4장 } \\
\text { 문화예술 } \\
\text { 기반 조성 }\end{array}$ & $\begin{array}{l}\text { 제20조(예술산업의 육성·지원) } \\
\text { 제21조(문화예술 연구개발 지원) } \\
\text { 제22조(문화시설의 조성 및 운영 지원) } \\
\text { 제23조(유휴공간의 문화적 활용 등) } \\
\text { 제24조(건축물에 대한 미술작품의 설치 등) } \\
\text { 제25조(문화예술인력 양성) } \\
\text { 제26조(실태조사 및 통합정보시스템) } \\
\text { 제27조(협의체 등) }\end{array}$ \\
\hline \multirow[t]{2}{*}{$\begin{array}{l}\text { 제5장 } \\
\text { 한국문화 } \\
\text { 예술 } \\
\text { 위원회 등 }\end{array}$} & $\begin{array}{l}\text { 제20조(한국문화예술위원회) } \\
\text { 제21조(설립등기 등) } \\
\text { 제22조(정관) } \\
\text { 제23조(위원회의 구성) } \\
\text { 제24조(위원장 등) } \\
\text { 제25조(위원의 임기) } \\
\text { 제26조(위원의 대우 및 겸직 금지) } \\
\text { 제27조(위원의 결격사유) } \\
\text { 제28조(관여금지) } \\
\text { 제29조(위원의 직무상 독립 등) } \\
\text { 제30조(위원회의 직무) } \\
\text { 제31조(위원회의 회의 등) } \\
\text { 제32조(소위원회) } \\
\text { 제33조(사무처) }\end{array}$ & $\begin{array}{l}\text { 제5장 } \\
\text { 한국문화 } \\
\text { 예술 } \\
\text { 위원회 등 }\end{array}$ & $\begin{array}{l}\text { 제28조(한국문화예술위원회) } \\
\text { 제29조(위원회의 구성 등) } \\
\text { 제30조(위원회의 심의·의결사항) } \\
\text { 제31조(위원의 대우 및 겸직 금지) } \\
\text { 제32조(위원의 직무상 독립 등) } \\
\text { 제33조(위원회의 회의 등) } \\
\text { 제34조(소위원회) } \\
\text { 제35조(지원심의회 등) } \\
\text { 제36조(사무처) } \\
\text { 제37조(감사) } \\
\text { 제38조(성과의 평가) } \\
\text { 제39조(예술의 전당) } \\
\text { 제40조(한국문화예술회관연합회) } \\
\text { 제41조(예술경영지원센터) }\end{array}$ \\
\hline & $\begin{array}{l}\text { 제34조(감사) } \\
\text { 제35조(성과의 평가) } \\
\text { 제36조(협의체의 구성) } \\
\text { 제37조(예술의 전당) } \\
\text { 제38조(한국문화예술회관연합회) }\end{array}$ & $\begin{array}{l}\text { 제6장 } \\
\text { 문화예술 } \\
\text { 진흥기금 }\end{array}$ & $\begin{array}{l}\text { 제42조(기금의 설치 등) } \\
\text { 제43조(문화예술진흥기금의 조성) } \\
\text { 제44조(문화예술진흥기금의 용도) }\end{array}$ \\
\hline $\begin{array}{l}\text { 제6장 } \\
\text { 보칙 }\end{array}$ & $\begin{array}{l}\text { 제39조(국고보조 등) } \\
\text { 제40조(감독) } \\
\text { 제41조(권한의 위임·위탁) }\end{array}$ & $\begin{array}{l}\text { 제7장 } \\
\text { 보칙 }\end{array}$ & $\begin{array}{l}\text { 제45조(국고보조 등) } \\
\text { 제46조(감독) } \\
\text { 제47조(권한의 위임·위탁) }\end{array}$ \\
\hline
\end{tabular}


해당 연구에서 제시한 정의(안)에는 과정으로서의 예술에 관한 인식 및 향후 환경 변화에 따른 다양한 예술양식에 대한 포용적 관점이 반영되어 있다. '문화'라는 용 어의 결합을 전제로 하고 있는 점, 향유 관련하여 구체적인 '예술향유권'까지 언급 하고 있지는 않지만, 연구에서 제시된 내용을 기반으로 향후 '예술'의 정의와 관련 된 다양한 대안 및 논의가 보다 구체적으로 개진될 수 있을 것이라 예상된다.

다만 설사「문화예술진흥법」이 개정된다고 하여, 그 자체가 향후 정부 정책의 변 화를 그대로 담보한다고 보기는 어렵다. 현재 예술향유지원 정책을 둘러싼 다양한 문제들을 단숨에 해결하는 기제로서 개정(안)이 작동할 수 있으리라 기대하긴 어려 울 수 있기 때문이다. 그럼에도 불구하고, 법령에서의 ‘정의' 하나, 법령을 구성하는 '장'의 변화 등은 당장 별 것 아닌 것처럼 보일 수 있으나, 향후 향유지원을 포함한 예술정책 전반에 걸친 중장기적 큰 변화로 이어질 수 있는 가능성을 마련해 줄 수 있다. 이런 점에서 향후「문화예술진흥법」 개정은 예술향유지원의 정체성을 확립하 고, 그 위상을 명확히 하기 위해 필연적인 과정임을 상기할 필요가 있다.

\section{나. 향유지원 정책 환경 재정비}

앞서 제4장 및 제5장에서 살펴 본 바와 같이 현재 중앙에서 지원하는 향유지원의 규모만 해도 대략 3,409억 원 규모다.137) 이들 사업들은 대부분 국민의 향유진작을 사업목적으로 제시하며 운영되지만, 각 세부 사업 목표와 전략, 정책수단 및 추진방 식 등은 재원 성격 및 주관부서(처) 등의 환경적 변수에 따라 제각기 산발적으로 운 영되는 경향이 크다. 이런 측면은 거시적 관점에서의 향유지원 정책 환경 재정비를 모색할 필요성을 의미한다고 하겠다.

먼저 향유정책의 종합적 현황 파악 및 향후 재정비 방향을 모색하기 위해 '예술향 유진작을 위한 포괄적 정책 R\&D' 추진을 먼저 검토해 볼 수 있을 것으로 사료된다. ‘포괄적 정책 R\&D'에서 다룰 의제는 국공립 예술단체를 포함한 향유지원 사업의 종합적 재검토, 접근성 관련 정책연구, 기존 사업 재정비 및 신규 사업 발굴 등을 들 수 있을 것이다. 본 연구에서는 연구기간 제약상 문화체육관광부 중심 중앙단위

137) 예산현황과 구조 분석은 제4장 제2절을 참조. 해당 수치는 본 연구에서의 분석대상인 중앙단위 사업에만 한정된 것으로 국공립 예술단체/기관/시설 등에서의 향유 관련 사업들을 포괄하면 향유지원 규모는 휠씬 늘어날 것으로 예상된다. 
사업만을 분석하였지만, 향후 국공립 예술기관, 단체, 시설 등에서 현재 진행하고 있는 다양한 교육프로그램이나 향유기회 확대를 위한 개별 사업들까지 포괄적으로 검토하는 '향유지원 현황에 관한 종합 분석 연구(가칭)' 가 추진될 필요가 있다. 이를 통해 중앙부처 뿐 아니라 개별 예술기관(단체, 시설 포함)에서의 향유지원 현황을 교차하여 살펴보고, 전체 향유지원 관련 정책지형을 총체적으로 파악할 수 있을 것 이다. 또한 향후 미래지향적 예술향유정책의 방향을 구체화하는데 긴요한 기초자료 로서 활용될 수 있을 것으로 보인다.

더불어 예술향유에 있어 ‘접근성’ 향상을 위한 종합적 분석과 방법론을 고민하는 정책 $\mathrm{R} \& \mathrm{D}$ 를 추진할 필요가 있다. 아직까지 국내 예술정책 관련 정책연구에서 '접 근성' 의제 중심의 연구는 본격화된 바 없는 것으로 파악된다. 최근 「장애예술인 문 화예술 활동 지원에 관한 법률(2020.06.09. 제정)」이 제정되었고, 박물관·미술관 등 을 중심으로 한 예술기관에서의 장애인 접근성 제고 관련 연구(김현경 2020)가 진 행되고 있기는 하다. 그러나 '접근성 제약'의 문제는 장애인뿐 아니라, 이들을 포함 한 전 국민 차원에서 다층위적으로 경험되는 것임을 상기해야 한다. 더욱이 예술지 원에서의 '향유' 지원이 핵심영역인 만큼, 향유를 제약하는 요소들에 대한 종합적 분 석 및 연구는 중앙단위 정책 차원에서 응당 담당해야할 몫임을 기억할 필요가 있다.

접근성 관련 그동안 정책적으로 파악되는 부분은 「국민문화예술활동조사」혹은 전신인「문화향수실태조사 등을 통해 시간 및 경제적 부담이 제약요소로서 늘 지 목된다는 점에 한정된다. 제약요소로서 '시간'과 '경제적 부담'은 한국 뿐 아니라 전 세계를 막론한 공통사안 이기도 하다. 그러나 보다 중요한 지점은 앞서 제3장에서 다룬 온라인 설문조사 및 FGI 결과에서도 확인된 바와 같이 '시간' 과 '경제적 부담' 이란 요소에는 노동시간의 문제, 돌봄/가사 등 보다 복잡다기한 “사회구조적 문제” 가 함께 맞물려 있다는 점이다. 매년 실태 조사결과에서 시간과 경제적 부담이 1,2 순위를 자리매김하는 것을 보고 이를 어쩔 수 없는 사회적 현상의 반영으로 볼 것이 아니라, 이제는 정책관점에서 이들 요소가 내포하는 함의를 다층위적으로 파악하 고, 이를 공략하기 위한 새로운 전략과 접근방안이 모색될 필요가 있음을 인식해야 한다. 더욱이 '물리적' 제약요소 이외에 '심리적' 제약요소가 접근성을 제약하는데 복합적으로 작동하고 있음이 본 연구의 조사결과를 통해 확인된 만큼, 향유자 입장 에서 경험하는 접근성 문제를 보다 포괄적인 관점에서 분석하고, 이를 해소하기 위 
한 개별적 정책대안을 하나씩 풀어갈 준비를 해야 할 것이다. 138$)$

다른 한편으로 국공립 예술기관/단체 시설 차원에서 향유지원 사업을 총체적으로 점검하는 한편, 이들 단체/기관/시설 차원에서 대국민 향유기회 확대를 위한 자체 적인 전략을 마련할 수 있도록 독려할 필요가 있을 것으로 보인다.139) 국가 단위로 추진되는 예술향유 지원이 국민의 입장에서 인식되는 것은 가장 우선적으로 국내 대표적인 국공립 예술기관을 통해서라고 해도 과언이 아니다. 예술향유활동 차원에 서의 고관여, 저관여, 무관심 그룹을 막론하고 해당 기관의 존재를 인식하고 있을 뿐 아니라, 이들 대표기관에서의 경험을 통해 국가 차원의 지원 수준과 정도를 인식 하는 경향이 강하다. 이미 국립현대미술관이나 국립중앙박물관, 국립극장이나 국립 극단 등은 자체 교육프로그램을 통해 향유기회 확대를 도모하기도 하고 있기도 하 지만, 이들 기관의 향유지원 관련 사업이나 교육 프로그램에 관한 종합적인 현황 파악은 아직까지 시도된 바 없다(국립극장 2019).140) 적어도 국립 층위의 예술기관 에서 향유지원 관련 사업운영 및 개발 등 개별적 노력은 대국민 향유기회 확대라는 대의적 차원에서 독려되어야 하는 사안이라고 할 수 있다. 그럼에도 불구하고 다른 한편으로 국공립 예술기관 존재의 본연의 목적인 좋은 작품을 개발하여 선보이는 '창작'에 방점을 두어야 한다는 의견도 제기된다. 물론 이 역시 중요하긴 하지만, 이들 국립기관이 수준 높은 작품을 개발하는 것이 궁극적으로 무엇을 위한 것인지 를 정책적 관점에서 함께 고민한다면, 향유지원 관련 국립기관의 노력은 당연히 필 요한 점임을 인식해야 할 것이다.

이런 점에서 국립 예술기관 주요사업의 성과지표에 '향유' 관련 부분을 개선, 반 영하는 것도 주요한 전략이 될 수 있다. 현재 국립 공연예술단체의 경우, ‘향유'와 관련된 지표는 거의 제대로 반영되지 못하고 있는 실정이다. 대부분 '공연/기획역량 강화’라는 항목하에 '유료객석(관람) 점유'(국립극단, 코리아심포니오케스트라, 국립 오페라단)이나 입장관객 수 중심으로 되어 있으며, 국립오페라단처럼 '문화예술향

138) 김현경(2020), 「장애인 접근성 강화를 위한 박물관·미술관 가이드라인 수립 방향 연구」, 한국문화관광 연구원.

139) 국공립 예술기관/단체/시설의 향유지원 사업은 본 연구의 연구대상 범위는 아니지만, FGI 등에서 일반 시민들은 정부지원을 한국의 대표적인 국공립 예술기관이란 매개를 통해 인식하는 경향이 강했다. 한국 의 대표기관으로서 이들 단체, 기관의 역할과 기능에 있어 보다 적극적인 향유지원에 대한 사업개발 및 고민이 확대되어야 한다는 점이 언급되었다.

140) 국립극장(2019), 「국립극장 문화예술교육 현황 분석 및 방향 설정」. 국립극장 내부자료. 
유 확대 성과 항목이 명시되는 경우도 있으나 실질적으로는 유료판매점유율로 성 과지표가 명시되어 있다. 그나마 '국립현대무용단'처럼 일부 기관은 창작 이외에 '관객 개발 및 저변확대사업' 성과항목을 별도로 책정하여 잠재관객개발 성과 평가 를 모색하고 있긴 하지만, 이 역시 프로그램 및 프로그램 당 참여자수에 한정된 제 약성을 보이고 있다. 향후 관객개발, 향유저변 확대가 국공립 예술기관 본연의 책무 중 하나로서 합의되고, 이를 반영하는 성과지표 개선 등을 통해 향유에 관한 정책인 식의 확산을 모색하는 것이 필요할 것으로 사료된다.

\section{다. 대국민 예술향유 인식제고}

‘시민 예술향유 인식 및 활동 양태’ 관련 FGI에서도 확인된 바와 같이 일반 시민 입장에서 중앙 정부 차원의 향유지원 인지도는 '문화가 있는 날' 정도를 제외하면 그리 높지 않은 상태로 보인다. 물론 모든 시민의 중앙정부의 정책을 일일이 다 알 고 있어야 한다고 주장하려는 것이 아니다. 더 근본적인 차원에서 보면 현재 정부가 상당한 규모로 향유지원을 추진하고 있음에도 불구하고 국민 입장에서 느끼는 정책 체감도가 낮음을 눈여겨 봐야 한다. 설문조사의 경우 예술향유지원 정책 모두를 모 른다는 응답자가 $18 \%$ 였다는 점, 지원정도가 부족하다는 의견이 상대적으로 높게 나오고 있다는 점은 바로 이러한 정책체감도 제고 차원에서 아직 보다 세심한 접근 이 필요함을 시사한다.

따라서 현재 정부가 시행하고 있는 예술향유 진작을 위한 다양한 지원정책뿐 아 니라, 예술향유의 중요성 및 이를 위한 정부의 정책적 노력에 대한 인식과 공감을 얻을 수 있는 체계적인 홍보전략 수립이 필요할 것으로 보인다. 현재 '문화가 있는 날’의 경우 단위사업 차원에서 다양한 홍보 캠페인을 추진하고는 있지만, 여전히 일 부에서는 ‘영화할인제도' 정도로 인식하고 있음도 부인하기 어렵다. “사람이 있는 문화, 예술이 있는 삶”이라는 슬로건을 내세웠던 이번 정부의「새예술정책」비전서 에서도 “예술향유”의 중요성을 강조했지만, 관련된 구체적인 정책 노력의 진행은 아 쉽게도 아직은 부각되지 못하고 있는 상황이다.

정부가 추진하고 있는 다양한 지원사업들 중심으로 하되 이들을 통합한 체계적 홍보전략을 수립·추진하는 것도 하나의 방법론일 수 있겠으나, 「새예술정책」의 슬 
로건인 “사람이 있는 문화, 예술이 있는 삶”은 그 자체로 대국민 예술향유 인식의 변화를 위한 훌륭한 자원으로 활용될 수 있음을 상기할 필요가 있다. 앞서 FGI 분석 에서 살펴본 바와 같이 예술향유의 장벽에는 '예술은 여전히 어렵고', '나와는 상관 없는' 것으로 인식하는 심리적, 정서적 걸림돌 요소도 주요하다. 따라서 정부가 우 리네 일상적 삶에서의 '예술'의 중요성을 인식하고 있음과 더불어, 일반 국민의 입 장에서 그들의 삶과 '예술' 간 거리감을 좁히고 친숙함을 점진적으로 경험하고 인식 할 수 있도록 하는 전략이 함께 추진될 필요가 있다.

아울러 다양한 지원사업에 관한 정보부족 문제는 무관심자 뿐 아니라 고관여자 경우에도 공통적으로 지적하는 지점이기도 함을 상기할 필요가 있다. 무료관람이 건, 교육이나 동호회 활동 기회이건 간에 지원정책의 존재 자체를 아예 모르기 때문 에 향유기회를 누리지 못하는 이들이 존재하고 있음을 기억하고, 한 번도 기회를 갖지 못한 이들이 계속 인지조차 못하는 상황이 지속되지 않도록, 그 간극을 좁힐 수 있는 대국민 홍보 방안 및 다각적인 홍보채널의 구축을 고려할 필요가 있다.

\section{2. 향유수요 변화 및 복합성 반영한 다원적 정책접근 개발}

다양한 예술향유 형태가 나타나고 기술적 환경변화가 일어나고 있음에도 현재 예 술향유 정책은 이러한 변화를 적절하게 반영하지 못하고 있음이 앞서 제기된 바 있 다. 그간 문화복지 차원에서 특정대상을 중심으로 관람형 향유 진작에만 치중되어 있던 예술향유 정책 및 관련 사업은 이러한 사회적·환경적·기술적 변화를 고려한 정책적 접근이 필요한 시점이며, 보다 수요자 중심적 관점에서 예술향유의 정책의 전환이 모색되어야 할 것이다.

앞서 제 3 장에서 다룬 일반 시민을 대상으로 한 설문조사 및 $\mathrm{FGI}$ 를 통해 확인된 바와 같이, 예술향유 인식의 범주 확장과 향유방식의 다양화, 그리고 기술적 환경변 화로 인해 예술향유의 양상이 변화하고 있음을 알 수 있었다. 하지만 앞서 분석에서 지적한 바와 같이 그간 예술향유 정책상에서는 이러한 예술향유 수요와 방식에 대 한 변화를 고려한 접근이 병행되었다기보다는 그간의 문화복지라는 명맥하에 유사 한 사업들이 반복되는 수준에 머물러 있었다고 할 수 있다. 따라서 향후 정책에 대 
한 접근은 예술향유가 보이는 복합적인 양상을 인식하고, 수동적인 향유자가 아닌 능동적인 수요자 관점에서의 향유자를 보다 입체적으로 지원할 수 있는 방식으로 선회되어야 한다.

본 연구를 통해 지속적으로 제기되었다시피, 예술향유 정책지원에 있어 예술이라 는 범주를 어떻게 바라볼 것인지, 사회적·기술적 환경 변화에 따라 예술향유라는 개념이 어떻게 인식되고 변화하고 있는지, 얼마나 다양한 형태의 예술향유 활동이 이미 행해지고 있는지, 그리고 예술향유를 하는 사람들의 내재적인 요인들 또한 얼 마나 다변화되고 있는지 등을 이해하고, 이러한 변화 및 복합성이 향유정책에 반영 될 수 있도록 면밀하게 검토할 필요가 있다.

\section{가. 향유환경 변화를 고려한 실태조사 개편}

앞서 제3장 제1절에서 현재 국내에서 시행되고 있는 예술향유와 관련된 「국민여 가활동조사」,「국민문화예술활동조사」,「서울시민 문화향유 실태조사」를 검토한 바 있다. 이 중「국민여가활동조사」는 예술향유를 포함한 여가 활동 전체를 다루고 있다는 점, 「서울시민 문화향유 실태조사」는 서울시민만을 조사 대상으로 하고 있 다는 점에서 국내 예술향유 전체에 대한 실태를 파악하기에는 한계를 가지고 있다. 이에 비해「국민문화예술활동조사 는 문화향유 수요 파악과 실태분석을 위해 1 년 주기로 시행되고 있는 바, 최근 국내 향유 실태를 파악하기에는 가장 적합한 실태조 사로 보인다. 141)「국민문화예술활동조사」에서 조사하는 항목은 문화예술 관람 및 참여, 문화예술교육, 자원봉사 활동, 동호회 참여 등을 포함하고 있어, 관람뿐만 아 니라 참여, 창작, 공유 등 최근 나타난 다양한 향유 양태를 조사 영역에 포함시키고 있다. 하지만 앞서 제3장에서 지적했듯이, 조사 결과는 문화예술행사 관람률 변화, 참여 경험률 변화 등 양적 변화를 보여주는 것에만 그치고 있어, 향유 동기나 인식 에 대한 조사는 조사 항목에 포함되어 있지 않다. 그렇다면 기술적 향유 환경 및 양태 등이 급속하게 변화하고 있는 현 상황에 비추어 볼 때, 이처럼 수치 변화만 제시하고 있는 실태조사 결과는 「국민문화예술활동조사」목적에 명시된 바처럼 예 술향유 정책의 개선점을 도출하고 정책수립에 필요한 정보를 제공한다는 차원에서

141) 원래「문화향수실태조사」로 불리다 2019년부터 변경된 조사로, 2005년부터 2년 주기였으나, 2019년 부터 1년 주기로 변경되었다. 
과연 얼마나 유의미하게 기능하고 있는 것일까?

앞서 설문조사 및 FGI를 통해 예술향유자의 주체적이고 내적 요소인 향유 동기, 목적, 가치에 대한 인식, 개인 효능감 정도가 결과적으로 어떻게 향유 방식 등과 연 계성을 갖는지를 확인하였음에도, 현 실태조사에서는 이러한 '원인'에 대한 실태 파 악은 생략된 채 '결과' 인 만족도 및 수치상의 변화만을 보여주고 있다는 점에서 개 선이 요구된다 하겠다. 따라서 향유자의 다양한 내적 요인 차원에서 왜 사람들이 예술을 향유하려고 하는지, 그리고 그렇지 않은 이유가 무엇인지 등 인과관계 및 상관관계를 파악하는 데에는 한계를 가지고 있다. 더불어 향유 환경 변화 차원에서 보면, 기술 환경 변화로 인해 온라인 콘텐츠의 다양화와 질적 향상이 온라인 매체를 통한 예술향유 수요 증가를 야기하고 있고, 단순 온라인 관람뿐만 아니라 예술교육 과 공유의 영역으로까지 온라인 매체가 그 영향을 미치고 있음에도, 「국민문화예술 활동조사 는 디지털 매체를 통한 향유 경험 유무 조사 수준에 그치고 있을 뿐, 매체 활용이 얼마나 다양화되고 기존 방식과 융합되고 있는지 ‘변화’의 양상을 파악하기 에는 여전히 미흡하다.

환경과 수요가 급속하게 변화하고 있는 현대 사회에서 이러한 변화를 감지하지 못하는 정책은 당연히 그 역할을 제대로 하지 못할 것임은 자명하며, 결국 수요자와 공급자가 따로 겉도는 정책 사업들만 반복될 수밖에 없을 것이다. 이것이 예술향유 에 대한 변화를 파악하고, 그 변화를 적극적으로 반영하기 위한 향유실태조사에 대 한 재정비가 필수적일 수밖에 없는 이유이다. 관람률, 참여률, 횟수 등 평면적 차원 의 조사가 아닌 입체적인 양상을 파악할 수 있는 실태조사 재설계를 통해, 매년 동 일한 항목을 조사하여 시계열적인 변화만을 추적하는 정태적인 방식이 아닌 기술 변화나 환경 변화에 따른 사람들의 인식, 태도, 양태 등을 지속적으로 추적할 수 있 는 동태적 관점으로 개편이 이루어져야 한다. 설문조사 형식으로는 미처 파악하지 못하는 부분들에 대해서는 정기적인 좌담회 개최 등을 통해 실제 국민들의 수요 및 인식 등을 보다 가까이에서 파악하고, 다변화되는 향유 환경을 이해할 수 있는 보완 적 제도도 고려해야 한다. 


\section{나. 보편적 예술향유자에 대한 입체적 지원 정책}

예술향유 지원사업은 크게 보편적 복지와 선별적 복지 사업으로 나누어진다. 선 별적 복지 사업은 경제적 취약 계층 또는 지리적·사회적 접근성에 제약을 받는 문화 소외계층과 같이 그 대상이 분명하게 정해져 있으며, 보편적 복지 사업의 대상은 선별적 복지 대상이 아닌 나머지 불특정 일반 국민을 대상으로 하고 있다. 주로 무 료나 할인 정책을 통해 예술향유에 대한 진입을 완화하고, '문화가 있는 날'과 같은 캠페인성 사업을 통해 국민들의 잠재적인 수요를 확대 하고자 하는데 목적을 둔다.

하지만 앞서 제3장에서 다룬 일반 시민 대상의 설문조사 및 FGI에서도 확인할 수 있었던 점은 예술향유의 관여 및 관심 정도에 따라 다른 내적·외적 방해 요소들 이 작용하고 있다는 것이다. 예를 들어, 예술향유 활동 고관여자 그룹의 경우, 주로 내적·심리적 요인보다는 외적·물리적 요소, 즉 비용, 시간, 정보 등이 예술향유 활 동의 걸림돌로 작용하고 있는 반면, 저관여자 그룹의 경우는 예술에 대한 지식 부족 등 문화자본 결여 요인이 예술향유 활동의 진입장벽으로 작동하고 있음을 알 수 있 었다.

따라서 예술향유의 보편적 저변 확대라는 차원에서 보면, 동일한 보편적 예술향 유 대상이라 할지라도 그 안에서 예술향유자 그룹을 세분화하여 특정 그룹이 가진 차별적 특성을 고려한 정책 설계가 이루어질 필요가 있다. 물론 문화복지 차원에서 예술향유 지원정책도 분명히 필요한 부분임은 틀림없다. 하지만 이와 함께 예술향 유 저변 확대를 위해서는 보편적인 예술향유자가 가진 이질적인 특성을 인지하고, 이에 대한 세분화된 지원 정책에 대해 고민하는 것도 필요하다. 예술향유 활동을 활발하게 하고 있으나 현실적 제약이 있는 그룹과 예술향유에 대한 니즈를 미처 인 식하지 못하고 있는 비향유자(무관심자) 그룹에 대한 정책적 접근은 분명히 달라야 할 것이다.

예를 들어, 설문조사 및 FGI에서 외적 걸림돌 요소로 지적된 정보 부족 문제의 경우, 정보 접근성 제약을 완화할 수 있는 장치가 필요할 것이며, 이를 위해 국공립 예술기관의 정보를 모은 종합 플랫폼 구축 등을 고려해볼 수 있을 것이다. 현재는 문체부가 공연예술통합전산망(KOPIS)과 같은 플랫폼을 운영하고 있으나, 이는 공 연 장르에만 한정되어 있다는 점, 전산시스템 구축을 통해 공연 관람 수를 파악하기 
위한 공급자 관점에서의 목적으로 운영되고 있다는 점에서 수요자 측면에서의 필요 한 정보를 제공한다고 보기는 어렵다. 최근 코로나19로 인해 문체부는 2020년 3월 국공립 문화예술단체의 온라인 공연·전시를 모두 찾아볼 수 있는 통합안내 페이지 를 개설했다.142) 이는 어린이 콘텐츠, 교육·체험 콘텐츠, 문화예술콘텐츠, 도서 콘 텐츠, 체육 콘텐츠, 온라인 공연, 실감형 콘텐츠 등 문체부와 소속 산하기관의 온라 인 콘텐츠를 확인할 수 있는 통합 플랫폼이다. 현재는 온라인 콘텐츠만 소개하고 있지만, 향후 여기에 오프라인 기반의 상호작용적 위치 기반 서비스 제공으로 근접 지역의 정보 제공, 모바일과의 연동, 할인정보 및 문화가 있는 날 정보 제공 등의 기능을 확장하고 홍보를 한다면, 지적되었던 정보 부족으로 인한 예술향유에 대한 장벽을 조금이나마 낮춰줄 수 있을 것으로 생각된다.

반면 설문조사 및 FGI 결과, 비향유자(무관심자) 그룹은 경험자가 인지하는 '즐거 움'과 '재미'와 같은 요인 대신 예술을 '재미없고', '거리감'이 있는 영역으로 인식하 고 있었다. 하지만 사실상 이들이 예술에 대해 가지고 있는 인식은 실제 경험보다는 오히려 예술에 대해 가지고 있는 편견이나 선입견이 예술 수용에 대한 저항으로 이 어지고 있다는 것이다. 이러한 그룹에게는 그간 예술이 가진 엘리트주의적 관점이 아닌 향유를 통해 일상에서의 재미와 즐거움을 줄 수 있는 대상이라는 인식 전환과 예술이란 어렵고 문화자본이 전제되어야만 향유할 수 있다는 관념을 완화시킬 수 있는 장치가 필요하며, 이를 위해서는 할인된 가격 혹은 무료로 대중예술이나 여가 콘텐츠와 결합한 형태의 양질의 예술 콘텐츠를 관람할 수 있는 기회 확대 등을 고려 해볼 수 있다.

\section{다. 능동적 향유자를 위한 지원사업 모델 개발}

예술향유는 관람뿐만 아니라, 경험, 창작, 공유, 일상에서의 예술, 후원, 기부 등 매우 다양하고 능동적 형태의 예술향유 방식으로 나타나고 있다. 이러한 능동적 형 태의 예술향유 방식 증가는 최근 온라인 기술 발전으로 인한 접근성 제고, 특히 코 로나19로 인해 이전에 비해 보다 온라인 매체 활용 기회가 증가하고 있다는 점과 영화, 게임, 대중음악 공연 등 순수 예술 영역이 아닌 콘텐츠 및 대중예술, 심지어

142) 홈페이지: https://www.culture.go.kr/home/index.do(최종접근: 2020.08.25) 
취미 및 여가 영역에 걸쳐 예술과 결합한 다양한 향유 양태가 나타나고 있다는 점과 연관 지어 볼 수 있다. 더구나 온라인 기술 발전과 같은 기술 환경 변화는 향유자들 이 보다 능동적이고 적극적으로 예술을 향유할 수 있는 기회를 제공해주고 있으며, 젊은 세대뿐만 아니라 중노년층도 온라인 매체를 통해 다양한 콘텐츠를 접하고 활 용할 수 있도록 해주고 있다.

이러한 능동적인 예술향유 활동 변화는 최근 중·노년층을 중심으로 불고 있는 디 지털 매체를 통한 향유 활동을 통해서도 확인되는 바이다. 정보통신정책연구원 자 료에 따르면, 2018년 기준 국내 70대 이상 스마트폰 보급률은 37.8\%, 60대는 80.3\%로 세계 최고 수준이다143). 더불어 2020년 초부터 시작된 국내 트로트 열풍 은 시니어 세대에게 디지털 기기 활용에 있어 중요한 증폭제로 작용하고 있다. 실례 로, 이제는 중노년층이 음원사이트에 접속하여 좋아하는 가수의 차트 순위를 올리 기 위해 음원을 스트리밍하거나 유튜브와 같은 온라인 플랫폼을 통해 동영상 조회 수를 올리는 현상이 낯설지 않을 만큼 시니어 세대들의 콘텐츠 향유 방식이 변화하 고 있다. 트로트 팬 카페에서 90년대 팬덤을 경험한 40대 팬이 60 70대 노년 팬들 에게 노하우를 가르쳐 주고, 이들이 다시 동년배에게 가르쳐 주는 등 디지털 지식을 서로 가르쳐주며 함께 학습하는 현상이 나타나고 있을 만큼144) 중노년층의 향유 방 식이 능동적이며 다변화되고 있음도 목도된다. 앞서 언급된 것처럼 '어르신 문화프 로그램 지원' 사업 방향을 전환할 계획이라는 사실에서도 알 수 있듯이 이제는 노년 층을 예술향유 기회를 가지지 못한 문화복지 수혜자 대상으로서 찾아가는 관람 형 식의 향유사업 대상으로서 인식하는 것이 아니라, 문화예술 영역에 기여하는 문화 적 '주체자'로서 바라보고 있음을 의미한다 하겠다.

이처럼 흥미와 취향에 대한 관심과 의지가 높아지고, 능동적으로 삶의 질 제고를 위해 투자하는 소비층이 증가하며, 향유 대상 확장 및 향유 형태 변화가 일어나고 있다. 또한 향유를 능동적으로 선택하며, 선택의 기준은 무엇보다 취향이 중요한 시

143) 김미리, 150만원어치 생수·참치 사서 뿌렸다... '아미' 안 부럽다, 실버덕질, 조선일보, 2020.08.22. https://news.chosun.com/site/data/html_dir/2020/08/21/2020082103336.html (최종접근: 2020.08.25)

144) 김미리, 150 만원어치 생수·참치 사서 뿌렸다... '아미' 안 부럽다, 실버덕질, 조선일보, 2020.08.22. https://news.chosun.com/site/data/html_dir/2020/08/21/2020082103336.html (최종접근: 2020.08.25) 
대를 맞고 있다. 그럼에도 예술향유 정책은 여전히 예술 영역 안에 머물러 있으며, 예술향유 지원정책이 가진 시혜적, 복지차원의 공공적 측면에만 치중되어 있다는 비판이 제기되고 있기에, 이러한 변화들을 보다 적극적으로 정책적 논의 대상으로 서 반영해야 할 시점이라고 생각한다.

그간 전통적인 향유방식으로 인식되던 물리적·공간적 매개를 통한 예술의 영역이 온라인과 다양한 방식으로 결합하는 환경 하에서, 향유자와 향유 방식 변화에 적극 적으로 대응할 수 있도록 빅데이터를 활용하여 수요 분석 및 수요자 발굴을 할 수 있을 것이며, 능동적인 향유자 수요에 대응하여 온라인 기반의 향유 콘텐츠 개발 등과 같이 그간 시도되지 않은 새로운 지원사업 모델들이 개발되어야 할 것이다.

\section{3. 창작-향유의 선순환 구조 형성}

예술정책에서 창작, (유통), 향유는 각각 분리된 영역이 아니라 상호 유기적으로 연계되어 있다. 향유 지원을 목적으로 하는 사업들도 궁극적으로는 예술분야의 저 변을 확대하는 간접적인 창작 지원 역할을 한다. 향유자 개인 차원의 삶의 질 향상 효과 뿐만 아니라, 적극적인 문화소비를 하는 예술향유층의 증가는 창작생태계의 활성화로 이어질 수 있기 때문이다. 예술가들의 창작활동도 결과적으로는 향유로 연결되어야 전반적인 예술생태계의 확장이 가능하고, 작업실이나 연습실에만 머물 러 있는 것이 아니라 향유자들과 작품을 통해 만나면서 에너지와 자극을 받아 선순 환을 이룰 수 있기 때문이다. 기존의 지원사업들이 '향유'를 사업의 목적으로 내세 우지만 사실상 예술가나 예술단체의 활동을 지원하는 유형의 사업이 많고, 창작지 원사업의 마지막 단계에는 결국 향유가 있기 때문에 단순히 예산의 비율만을 놓고 창작과 향유 사업의 비중을 논하기는 어렵다고 할 수 있다.

앞에서 분석한 예술향유 지원사업들에는 대부분 어떤 형태로든 예술가와 작품이 들어갈 수밖에 없기 때문에 창작과의 연결고리는 갖고 있다고 볼 수 있다. '미술 창 작 및 향유 지원'사업의 '작가미술장터'처럼 관람객의 향유를 작품 구매 활동으로 연계해 소장문화 확산을 유도하고 작가들의 판로를 개척하는 사업 유형도 있다. 반 면 통합문화이용권은 본인이 금액을 충전해서 추가로 사용하는 사례 등이 나오고 
있긴 하지만, 창작활동의 활성화와의 직접적인 연결성을 보기에는 아직 약한 면도 있다. 교육 지원형 사업도 예술가가 자신의 작업을 기반으로 하는 프로그램들은 예 술가의 창작활동과 교육 대상자의 향유활동을 동시에 지원해 주는 사업이 될 수 있 지만, 예술활동보다는 교육이 강조되는 측면이 있다. 한편 기존의 예술가와 예술단 체, 신작이나 프로젝트를 지원하는 창작 중심의 사업에서 향유자는 중요한 고려 대 상이 아니거나 후순위였던 경우가 많았다. 예술생태계의 관점에서 보았을 때 창작 과 향유의 선순환 고리를 정책적으로 좀 더 강하게 하고 여러 개의 고리가 입체적으 로 돌아갈 수 있게 만들어 줄 필요가 있으며, 이는 코로나19로 인해 도래한 예술 환경의 변화와도 맞물려 돌아가야 하는 부분이다.

\section{가. 향유자-창작자 간의 소통 활성화}

향유자들 중에는 더 이상 수동적인 관객의 입장에 만족하지 않고 적극적으로 창 작에 개입하거나 예술가와 직접 소통하고 교류하는데 불편함을 느끼지 않는 유형이 있다. 적극적인 향유자들은 단순히 관람객으로 소비만 하는 게 아니라 예술가를 직 접 만나보거나 작업에 참여하고자 하는 욕구를 갖고 있다. 예술가들도 과거에는 향 유층에 대해 고려하지 않거나 잘 모른다는 식의 반응을 보이는 경우가 많았지만, 요즘에는 기본적인 태도가 달라졌다. 향유층과 어떻게 소통할지에 대한 고민과 관 심이 많고, 이를 창작에 녹여내려는 시도를 한다. 관객이 직접 작품에 참여해 같이 완성해 나가거나, 공동 창작을 거쳐 무대에 오르는 참여형 전시나 공연의 사례는 이미 상당히 많지만 앞으로 더 많아질 것으로 예측된다. 유튜브, 인스타그램 등 소 통 채널이 증가하고 방법도 용이해지면서, 대중문화 영역에서는 라이브 방송을 통 해 대중들과 실시간으로 소통하고 의견을 받아 즉시 반영하거나 이를 콘텐츠로 만 드는 등 쌍방향의 제작 문화가 이미 대세로 자리 잡았다.

향유자가 예술가의 창작 과정에 적극 개입하며 후원까지 하는 방식으로는 크라우 드 펀딩이 있다. 이제 향유자들은 다양한 크라우드 펀딩 플랫폼에 올라온 문화예술 분야 프로젝트에 의견을 내거나, 직접 선택해서 원하는 만큼 후원을 할 수 있다. 크 라우드 펀딩에 참여하는 작가들은 공공지원 외의 새로운 재원 조성의 경로를 개척 하며 향유자와 직접 소통하며 작업을 발전시켜나갈 수 있다. 공공에서는 향유자와 
창작자를 매개하는 역할을 하며, 작가의 프로젝트나 작품을 후원하거나 기부하는 문화가 활성화될 수 있도록 캠페인 등을 통해 사회적인 분위기를 조성하고 플랫폼 의 접근성과 편의성을 높이고 확장하는 접근법이 필요하다. 일례로 예술위원회는 크라우드 펀딩 플랫폼 텀블벅과 '크라우드펀딩 매칭지원사업'을 진행해 왔으며, 2020년에는 코로나19 긴급지원으로 후원 프로젝트를 진행하고 있다. 145) 예술가들 은 후원을 받고 새로운 가능성을 시험해보면서 창작활동을 이어나갈 수 있고, 향유 자들은 후원자이자 기부자가 되어 예술가를 적극적으로 지지하며 향유 활동의 몰입 도와 만족도를 높일 수 있는 방법이다.

적극적인 향유자가 등장하는 반면, 오페라, 현대무용, 발레 등은 관람 전에 사전 지식이 필요하다고 느끼거나 아예 거리를 두는 관객층도 여전히 존재한다. 국공립 예술단체를 중심으로 관람객 대상의 해설이 있는 공연, 프리뷰 강의, 리플렛 파일 다운로드 등의 방식으로 공연 콘텐츠에 대한 자세한 정보를 제공해 추가적인 정보 를 찾아보고 싶은 관객들의 관심을 충족시키고, 관람 경험이 많지 않은 관객들의 작품에 대한 기본적인 이해도를 높일 수 있는 장치를 지속적으로 마련하고 강화해 야 한다. 각종 SNS채널 활용은 기본적이고, 포털 사이트보다 검색 활용도가 높아진 유튜브에 내용이 알차고 흥미를 유발할 만한 영상을 제작해 꾸준히 업데이트 해두 는 것도 알고리즘에 의한 노출과 공연 정보 아카이브 차원에서 의미가 있을 것이다. 이러한 관객개발과 홍보 활동에는 국공립 예술단체의 단원이나 연출 등 예술가와 제작진이 적극 참여할 수 있게 한다. 결과물뿐 아니라 제작과정을 궁금해 하는 관객 을 위해 연습 장면 등을 담은 메이킹 영상을 만든다거나, 출연진 인터뷰, 코멘터리, 작가와의 대화 등 온·오프라인을 막론하고 관객과의 소통에 지금보다 더 적극적으 로 나설 필요가 있어 보인다.

한편, 온라인을 통한 예술향유가 보편화되고 코로나 19 로 인해 폭발적인 증가세 를 보이면서, 예술가들도 창작활동에서 이를 고려하고 적극 활용해야 하는 시대에 도달했다. 온라인 향유는 현장감을 완전히 대체할 수는 없겠지만, 무료이거나 저렴 한 비용으로 비교적 손쉽게 접할 수 있어 향유의 걸림돌이었던 시공간의 제약이 해 소되고 진입 장벽이 낮아지는 장점이 있기 때문에 보완재의 역할은 충분히 할 것으

145) 2020 한국문화예술위원회 코로나19 긴급지원사업, https://tumblbug.com/collections/artistree2020corona19 
로 보인다. 가상현실로 구현된 온라인 전시관에서 실제 전시 공간 안에 있는 것처럼 몰입해서 작품을 관람할 수 있거나, 오프라인에서만 느낄 수 있는 공연의 현장감, 감동의 격차를 줄여주는 기술적인 면이 더욱 향상되고 보완된다면 온라인을 통한 예술향유의 비중은 더 늘어날 것으로 예상된다.

온라인 영상 제작이 의무화 되면서 문예회관을 중심으로 한 대규모 공연장의 경 우 실시간 중계나 녹화를 위한 최첨단의 촬영 장비, 기술인력 확보가 필수적이다. 국공립 문화시설을 중심으로 장비와 인력을 확보해나가면 해당 시설에서 기획한 행 사에 참여하거나 시설을 대관하는 예술가와 단체들도 이를 활용할 수 있을 것이다. 예술단체나 예술가가 개별적으로 온라인상으로 공개할 작품을 제작하거나 편집 영 상과 생중계를 통해 관객과 만나고자 할 경우, 촬영과 녹화를 할 수 있는 스튜디오 와 같은 장소, 방송과 편집 기술, 카메라, 마이크, 조명 같은 장비를 모두 갖추기 힘들기 때문에 이에 대한 교육과 지원이 뒷받침 되어야 할 것이다. 온라인은 이제 창작자 입장에서 창작 과정에 기본적으로 고려해야 할 요소로 자리 잡게 될 것이고, 이에 따른 단계적인 유료화 방식과 전략, 여기에서 고려해야할 사항들에 대해서도 심도 깊게 고민해야 한다.

\section{나. 향유자에 대한 이해와 새로운 관객개발을 위한 리서치 강화}

최근 증가하고 있는 빅데이터를 활용한 분석은 관람객의 성별, 연령대, 거주 지역 같은 인구통계학적 속성과 객석점유율, 유료관객비율 등의 기초적인 통계수준에서 벗어나, 향유자들의 선택 동기, 빈도 등을 향유 유형별로 보다 구체적이고 심층적으 로 파악하는 데 도움이 될 수 있다. 관람객의 예매 패턴, 이동 경로, 관람 동선, 관련 소비 양태에 관한 데이터, SNS상에 올라온 관람객의 후기, 평가점수, 댓글 등을 수 집하면 한 단계 높고 깊은 수준의 관람객 분석 결과를 얻을 수 있다. 수집된 데이터 들을 복합적으로 분석해 기존과는 다른 방식의 관객개발에 접근할 수 있는 가능성 도 보인다. 예술향유층은 일부 마니아층으로 파이가 한정되어 있는 경향이 있는데, 빅데이터를 통해 기존 관객의 새로운 수요를 파악하고 잠재적인 관객층을 발굴하거 나 비관람객 대상의 접근 전략도 모색해볼 수 있을 것이다.

문체부는 2019년 6월 24일 발표한 ‘박물관·미술관 진흥 중장기계획’에서 빅데이 
터를 활용해 박물관이나 미술관을 찾는 관람객의 특성에 맞는 맞춤형 전시행사나 교육 콘텐츠를 제공하고, 세분화된 관람객의 특성을 바탕으로 한 고객관리와 맞춤 형 컨설팅을 지원할 방침이라고 밝힌 바 있다. 최근 서울시는 SNS에서 시민들이 표현하는 관심사 빅데이터(다음소프트)와 소비(신한카드)·구매(롯데멤버스)데이터, 대중교통 등 공공데이터(서울시)를 융합해 분석한 결과를 내놓으면서, 그 예시로 ‘나홀로 전시관람’의 25 개 자치구별 분석을 실시해 지수로 산출하기도 했다. ${ }^{146)}$ 이를 통해 빅데이터 분석 결과가 시민수요를 반영한 정책 설계에 활용 가능함을 보 여주었다. 공연예술분야에서는 현재 공연DB를 축적하면서 예매 관련 각종 정보를 수집하는 공연예술통합전산망(KOPIS, 예술경영지원센터) 데이터의 활용도를 높이 는 방법이 있다. KOPIS는 수집된 정보를 외부에 공개하는 개방형 API이기 때문에 항목별 정보를 활용해 다양한 분석을 하거나 별도의 앱을 만들 수도 있다.

〈표 6-6〉 서울시 빅데이터 분석 결과 '나홀로 전시관람'

\section{나홀로 전시관람(\#여가생활 \#유동 \#혼자)}

(1) 나홀로 전시관람 지수: SNS 데이터와 카드소비 데이터를 융합하여 각 자치구의 나홀로 전시관람 지수 를 산출한 결과, 나홀로 전시 관람이 가장 활성화된 자치구는 종로구이며, 박물관 및 전시 인프라가 집중된 종로구, 용산구의 지수가 독보적으로 높게 나타나고 있다.

(2) 나홀로 전시관람 이동경로: 카드 데이터를 바탕으로, 나홀로 전시관람 항목의 소비가 자신의 거주지에 서 발생한 경우 혹은 다른 자치구에서 발생한 경우를 산정하여, 이동한 경로를 분석한 결과 강서구, 중랑구의 경우 전시 관람을 즐기기 위해 자신의 지역이 아닌 용산구, 종로구로 이동하는 것을 확인할 수 있다.

(3) 정책 활용 예시: 주요 관심사가 '나홀로 전시 관람인 시민들의 카드소비 데이터를 분석한 결과 전시관 람 수요-공급 간 차이가 가장 두드러진 자치구는 성북구로 나타났다. 성북구 주민들은 대형 전시관이 없어 꿈의숲 아트센터 등 전시 인프라가 갖춰진 강북구를 많이 방문하는 것으로 분석됐다. 이런 결과 를 토대로 향후 지역 간 문화격차를 줄이기 위한 전시관 확충이나 찾아가는 미술관 사업 등 관련 정책 을 추진할 수 있을 것으로 기대된다.

국공립 기관의 경우 자체적으로 확보하고 있는 기존 고객, 회원의 정보를 기본적 으로 활용하면서 이를 빅데이터 분석으로 확대해가며 데이터를 기반으로 한 세밀한 접근을 시도해 볼 수 있을 것이다. 고객별 맞춤형 큐레이션으로 일회성 관객을 고정 관객이자 후원 회원으로 만드는 전략도 요구된다. 관객의 입장에서는 회원으로 가 입한 기관이나 단체를 통해 유튜브나 넷플릭스와 같은 알고리즘 형태로 '해당 공연

146) 서울시. 2020.07.16. https://news.seoul.go.kr/gov/archives/514144\#scrap 
을 본 관객이 본 다른 공연', '관심을 가질만한 공연' 등 취향에 맞는 추천을 받아 볼 수 있다.

창작자의 입장에서는 막연하게만 알고 있는 관객의 특성을 보다 구체적으로 접근 해 분석해 보고 싶어도 시간과 비용적인 면에서 현실적인 어려움을 느낄 수 있다. 예술가나 단체들이 자체적으로 관객, 교육대상자 등에 대한 스터디와 리서치, 관련 아카이빙 작업을 할 수 있도록, 관련 인력, 플랫폼 구축, 출판 작업, 연구 모임, 교육 등을 지원할 수 있을 것이다. 147 ) 공공에서 창작지원사업 진행시에는 관객개발 부분 을 형식적인 항목이 아닌 필수로 포함하고 관객개발 항목을 평가지표에 넣거나, 별 도로 관객개발 지원사업을 진행할 수 있다. 민간의 소규모 단체와 개인 예술가 차원 에서는 빅데이터에 접근하기는 어렵기 때문에, 앞선 서울시 사례에서처럼 공공 차 원에서 예매대행사, 신용카드사, 포털사이트 등 각종 예술향유와 관련 있는 주요 데 이터를 보유하고 있는 민간 기업들과 협력해 빅데이터를 활용한 향유자의 특성 분 석 결과, 특정 공연 및 전시 등의 관람객 분석 자료 등을 공연 단체와 예술가들에게 제공하는 방식으로 도움을 줄 수 있을 것이다.

\section{다. 사회적 거리두기·비대면 관람과 향유-창작지원의 연계}

코로나 19 로 관람객의 향유활동 자체에 큰 제약과 변화가 생김에 따라 창작의 방 식과 전시나 공연의 운영 방식도 달라져야 하는 상황이다. 중앙 정부와 지자체의 방역 지침에 의해 전면 취소되거나 전체적으로 줄어든 횟수와 기간, 오프라인 관람 객수로 창작분야에 대한 공공지원은 더 절실해진 상황이다.

코로나19 이후 전시의 경우 30 분, 1 시간 단위로 소수의 인원만 사전 예약을 받아 관람하는 방식이 자리 잡는 분위기다. 관람객 간 일정한 거리를 유지하기 때문에 상대적으로 관람 인파에 시달리지 않고 전시장 전체를 빌린 듯 조용히 관람할 수 있는 환경이 조성되고 있기도 하다. 148 ) 공연장에서도 객석 거리두기를 시행하는 경

147) 예술위에서는 창작촉진, 관객개발, 유통활성화를 위해 지난 2018년 '공연예술 창작활성화 및 관객개발 을 위한 예술프로젝트 지원사업'을 진행한 바 있다. 우수작품 자료집 제작, 유통활성화 사례집 발간, 공 연예술 시장 현황 파악 및 분석을 위한 연구, 잠재관객층인 어린이 대상 공연 홍보, 예술가의 창작활동에 일반 국민이 참여하고 즐길 수 있는 커뮤니티형 공연예술 창작활동지원, 지역거주민을 위한 관객개발 활동 및 공연예술 향유 증진활동 지원, 해설을 곁들인 부분공연, 영상 콘텐츠를 통한 유통이나 비평 등 예시가 매우 광범위하게 제시되었다. 
우 혼자 오는 관객은 오히려 옆자리에 앉은 관객에게 방해받지 않고 쾌적한 환경에 서 관람할 수 있다. 사실 동반자 없이 혼자 공연이나 전시를 관람하는 트렌드는 코 로나19 이전부터 있었다. 인터파크의 1인 예매 관객은 2005년 11\%에서 2018년 $46 \%$ 로 증가했고, ${ }^{149)}$ 전시나 공연을 혼자 관람했다는 '혼공' 등의 해시태그가 SNS 에 자주 올라왔다. 1 인 관람 또는 소규모 인원 관람 문화의 확산과 인식의 전환은 창작지원사업의 내용적인 부분과도 연결될 수 있다. 한정된 전시 기간 내 관람할 수 있는 관객 수와 1 회차 공연에서 수용할 수 있는 관객 수가 제한되기 때문에 그만 큼 연장해서 전시나 공연을 할 수 있도록 연장 기간에 해당하는 대관료나 인건비 등을 공공에서 지원하는 것을 고려할 수 있다. 만약 공연장 전체 좌석의 $1 / 4$ 만 관객 을 받도록 규제를 한다면 나머지 비워두어야 하는 3/4의 좌석을 공공에서 구입해 티켓 가격을 보상해주는 지원사업 형태도 나올 수 있다. 관객 입장에서는 1 명이 1 자리를 구입하면 옆의 1 자리도 같이 확보되지만, 1 명이 같이 올 수 있는 것이 아니 라 그 자리는 비워두어야 하는 새로운 개념의 ' $1+1$ 티켓’ 이 된다. 소수의 관객만 받 을 경우 티켓 가격의 인상이 불가피해지고 이로 인한 향유자의 경제적인 부담이 더 커질 수 있기 때문에, 관람객에게는 인상된 부분에 대해 할인 혜택을 제공하거나, 할인된 가격만큼 예술가나 단체에 지원해주는 방법 등 공공 영역에서 다양하게 개 입할 수 있는 방법을 검토해 볼 수 있을 것이다.

코로나19로 인해 적용하고 적응할 수밖에 없게 된 관람 문화의 변화는 예술가들 에게는 창작 아이디어의 원천이 될 수도 있다. 예술가들은 코로나 19 이전보다 관객 개발 측면을 더 고민하고, 체온을 측정하고 오랜 시간 마스크를 쓰고 있어야 하는 관객의 입장을 고려하지 않을 수 없는 상황이 되었다. 구체적으로는 일정시간 동안 그 공간에서만큼은 안전하게 단독으로 관람할 수 있는 작품을 구상하거나, 대면을 하지 않고 온라인만으로 진행하는 공동창작 작품 등이 나올 수 있다. 최근 코리아나 미술관이 문체부가 주최한 '2020박물관 미술관 주간'에서 진행한 천경우 작가의 〈Presences(프레즌시스)〉전시는 일반 시민 14 명이 참여해 무대 세트와 같은 전시

148) 연합뉴스. 2020.03.26. 갤러리 전세 내볼까 - 코로나가 바꾼 전시 풍경, https://www.yonhapnewstv.co.kr/news/MYH20200326017900641

149) 인터파크 보도자료, 2019.05.21. 2005년 이후 티켓 예매 ‘혼공족' 분석, https://incorp.interpark.com/communication/CompanylnfoView.do?_method=dtl\&sc.brdNo $=900117 \&$ sc . ntcNo=905\&sc . page $=1$ 
공간에 하루에 1 명씩 머물면서 비대면으로 다른 사람의 흔적과 물건을 공유하는 방 식이었다. 코로나 19 를 겪은 예술가들의 경험과 생각이 반영된 시도들은 새롭게 발 표하는 작품들과 창작지원사업에 공모하는 작품들에서도 자연스럽게 반영이 될 것 이고, 이러한 작품관의 변화와 전에 없던 시도들을 지원해주는 사업 유형을 포스트 코로나형 지원사업으로 새롭게 구상해볼 수 있을 것이다.

문체부는 2020년 9월 9일, 제 15 차 사회관계장관회의에서 '코로나 일상 속 비대 면 예술 지원 방안'을 발표했다. 150) '코로나 일상 속 지속가능한 예술생태계 조성' 을 비전으로 설정하고, 4 개의 중점 추진과제-1 다양한 예술 실험 지원으로 새로운 예술 성장 유도, (2) 온라인 기반 구축으로 언제 어디서나 만나는 예술, (3) 미래 일자 리 및 혁신기업 육성으로 생태계 대응력 강화, (4) 비대면 예술 향유기반 확대로 예 술성장의 토양 마련를 제시했다. 국립 공연장(예술단체)의 온라인 공연 모델 창 출, 고품질 공연영상 생중계 지원, 공연 영상화 종합 제작공간(스튜디오) 조성, 공연 수출 온라인 장(플랫폼) 조성 등을 통해 비대면 시대에 적합한 예술향유 여건을 마 련하고자 한다. 또한 온라인 문화예술교육 콘텐츠 및 프로그램 개발(학습주제 연계, 온라인 콘텐츠 감상교육 등), 코로나 시대에 정서적 치유를 위한 예술치유 꾸러미 제공 등의 사업도 진행할 계획이다. 이 같은 새로운 형태의 예술향유 기회를 제공하 는 일은 코로나 19 에 대응하는 예술향유 정책이기도 하지만, 기술발전에 따른 사회 변화에 조응하는 정책이란 점을 고려하여 향후 지속적으로 그 효과성과 적합성이 검토, 발전되어질 필요가 있다고 하겠다.

150) 아래의 내용은 문화체육관광부 보도자료, 2020.9.9. '코로나 일상 속 지속 가능한 예술생태계를 만든다' 참조 


\section{4. 예술향유 지원을 위한 추진 체계 재정비}

앞서 제5장 제 2 절에서 언급한 예술향유 지원사업 분석을 통해 다양한 문제들이 제기된 바 있다. 현재 예술향유 지원사업의 문제점은, 자발성이 미흡한 공급형 위주 의 사업, 일부 창작·향유-일자리 사업 성격의 중첩성으로 인한 정체성 모호, 복잡한 재원 출처로 인한 예산구조 및 사업의 중복성, 무료 관람정책이 가진 딜레마 등으로 요약할 수 있다. 이러한 예술향유 지원사업의 구조상의 문제와 관련하여 효율적인 추진을 위한 체계 재정비 및 협력체계 구축이 필요하다.

\section{가. 향유 지원사업 운영 체계 및 역할 재정비}

향후 현재 진행되고 있는 향유 지원 사업들의 목적과 성격을 보다 면밀하게 검토 하여 적합한 부서로의 이관 및 운영주체 및 기관 재정비는 필수적일 것으로 보인다. 사업분석에서 제시된 바와 같이 현재 향유 관련 사업들은 정책목적 및 수단, 그리고 성과지표, 아울러 사업 관련 주관 단체/부서/기관 등의 배분이 향유지원이라는 통 합적이고 체계적인 정책 전략에 따라 구성된 것이 아닌, '단위사업'별 태생의 역사 와 재원출처에 따라 담당 주체의 지정 등이 서로 다른 맥락에 따라 구조화되었기 때문이다. 이번 연구에서 제시한 분석을 기초자료로 삼아 향후 종합적인 검토를 거 쳐 이들을 총체적으로 재정비하는 본격적인 정책적 노력이 필요하다.

대표적인 사업으로 '통합문화이용권 사업'을 들 수 있는데, 이는 소외계층을 대상 으로 하는 직접 지원의 선별적 복지 사업에 해당하며, 한국문화예술위원회가 주관 하고 있다. 역사적 맥락에서 창작지원에 방점을 두었던 예술위가 취약계층 대상 사 업을 하게 된 배경에는 사실상 문화예술진흥기금에 복권기금이 유입되었던 맥락과 불가분의 연관이 있음은 주지의 사실이다. 복권기금 취지상 소외계층을 중심으로 지원해왔으며, 오랜 시간 동안 이들 소외계층 위주의 사업들이 예술위 관할 하에 지속되면서 고착된 결과로 보인다. 운영기관의 자체의 문제라기보다 재원 출처의 성격으로 인해 특정 계층 중심으로 사업이 진행될 수밖에 없었던 당시의 상황이 있 었고, 이는 결과적으로 당초 예술위가 하고 있었던 사업들과는 완전히 다른 맥락의 사업들이 지속되어왔던 것으로 보인다. '통합문화이용권' 사업은 경제적 소외계층 을 대상으로 하는 사업이라는 점, 그리고 그 영역이 문화예술을 넘어선 관광과 스포 
츠까지 아우르고 있는 현실적 측면을 고려하여 사업의 성격과 취지에 맞게 운영체 계 및 운영주체에 대한 재정비를 재점검해 볼 필요가 있다. 이것이 곧 단순히 '통합 문화이용권' 사업을 타 기관이나 타 부처로 단순 이관 하는 것만이 타당하다는 뜻은 아니다. 보다 근본적으로는 향후 예술위가 지향해야 하는 ‘향유지원' 사업을 어떻게 포지셔닝할 것인가에 관한 근원적 질문이 전제되어야 하기 때문이다. 본 연구의 다 양한 분석 및 논의의 결과를 토대로 볼 때, 예술위 차원에서 중점을 두어야 하는 앞으로의 향유지원 사업은 예술에 대한 접근성이 단순히 경제적, 지리적 등 '물리 적' 제약만이 아니라 내적, 심리적 제약도 함께 작동하고 있음을 염두에 두고 이들 접근성 해소를 위한 보다 통합적 시각에서의 포괄적 전략을 마련하는 역할을 포용 해야 할 것으로 보인다. 따라서 단순히 취약 계층의 경제적 제약 해소에만 집중하기 보다는, 이들 접근성 제약문제의 입체적 속성과 특성을 감안하되 창작 영역(예술가 와 예술단체 등)과 향유 영역이 결합하고 연계될 수 있는 전략에 중점을 두면서 이 들에 대한 지원을 강화하는 방향으로 선회하는 것이 타당할 것으로 판단된다.

유사한 관점에서 일련의 순회형 사업들의 경우 ‘현재의 사업모델 그대로'를 기준 으로 할 때, 사업 목표와 방식의 전환 혹은 사업운영 주체 조정을 보다 심도 깊게 검토할 필요가 있을 것으로 사료된다. 앞서 살핀 것처럼, 예를 들어 '신나는 예술여 행' 경우, 향유 사업을 대의적으로 표방은 하나 예술현장에서는 오히려 창작지원 사 업처럼 포지셔닝되고 있는 문제를 제기한 바 있다. 이는 역설적으로 창작지원을 당 초 기관의 정체성에 두었던 예술위에서 운영하고 있기 때문에 복합적으로 나타난 결과로 해석될 수도 있다. 물론 현재는 복권기금으로 운영되던 소외계층 중심 사업 에서 문화예술기금으로 재원이 전환되면서 수혜 대상 역시 일반 시민을 대상으로 하는 보편적인 향유사업으로 전환되었음에도, 여전히 예술단체들의 입장에서는 창 작지원 사업에 선정되지 못했을 경우, 차선책으로서 지원하는 사업으로 인식되고 있음을 간과하기 어렵다.151)

다시 말하지만, 이는 단순히 창작과 향유가 분리되어야 한다는 관점에서 접근하 자는 것이 아니다. 향유지원의 향후 방향성에 대한 검토를 전제로 각 사업목적과

151) 그 과정에서 ‘향유’대상에 대한 적극적 고민과 작품설계가 기반이 되기보다는 단체나 기관이 본래 창작하 고자 했던 작품의 축약 버전이나 파일럿 정도를 선보이는 사업 정도로 인식되고 있는데, 담당주관 기관 역시 공유하고 있는 문제의식이다. 
취지에 적합한 방식으로 사업운영과 설계가 재검토 되어야 할 필요가 있다는 의미 다. 앞서 해외사례 중 아일랜드 예술위원회에서 살펴본 바와 같이, 향후 예술위에서 추진하는 '향유'지원은 오히려 향유대상에 대한 연구와 고민을 작품개발에 적극 반 영하고 '공동창작'이나, '참여적 창작' 등 다양하고 실험적인 방식을 '예술단체'와 '기관' 입장에서 실험적으로 고민할 수 있게끔 독려하는 것을 사업의 골자로 삼을 수 있을 것이다. 이 경우 오히려 이들 기관/단체 입장에서도 향유자와 만나는 다양 한 예술창작의 방식을 발굴하고 기획·개발하는데 기여할 수 있을 것으로 보이며, 현재 사업목적과 결과에서 보여지는 정체성의 모호 문제는 해소될 수 있을 것으로 사료된다.

종합하자면 결국 ‘향유 지원사업의 운영 및 지원체계 재정비’는 앞서 일부 예시로 언급한 사업에만 국한된 것이 아닌 기존 중앙주도 사업들의 취지와 목적, 현재 사업 별 운영주체들의 적합성, 그리고 성과에 대한 보다 종합적인 분석을 기반으로 운영 방식 및 체계, 그에 걸맞는 주체를 재정비할 필요가 있음을 시사한다.152) 이를 위해 문체부 내에서 담당부서 및 운영 기관 간의 명확한 역할 구분과 사업 분류에 대한 보다 종합적 점검을 통해 거시적이고 장기적 차원에서 향유 지원사업의 효과적인 운영이 가능하도록 체계 및 역할에 대한 조정이 이루어질 필요가 있다.

\section{나. 일률적인 무료지원 모델 재설계}

예술향유 지원사업은 접근성 제고를 강조하고 있으며, 경제적인 접근성 장벽을 낮추기 위해서 무료 관람제도를 시행하고 있다. 이와 관련한 대표적인 사업으로 국 민 문화향수 기회 확대를 목적으로 2008년부터 시작한 국공립 박물관-미술관 무료 관람 정책을 들 수 있다.

이러한 무료정책에 있어서 고민해 보아야 할 점은 향유 확대라는 측면에서 과연 무료 관람이 기여하고 있다고 볼 수 있을까 하는 점이다. 물론 문화적 소외계층을 위해서는 이러한 무료 관람 제도를 통해 누구나 예술을 향유할 수 있는 기회를 갖도 록 하는 지원은 당연히 중요하고 필요하지만, 전문가들의 의견에 따르면 예술생태

152) 본문에서 한국문화예술위원회 사업 중심으로 논의한 것은 일례일 뿐, 해당 사업 혹은 관련 주체만 재정 비가 필요하다는 의미가 아님을 유의할 필요가 있다. 
계 차원에서 봤을 때 이러한 무료지원을 통한 문화복지가 예술생태계 활성화에 도 움을 주고 있다고 보기는 어렵다는 것이 중론이다. '모두를 위한 예술향유'라는 취 지의 상징성이 갖는 의의는 분명하나, 기존 관객 외에 무관심자나 경험이 없는 이들 에까지 과연 그 실효성이 획득되고 있는가에 관한 부분이 아직은 요원하기 때문이 다. 물론 향유 저변 확대와 수요 개발이라는 차원을 어떻게 정의하고 해석하느냐에 따라 달라지기는 하겠지만, 문화예술교육을 받고, 동아리 활동을 하기 때문에 공연 장이나 박물관의 관람률이 제고되는 것인가, 혹은 반대로 무료관람을 한다고 하여 예술향유가 확대되는 것인가에 대해서는 사실상 인과나 상관관계가 있다고 판단하 기는 어려운 부분일 것이다. 「국공립 박물관·미술관 무료관람 정책 성과 분석 및 개선방안 연구」(김현경 외 2019) 결과에서도 확인되듯이, 사실상 무료관람 결과 소 외계층의 접근성 확대보다는 단체 관람객의 비중이 높았으며, 사회문화적 환경 변 화를 고려해볼 때, 무료관람 정책만으로는 관람객 확대를 기대하기에는 한계가 있 는 것으로 나타났음을 상기할 필요가 있다.

동일한 연구 결과에 따르면, 무료관람을 통해 관람객 수 증가 효과는 분명이 있었 지만 지속적인 관람객 증가에 영향을 미쳤다고는 보기 어려우며, 오히려 관람객 증 가세가 둔화되고 있음을 알 수 있었다. 따라서 무료 지원제도의 취지가 보편적 복지 차원에서 접근성을 확대하기 위한 것임에는 공감하지만, 이러한 결과를 과연 어떻 게 해석해야 할지에 관해서 보다 심도 깊게 고민해 보아야 하며, 그간의 대부분 일 률적으로 적용되던 국공립 박물관. 미술관의 무료관람이라는 정책적 접근 방식에 대 한 재설계가 고려되어야 할 것이다. 그간 공급자 측면에서 무료지원 방식으로 접근 하면 무조건 향유가 확대할 수 있다는 단순 논리에만 갇혀 있었던 것은 아닌지, 그 리고 초기 추진 목표인 문화복지와 실제 적용되는 방식의 간극으로 인해 정책적 실 효성이 과연 적절하게 작동하고 있는 것인지 등의 보다 냉철한 논의가 이루어져야 한다. 관객개발 관점에서 일률적으로 적용되고 있는 무료지원을 넘어서서, 무료관 람자가 유료 향유자로 전환될 수 있는 전략이 모색되어야 하며, 무료관람이 보다 심화된 예술향유 경험으로 연계될 수 있는 정책사업 모델 재설계에 대한 방안 논의 가 이제는 본격화 될 필요가 있을 것으로 보인다.

이때 아울러 고려해야할 지점은 정부입장에서 무료관람이나 할인혜택 같은 향유 진작을 위한 제도를 '하나의 고정된 틀'로 만들어 중앙에서 일괄적으로 기관에 하 
달, 적용하는 방식 보다는 국공립예술기관이나 단체 중심으로 “관객개발” 차원에서 향유진작을 위한 다양한 정책적 접근과 방식을 고민하여 현장에 적용하고 발전시킬 수 있도록 독려하는 방식을 우선적으로 고민할 필요가 있다는 것이다. 이 경우 중앙 의 역할은 기관이나 단체입장에서 향유진작을 위한 관객개발 전략이 자체적인 수익 구조와의 연계 하에서 유기적으로 고민될 수 있도록 제도적 제약 등을 풀어주거나 조율해주는 방식을 적극 고민해볼 필요가 있다.

\section{다. 관련 운영 주체 및 사업 간 연계 강화}

앞서 제 5 장 제2절의 예술향유 지원사업 분석에서 기관별 유사중복 사업에 대한 문제를 제기한 바 있다. 이러한 유사성의 문제와 통합적 관점에서의 향유 지원을 위해서 예술향유와 관련 있는 운영주체 및 사업 간의 연계 강화가 필요하다.

예를 들자면, '지역문화 생태계 구축 통합운영' 사업은 2020년 처음으로 시도된 사업이다. 그간 시설, 프로그램, 단위 사업 중심으로 지원되던 사업의 한계를 극복 하고, 수요자 중심으로 문화현장 생태계를 직접 지원하는 전달 체계를 구축하고자 시작되었다. 여기에는 인생나눔교실(문화정책과), 무지개다리(문화정책과), 문화이 모작(지역문화정책과), 지역문화 콘텐츠 특성화(지역문화정책과), 지역문화 전문인 력 배치(지역문화정책과), 생애전환 문화예술교육(문화예술교육과) 등 총 6개의 사 업이 통합되어 진행되고 있다. 첫 해 사업으로 아직 그 결과는 나오지 않았으나, 이 처럼 문체부 내 부서 및 기관이 연계하여 통합적인 사업 추진을 시도했다는 점에서 큰 의미가 있다 하겠다. 또한 박물관 무료 관람 정책에 대한 개선 방안으로 관람률 향상을 위해 여러 사업들을 결합시킨 '정책 패키지' 브랜드 (가칭)〈모두를 위한 박물 관> 사업이 제안되기도 하였다(김현경 외 2019). 이는 별도의 예산 투입 없이 일반 국민부터, 시니어, 청소년, 장애인까지의 전 대상을 기존 사업들로 묶어서 재정리한 다는 차원에서 설득력을 가질 수 있을 것으로 판단된다.

궁극적으로는 결국 예술향유와 관련한 부처, 기관, 사업 간에 협력 체계 구축을 위한 거버넌스 재정비가 필요할 것으로 판단된다. 가령, 문체부 산하의 한국문화예 술교육진흥원과 지역문화진흥원에서의 동일한 수혜 대상의 향유지원 사업의 경우, 협력 관계 구축을 통해 새롭고 융합적인 지원 사업을 추진할 수 있을 것이다. 개별 
사업을 통합하거나 혹은 예술향유의 중요성과 가치를 알리기 위한 캠페인 등을 상 호 연계하여 진행하는 것 등도 고려해 볼 수 있다. 이러한 검토와 재정비는 특히 변화하는 향유환경에 대한 이해를 반드시 기반으로 삼을 필요가 있다. 특히 중·노년 층을 포함한 주체적인 향유자 확대, 다양한 향유 활동과 융복합화, 세대 간의 통합 의 중요성, 기술과의 융합 등과 같은 사회문화적 변화에 대응하기 위해서라도 향유 자들의 수요를 파악하고 그에 걸맞는 사업 추진 중요성이 더욱 높아졌기 때문이다.

보편적 관점에서의 '예술이 있는 삶'이라는 비전에 조금씩 점진적으로 다가가기 위해서는 향유자 수요 변화에 적극 대응하면서, 동시에 이를 반영한 다양한 관련 주체들 간의 협력 체계 구축 및 효율적인 사업 추진은 필연적으로 요청된다 하겠다. 



\section{참고문헌}

- 강윤주 외(2012), 생활예술 지원정책방안 연구, 문화체육관광부.

- 강윤주·지혜원(2016), 생활예술 오케스트라를 통해 보는 예술의 사회적 가치. 문화 와 사회, $187-225$.

- 김두이·금현섭(2018), 문화예술향유의 다양성 측면에 대한 분석: 혼종성과 균등성을 중심으로. 문화정책논총, 32(2), 115-143.

- 김상훈 외(2016), 예술관객 확대를 위한 비관객 세분화 전략, 문화체육관광부.

- 김서용·김혜선(2007), 문화자본은 중요한가?-문화격차와 주관적 안녕에 대한 실증 분석. 한국정책학회 동계학술발표논문집.

- 김세훈(2005). 사회적 취약계층 문화활동 지원을 위한 법.

- 김세훈(2018), 문화향유증진사업 정책 논거와 쟁점-문화가 있는 날 기획사업을 중심 으로. 문화예술경영학연구, 11(2).

- 김세훈 외(2015), 2014 문화예술진흥기금 지원사업 종합진단 및 개선방안 연구, 문 화체육관광부.

- 김세훈 외(2017), 2017 문화가 있는 날 사업평가 및 발전방안 연구, 지역문화진흥원.

- 김응천·김재범(2014), 예술 공론장 개념을 통한 예술의 공공성에 관한 탐색적 연구. 예술경영연구, 29.

- 김인설(2012), 사회자본이론(Social Capital Theory)을 통해서 본 예술의 사회적 영향. 문화예술경영학연구, 5(2).

- 김 진 외(2016), 문화예술진흥기금 지원실태조사 연구, 한국문화예술위원회.

- 김태형·김미현(2015), 서울시민의 문화향유 유형에 관한 연구 : 문화환경 만족도와 문화향수 수준을 중심으로, 지방정부연구, 19(3).

- 김혜인·김연진 외(2018), 2020 문화예술트랜드 분석 및 전망, 한국문화관광연구원.

- 김현경(2020), 장애인 접근성 강화를 위한 박물관-미술관 가이드라인 수립 방향 연 구, 한국문화관광연구원.

- 김현경·최혜경(2017), 박물관의 사회적 기능 확대 방안 연구, 한국문화관광연구원. 
- 김현경 외(2019), 국공립 박물관미술관 무료관람정책 성과 평가 및 개선방안 연구, 문화체육관광부.

- 김호현, MZ세대의 문화소비, 웹진문화관광, 2020.04, http://www.kcti.re.kr/webzine2/webzineView.action?issue_count=107\&m enu_seq=5\&board_seq $=1$.

- 김휘정(2013), 문화복지정책의 동향과 문화복지사업의 발전 방향. 예술경영연구, 26.

- 나보리·나은(2019), 문화예술향유활동 만족도 연구-관람과 참여를 구분하여. 한국예 술연구, 26.

- 노영순 외(2015), 문화융성 정책의 성과와 과제, 한국문화관광연구원.

- 류정아(2015), 문화예술 지원정책의 진단과 방향 정립: 팔길이 원칙의 개념을 중심 으로, 한국문화관광연구원.

- 류태건(2008), 7 개 광역시 문화발전 비교: 지역주민들의 문화활동을 중심으로. 한국 지방정부학회 학술대회 발표자료집.

- 문순덕·조현성(2016), 제주지역의 문화복지 정책 실태와 발전방안, 제주발전연구원

- 문화관광부(2004), 창의한국.

- 문화관광부(2004), 새로운 한국의 예술정책: 예술의 힘 미래를 창조합니다.

- 문화체육관광부(2011), 국립예술단체의 효율적 통합 운영방안 마련 연구.

- 문화체육관광부(2017), 문화가 있는 날 인지도 조사 결과보고서.

- 문화체육관광부(2018), 문화비전2030-사람이 있는 문화.

- 문화체육관광부(2018), 2018 문화향유실태조사.

- 문화체육관광부(2019), 2019 국민문화예술활동조사.

- 문화체육관광부(2019), 통합문화이용권 사업지침.

- 문화체육관광부(2019), 2018년도 국민여가활동조사.

- 문화체육관광부(2019), 새예술정책(2018-2022): 사람이 있는 문화, 예술이 있는 삶.

- 문화체육관광부(2019), 2018 문화예술정책백서.

- 문화체육관광부(2020), 2020년도 예산·기금운용계획 개요.

- 문화체육관광부(2020), 2020년도 예산·기금운용계획 사업설명서.

- 박승현(2018), 예술의 사회적 가치: 삶의 예술을 위하여, 생활예술, 강윤주·심보선 외 지음, 파주: 살림.

- 배영(2013), 여가활동에서 문화 콘텐츠 소비에 영향을 미치는 요인에 대한 연구-클 래식, 뮤지컬, 영화관람에 대한 개인속성요인과 문화자본 요인을 중심으로. 한국사 회, 14(1). 
- 백선혜(2017), 서울문화재단블로그,

https://m.blog.naver.com/PostView.nhn?blogId=i_sfac\&logNo=221119929 160\&proxyReferer=https:\%2F\%2Fwww.google.com\%2F, 2020.05.14. 최종접근).

- 생활문화진흥원(2017), 2017 '문화가 있는 날' 생활문화동호회 지원사업 평가연구 보고서.

- 서순복(2009), '문화적 자본'이론을 활용한 지역문화향유의 함의에 관한 연구, 한국 사회와 행정연구, 20(1).

- 서우석·양효석(2013), 문화적 박탈감을 통해 살펴 본 문화복지 대상 범위연구, 문화 정책논총, 27(1).

- 서울문화재단(2016), 2016 서울시민 문화향유 실태조사.

- 서울문화재단(2018), 2018 서울시민 문화향유 실태조사.

- 성연주(2018), 성인기 문화예술교육을 통한 문화예술향유 확대: 장르별 차이를 중심 으로, GRI 연구논총, 20(3).

- 신나리·박치성(2019), 문화복지 정책대상 범위에 대한 탐색적 연구 문화향유를 중심 으로. 한국사회정책, 26(2).

- 성제환(2012), 문화 소비자본이 문화·예술상품 수요에 미치는 효과에 관한 연구, 문 화경제연구, 15(1).

- 심광현(1993), 문민정부의 개혁과 90년대 문화정책의 기본과제, 문화정책논총, 5.

- 양건열 외(2002), 문화정체성 확립을 위한 정책방안 연구, 한국문화정책개발원.

- 양현미 외(2012), 미래환경 변화에 따른 예술정책의 기본방향 연구, 문화체육관광부.

- 양혜원 외(2015), 문화가 있는 날 제도적 개선방안 연구, 한국문화관광연구원.

- 양혜원 외(2019), 예술의 가치와 영향 연구: 국내외 담론과 주요 연구결과 분석, 한 국문화관광연구원.

- 양혜원 외(2020), 문화예술진흥법 정비를 위한 사전연구, 문화체육관광부.

- 에릭 부스(2009), 일상, 그 매혹적인 예술, 강주헌 역, 서울: 에코의 서재.

- 에릭 부스(2017), 음악을 가르치는 예술가: 효과적인 음악교육을 위한 실용적인 조 언들, 오수원 역, 서울: 열린책들.

- 유지연 외(2018), 2017 생활문화센터 실태조사, 지역문화진흥원.

- 윤혜란 외(2016), 공연 예술 관람객 향유 확대방안 연구, 한국문화예술위원회.

- 염신규 외(2018), 대국민 향유증진을 위한 소외계층 문화순회사업 개선방안 연구, 한국문화예술위원회. 
- 이경언 외(2016), 예술 향유 능력 제고를 위한 중학교 예술교육 지원 방안, 한국교육 과정평가원.

- 이규석(2017), 문화예술 지원구조의 혁신을 위한 정책과제들, 새 정부 문화정책, 문 화사회를 위한 정책과제들 토론회 자료집.

- 이기현 외(2011), 콘텐츠의 문화적 향유 확대방안 연구, 문화체육관광부.

- 이상수(2013), 문화 참여의 유형과 그 결정요인에 관한 연구 ; 소비활동과 생산활동 의 결합을 통하여, 한국사회학회 사회학대회논문집.

- 이상수·이명진(2014), 문화 선호와 참여의 다양성에 관한 연구: 사회경제적 지위와 사회 연결망의 영향을 중심으로, 한국사회학, 48(5).

- 이 원 외(2010), 콘텐츠 향유 격차 해소를 위한 지수 개발 연구, 문화체육관광부.

- 이재호 외(2010), 지방자치단체의 상대적 문화향유 측정과 문화정책추진 방향 연구, 지방정부연구, $14(2)$.

- 이호영·서우석(2010), 디지털시대의 문화자본과 불평등, 문화정책논총, 23.

- 장미혜(2001), 문화자본과 소비양식의 차이, 한국사회학, 35(3).

- 장세길(2016), 문화민주주의를 넘어: 전라북도 사례로 살펴본 새로운 문화전략 모 색, 지역사회연구, 23(2).

- 장현선 외(2019), 2018년도 통합문화이용권사업 성과평가 연구, 한국문화예술위원회.

- 정갑영(1993), 우리나라 문화정책의 이념에 관한 연구, 문화정책논총, 5.

- 정갑영(1996), 문화복지 정책의 이념적 근간으로서의 문화권, ARKO 문화예술, 한국 문화예술진흥원. http://www.arko.or.kr/zine/artspaper96_10/19961002.htm.

- 정갑영(2005), 우리나라 문화복지 정책의 흐름과 전망, 문화정책논총, 17.

- 정광렬 외(2010), 예술정책의 성과와 과제, 한국문화관광연구원.

- 정광렬 외(2015), 맞춤형 문화복지 정책 및 서비스 전달체계구축방안 연구, 한국문 화관광연구원.

- 정광렬 외(2017), 생활문화 활성화를 위한 정책기반 구축 방안 연구, 한국문화관광 연구원

- 정광호·최병구(2006), 문화격차 분석과 문화바우처 정책설계, 지방정부연구, 10(4).

- 정무성 외(2015), 복권기금 문화복지사업 수혜대상 연구, 한국문화예술위원회.

- 정종은 외(2017 a), 예술정책 미래비전과 전략 연구, 문화체육관광부.

- 정종은 외(2017 b), 서울 생활예술 2031 액션플랜 연구, 서울문화재단.

- 정철현·황소하(2010), 예술마케팅 기법을 통한 서울시민의 문화향수 확대 방안, 서 울도시연구 11(1). 
- 조현성 외(2013), 문화동호회를 활용한 문화 자원봉사 활성화 방안, 한국문화관광연 구원.

- 조현성·최보연(2016), 문화예술교육 중장기 추진방향, 한국문화관광연구원.

- 조현성·연수현(2019), 혁신적 포용국가 달성을 위한 문화정책 발전방향 연구, 문화 체육관광부.

- 지역문화진흥원·문화가 있는 날 사업추진단(2018), 2018 문화가 있는 날 공모사업 설명회 자료집.

- 지역문화진흥원(2018), 2018 문화가 있는 날 사업 성과평가 및 통합 홍보마케팅 실 행연구.

- 지역문화진흥원(2019), 2018 생활문화동호회 실태조사 연구보고서.

- 지역문화진흥원(2019), 근로시간 단축에 따른 문화생활 변화 실태조사 보고서.

- 지역문화진흥원(2019), 2018 생활문화동호회 활성화 지원사업 성과평가 연구 결과 보고서.

- 지역문화진흥원(2019), 생활문화공동체만들기 10년 성과평가 아카이빙 보고서.

- 차지민(2020), 미국 국립예술기금(NEA), 미국인들의 예술참여 패턴 : 대중의 예술 참여에 대한 2017년 설문 보고서 (U.S. Paterns of Arts Participation: A Ful Report from the 2017 Survey of Public Participation in the Arts), 문화예술 지식정보시스템, 해외자료브리핑 제70호, 한국문화관광연구원.

- 최은용(2014), 문화자본이 문화향유 태도에 미치는 영향, 무용역사기록학, 32.

- 최보연 외(2017), 문화예술교육 지원정책 분석 및 개선방향, 한국문화관광연구원.

- 최샛별(2006), 한국사회에 문화자본은 존재하는가? 문화와사회, 1, 123-158.

- 최인호 외(2018), 통합문화이용권 빅데이터를 활용한 문화소외계층 문화향유 실태 분석 및 개선방안 연구, 한국문화예술위원회.

- 최영섭·김민규(2000), 한국인의 문화소비 결정요인에 대한 일 고찰, 문화정책논총, 12.

- 한국문화예술교육진흥원(2019), 2018 한국문화예술교육진흥원 연차보고서.

- 한국문화예술교육진흥원(2020), 2019 국고 보조사업 실적보고서.

- 한국문화예술교육진흥원(2020), 2020년 한국문화예술교육진흥원 예산서.

- 한국문화예술위원회(2019), 아르코비전 2030.

- 한국문화예술위원회(2019), 2018년 한국문화예술위원회 연차보고서.

- 한국문화예술위원회(2019), 2019 문예회관과 함께하는 방방곡곡 문화공감 사업 결 과보고서. 
- 한국문화예술위원회(2020), 신나는 예술여행 2020년 선정프로그램.

- 한국문화정책개발원(1988), 문화예술 수용 및 향수능력 실태조사.

- 한승준 외(2016), 문화예술정책 현황진단 연구, 한국문화예술위원회.

- 허식·윤수영(2013), 문화서비스의 가구소비지출 결정요인에 관한 연구, 재정정책논 집, 15(4).

- 허은영 외(2018), 예술향유정책 현황 및 개발방안 연구, 문화체육관광부.

- 호영성 외(2018), 2017 공연예술 관람객 향유 확대방안 연구, 한국문화예술위원회.

- 홍윤미 외(2015), 문화예술향유에 영향을 미치는 결정요인에 관한 연구, GRI 연구 논총, $17(1)$.

- 64 Million Artists(2016), Everyday Creativity.

- Arts Council England(2018), The Active Lives Survey.

- Arts Council Ireland(2015), Making great art work: leading the development of the arts in Ireland. Arts Council Strategy(2016-2025).

- Arts Council Ireland(2016), Glossary: making great art work.

- Ateca-Amestoy, V.(2015), Enhancing participation in the arts in the EU: challenges and methods., Springer.

- Australia Council for the Arts(2010), More than bums on seats: Australian participation in the arts. Sydney: Australia Council.

- Barbour, E., \& Beyers, W. (2011), California's Arts and Cultural Ecology.

- Belfiore, E.(2020), Policy discourse, cultural value and the "problem of participation". in E. Belfiore \& L. Gibson (Eds.), Culture and Power: Histories of Participation, Values and Governance. London: Palgrave.

- Belfiore, E., \& Bennett, O.(2007), Determinants of impact: Towards a better understanding of encounters with the arts. Cultural trends, 16(3), 225-275.

- Belfiore, E., \& Bennett, O. (2010), Beyond the “Toolkit Approach": arts impact evaluation research and the realities of cultural policy-making. Journal for cultural research, 14(2), 121-142.

- Belfiore, E. \& Hardley, S.(2018), Cultural democracy and cultural policy. Cultural Trends, 27(3): 218-223. 
- Bollo, A., Da Milano, C., Gariboldi, A., \& Torch, C. (2017), Study on Audience Development-How to place audiences at the centre of cultural organisations. European Commission, Brussels Google Scholar (http://scholar. google. com/scholar_lookup.

- Bonet, L., Calvano, G., Carnelli, L., Dupin-Meynard, F., \& Négrier, E. (2018), Be SpectACTive! Challenging Participation in Performing Arts.

- Brown, A. S.(2004), The Values Study: Rediscovering the Meaning and Value of Arts Participation. Hartford, CT. Connecticut Commission on Culture \& Tourism.

; UNESCO(2012: 19-20) 원 출처 링크: https://www.giarts.org/sites/default/ files/values-study-rediscovering-the-meaning-and-value-of-arts-particip ation.pdf.

- Brown, A. S.(2006), A fresh look at arts participation. Working Paper 18, newsletter of Wolf, Keens \& Co., 1-2. http://wolfkeens. com/BIGPICTURE/pages/wp18. html.

- Brown, A.S., \& Ratzkin, R. (2011), Making sense of audience engagement. Volume I.

- Brown, A.S., Novak-Loenard, J.L. \& Gilbride, S(2011), Getting in on the act: how arts groups are creating opportunities for active participation. The James Irvine Foundation.

- Bunting, C., Chang, T.W., Goldthorpe, J.,, Keaney, E., \& Oskala(2008), From indifference to enthusiasm: patterns of arts attendance in England. London: Arts Council England.

- Casale, L. (2017), Arts Engagement Literature Review Summary. Companion to "Building the Field of Arts Engagement". James Irvine Foundation.

- Connecticut commission on culture and tourism. (2004), The Values Study: Rediscovering the meaning and value of arts participation. Connecticut commission on culture and tourism.

- DeVita, M. C., \& Christine, M. (2008), Arts for all: Connecting to new audiences. Accessed October, 1, 2013.

- DiMaggio, P., \& Mukhtar, T. (2007), Arts Participation as Cultural Capital in the United States. 
- Doris Duke Charitable Foundation. (2018), The Paradigm Shifting Power of Audience building/Community engagement. Audience \& Community engagement.

- Dunphy, K. (2015), A holistic framework for evaluation of arts engagement. In Making Culture Count (pp. 243-263). Palgrave Macmillan, London.

- Ebrey, J. (2016), The mundane and insignificant, the ordinary and the extraordinary: Understanding everyday participation and theories of everyday life. Cultural trends, 25(3), 158-168.

- Ellis, A. (2017), Building the Field of Arts Engagement: Prospects and Challenges. James Irvine Foundation.

- England, A. C. (2018), Taking part survey: England adult report, 2017/18.

- European Commission. (2012), European Audiences 2020 and Beyond. Publications Office of the European Union.

- Evans, G. (2016), Participation and provision in arts \& culture-bridging the divide. Cultural Trends, 25(1), 2-20.

- Gibson, L., \& Edwards, D. (2016), Facilitated participation: Cultural value, risk and the agency of young people in care. Cultural Trends, 25(3), 194-204.

- Hadley, S. (2017), European Commission final report: Study on audience development-how to place audiences at the centre of cultural organisations. Cultural Trends, 26(3), 275-278.

- Hadley, S., \& Belfiore, E. (2018), Cultural democracy and cultural policy. Cultural Trends, 27(3), 218-223.

- Hanquinet, L., O’Brien, D., \& Taylor, M. (2019), The coming crisis of cultural engagement? Measurement, methods, and the nuances of niche activities. Cultural Trends, 28(2-3), 198-219.

- Iyengar, S. (2018), US trends in arts attendance and literary reading: 2002 $-2017$.

- JACKSON, A.(2015), IMAGINING ARTS ORGANIZATIONS FOR NEW AUDIENCES: VALUES AND VALUING.

- Jackson, A. (2018), DESK REVIEW OF ACNI'S FIVE YEAR STRATEGIC PLAN FINAL REPORT. Annabel Jackson Associates. 
- Jancovich, L.(2017), The participation myth. International Journal of Cultural Policy. 23(1), 107-121.

- Johanson, K., Glow, H., \& Kershaw, A. (2014), New modes of arts participation and the limits of cultural indicators for local government. Poetics, 43, 43-59.

- Kawashima, N. (2000), Beyond the division of attenders vs. non-attenders: a study into audience development in policy and practice.

- Keaney, E.(2008), Understanding arts audiences: existing data and what it tells us. Cultural Trends, 17(2), 97-113.

- Lee, S., Gean, K. (2017), The Engagement Revolution A study of strategic organizational transformation in 10 California arts nonprofits. Slover Linett Audience Research.

- Leguina, A., \& Miles, A. (2017), Fields of participation and lifestyle in England: revealing the regional dimension from a reanalysis of the Taking Part Survey using Multiple Factor Analysis. Cultural Trends, 26(1), 4-17.

- Literat, I. (2012), The work of art in the age of mediated participation: Crowdsourced art and collective creativity. International Journal of Communication, 6, 23.

- López-Sintas, J., \& Katz-Gerro, T. (2005), From exclusive to inclusive elitists and further: Twenty years of omnivorousness and cultural diversity in arts participation in the USA. Poetics, 33(5-6), 299-319.

- London, M. T. M. (2010), Digital audiences: Engagement with arts and culture online. MTM London.

- Lynch, B. (2011), Whose Cake is it Anyway?: A Collaborative Investigation Into Engagement and Participation in 12 Museums and Galleries in the UK. Paul Hamlyn Foundation.

- Markusen, A., \& Brown, A. (2014), From audience to participants: New thinking for the performing arts. Análise Social, 866-883.

- Matarasso, F. (2010), Full, free and equal: On the social impact of participation in the arts, Version 2.0 (9/2010).

- Merli, P. (2002), 'Evaluating the Social Impact of Participation in Arts Activities', International Journal of Cultural Policy, vol. 8, no. 1, pp. 107-118. 
- Merli P. (2004), Evaluating the social impact of participation in arts activities A critical review of Francois Matarasso's Use or Ornament. 17-21.

- Miles, A., \& Gibson, L. (2016), Everyday participation and cultural value.

- McCarthy, K. F., \& Jinnett, K. J. (2001), A new framework for building participation in the arts. Rand Corporation.

- McCarthy, K. F., Ondaatje, E. H., \& Zakaras, L.(2001), Guide to the Literature on Participation in the Arts (No. DRU-2308-WRDF). RAND CORP SANTA MONICA CA.

- Morrone, A.(2006), Guidelines for measuring cultural participation. UNESCO Institute for Statistics.

- Novak-Leonard, J., Baach, P. E., Schultz, A., Farrell, B., Anderson, W., \& Rabkin, N. (2014), The changing landscape of arts participation: A synthesis of literature and expert interviews (No. TEXTUAL).

- Novak-Leonard, J., \& Brown, A. S. (2011), Beyond Attendance: A Multi-Modal Understanding of Arts Participation. Based on the 2008 Survey of Public Participation in the Arts. Research Report\# 54. National Endowment for the Arts.

- Novak-Leonard, J., Reynolds, M., English, N., \& Bradburn, N. (2015), The cultural lives of Californians: Insights from the California survey of arts \& cultural participation.

- Novak-Leonard, J., Wong J. \& English N.(2015), A Closer look at arts engagement in California, Insights from the NEA's Survey of Public Participation in the Arts. The James Irvine Foundation.

- Novak-Leonard, J. L., O'Malley, M. K., \& Truong, E.(2015), Minding the gap: Elucidating the disconnect between arts participation metrics and arts engagement within immigrant communities. Cultural Trends, 24(2), 112-121.

- Rabkin, N. (2017), Hearts and minds: The arts and civic engagement. James Irvine Foundation.

- Rabkin, N., \& Hedberg, E. C. (2011), Arts Education in America: What the Declines Mean for Arts Participation. Based on the 2008 Survey of Public Participation in the Arts. Research Report\# 52. National Endowment for the Arts. 
- Rajan, K. B., \& Rajan, R. S. (2017), Staying Engaged: Health Patterns of Older Americans who Participate in the Arts, an Analysis Based on the Health and Retirement Study. National Endowment for the Arts.

- Reeves, M. (2002), Measuring the Economic and Social Impact of the Arts: A Review. Arts Council England, London.

- Reeves, A. (2015), Neither class nor status: Arts participation and the social strata. Sociology, 49(4), 624-642.

- Silber, B., \& Triplett, T. (2015), A decade of arts engagement: findings from the Survey of Public Participation in the Arts, 2002-2012. National endowment for the arts.

- Stallings, S. N., \& Mauldin, B. (2016), Public engagement in the arts: A review of recent literature.

- Hill, K., (2018), Canadians' Arts, Culture, and Heritage Participation in 2016. Statistical Insights on the Arts.

- Stevenson, D., Balling, G., \& Kann-Rasmussen, N. (2017), Cultural participation in Europe: shared problem or shared problematisation? International journal of cultural policy, 23(1), 89-106.

- Tait, R., Kail, A., Shea, J., McLeod, R., Pritchard, N., Asif, F. (2019), How can we engage more young people in arts and culture? A guide to what works for funders and arts organisations. The Mohn Westlake foundation.

- The Audience Agency(2017), Greative People and paces Profiling and Mapping 2014-2016 National Report.

- The James Irvine Foundation. (2016), Investing in Cultural Participation and Financial Sustainability. Cross-Cohort Analysis of the Arts Regional Initiative, 2009-2014. HARDER+COMPANY COMMUNITY RESEARCH.

- The James Irvine Foundation. (2019), Innovation and Impact: When Arts Organizations Take Risks. Concluding Evaluation of the Exploring Engagement Fund, 2012-2018. HARDER+COMPANY COMMUNITY RESEARCH.

- Tomka, G. (2013), Reconceptualizing cultural participation in Europe: Grey literature review. Cultural trends, 22(3-4), 259-264.

- Tomka, G. (2016), Audience Explorations: Guidebook for Hopefully Seeking 
the Audience. IETM.

- UNESCO Institute for Statistics. (2009), Framework for Cultural Statistics.

- UNESCO Institute for Statistics(2012), MEASURING CULTURAL PARTICIPATION: 2009 UNESCO FRAMEWORK FOR CULTURAL STATISTICS HANDBOOK No.2. United NAtions of Educational, Scientific and Cultural Organization.

- Visser, J., \& Richardson, J. (2013), Digital engagement in culture, heritage and the arts.

- Walmsley, B. (2016), From arts marketing to audience enrichment: How digital engagement can deepen and democratize artistic exchange with audiences. Poetics, 58, 66-78.

- Walmsley, B. (2019), Audience Engagement in the Performing Arts: A Critical Analysis. Springer Nature.

- Zakaras, L., \& Lowell, J. (2008), Cultivating demand for the arts: Arts learning, arts engagement, and state arts policy (Vol. 640). Rand Corporation.

- Zakaras, L. Lowell, J.F.(2015), Cultivating demand for the arts: arts learning, arts engagement and state arts policy, Rand Institute.

- 2019 실버문화페스티벌 웹사이트, http://www.silverfestival.co.kr

- $\mathrm{e}$ 나라도움 보조사업 현황, https://opn.gosims.go.kr/opn/ih/ih001/getIH001002QView.do

- 경기문화재단 지원공고, https://www.ggcf.or.kr/pages/board/view.asp?MU_IDX=18\&BOARD=500 \&BOARD_CATE $=\& B O A R D \_I D X=14551$ \&pageStatus $=V \&$ searchBoard $=500$

- 독서in>책읽어주는 문화봉사단, https://www.readin.or.kr/home/volunteerIntro/contents.do

- 문화가 있는 날 웹사이트, https://www.culture.go.kr/wday/index.do

- 문화품앗e 웹사이트, https://csv.culture.go.kr/frt/main.do

- 지역문화진흥원, http://www.rcda.or.kr/business/business2_new.asp

- 한국문화예술교육진흥원, https://www.arte.or.kr/business 
- 한국문화예술위원회, https://www.arko.or.kr

- 한국문화예술회관연합회, https://www.kocaca.or.kr/Pages/Business/Business01.aspx

- 한국문화원연합회, https://kccf.or.kr/dspv1User/UserMain.do

- 한국작가회의 웹사이트, http://www.hanjak.or.kr/

- 한국출판문화산업진흥원, http://www.kpipa.or.kr/main/main.do 



\section{ABSTRACT}

\section{A Study of Arts Engagement Policy and Its Prospects}

The purpose of this study is to suggest ultimate value and goals arts engagement policy should pursue and set up policy directions to achieve them by analyzing underlying problems of current policies.

The study outlines problems surrounding arts engagement policies and policy conversation, which include value orientation ambiguity of governments' policy initiatives, misconception about the policies as condescending, and lack of policy response to gain relevance toward changing world. The problems point to the need to look into the policies in general from a comprehensive perspective.

It reviews recently emerging academic discussion on arts engagement as well as policy discourse overseas. The government programs in progress are also meticulously examined, which is followed by in-depth analysis on diverse forms of arts engagement and complex and multi-level demands for arts from the perspective of general public through public survey and focus group interviews.

Based on the analysis, this study presents policy vision of realizing everyday life filled with arts and charts four directions of the policies to fulfil the vision. They are to create policy environment to enhance universal arts engagement, to adopt pluralist policy approaches against the changing nature of arts engagement demand, to develop a virtuous circle between arts production and arts engagement, and to reorganize the support system for arts engagement. By devising specific 
policy strategies in line with the four policy directions, it highlights the role and value of future-oriented arts engagement policies that can contribute to improved quality of life using arts effectively.

\section{Keywords}

Arts Engagement, Arts Engagement Policy, Policy Conversation, Changing Nature of Arts Engagement Demand, Everyday Life 


\title{
집필내역
}

연구책임

조현성 한국문화관광연구원 선임연구위원: 연구총괄, 3장 2절 일부, 4장 1절 일부, 5장 2절 일부, 6장 2절 일부

최보연상지대학교 문화콘텐츠학과 조교수: 연구총괄, 2장 1절 및 2절 일부, 4장 1절 및 2절 일부, 5장 2절 일부, 6장 1절 및 2절 일부

\author{
공동연구 \\ 전민정 프락시스 교육연극연구소 책임연구원: 2장 1절 일부, 5장 1절 및 2절 일부, \\ 6장 2절 일부 \\ 유지연 창원대학교 문화테크노학과 조교수: 2장 1절 일부, 3장 1절 및 2절 일부, \\ 6장 2절 일부 \\ 서지혜 인컬쳐컨설팅 대표: 2장 1절 및 2절 일부
}

\section{예술향유정책 분석 및 방향 연구}

발행인 김대관

발행처 한국문화관광연구원

서울시 강서구 금낭화로 154

전화 02-2669-9800 팩스 02-2669-9880

http://www.kcti.re.kr

인쇄일 2020년 10월 19일

발행일 2020년 10월 19일

인쇄인 (사)한국장애인이워크협회 일자리사업장

I S B N 978-89-6035-820-193300

DOI https://doi.org/10.16937/kcti.rep.2020.e13 


\section{A Study of Arts Engagement Policy and Its Prospects}

\section{口补口 \\ Q14:

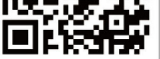

아래의 DOI 또는 $\mathrm{QR}$ 코드를 통해

이 보고서를 무료로 다운로드할 수 있습니다.

https://doi.org/10.16937/kcti.rep.2020.e13
Jo Hyeonseong $\cdot$ Choe Boyun 